\title{
ORCHIDS AND ORCHIDOLOGY IN CENTRAL AMERICA. 500 YEARS OF HISTORY*
}

\author{
Carlos Ossenbach \\ Centro de Investigación en Orquídeas de los Andes “Ángel Andreetta”, \\ Universidad Alfredo Pérez Guerrero, Ecuador \\ Orquideario 25 de Mayo, San José, Costa Rica \\ caossenb@racsa.co.cr
}

\section{INTRODUCTION}

\section{Geographical and historical scope of this study.} The history of orchids started with the observation and study of species as isolated individuals, sometimes grouped within political boundaries that are always artificial. With rare exceptions, words such as "ecology" or "phytogeography" did not appear in the botanical prose until the early XX century.

Although Humboldt and Bonpland (1807), and later Oersted, had already engaged in the study of "plant geography", botanical exploration in our region seldom tried to relate plants with their life zones. The XIX century and the first decades of the XX century are best defined by an almost frenetic interest in the identification and description of new species, without bothering too much about their geographical origin. No importance was given to the distribution of orchids within the natural regions into which Central America is subdivided.

Exceptions to this are found in the works by Bateman (1837-43), Reichenbach (1866) and Schlechter (1918),

* The idea for this book was proposed by Dr. Joseph Arditti during the 1st. International Conference on Neotropical Orchidology that was held in San José, Costa Rica, in May 2003. In its first chapters, this is without doubt a history of orchids, relating the role they played in the life of our ancient indigenous people and later in that of the Spanish conquerors, and the ornamental, medicinal and economical uses they gave to these plants. It is not until the late XVIII century, but above all in the XIX century that we can talk about a history of orchidology, with the development of botanical science and the establishment of the bases of modern orchidology by Lindley. But the XIX century was also the time of legendary commercial collectors who, frequently with the complicity of men of science, collected with a frenzy often bordering on madness. Orchid knowledge became sometimes a synonym of orchid destruction. During the second half of the XX century the world developed a growing conscience of the negative impact of man on his natural habitat and I would like to believe that, in the future, orchidology will devote itself in an increasing manner to the study of orchids as a means to preserve them. Motivated by this belief, I decided to write this history, that will be more a story about orchids and men than a story about orchids and science, hoping that mankind will rediscover the harmonious relation with nature that characterized the life of the first inhabitants of our region. The great naturalist Alexander F. Skutch, who chose a life of study and contemplation amidst the forests of southern Costa Rica, expressed it in much better words: "Sometimes, before leaving the hilltop, I visit the old Indian burial ground. Despite promises of golden ornaments, I have never permitted anyone to excavate these graves, for I believe that we should treat the burials of alien races with the same respect that we desire for our own. Sometimes, in a meditative mood, I ask myself whether, from the moral standpoint, my title to this land is as valid as that of the men whose dust lies beneath the red clay. Perhaps the only answer to this perplexing question is that he most deserves to have the land who makes the best use of it. If my love of the mountains and rivers and forests is greater than theirs, if these things speak more meaningfully to me and I am more keenly appreciative of their beauty; if I strive harder to preserve this natural setting in its pristine splendor and to conserve the soil's fertility - then perhaps I can justify my possession of this land that once belonged to them. If I fall short of the aborigines in these respects, then I - and the whole line of too-aggressive palefaces who transmitted to me what was once theirs - are but piratical intruders, whose right to this land would be hard to defend. Enlarging on this theme, it seems to me that, unless evolution miscarries, the ultimate possessor of the earth will be the race that most appreciates its grandeur and beauty and cherishes it most carefully, that rules it as a generous and compassionate lord instead of raping it like a greedy tyrant, as men have all too commonly done" (Skutch, 1971: 223-224). 
but above all the monumental account by Godman and Salvin on the Central American biology, in which Hemsley wrote the botanical part (Hemsley, 1883). The enumeration of species in this work is followed by a detailed description of the known localities of collection from which the phytogeographical regions of Central America can already be inferred.

In the first chapters, our history centers on MexicoTenochtitlan, capital of the Aztec empire and later of the Viceroyalty of New Spain. The first descriptions of orchids for our area of study (with a medicinal rather than botanical purpose) originate in locations that, although outside of the geographical area with which we are concerned, were strongly influenced by the ancestral culture of the Maya and maintained a close interaction, during the centuries preceding the Spanish conquest, with the rest of Central America. It is no coincidence that the northern limit of the cultural expansion of the Mayas overlaps very approximately with what today is considered the northern limit of Mesoamerica: the Isthmus of Tehuantepec. The southern region of Central America during this period offers only a few references to the use of orchids in ritual ceremonies of the indigenous cultures of northern Colombia, Panama and Costa Rica.

During the colonial period and especially since the XVIII century, Guatemala became more and more the political and cultural center of the region. Important during this period are the works of Friar Francisco Ximénez and, above all, the arrival in Guatemala of the expedition of Sessé and Mociño. After independence from Spain, Chiapas was separated from the Captaincy General of Guatemala. Due to its annexation to Mexico, the northern border of Guatemala became the first artificial border in northern Central America. The botanical exploration of southeastern Mexico and the Yucatan peninsula, isolated from Guatemala as well as from Mexico itself for geographical and political reasons, was delayed until the late XIX century. The separation of Belize, that had become a British possession in the last third of the XVIII century, contributed to this problem. Something similar occurred to the south. Panama remained as a part of Colombia and its integration with the rest of Central America did not begin until the second half of the XIX century (Fig. 1A-B).

Modern history of botanical exploration and of orchids in Central America, initiated by the botanists of the expedition of Malaspina, continued during the first decades of the XIX century with the exploration by Cuming of the Pacific coast belt and the arrival of Skinner in Guatemala. It gained strength at the end of the first half of the century with the fortunate arrival of the illustrious trio formed by Oersted, von Warscewicz and Wendland. In the second half of the century, knowledge about our orchids grew in an accelerated form and experienced an enormous boom during the first decades of the XX century. The publications by Reichenbach (1866) and Hemsley (1883), and later Schlechter (1918), opened the eyes of the world to the richness of orchid diversity in Central America.

Their place was taken by Standley and especially Ames after World War I. Ames, Hubbard and Schweinfurth published in 1936 a work of great importance at the generic level, The Genus Epidendrum in the United States and Middle America (Ames et al., 1936), but it was not until the first years of the second half of the XX century that a new attempt was made to see the orchids of Central America in a more phytogeographical than political context, with the publication by L. O. Williams of his Enumeration of the Orchidaceae of Central America, British Honduras and Panama (Williams, 1956), preceded some years before by The Orchidaceae of Mexico (Williams, 1951). During the last decades of the XX century and at the beginning of the third millennium, the investigation of our orchids showed an increasing emphasis in the study of our natural regions. A higher awareness of the multiple threats to the conservation of our biodiversity contributed to generate a growing interest in studying orchids from an ecological and phytogeographical point of view. An example of this is the publication of the monumental Flora Mesoamericana (Missouri Botanical Garden, UNAM, Field Museum of Natural History, in press), preceded by works of smaller scale but no less importance, such as Field Guide to the Orchids of Costa Rica and Panama by Dressler (1993) and the Synopsis of the Orchid Flora of the Mexican Yucatan Peninsula by Carnevali et al. (2001).

Our history has important gaps that cannot be avoided. Research on our species started in Guatemala with Mociño and continues there through the present days. After the travels by Oersted, von Warscewicz and Wendland, the orchid floras of Nicaragua, Costa Rica and Panama were brought into the light of day. 
In Belize, the Botanical Station was founded in 1892 and by 1899 there were already reports of 23 orchid species. However, it is surprising that for the combined territories of Honduras and El Salvador, Hemsley (1883) and Schlechter (1918) only mention a scarce dozen species. Knowledge of orchids of El Salvador began with the publication of the Lista preliminar de las plantas de El Salvador by Standley and Calderón (Standley \& Calderón, 1925) and another 50 years had to pass until the publication of Las Orquideas de El Salvador by Hamer (Hamer, 1974-1981). Honduras is still mostly unknown territory. With the exception of the few species mentioned by Ames in Standley's Flora of the Lancetilla Valley (1931) and the work of L. O. Williams (1956), not one single work has ever been published about the orchids of this country.

To summarize, the historical scope of this study covers the years from the beginning of formal botanical exploration (the arrival of the Malaspina expedition in Panama) to the present. It is preceded by two chapters about orchids during the prehispanic period and the first three centuries of Spanish rule.

The geographical scope corresponds to the presently accepted concept of Mesoamerica, an area that reaches from the isthmus of Darien, in Panama (and that should probably include the northern regions of the Colombian departments of Chocó, Córdoba and Antioquía ${ }^{1}$ to southeastern Mexico (the states of Yucatan, Quintana Roo, Campeche, Tabasco, Chiapas and the eastern regions of the states of Veracruz and Oaxaca). The area includes the Bay and Swan Islands in Honduras and Cocos Island in Costa Rica ${ }^{2}$.

\section{Political history of Central America}

"Venient annis saecula seris quibus Oceanus, vincula
rerum, laxet et ingens pateat telus tethysque novos
detegat Orbes nec sit terris ultima Thule." ("Years
will come with the passing of the centuries when the
Ocean, opening its barriers, will let us see a land of
immense extension, a new world that will appear in
the dominions of Thethis, and no longer shall Thule
be the limit of the Universe".
Seneca, who was a Spaniard (54 B.C. - 39 A.C.)
"I arrived at Cape Gracias a Dios ${ }^{3}$ and from there our Lord gave me prosperous wind and current. This was on September 12" (Masiá, 1971: 247) Columbus described with these words, in the navigation $\log$ of his fourth voyage to America, the discovery of the coast of Central America, in what we call today Honduras. It was the year of 1502. Columbus continued south, touching land in Nicaragua and Costa Rica, and arriving finally in Veraguas (today Bay of Almirante, in Panama). From there he sailed to Jamaica. In 1504 he returned to Spain, where he died in poverty in 1506 . Columbus is credited with the first recorded comment on canopy-adapted vegetation; he wrote that tropical trees "have a great variety of branches and leaves, all of them growing from a single root" (Benzing, 1971: 1). The land that Columbus had just discovered was inhabited, in the northern two thirds of Mesoamerica, by descendants of the ancient Mexican civilizations that had disappeared 600 years earlier and were now under the influence of the Aztec Confederation, with its political center in Tenochtitlan, in the Valley of Mexico. Living together with dozens of other languages, nahuatl or dialects derived from it became a lingua franca that facilitated the cultural and commercial exchange between the nations of the area.The southern third of Mesoamerica had been settled by tribes whose culture and language originated in the Chibcha civilization of northern South America (Fig. 1C).

The conquest of Central America began in 1508, with the expedition of Alonso de Ojeda and Diego de Nicuesa to Panama. During the next decades, while Pedrarias Dávila was governor of the new land, Panama was the point of origin for numerous penetrations to the North, during which the present territories of Costa Rica and Nicaragua were explored and conquered. In northern Mesoamerica, Hernán Cortés began his conquest of Mexico in 1519 that culminated victoriously when the Aztec Empire surrendered in 1521. Emperor Charles I created, in 1535, the first Vicekingdom on American soil with the name of New Spain. Pedro de Alvarado, lieutenant of Cortés, attempted from Mexico the conquest of the present territories of Guatemala, Honduras and El Salvador in 1524. The conquest was

\footnotetext{
${ }^{1}$ Quesada, R. (1980, Costa Rica, la frontera sur de Mesoamérica) defines the basin of the Atrato river in the Colombian Chocó as the "southern limit of southern Central America".

${ }^{2}$ The term Mesoamerica is a subject of discussion. Attempting to define a region composed of countries that present a similar phytogeographical character and that have their origin in a common geological past, the term "Central America" was used until
} 
successfully concluded in 1568 , with the establishment of the Captaincy General of Guatemala that included Chiapas, Soconusco, Guatemala, El Salvador, Verapaz, Honduras, Nicaragua and Costa Rica.

During the XVI Century, the history of Central America cannot be separated from that of Mexico. Beginning with the XVII Century however, although nominally dependant on the Vicekingdom of New Spain, the distance from the capital gave the Captaincy General of Guatemala more autonomy to establish relations with the mother country.

In the south, Panama took a different course. After Vasco Núñez de Balboa discovered the Pacific Ocean in 1513 and Pizarro conquered the Inca Empire in 1533, Panama became the crossing point for all communications between Spain and the future Vicekingdom of Peru. The separation of Panama from the rest of Central America was consolidated in 1717, when Spain established in Santa Fe de Bogotá the Vicekingdom of New Granada, into which Panama was integrated. After the defeat of the Invincible Armada in 1588, Spain consumed herself in sterile wars against Great Britain and France. The growing British Empire gained commercial advantages and set foot in the
Caribbean, invading Jamaica in 1655. In 1673, through the Treaty of Paris, the Spanish allowed the British to $\log$ in a prescribed area of Belize (Miller Carlstroem \& Miller, 2002: 13). The famous buccaneer and cartographer William Dampier alternated his life between logging in Belize and Honduras and plundering the Spanish fleets in the Caribbean between 1675 and 1688 .

France and Holland did not stay behind. From the Lesser Antilles to the Guyanas, Spain lost slowly the absolute control it had exercised during the XVI Century over the Caribbean and its coasts (Fig. 2A).

The decadence of the Empire continued throughout the XVII Century. Without precious metals to offer to the crown, the Central American colonies languished under the Hapsburg kings Philip III, Philip IV and Charles II. Unable to beget an heir, the last monarch of the Hapsburg dynasty made his will, in 1700, in favor of Philip of Anjou, grandson of Louis XIV, King of France: with him, the house of Bourbon arrived at the throne of Spain (García de Cortázar \& González Vesga, 1994: 337).

Under Philip V (1700-1746) and Fernando VI (17461759), Spain attempted to reorganize the Empire. In the second half of the XVII Century the enlightened

the first years of the XX century. This was the term used by Hemsley (1883) in his Biologia Centrali-Americana and Schlechter (1918) in his Kritische Aufzählung der bisher aus Zentral-Amerika bekanntgewordenen Orchidaceen. Both used the term in a very broad sense, including in their catalogues the species known from western Panama to the Río Grande, which marks the border between Mexico and the United States. Williams (1956) comes much closer to the geological and phytogeographical reality when he writes about the Orchidaceae of Central America, British Honduras and Panama, adding in his introduction that southeastern Mexico (to the isthmus of Tehuantepec) belongs biologically to Central America. Williams is the first to insinuate in the title of his work the political and historical differences of Panama and Belize with respect to the five Central American nations sensu strictu. In the last decades of the XX century the term "Mesoamerica" begins to gain adepts in our region, mainly through the publication of the Flora Mesoamericana by the Missouri Botanical Garden, as the region that comprises all of Panama through southeastern Mexico (states of Yucatan, Quintana Roo, Campeche, Tabasco, Chiapas and the eastern part of Veracruz and Oaxaca). The area includes the Swan and Bay Islands in Honduras and Cocos Island in Costa Rica. This definition is contradictory for various reasons. The northern limit is defined by a geological accident, the isthmus of Tehuantepec, an imaginary line that crosses the southeastern part of the Mexican states of Veracruz and Oaxaca. The southern limit is formed by the border between Panama and Colombia. If we accept the theory that Central America was probably an archipelago without continental connection with either North or South America (following Dressler, 1993), then we would accept the northern limit (Tehuantepec) but would have to establish the southern limit in its geological counterpart, the isthmus of Panama. But even the most superficial study about the distribution of plants in the region will show that, in phytogeographical terms, many species escape their geological limits. Therefore, these limits should be extended to the Colombian Chocó and northern Ecuador in the south and to the Mexican states of Michoacán, Mexico and Puebla in the north. Quesada (1980) defines the watershed of the Atrato River in the Colombian Chocó as the "southern limit of southern Central America". To confuse things even more, the database of the Missouri Botanical Garden includes under "Mesoamerican specimens" all plants collected between northern Mexico and eastern Panama, returning curiously to the old definitions of Hemsley and Schlechter. To make matters worse, Jorge León (pers. com., 2003) is right in stating that Mesoamerica is not a geographical but a cultural term, that comprises the areas that in pre-Columbian times were under the influence of the ancient Maya civilization in Guatemala and Yucatan, as well as those that were dominated (centuries later) by those cultures that had their center of power in Mexico-Tenochtitlan. Those territories had their northern limit in the present Mexican states of Sinaloa, Zacatecas, San Luis Potosi, Nuevo Leon and Tamaulipas and their southern limit in northwestern Costa Rica. Excluded from the term "Mesoamerica" in a cultural sense are the totality of Panama, most of Costa Rica and the Atlantic coast of Nicaragua and Honduras: territories that were under the influence of the Chibcha cultures of northern South America. ${ }^{3}$ Gracias a Dios, in English “Thanks to God". Columbus gave this name to the cape after he had sailed over 70 days against a terrible storm. 


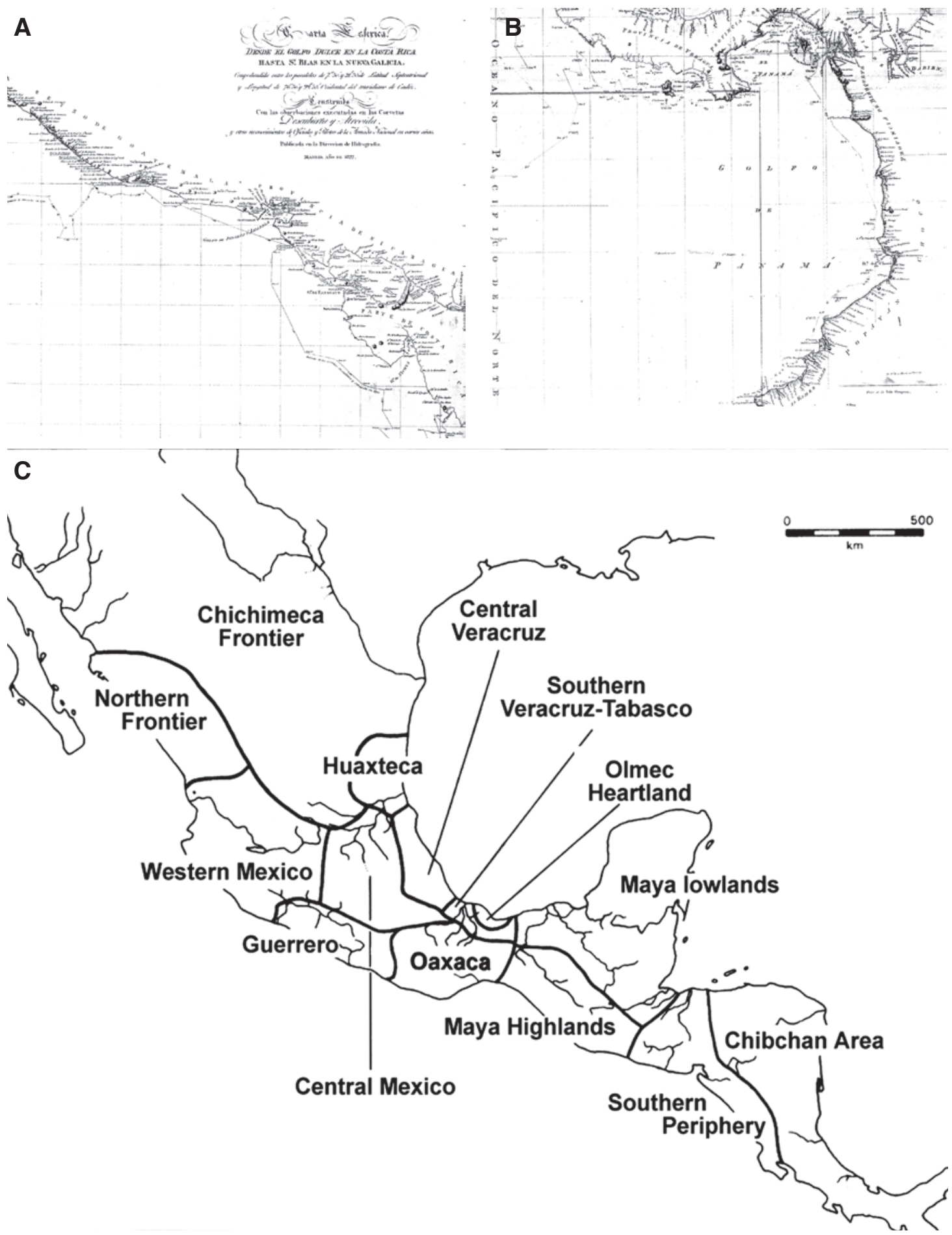

Figure 1. A - Map of the Pacific Coast of Central America and South Western Mexico. From Malaspina, $1990: 240$. B - Map of the northern South American Pacific Coast and of Panama. From Malaspina, 1990: 240. C — Map of Central America showing the limits of the ancient Mesoamericancultures. In Carmack et al., 1996: 30. 


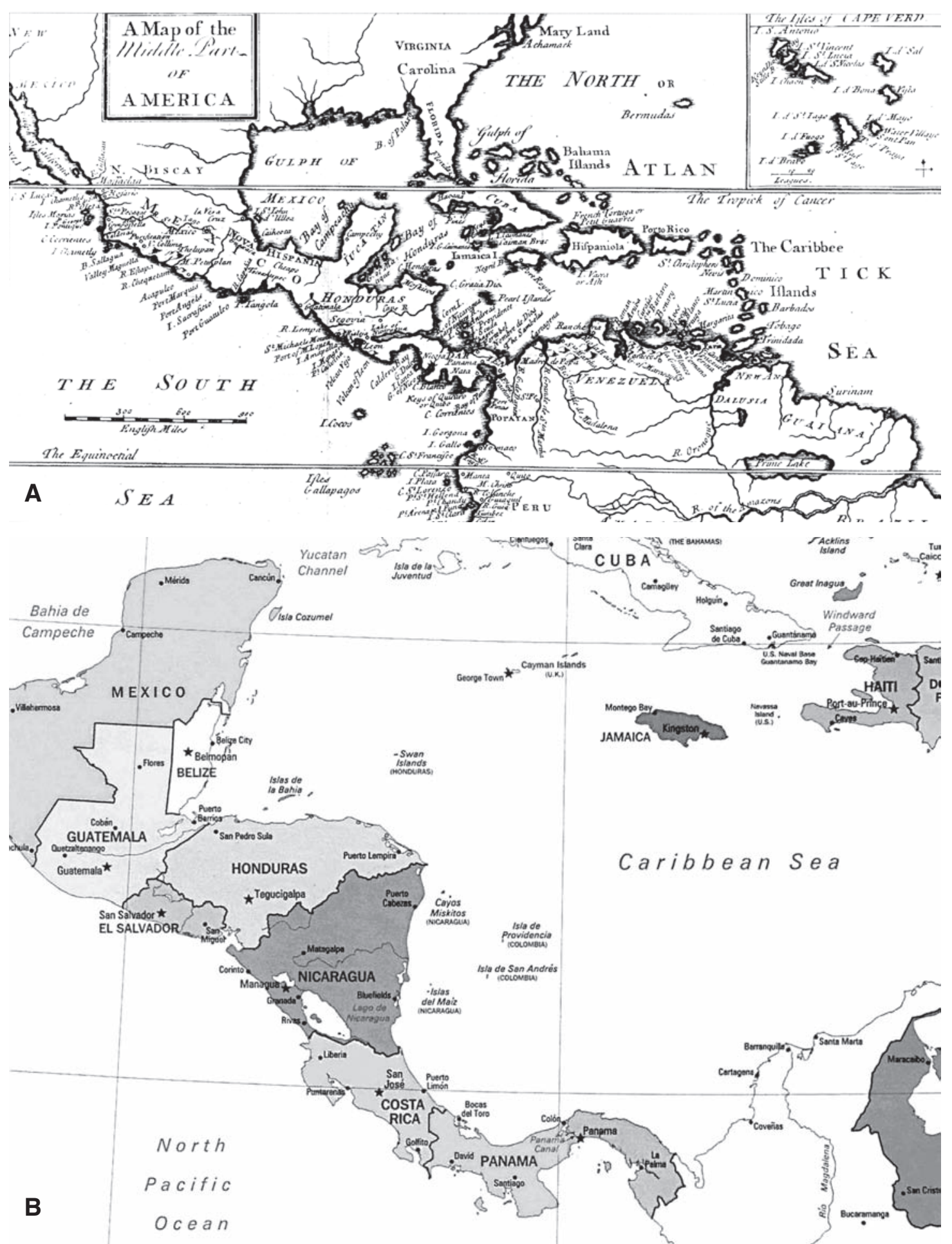

Figure 2. A - Map of Central America and the Caribbean (1675). In Dampier, 1998: 23. B - Political map of Central America. Magellan Geographix, 1992, Santa Barbara, California. 
despotism penetrated the social sectors close to the crown. When Charles III became king (1759), the ideas of the Enlightenment gained force, pretending to reorganize the Spanish society on the foundations of utility, prosperity and happiness (García de Cortázar \& González Vesga, 1994: 370).

These new ideas, and the crumbling of the Spanish administrative apparatus under French occupation at the beginning of the XIX century, opened the way to the independence of the American colonies. On September 15, 1821, the Captaincy General of Guatemala declared its independence from Spain, followed by Panama on November 28 of the same year. While Panama remained united to Colombia, the rest of Central America became part of the short lived Mexican Empire of Agustín de Iturbide. In 1823, the United Provinces of the Center of America were born. The Federation dissolved in 1838 , giving way to the present republics of Guatemala, Honduras, El Salvador, Nicaragua and Costa Rica. Only Chiapas, historically part of the Captaincy of Guatemala, maintained its union with Mexico.

The discovery of gold in California in 1848 brought thousands of adventurers who used the routes of the Isthmus of Panama and the San Juan River in Nicaragua as the shortest way between Atlantic and Pacific. An interest in the region woke up that led William Walker, with the support of pro-slavery North Americans, to take possession of Nicaragua, threatening to expand his dominions to the rest of Central America. Following several military campaigns, Walker was finally defeated and executed in Honduras, in 1860.

In 1903, North American interests in the construction of an interoceanic canal led, on November 3, to the separation of Panama from Colombia. While U.S. naval forces prevented the Colombian army from intervening, the United States recognized the new republic officially on the 13 of the same month. Five days later, the HayBunau Varilla Treaty was signed, in which Panama ceded the strip of its territory through which the future canal was to be built, in perpetuity to the United States.

In Belize, the battle of Saint George's Caye, in 1798, marked the beginning of full British control, although the territory did not become a colony of the crown until 1871, under the name of British Honduras. In 1973 it changed its name to Belize, and despite the protests of Guatemala, who claimed it as part of its territory, on September 21, 1981, Belize officially became an independent nation, but it remains a member of the British Commonwealth (Miller Carlstroem \& Miller, 2002: 14).

After almost 500 years, Central America had finally reached its present political configuration (Fig. 2B).

\section{Central America: biodiversity and phytogeography}

"The world is so large and beautiful, and has such a diversity of things so different one from the other, that it brings admiration to all who think and contemplate it well".

(Francisco López de Gómara, 1982)

Few regions in the world can compete with Central America in floristic diversity. This diversity can only be understood through the study of its phytogeography. The great number of microclimates in a territory of barely 650.000 square kilometers (slightly more than the area of Spain), has produced, in the case of the Orchidaceae, almost 3,000 different species in the Central American area, approximately one tenth of all species known worldwide. Ossenbach et al., (2007), indicate a total of 2,670 species for the region.

The Panama land bridge -here considered to be the Isthmus of Panama and all the land northward to the Isthmus of Tehuantepec in the Republic of Mexico- is one of the most interesting and challenging parts of this planet to study with regard to questions of past and present biogeography. This is the only extant land bridge of biogeographical significance, and in past geological times its importance as a passageway for flora and fauna between continents may have been equaled only by the Bering land bridge (D’Arcy \& Correa, 1985: 117).

Friar Bartolomé de las Casas in his General History of the Indies (chapter XLII) makes reference to Columbus's astonishment when first seeing the trees loaded with epiphytes: "He saw there many trees, very different from those in Castilla, and they had the branches in many different manners, and all from one trunk or one stem, and one branchlet in one form and the next in other, so that it was the greatest marvel of the world, such was the diversity from one to the other, and those were not grafted, because the Indians did not cure them ..." (cited in Masiá, 1971: 223).

Alexander von Humboldt was a pioneer when he wrote, in 1807, about the relationship between climate and vegetation. For this he has been called, with justice, the "Father of Plant Geography". Richard B. Hinds, surgeon 
on board of H.M.S Sulphur, who explored the Pacific coast of Central America between 1836 and 1842, wrote in 1843 about The regions of vegetation (Hinds, 1843, cited in Jörgensen, 2003: 5). Schlechter cites Galeotti, who in 1844, divided the climatic zones in Mexico in "warm regions", "temperate regions", "temperate regions rich in Cactaceae" and "cold regions" (Schlechter, 1918: 332). Somewhat later, Anders S. Oersted, who visited Central America and the Caribbean about the middle of the XIX Century, illustrated the vegetational zones of a tropical island taking Jamaica as an example (Fig. 3A).

The phytogeography of Central America in general has been considered by Grisebach, in 1884, based on a few personal and a lot of foreign observations, in his work Vegetation der Erde. Andreas Schimper published his classic Plant geography upon a physiological basis (Schimper, 1898). Richer in regional information than the phytogeography of Grisebach (1872), Schimper's book divides the region from Mexico to Colombia into monsoon rain forests, thin and monsoon forests, and xerophilic vegetation (woodland savannas) (Gómez, 1986: 13). The progress in phytogeographical knowledge in the XX Century is described by G. S. Hartshorn who, in the case of Costa Rica ${ }^{4}$ says: "The first essays for the description of the phytogeography of Costa Rica highlight a few floristic regions, based mainly on altitude. Pittier recognizes three altitudinal bands: (1) a basal zone from sea level to $1,000 \mathrm{~m}$, with a mean temperature between $28^{\circ}$ and $21^{\circ} \mathrm{C}$; (2) a montane or intermediate zone from $1,000 \mathrm{~m}$ to $2,600 \mathrm{~m}$ with a mean temperature between $21^{\circ}$ and $14^{\circ} \mathrm{C}$; and (3) a superior or Andine zone above $2,600 \mathrm{~m}$ with mean annual temperatures between $15^{\circ}$ and $5^{\circ}$ C" (Hartshorn, cited in Janzen, 1991: 120).

In a very comprehensive essay about the phytogeographical regions of Costa Rica, Wercklé described four regions: (1) the Atlantic or Caribbean region from sea level to $800 \mathrm{~m}$; (2) The Pacific region, from sea level to $800 \mathrm{~m}$; (3) the temperate region from 800 to 1,500 $\mathrm{m}$; (4) the cold region above 1,500 m. (Wercklé, 1909). Standley followed the phytogeographical divisions of Wercklé, but affirmed that the cold region had to be subdivided into a low and a high band. In addition, Standley was the first to point to the difficulty consisting in assigning one single altitudinal limit to a particular type of vegetation (Standley, 1937-38).
Some decades later, L. R. Holdridge, who lived for long years in Costa Rica, proposed in 1947 his system of "Life Zones" (Fig. 3B) in which he assigned a primary importance to temperature and rainfall and considered the fluctuation and distribution of these climatic parameters as the main determinants of the vegetation of the world. The vegetation of each life zone has a physiognomy and a particular structure that are present every time that similar bioclimatic conditions occur (Holdridge, 1947).

To describe and illustrate in a simple manner the Central American phytogeographical regions, we follow Smith and Johnston (1945: 11) who, oversimplifying, define for the region three basic zones: (1) the tropical or subtropical rainforest; (2) the tropical deciduous forest; y (3) the montane zone (Fig. 3C).

Tropical or subtropical rainforest: this zone extends along the Atlantic coast, from Panama in the South to the Yucatán peninsula in the North, although we find similar forests in some points of the Pacific coast (Darién in Panama, Osa peninsula in Costa Rica). It corresponds to the "tierra caliente Atlántica" (= Atlantic warm region) of Standley. The vegetation is determined by high temperatures and rainfall and alluvial soils. On its western limits, the rainforest ascends the mountain sides until it merges with the premontane forest. A certain monotony in the climatic conditions along the year may be the cause for a relatively low biodiversity. In Central America we find in this zone approximately $25 \%$ of all orchid species that are known for the region. However, all generalizations are dangerous. As Smith and Johnston warn, it is not to be assumed that the rain-forests thus outlined are uniform in constitution. On the contrary, they disclose a high degree of local differentiation, being grouped together only because of a superficial resemblance and because they are acted upon by more or less similar climatic forces (Smith \& Johnston, 1945: 14). This is equally valid for all other phytogeographical zones.

Tropical deciduous forest: for Central America, this zone extends along the Pacific coastline and is characteristic because of its two well differentiated seasons. It corresponds to the "tierra caliente Pacífica" (= Pacific warm region) of Standley. The appearance of the vegetation undergoes striking changes during the year. It is the zone where the variety of orchids is

\footnotetext{
${ }^{4}$ Although each of the countries in the region shows phytogeographical differences, it is valid to generalize for Mesoamerica using Costa Rica as a model.
} 

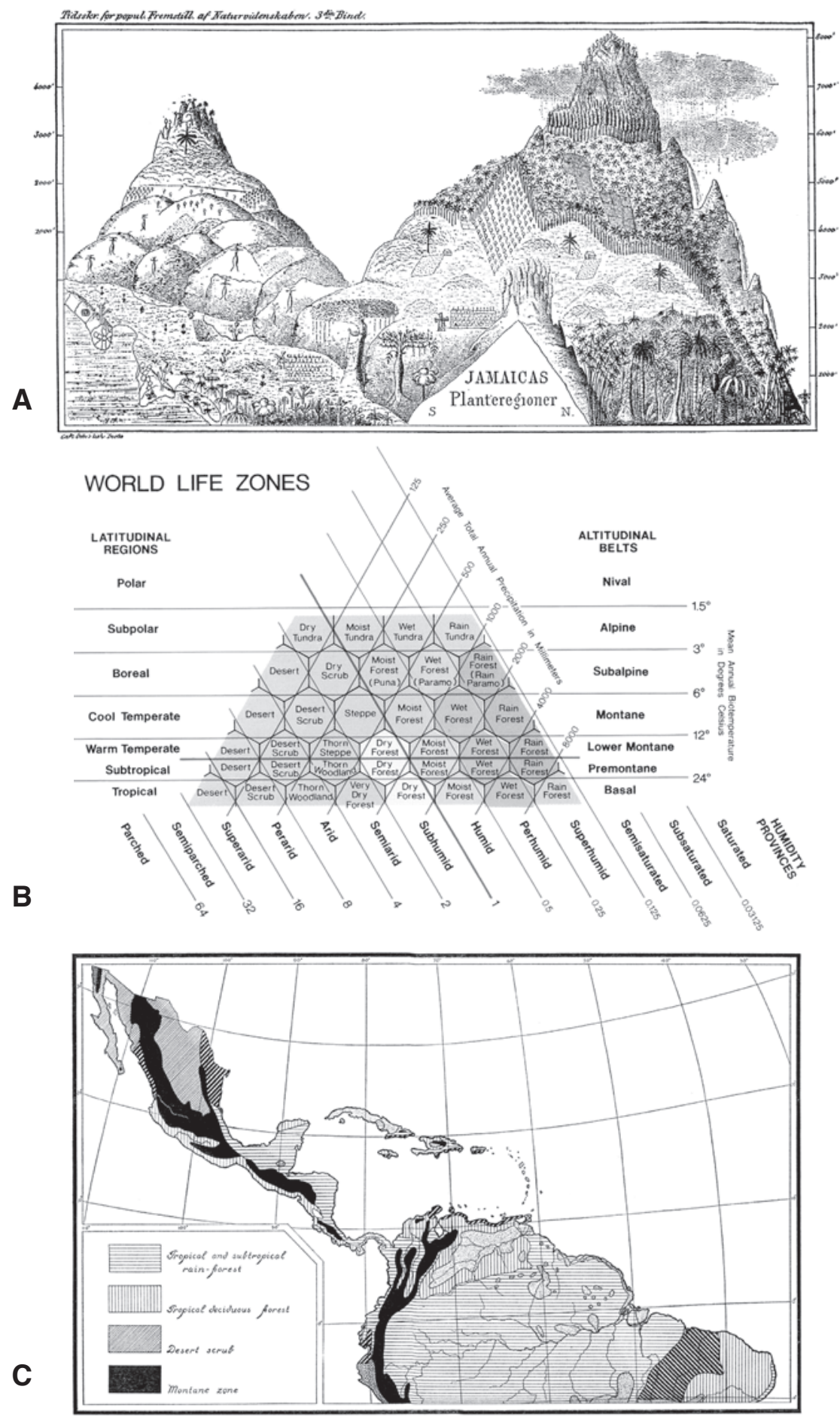

FiguRE 3. A - Illustration by Oersted (1857) of the vegetational zones in Jamaica. In Verdoorn, 1945, p. xiv. B — "Life Zones" of L. R Holdridge. In Hall \& Pérez Brignoli, 2001: 23. C — Phytogeographical regions of Central America after Smith \& Johnston, 1945: 12. 
smallest, with only about $15 \%$ of all species, those that have evolved to support periods of drought that can last up to eight months.

Montane zone: this zone is formed by the mountain ranges that cross Central America from Northwest to Southeast, forming the backbone of the subcontinent. It corresponds to Standley's "tierra templada" (= temperate region) and "tierra fría" (= cold region). Well developed temperate forests, characterized by oak and pine, are found in the central highlands of Guatemala and Honduras and south to northern Nicaragua. Many elements in the temperate flora of southern Mexico and Central America appear to have migrated from northern centers. South of Nicaragua the temperate flora appears to have more affinity with that of the northern Andes in South America (Smith \& Johnston, 1945: 17). Schlechter places the limit between the Andine and the North-American influence zones in Guatemala (Schlechter, 1918: 332). Sapper, however, affirms that: "Although this forest in its general character, with its diverse gigantic and luxuriant trees, its rich variety of orchids ... reminded me completely of the similar and humid forests of Guatemala, Honduras and Nicaragua, it produced however a strange impression, because these species of plants are generally different from those of my adoptive motherland, Guatemala, since the region of the South American flora begins in Costa Rica" (Sapper, 1902: 83). The biodiversity in the temperate regions, especially in what is commonly known as "rainforest", is amazing. $60 \%$ or more of all orchid species known in Mesoamerica are found at elevations of over $900 \mathrm{~m}$. In an example that is not exceptional, Pupulin et al. counted 39 species and 504 individuals of Orchidaceae in one single tree at San Ramón Forest Reserve, Costa Rica, at 1,350 $\mathrm{m}$ above sea level (Pupulin et al., 1995: 49).

The "páramos" (= high, bare and cold regions of tropical South America) in Costa Rica deserve special mention. Although almost no orchids are found in this region, they represent the northern limit of the Andine 'páramo', today restricted to the highest peaks of the Cordillera de Talamanca. Their peculiar vegetation can not be found elsewhere in Central America.

The importance of phytogeographical differentiation and its relation to biodiversity is clear. If we compare the totals of species of Orchidaceae in each of the Central American countries, and using Standley's terminology, we will find that Costa Rica, Panama and Guatemala, where the "tierra templada" is larger in proportion to the total area of the national territory, have the highest numbers of species. Belize, Honduras and Nicaragua follow, with a larger proportion of "tierra caliente Atlántica" and total numbers of species that are significantly lower. El Salvador, finally, has the smallest number of species and this corresponds with the largest proportion of "tierra caliente Pacífica".

\section{OrChIDS IN THE PREHISPANIC PERIOD}

"Then they ordered the Creation and the growth of the trees and vines and the birth of life and the creation of man".

Popol Vuh, XVI Century ${ }^{5}$

The area of influence of the Chibcha culture. The Chibcha culture extended its influence from Colombia to the North, reaching Panama, Costa Rica (with the exception of the Nicoya peninsula) and part of the eastern coast of Nicaragua (the Coast of the Miskitos) and Honduras. There are no written documents that could explain the relations of the indigenous population of southern Central America with nature in prehispanic times. However, archaeology has discovered what could be the first representations of orchids before Columbus. Pieces of golden jewelry, dating probably from the VIII Century (A. C.), and found in the valley of El General, Costa Rica, that are popularly known as eagles or vultures, show a surprising resemblance to the labellum of Oncidium cebolleta (Jacq.) Sw. Costa Rican naturalist Anastasio Alfaro (1865-1951) was the first to observe this likeness. While describing Oncidium cebolleta, Alfaro says: “... the sepals and petals are spotted with brown and are so small that two of them hide behind the labellum; this resembles a small eagle cast in gold, of sixteen millimeters, pure yellow with the crown spotted red-brown." (Alfaro, 1935: 19) ( Fig. 4A).

Atwood and Mora de Retana confirm Alfaro's observation: "In the Museo Nacional and Gold Museum at San José are exhibited numerous gold artifacts labeled as águilas (eagles) and zopilotes (vultures),

\footnotetext{
${ }^{5}$ The Popol Vuh, or 'Book of the Community' of the Mayans, was written in the language of the Quiché shortly after the Spanish conquest, with the help of the Latin alphabet, and translated into Spanish in the first years of the XVIII Century by friar Francisco Ximénez (1666-1729).
} 
but we believe that they resemble the animated lips of Oncidium cebolleta. The general shape is consistent with this orchid, and the use of gold seems appropriate. More convincingly, some of the artifacts are life-size and others display what can be interpreted as the typical callus of the orchid animated as the belly and claws of a bird." And they continue: "Oncidium cebolleta is known to have been used by pre-Columbian Americans in Mexico, perhaps as a hallucinogenic drug. In view of these observations, we believe that the significance of the gold artifacts needs to be reconsidered" (Atwood \& Mora de Retana, 1992: text to plate 1467) (Fig. 4B). And Lawler confirms: "Oncidium cebolleta (Jacq.) Sw.: The alkaloid-containing orchid is an important replacement for peyote among the Taraumaras of México and may be hallucinogenic".

The Bribrí Indians from Costa Rica and Panama call this species sulër kili ("symbol of the spear") and use it as a medicine against heartache. "They cut the plant in little pieces, then crush it and seeth it; let it cool. Adults must drink half a glass and infants one spoonful, three times a day" (García Segura, 1994: 52). In the language of the Cabecar, it is called suLègLi and they say it cures colics. "You crush three stems, put them in cold water and drink the juice, without heating it. You must drink it every now and then, until your stomach feels better" (Palmer, 1992: 104). From the fact that the pre-Columbian goldsmiths represented precisely this orchid can be inferred that they gave it a special, possibly sacred value. Oncidium cebolleta, a species that is found from Mexico to northern South America, contains alkaloids with hallucinogenic properties, and my conclusion is that this orchid played an important part in indigenous rituals.

Hernando Colón, in the account of his father's fourth voyage, written in 1521, describes the interchange between the Indians of Cariay (today Port Limón, Costa Rica) and the Spaniards: "Seeing that we were men of peace, they showed great desire to obtain things from us in exchange for their own, which were arms, cotton blankets and shirts, and small eagles of guanines ${ }^{6}$ which they carried hanging from their necks, in the same way we carry the Agnus Dei or any other relic" (Incer, 1990: 46). From the account of Hernando Colón we may deduct again the religious importance of the eagles in the culture of those Indians.
We have information from another culture, close to that of the Chibchas that utilized hallucinogenic fungi that seems to confirm this theory: "The Sinú culture of Colombia (from 1200 to 1600) has yielded many enigmatic gold pectorals with mushroom-like representations. They may imply the existence of a cult using these intoxicating fungi... Many of the pectorals have winglike structures, possibly signifying magic flight, a frequent characteristic of hallucinogenic intoxication" (Schultes et al., 1992: 65). In the Darién, the border region between Panama and Colombia, the Choco Indians still mix the flowers of Cycnoches tonduzii Schltr. with genipab (= Genipa americana L., from the Rubiaceae) and rub the mixture on their hands to bring luck to the fishermen (Duke, 1956: 194). Finally, Donald Beaton, gardener of Sir William Middleton, quotes George U. Skinner in a letter to John Lindley (April 24, 1841): "Laelia superbiens ... is one of the few plants whose magnificent flowers attract the notice of the Indians of Panama; they carry it about with them, and plant it before their doors...".

\section{The northern region of Central America before the Spanish conquest}

"Zan tlaocolxochitl, tlaocolcuicatl on mani Mexico nican ha in Tlatilolco, in yece ye oncan on neiximachoyan, ohuaya."

("Only sad flowers, sad songs, are here in Mexico, in Tlatilolco, in this place these alone are known, alas" in Brinton, 1890: 82-83)

The zeal of the Catholic Church in its efforts to christianize the indigenous populations led to the destruction of hundreds of documents that could have thrown light on many unknown aspects of the prehispanic history and culture of these people. One of the saddest episodes occurred in the village of Mani (Yucatan) in 1562, when the infamous Franciscan Diego de Landa (1524-1579) presided over an Auto de Fe in which he caused to be burned some 5,000 idols and 27 rolls of Maya codices, which he could not read and described as "work of the devil". "We found a great number of books... and since they only contained superstitions and perfidies of the devil, we burned them all..." (Landa, 1978). Eduardo Galeano remembers the moment in a dramatic way:

${ }^{6}$ Guanines: gold of low fineness alloyed with copper. 
"Fray Diego de Landa throws into the flame, one after the other, the books of the Mayans. The inquisitor curses Satan, and the fire crackles and devours. Around the incinerator, heretics howl with their heads down. Hung by their feet, flayed with whips, Indians are doused with boiling wax as the fire flares and the books snap, as if complaining. Tonight, eight centuries of Mayan literature turn to ashes. On these long sheets of bark paper, signs and images spoke: they told of work done and days spent, of the dreams and wars of a people born before Christ... In the center, the inquisitor burns the books. Around the huge bonfire, he chastises the readers. Meanwhile, the authors, artist-priests dead years or centuries ago, drink chocolate in the fresh shade of the first tree of the world. They are at peace, because they died knowing that memory cannot be burned. Will not what they painted be sung and danced through the times of the times?" (Galeano, 1985: 137) (Fig. 4C).

After most of the Mayan manuscripts were lost, our remaining sources of information about the knowledge and use of orchids by the inhabitants of prehispanic northern Central America come to us from the Aztec world, whose center of power, Tenochtitlan, lies outside of the geographic area of our present study. However, several arguments speak in favor of establishing a valid relationship between the information that we have from the Aztec world and the knowledge that the peoples from other parts of Central America had about orchids:

a) Aztec knowledge about orchids had been transmitted to them by the preceding civilizations, especially the Maya. The fact that most species of Orchidaceae known and used by the Aztecs are found in areas that, until today, still show strong evidence of the ancient Maya culture gives strength to this argument. The following is the geographical distribution in the ancient Maya regions of some of the species known by the Aztecs:

-Arpophyllum spicatum La Llave \& Lex.: Veracruz, Oaxaca, Chiapas, Guatemala

-Artorima erubescens (Lindl.) Dressler \& Pollard: Oaxaca

- Bletia campanulata La Llave \& Lex.: Oaxaca, Guatemala

-Catasetum integerrimum Hooker: Veracruz, Campeche, Chiapas, Guatemala

-Euchile citrina (La Llave \& Lex.) Withner: Veracruz, Oaxaca
-Encyclia pastoris (La Llave \& Lex.) Schltr.: Veracruz, Oaxaca

- Govenia liliacea (La Llave \& Lex.) Lindl.: Chiapas, Guatemala

- Govenia superba (La Llave \& Lex.) Lindl.: Veracruz, Guatemala

-Laelia anceps Lindl.: Veracruz, Oaxaca, Guatemala

-Laelia autumnalis Lindl.: Oaxaca

- Laelia speciosa (Kunth) Schltr.: Veracruz, Oaxaca - Myrmecophila tibicinis (Batem.) Rolfe: Yucatán, Quintana Roo, Guatemala

- Vanilla planifolia Andrews: Veracruz, Oaxaca, Yucatán, Quintana Roo, Guatemala

b) The Mexican tribes extended their cultural and economical influence to regions as distant from its political center as the Lake of Nicaragua or the Nicoya Peninsula in Costa Rica, long before the arrival of the Spanish conquerors. In his account of the archaeological explorations of Carl Bovallius on an island in the Lake of Nicaragua in 1882, Linné comments: "The Mexican colony that has been found in the neighborhood left few traces, but the strangers who came from so far enriched the art of these regions with the Feathered Serpent and other demons" (Linné, S., 1960: 126). Dr. A. Chapman comments that the long distance trade of these merchants [the Aztecs] had the Mayans as main partners, but that they traveled as far as the border between Costa Rica and Panama (Chapman, 1959). Braswell gives numerous examples to demonstrate the interaction between the Mayans of the classical period and the Mexican cultures before the Aztecs (Braswell, 2003). Coe affirms that elements of the Maya culture had penetrated to the center of Mexico during the turbulent times at the end of the classical period (Coe \& Coe, 1996: 71). The Aztec knowledge of the medicinal and economical uses of many orchid species, inherited in part from the Mayans, spread thus throughout Central America.

The most important source for the understanding of Aztec knowledge about plants and nature is, without doubt, friar Bernardino de Sahagún (1499?-1590), whose work is recognized as the main chronicle of the prehispanic period (Fig. 4D). He arrived in Mexico in 1529 , as an instructor at the Imperial College of 

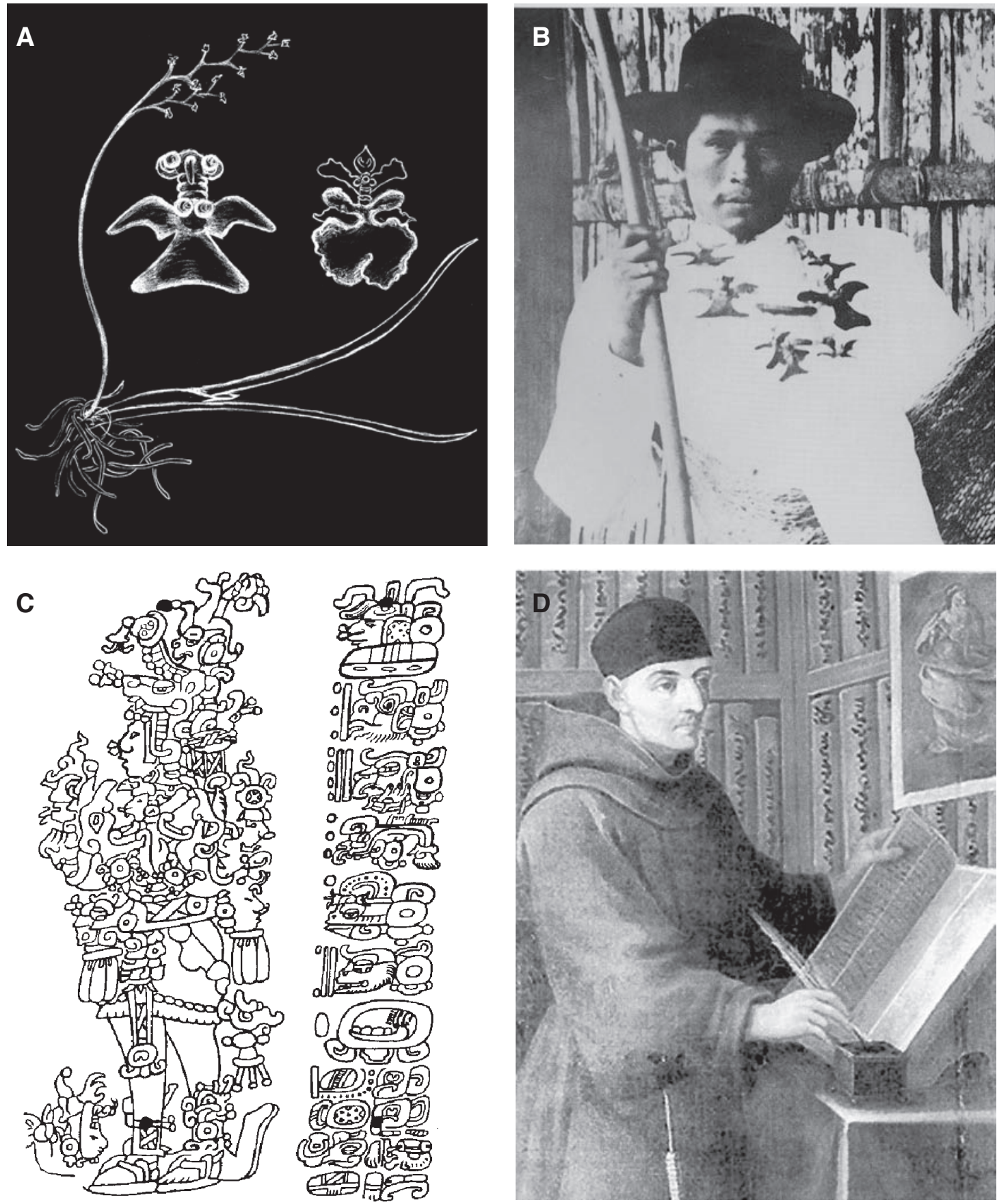

Figure 4. A - Oncidium cebolleta (Jacq.) Sw.: comparison between the labellum and a golden "eagle" of the Costa Rican Indians. Illustration by P. Casasa. B - Don Pedro, last Indian king from the Talamanca region in Costa Rica, decorated with the 'eagles'. From the book Costa Rica en Blanco y Negro: 1880-1950, published by the Banco Nacional de Costa Rica, 1998. C — Guatemala: Mayan hieroglyphs on the famous 'Leyden-plate'. In http://users.skynet.be/fa039055/forgtgtm. $\mathrm{htm}$. The Leyden-plate is a jadeite plaque, engraved on both sides, showing Mayan hieroglyphs and numbers. It was found in 1864 in Guatemala. D — Bernardino de Sahagún (1499?-1590). In Catholic Encyclopedia, 2003. 


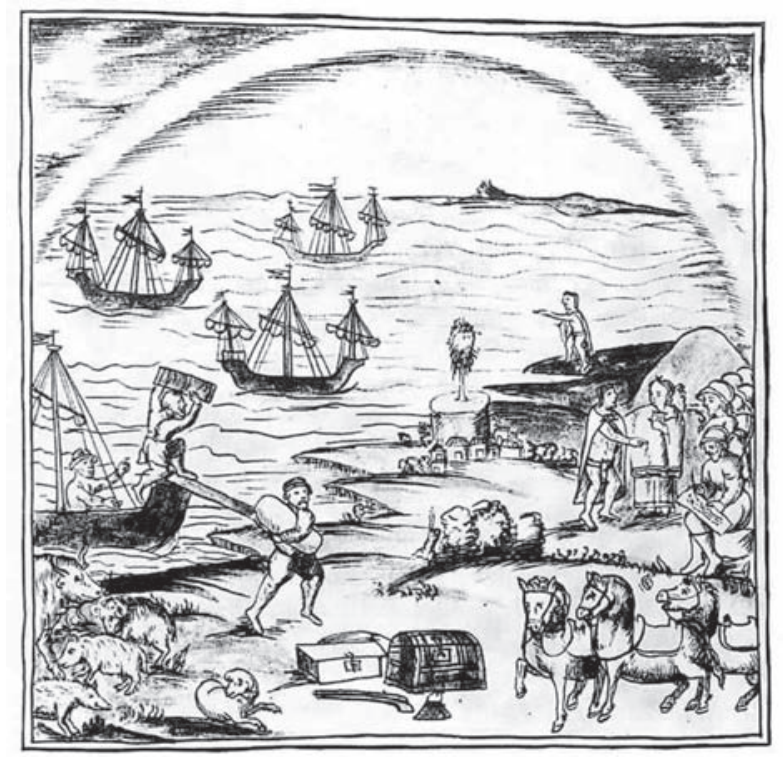

A
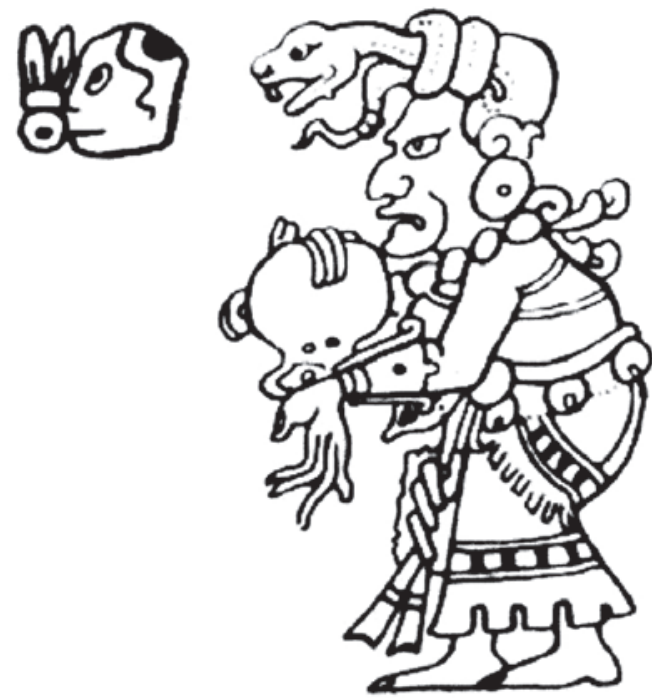

B
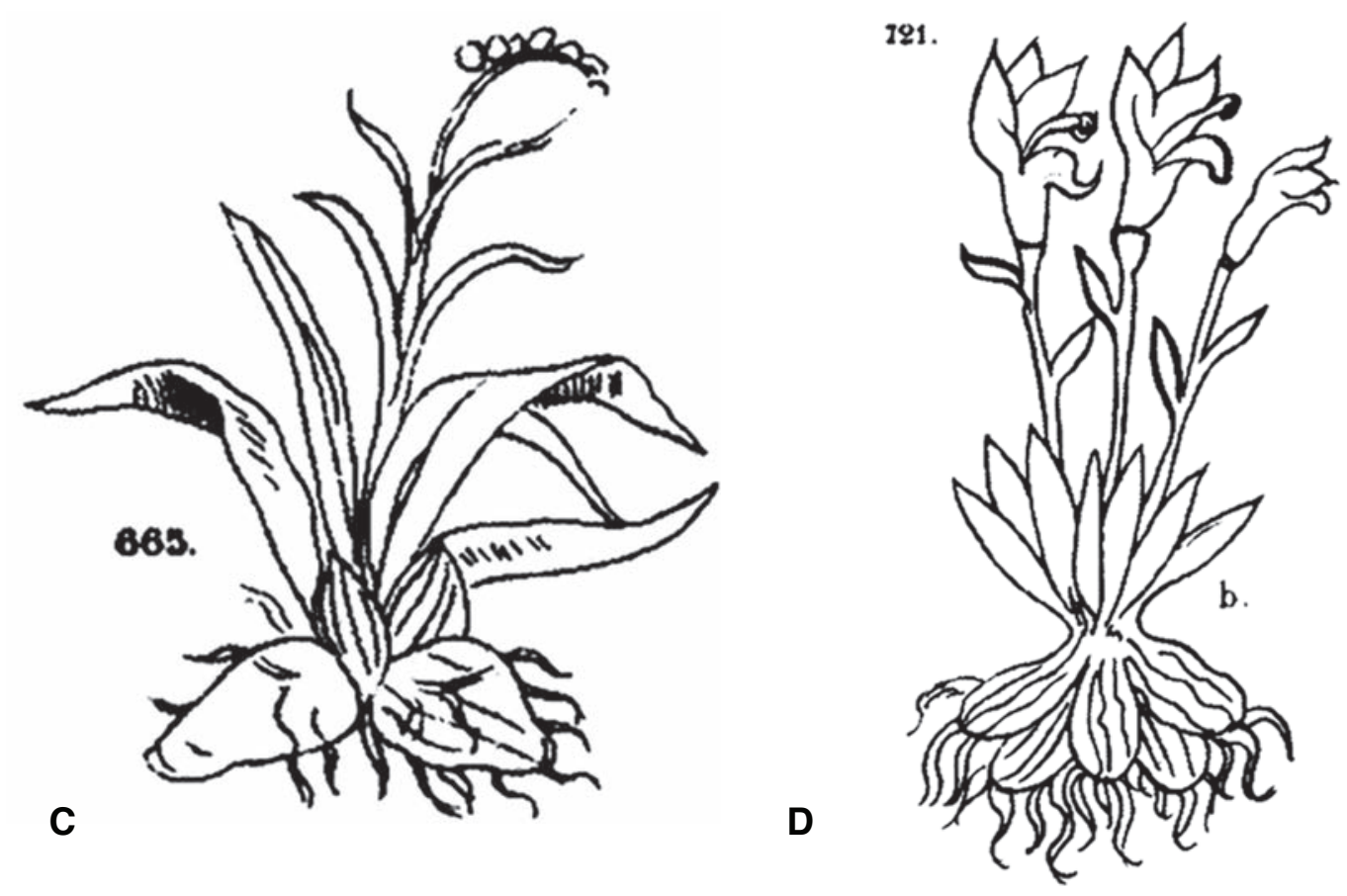

Figure 5. A - Arrival of the Spaniards in Mexico. Florentine Codex. B - Ix chel, the Maya goddess of medicine. Dresden Codex. C - Plant of tzacutli, Florentine Codex. Dibble \& Anderson, 1963, fig. 665. D - tzacuxóchitl xiuitl (Bletia campanulata), Florentine Codex. Dibble \& Anderson, 1963, fig. 721b. 
Santa Cruz de Tlatelolco (Gómez-Pompa, 1993: 29) and dedicated the rest of his life to the observation and study of the customs, language and history of its ancient people. Since 1540 he dedicated himself with intelligence, method and perseverance to the great work of his life: the study of the things of Mexico before the arrival of Cortés. Between 1547 and 1577 he wrote the History of the things of New Spain (Sahagún, 1988). "With the permanent help of old men, of his trilingual students (Nahuatl, Spanish and Latin) and of scribes, he compiled and described everything about the life of the ancient Mexicans...." (Ballán, 1991: 260). "Schemes of friars of his same order moved King Philip II to collect all versions and copies of Sahagún's work, fearing that the Indians would remain attached to their beliefs if they were preserved in their native tongue. Following this order, Sahagún handed over to his superior, friar Rodrigo de Sequera, a copy in Spanish and Mexican. This version was taken by father Sequera to Europe in 1580 and is today known as the Manuscript or Copy of Sequera, identified as the Florentine Codex" (Tudela, 1952: 1092). It is beautifully illustrated and owes its name to the Medicea Laurenziana Library of Florence, where it is conserved (Fig. 5A). The work of Sahagún has an extraordinary value because it describes the customs and uses of the Aztecs based on witnesses who had lived in the century before the Spanish conquest. It is in volume XI (Animals, plants and minerals of the Indian geography), where we find most information about the knowledge and use of orchids by the ancient Aztecs (Dibble \& Anderson, 1963). All authors who have subsequently studied this period have used Sahagún as a primary source of reference.

\section{Orchids in the cultures of Mayans and Aztecs. Called} by the Mayans sisbic and by the Aztecs tlilxóchitl or mecaxóchitl, interest in vanilla (Vanilla planifolia Andrews) began in the indigenous prehispanic world and continues to our days. Therefore, we will only mention vanilla here as a fundamental species in the prehispanic orchidology of Central America. We will refer to it later in a more extensive form (see next chapter, "The history of Vanilla") (Fig. 5B).

Besides vanilla, the inhabitants of prehispanic Central America used other orchids as medicinal plants. Catasetum maculatum, was used among the Mayans in Yucatan to heal sores and tumors (Appel
Kunow, 2003: 115). Balick et al. (2000) mention also the medicinal use given by the Mayans in Belize to Lockhartia pittieri Schltr., Oncidium cebolleta and Sobralia fragans Lindl. (Balick et al., 2000: 163, 170). Among the Aztecs, Arpophyllum spicatum and Encyclia pastoris, were used against dysentery, as was years later documented by Francisco Hernández (Hágsater et al., 2006: 41). The bulbs of Euchile citrina were applied on infected wounds, and infusions of Laelia autumnalis were a remedy against cough.

Also important was the use of several species that contain mucilaginous substances to prepare agglutinating or adhesive products. “... preferred for its mucilaginous characteristics is Encyclia pastoris" (García Peña \& Peña, 1981: 62), known in Nahuatl as tzacutli. Sahagún describes it as follows: "The branches are slender. It has stems. Its root is sticky; this is named tzacutli. It is an adhesive. I glue it." (Fig. 5C). "To prepare it, they cut the pseudobulbs in slices and dried them in the sun; then they stored them and, when the time was right, they soaked them in water to dissolve the mucilage and give it different uses. This process was in the hands of apprentices" (García Peña \& Peña, 1981: 62). Tzacutli was used as a glue to prepare feather ornaments for the robes of the priests and as a mordent for pigments. Other species of orchids used with the same purpose were: Bletia campanulata (Fig. 5D):"Its foliage is like that of the tzacutli. It is tall. [Its blossoms] are chili red, rose, dark blue. It is tender, very tender..." (Dibble \& Anderson, 1963: 211), B. coccinea La Llave \& Lex., Cranichis speciosa La Llave \& Lex., C. tubularis La Llave \& Lex., Govenia liliacea, G. superba and Laelia autumnalis. "Laelia autumnalis and Laelia speciosa, were and are still used in the fabrication of candies during the festivities of the Day of all Souls; it is probable that this practice was not customary in prehispanic times but only after the arrival of the Spaniards" (García Peña \& Peña, 1981: 63). Among the Mayans, the pseudobulbs of Myrmecophila tibicinis were used as help during childbirth and employed as trumpets and flutes (Arditti, 1992: 637). Bateman, in 1838, called this plant Epidendrum tibicinis, referring to the Latin word tibicen, or trumpeter (Miller, 1959: 353) (Fig. 6A).

But not everything in life is utilitarian. Richard Evans Schultes wrote in 1992: "The role that horticulture has played in the ethnobotanical employment of plants is not often recognized. It is quite generally presumed that 
aboriginal peoples usually do not cultivate plants merely to beautify their surroundings. The opposite is true in many, if not most societies. In a number of instances, it is probable that the species were first ornamentally valued but were eventually found to be of more practical value as foods, medicines, narcotics, poisons or for other economic applications" (cited in Griffiths, 1992). Other sources confirm what Schultes said. Nuttall mentions the following example: "The most important of all the ancient gardens of Mexico was that of Huaxtepec which Montezuma had inherited from his predecessor, Montezuma the Elder. Placing Pinotetl as the principal overseer, he first restored its waterways and then dispatched messengers to the tropical coastal region with a request to the Lord of Cuetlaxtla for plants with roots of the vanilla orchid, of cacao and magnolia trees and many valuable vegetables" (Nuttall, 1923: 454). Alvarado Tezozomoc, in his Crónica Mexicana, gives us a detailed description of the gardens of Huaxtepec. According to him, the most primitive gardens of the Nahuas were the artificial islands and peninsulas that were constructed in lagoons (Alvarado Tezozomoc, 1873). Additional information has been furnished by the accounts of Doctor Cervantes de Salazar, whose chronicle of Mexico was published in 1565: "In these flower gardens Montezuma did not allow any vegetables and fruits to be grown, saying that it was not kingly to cultivate plants for utility or profit in his pleasance. He said that vegetable gardens and orchards were for slaves and merchants" (Nuttall, Z., 1923). Antonio de Solís indicates that Moctezuma "did not like fruit trees nor eatable plants in his recreations, but said that orchards were possessions of ordinary people, seeming more proper of princes the delight without utility. All were flowers of rare diversity and fragrance [...] bringing into his gardens all the genera produced by the benignity of those lands" (Solís, 1970: 195) (Fig. 6B).

Bateman, citing Francisco Hernández, indicates the same: “... for Hernández assures us, that in Mexico the Indian chiefs set the highest value on their blossoms [the orchids], for the sake of their great beauty, strange figure, and delightful perfume..." (Bateman, 183743: 2). Stanhopea hernandezii (Kunth) Schltr. and $S$. tigrina Batem., had great ornamental value during the prehispanic period, and were called by the Aztecs coatzontecoxóchitl or coatzontemacoxóchitl, because their flowers resemble serpent heads: "It is like the head of a serpent; that is the way it is by nature" (Dibble \& Anderson, 1963: 211) (Fig. 6C). "[S. hernandezii $]$ is sought by the Indian Princes because of its beauty and elegance." (Hágsater et al., 2005: 40). "From cozticcoatzontecoxochitl, which some authors have identified as Prosthechea citrina, Hernández tells us that 'the flowers are used to adorn the wreaths, garlands and bouquets whose use is so frequent among the Indians" (Hágsater et al., 2005: 41). Artorima erubescens, Laelia anceps, L. autumnalis, L. speciosa and Oncidium spp. were also used ornamentally (Tab. 1).

In his notes on the classification of plants by the Aztecs, Gates says: "The ornamental plants, the flowers or xochitl, made another grand division, often with definition of the odor, although beauty was the desired feature, even with no odor... Among the orchids, coa-tzonteco-xochitl, snake-head flower, an Anguloa; another is yellow, the coztic-coa-tzontecoxochitl, of the Sobralia" (Gates, 2000). Finally, Acosta writes that "the Indians are great friends of flowers and in New Spain more than anywhere else in the world..." (Acosta, 2003: 265).

Two centuries later, Friar Francisco Ximénez was one of the first to describe the epiphytic growth of orchids. In one of his manuscripts, dated in 1722, we find a beautiful example of the ornamental value they had for the Mayans in Guatemala: "All those flowers, although many and diverse, all of them agree to grow from little onions, whose roots stick to the bark of the oaks as if they were deeply rooted in the earth and they grow some leaves somewhat thick, but all different from the others. And those little onions taken from those trees are transplanted by many Indians to their houses, sticking them to another tree and there it roots and is conserved and gives its flower. And so they have the trees of their houses full of different flowers that they bring from the forest” (Ximénez, 1967: 313).

The history of Vanilla. As a constituent of the native flora, Vanilla planifolia occurs naturally in the moist, tropical forests of eastern and southern Mexico, Central America, and northern South America. In Mexico, its northern limits are found in central Veracruz near the Gulf Coast, and in Michoacán or Colima on the Pacific. The true vanilla now found growing wild in parts of the West Indies probably represents an escape from cultivation of vines introduced during the 
TABLE 1 - List of the orchids known by Central American Indians during the prehispanic period, with their uses and vernacular names. Compiled from García Peña \& Peña (1981), Wright (1958), Ximénez (1967), Balick et al. (2000), and Appel Kunow (2003).

\begin{tabular}{|c|c|c|c|}
\hline Botanical name & Vernacular name & Language & Use \\
\hline Arpophyllum spicatum La Llave \& Lex. & tzauhxilotl & Nahuatl & Against dysentery \\
\hline Artorima erubescens (Lindl.) Dressler \& Pollard & güitzl & Zapotec & Ornamental \\
\hline Bletia campanulata La Llave \& Lex. & tzacuxóchitl xiuitl & Nahuatl & $\begin{array}{l}\text { Adhesive } \\
\text { Ornamental } \\
\text { Against dysentery }\end{array}$ \\
\hline Bletia coccinea Lex. & tonalxóchitl & Nahuatl & $\begin{array}{l}\text { Adhesive } \\
\text { Ornamental } \\
\end{array}$ \\
\hline Catasetum integerrimum Hook. & chitcuuc & Maya & $\begin{array}{l}\text { Adhesive } \\
\text { Mordent for pigments }\end{array}$ \\
\hline Catasetum maculatum Kunth & chitcuuc & Maya & To cure wounds and tumors \\
\hline Cranichis speciosa La Llave \& Lex. & atzautli & Nahuatl & $\begin{array}{l}\text { Against dysentery } \\
\text { Adhesive } \\
\text { Mordent for pigments }\end{array}$ \\
\hline Cranichis tubularis La Llave \& Lex. & acaltzauhtli & Nahuatl & $\begin{array}{l}\text { Adhesive } \\
\text { Mordent for pigments }\end{array}$ \\
\hline Encyclia pastoris (La Llave \& Lex.) Schltr. & tzacutli & Nahuatl & $\begin{array}{l}\text { Against dysentery } \\
\text { Adhesive } \\
\text { Mordent for pigments }\end{array}$ \\
\hline Euchile citrina (La Llave \& Lex.) Withner & cozticoatzontecoxóchitl / auroriqua & Nahuatl & Treatment of infected wounds \\
\hline Govenia liliacea (La Llave \& Lex.) Lindl. & iztactepetzacuxóchitl & Nahuatl & $\begin{array}{l}\text { Adhesive } \\
\text { Mordent for pigments }\end{array}$ \\
\hline Govenia superba (La Llave \& Lex.) Lindl. & cozticzacatzacuxóchitl & Nahuatl & $\begin{array}{l}\text { Adhesive } \\
\text { Mordent for pigments }\end{array}$ \\
\hline Laelia anceps Lindl. & tzicxóchitl / güichila & Nahuatl & Ornamental \\
\hline Laelia autumnalis (La Llave \& Lex.) Lindl. & chichiltictepetzacuxóchitl & Nahuatl & $\begin{array}{l}\text { Against cough } \\
\text { Adhesive } \\
\text { Ornamental }\end{array}$ \\
\hline Laelia speciosa (Kunth) Schltr. & itzmaqua & Nahuatl & Ornamental \\
\hline Lockhartia pittieri Schltr. & & & Medicinal \\
\hline Myrmecophila tibicinis (Batem.) Rolfe & $\begin{array}{l}\text { dac kisin } \\
\text { hom-ikim }\end{array}$ & $\begin{array}{l}\text { Maya } \\
\text { Maya }\end{array}$ & $\begin{array}{l}\text { Help during childbirth } \\
\text { Employed as trumpets } \\
\text { and flutes }\end{array}$ \\
\hline Oncidium cebolleta (Jacq.) Sw. & \begin{tabular}{|l} 
sulër kili \\
suLègLi
\end{tabular} & $\begin{array}{l}\text { Bribrí } \\
\text { Cabécar }\end{array}$ & \begin{tabular}{|l} 
Medicinal \\
Hallucinogenic
\end{tabular} \\
\hline Oncidium spp. & ru xiquín tucur / ru xiquín choy & Maya & Ornamental \\
\hline Sobralia fragans Lindl. & te-lum-pim & Maya & Medicinal \\
\hline Stanhopea hernandezii (Kunth) Schltr. & coatzontecoxóchitl & Nahuatl & $\begin{array}{l}\text { Against tiredness } \\
\text { Ornamental }\end{array}$ \\
\hline Stanhopea tigrina Batem. & $\begin{array}{l}\text { coatzontemacoxóchitl } \\
\text { chichiltic tepetllavhochitz }\end{array}$ & Nahuatl & Ornamental \\
\hline Vanilla planifolia Andrews & $\begin{array}{l}\text { mecaxóchitl } \\
\text { tlilxóchitl } \\
\text { sisbic } \\
\text { zacanatum shanat }\end{array}$ & $\begin{array}{l}\text { Nahuatl } \\
\text { Nahuatl } \\
\text { Maya } \\
\text { Totonac }\end{array}$ & $\begin{array}{l}\text { Flavoring } \\
\text { To aid digestion } \\
\text { Cordial } \\
\text { Appetizer } \\
\text { Aphrodisiac } \\
\text { Diuretic } \\
\text { Ritual }\end{array}$ \\
\hline
\end{tabular}


colonial period. (Bruman, 1948: 361). Oersted wrote, around 1846, that vanilla dominated among the orchids of the Atlantic region of Costa Rica (Oersted, 1863). The Olmecs (ca. 1500 A. C. -400 D. C.) who "not only engendered Mesoamerica but also brought forth the first Mesoamerican empire" (Mann, 2006: 235), possibly transferred to the Mayans the use of the seeds of cacao (kakawa) for the preparation of a beverage. According to Maya mithology, Hunahpú gave cacao to the Maya after humans were created from maize by the divine grandmother goddess Ixmucané.

The Mayans perfumed this beverage (which we call today chocolate, from the Nahuatl chocolatl) with different spices, among them chili and vanilla. "Among the plants that are cultivated to season and perfume the foods are chili or ají, vanilla ... and other herbs, leaves and roots" (Morley, 1961: 189). The early Mayans of Mexico were also familiar with vanilla and its uses, their name for it being sisbic [or zizbic, as Bruman calls it ${ }^{7}$ ] (cited in Reinikka, 1995: 15). A Totonac legend says that vanilla originated in the deaths of Tzacopontziza ('Morning Star') and Zkatan-oxga ('Running Deer'), who were killed by the gods for their forbidden love. In the desolated place of their sacrifice, a single tree grew (Zkatan-oxga) and shortly later a vine embraced it (Tzacopontziza). So, the lovers remain together through the ages. The Totonac called vanilla zacanatum shanat (= black mother vanilla) (Ecott, 2004: 7-8).

Balick et al. mention the medicinal and ritual use of vanilla among the native population of Belize (Balick et al., 2000: 171). Duke, in one of his many ethnobotanical papers, refers to the use as a perfume of Vanilla fragrans (Salisb.) Ames by the Chocoe Indians in the Panamanian region of Darien (Duke, 1956: 209). García Peña \& Peña refer to $V$. planifolia in the Aztec world: "One of the oldest records for the utilitarian character of orchids in America belongs to the Aztec kingdom of Itzcoatl (1427-1440) in Mexico; it mentions vanilla, the vine orchid, collected in the eastern coast. This plant was used as payment for tributes during the kingdoms of Moctezuma Ilhuiacamina (1440-1469) and Axacayatl (1469-1482)" (García Peña \& Peña, 1981: 60). "Some authors (i.e. Torquemada, 1969) state that vanilla was part of the tributes paid to the Aztecs by the Totonacs and other Indian tribes (Fig. 6D) as early as during the reign of Izcóatl (1427-1440)..." (Hágsater et al., 2005: 47).
Moctezuma (1502-1520) flavored the beverage "chocolatl", a cacao drink, with the ripe fruit of this orchid and with honey" (García Peña \& Peña, 1981: 60). Bernal Díaz del Castillo, again referring to Emperor Moctezuma, tells us: “... from time to time they brought him cups of fine gold, with a certain beverage made of cacao, that they said was for success with women..." (Díaz del Castillo, 1916: 185). "Then, by himself in his house, his chocolate was served: green cacao-pods, honeyed chocolate, flowered chocolate, flavored with green vanilla" (according to Sahagún in Coe \& Coe, 1996: 89). "Vanilla was not only the most widely used flavoring, but was also recommended to aid digestion, and was considered good for the heart, the stomach, as an appetizer, diuretic and to attenuate viscous humors" (García Peña \& Peña, 1981: 61).

Sahagún says about vanilla: "Mecaxóchitl: Its growing place is the hot lands, at the water's edge. It is like a slender cord, a little rough. It is of pleasing odor, perfumed. Its scent is dense; one's nose is penetrated. It is potable. It cures internal [ailments]" (Dibble \& Anderson, 1963: 192 (Fig. 6E). However, according to Gates (2000: 133) mecaxóchitl is Piper amalago, L. and not Vanilla planifolia. León, J., 2003 (pers. comm.) confirms this stating that the illustration does not represent an orchid. He also calls it tlilxóchitl: "It is cord-like... Its bean is green, but it is black when dried... It is perfumed, fragrant, precious, good, potable, a medicine. Roasted, this is mixed with chocolate" (Dibble \& Anderson, 1963: 198) (Fig. 6F).

According to Reinikka, the first reference to tropical orchids in the western hemisphere is the description and illustration of vanilla in the Codex Badianus from 1552 (Reinikka, M. A., 1995: 15) (Fig. 7).

Francisco Hernández published a manuscript in which figured a woodcut of two fruits and a portion of the vine of vanilla, under the name Arico aromatico, with the native appellation tlilxóchitl (Fig. 8A). Hernández writes about three aphrodisiac spices that the Aztecs used in their chocolate. The second of Hernández's reputedly aphrodisiac trio was tlilxóchitl ('black flower'), none other than our familiar vanilla (Vanilla planifolia). Hernández makes a distinction calling chocolatl the beverage that contains only cacao and seeds of pochotl (Ceiba spp.) and atexli that was flavored with vanilla (Coe, 1994: 104-105). Hernández, following the

\footnotetext{
${ }^{7}$ According to Bruman, zizbic seems to refer to Vanilla claviculata, an inferior species that is not the vanilla of commerce.
} 

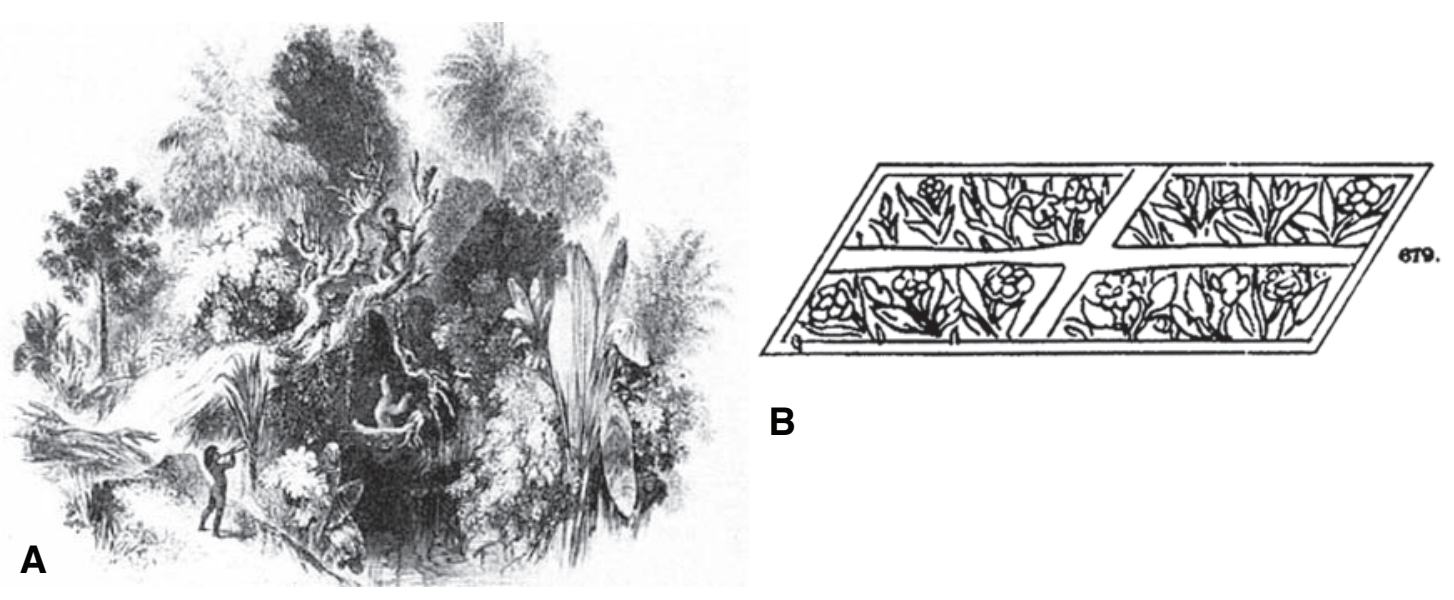

B
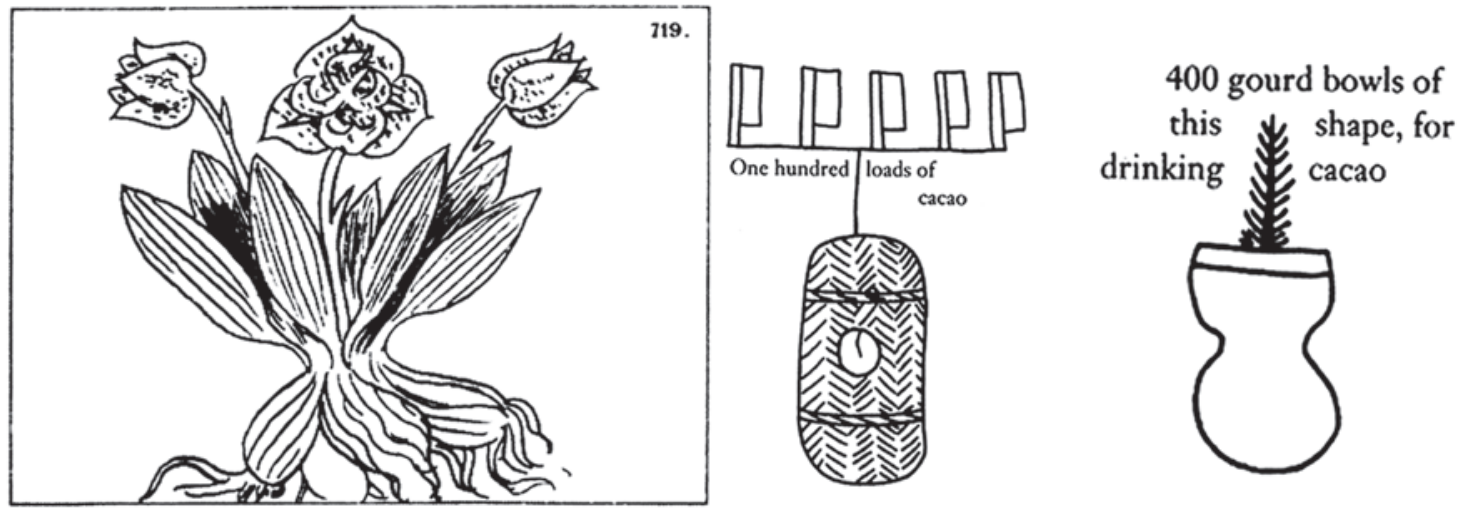

C

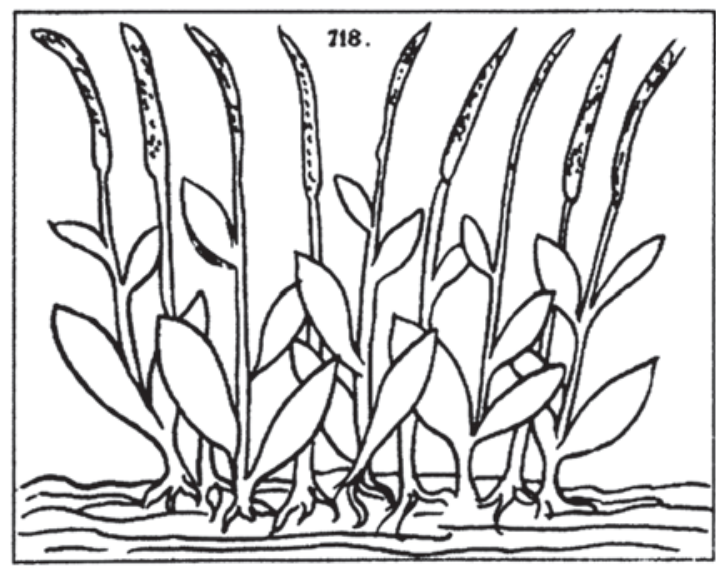

E

D

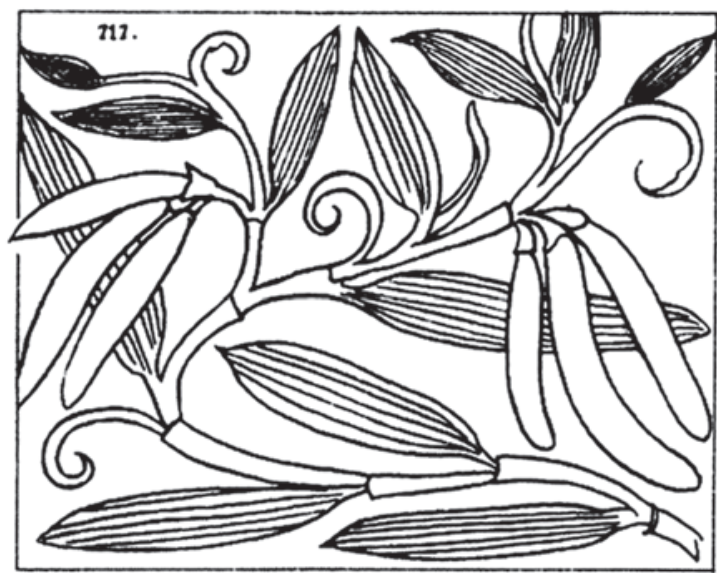

$\mathbf{F}$

FIGURE 6. A - Indian child playing the 'trumpet' with the hollow pseudobulb of Myrmecophila tibicinis. In Batemann, 183743: 76. B - Gardens of Ancient Mexico. Florentine Codex. Dibble \& Anderson, 1963, fig. 679. C_Coatzontemacoxóchitl (Stanhopea tigrina). Florentine Codex. Dibble \& Anderson, 1963, fig. 719. D — Representation of tributes in the Codex Mendoza, in Berdan \& Rieff Anawalt, 1997, pl. 46v. E - Mecaxóchitl. Florentine Codex. Dibble \& Anderson,1963, fig. 718. F — Tlilxóchitl. Florentine Codex. Dibble \& Anderson,1963, fig. 717. 


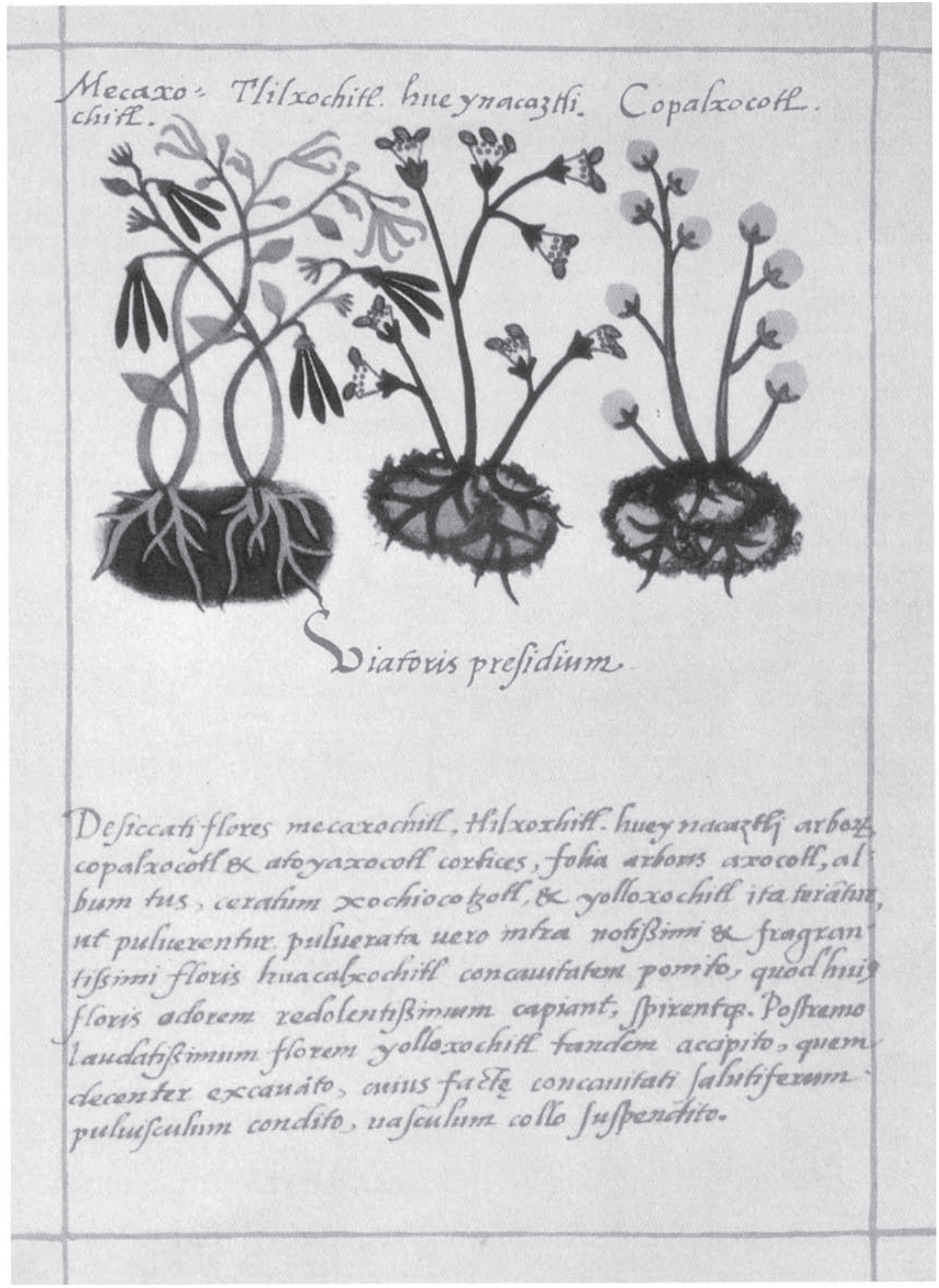

Figure 7. Mecaxóchitl or Tlilxóchitl (first from the left). Plate 104 of the Codex Badianus. In Ospina, 1997:1161. 

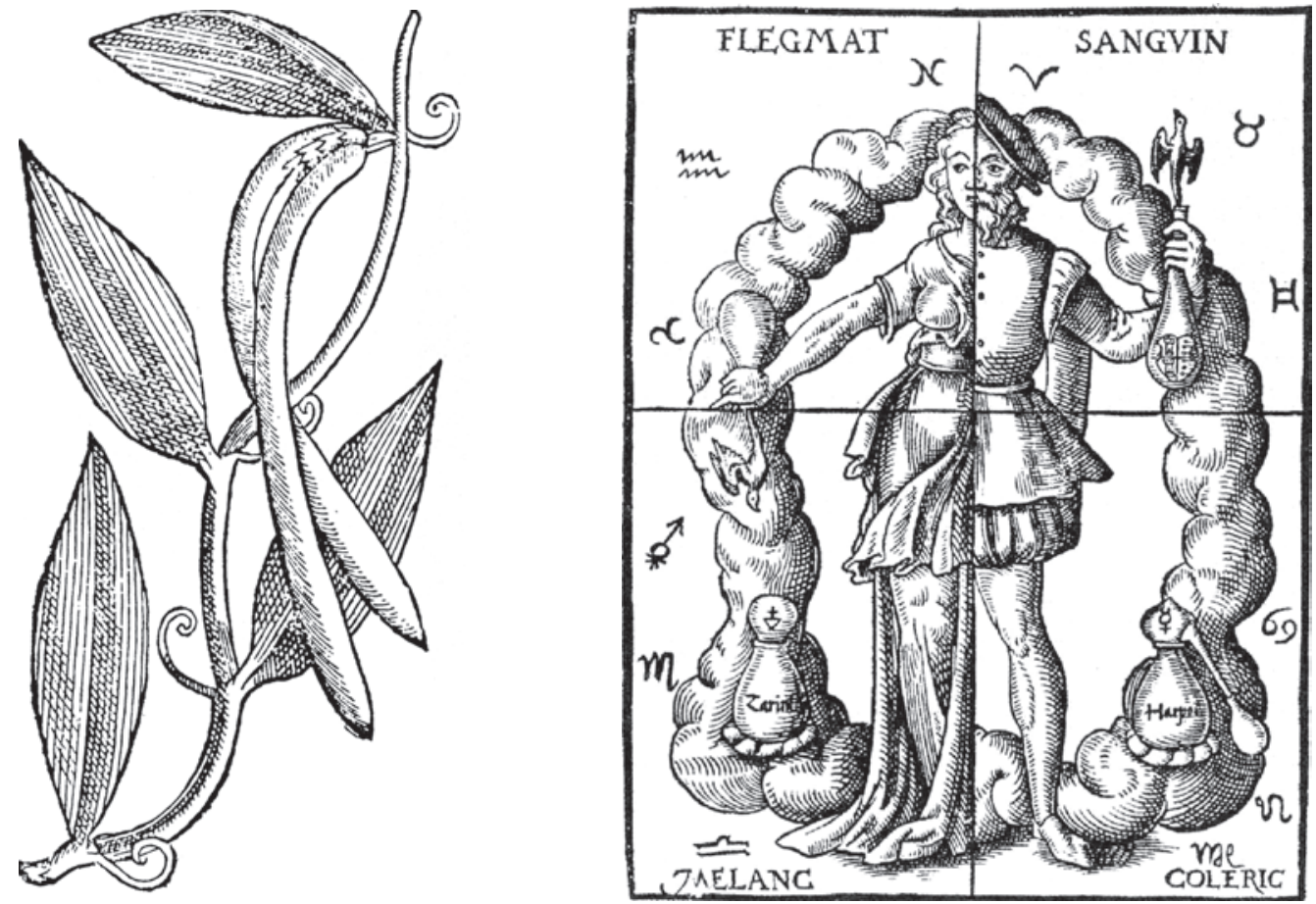

A

B

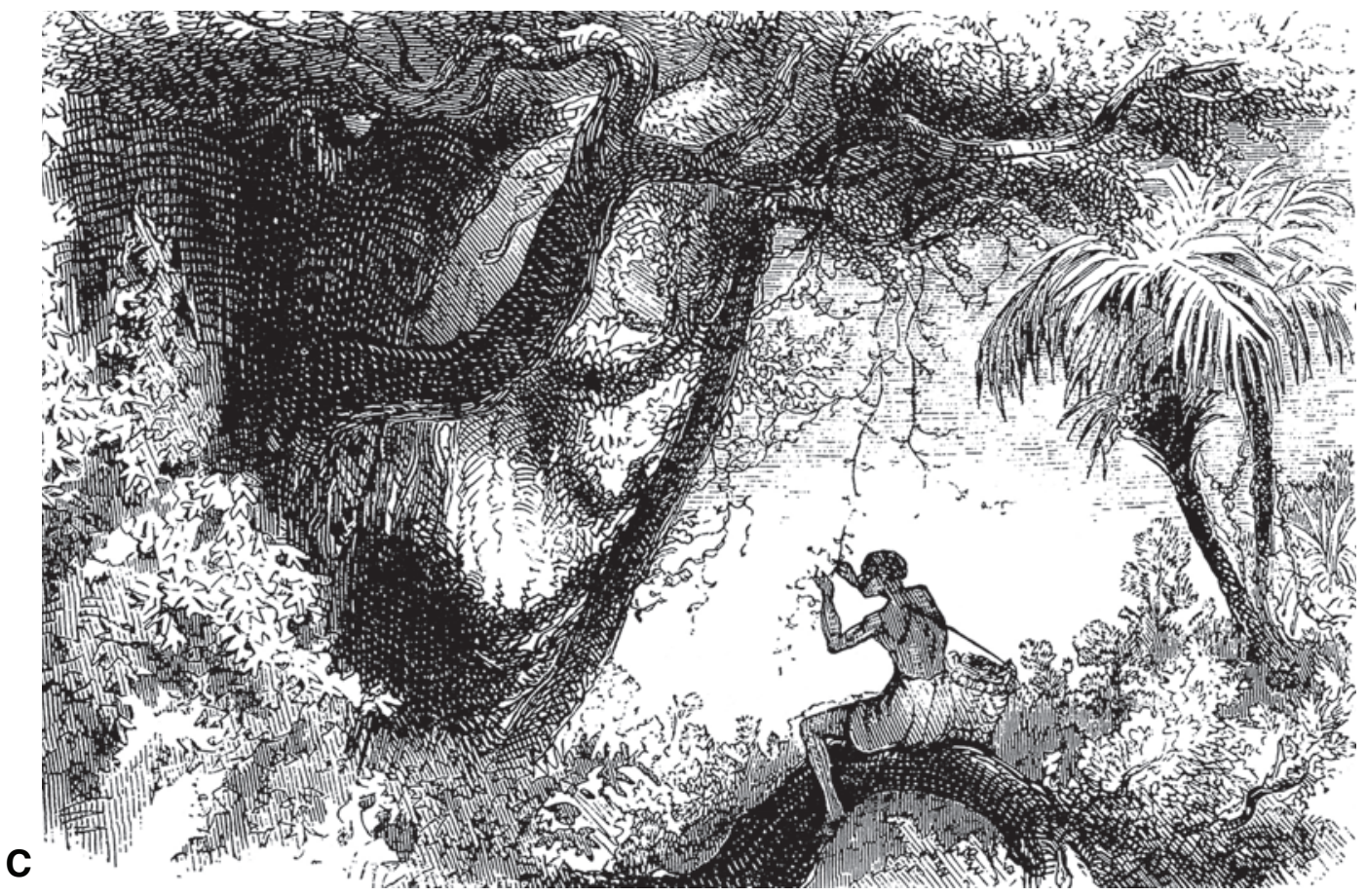

FiguRE 8. A - Arico aromatico-tlilxóchitl. Hernández, 1959. B - Sixteenth-century woodcut showing the four temperaments. In Coe \& Coe, 1996: 127. C — Gathering vanilla. In Dampier, 1998: 121-122. 


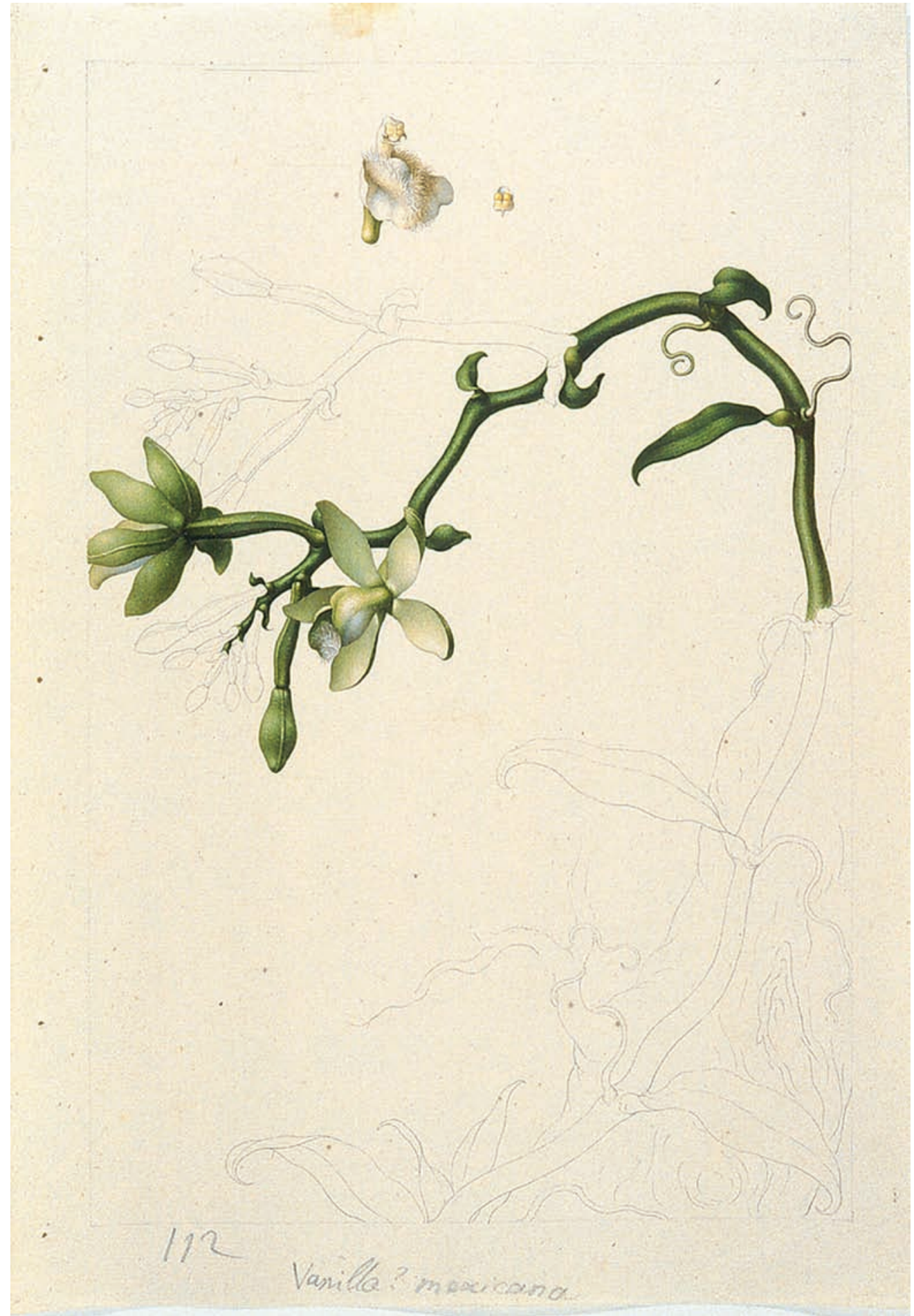

FiguRE 9. Vanilla (labeled as Vanilla mexicana). No. 1407 of the illustrations of the botanical expedition of Sessé and Mociño in the Torner Collection, Hunt Botanical Institute for Botanical Documentation. 
principles of Galenic theory of curing by contraries, so that "hot" fever called for a "cold" drug, continues: "Adding the mecaxóchitl flavoring to chocolate not only gives it an agreeable taste, but because it, like most cacao spices, is 'hot' by nature, it 'warms the stomach, perfumes the breath...[and] combats poisons, alleviates intestinal pains and colics", and so on" (Coe \& Coe, 1996: 123). It should be recalled that in Galen's theory and practice, the body contained four humors (black bile, yellow bile, phlegm and blood), and that good health depended on a balance between them. Each of these humors had specific properties - 'hot' or 'cold' and 'dry' or 'moist'. In the European Baroque Age, the humoral theory was extended to include all sorts of phenomena and conditions, such as the divisions of the day, the four seasons, and even the cardinal points. Those with too much blood were sanguine, those with too much phlegm were phlegmatic, those with too much yellow bile were choleric, and those with too much black bile were melancholic (Fig. 8B).

Alonso de Molina began the introduction of the present name of vanilla, by translating in his dictionary the word tlilxóchitl as "ciertas vaynicas de olores" (= certain fragrant little pods) (Molina, 1571: 148). Referring to the town of Lucu, on the banks of the Belize River, Diego López de Cogolludo, in his History of Yucatán, indicates that Friar Bartolomé de Fuensalida saw there, in 1618, the best achiote (annatto tree) he had ever seen, together with fruits of vanilla that the natives called cizbiques (López de Cogolludo, 1954). The observations of Dampier in the second half of the XVII century (see later), about the use of vanilla by the natives of Bocas del Toro (Panama) let us assume that knowledge about the uses of vanilla spread to the rest of Central America after the conquest of Mexico. It is possible that this knowledge was brought from Yucatan to Panama by the Miskitos, who in the XVII century made frequent incursions to the territories located to the north and south of their dominions. The Miskitos and Sumas of the coasts of Nicaragua and Honduras used Vanilla that they called diti bainia, to flavor a beverage "made of cacao and maize" (Conzemius, 1984: 198).

That vanilla was brought into Europe by the Spaniards in 1510 (as mentioned by Reinikka, Jacquet, and other authors) is highly improbable, since the first Spanish expedition to the mainland was that of Ojeda and Nicuesa in 1508 to Panama, and we cannot find any reference to this orchid until the conquest of Mexico by Hernán Cortés in 1519.

The Flemish botanist Charles de l'Ecluse (15261609), also known as Carolus Clusius, in his Exoticum liber decem, provided the first botanical description of vanilla in 1605, as Lobus oblongus aromaticus. The description is from a plant provided by Hugh Morgan, pharmacist to Queen Elizabeth I. (Jacquet, 1994: 78). It was this Morgan who first called attention to vanilla as a spice that could have other medicinal and culinary uses, besides being a flavoring for chocolate. Vanilla begins to separate from chocolate and starts a life on its own. L'Ecluse made his first experience with American plants through the works of Nicolás Monardes (1493$1588)^{8}$, that he had read during his travels to Spain and which he later translated into Latin (Laca Menéndez de Luarca, 1999: 98).

In 1658 the term vaynilla appeared in a work by William Piso, who added that this name was given by the Spaniards." (Reinikka, 1995: 15). According to Piso, who again follows Galenic theory, vanilla is "hot in the 3rd degree," and the mecaxóchitl spice "hot in the $4^{\text {th }}$ degree" and "dry in the $3^{\text {rd }}$ degree". Piso had taken part, as official surgeon, in the Dutch expedition to the north of Brazil under the command of the Count of Nassau-Siegen, in 1638. He assumed charge of botanical studies insofar as they pertained to medicine (Steele, 1964: 14).

Friar Bernabé Cobo, in his history of the New World, published in 1653 (Cobo, 1892) gives a detailed account of the necessary procedures to cure the pods of vanilla, which he praises as "very precious to put into the chocolate", stating that the best vanilla is that which grows in Chiapas (Pérez de Antón, 2005: 122).

William Dampier observed vanilla plants growing in the south of Mexico (1676) and in Bocas del Toro (today Panama), in 1681. In his work A New Voyage Round the World he mentions that the Indians sold vanilla to the Spaniards and describes the method that they followed to cure the fruits: "This Cod grows on a small Vine which climbs about and supports itself by the neighbouring Trees. It first bears a Flower, from where

\footnotetext{
${ }^{8}$ Monardes, N., 1574, Primera y Segunda y Tercera Partes de la Historia Medicinal de las Cosas que se traen de nuestras Indias Occidentales que sirven en Medicina. Sevilla.
} 
the Cod afterwards proceeds. It is first green, but when ripe turns yellow. Then the Indians, whose Manufacture it is, and who sell it cheap to the Spaniards, gather it and lay it in the Sun, which makes it soft. Then it changes to a Chestnut colour. They frequently press it between their fingers which makes it flat.... These Vines grow plentifully at Boccatoro, where I have gathered and tried to cure them, but could not, which makes me think that the Indians have some Secret that I do not know of to cure them... They are commonly sold for Threepence a Cod among the Spaniards in the West Indies... for they are much used in chocolate to perfume it. Some will use them in Tobacco, for they give a delicate scent. Could we have learnt the art of it, several of us would have gone to Boccatoro yearly and cured them" (Dampier, 1998: 121) (Fig. 8C).

Francesco Redi (1626-97), a talented Italian scientist and physician to the Medici court, published his Experimenta circa res diversas naturales (Redi, 1675), a work on 'diverse natural matters, in particular those carried to us from the Indies'. Redi's work contains a detailed illustration of a vanilla pod, and what is certainly the first microscopic view of a vanilla seed. In 1701, the English traveler Ellis Veryard published his Choice remarks, concerning his voyage to Spain during the latter half of the XVII century. His account of how the Spaniards manufactured their chocolate says: “...Next you are to add twenty-five Bainillas ... finely powder'd, proceeding to mix...” (Veryard, 1701). In 1703, the French botanist Charles Plumier (16461704), who had seen the plants during his travels to the Antilles, described the genus as Vanilla (Plumier, 1703), although in 1749 Carl von Linné theorized that Vanilla was the source, as well as a species, of the Orchis genus, prescribing it as a powerful aphrodisiac elixir (Reinikka, 1995: 18-19). Robert Miller, in 1739, collected seeds and cuttings of Vanilla planifolia near Campeche, from which the cultivation in greenhouses of this species began in England.

Denis Diderot (1718-1784), the great French encyclopedist, disapproved of the tastiest flavorings that people added to chocolate, which did nothing but add "fire" to the body. He warned about the use of vanilla: "The pleasant scent and heightened taste it gives to chocolate has made it very popular, but long experience having taught us that it is extremely heating, its use has become less frequent, and people who prefer to care for their health rather than please their senses abstain completely." (Diderot, 1778: 785). The aphrodisiac properties of vanilla were also mentioned by the German physician Bezaar Zimmerman, who in 1762 published a treatise entitled "On experiences", in which he claimed that "no fewer than 342 impotent men by drinking vanilla decoctions, have changed into astonishing lovers of at least as many women" (Siegel, 2008: 145). Vanilla made its debut in the United States in 1789, when the U.S. ambassador to France, Thomas Jefferson, had his secretary in Paris ship him a bundle of fifty cured beans wrapped in newspaper. Thomas Jefferson's recipe for vanilla ice cream can be found in his papers at the Library of Congress (Gand \& Weiss, 2006: 12).

In 1753, Linné, in his Species Plantarum, described vanilla as Epidendron vanilla, and it was his countryman Olof Swartz who reestablished the genus Vanilla in 1799 (Swartz, 1799: 66). Finally, in November 1808, Henry Charles Andrews (1794-1830) published the description of Vanilla planifolia that is valid today in The Botanists Repository of New and Rare Plants (Jackson \& Andrews, 1808). The description was based on a plant cultivated by Charles Greville that had flowered the year before (Soto Arenas, 1999: 18). A beautiful illustration of Vanilla sp. is included in the Torner Collection that contains the illustrations of the expedition of Sessé y Mociño to New Spain (Fig. 9).

In 1835, Lindley separated the genus Vanilla from the Orchidaceae and proposed it as the type for a new family, the Vanillaceae (Lindley, 1835: 73) .

Orlando W. Roberts, English traveler along the Central American East Coast in the years before the independence of the region from Spain, comments in his book that the Indians in the region of Darién form parties for drinking preparations of cocoa, of which they drink immense quantities A few pages later he tells that they "also produce vanilla, a valuable plant..." (Roberts, 1965: 77, 80). With regard to the cultivation of vanilla in the region of the San Juan River he writes: "The country from San Juan River to

\footnotetext{
${ }^{9}$ Bateman, in the introduction to his The Orchidaceae from Mexico and Guatemala, says: "In this list the Vanilla is not included, as that plant has recently been separated (no doubt, most judiciously) by Dr. Lindley, from the natural order "Orchidaceae" and constituted the type of a new order of its own".
} 
this point [Bluefields, Nicaragua] abounds in vanilla of the finest quality. This plant climbs with ease to the top of the highest tree. At a distance the leaves slightly resemble those of the vine; the flowers are of a white colour, intermixed with red and yellow, when these fall off, they are quickly succeeded by the pods, growing in bunches not unlike the plantain, and generally of the thickness of a child's finger. The pods are green at first, grow yellow, and finally brown; the method used to preserve the fruit, is to gather it when yellow, before the pods begin to open or burst - it is then laid in small heaps for the space of three of four days to ferment. The fruit is afterwards spread in the sun to dry; and when about half dried, flattened with the hand, and rubbed over with cocoa, palm or other oil: - it is once more exposed to the sun, to be fully dried, rubbed over with oil a second time, put in small parcels, and closely covered over with the dried leaves of the plantain. [...] The vanilla plant is also found on most parts of the Mosquito Shore, and in the neighborhood of Breo del Rero and Chiriquí Lagoon; it requires heat, moisture, and shade, to bring it to perfection, and when used in that state it gives a most delicious flavour to coffee, chocolate, etc., forming an important article of commerce, especially among the Spaniards" (Roberts, 1965: 99-100).

Carl Berthold Seemann, in 1848, indicated that "[the] fruit of the Vanilla (Vanilla sp.) and Vanilla chica (Sobralia sp. or Selenipedium chica) are spices employed in flavoring sweetmeats, chocolate and puddings" (Seemann, 1852-1857: 69). Moritz Wagner and Carl Scherzer, in 1853, observed Vanilla plants growing wild in the region of Miravalles, in northwestern Costa Rica: "The parasitic plant of the family of the orchids that provides the precious vanilla (Epidendron vanilla), with long, slim and aromatic ovaries, grows wild in the lower and shady places near the banks of the rivers"). And near the Río Grande (Pacific Coast): "Very frequent, especially in shady places, are several species of vanilla that may be distinguished for their thick leaves, their multicolored flowers of marvelous forms and their siliquous and thin fruits which exhale a delicious aroma" (Wagner \& Scherzer, 1974: 168, 225). Wells described the cultivation and trade of Vanilla in the Honduran region of Olancho, and gave it the scientific name of Vanilla axillans [sic] (Wells, 1857) ${ }^{10}$. Wells states that Vanilla shows preference for two species of host trees, "indio desnudo" (Bursera simaruba (L.) Sarg.) and "guachipilín" (Casearia sylvestris $S w$.), and gives a detailed description of plant habitat, flowers, and fruits. As to cultivation, Wells mentions a promising experimental plantation in the village of Pespire. The greatest part of the Vanilla from Olancho was taken to the market of Tegucigalpa, although a small amount was sent to Trujillo, on the North coast, and to Belize. According to Wells, in good localities a diligent native could collect between two and four pounds a day. Hartwell (1967-1971) includes Vanilla in his list of plants used against cancer. And more recently, Alan Hirsch, M.D., of Smell and Taste Treatment and Research Foundation Ltd., in Chicago, studied the relationship between smell and arousal. He found that several smells increased blood flow to the penis, including lavender, pumpkin pie, doughnut and black licorice. However, smelling vanilla caused the greatest degree of arousal in older men (Siegel, 2008: 145).

For over 300 years after its discovery by Hernán Cortés, vanilla was only produced in Mexico. Cultivation was tried in many countries, but the delicate orchid never bore fruit. The mystery was not solved until 1838, when the Belgian Charles Morren discovered that common insects cannot pollinate the flower and that its natural fertilizers, bees from the genus Eulaema, do not survive outside Mexico. Morren developed the method to pollinate vanilla flowers by hand (Morren, 1838). Soon the French began to cultivate vanilla in their colonies in the Indic Ocean, the Dutch in Indonesia and the British in Jamaica and India. Finally, in 1858, Gobley isolated vanillin, the crystalline component of vanilla, opening the way to industrial production of substitutes for $V$. planifolia.

"In spite of competition from other tropical regions, in spite of the large-scale commercial production of synthetic vanillin, Mexican vanilla has held its own. At its best it has a quality unequaled elsewhere, and its excellence is recognized by its great demand" (Bruman, 1948: 372). In the region of Totonicapán, the cultivation of Vanilla is an important economic factor. "The Totonacs found the way of growing vanilla, planting it in acahuales (secondary forests), and learned how to guide and prune the plants" (Hágsater et al., 2005: 50).

${ }^{10}$ Wells means Vanilla axillaris Mill., a Mexican species described in 1768. 
The following species of Vanilla can be found in our region:

$\begin{array}{ll}\text { V. hartii Rolfe } & \text { V. planifolia } \text { G. Jackson } \\ \text { V. helleri Hawkes } & \text { V. pompona } \text { Schiede } \\ \text { V. } \text { inodora } \text { Schiede } & \text { V. sativa } \text { Schiede } \\ \text { V. insignis Ames } & \text { V. sylvestris Schiede } \\ \text { V. odorata } \text { Presl } & \text { V. trigonocarpa } \text { Hoehne } \\ \text { V. phaeantha } \text { Rchb. f. } & \end{array}$

\section{From the codex Badianus to Carl von Linné}

"Nature does not proceed by leaps and bounds" Carl von Linné

The Codex Badianus. The first descriptions of orchids that we know of for the Americas are in the Aztec Herbal of 1552 (Ospina, 1997: 1160), written in Mexico with the title Libellus de Medicinalibus Indorum Herbis (De la Cruz \& Badiano, 1996). Its author was the Aztec physician Martín de la Cruz and it was translated from Nahuatl into Latin by another native named Juan Badiano. It is therefore commonly known as the Codex Badianus or Codex de la Cruz-Badianus. There are two versions, one says that the work was for Emperor Charles V, and the other that the work was conceived by Francisco, the son of the Viceroy don Antonio de Mendoza, as a gift for Phillip II (by now King of Spain), in an effort to demonstrate that the Indians were "knowledgeable, capable of learning from Europeans and very worthy of support from the Viceroyalty and the protection of the King" (Gómez, 2008: 82). De la Cruz and Badiano were two outstanding students of the Imperial College of Santa Cruz de Tlalelolco, were they met Fray Bernardino de Sahagún.

During the early XVII century, the Latin version became part of the library of Cardinal Francesco Barberini, and it is therefore also known as Codex Barberini (Gómez-Pompa, 1993: 29). In 1990, during a visit of Pope John Paul II to Mexico, the manuscript was presented as a gift from the Vatican to the Mexican people and is since then preserved at the National Library of Mexico. The first Spanish version, although incomplete, was published in 1955 by Francisco Guerra. "It is not only the earliest complete Mexican medical text which has thus come to light, but it is the only medical text known to be the work of Aztec Indians" (Emmart \& Sigerist, 1940: xiii).
In the previous chapter (The history of vanilla), reference was already made to tlilxóchitl ( $V$. planifolia) that, according to this codex, was used, with a mixture of other plants, in a prescription for viatores presidium (Fig. 7), namely "protection for travelers". “... pulverized herbs wrapped in a magnolia leaf and hung around the neck so that the voyager could 'catch and inhale the very redolent odor' " (Benzing, 1990: 1). Another orchid by the name Tzacouhxochitl (from tzacouh $=$ glue and xochitl $=$ flower) was used as an adhesive and in a concoction prescribed for timoris vel micropsychiae remedium, that could be translated as a "remedy against shyness". This orchid is either Bletia campanulata or Catasetum maculatum (Ospina, 1997: 1160).

According to Ospina, the illustrations of the Aztec Herbal also represent the first attempt in the Americas to coordinate the floristic or medical descriptions of plants with their ecological circumstances. The plants are depicted in full, that is, including flowers, leaves, stems and roots, and around the roots there are various pictorial symbols that undoubtedly refer to the ecology of the plant. Thus, a blue background coloring... would indicate that the plant grew near the water...; the relationship between plants and ants is shown by clear pictures of these insects in the plant's roots, and so on. This Herbal will, therefore, stand as our first known reference for future works on the orchids and their ecology in the Americas (Ospina, 1997: 1160-61).

The expedition of Francisco Hernández to New Spain (1570-1577). It was in the year of 1570 when Spain started her first scientific expedition to the New World. In charge was Francisco Hernández (15171587), with the title of First Physician General of the New Indies, Islands and Terra Firma of the Ocean; he carried instructions to write a natural history of these lands and to "draw the herbs and other natural things" (San Pío Aladrén \& Puig-Samper, 2000: 11). It is quite possible that the works of Badiano and Sahagún had a strong influence on Emperor Philip II and led him to finance the most import botanical expedition of his time (Gómez-Pompa, 1993: 30). Hernández was the first European to investigate the flora of Mexico, although from a medicinal rather than a botanical standpoint (Hemsley, 1887: 117-18). Besides the scholar, three illustrators, three scribes, a cosmographer 
and several Indian medicine-men took part in the expedition. On March 1, 1571, Hernández presented his title of Protomédico in the palace of the Viceroy, in Veracruz. During the following six years, the expedition collected more than 3,000 plants, 500 animals and 35 minerals. "As the first expedition of natural history ever sent out by a government, the Hernández venture is a landmark in the annals of botanical science. Although he classified his plants largely according to unscientific Aztec standards, and his descriptions are often too brief or vague, Hernández preserved a body of ethnobotanical lore that probably otherwise would have been lost" (Steele, 1964: 7) (Fig. 10A).

In 1577, Hernández returned to Spain, having completed a total of six volumes of text and ten volumes of illustrations of what he called Rerum Medicarum Novae Hispaniae Thesaurus, seu Plantarum, Animalium, Mineralium Mexicanarum Historia or Natural History of New Spain. The work languished in the library of El Escorial and Hernández died in 1587 without ever having seen it published. "This pattern of failure would be repeated many times over, for the eyes of Spanish authorities were invariably bigger than their stomachs when it came to digesting the vast quantities of botanical knowledge unceasingly offered up by the Indies" (Steele, 1964: 7).

In 1580, Philip II ordered the first physician of Naples, Dr. Nardo Antonio Recchi, to distil the essence of Hernández's findings. In doing his duty, however, Recchi not only excluded all of the natural history that seemed of no use in medicine, but ended in publishing nothing either (Steele, 1964: 6). Fortunately, Friar Francisco Ximénez [who must not be confused with the translator of the Popol $\mathrm{Vuh}$ ] saw the need to furnish a medical guide for the haciendas and towns of Mexico that had neither physician nor pharmacist, and in 1615 at Mexico City published the first edition of Hernández work. He based it, however, upon the incomplete summation by Recchi (Steele, 1964: 6). Recchi died before completing his work and his manuscripts came into possession of Federico Cesi, Prince of Acquasparta (1585-1630), founding member of the Accademia dei Lincei, in Roma. Cesi's intention was to continue the publication of the work of Hernández with the help of other experts. Johannes Schreck (who became a monk in 1628 and took the name of Giovanni Terrenti or Terenzio), in charge of the botany, traveled
TABLE 2. Orchids in the 1651 edition of the Thesaurus (from Jenny, 1993:4).

\begin{tabular}{l|l|l}
\hline Page 38 & Tlilxochitl & Vanilla \\
\hline Page 166 & Coatzonte Coxochitl & Stanhopea hernandezii \\
\hline Page 349 & Amazauhtli & $\begin{array}{l}\text { Oncidium (illustrated } \\
\text { without flowers, un- } \\
\text { doubtedly from the } \\
\text { group of } \text { Oncidium } \\
\text { luridum or } \text { Oncidium } \\
\text { cavendishianum })\end{array}$ \\
\hline Page 368 & Chichiltic tepelauhxochitl & $\begin{array}{l}\text { Laelia } \text { cf. speciosa } \text { or } \\
\text { Schomburgkia }\end{array}$ \\
\hline Page 433 & Tzauxochitl & Laelia or Encyclia \\
\hline
\end{tabular}

to Madrid in 1616 on behalf of the Lincei, to study Hernández's manuscripts. In 1628 the Accademia finally published the first part of the Thesaurus. The same Accademia would publish, in 1651 and under the guidance of Francesco Stelluti, an augmented version. Before the work by Hernández could be fully valued, his manuscripts were destroyed by the great fire at El Escorial in 1671.

Among the plants mentioned in the 1651 edition are five species of Orchidaceae, all clearly illustrated and described in Latin (Tab. 2).

In both editions (1628 and 1651) the illustrations and descriptions coincide exactly. The Aztec names are undoubtedly from Hernández, while the Latin equivalents are by Terenzio. Unfortunately, only two species can be identified with certainty. The others are illustrated without flowers, or with little detail (Fig. 10, B-E). Alzate comments in 1791, referring to the work of Hernández, about another orchid called cozticxochitl ("yellow flower"), that he also calls istontle, istontli, iztamaxuchitl and cocotlacotl (Alzate y Ramírez, 1791). The Botanical Register, under plate \#13, Govenia liliacea (La Llave \& Lex.) Lindl., states that "the first notice we have of the existence of this species is from Hernández who, in the Madrid edition of his work, calls it by the many-syllabled name of 'Iztactepetzacuxochitl Icohueyo'" (Sprunger, 1991: 123). This indicates that Hernández work was still known in Lindley's time.

Stanhopea hernandezii deserves a special mention. The romantic interpretation of many authors that the Latin description that appears in the editions of 1628 and 1651 (Lyncis flore seu Lyncea $=$ Lynx flower, 
also Lyncea) was a premonition of Hernández that it would be the Accademia dei Lincei that would rescue his works from oblivion (such as Bateman in his Orchidaceae of Mexico and Guatemala) is opposed by the much more pragmatic opinion of Jenny (1993: 5) who maintains that Hernández could have no knowledge of the Roman academy and that it was Terenzio, member of the Lincei, who invented the name. James Bateman (1811-1897) used the flower of Stanhopea hernandezii to embellish the frontispiece of his Orchidaceae of Mexico and Guatemala (Fig. 10F) and went to the extreme of assuring that Hernández "ventured to dedicate it, as the loveliest plant of the Mexican Flora, to the Lyncean Academicians of Rome, by whom it was immediately adopted ..." (Bateman, 1837-43: 7). Bateman forgot that Hernández had died when Cesi was barely two years old.

We do not know if the loss of a great part of Hernández's work was due to neglect or to the zeal of the Spanish Inquisition. But it is sad to record that a work of such value shared the same fate of the herbal of Martín de la Cruz, lost in the vaults of the Vatican, or the monumental work of Sahagún, confiscated to satisfy religious intolerance.

\section{A new dark age}

"Many died in the flames and it gave me so much pleasure to see them burn that, poking the fire, I said: Heretic dogs, minister I am of the Holy Inquisition!" Pedro Calderón de la Barca The siege of Breda, 1640

In the second half of the XVI century, the Spanish Empire reached its maximum expansion. Phillip II could proudly say that the sun did not set in his dominions. The American continent excited the curiosity of erudites and travelers. But the chronicles of Bernal Díaz del Castillo, Francisco López de Gómara, Gonzalo Fernández de Oviedo and Fray Bernardino de Sahagún gave way to a long century of silence and darkness. As religious problems exacerbated in Europe, the Spanish Inquisition unleashed its aggressiveness against the liberty of thought. "... Charles I attempts to avoid ideological corruption applying his Index of forbidden books [Index Librorum Prohibitorum] which his son Philip would extend prohibiting the importation of foreign books and the travel of students to the European universities" (García de Cortázar, F., González Vesga, J. M., 1994: 336). In 1571, the Holy Office of the Inquisition was established in Mexico, to investigate and punish religious crimes. Between 1571 and 1600,600 persons were condemned by the tribunal of the Inquisition in Mexico, 13 of them to die in the flames. (Carmack et el., 1996: 158).

"The sword, the open grave to bury them alive, the stake, awaited those who sold, bought or copied heretic books; those who painted or sold defamatory images, damaged or broke the images of the saints, those who celebrated in their homes clandestine reunions or permitted them; those who discussed in public or secretly about the Holy Scripts" (Schneider, 2002: 193).

From a military standpoint, the defeat of the Invincible Armada in 1588 was the first of a series of disasters that continued during the Thirty Year War (1618-1648) and marked the end of Spanish hegemony in Europe. With the treaty of Utrecht (1713), Spain said farewell to her last continental possessions. The finances of the Spanish monarchy looked even worse: the bankruptcy of 1557 repeated itself monotonously in $1575,1607,1627,1647,1662$ and 1666. The peninsula suffers from depopulation (between 1575 and 1650 the Spanish population diminished by 20 per cent) and economic recession. Instead of promoting local production, the American gold finances luxury purchases in foreign markets. While the rest of Europe increased its production, Spain lied in financial chaos. The universities served as recruiting centers for the imperial bureaucracy. The crown encouraged all disciplines related to administration while the flames of the autos de fe of the Inquisition strangled humanism and religious pressures suppressed scientific investigations.

"Medieval and modern at the same time, the imperial society of the XVI and XVII centuries is a society in transit... The spirit of exultation of the kingdoms of Charles I and Philip II is replaced by the prosaic reality of the smaller Hapsburgs... The bitterness of military failures, the decline in the liberty of thought, growing delinquency, hunger, bureaucratic and religious hypertrophy... chained a community which had been alive hundred years earlier" (García de Cortázar \& González Vesga, 1994: 270-71). We must therefore not be surprised if, from the last third of the XVI to the latter XVII century, the history of orchids 


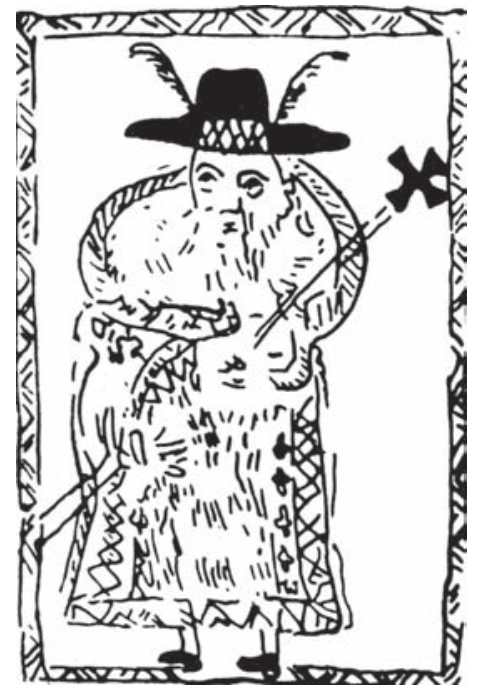

A

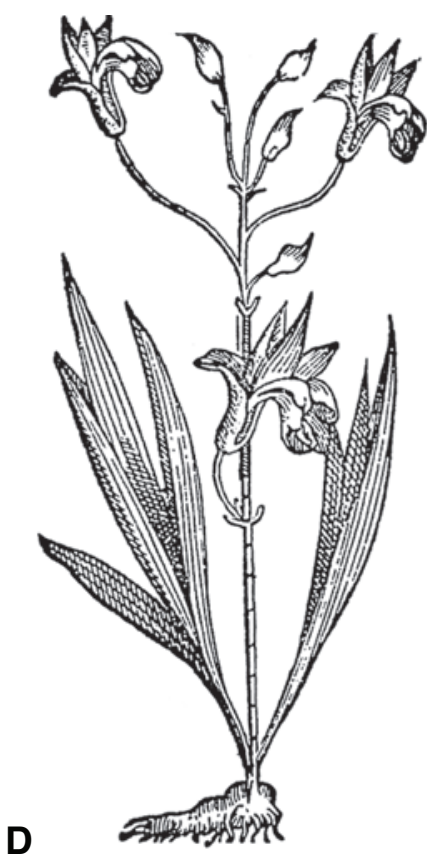

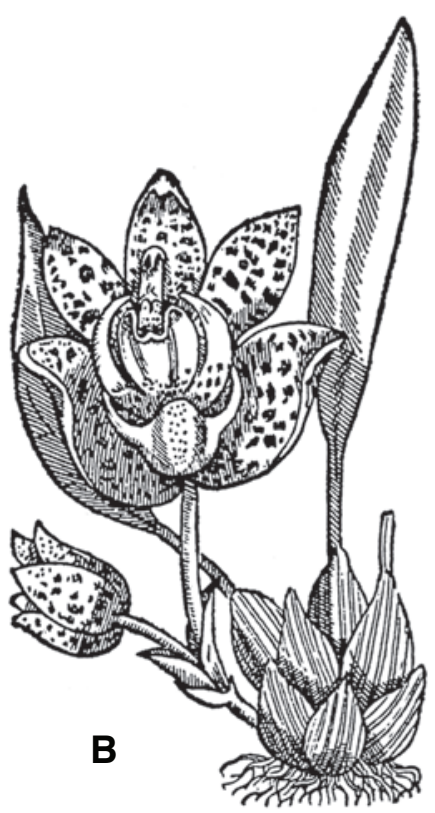
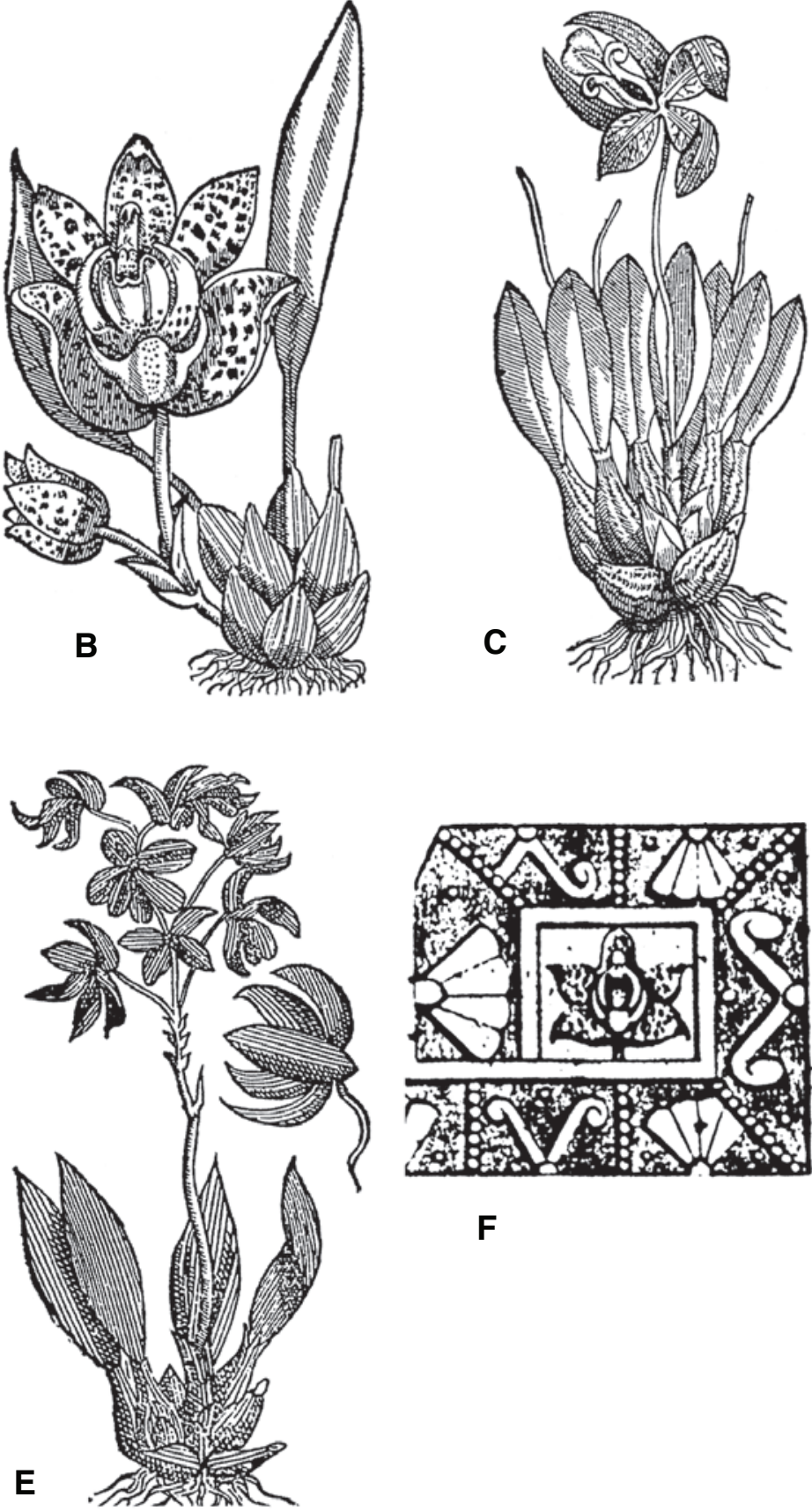

$\mathbf{F}$

Figure 10. A - The questioner. Native drawing of a Spaniard of the XVI century who asked the Indians about their traditions, plants and antiquities. It is generally assumed that it represents Francisco Hernández. In Lozoya, 1984. B - Coatzonte coxochitl (Stanhopea hernandezii). In Jenny, 1993: 1. C - Chichiltic tepetlauxochitl (Laelia speciosa). In Jenny, 1993: 3. D - Tzacuxochitll (Prosthechea vitellina). In Hágsater et al., 2006: 40-41. E — Tzacutli (Bletia jucunda). In Hágsater et al., 2006: 40-41. F — Enlarged detail from the frontispiece of the work of Bateman with the illustration of Stanhopea hernandezii. 

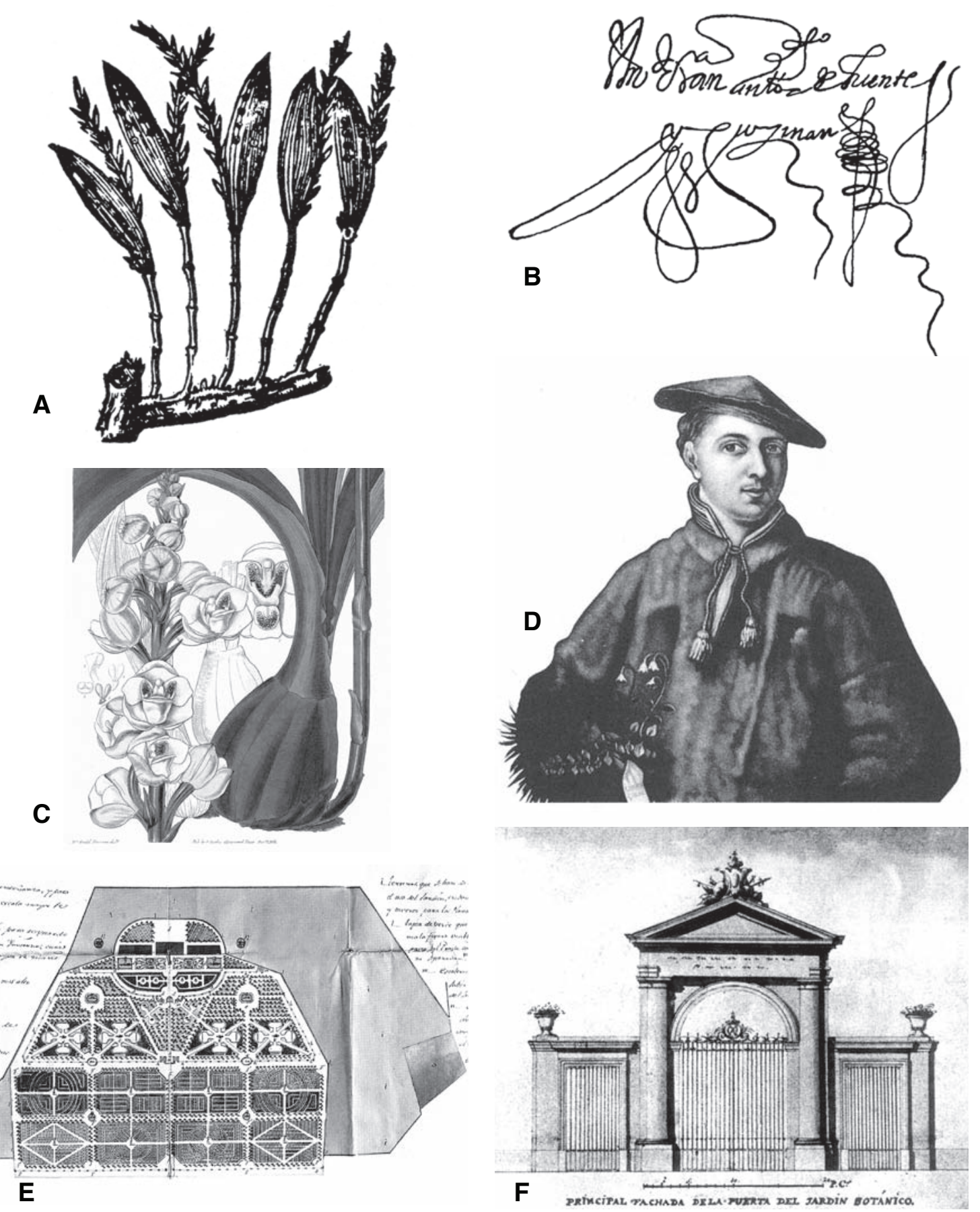

Figure 11. A - The 'Stelis' of Tabernaemontanus. In Nieder \& Barthlott, 1992: 244. B — Signature of Francisco Antonio de Fuentes y Guzmán, as flowery as his 'Recollection'. C - Peristeria elata Hook. In Curtis’s Botanical Magazine, plate 3116. D — Carl von Linné (1707-1778). In Coe \& Coe, 1996: 18. E — Original site plan for the Royal Botanical Garden in Madrid. In San Pío Aladrén et al., 2005: 136. F - Original sketch for the main entrance gate to the Royal Botanical Garden in Madrid. In San Pío Aladrén et al., 2005: 137. 
in Central America shows a void that lasted almost 125 years, in what Carlos Fuentes called "the long night of El Escorial". In Steele's words, "the seventeenth century was sterile" (Steele, 1964: 11). IIt should not surprise us either that the only exceptions during this period came from Central Europe. In 1588, the German Jacob Theodor, better known as Tabernaemontanus (1522-1590), publishes the Neuw vollkommentlich Kreuterbuch ("New Complete Herbal").

In this work, without indication of origin, a plant named Indianisch Mispel or Viscum Indicum is illustrated, that according to Nieder \& Barthlott is a species of Stelis, although, in the opinion of Béhar and Pupulin (pers. comm., 2007) its 'lepanthiform' sheaths could indicate that it is rather a species of the genera Trichosalpinx or Lepanthopsis (Fig. 11A). All three genera have a wide range of distribution and can be found from Mexico and Central America through the Caribbean and South America. It is therefore clearly speculative to include this curious reference of Tabernaemontanus in the history of the orchids of Central America. The woodcut was probably prepared from a herbarium specimen that could have been collected in almost any region of the Americas. Tabernaemontanus incurred in an understandable error, including an epiphyte orchid in a genus (Viscum) that is a parasite. The famous German philosopher Immanuel Kant made the same mistake two hundred years later when, writing about the cultivation of vanilla, he said that you "... only have to tie it unto a tree, from which it takes its juice" (Nieder \& Barthlott, 1992: 243).

As the second exception, we already mentioned the botanical description of vanilla by l'Ecluse in 1605 . It was ironically the same Charles de l'Ecluse who published, in 1576, a flora of Spain (Rariorum aliquot stirpium per Hispanias observatorum historia), just as Spain debated about the necessity of expanding the index of prohibited books of 1559 (the new index was finally published in 1584) (Jacquet, 1994: 78).

The "English American" - the journey through Mexico and Central America of Thomas Gage (1625-1637). Thomas Gage (1597?-1656) was one of the most peculiar characters that ever visited our region. Of Irish origin and born into a traditional Catholic family, Gage studied in France and Spain in convents of the Jesuits by decision of his parents, who wanted him to become - together with his four brothers- missionaries for the conversion of England (one of the main objectives of the Spanish Jesuits). While studying in Valladolid, Gage decided to leave the Jesuits and joined the Dominicans, and it was as part of a Dominican group on route to the Philippines that he arrived in Veracruz in 1625, one the first nonSpaniard to do so since the Spanish conquest of the territory (despite of the presence of foreigners in the Spanish colonies being strictly prohibited by a Royal decree). From Mexico he went on to Guatemala and entered the order's mission in the city. Gage lived for twelve years in New Spain, for the most part in Guatemala and among the indigenous population. He came to know the customs, the language, and the feelings of the Indians as very few before or after him. He returned to England in 1637, traveling through Nicaragua, Costa Rica, Panama and Cuba, and then in 1642 publicly abandoned the Catholic Church for a Puritanical form of Anglicanism. Gage later called himself "the only Protestant that was ever known to have traveled to those parts" (in the introduction to his book). He embarked in 1654 as chaplain of Cromwell's expedition to the Antilles and died finally in Jamaica in 1656. Gage published in 1648 the account of this travels through America in A New Survey of the West Indies being A Journal of Three thousand and Three hundred Miles within the main land of America. His narrative was very popular in his time and one of the reasons were the fantastic accounts of Gage (a mixture of imagination and truth, full of exact details but also of exaggerations, of descriptions of gold mines and fabulous treasures). Gage's work was widely read and discussed and translated to several other languages.

In his work, Gage mentions in several occasions the use given to vanilla in relation to the preparation of chocolate (see above "The history of Vanilla").

The renaissance of science. Slowly, in the last decades of the XVI century, Spanish intellectuals began to rebel against the disciplinary power of the Church. The challenging 'philosophic letter' of Juan de Cabriada, a militant manifest, openly in favor of laboratory experiments, raised in 1687 waves of enthusiasm and also scared rejections. With the change of the century, methods of direct observation gained more and more importance. Fernando VI paid special 
attention to the botanical gardens, founding the Royal Botanical Garden in Madrid (1755), followed soon by the botanical gardens of Valencia, Barcelona and Zaragoza. Spain opens its doors to foreign scientists. The botanist Loefling, pupil of Linné, brought his Spanish colleagues up to date, as reflected in the works of Barnades, Mutis or Gómez Ortega (García de Cortázar \& González Vesga, 1994: 405). In a last attempt to maintain ideological repression, an edict by the Inquisition in 1759 prohibited the reading of the French Encyclopedia.

Two small works were published in Central America, of more descriptive than scientific character, in which we find the first descriptions of orchids after the obscurantist interregnum. In 1690, the historian and poet Francisco Antonio de Fuentes y Guzmán (16431700) wrote in Guatemala his Recordación Florida, discurso historial y demostración natural, material, militar y politica del Reyno de Guatemala (=Flowery recollection, historical discourse and natural, material, military and political demonstration of the Kingdom of Guatemala), published in Madrid in 1882. Fuentes y Guzmán described what is probably a species of the genus Laelia: "The herb that, in the manner of a lily, grows in the formation of its leaves and is called Zayte by the candy makers and Cebollin (= little onion) by peasants and shepherds, grows its roots like a potato or a truffle, covered by a skin or membrane as subtle as the skin of an onion, but tending to be green. Its roots are thick as the wire of the blacksmiths. Its interior is not covered by skins like the onion, but between fibers like a cord it grows white dough of glutinous juiciness. This dough is used by candy makers for drops and cakes, because it gives them firmness. It is also used by carpenters to weld and join the musical instruments and to improve the firmness and softness of their voices" (Fuentes y Guzmán, 1932: 246-47). But perhaps the most curious remark of Fuentes y Guzmán is his reference to the epiphytic habit of orchids. Not able to understand how a plant grows on a tree, he calls them "grafts". In the last paragraph of his work, Fuentes y Guzmán shows the fear still inspired by the Inquisition: "All what is written in the first part of our history of the Kingdom of Guatemala I submit with utmost catholic humiliation to the correction of our mother, the Holy Roman Catholic Church, as her obedient son" (Fuentes y Guzmán 1932: 418) (Fig. 11B).
Born in Andalusia in 1666, Friar Francisco Ximénez (1666-1729) arrived in Guatemala when he was 22 years of age and became famous for his translation of the Popol Vuh, the sacred book of the Quiché, in the first years of the XVIII century. The manuscript which Father Francisco Ximénez found in his parish at Chichicastenango ranks highest among the documents composed by the American Indians after they had learned to write their own languages by means of the Latin letters which the Spanish missionaries had taught them. Its author was undoubtedly one of the first students who learned from the friars the marvelous art of phonetic writing. The Quiché chronicler knew that in olden times there was a book which contained the traditions and accounts of his people, and, knowing them perfectly, he had the happy inspiration of recording them. The author of the Manuscript says that he writes it because now the Popol Vuh, or the original "Book of the People," as Ximénez calls it, is no longer to be seen. We have no facts by which to identify this original book other than those which its unknown author gives. Nevertheless, from the knowledge that we have of the American Indians' system of writing before the Conquest, it seems doubtful that the ancient Quiché book could have been a document of set form and permanent literary composition. Rather one must suppose that it might have been a book of paintings with hieroglyphs which the priests interpreted to the people in order to keep alive in them the knowledge of the origin of their race and the mysteries of their religion.

The Manuscript of Chichicastenango has no title. It begins directly with these words:

"This is the beginning of the old traditions of this place called Quiché. Here we shall write and we shall begin the old tales, the beginning and the origin of all that was done in the town of the Quiché, by the tribes of the Quiché nation."

Less known is Ximénez's Historia Natural del Reino de Guatemala (= Natural History of the Kingdom of Guatemala), a work written in 1722 but not published until 1967 and considered to be the first medical botany of Guatemala. Ximénez marvels about the nature that surrounds him: "If any flowers resemble our Divine Maker with more property, I have no doubt that they are the flowers of this America, for there are so many and so admirable." A good observer, Ximénez is one of the first to describe the epiphytic character and sympodial 
growth of orchids, without understanding the formation of fruits and seed. In book XI of his work, About the flowers, he dedicates a chapter to orchids under the title: "Flowers of the trees": "No seed is recognized in them from that they reproduce, but from one little onion new others are born and if one gives once a flower, it will not give it again, and it leaves other onions at its foot produced from itself and so those plants multiply" (Ximénez, 1722: 313). He tells us also how orchids are only found in adult trees: "On the other hand, one sees an oak growing, that had its bark clean, and suddenly out of him comes some genus of those flowers, which are without number. And this can only be seen when the oak is old" (Ximénez, 1722: 303).

Ximénez continues describing several species of orchids. He mentions the monjitas (= little nuns - Lycaste spp.), the flower of Saint Martin (Laelia superbiens Lindl.) and the flower of Sacrament ("They give it this name because it flowers at the time of Lent and they put this flowers on the altars. It is very fragrant and out of the onion rise long twigs, about a vara $^{11}$ long and it all fills with little flowers like a real $^{12 "}$ (Ximénez, 1722: 314). Ximénez also mentions the miniatures: "Others give smaller flowers and still others give some that are extremely small."

As it is a terrestrial, it does not surprise us that Ximénez fails to recognize Peristeria elata (Fig. 11C) as an orchid, although it attracts his attention that they have not been able to acclimate it to Guatemala: "In the fields near the city of Panama grows a herb whose flower is a well formed white dove, that is the reason that they call this the flower of the Holy Spirit, and it is so unique to that land, that it has not been possible to take it to another, notwithstanding all efforts that have been made...". Ximénez mentions a total of more than 12 species, ending with a reference to the great variety of orchids existing in the region and to the impossibility of describing them all: "There are [so] many others that grow on onions that I do not remember any more" (Ximénez, 1722: 304).

Little more can be told about orchids in Central America during the XVII and the first half of the XVIII centuries. While Sloane and Plumier explored the Antilles and England and France increased their knowledge about the floras of their colonies, Spanish

\footnotetext{
${ }^{11}$ vara $=$ unit of length, about $2.8 \mathrm{ft}$.

${ }^{12}$ real $=$ a silver coin.
}

science continued in a profound lethargy. Botanical interest slowly extended from the British colonies to Tierra Firme. "A few botanical specimens may have been garnered by the British buccaneer William Dampier (1652-1715).... [who] stopped at Cocos Island and Cabo Blanco [Costa Rica] in June and July (respectively) of 1684 aboard the pirated ship Batchelor's Delight..." (Hammel et al., 2004: 2). During his voyages to the Caribbean and Central America, the Scott William Houston spent four years (1729-1733) in Cuba, Veracruz, Campeche and Jamaica, collecting specimens and seeds (Steele, A. R., 1964: 15). There are however no orchids among his collections. In the previous chapter (The history of vanilla) we already commented about the collections of R. Miller in Campeche in 1739. Shortly afterwards, the Swede Carl von Linné (1707-1778) set the foundation for modern botanical nomenclature. "According to present rules, the terminology of orchids starts on May 1, 1753... “ (Jacquet, 1994: 96). With Linné, “... botanical science came to life, if not yet to maturity" (Steele, 1964: 9) (Fig. 11D).

\section{ENLIGHTENMENT AND INDEPENDENCE}

\begin{abstract}
"Hispaniae Florae nullae nobis innoterunt, adeoque plantae istae rarissimae, in locis Hispaniae fertilissimis, minus detectae sunt. Dolendus est, quod in locis Europa cultioribus, tanta existat nostro tempore barbaries botanices." (= Nothing comes to us from the Hispanic Flora, because these rare plants that live in the fertile regions of Spain are barely taken into consideration. It is painful to see that so much botanical barbarity exists in such enlightened places of Europe)
\end{abstract}

Carl von Linné, Bibliotheca botanica, 1751

The Age of Reason. Fernando VI, who ascended to the throne in 1746, proved that Spanish botany only needed the support of the crown in order to grow. After a petition of Secretary of State José de Carvajal, Linné sent to Spain one of his favorite pupils, Pehr Löfling (1729-1756). "Löfling cast off to bring light to Darkest Spain in May, 1751" (Steele, 1964: 31). As proof that the XVIII century desire for "useful knowledge" had 
penetrated Spanish consciousness, the government decided to send Löfling, together with other experts, on an expedition that should explore Venezuela. This expedition bore little results, due to the premature death of Löfling in the region of the Orinoco river, but above all because the Spanish government refused to lend or even show Linné the material collected by his pupil and especially the manuscripts that he compiled during his brief stay in America. To this day, nobody knows what happened to Löfling's herbarium, one of the first collections made in America.

The advantages that Enlightenment saw in utilitarian science were expressed by Linné: "Various nations consider it a raison d'etat to hide their advantages, especially in the distant colonies. But Señor Carvajal was too great a statesman to let himself be deceived by these motives. He knew that the rich resources of nature are inexhaustible and that, using them with the necessary knowledge, one had no need to fear their lack. He saw how the French and English, in many varied ways, had learned to exploit their colonies after having learned to know their territories and products in a better manner" (Rydén, 1957: 204-205. The quote is from the prologue of Linné in his Iter Hispanicum, 1758).

Though its beginnings were tortuous and slow, Spanish botany entered an era of excited ferment in the last half of the eighteenth century (Steele, 1964: 46). The Royal Botanical Garden of Madrid was founded in 1755. On October 17, 1755, Fernando VI signed a royal order: "Wishing the King the furtherance of the Arts and Sciences, and especially those whose progress promise great advantages to the health of his subjects, has he come to grant to his Royal Protomedicate the use of his garden at Migascalientes with the purpose of forming there a Royal Garden and improving in these Kingdoms the important study of Botany" (Fig. 11, E-F). José Quer (1695-1764) was named as its first professor of Botany. He would publish, between 1762 and 1764, the first Spanish flora, in four volumes, which was left unfinished at the time of his death (Quer, J., 1762, Flora Española o Historia de las plantas que se crían en España, Madrid) (De San Pío Aladrén et al., 2005: 23).

Moved by the necessity of reviving the Spanish economy and reducing unemployment, the Count of Campomanes, in his famous Discourse on the furtherance of popular industry (1774), mentioned the importance of studying natural history. Thus was the idea born to send expeditions to the principal regions of the empire. In 1777 the expedition of Ruiz and Pavón departed for the Viceroyalty of Peru, followed in 1787,1789 y 1799 by those of Sessé and Mociño to New Spain, Malaspina to the Pacific and Mutis to New Granada. All this research, made during twenty years in the most fertile regions of the new continent, has not only enriched the domain of science with more than four thousand new species of plants; it has also contributed greatly to spread the taste for natural history among the inhabitants of the country (Steele, 1964: vii, who cites Alexander von Humboldt, in his Essai politique sur le royaume de la Nouvelle-Espagne (1811).

Under the influence of the ideas of Enlightenment and the political events that shook France and the English colonies in North America, Spain experimented in the last third of the XVIII century a cultural and scientific renaissance that, ironically, would be a principal cause for the loss, few years later, of its American empire. King Charles IV, great promoter of the botanical exploration of America, and his wife María Luisa, where honored by Ruiz \& Pavón in the naming of the genus Carludovica, from the family of the Cyclanthaceae (From the Latin Carolus $=$ Charles, and Ludovica $=$ Luisa, Louise $)^{13}$.

\section{The expedition of Alessandro Malaspina to the} Pacific (1789-1794). On July 30, 1789, after many months of careful planning, two small corvettes left the port of Cádiz. Commanding some 200 men, Alessandro Malaspina (1754-1810), one of the most brilliant officers of the Spanish Navy, went ahead with the most ambitious project of Spanish enlightenment: the scientific exploration of the American coasts and of the greater part of the islands of the eastern Pacific (Fig. 12). Malaspina had been born in Italy but was educated in the Company of Naval Guards in Cádiz, which was at that time the most prestigious naval school in Europe. He took part in the Spanish-English wars and in 1782 began a brilliant career in the Spanish Armada. Between 1786 and 1788, commanding the frigate Astrea, he circumnavigated the globe by order of the

\footnotetext{
${ }^{13}$ The type species for Carludovica is Carludovica palmata Ruiz \& Pavón, the well known "paja toquilla" from which the famous 'Panama' hats are made.
} 


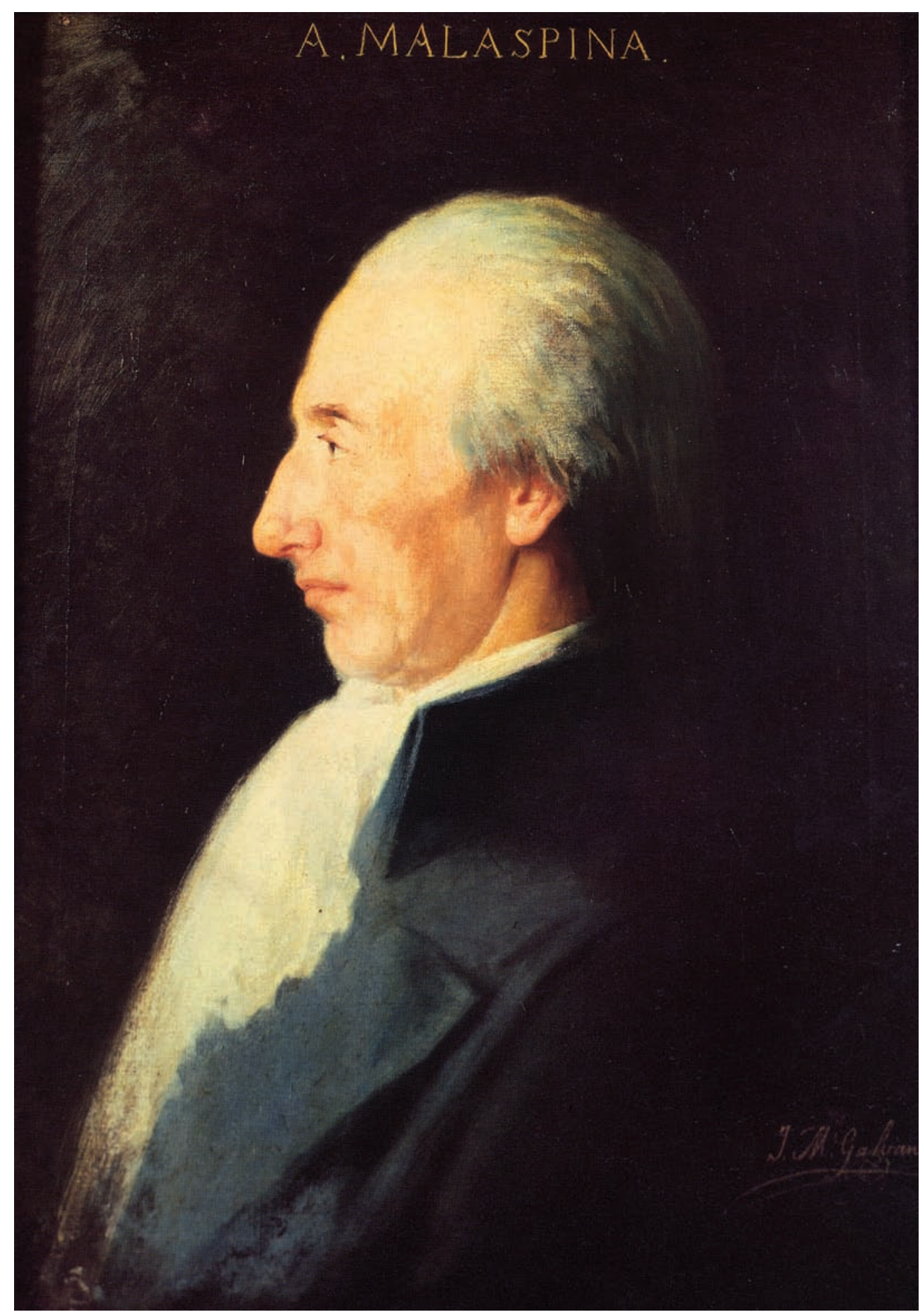

Figure 12. Alessandro Malaspina (1754-1810). Navy Museum, Madrid. 


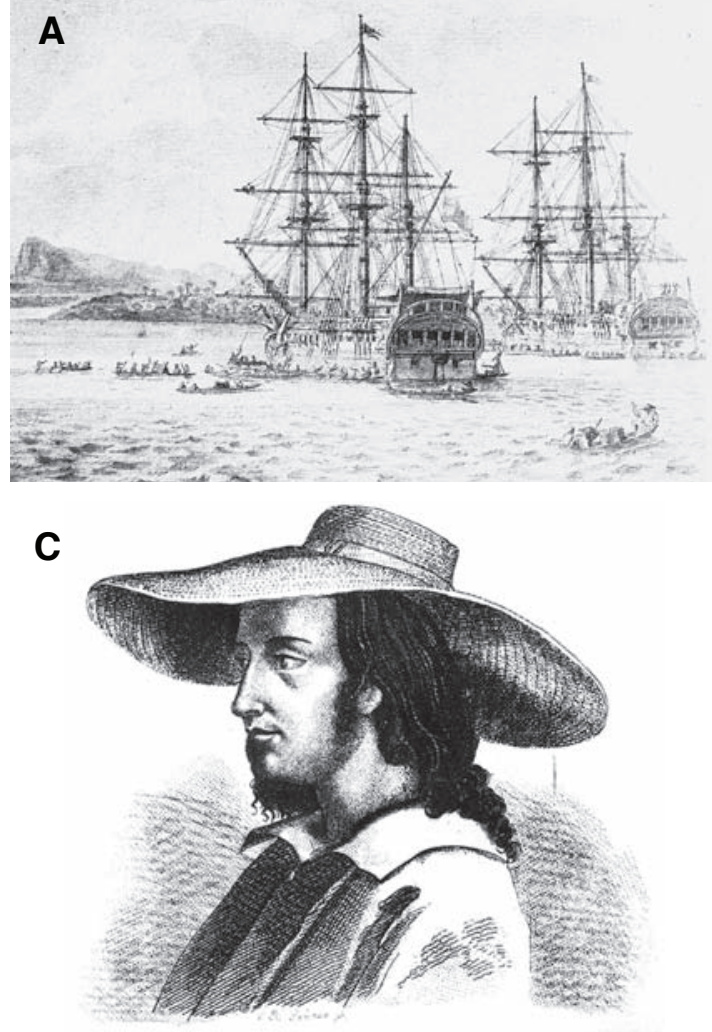

B

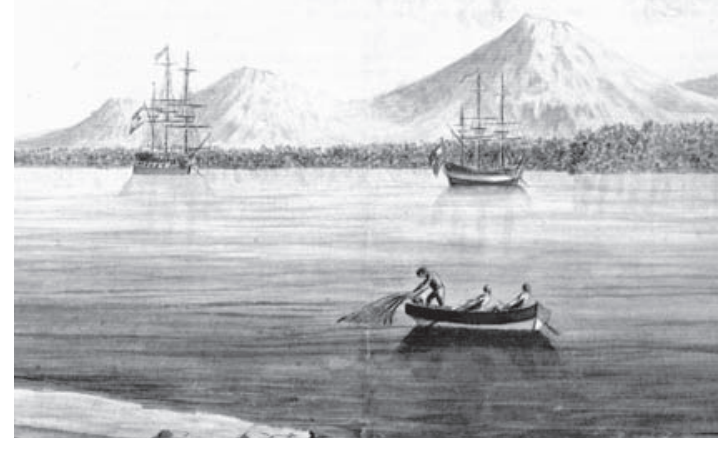

$\mathbf{E}$
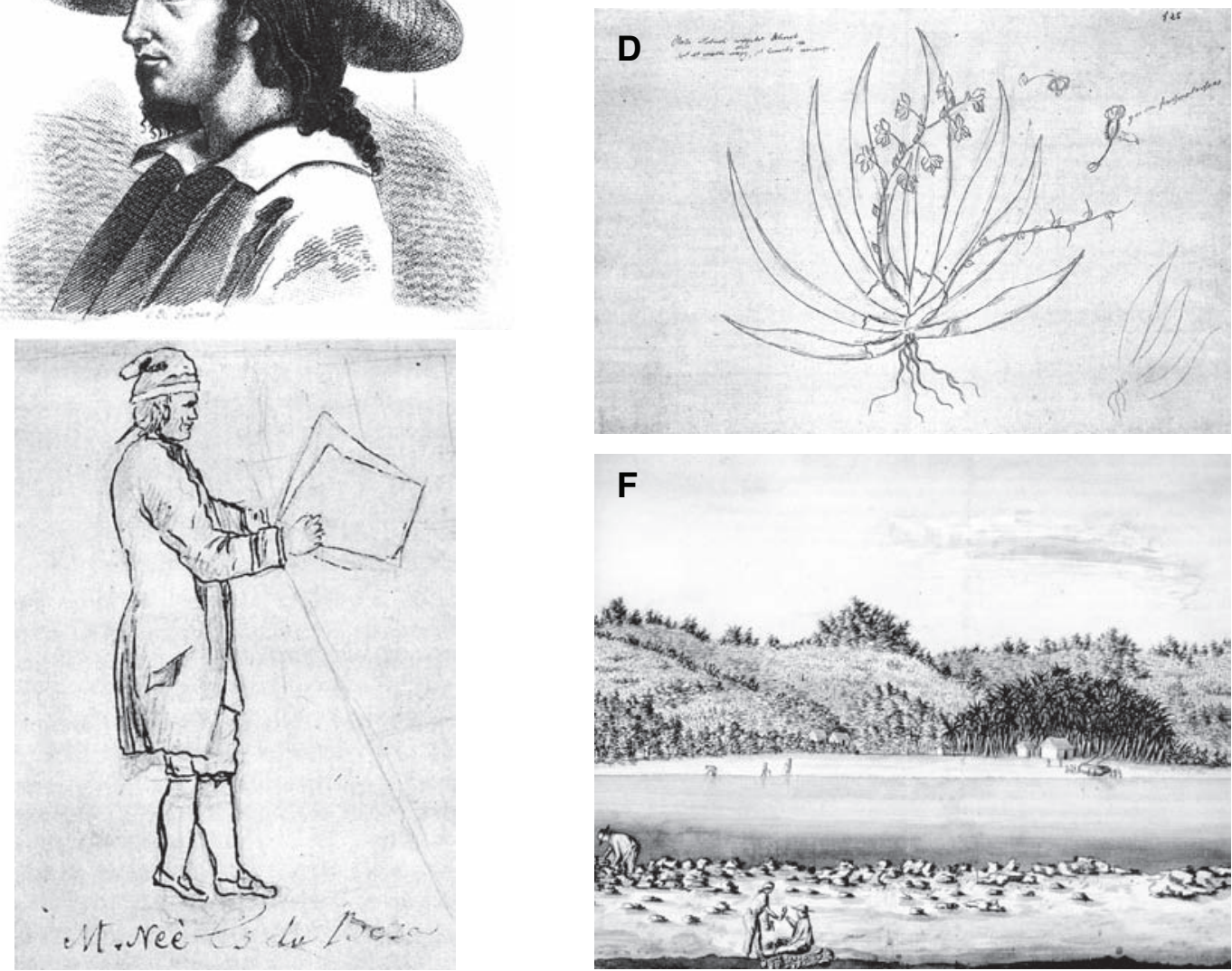

\section{$\mathbf{F}$}

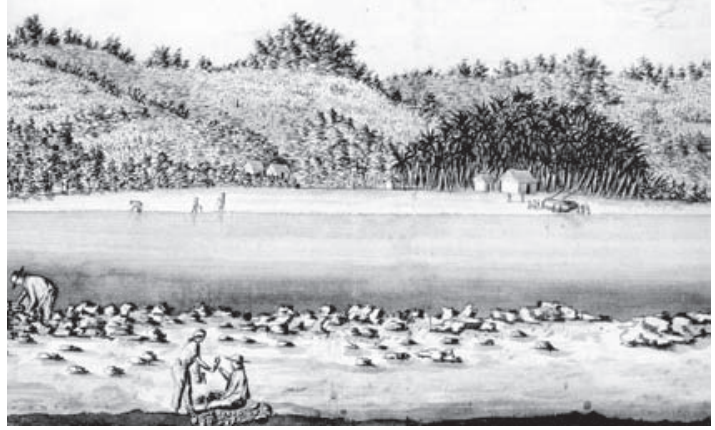

Figure 13. A - The corvettes 'Descubierta' and 'Atrevida'. Navy Museum of Madrid. B - El Viejo volcano from the port of Realejo. Drawing by José Cardero (fragment). Museo de América, Madrid. C — Thaddeus Haenke (1761-1817). Portrait by V. Grüner, in Real Jardín Botánico de Madrid, 1989: 83. D — Epidendrum iridifolium. Collection and drawing by Haenke. In Ibañez Montoya, 1990: 69. E — Louis Neé (ca. 1734-1807). Sketch by Felipe Bauzá, in Real Jardín Botánico de Madrid, 1989: 59. F — The naturalists on the island of Naos, Panama. Drawing by José Cardero (fragment). In Malaspina, A., 1990: 211. 
Royal Company of the Philippines. In a letter from September 1788 to the Naval Ministry, together with his colleague José Bustamante y Guerra, he explained the ideas that inspired him to his expedition: "to increase the knowledge about natural sciences (biology, botany, zoology and geology), to undertake astronomic observations and to 'construct hydrographical charts for the most remote regions of America' " (Becquer Casaballe, 2003: 2). The government approved his proposal as a "scientific and political voyage around the world" and gave the order for the construction of two corvettes, that were baptized "Santa Justa" and "Santa Rufina", names which Malaspina immediately changed to "Descubierta" and "Atrevida", in honor of the ships "Discovery" and "Resolution" of the English explorer James Cook (although the second name is not the most fortunate of translations) (Fig. 13A).

The expedition did not have the intention of discovering new territories, but of exploring in depth those already known. Malaspina, a man of vast culture, was therefore very meticulous in the selection of the scientists who were to accompany him. The most prominent among the botanists chosen for the expedition, were Pineda, Haenke and Neé. Malaspina professed great admiration for these three men and their scientific qualities. In addition to this, Malaspina had sought and received the advice of the most prominent European men of science of his time, among them Joseph Banks, president of the Royal Horticultural Society (Soler Pascual, 1999: 29). The artists of the expedition were José Cardero, Felipe Bauzá, José Guío and Francisco Lindo.

Antonio Pineda was born in Guatemala in 1751 and received his education in Spain under the guidance of Casimiro Gómez Ortega, soon standing out as a naturalist and botanist. He held the position of Infantry Lieutenant of the Spanish Royal Guards when Malaspina, in 1788, asked for his designation as director of the natural history research of the expedition. After being appointed in the month of December, Pineda proposed as his assistants for Botany and Mineralogy Louis Neé, employee of the garden of the Royal Boutique, and the chemist
Florian Coetanfeu. While the gardener, stimulated by his precarious position, accepted the offer without thinking it over, and tried to obtain substantial benefits by tergiversing his curriculum, the chemist used the subterfuge of his family to resign from the expedition. Finally, Tadeo Haenke was admitted as the third expeditionary naturalist" (Puig Samper et al., 2001: 50). In Central America, Pineda took part of the exploration of Panama and somewhat later in the ascend to the El Viejo volcano, in Nicaragua, together with Haenke (Fig. 13B). While exploring the island of Luzon (Philippines) Pineda fell sick and died in June of 1792 .

Thaddeus Peregrinus Xaverius Haenke was born in Bohemia in 1761. He studied natural sciences in the universities of Vienna and Prague. In 1786 Haenke was selected as a botanist to participate in the first multidisciplinary expedition to the Giant Mountains (Krkonoše, Riesengebirge) organized by the Royal Czech Society. The results of that expedition were published in 1788. This was the most important work of Haenke from Bohemia, and he was awarded for it a silver medal by the Royal Czech Scientific Society. Haenke always wanted to travel to distant places and study the botany of new, botanically uncharted areas. He was interested in participating in Captain Billings' expedition sponsored by the Russian Catherine II, but Billings ultimately did not take any scientists with him $^{14}$. In 1789 Haenke was offered the position of a botanist in the Malaspina expedition and he eagerly accepted the offer. The Austrian Emperor Joseph II learned about Haenke, now one of the best botanists in all of Austria, and did not want to allow Haenke to leave the country. Emperor Joseph II allowed Haenke to leave only after the intervention by Professor Jacquin, but Haenke had to agree that he would return back to Austria after the expedition. By misfortune, Haenke arrived in Cádiz one day after the corvettes had sailed. This forced him to take another vessel to Buenos Aires, crossing the Andes all the way to Chile and finally joining the group in Valparaíso. "But this contrariety served the purpose of forcing Haenke [...] to cross the South American all the way to Santiago

\footnotetext{
${ }^{14}$ Captain Joseph Billings, an English navigator, had earlier accompanied Captain James Cook on his third voyage to the Pacific, and subsequently entered the Russian navy, initially as a lieutenant. In 1785, Empress Catherine II of Russia, acting for her government, commissioned Billings to command an expedition to search for the Northeast Passage, forming the "Northeastern Secret Geographical and Astronomical Expedition" (1785-94).
} 
de Chile and collecting on the way some 250 species of plants" (Puig Samper et al. 2001: 18) (Fig. 13, C-D). Haenke's botanical findings were published by Presl in 1827 with the title Reliquiae Haenkeanae seu Descriptiones et Icones Plantarum quas in America Meridionali et Boreali, in Insulis Phillipinis et Marianis Collegit. In 1793, when the expedition was preparing for the return voyage to Spain, he stayed in El Callao (Peru), wanting to continue his botanical explorations. Some years later he established himself in Bolivia, from where he continued sending the results of his collections. He died in the city of Cochabamba in 1816 (Slavik \& Ceska, 2002).

Louis Neé (ca. 1734-1807), French by birth, was working in Madrid in the garden of the Royal Pharmacy when Pineda proposed him as a member of the scientific group. He was accepted and, during the five years of the expedition, collected an important herbarium with over 10,000 specimens (Fig. 13E). Before leaving Madrid for Cadiz, where the expedition was to embark, Neé insisted in receiving a certain amount of money in advance, to cover his travel expenses and for the "subsistence of his family, which was left in charge of his wife, Doña Francisca Luz". His request was finally granted and, with all financial matters settled, Neé writes: "the day of the expedition June 5, I left Madrid for Cadiz in the company of Don Antonio Pineda, Don Vicente Tofiño and Don Felipe Bauzá. I presented myself to the Commander, don Alejandro Malaspina and to don José Bustamante, second Commander of the expedition, who greeted me with great kindness. Our departure took place on July 30, at ten o'clock in the morning" (Muñoz Garmendia, \& Sanz Álvarez, 1990:31). In the course of the expedition, Neé dedicated himself mainly to the collection of plants, although he also collected other objects, such as shells, minerals and ethnographic materials. These collections were made mostly alone, or in the company of Antonio Pineda, who was the member of the expedition with whom he worked together more often. The impression arises that the two botanists, Neé and Haenke, did not intend to form a team nor to sum efforts for a future joint publication. Each one collected on his own and made the descriptions separately, without taking part, apparently, in any attempt of cooperation. The herbaria were sent separately to Cadiz and the distrust went so far that Neé, on March 22, 1979, writes to Juan de Lángara: 'since the valuable collection has already been made, of which mister Haencke, the renowned German botanist and fellow traveler has duplicates, be it published in Spain as soon as possible so that the foreigners cannot anticipate us in prejudice of the national honor and that of the undersigned, who has worked so hard to be the first author and discoverer' (Muñoz Garmendía, \& Sanz Álvarez, 1990:37). Neé was the only of the three botanists to return to Europe. Of importance for Mesoamerica are his collections, together with Pineda and Haenke, in Panama, Nicaragua and Mexico.

During the period of interest for this study, Malaspina's corvettes sailed from El Callao in Peru to Guayaquil in Ecuador, from where they departed to Panama in October of 1790. The surroundings of the city of Panama and the island of Taboga where explored in December 1790 (Fig. 13F). From the journal of Luis Neé we have the following dates:

\section{October, 28:}

Weighing anchor in the port of Guayaquil towards Panama.

November, 16:

Arrival at Pericó Island, close to Panama.

November, 17/December, 10:

Suroundings of Panama, towards Punta Mala, Ancón Hill, the coast, convent of the Nuns of the Concepción, towards San Lázaro, Coconut Orchard, Pericó Island and others surrounding the harbor, coastline towards Arenal Grande.

Excursion of 7 leagues towards Portobelo, on the Atlantic coast.. Pineda follows the Cruces River.

December, 10:

Weighing anchor from Panama.

December, $11 / 14$ :

Anchoring at Taboga Island. Neé and Haenke collect on Taboga Island

December, 15:

Setting sail from Taboga Island.

It was then when Malaspina first studied the possibility of building a canal to communicate both oceans. In the first months of 1791, the corvettes sailed towards Costa Rica and separated. While the Atrevida, after visiting the island of Cocos, set a straight course to Acapulco, the Descubierta navigated along the Central American coast, landing in El Realejo (Nicaragua) and Sonsonate (El Salvador), arriving in Acapulco on March 25. 
It is again Luis Neé who gives us the dates in his journal:

January 17 / 30:

Sojourn of the corvette "Descubierta" in the harbor of Realejo (Nicaragua). Pineda and Haenke explore the surroundings of Realejo and go to the El Viejo volcano from January 20 to 22; on the 23, Pineda and Malaspina went to the Cardón Island, collecting mainly shells; Cayetano Valdés traveled to León and to the Telica volcano, collecting materials for the Natural History collection. On January 30, the "Descubierta" set sail for Acapulco (Muñoz Garmendia, \& Sanz Álvarez, 1990:338).

Presl, in his Reliquiae Haenkeanae, gives us the following description of the journey of the expedition along the Central American coast:

"Mense Decembre e sinu portuque Guayaquil UTERQUE NAVIS ABIT, CURSUM SEPTENTRIONEM VERSUS Direxit ET IN SINU ET PORTU PANAMA COMmoRaVit. Plantarum PANAMENSIUM Fasciculus DILIGENTIAM POPULARIS NOSTRI IN HOC ORBIS LOCO DEMONSTRAT. NAVES Malaspina ducente II. Februarit 1791 ad Acapulco in Nova Hispania pervenerunt, postquam portum et URBem Guatimala tetigerunt" [By the month of December both ships departed from the gulf and the port of Guayaquil, directing their course toward the North, and arrived to the gulf and port of Panama. The fascicle of the Panamanian plants demonstrates the diligence of our people in this place of the world. The ships conduced by Malaspina came to Acapulco in New Spain on February 2nd, 1791, after having touched the port and city of Guatemala] (Presl, 1827).

After exploring the interior of Mexico and the northwest coast of the continent all the way to Alaska, the expedition continued in the first months of 1792 to the Marianne and Philippine islands. In 1793 the group was again in Peru and returned finally to Cádiz in September of 1794. It is noteworthy that, while the expeditions of Malaspina and Sessé and Mociño coincided during the year of 1791 along the Mexican Pacific coast, history does not record any encounter between either groups (Novo y Colsón, 1885).

Haenke's herbarium, with over 15,000 specimens, was dispersed among numerous European herbaria. In 1827, Carl Boriwog Presl compiled an important part which was conserved in Prague and Vienna and published his Reliquiae Haenkeanae, where he enumerated 27 species of orchids. In the second volume we find the only illustration of an orchid in our area of study, that Haenke named Dendrobium mexicanum and Christenson (1991) identified later as Eulophia alta (L.) Fawc. \& Rendle (Fig. 14A). Among Haenke's collections, Presl described at least four new species of orchids, which are widely distributed in our region: Oncidium obovatum Pres1 [= Barkeria obovata (Presl) Chistenson], Elleanthus linifolius Presl, Elleanthus lancifolius Presl and Vanilla odorata Presl.

The herbarium of Neé stayed during long years in Madrid, in unopened boxes, without anybody bothering to study it. It came to the botanical garden of Madrid where, fortunately, it could not be reached by Pavón, who had an offer from Webb to purchase it. Things remained unchanged until recently, in 1980, the 'Ancient General Herbarium', which had survived more or less intact, was diluted in the 'General Herbarium' (that now holds over 466,000 sheets), thanks to an unfortunate and hasty decision of the 'conservators' (Real Jardín Botánico de Madrid, 1989: 70). Thanks to this, the study of the original specimens collected by Neé has become an almost impossible task. However, 370 sheets of botanical illustrations have survived, which are now one of our main sources of information about the collections by the botanists of Malaspina's expedition. Among them we find four species of Orchidaceae. One is an illustration of Caularthron bilamellatum (Rchb. f.) R. E. Schult., collected in Guayaquil (Ecuador). The other three are Catasetum sp., from the island of Taboga (Panama), Ionopsis utricularioides ( $\mathrm{Sw}$.) Lindl. from the port of San Blas (state of Nayarit, Mexico) and Laelia sp. from the mines of Real del Monte (state of Hidalgo, Mexico). By far, the most interesting for us is the illustration by José Guío, draftsman of the expedition, of a species of Catasetum in the island of Taboga (Panama) during the last days of December 1790 and given by Neé the number 19. It is probably the first botanical illustration of a Central American species of Orchidaceae, with the exceptions of those by De la Cruz, Sahagún, Hernández and Tabernaemontanus, in the XVI century (Fig. 14B). The other two illustrations are from species that where not collected within our area of study. However, Ionopsis utricularioides (Fig. $14 \mathrm{C}$ ) is a common species in all Mesoamerica and 
Laelia sp. (Fig. 14D) was collected not far from the limits of modern Central America.

Sharing the fortune of the other Spanish botanical expeditions, Malaspina never saw the publication of the botanical results of his voyage. His proposal to the king for a political reorganization of the empire brought him charges of treason to the state. Imprisoned in Galicia from 1796 to 1802, Malaspina was liberated thanks to mediation by Napoleon but had to leave Spain and return to his native Italy, where he died in 1810. Malaspina's was doubtless the best organized of all Spanish scientific expeditions to America. An important factor for this was the fact that it was the only one which was structured along strict military lines.

\section{The Royal Botanic Expedition of Sessé and Mociño} to New Spain (1787-1803). After the Jesuits were expelled from Spain in 1767 , an original copy in five volumes of the manuscripts of Francisco Hernández was found in the library of the Imperial College of Madrid. Casimiro Gómez Ortega, director of the Royal Botanical Garden, decided to publish the manuscripts, but found himself with two problems: the work by Hernández was no longer up to date and the original drawings were missing. In the meantime, in January 1785, the Spanish physician Martín de Sessé y Lacasta (1751-1808), who served in Cuba in the squadron of the Marquis del Socorro, proposed to Gómez Ortega the idea of establishing a botanical garden and a chair of Botany in the Mexican capital (Fig. 15A). As he wrote: "Considering you one of the lovers of the flora, I dare to interrupt your occupations with the following discourse aimed at making them shine and give fruit in this part of the New World" (Letter from Sessé to Gómez Ortega, January 30, 1785). The idea had already been expressed by Löfling, who in a letter to Linné dated June 24, 1753, writes: "I gave him [the Marquis of Grimaldi] to think that it would be of advantage to go to Mexico, where Hernández had been, but ob fata seculi (= for destiny's fate) he left his observations obscure and imprecise" (Muñoz Garmendia, \& Sanz Álvarez, 1990:25).

The idea to complete the publication of the work of Hernández with documents and drawings that could eventually be found in Mexico, and the timely proposal of Sessé, where the motives for the promulgation by King Charles III of the Royal Order of October 27,
1786. The establishment of the Botanical Garden in New Spain, the Chair of Botany (the first in America) and the formation of an expedition that should "form the drawings, collect the natural productions and complete the writings of Francisco Hernández" , was ordered (Maldonado Polo, 1996: 25). The expedition was therefore organized as an extension of the enterprise that had started two centuries earlier. It was composed initially by Martín de Sessé, Vicente Cervantes, José Longinos Martínez, Juan del Castillo and Jaime Senseve.

The Garden and the Chair of Botany were inaugurated in May, 1788 (Fig. 15B). A short time later, during the second course of botany (1789), a brilliant student stood out who was destined to have a prominent role in the expedition at the side of Sessé: the Creole José Mariano Mociño (1757-1820) (Fig. 15C). In 1787 Sessé had already started his field activities, which extended initially until 1794. In different excursions, joined by Mociño after 1790, the expeditionaries explored the central regions of Mexico, including the Pacific Coast and the Gulf of Mexico. Other itineraries brought members of the expedition to the north of Mexico, California and the coast of the Canadian Pacific. Of particular interest to our study is the excursion of Mociño to the Gulf coast (1793-1794) where he seems to have explored the region to the south of Veracruz and adjacent Tabasco. "Southeastern Mexico, as far as the Isthmus of Tehuantepec, belongs also to biological Central America" (Williams, 1956:1) (Fig. 15, D-F; Tab. 3). In the Torner collection of the Hunt Institute for Botanical Documentation we find beautiful orchid illustrations, drawn by the draftsmen of the expedition, Juan de Dios Vicente de la Cerda y Atanasio Echeverría y Godoy (Fig. 16-18; 19B-C). The term given to the expedition expired in October, 1794. Since the territories of the southern regions of the Vicekingdom -the border of Guatemala- had not yet been explored, Sessé asked for an extension, which was approved by Royal Order of September 15, 1794. It was resolved that the expedition should explore, for a period of two years, the kingdom of Guatemala and simultaneously the Windward islands. Ever since the expedition of Malaspina had touched Central American lands, clear consciousness existed that these territories could not be left out by the members of the expedition to New Spain. 


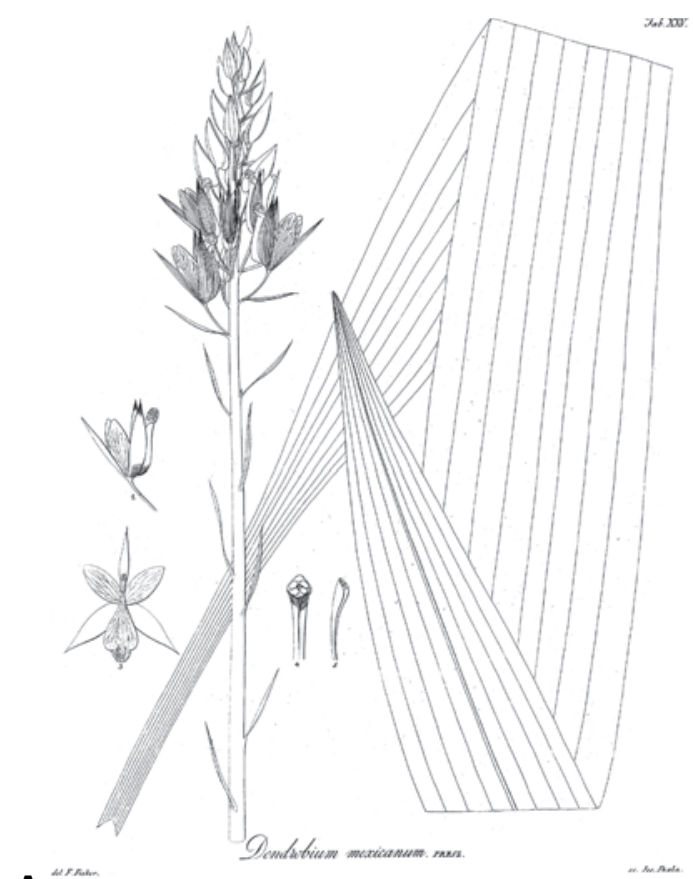

A

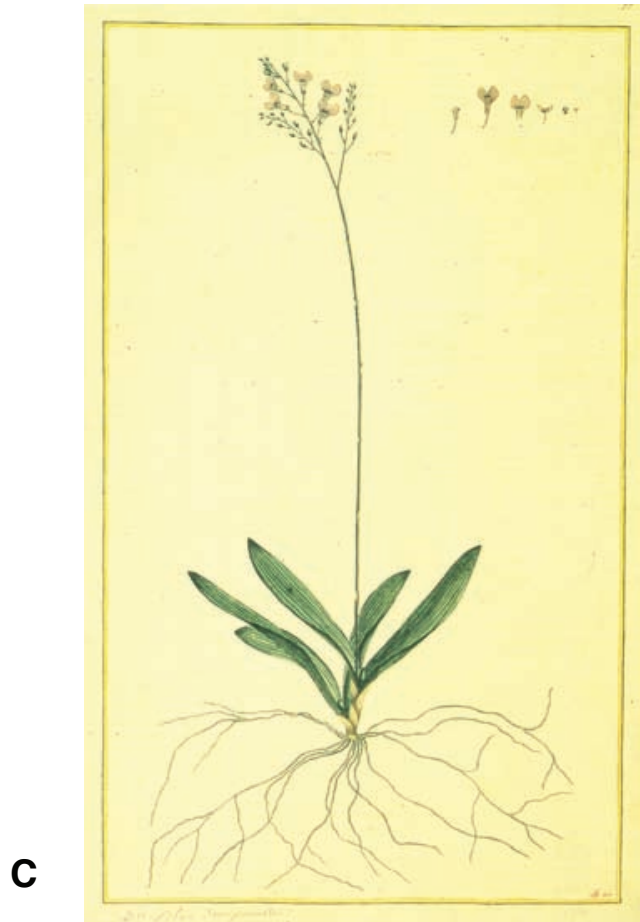

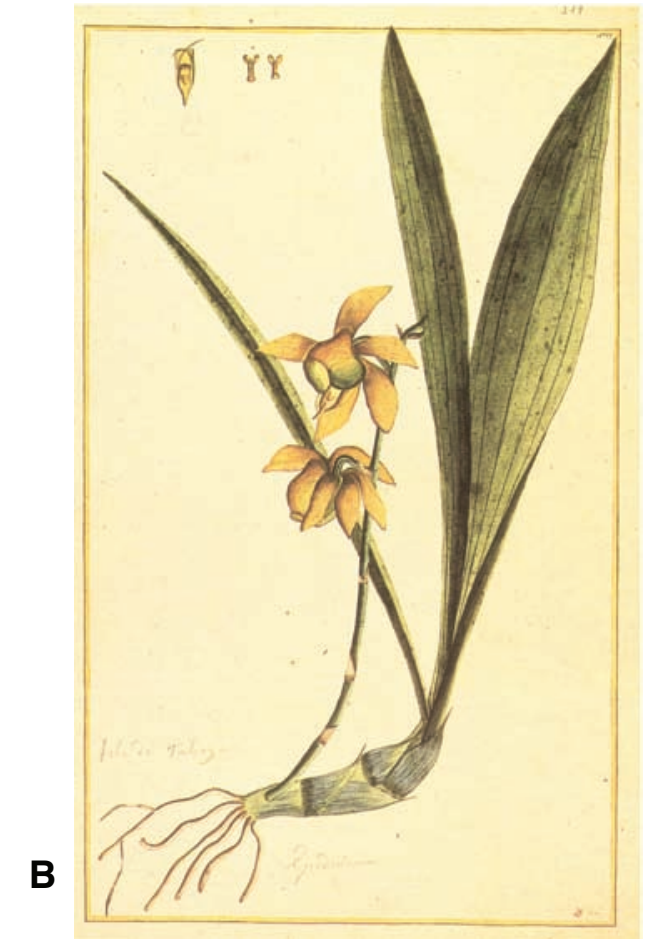

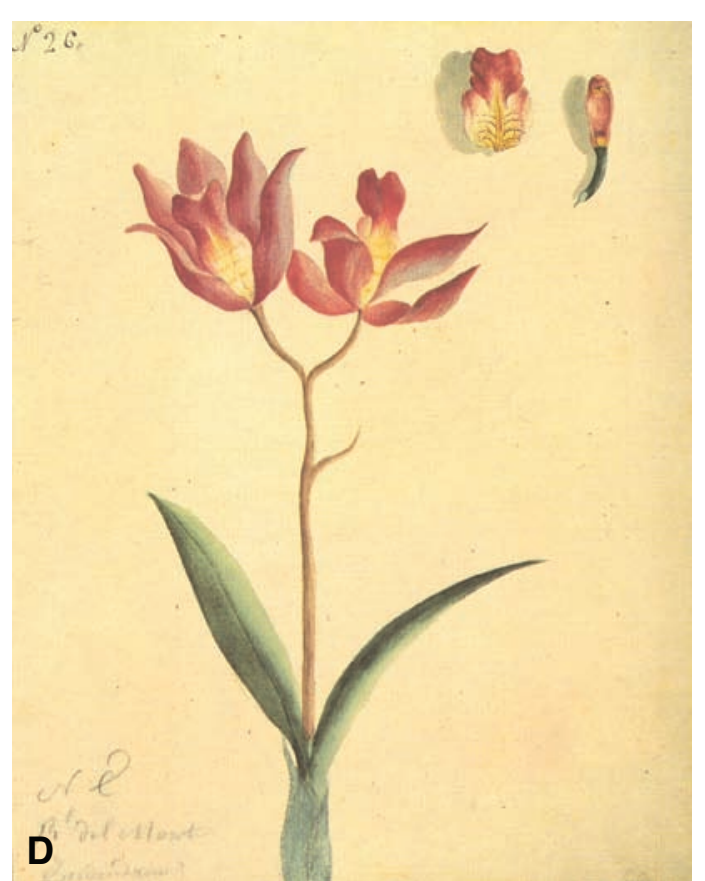

Figure 14. A - Dendrobium mexicanum. In Presl, C., 1827, (2): 102. B — Catasetum sp. Illustration by José Guío in Real Jardín Botánico de Madrid, 1989: plate 137. C - Ionopsis utricularioides (Sw.) Lindl. Illustration by José Guío in Real Jardín Botánico de Madrid, 1989: plate 1260. D — Laelia sp. Illustration by Francisco Lindo in Real Jardín Botánico de Madrid, 1989: plate 198. 

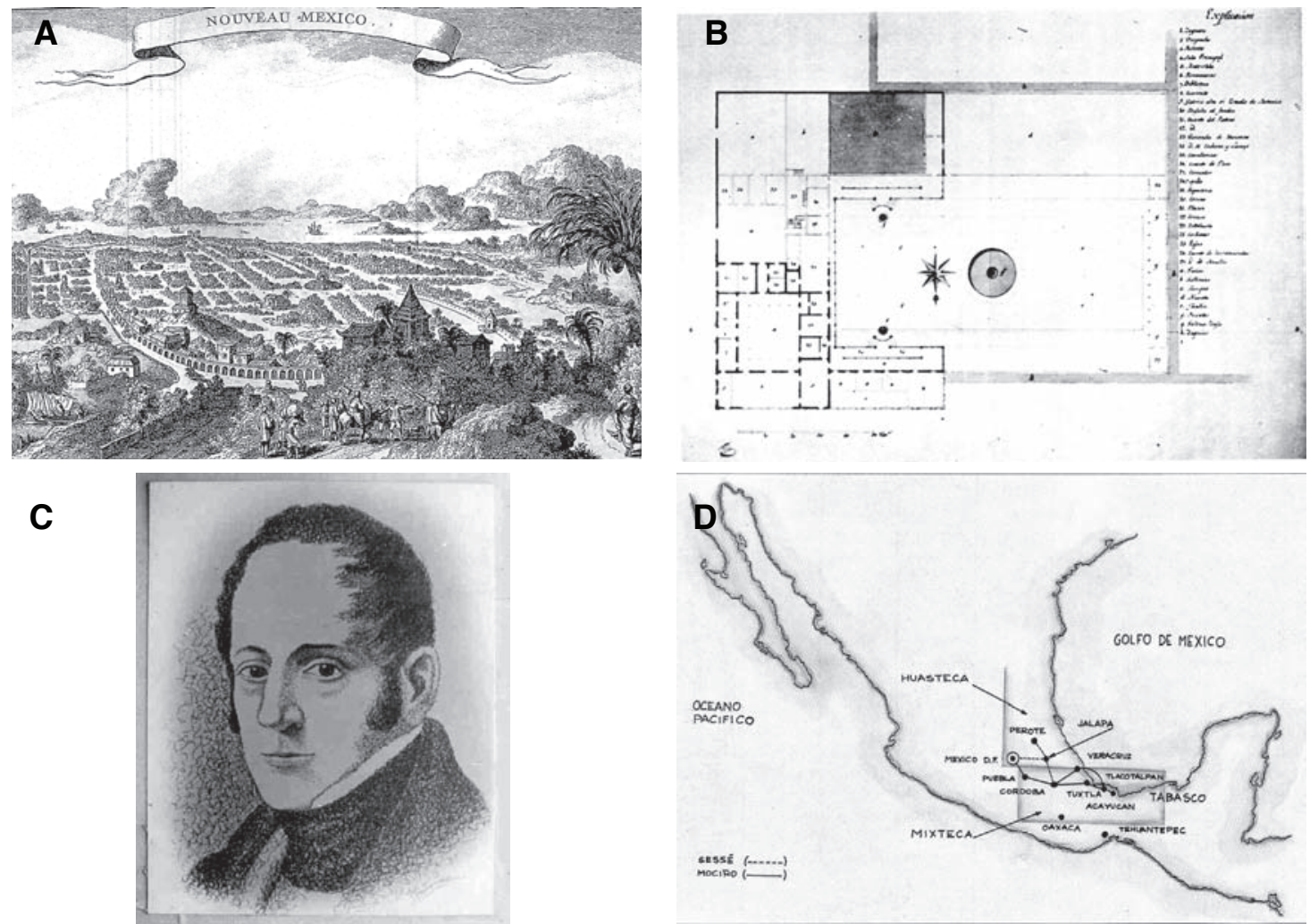

\section{Iivex Plantarum ILORAE MEXICANAE.}

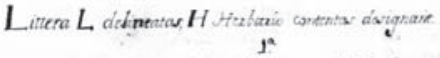
MONANDRIA MONOGINIA

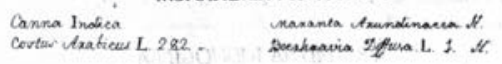

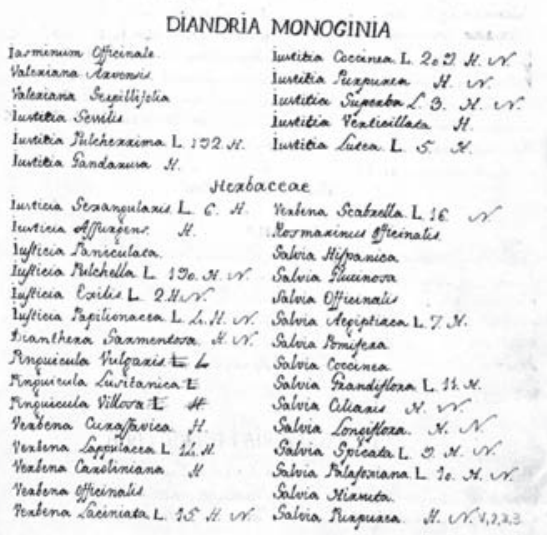

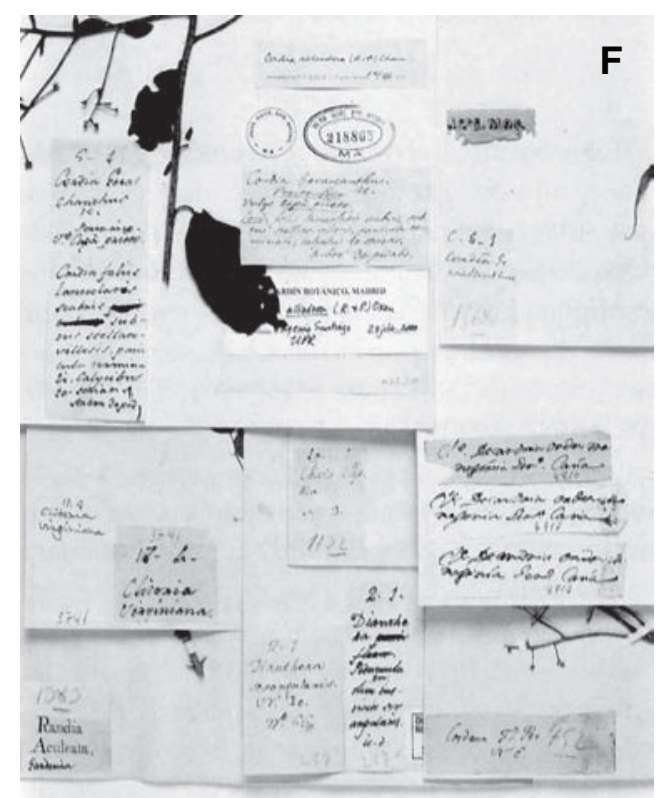

15. A - View of Mexico, 1754. In San Pío Aladrén, 2000: 41. B - Plan of the Botanical Garden in Mexico. In Maldonado Polo, 1996: 30. C - José Mariano Mociño (1757-1820). Portrait courtesy of Esthela Sandoval. D — Routes of Sessé and Mociño, 1793-94. In Maldonado Polo, 1996: 50. E - Manuscript by Mociño, part of his index of collected plants. In San Pío Aladrén, 2000: 59. F — Labels from the Mociño herbarium. In San Pío Aladrén, 2000: 65. 
C

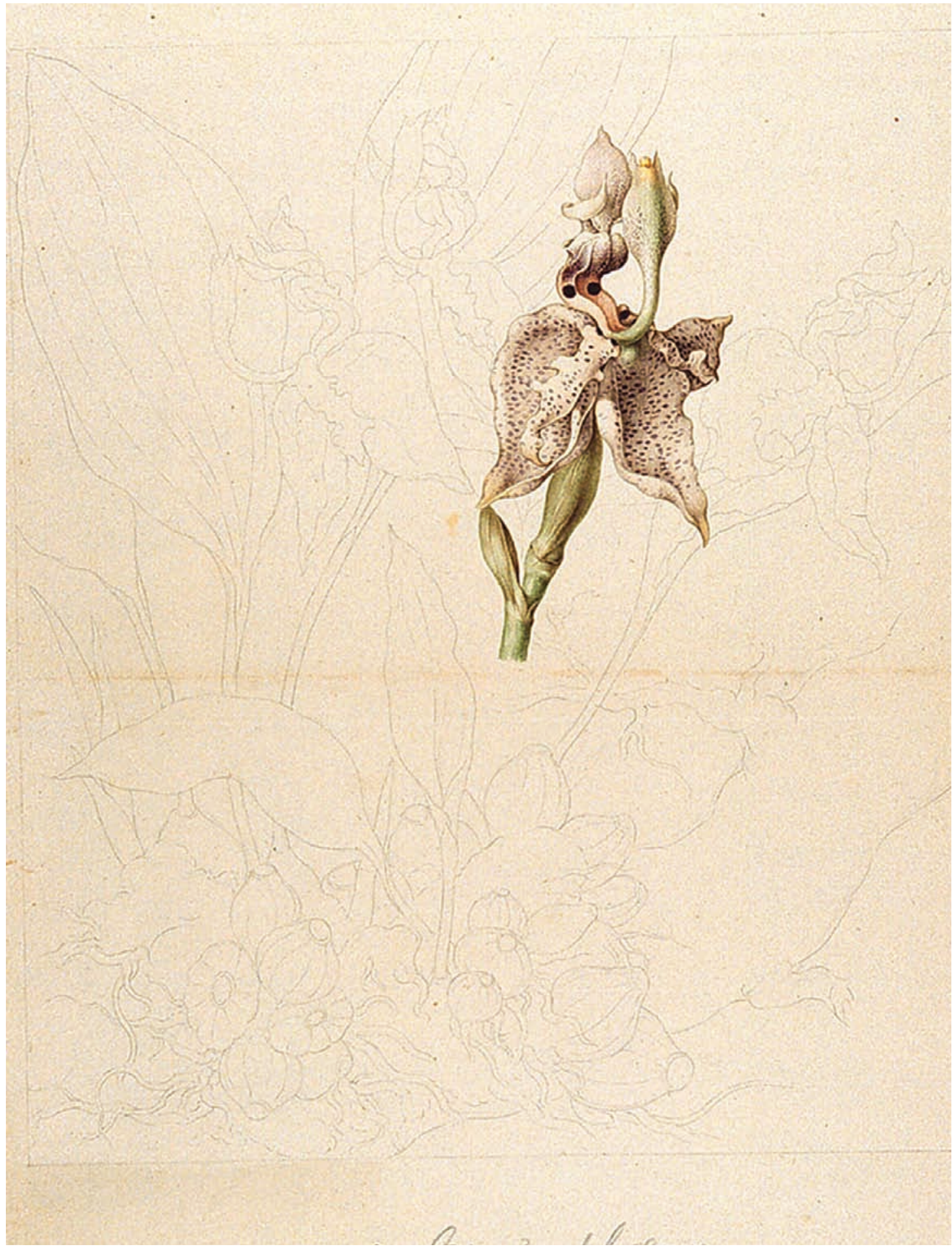

FiguRE 16. Stanhopea oculata (Lodd.) Lindl. No. 0164 of the illustrations of the expedition of Sessé and Mociño in the Torner Collection. Hunt Institute for Botanical Documentation. 


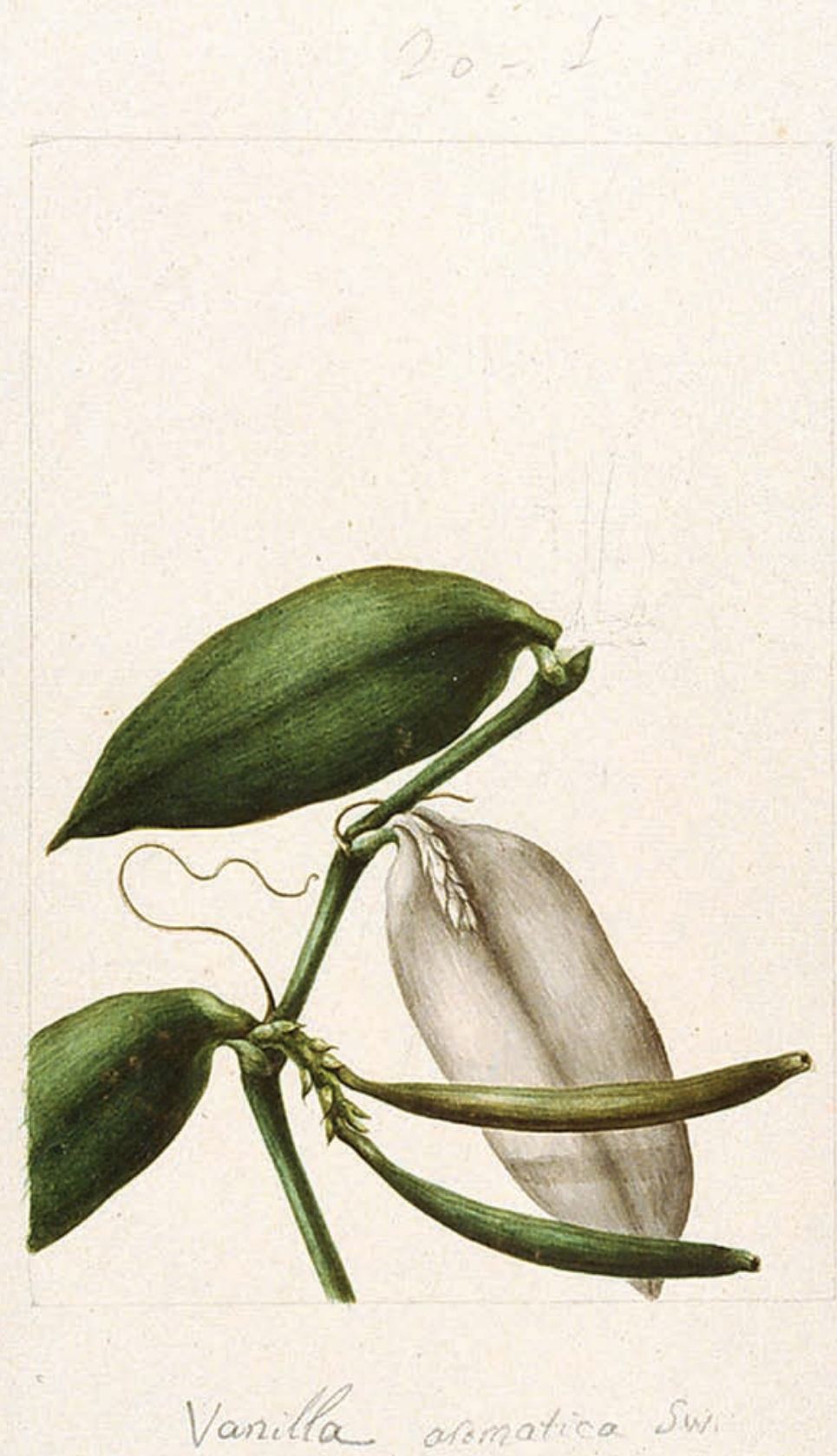

Figure 17. Vanilla pompona Schiede. No. 0483 of the illustrations of the expedition of Sessé and Mociño in the Torner Collection. Hunt Institute for Botanical Documentation. 

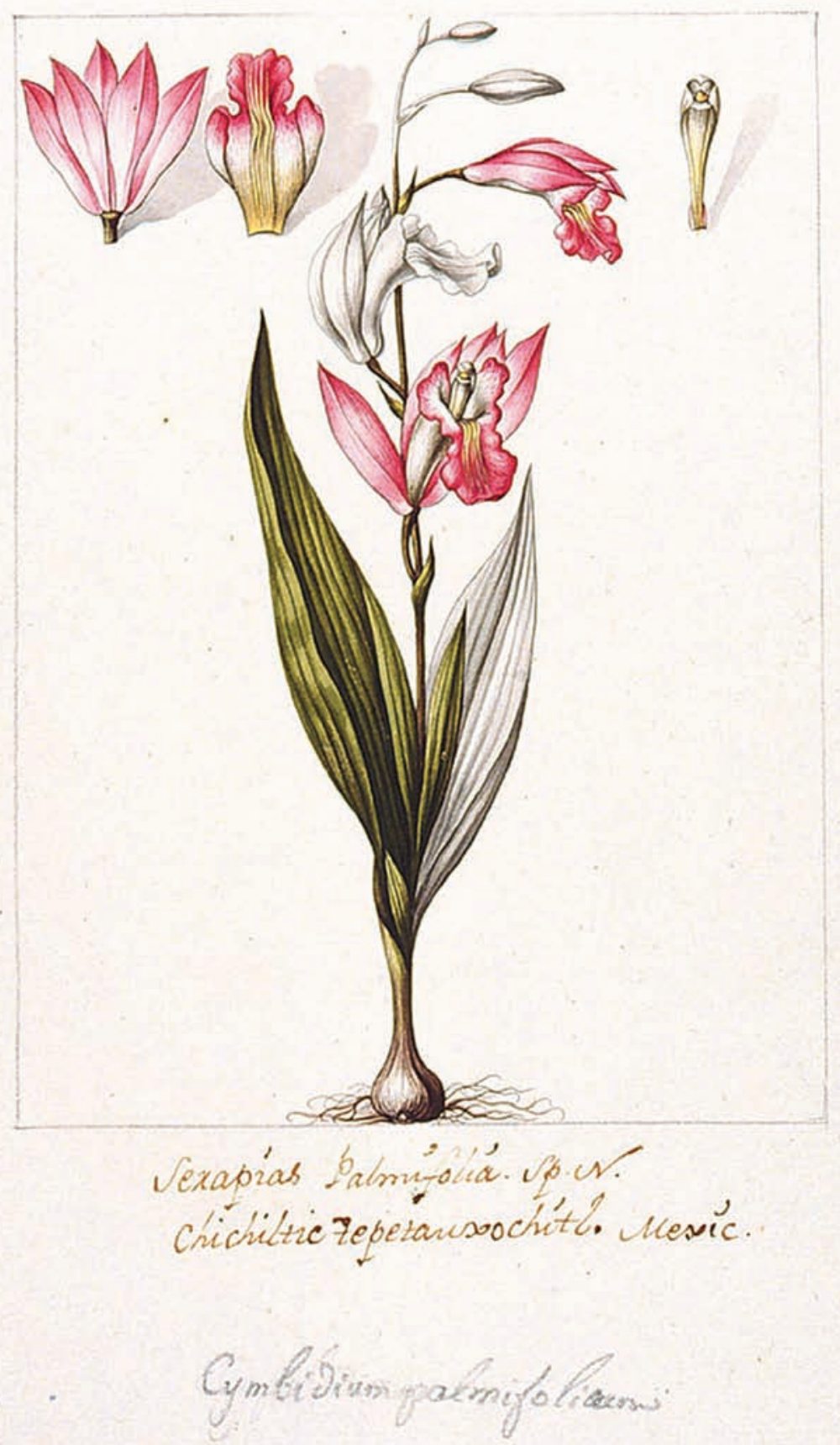

FiguRE 18. Bletia roezlii Rchb. f. $\mathrm{N}^{\circ} 0091$ of the illustrations of the expedition of Sessé and Mociño in the Torner Collection. Hunt Institute for Botanical Documentation. 

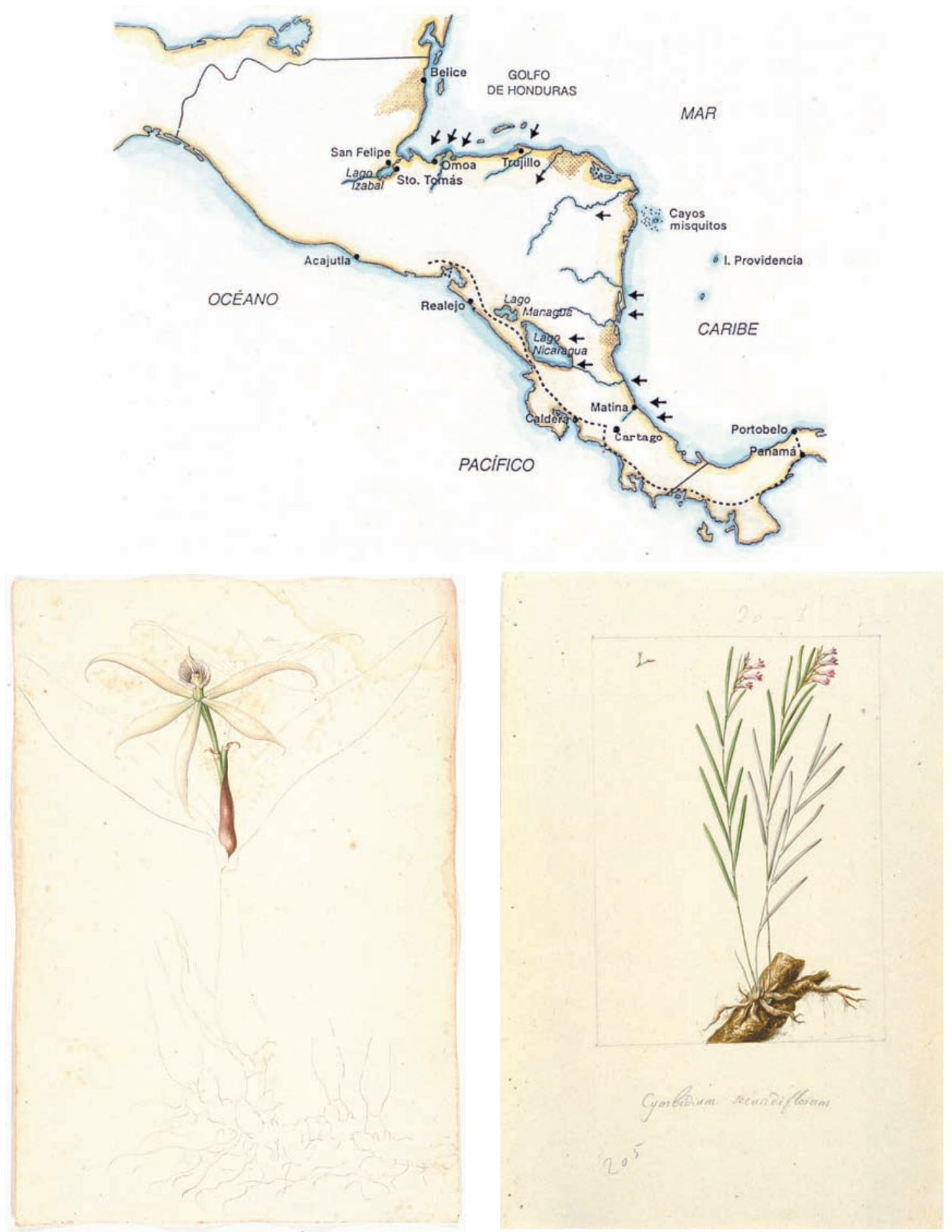

Figure 19. A - Route of Mociño and De la Cerda through Central America. In Maldonado Polo,1996: 74. B — Prosthechea baculus (Rchb. f.) W. E. Higgins. No. 1933 of the illustrations of the expedition of Sessé and Mociño in the Torner Collection. Hunt Institute for Botanical Documentation. C — Isochilus linearis (Jacq.) R. Br. No 0829, id. 
TABLE 3. Orchids collected by Mociño during the excursion of 1793-94 (From McVaugh, 2000: 408-424). Not included are the unidentified species.

\begin{tabular}{l|l|l}
\hline Name used by Sessé and Mociño & Botanical name that is valid today & Locality of collection \\
\hline Epidendrum acuminatum & Prosthechea baculus (Rchb. f.) W. E. Higgins & San Andrés Tuxtla \\
\hline Epidendrum capitatum & Elleanthus cynarocephalus (Rchb. f.) Rchb. f. & Volcán de San Martín, Tuxtla \\
\hline Epidendrum cornutum & Stanhopea oculata (Lodd.) Lindl. & Orizaba, Veracruz \\
\hline Epidendrum ellipticum & Cranichis sylvatica A. Rich. \& Gal. & San Andrés, Tuxtla \\
\hline Epidendrum emarginatum & Pleurothallis tubata (?) (Lodd.) Steud. & Acayucán \\
\hline Epidendrum guttatum & Oncidium lankesteri Ames & Córdoba, Veracruz \\
\hline Epidendrum lamellatum & Corallorrhiza macrantha Schltr. & Orizaba, Veracruz \\
\hline Epidendrum lineare & Isochilus linearis (Jacq.) R. Br. & San Andrés, Tuxtla \\
\hline Epidendrum nutans & Nidema boothii (Lindl.) Schltr. & Córdoba, Veracruz \\
\hline Epidendrum paniculatum & Epidendrum diffusum Sw. & Córdoba, Veracruz \\
\hline Epidendrum pulchellum & Encyclia pterocarpa (Lindl.) Dressler & San Andrés, Tuxtla \\
\hline Epidendrum pusillum & Erycina pusilla (L.) N. H. Williams \& M. W. Chase & Veracruz \\
\hline \begin{tabular}{l} 
Epidendrum tigrinum \\
\hline Epidendrum vanilla
\end{tabular} & Epidendrum raniferum Lindl. & Papantla, Veracruz \\
\hline Orchis pauciflora & Vanilla pompona Schiede & Córdoba, Veracruz \\
\hline
\end{tabular}

The expedition split in two and in May, 1795, a first group at the command of Sessé sailed from Veracruz to explore the islands of Cuba, Santo Domingo and Puerto Rico. The second group, lead by Mociño, departed in June of the same year from Mexico on a southern route. Another of the scientists, José Longinos Martínez, started a few days before and arrived in Guatemala before Mociño, who encountered multiple delays during his trip. Mociño and De la Cerda finally arrived in Guatemala in October, 1796. In the first days of the year 1797, Mociño and De la Cerda initiated in Guatemala a long journey, exploring during the next two years the Pacific Coast belt of Central America. Their route would take them through El Salvador, Honduras and Nicaragua, reaching finally Cartago, in Costa Rica. The route from the capital of Guatemala to Nicaragua was called the "passage of Nicaragua" and passed through Cartago, from where it continued to Panama. Mociño and De la Cerda kept always, except for small variations, to this route by way of Ahuachapán, Sonsonate, San Salvador, Cojutepeque, San Vicente, Zacatecoluca, San Miguel and Conchalagua, all towns in the territory of El Salvador. Then, bordering the Gulf of Fonseca, they traveled through Choluteca in Honduras until they arrived in Nicaragua. Following the same route along the coast, they were in El Viejo, Realejo, Chinandega, León, Nagarote, Mateare and Managua. From this last city they directed themselves to the Lake of Nicaragua, bordering it along its southwestern margin and crossing to the island of Ometepe, passing later through Masaya and Granada, and arriving finally in the town of Nicaragua (afterwards named Rivas) (Taracena, 1983) (Fig. 19, A). Vegetal specimens from the Gulf of Nicoya and Cartago have been identified, allowing the assumption that the expedition, or part of it, continued its route further to the south. The return journey followed the same route, and the expeditionaries arrived back in Guatemala at the end of March, 1798, after having survived the earthquake of San Salvador, in February of the same year.

The most important botanical result of the expedition to Central America is the manuscript of the Flora de Guatemala, that Mociño intended to publish later together with the Flora de México. Although the results may seem meager, the relatively low number of species described in the manuscript (a total of 526) may obey to the fact that the botanists, in 
TABLE 4. Orchids included in the Flora of Guatemala of Mociño.

\begin{tabular}{l|l|l}
\hline Name used by Mociño (genus) & Name used by Mociño (species) & Botanical name valid today \\
\hline Serapias & $\begin{array}{l}\text { "Serapias bulbis ovatis, compressis, } \\
\text { foliis ensiformibus, nectarii labio } \\
\text { trifido; lacinia intermedia rugosa } \\
\text { glandulosa" }\end{array}$ & $?$ \\
\hline Epidendrum & emarginatum & Pleurothallis tubata (?) (Lodd.) Steud. \\
\hline & acuminatum & Prosthechea baculus (Rchb. f.) W. E. Higgins \\
\hline & pusillum & Erycina pusilla (L.) N. H. Williams \& M. W. Chase \\
\hline & viridiflorum & $?$ \\
\hline & veracrucense & $?$ \\
\hline & nervosum & $?$ \\
\hline & ellipticum & Cranichis sylvatica A. Rich. \& Gal. \\
\hline
\end{tabular}

this case Mociño, only treated new species that they found on their way, not mentioning those previously found during the earlier excursions. "Of strong influence must have been also the fact that the Central American territories where less explored from the botanical standpoint than other regions of New Spain, at least less well known to the European explorers in the XVIII and the preceding centuries, that impeded their [the plants'] identification and knowledge. Thus, many plants where stored and not included in the list" (Maldonado Polo, 1996: 121-122).

McVaugh warns: "Botanists of the future, if working with the collections of Sessé and Mociño... will do well to remember, however, that any individual specimens of unknown origin may have been collected in Guatemala, in El Salvador, in Nicaragua or even in Costa Rica" (McVaugh, 1977: 49). No trace is left from the drawings made for the Flora de Guatemala, most of them having been destroyed in the earthquake of San Salvador of 1798. Notwithstanding, this work can however be considered as the first modern flora of Central America. The number of orchids described in this flora is pitifully small, and no locality of collection is indicated for any of them. A total of two genera and 10 species are described (Tab. 4; Fig. 19, B-C).

The authorized term for the extension of the expedition expired and it was not until May, 1798, that Sessé returned to the Mexican capital. Mociño did the same in February, 1799. New hindrances, particularly the war with England, delayed the return of the expeditionaries to Spain, that finally took place in 1803 .

The last months of the expedition in Mexico coincided with the arrival of Alexander von Humboldt in the capital of New Spain, in April, 1803. Although the name of von Humboldt is not directly relevant to us (his collections lie all outside of our area of study), it is interesting to note that both Mociño and Cervantes met the great German naturalist, before the departure of Mociño to Cádiz, in June of that year. After their encounter Humboldt wrote: "MM. Cervantes, Sessé et Mocino nous feront connoitre sous peu la flore de ce pays; mais sur un terrain aussi immense la nature est pour ainsi dire inépuisable, et nous possédons sans doute plusieurs végétaux mexicains qui ont échappé á la sagacité de ces botanistes" (= Messrs. Cervantes, Sessé and Mociño made known to us in a short time the flora of that country; but in such an immense territory nature is -we could say-inexhaustible, and we possess without doubt several Mexican vegetables which have escaped the sagacity of these botanists) (Humboldt \& Bonpland 1808: iii).

The material collected by the expedition arrived in Spain during days of great political convulsion. Mociño was made responsible for publishing the results of the expeditions to Mexico, Guatemala, California and the Windward Islands. To do so he 
was given the help of the Mexican Pablo La Llave (1773-1833) (González Bueno \& Rodríguez Nozal, R., 2006: 173) But the wartime situation in which Spain found itself did not favor the project. The main part of the collections (particularly the herbarium) came to the "Botanical Office"15 controlled by Pavón, especially after the forced exile of Mociño to France in 1813, accused of collaborating with the French occupation forces. The attempts by Sessé and Mociño to publish a Mexican flora never bore fruit (Fig. 20A). Between herbarium specimens and botanical drawings made during the expedition, we are left with a total of 136 species of Orchidaceae. In many cases the species have not been identified. In others there is no information about the locality of collection, so that we can not be sure if they belong to our area of study.

In spite of the circumstances that prevented the publication of the scientific results, there is no doubt that the Royal Botanical Expedition to New Spain is a milestone in the history of our orchids.

\section{The dispersal of the botanical collections}

"Misfortunes always pursue men of genius" Miguel de Cervantes, Don Quixote

Pavón, starting in 1814, and in charge of the Botanical Office, began to handle the collections as if they were his own, selling specimens of the herbarium of the expedition to New Spain and duplicates of that of the flora of Peru and Chile, so squandering the funds which were under his care. In the meantime, in England, the opulent botanist Aylmer Bourke Lambert (1761-1842) (Fig. 20B) was named in 1798 as one of the first members of the Linnean Society. A passionate collector, Lambert amassed, through tenacity and wealth, a large library and one of the most important herbaria of his time. We do not know how Lambert got notice of Pavón's dealings, but we know that between 1814 and until 1825 Pavón sold to him more than 15,000 botanical and zoological specimens that were kept at the Botanical Office in Madrid.

But Lambert was not the only one to receive materials from Pavón. As an example, let us mention the almost 5,000 specimens which Philip Baker Webb received between 1826 y 1827 , that today form part of the herbarium of the Botanical Institute of Florence, as part of a legacy from Webb to the Duke of Tuscany (Fig. 20C).

John Lindley and the Lambert herbarium. Pavón's conduct does not admit excuses. But if we look at this case from a practical point of view, the sale of the herbarium specimens of the expedition was perhaps the best way to bring the botanical richness of New Spain into the hands of the botanists of those times (although this was surely not the motive of Pavón). The main herbarium that was conserved at the Royal Botanical Garden in Madrid (probably with about half of the original number of specimens) was not unpacked until 1930. The specimens were numbered and sent on loan to Chicago where, between 1936 and 1964, all were identified and photographed, before being returned to Madrid (McVaugh, 2000: 1). In other words: all specimens that were not sold by Pavón had to wait over 140 years before they could be studied!

Generous with his colleagues and friends, Lambert always gave them free use of his library and herbarium. In this manner the great John Lindley (1799-1865) (Fig. 21A) was able to study and identify many of the specimens that came from Madrid. In his monumental work The Genera and Species of Orchidaceous Plants (1830-40) Lindley mentions a total of 12 species based on material that had been sold by Pavón to Lambert.In all of his descriptions we find the following note by Lindley 'Hab. in Mexico; Pavon, (exam. s. sp. in Herb. Lambert)'. This note was the reason why Pavón was considered, for many years, the collector of this species, forgetting that he had never been to Mexico. Two of the species described by Lindley (Epidendrum fruticosum $\mathrm{y}$ Epidendrum radicans) have, as the name of their author, 'Pavon ex Lindl.' This indicates that Lindley respected an epithet that had already been suggested by Pavón (Fig. 21B).

\section{Augustin De Candolle and the "Ladies of Geneva"} The 2,000 illustrations of the botanical expedition to New Spain went a different way. Mociño marched

\footnotetext{
${ }^{15}$ The Botanical Office ("Oficina Botánica”), located in Madrid as a dependence of the Ministry of Justice of the Indies, was conceived as a State Center for the study and publication of the American flora.
} 
TABLE 5. Species described by Lindley based on specimens in the Lambert herbarium that had been bought from Pavón.

\begin{tabular}{l|l}
\hline Name given by Lindley & Botanical name that is valid today \\
\hline Epidendrum bidentatum Lindl. & Encyclia bidentata (Lindl.) Hágs. \& Soto Arenas \\
Epidendrum floribundum H. B. K. & Epidendrum paniculatum Ruiz \& Pavón \\
Epidendrum fruticosum Pavon ex Lindl. & Epidendrum fruticosum Pavon ex Lindl. \\
Epidendrum polyanthum Lindl. & Epidendrum polyanthum Lindl. \\
Epidendrum radicans Pavon ex Lindl. & Epidendrum radicans Pavon ex Lindl. \\
Epidendrum raniferum Lindl. & Epidendrum raniferum Lindl. \\
Epidendrum vitellinum Lindl. & Prosthechea vitellina (Lindl.) W. E. Higgins \\
Eucnemis brevilabris Lindl. & Govenia liliacea (Lex.) Lindl. \\
Oncidium funereum Lindl. & Oncidium reflexum Lindl. \\
Oncidium pauciflorum Lindl. & Oncidium pauciflorum Lindl. \\
Ponera juncifolia Lindl. & Ponera juncifolia Lindl. \\
Stanhopea bucephalus Lindl. & Stanhopea oculata (Lodd.) Lindl.
\end{tabular}

with them to his exile in Montpellier, where he met the Swiss botanist Augustin Pyramus De Candolle (1778-1841) (Fig. 21C), who was impressed by the quality of the work. A short time later Mociño, who seemed to have lost all hopes of returning to Spain, gave the drawings and the manuscripts of the Flora Mexicana to De Candolle, who took them with him in 1816 to Geneva. Six months later, in April, 1817, he received a letter from Mociño, who was still in Montpellier, letting him know that he had received permission to return to Spain, and asking him to return the collections. Honest until his last days, Mociño dared not to go back without the drawings: they belonged to the Crown (McVaugh, 1998).

With the help of more than 120 volunteers, most of them ladies of Geneva's high society, De Candolle managed to copy almost 1,200 plates in only 10 days. Together with 300 duplicates, that were a gift from Mociño, he formed a collection of 13 bound volumes known today as the Flora of the Ladies of Geneva. Many species discovered during the expedition to New Spain could be known during the XIX century thanks to this work. Since, as we shall see later, the original drawings of Mociño disappeared from 1817 until 1981, the collection of copies and duplicates in Geneva became the only source of knowledge about the illustrations of the expedition. In De Candolle's two main works, his Regni Vegetabilis Systema Naturae (1817-1821) and his Prodomus Systematics Naturales Regni Vegetabilis (1824-1873, completed by his son
Alphonse), more than 300 species of plants were described based on the drawings of the expedition. Encyclia candollei (Lindl.) Schltr. was dedicated to De Candolle. Apparently only 10 species of orchids were copied. Most of them have been identified to date, although -again- we can not be certain that they belong to our area of study, since no localities of collection are indicated. The originals of six of these copies are still preserved in the Torner Collection of the Hunt Institute.

With the recovered collections, Mociño returned to Spain, where the illustrations disappeared after his death. In 1981 they were discovered by the

TABLE 6. Orchidaceae in the "Flora of the Ladies of Geneva" (Torner: Number of the original drawing in the collection of the Hunt Institute; Icones: original number assigned by Sessé y Mociño; DC: Number assigned by De Candolle).

\begin{tabular}{l|c|c|c}
\hline Botanical name & Torner & Icones & DC \\
\hline Bletia roezli & 0091 & 258 & 1196 \\
Cypripedium irapeanum & 1112 & 294 & 1225 \\
Encyclia lancifolia & 0370 & 253 & 1225 \\
Prosthechea radiata & & 253 & 1190 \\
Govenia sp. & & 258 & 1196 \\
Malaxis carnosa & 0218 & 175 & 1219 \\
Malaxis unifolia & 0219 & 176 & $1219 *$ \\
Spiranthes cinnabarina & & 174 & 1221 \\
Sacoila lanceolata & & 173 & 1220 \\
Stenorrhynchos aurantiacus & 1751 & 174 & 1221 \\
\hline
\end{tabular}




\section{PLANTAENOUAEHISPANIAE NUTU, OPE,ET AUSPICIO BENIGNISSIMI RECIS CAROLIIN.} HICUSOUE: COIECTAE,ETINNEANO SSTEMATE ORDINADF; QUARUM TERCENTAE. AUT PURES

A NEMINE VNGUAN EDTTAE VIDENTUR, ET RARIORES ICONIJUS AD VIVUM REPRAFSENTANTUR.

A

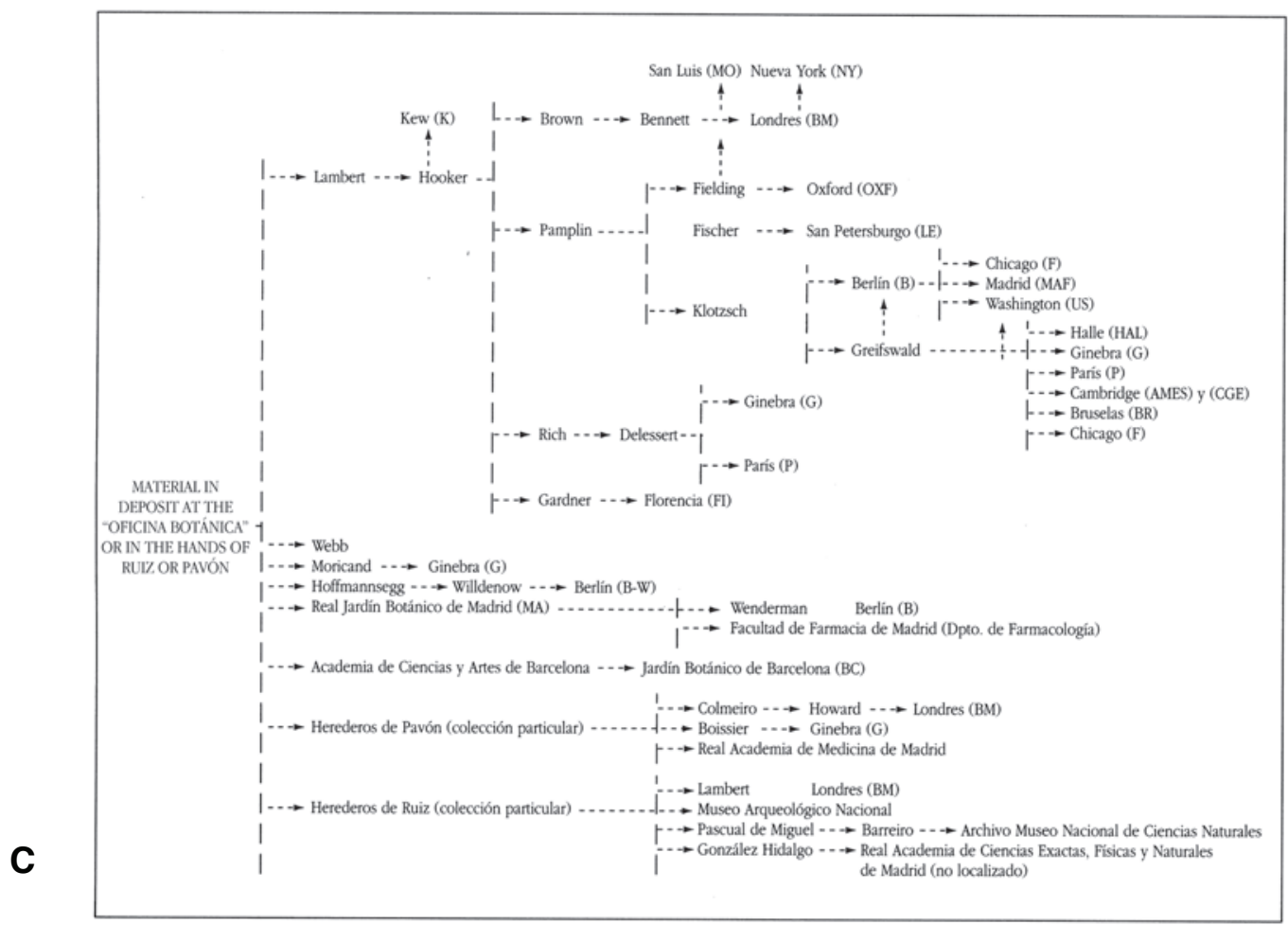

Figure 20. A - Front cover of Mociño's unpublished manuscript for the Flora of New Spain. San Pío Aladrén, 2005: 72. B Aylmer Bourke Lambert (1761-1842). Courtesy of the Oakes Ames Herbarium, Harvard University. C — Dispersal of the botanical collections proceeding from the expeditions to Peru and New Spain. San Pío Aladrén \& Puig-Samper, 2000: 11. 
A
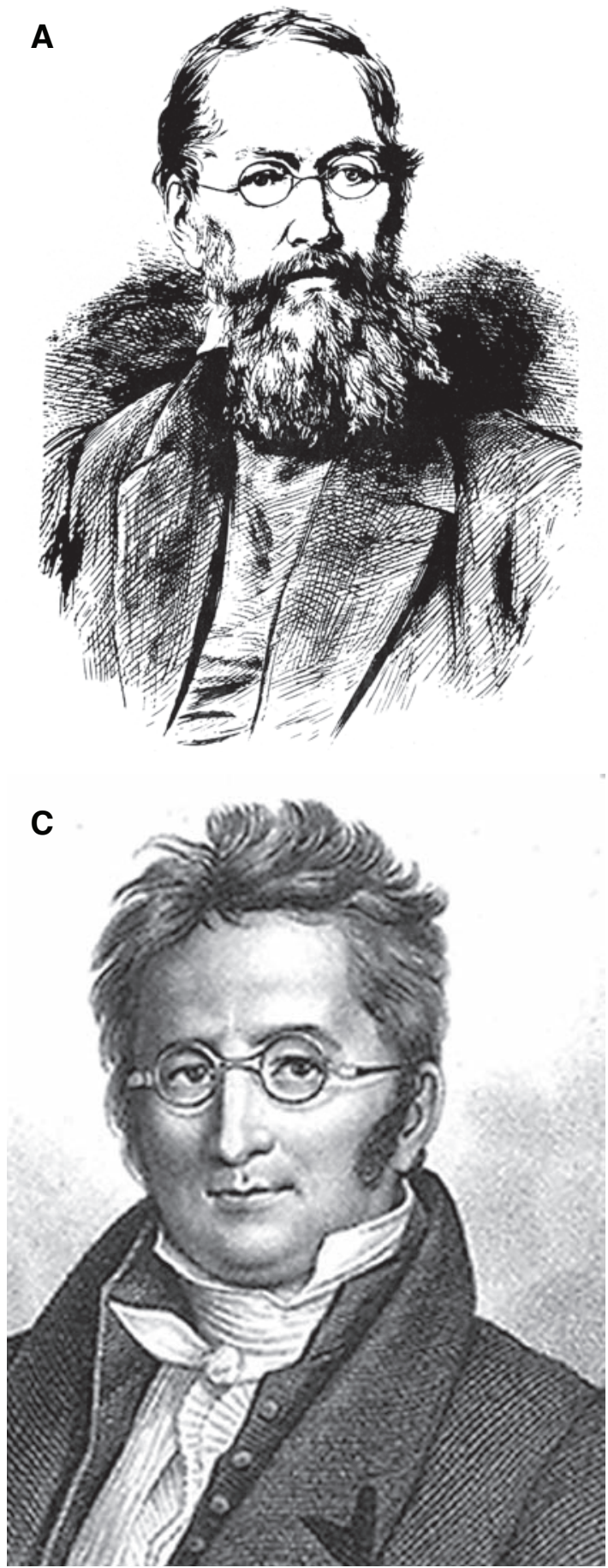

B
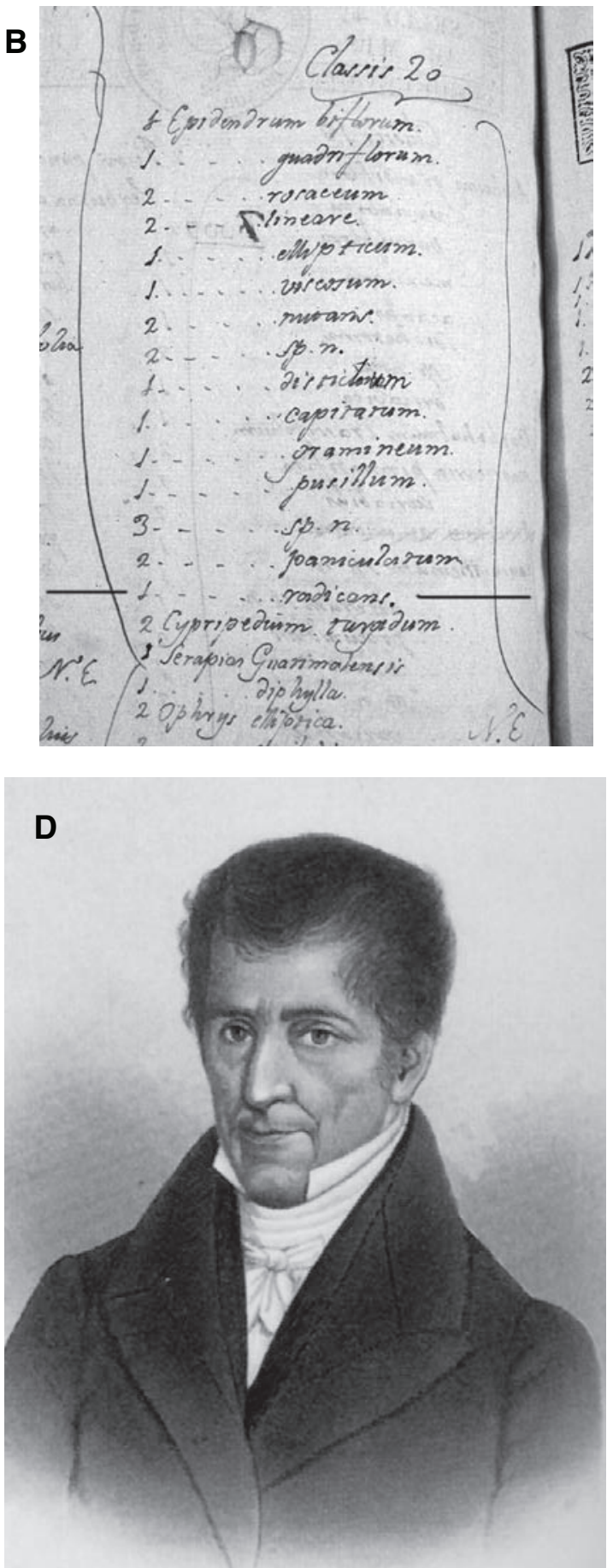

Figure 21. A — John Lindley (1799-1865). From a contemporary etching. In Orquídea (Mex.), June 1975: 90. B — Copy of a page of the list of specimens sent by Pavón to Lambert, where the epithet radicans was used for the the first time. Courtesy of the British Museum of Natural History and of Henry Oakeley. C - Augustin Pyramus De Candolle (1778-1841). Courtesy of the Oakes Ames Herbarium, Harvard University. D — José Cecilio del Valle (1777-1834). Hall \& Pérez Brignoli, 2001: 168. 
Hunt Institute for Botanical Documentation of Pittsburgh, Pennsylvania, in the private library of the Torner family in Barcelona, and acquired for the ridiculous sum of 2,000 pesetas (ca. \$12) for each illustration. As had happened 160 years earlier with the herbarium specimens, the illustrations of the expedition of Sessé and Mociño went abroad under the accommodating eyes of the Spanish government.

Poor and sick, Mociño died in Barcelona in 1820. His friend, the Spanish botanist Mariano Lagasca, wrote in November of the same year to De Candolle: "Mociño noster sex abhinc mensibus e vita discessit in urbe Barcinonensi ... Vir certe melioris fortunae dignus" (McVaugh, 1998).

The history of the expedition to New Spain does not have a happy end: Sessé in 1808 and Mociño in 1820, died without fulfilling their dream of publishing the floras of Mexico and Guatemala. Lambert died in 1842 and the provision in his will that his herbarium should be kept intact was not obeyed. His collections were auctioned in separate lots and dispersed all over the world (Anonymous, 1842). An important part of the materials that Pavón had sold to Lambert passed into the hands of the British Museum of Natural History, where they still remain. Another significant portion is today in Geneva. Pavón was finally asked to account for his acts in 1831 and three years later the Board of the Science Museum of Madrid suspended him from his salary. A sad guardian of the treasures brought from America by the botanical expeditions of the latter XVIII century, he died in disgrace in 1840 .

Mariano de la Paz wrote these words in reference to the collections of the Spanish expedition of 1862 to the Pacific ${ }^{16}$, words that are valid for practically all materials that came to Spain as a product of the great expeditions of the Century of Light: "These precious collections, brought together at so much effort, await, as many others of similar origin which have been neglected for years in the limbus of Science, the doubtful arrival of a naturalist savoir, who will glorify their authors, bringing them to light, if moths and ants did not get to them first" (Real Jardín Botánico de Madrid,1989: 97).

\section{The Cabinet of Natural History of Guatemala.}

Aside from its scientific achievements, the Royal Botanical Expedition to New Spain, bearer of the ideas and ideals of the Enlightenment, had a strong influence on the social and political environment of Central America in the last years of the XVIII century.

The Royal Economical Society of Friends of the Country of Guatemala was founded in 1795 , as a result of the new ideas that were slowly imposing themselves upon the colony. Life in the capital of Guatemala went on in this ambience of reforms, in the last years of the XVIII century, when the expedition arrived, proceeding from the largest and most advanced city in America, which was the capital of Mexico" (Maldonado Polo,1996: 78-79). Longinos Martínez established contacts to the Society, that had among its priorities the development of natural history.

In December 1796, and due to the efforts of Longinos Martínez, the Cabinet of Natural History of Guatemala was solemnly inaugurated, with the presence of the prominence and high authorities of the Captaincy General. As we will see, the presence this day of José Cecilio del Valle (1777-1834) (Fig. 21C) was of extraordinary importance. During the inauguration, the museum of natural history opened its doors to the public and the first pupils were tested: Pascasio Ortiz de Letona and Mariano Antonio de Larrave. Mociño and Longinos Martínez shared their knowledge, carrying out the first physical and chemical analysis of the drinking water in the area around the city.

Although the Society was prohibited in 1799 , its ideas prevailed. And it is no coincidence that it was Del Valle who drafted, twenty two years later, the declaration of independence of the Captaincy General, that was signed in Guatemala on September 15, 1821, and that we find the name of Mariano Larrave amongst those who signed it.

At the end of this period we must mention what was perhaps the best posthumous homage that Mociño received: that of his friend Pablo La Llave, who in 1832 designated the resplendent quetzal, the mythical bird of freedom in Central America since prehispanic times, with the name of Pharomachrus mocinno.

${ }^{16}$ The "Spanish Scientific Commission of the Voyage to the Pacific (1862-1866)" explored mainly South America, with the exception of a short visit to Taboga Island (Panama), from where no collections of Orchidaceae are recorded. 


\section{THE NEW REPUbLICS}

By the law of the seas and the distances, America can only belong to itself"

Fray Servando Teresa de Mier (1811)

Times of change. After independence in 1821, the Central American republics joined the ephemeral Mexican empire of Agustín de Iturbide. The Central American Federation was constituted in 1825, under the name of United Provinces of the Center of America. Mexico became a federal republic in 1824, under the name of the United Mexican States.

In those confusing times, the spirit of Enlightenment remained present for a short period of time. "On October 5, 1825 [José Cecilio del Valle] addressed a letter to the Secretary of the Supreme Government proposing an expedition, financed by European and Guatemalan investors. He even proposed that Alexander von Humboldt should come back to America, suggesting he start with the Central American regions. The German never came back, but a large number of botanists started exploring the area during the XIX and XX centuries" (Brading, 1991: 639).

In Mexico, Juan Martínez de Lexarza (1785-1824), Pablo de La Llave (1773-1833) and Vicente Cervantes (1755-1829) continued the work started by Sessé and Mociño, of whose expedition Cervantes had been a member. A word about Cervantes: such was his prestige in Mexico, where he held the chair of Botany, that the Mexican government, although he was a Spaniard, maintained him in his position after independence. He directed the Chair and the Botanical Garden until his death, and was also in charge of the pharmacy of the Hospital of San Andres, where he set up an excellent chemical laboratory. Cervantes was a brilliant investigator of the Mexican flora and described many new species. He kept a close scientific relationship with Antonio José Cavanilles, the great Spanish botanist, to whom he sent large amounts of material, and had also connections with Alexander von Humboldt and Aimé Bonpland, whose friendship he had made during their stay in Mexico. William Bullock, who arrived in Mexico in 1823, visited the Botanical Garden and praised its beauty and the perfection with which the plants were kept. He met Professor Cervantes and was thankful for receiving a total of 31 plants, for which Cervantes provided the botanical names. No orchids are found in this list (Bullock, 1825: 147-152).
Lexarza's work, Novorum Vegetabilium Descriptiones, was published in 1824-1825. One hundred species where described, in conjunction with La Llave and Cervantes, as new to science. The Orchidianum Opusculum that appeared in the second fascicle of 1825 includes the descriptions of 50 new species of Orchidaceae distributed in 20 genera, of which 4 proved to be new. Lexarza proposed here a new classification of orchids, based on an analysis of their seeds and pollen.

"Lexarza gave promise of making an accomplished botanist, but he attempted too much and was cut off young. Several of his orchids have not been identified in consequence of their descriptions being imperfect" (Hemsley, 1887: 122). The Mexican state of Michoacán, where most of the plants described in the Novorum Vegetabilium Descriptiones were collected, lies outside of our limits. It is therefore not clear if Lexarza should be included in this story. However, there are evidences that he, or La Llave (or both) collected plants from other families in the area of Veracruz, many of which can also be found in other regions of Central America.

The following species, among others, were dedicated to Lexarza: Cypripedium lexarzae Scheidw., Macroclinium lexarzanum (Hágs. \& González) Dodson, Maxillaria lexarzana Soto Arenas \& Cabrera and Notylia lexarzana Hágs. \& González. On the other hand, La Llave is remembered in Epidendrum llavei Steud. and Schiedeella llaveana Schltr. And both honored their friend Cervantes with Rhynchostele cervantesii (La Llave \& Lex.) Soto Arenas \& Salazar. The works of Lexarza, De La Llave and Cervantes are the last examples of 'Spanish botany' in Central America. It does not surprise us therefore, that many of their collections went the same way as those of the great Spanish expeditions of the preceding century and ended up lost in the hands of Spanish bureaucracy.

In 1836, Joaquín Velásquez, assigned to the Mexican Legation in Rome, brought with him a small collection of dried plants and seeds collected in Guatemala, which formed the basis of the Florula Guatimalensis (1840) of Antonio Bertoloni (1775-1869) although no species of Orchidaceae are mentioned in this work. Bertoloni was the most important Italian botanist of his time and was also interested in exotic plants that he received from his friends. His collections of samples are kept in 
the archives of the Botanic Garden of Bologna.

Those were times of change. The Central American Federation was dissolved in 1838 . While the newly born Central American nations took their first steps in republican life, other powers, particularly Great Britain and the United States, sharpened their weapons to fill the void left by Spain. "All Europe is now, after those immense territories were opened, occupied with commercial speculations in those directions" (Schott, F., Preface by the translator in Bullock, 1825: vi).

Central American society, overwhelmed with political, economical and social problems of great magnitude, could not find time or resources for the development of the natural sciences. As Wells wrote in 1857: "Since their separation from the Spanish authority, the Central American States have been, with brief intervals, a sorrow example to all lovers of republican institutions. The experiment of selfgovernment has proved to be a pitiful failure, after thirty years of revolutions and exhausting wars" (Wells, 1857: 419). In fact, with the notable exception of the trio formed by Martínez de Lexarza, de La Llave and Cervantes, we can not talk about a national science in Central America until the last quarter of the XIX century. The scientific discovery of the natural richness of the region was left in hands of foreign explorers, collectors and travelers, who would soon start arriving at its shores.

\section{Orchidomania}

“... it was neither to provide us with food or raiment, nor to protect us from disease or cold, that tropical forests were made to teem with an almost endless variety of the tribe [Orchidaceae]: either, therefore, in the cheerless spirit of atheism, we must suppose them to have been created in vain, or we must conclude that their office was something other and higher than to minister to the mere animal necessities of our nature. No; it was to yield us a pleasure of an intellectual kind, and so to win our affections from more hurtful things, that these most worthless of plants were clothed in unrivalled charms; - it was to provide a rich banquet in the temple of Flora, which, while it yielded the utmost enjoyment to her most constant votaries, might, at the same time, draw round her innocent table those who were more rarely numbered among her guests; an entertainment, in short, which might attract the man of pleasure by its splendour, the virtuoso by its rarity, and the man of science by its novelty and extraordinary character. It is, we are convinced, on this principle alone that we can attempt to understand the 'Orchido-Mania', which now pervades all (and especially the upper) classes, to such a marvellous extent. Not contented with the exertions of our foreign connexions, we send men expressly to all the points of the compass, to swell the number of the species in cultivation; and in this zeal for their introduction, the amateur, the nurseryman, and the public establishment, all vie with each other. The nobility, the clergy, those engaged in the learned professions or in the pursuits of commerce, seem alike unable to resist the influence of the prevailing passion; nay, if we may trust a paragraph in a morning paper, it has even extended to Windsor Castle itself."

James Bateman, in the introduction to

Orchidaceae of Mexico and Guatemala (1843)

Around the same time that Pavón was dealing with Lambert and selling the botanical samples of the Royal Spanish expeditions, enthusiasm for orchids increased in England. "Exotic orchids arrived in Europe at a propitious moment, an epoch pulsing with an appetite and admiration for exotic flora. They represented the fascination and loveliness of far-off lands that were fast coming closer as colonialists built up the great empires of the nineteenth century. It was in such conquered territories that orchids were uprooted or stripped from trees and rocks, beginning their long journey to hothouses and herbaria" (Berliochii, 2000: 57-58).

The Royal Horticultural Society was founded in 1804 by Sir Joseph Banks (1743-1820) and a few years later started sending out collectors to the tropical regions (Fig. 22A). In 1812, Joachim Conrad Loddiges (1738-1821), was becoming fairly successful in cultivating the 'Epidendrums' or 'air plants', as nearly all the epiphytic species were termed, and increasing numbers of their plants began appearing at the newly established horticultural exhibitions" (Reinikka, 1995: 26). The nurseries of Loddiges in Hackney, managed after his death by his son George (1784-1846), signaled 
the beginnings of commercial orchid cultivation, and many plants grown by Loddiges became the types for new species, described chiefly by Lindley in Edwards' Botanical Register.

Through its expanding collection of tropical plants, the Royal Horticultural Society contributed to the popularization of the orchids among the wealthy classes. The fashion of growing orchids as a hobby had its real beginning in 1833 when William Spencer Cavendish, sixth Duke of Devonshire, discovered a plant of Oncidium papilio at one of the aforementioned exhibitions (Fig. 22B).

"A number of commercial nurseries found it highly profitable to supply the demand for new species, and several hired collectors to travel into the tropical areas of the world where they might locate new sources of species that had already become horticulturally popular - and to collect new species which might stimulate further interest and profit" (Reinikka, 1995: 27). A new breed of adventurers started exploring the tropics in search of new species. The mania for possessing orchids raised the prices of all available plants. Great auctions were held in London and Liverpool where prices of one hundred pounds for a single plant were not unusual. "This is the epic phase in the orchid's history, written in the sweat and blood of a group of adventurers and explorers - the hunters of wild flowers that could sometimes prove every bit as dangerous as their animal counterparts" (Berliocchi, 200: 59-60) (Fig. 22C).

The invention, in about 1829, of the "Wardian case", by Dr. Nathaniel Bagshaw Ward unleashed a revolution in the mobility of commercially important plants. Dr. Ward was a physician with a passion for botany who accidentally discovered that fern spores were germinating and growing in a bit of soil inside of a bottle, thus protected from the contamination of the outside air. Ward communicated his discovery to George Loddiges, who had a carpenter build him closely-fitted glazed wooden cases. The first "Wardian cases" were shipped to Australia in 1833, filled with British ferns and grasses, and after a voyage of several months the plants were found still in good condition (Gómez, 2007: 481-482). Wardian cases soon became features of stylish drawings rooms in Western Europe and the United States. In the polluted air of Victorian cities, the fern craze and the craze for growing orchids that followed owed much of their impetus to the new Wardian cases.

By 1834, 'orchidomania' had spread throughout England. But orchid cultivation also flourished elsewhere. M. Pescatore, of St. Cloud, near Paris, was one of the first Europeans outside England to grow orchids as a leisure activity, having cultivated a large collection of plants for many years - as had Consul Schiller of Hamburg, Germany (Reinikka, 1995: 31). According to Linden, Jean-Pierre Pescatore (1793-1855) had 'la plus riche collection d'Orchidées $\mathrm{du}$ continent' (= the richest orchid collection of the Continent). Reichenbach dedicated to him the genus Pescatoria. Many personalities from other countries were instrumental also in the discovery and introduction of new species. As orchid cultivation gained in fashionability in England, horticulturists in Belgium were quick to recognize that trade in tropical and subtropical orchids could be profitable. In 1838 the passion for orchids had already extended to the United States, where John Wright Boott, of Boston, received a collection of plants sent to him from England by his brother James. Years later (ca. 1870), General John F. Rathbone, of Albany, New York, wrote: "I was so delighted with the plant and flowers that I caught the Orchid fever, which I am happy to say is now prevailing to considerable extent in this country, and which I trust will become epidemic" (Reinikka, 1995: 31).

Very soon, scientists and collectors would turn their eyes to the natural richness of Central America, thus beginning one of the most interesting periods in the history of the orchids of this region (Fig. 23A).

\section{Britannia rules the waves}

"To thee belongs the rural reign
Thy cities shall with commerce shine
All thine shall be, shall be the subject main
And every shore it circles thine."

'Rule Britannia' from Thomas Augustine Arne (1710-1788)

Orlando W. Roberts, an English merchant who arrived at the Gulf of Darién in 1816 and conducted trade with the natives of the Central American East coast during seven years, wrote an interesting account of his travels in his book Narrative of Voyages and Excursions on the East Coast and in the Interior of Central America, 
published in 1827. Roberts sailed along the coast from Panama to Cape Gracias a Dios, in Honduras, and spend considerable time with the Miskitos in Nicaragua and with the "Valientes" in Panama. His descriptions of the natives' use of cocoa and vanilla are in the chapter about The History of Vanilla. But Roberts was also important because he was one of the first travelers to explore a passage from the Atlantic to the Pacific. For this, he navigated the San Juan River to the Lake of Nicaragua, and went then on to the Pacific. In San Juan del Norte, Roberts was detained by the Spanish authorities and sentenced to death for being a spy for the independentists. Roberts escaped narrowly and was later acquitted of all charges (Fig. 23B).

Immediately after independence, the opening of commercial relations with the British created a sudden rise in business. Merchants from Belize, who had been trading illegally with Guatemala for the preceding twenty years, gained access and direct contacts to most of Central America" (Wortman, 1991: 227). Britain had prevailed in the long-lasting naval war against Spain and France between 1790 and 1815 and had almost gained a monopoly on world naval trade. The United States, whose power increased day by day, responded quickly. In 1823 president Monroe formulated the 'Monroe Doctrine', that stipulated that the American continent should not be subject to European colonization and that the United States would not tolerate European intervention. This doctrine can be resumed in the classic expression: 'America for the Americans'. It was the beginning of the fight among the powers on Central American soil, a fight that initially favored Great Britain and that only in the second half of the century would turn slowly in favor of the United States.

Burdened by great economic problems, the first federal president, Manuel José de Arce, embarked on a bold revolutionary program. The tax reform eliminated unpopular Spanish levies, but left little revenue to cover the debt assumed from the colonial and imperial governments or to pay for expensive new projects. Arce turned to British capitalists to meet the financial crisis, but a loan from the London firm of Barclay, Herring \& Richardson produced only a small amount of cash for the federation. Since the government repaid practically none of it, the loan did not place an immediate burden on the federation's finances, but the indebtedness remained for decades, providing repeated opportunities for British diplomats to negotiate favorable concessions for British economic interests" (Woodward, 1997).

Possible routes for the construction of an interoceanic canal in Central America began to be explored. "In the monumental work in which he describes his voyage to the New World from 1799 to 1804, Alexander von Humboldt names nine possible routes for an interoceanic canal and urges scientific studies in order to decide which was the most advantageous, since only incomplete studies had been done on some of them. Among these routes he names that of Nicaragua, to that he assigns the first place, and the route of Panama, that he places fourth after those of Atrato and Tehuantepec. A real comparative study between the various canal routes was not undertaken until many years later, but the Panama route was explored in 1827 by Lloyd and Falmare, in 1831 by Peacock and in 1844 by Garella; and that of Nicaragua in 1837 by Baily, in 1848 by Oersted and in 1850 by Childs. In addition to these explorations there were many projects that used information of prior surveys. Among these we can cite those of Prince Louis Napoleon in 1846, Squier in 1849 and Belly in 1858" (Montiel, 1969). Let us remember that Panama had been discovered by Christopher Columbus on his 4th trip in 1502. It was then that a canal was first envisioned by King Carlos V of Spain who ordered the very first topographic studies for the construction of a canal through the narrowest part of the isthmus (80 kilometers). A Royal Order from February 20, 1534 to the Governor of Panama Pascual de Andagoya said that "having been informed that the River Chagres, that enters into the North Sea, can be navigated with caravels for three or four leagues, and other three or four in barges, and that from there to the South Sea there are another four leagues by land... you shall go to see the land from the River Chagres to the South Sea and examine what form and order can be given to open that land so that, once opened, the South Sea can join said river, so that navigation can happen, and to explore what difficulties it has, be it by the tides of the sea or by the height of the land, and what cost in money and men will be necessary, and in what time it can be done..." (Ediciones Balboa, 2007: 5). This was a visionary project but unfortunately such an enterprise was beyond the capabilities of the period. Andagoya informed his King that, although the canal could be built, it would demand more resources than 
those available to any ruler of that time (Sosa \& Arce, 1964: 80).

Basil Hall (1788 - 1844) a British naval officer from Scotland, was probably the first European to set foot in our region after the independence from Spain. In the years of 1820 to 1822 , Hall sailed in the command of H.M.S. Conway along the Pacific coast of South and Central America. In February of 1822 he anchored in Panama, where he stayed for a few days, sailing from there to Acapulco, in Mexico. While in Panama, Hall discussed with one of the merchants of the place, who had particularly studied the question of cutting a passage across the isthmus. "He was of the opinion that an immense and immediate advantage would be gained by making a good road from sea to sea across the isthmus; which might be done very easily, and at an expense incalculably less than a canal could be cut, under the most favourable circumstances..." (Hall, 1824: 158-159).

In 1825, an Englishman by the name of John Hale signed a colonization agreement with the Costa Rican government of Juan Mora Fernández. "The purpose of Hale was to form this colony with North American and British families..., and in the year 1826 he published a pamphlet in the city of New York, with the intention of making the new land known to the future settlers, a land overflowing with natural richness, which only awaited their arrival to become a paradise" (Hale, 1826).

"The natural history of foreign seas and countries is abundantly studied by men who 'live at home at ease' in the midst of cabinets and books, dependent for their specimens of birds, shells, or insects, on the stores of dealers in such objects; but the number of those who have undergone the arduous personal exertion of collecting them, with a scientific spirit, in their native haunts, is comparatively few. Of this small number the life and adventures of Mr. Hugh Cuming present one of the most remarkable instances of record" (Dance, 1980: 477). Hugh Cuming (1791-1865) (Fig. 24A) landed in Central America in 1829, during one of his multiple voyages. Born near Kingsbridge in Devon, Cuming's early interest in natural history was fostered by well-known naturalist George Montagu (1751-1815). Around 1820, Cuming traveled to Chile, where he established a sail making business. Interested in natural history, he sold his business and built a yacht designed with the sole purpose of collecting specimens for the British Museum and some botanical gardens. It was a schooner which he named Discoverer, fitted out expressly for the purpose of storing natural objects (Dance, 1980: 478). In 1831 he returned to England with a huge load of animals, plants and shells for several museums and gardens. "It may also be mentioned that Hugh Cuming, the well-known and extensive collector of objects of natural history, collected in Taboga I. and in the Pearl Islands, Panama, and Montijo Bay, Chiriquí river, around 1829 , and there is a set of his plants in the Kew Herbarium; but it is impossible to distinguish in many cases which were collected within our limits, because they are labeled 'Panamá et Colombia occidentalis" (Hemsley, 1887: 133). According to Dance, Cuming collected in our region in the Gulf of Panama, Pearl Islands, Gulf of Chiriquí, Puntarenas (Costa Rica), El Realejo (Nicaragua) and the Gulf of Fonseca, in Honduras (Dance, 1980: 482). At least four of Cuming's specimens from Central America became the types for new species described by Lindley: Aspasia epidendroides ('Cuming s.n.'), Oncidium (=Chelyorchis) ampliatum ('Cuming 1312') (Fig. 24B), Dichaea panamensis ('Cuming 1292') and Hexisea (=Scaphyglottis) bidentata ('Cuming s.n.'). All four are still quite common in Central America. Cuming collected later in the Philippines and although he was barely capable of signing his own name, his botanical instinct led him to the discovery of thirtythree new species of orchids. He was called, with good reason 'The Prince of Collectors'. For 20 years, he acted as a dealer in natural history material, buying and selling collections obtained by other naturalists in many parts of the world." Cuming developed a reputation for returning "living" plants to England (Herman, 1994: 14). "Such men as Cuming live after their death, and hence the marvellous increase within a very few years, in our knowledge of Nature, and of God's bounty to the world" (Dance, 1980: 495).

The father of Hugh Low ( 1824 - 1905 ), a Scot by birth, established in 1820 one of the most prestigious English nurseries in Clapton, near London. Young Low followed soon his father's ideals. The firm was one of the first to receive orchids from the Tropics. John Henchmann (1814

${ }^{17}$ The name appears indistinctly as Henchman or Henchmann. 

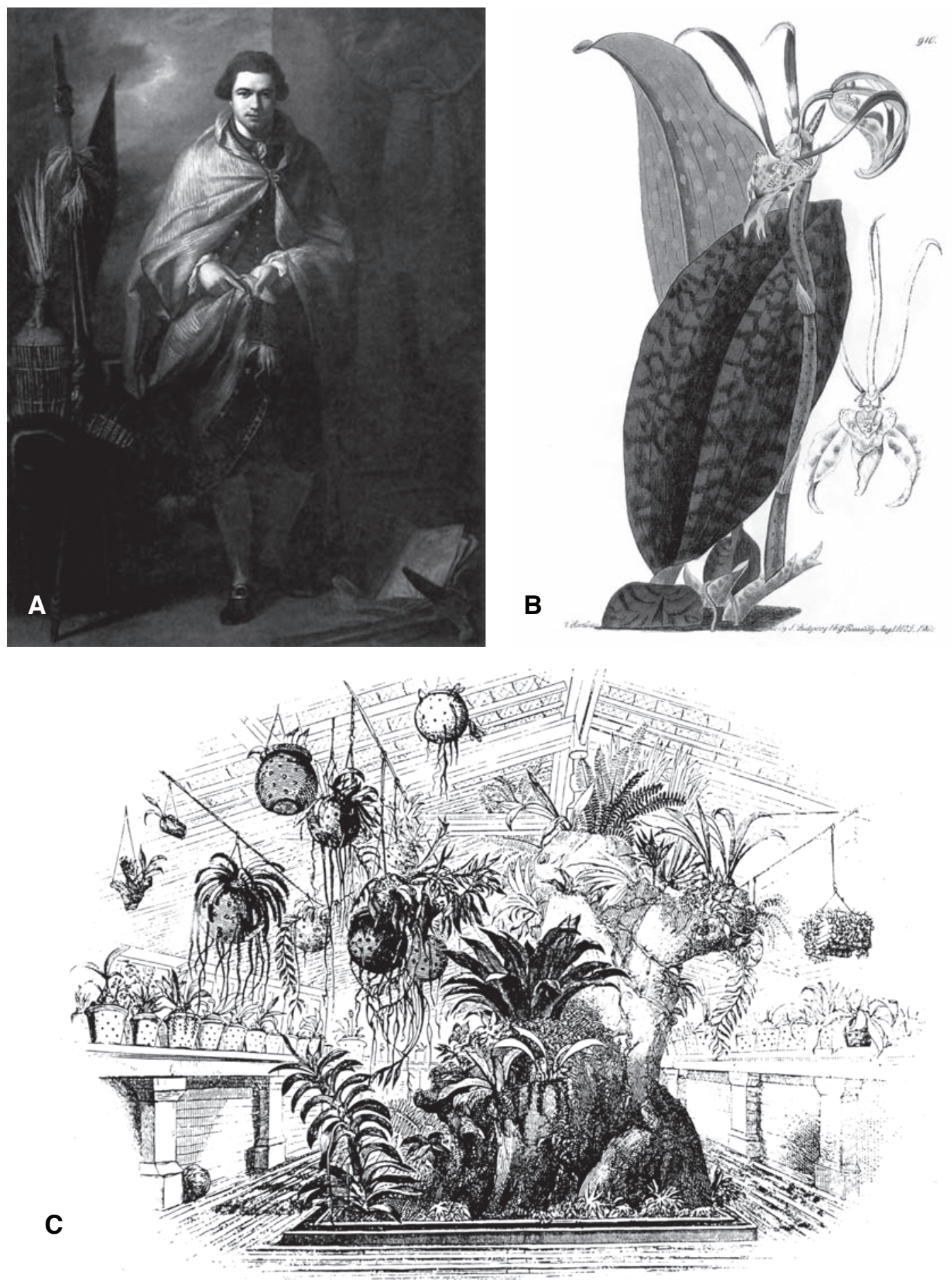

Figure 22. A - Sir Joseph Banks (1743-1820). Portrait by Benjamin West, courtesy of the Hunt Institute for Botanical Documentation. B - Oncidium papilio, Edwards Botanical Register, plate 1825. C - Typical British greenhouse: the 'epiphyte house' of Bateman at Knypersley Hall. In Bateman, 1837-43: 18. 

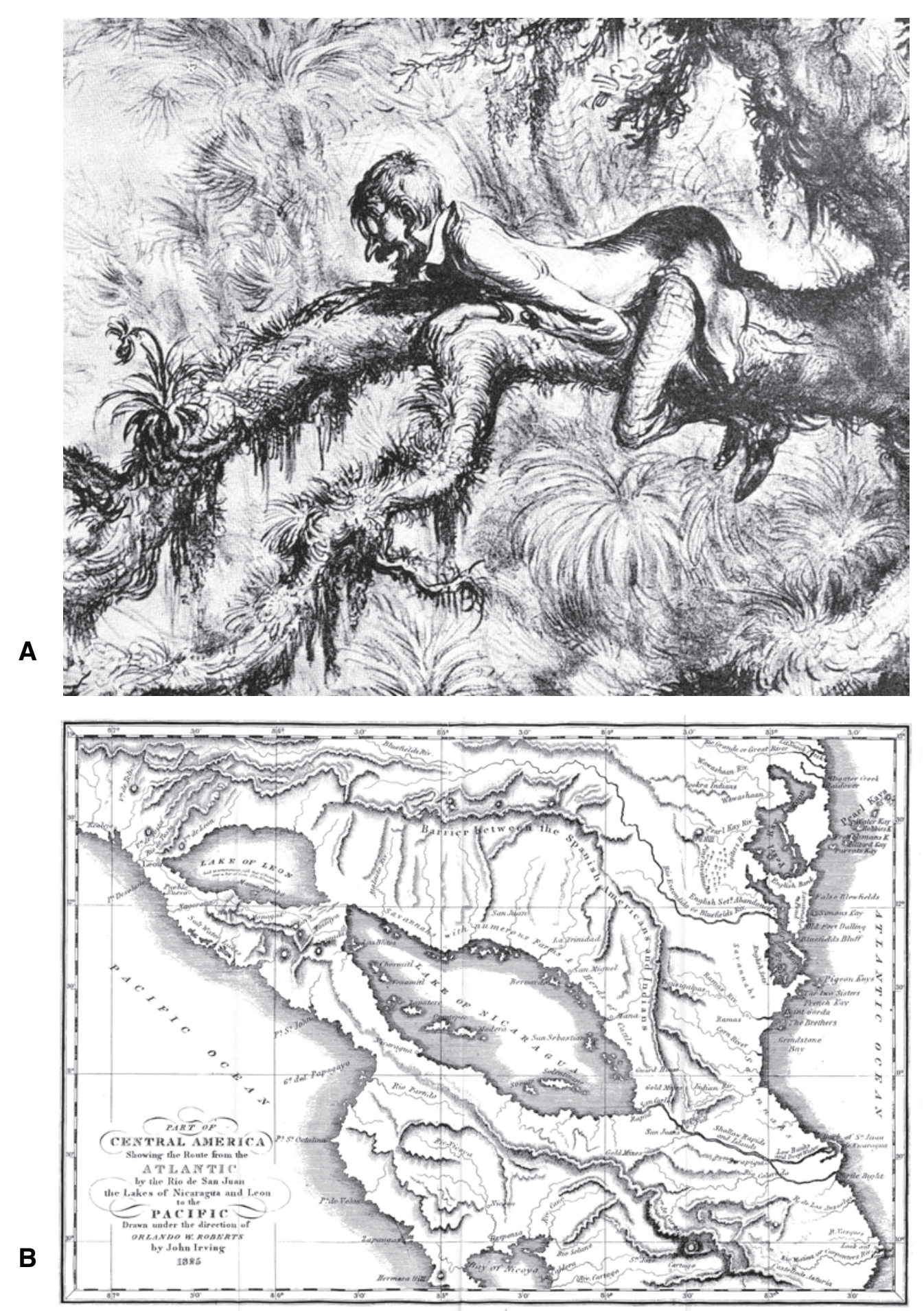

FiguRE 23. A — The Plant Hunter. Drawing by Paul Weber, 1941, from Hamer, 1974 (courtesy of Hedwig Hamer). B — Map of Nicaragua by Orlando Roberts. In Roberts, 1965. 
$-1893)^{17}$, working for Low, collected in Mexico between 1835 and 1840, especially in the region of Veracruz, discovering an important number of new species of Orchidaceae: Laelia barkeriana Knowles \& Westc. ('Plant cultivated by G. Barker, sent to him by J. Henchman from the vicinity of Jalapa'), Oncidium luridum var. henchmannii Knowles \& Westc. (Henchmann s.n.), Maxillaria henchmannii Hook. (Henchmann s.n.), Maxillaria cucullata Lindl. ('a native of Equinoctial America, whence it is said to have been brought by Mr. Henchman') (Fig. 24C), Humboldtia octomerioides (Lindl.) Kuntze (Henchmann s.n.), and Stanhopea tigrina Bateman ex Lindl. ('Henchman s.n., 1835, Habitat in Mexico, propè urbem Xalapam'). He also worked for George Barker and had been before in Venezuela, from where we know of at least one collection, Chysis aurea Lindl. ('in the valley of Cumanacoa, in Venezuela, Mr. Henchman s.n.').

Much later, in 1864, Captain John M. Dow mentions a collector by the name of Macgee, who collected orchids for Low in Guatemala, but we have no other information about him (Letter from Dow to Skinner, Feb. 20, 1864).

The genus Barkeria was first described by Knowles and Westcott in 1838 and named in honour of George Barker (1776-1845) of Springfield, England, who had imported a plant from Mexico. Barker was a pioneer in importing orchids, mainly from Mexico, among which many new species were discovered. A few of them are: Trichopilia tortilis Lindl. (G. Barker s.n., Mexico), Pleurothallis (=Restrepiella) ophiocephala Lindl. (Mexico, Loddiges \& Barker s.n.), Odontoglossum cordatum Lindl. ('George Barker s.n., flowered in cultivation, originally from Mexico'), Microstylis excavata Lindl. (Mexico, Mr. Barker s.n.), and Laelia furfuracea Lindl. (Karwinski, Oaxaca). Barker is undoubtedly an important figure in the introduction of orchids from our region to Europe, in the early years after the independence of the Central American countries from Spain. "As a botanist, Mr. Barker was much distinguished. He bestowed considerable attention on the cultivation of orchidaceous plants, of which he had a collection that is believed to have been almost unique, and certainly was unsurpassed in value by that of any private horticulturist in Europe" (Urban, 1846: 324-325).
John Ross (?-?), who collected orchids between 1837-1840 in Mexico, sent many plants to Barker, among them several species of Odontoglossum for which Schlechter, in 1916, proposed the name of Rossioglossum in his honor (Schlechter, 1916: 153). The name was formally published as a new genus by Garay and Kennedy in 1976. Another species named for him was Odontoglossum rossii Lindl., today Rhynchostele rossii (Lindl.) Soto Arenas y Salazar ('A charming plant, sent to Mr. Barker from Mexico by his collector Mr. Ross, after whom it is named'). "Ross started in 1837, but his collection did not reach England till the following year. It included the beautiful Odontoglossum rossii and Peristeria (Acineta) barkeri, the latter being discovered in a dark ravine in the neighbourhood of Xalapa" (Anonymous, 1931: 364). Other collections by Ross include Peristeria barkeri Bateman (Ross s.n., Jalapa), Galeandra baueri Lindl. ('Ross s.n., Mexico'), Laelia majalis Lindl. ('Habitat in Mexico - Schiede, Hartweg, Ross'), Epidendrum aloifolium L. and Chysis laevis Lindl. ('Habitat in Mexico - Ross').

The British naval expeditions to the coasts of Central America, the most important being those of H.M. S. Conway (1822), H.M.S. Blossom (1827) and of H.M.S. Sulphur (1836), had undoubtedly also scientific purposes, but their main goal was the geographical exploration and the construction of reliable maps preparing for a future domination of the region and the control of the canal routes.

The decade which began in 1840 "is the epoch of maximum English power in Central America. Great Britain would try to confront the growing power of the United States and both nations would choose the border region between Costa Rica and Nicaragua as the ground where they would test their forces..." (Obregón Quesada, 1993: 75). Great Britain, who already had a stronghold in Belize, pretended in addition the control of the access to the San Juan river.

"A new period of activity set in, and continued almost unbroken for many years; but few of the numerous travelers had received a scientific training, hence the botanical results were by no means so satisfactory as they might have been. Indeed, the principal object of many of these travelers was the introduction of living plants into European gardens" (Hemsley, 1887: 123). 


\begin{abstract}
"If we are requested to select the most interesting from the multitude of vegetable tribes, we should, on the whole, perhaps, be willing to give the preference to the natural order of Orchideae. Whether we consider general elegance of individuals, durability of blossoms, splendid colours, delicious perfume, or extraordinary structure, it would be difficult to select any order superior to Orchideae in these respects, and few even equal to them."
\end{abstract}

John Lindley, Collectanea Botanica (in Stearn, 1999: 107)

The increasing interest in the botanical exploration of Central America had its counterpart in the enormous figure of John Lindley (1790-1865), who in 1830 began in England the publication of his famous work The Genera and Species of Orchidaceous Plants, describing numerous species which were new to science. The Austrian botanist Stephan Ladislaus Endlicher (18041849) published his Genera Plantarum secundum Ordines naturales disposita between 1836 and 1841 . In this work, Endlicher recognized 367 genera of Orchidaceae, of which 117 had been established by Lindley (Stearn, 1999: 57). Another of Lindley's ventures was the founding, with Joseph Paxton and others, of The Gardeners ' Chronicle in 1841, of which the horticultural part was edited by Lindley. Lindley's editorship for twenty years ensured the maintenance of a high standard which earned it international repute. Many species were dedicated to Lindley, of which only a few, that are found in the American tropics, shall be mentioned: Aspidogyne lindleyana (Cogn.) Garay, Barkeria lindleyana Batem. ex Lindl. (Fig. 24D), Bletia lindleyana Rchb. f., Catasetum lindleyanum Mansf., Cattleya lindleyana Rchb. f., Cyclopogon lindleyanus (Link, Klotzsch \& Otto) Schltr., Laelia lindleyana Nichols., Lepanthes lindleyana Oerst. ex Rchb.f., Malaxis lindleyana Rchb. f., Maxillaria lindleyana Schltr., Odontoglossum lindleyanum Rchb. f. \& Warsz., Odontoglossum lindleyi Galeotti ex Lindl., Oncidium lindleyi (Lindl.) R. Jiménez \& Soto Arenas, Phragmipedium lindleyanum (R.H. Schomb. ex Lindl.) R.A. Rolfe, Pleurothallis lindleyana Cogn., Sobralia lindleyana Rchb. f., Stanhopea lindleyi Zucc., and Stelis lindleyana Cogn.
Oakes Ames, for many years the leading American orchidologist, stated that Lindley 'laid the foundations of modern orchidology'. With that verdict there is and has long been unanimous agreement (Stearn, 1999: 66).

George Ure Skinner (1804-1867) (Fig. 25), businessman, diplomat and amateur botanist is without doubt the most fascinating character in the history of the orchids in Central America during the first half of the XIX century. "Son of a Scots clergyman, Skinner steadfastly refused to follow his father's vocation or in any way to consider an ecclesiastical or academic career. The call he heard was from the world of Mammon..." (Berliocchi, 2000: 72). He arrived in Guatemala in 1831 and joined Carl R. Klee, Consul of the Hanseatic Towns, with whom he founded the firm of Klee, Skinner \& Co. ${ }^{18} \mathrm{He}$ was actively engaged in the political and commercial life of the Central American Federation, not only pursuing his own interests but as an active agent of those of Great Britain. A skilled diplomat, he enjoyed the sympathy of most of the Central American politicians of that time. This made him a valuable adviser of the omnipotent English Consul Frederick Chatfield and turned Skinner into one of the principal ideologists of English policy in Central America, which pretended territorial gains in exchange for the unpaid debt resulting from the loan that had been granted years before to the government of Manuel José de Arce. Klee, Skinner \& Co. became the most important British company not only in Guatemala but in the whole of Central America in the period before 1850 (Naylor, 1988: 120).

The only route of these days from Europe to the highlands and the capital of Guatemala was via Jamaica to Belize, then along the Río Dulce to Izabal (a small port on Lake Izabal), and from there by mule over the terrible road across the Mountains of the Mico, a 10day long ride. This route was used by all travelers until the inauguration of the Panama railway. It became then much easier to travel to Panama, take the train across the isthmus and then a ship to Port San José or Iztapa, on the Pacific Coast of Guatemala.

In relation to Skinner's and Klee's activities on Lake Izabal, Pérez de Antón (2005: 80) calls our attention to what he describes as "the first manifestation of Spanglish in Central America”. Klee, Skinner \& Co.

\footnotetext{
${ }^{18}$ According to Wagner (2001: 118), Klee was the first German immigrant to Guatemala.
} 

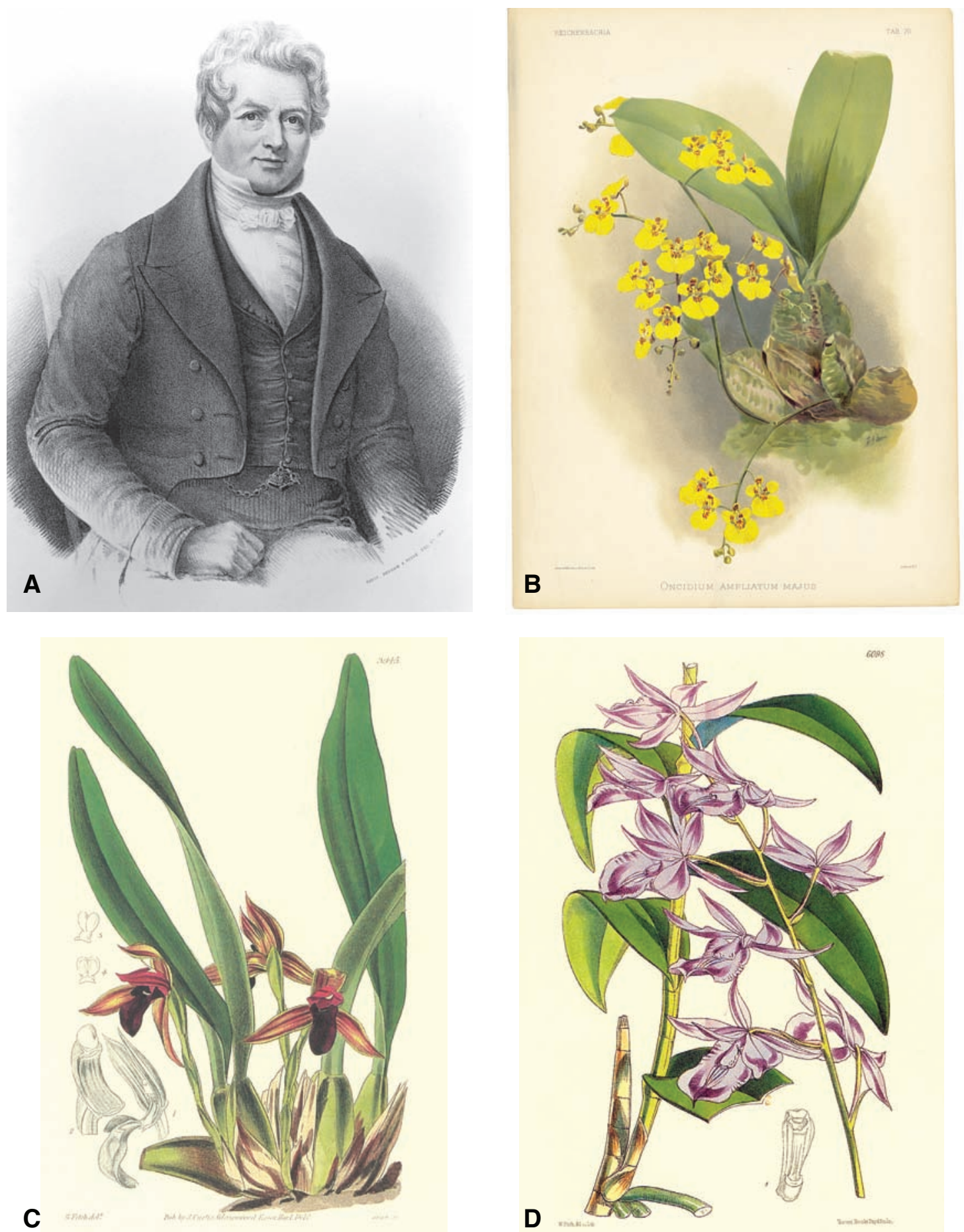

FiguRe 24. A - Hugh Cuming (1791-1865). From a litograph by Hawkins, 1850. Courtesy of Rudolf Jenny. B - Oncidium ampliatum Lindl. From Reichenbachia. C - Maxillaria cucullata Lindl. Curtis' Botanical Magazine, Plate 3945. D - Barkeria lindleyana Batem. ex Lindl. Curtis's Botanical Magazine, plate 6098. 


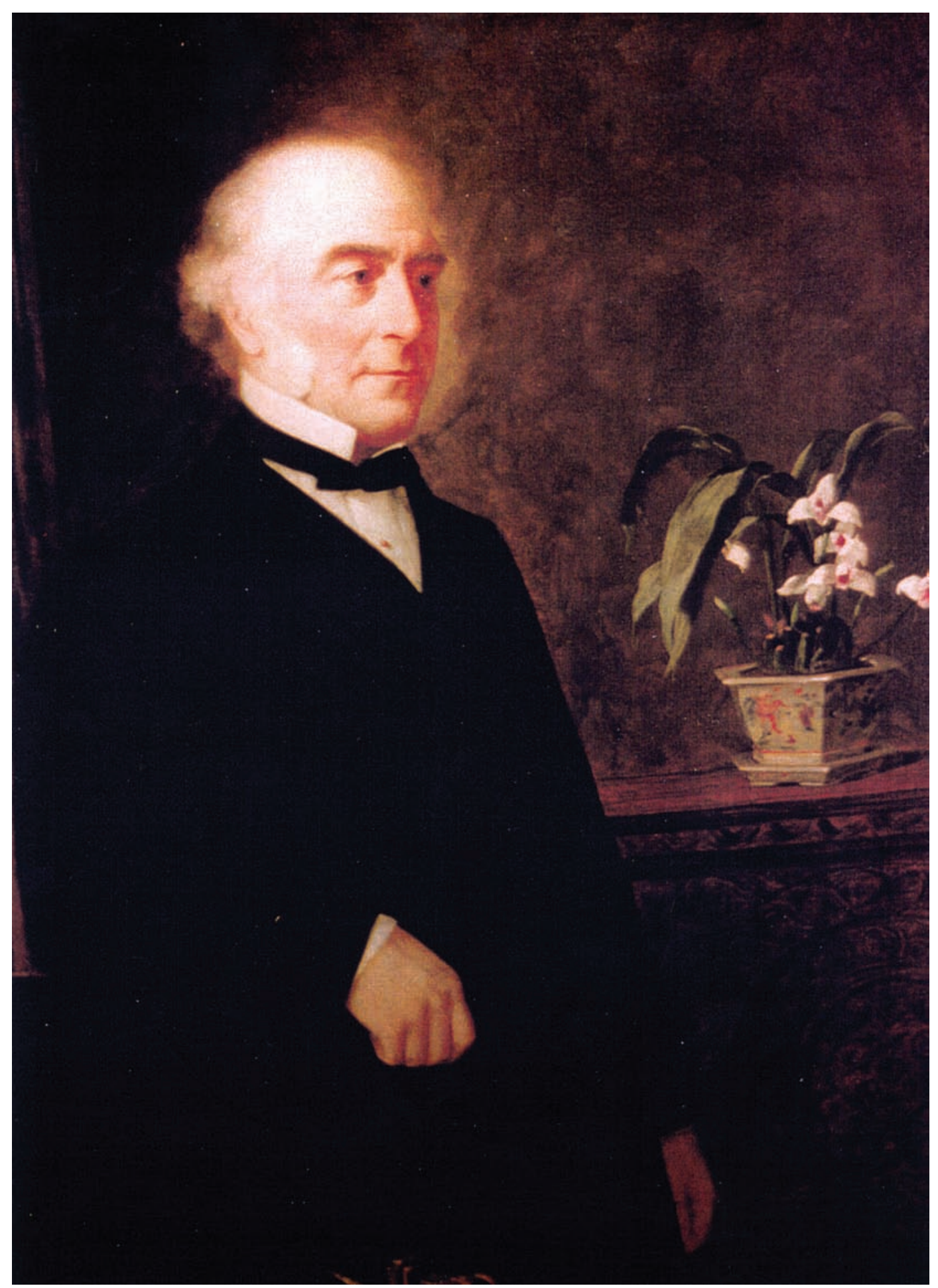

FiguRE 25. George U. Skinner (1804-1867). Portrait by George Washington Bronlow (ca.1860). Courtesy of the Hunt Institute for Botanical Documentation. 

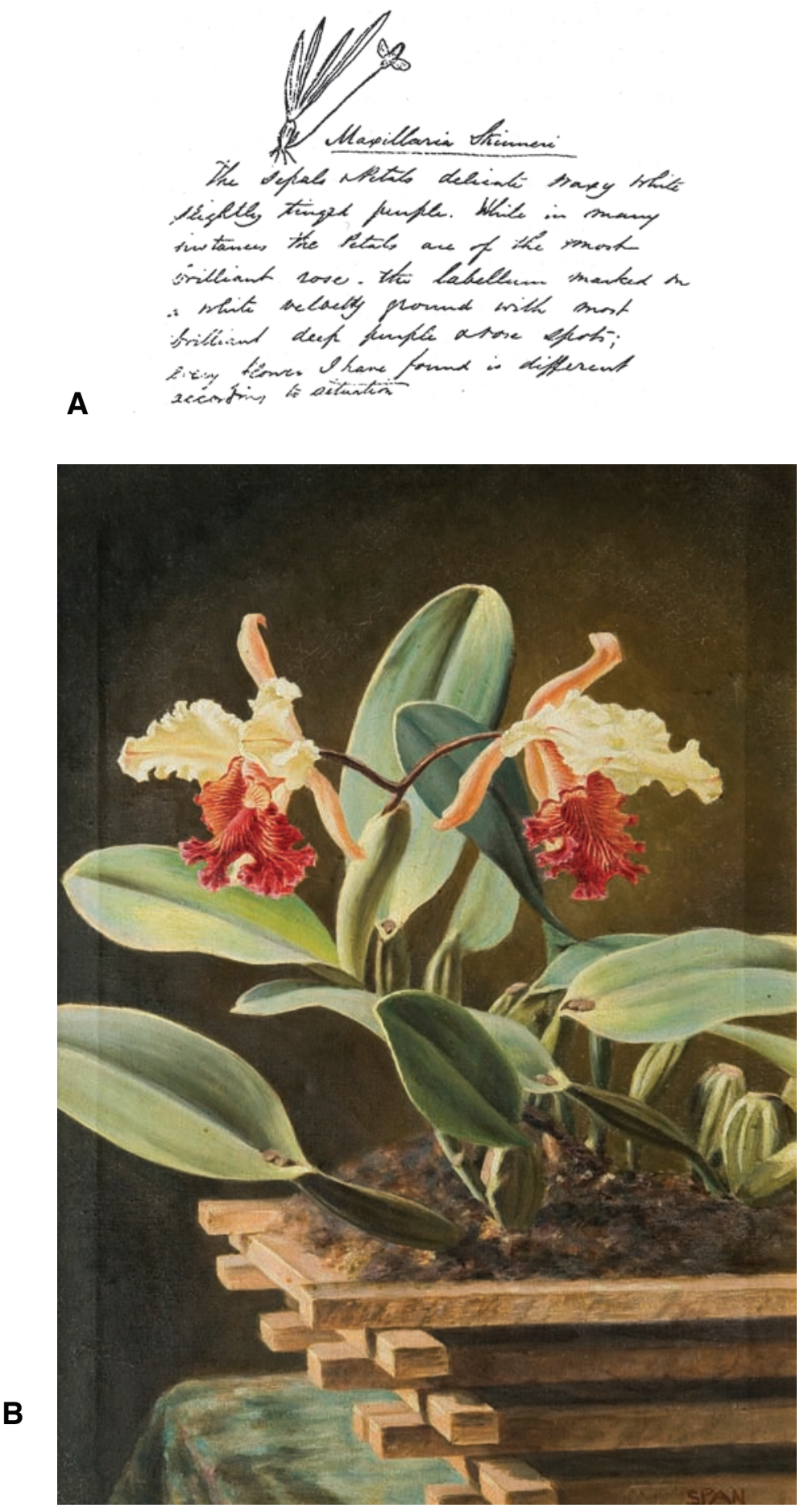

FiguRE 26. A - Lycaste skinneri. Field note and sketch by Skinner in a letter to Hooker dated December 26, 1840. The alba variety of Lycaste skinneri is the so-called 'White Nun', the National Flower of Guatemala. In Hamilton, 1991: 776. B - Cattleya dowiana. Painting by Emilio Span. Courtesy of Dr. Ricardo Kriebel. 


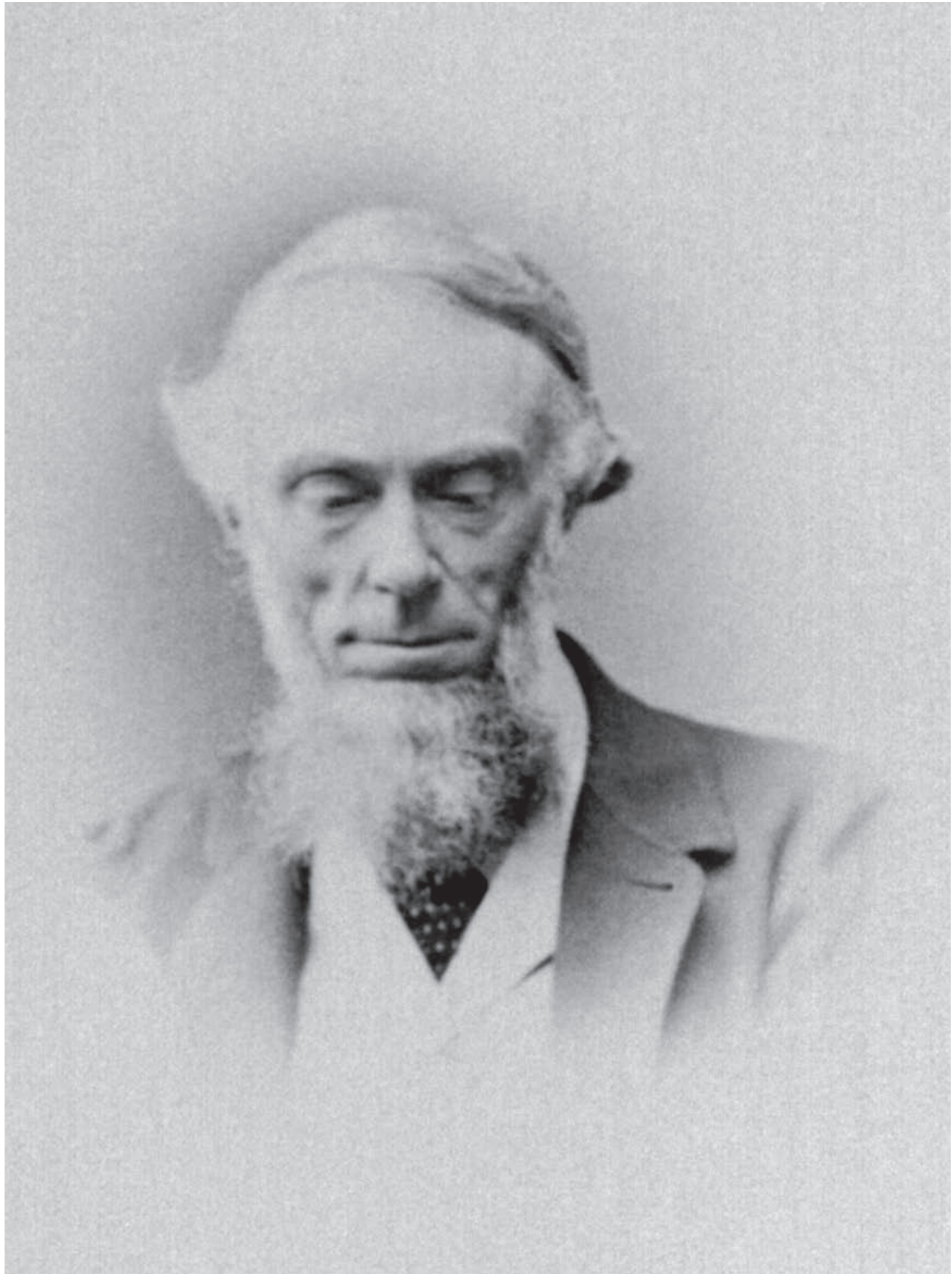

FiguRE 27. James Bateman (1811-1897). Courtesy of Rudolf Jenny. 
built warehouses on the northern shore of the lake which, in their correspondence, were referred to as The Store. The place prospered and grew until it became a small village, which kept the name and is called today El Estor. Since his arrival in Guatemala Skinner showed interest for its natural beauties, collecting birds and insects that he sent to England, persuaded by his friend, the ornithologist and writer John Gould. So began his relation with Bateman, who convinced him to collect orchids. "In his first letters Bateman showed Skinner by means of descriptions and a few rough sketches what he was looking for; Skinner quickly learned all he needed to know how to get started (Hamilton, 1990: 1241)." Bateman wrote years later: "My letter [to Skinner], dated March 17, 1834, reached him in due course, and as he never tired of telling me, the day of its arrival was as it were a new birthday, for it gave a fresh interest to his life, which never left him to his very latest hour" (Hamilton, 1992).

During more than 30 years he traveled constantly between Guatemala and England, dedicating more and more time to the orchids. Because of his knowledge of the land and his excellent relations, he was a great help to other naturalists who explored Central America in his time, such as Hartweg, Friedrichsthal, von Warscewicz and Salvin. All important orchidologists of his time, from Lindley to Bateman and Bentham, were his friends, but important above all was his friendship with Sir William Jackson Hooker, a Scot like him who was later (1841) to be appointed as Director of the Royal Botanic Gardens at Kew.

The almost constant political unrest frequently interrupted his activities. In 1839 he wrote to Hooker: "Such has been the state of this Country that my occupations legitimate have been stopped and had it not been for my thirst after Orchidaceae long ere I [would have] cut my throat" (Hamilton, 1990: 1239). Although he collected chiefly in Guatemala, he obtained plants from all Central American countries. Captain John M. Dow, in a letter to Skinner dated December 30, 1861, recollects his excursions with Skinner in Nicaragua (El Realejo) and Costa Rica (Puntarenas and Barranca). A note by Lindley, in his description of Epidendrum clavatum Lindl. seems to point to the fact that Skinner collected at some moment of his life in Venezuela: "Found in August, 1834, near Cumaná [Venezuela], by Mr. Skinner”.
He also collected in the Bahamas. The 'Botanical Register', in its note below plate \# 61, Epidendrum altissimum Jacq., says: "Found in rocky parts of the Bahamas by the indefatigable Mr. Skinner, from whom I received it in the summer of 1837. "Skinner tells us about his landing on Crooked Island, Bahamas and says: “... was much struck with the appearance of a rock of lava bearing such curious varieties of plants, I made a considerable collection of Orchideae, principally Epidendreae...." (in a letter to Hooker, February 28, 1837).

Within his collections, almost a hundred new species were found. Some of the types collected by Skinner are: Barkeria skinneri (Batem. Ex Lindl.) A. Rich. \& Gal., Catasetum integerrimum Hook., Clowesia russelliana (Hook.) Dodson, Coelia guatemalensis Rchb. f., Cycnoches egertonianum Batem., Deiregyne pyramidalis (Lindl.) Burns-Bal., Epidendrum papillosum Batem., Epidendrum stamfordianum Batem., Guarianthe aurantiaca (Batem. ex Lindl.) Dressler \& N. H. Wms., Guarianthe skinneri (Batem.) Dressler \& W. E. Higgins, Lycaste skinneri (Batem. ex Lindl.) Lindl. (Fig. 26A), Odontoglossum uroskinneri Lindl., Oncidium skinneri Lindl., and Xylobium elongatum (Lindl.) Hemsl. Two of Skinner's discoveries were later declared as National Flowers. The alba variety of Lycaste skinneri, "a thing too beautiful for words" (Boyle, 1983: 81) is today the National Flower of Guatemala, while Cattleya (= Guarianthe) skinneri is the National Flower of Costa Rica. “...The invaluable Lycaste skinneri, which now enjoys, and, indeed, richly merits an amount of popularity - a popularity which is ever in the increase such as has not been accorded to any other orchid with which I am acquainted" (Hamilton, 1992: 18).

At the end of his life he pursued, in an almost obsessive way, the collection of the famous Catlleya dowiana (dedicated to Captain John M. Dow, of the Pacific Steamship Company) (Fig. 26B), which had been discovered years before by Warscewicz. With this purpose he hired (together with Salvin, for whom Arce had previously worked) a Guatemalan collector by the name of Enrique Arce, who also collected birds. Arce traveled first to Costa Rica and then to Panama, on board of Captain Dow's ship. Dow, generous as always, had promised free passage for Arce and his equipment and collections (Letter from Dow to Salvin, 
February 1, 1864). On Feb. 9, 1864, Arce arrives at Puntarenas, travels first to the North, along the Gulf of Nicoya, and goes later to the highlands. At the end of that year, Arce arrives in Panama. His younger brother is his companion on his expedition. "Arce is now here... The poor fellow has been very sick with fever, and his little brother almost died from the same cause... I have advised him Arce not to start on his expedition to Chiriquí until he is in a condition to insure his ability to go straight through" (Letter from Dow to Salvin, December 19, 1864). However, Arce seems to have been more successful in collecting birds than orchids. Another collector was sent by Skinner to Central America. In one of Skinner's last letters, to Captain Dow in Panama on October 17 $7^{\text {th }}$, 1866, he said: "By this steamer we have sent you a fine young fellow, a Mr. Carl Kramer, who is to go on at once to Costa Rica. If Arce is still in Panama when this reaches, he will go on with him, but Arce has been so dilatory about going after the birds and plants we want, that others have been beating us in our manor. Cattleya dowiana surpasses all the Cattleyas yet known... we must get a batch of it.... And I hope you will for Dowiana's sake take care that his [Kramer's] collections reach us well, ... for my credit is at stake. I never was beat. ...Dowiana for ever." About the naming of Cattleya dowiana we follow Veitch: "It was the wish of Warscewicz, the original discoverer, that his plant should bear the name Lawrenceana, in compliment to Mrs. Lawrence of Ealing, a generous patroness of Horticulture, but as his specimens miscarried, this fact was not made known until after Bateman had named it in compliment to Captain J. M. Dow of the American Packet Service, to whose kindness orchidists and men of science owe so much" (Veitch, 1906: 116-117).

Skinner's partner Klee also discovered a new species: Epidendrum myrianthum Lindl. (Klee s.n.), again collected in Guatemala.

In December 1866, Skinner arrived in Panama, on his way to Guatemala, where he pretended to wrap up his business for he wanted to retire in England. He crossed the Isthmus in a railcar and still had time to collect his last orchids. In those days he wrote to
Veitch: "I have sent home a box, with orders that it may be sent to you at once. You will find an Ionopsis which may be good, Pleurothallis, and some very curious Epidendra" (Hamilton, 1993: 182). A few days later, on January $9^{\text {th }}, 1867$, he died in Colón, Panama, a victim of yellow fever. He was buried at Mount Hope Cemetery, in Colón and his tombstone bears the following inscription:

"S.I.M. GEORGII URE SKINNER F.L.S. E. SCOTIA ORTI
QUEM INTER OCEANOS CUM TRIGANTANOVIES TRANSIISSET GUATEMALAM ASCENSURAM DEUS MISERECORS MUNDANO EX MARI PORTUM IN OPTATUM VOCAVIT DIE JANUARII NONE A.D. MDCCCLXVII R.I.P. BEATI MUNDO CORDE CUONIAM IPSI DEUM VIDEBRUNT. DEO GRATIAS.” 19

Lindley dedicated to him the genus Uroskinnera, from the Scrophulariaceae. Captain John M. Dow, after receiving the sad news of Skinner's death, wrote to his wife (March 30, 1867): "May the mantle of his energy and enthusiasm for science rest on his friends who still await the call which he received, to rest from his labour."

After Skinner's death (Klee had passed away in 1853), Klee's son inherited his business interests in Guatemala, but had to accept the condition to use 'Skinner' as his second name. He named himself therefore Jorge Skinner Klee. His son joined both family names and since that time the family name Skinner-Klee is common in Guatemala, where numerous descendants of both partners still live and carry their combined names (Wagner, 2007: 43).

James Bateman (1811-1897) (Fig. 27) was undoubtedly the greatest beneficiary from Skinner's collections. Within ten years of beginning his relation with Skinner, "Bateman possessed the finest examples of Guatemalan orchids then available in England" (Reinikka, 1964: 297). "After several years of enjoying the orchidaceous bounty sent to him by Skinner, Bateman conceived the brilliant idea of sharing his good fortune with the rest of the world... by publishing a book with the largest illustrations of orchids ever seen.... The title would be The Orchidaceae of Mexico

\footnotetext{
19 "In loving memory of George Ure Skinner, F.L.S., born in Scotland, who when he had crossed the oceans thirty-nine times and was about to go to Guatemala, was summoned by a merciful God from the wordly sea to a pleasant haven on the 9th of January 1867. R.I.P. Blessed are the pure in the heart for they shall see God. Thanks be to God." - Translation by Mary Raymond Daniell, great-granddaughter of Skinner. In Hamilton, 1993.
} 
and Guatemala" (Hamilton, 1990: 1242-43). "It is this... eccentric but exquisite study - in so gargantuan a format as to make no more than 125 copies feasible in the first print run - which more than justifies Bateman's place in the pantheon of orchid pioneers" (Berliocchi, 2000: 53) (Fig. 28A).

Skinner was the key element in the creation of Bateman's book, because all the wealth and enthusiasm of Bateman would have been of little use without Skinner's plants. Over half of the species illustrated by Bateman in his monumental work had their origin in collections by Skinner. “... in fact, the inclusion of Guatemala in the work must have been due entirely to the collections of Skinner" (Williams, 1972: 200). Their friendship was strong, and in 1860 Skinner took Bateman's eldest son back to Guatemala, to see the source of his discoveries (Herman, 1976: 59). In gratitude for his great contributions to botany, Bateman proposed Skinner as a member of the prestigious 'Linnean Society' in June 1866. The recommendation was accepted shortly before Skinner's death, on December 6 of the same year. Bateman was deeply religious and he strongly believed that hybridization by man was interfering with the work of God (Rigby, 2000). Lindley named the genus Batemannia in honor of this great British orchidologist. "His enthusiasm for orchids remained strong throughout his long life, and when he died, at eighty-six years of age, on November 27,1897 , the orchid world was irreparably saddened by the loss of one of his most knowledge and energetic pioneers" (Reinikka, 1964: 298).

William Jackson Hooker (1785-1865), Skinner's friend and from 1841 to 1865 Director of the Royal Botanic Gardens at Kew, described in 1831 a beautiful terrestrial orchid from Panama as Peristeria elata. It had been sent in 1826 by Mr. Henry Barnard, a Peruvian merchant, to Mr. Robert Harrison, of Liverpool, in whose stove it flowered for the first time in England in 1831 (Veitch, 1963: 128). This orchid, known popularly as the 'Holy Ghost Orchid', is today Panama's National Flower. Although without formal botanical training, William Hooker became one of the most influential British botanists of his time. He had managed a brewery before becoming Professor of Botany at Glasgow University (1820-1840). After the death of Banks, Kew Gardens was allowed to sink into decline. The appointment of William Hooker as its Director in 1841 revitalized the gardens and herbarium... Hooker published tirelessly, particularly in the journals which he edited, Botanical Miscellany and The Journal of Botany. He was succeeded by his son, Joseph Dalton Hooker (1817-1911).

In a letter to Hooker (1861) Charles Darwin referred to his passion for orchids: "What frightful trouble you have taken about Vanilla; you really must not take an atom more; for the orchids are more play than real work".

Karl Theodor Hartweg (1812-1871) (Fig. 29A), German by birth, was one of the first collectors hired by the Royal Horticultural Society to explore the lands of Mexico and Central America. He traveled to Mexico in 1836. "The principal object of his journey was to collect and transmit living specimens or seeds of ornamental plants and trees; but he also made large collections of dried plants, the numerous novelties of which were published by the late Mr. George Bentham [who was the President of the Royal Society] between 1839 and 1842 under the title Plantae Hartwegianae ${ }^{20 "}$. "[He] was told in his instructions most clearly to confine himself as much as possible to mountainous districts, where plants would be found that would not necessarily require stove treatment" (Cox, 1955: 265). The contract signed September 21, 1836, between Hartweg and John Lindley read: "... the greatest object of your mission is to procure ... plants that are likely to be capable of enduring the open air in England and that these objects will be more completely attained the more you avoid what is called the Tierra caliente and keep to the Tierra fria or the upper limits of the Tierra templada" (Yearsley, 2008: 1).

In Mexico he met Sartorius, in whose estate (El Mirador) he made important collections. A few months after his visit there, he met Linden in Chiapas, around 1839-1840. "In a way reminiscent of Stanley's later encounter with Livingstone in the Congo, the two explorers met at a bend on the trail leading to Comitán [...], respectively exclaiming 'Hartweg!' and 'Linden!' though they had never seen each other before. Their paths had nearly crossed several times during the previous few years and each knew the other by reputation - but chance never brought them together. They were to meet again in Colombia in 1842..." (Ceulemans et al., 2006: 55).

\footnotetext{
${ }^{20}$ Bentham, G., 1838-57, Plantae Hartwegianae imprimis Mexicanas adjectis nonnullis Grahamianis enumerat novasque describit.
} 
At the beginning of 1839 he received instructions to travel to Guatemala and, on Lindley's recommendation, made contact with Skinner. The political situation in Guatemala was dangerous, and Hartweg wrote to Skinner asking if it was convenient to undertake the journey. "In a few days the post passes through here for Guatemala, when I shall write to Mr. Skinner and ask his opinion on the subject, as well as the present state of the country" (letter to the Royal Horticultural Society, March 19, 1839). In a letter to Hooker in April of the same year, Skinner relates his answer to Hartweg: "He asks if he should come on. I write him, 'By all means', $\&$ have given him letters of introduction to every town on the route \& moreover sent him dried specimens of Orchidaceae that will bring him on in spite of himself." Hartweg arrived in Guatemala, where he met Skinner who joined him on many of his collecting trips. "An intrepid and indefatigable plant hunter, Hartweg possessed both great good sense and intuition... earning fame as the collector of the greatest number of orchid species in the first half of the nineteenth century" (Berliocchi, 2000: 75).

Among the numerous new species of orchids discovered by Hartweg during his five years of exploration in Mexico and Central America one can mention: Arpophyllum alpinum Hartweg ex Lindl. (Hartweg s.n., Mexico), Arpophyllum giganteum Lindl. (Hartweg s.n., Guatemala), Barkeria spectabilis Batem. ex Lindl. (Hartweg s.n., Guatemala), Coelia macrostachya Lindl. (Hartweg s.n, Guatemala), Cranichis apiculata Lindl. (Hartweg s.n., Guatemala), Cypripedium molle Lindl. (Hartweg s.n., México), Rhyncholaelia glauca (Lind1.) Schltr. (Hartweg s.n., Mexico), Rhynchostele pygmaea (Lindl.) Rchb. f. (Hartweg 568, Guatemala), Sarcoglottis cerina (Lind1.) P. N. Don (Hartweg s.n., Guatemala), Sarcoglottis rosulata (Lind1.) P. N. Don (Hartweg s.n., Guatemala), and Schiedeella trilineata (Lindl.) Burns-Bal. (Hartweg s.n., Guatemala). However, his collections from Guatemala seem scanty (only 107 numbers). This small harvest leads to the speculation that part of Hartweg's material could have been lost. In Guatemala's rich flora, 107 numbers could easily be collected in three or four days. Bentham's account of Hartweg's collections in Guatemala consists of only 24 pages (Williams, 1972: 200-201).
On January 1 of 1841 he departed for South America and Jamaica, returning finally in 1843 to England. The Royal Horticultural Society was so satisfied with his work that he was sent on a second mission to Mexico and California. During this final journey he traveled together with Heller (Anonymous, 1854: 117). Tired of traveling and after a bitter dispute with the Royal Horticultural Society regarding his payment, he returned to Germany in 1848 , where he was named Director of the Gardens of the Great Duke of Baden, in Schwetzingen. There he died in 1871.

A great number of orchid species were dedicated to Hartweg, among them: Aa hartwegii Garay, Anacheilium hartwegii (Lindl.) Pabst, Moutinho \& Pinto, Fernandezia hartwegii (Rchb. f.) Garay \& Dunst., Oncidium hartwegii Lindl., Pachyphyllum hartwegii Rchb. f., Paphiopedilum hartwegii (Rchb. f.) Pfitzer, Phragmipedium hartwegii (Rchb. f.) L.O. Williams, Pleurothallis hartwegiaefolia H. Wendl. \& Kraenzl., Pleurothallis hartwegii Lindl., Prosthechea hartwegii (Lindl.) W.E. Higgins, and Telipogon hartwegii Rchb. f. Lindley dedicated to him the new genus Hartwegia, today a synonym of Domingoa Schltr.

"From the moment of the dissolution of the Federal Republic of Central America in 1838, the situation changed dramatically. On one side, Nicaragua became conscious of her lack of control over the Caribbean coast and on the other, English policy, now opposed to the unity of Central America, became more and more aggressive. Great Britain ended granting the Mosquitoes a protectorate in 1845 , confirming what had been affirmed some years before, in 1838, when it was said that this region was in fact English territory. Not contented with this, on January 1 of 1841 , the superintendent of Belize, Alexander MacDonald, who competed in aggressiveness and illegitimate acts with the Charge of Affairs and soon General Consul of Great Britain in Central America, Frederick Chatfield, attacked and seized San Juan del Norte. British supremacy reached its highest point in 1848 , after declaring that San Juan del Norte belonged to the Mosquito kingdom and renaming it Greytown" (Bell, 1989: 65). “...The Nicaraguans were witnesses, as was Costa Rica, of the fight among the powers in the region [...] Although by 1860 the British recognized that the Atlantic coast was Nicaraguan territory (Treaty of Managua) they did not withdraw from this area until 
the Altamirano-Harrison Treaty of 1905. [...] English pressure on Nicaragua, Honduras and El Salvador to secure rights on lands in the proximity of the future canal and on the sites which would help to defend it was enormous; they pretended from Nicaragua the mouth of the San Juan River and the port of San Juan del Norte; from Honduras the Bay Islands in the Caribbean and the Island of Tigre in the Gulf of Fonseca and to have economical control on all three" (Obregón Quesada, 1993: 75).

"[In 1840] ....began a decade of relative tranquility and colorless governments, during which the most relevant fact was the arrival in San José of the English seaman William LeLacheur, who harbored in Caldera to repair his ship and to find cargo, since he had lost the load of skins that he brought from the north during a storm. A coffee grower, Nicaraguan of Guatemalan origin, who had established himself in San José, called Mariano Montealegre, entrusted him his harvest, with instructions to try to sell it in London, based solely on LeLacheur's word of honor. The first shipment of coffee to Europe passed through Chile [...] and then, via Cape Horn, found its way to London. Over a year later, the English seaman returned and handed to Montealegre the hefty product of the sale. The London market was open" (Cañas, 2000).

The expedition of H.M.S. Sulphur (1836 to 1842), was the third of a series of voyages organized by the British Navy for the exploration, mainly for cartographic purposes of the American Pacific coast and the islands of the South Pacific. It was commanded by Sir Edward Belcher (1799-1877) and had been preceded in 1822 by the H.M.S. Conway and in 1827 by the H.M.S. Blossom at the command of Captain F. W. Beechey, who explored the Mexican Pacific coast (San Blas, Mazatlán and Acapulco, with Lay as naturalist). The botanists of the expedition, Andrew Sinclair (1796-1861), George Barclay and Richard B. Hinds (1812-1847), made important collections in Panama, Nicoya (Costa Rica), El Realejo (Nicaragua) (Fig. 28B) and the Gulf of Fonseca (Honduras), whose botanical descriptions where written by George Bentham. The collections of this expedition are kept in London (BM), for instance Oncidium ampliatum Lindl. (Barclay 2769, Costa Rica). Botanical collections were not the priority for the expedition. The orders of the Sulphur (Belcher, 1843), read, "Great collections of natural history cannot be expected, but ... the medical officers must, undoubtedly, be anxious to contribute their part to the scientific character of the expedition" (Jörgensen, 2003).

However, Hinds and Barclay found little to interest them: "Our visits to the Gulfs of Nicoya and Fonseca were not productive, indeed the sameness of an unbroken but dreary and profitless forest was nowhere more forcibly felt" (Hinds, 1844: 62).

At least five specimens collected by the expedition of the Sulphur were determined as new species by Lindley: Epidendrum chinense (Lindl.) Ames (Hinds s.n. Guatemala), Ornithocephalus bicornis Lindl. (Sinclair s.n., Panama), Scaphyglottis fasciculata Hook. (Sinclair s.n., Nicaragua), Oncidium stipitatum Lindl. (G.W. Barclay 958, Panama), and Encyclia trachycarpa (Lindl.) Schltr. Among the collections by Barclay we find Catasetum viridiflavum Hook. and Maxillaria acutipetala Hook. with the indication 'Central America, Pacific side'. "Belcher (1843), Captain during most of the voyage, described the journey but put little emphasis on the scientific aspects and hardly mentioned the botanists of the expedition. The last third of Belcher's second volume (1843) is an article written by Hinds in which he resumes The regions of vegetation" (Jörgensen, 2003: 5).

George Bentham (1800-1884) (Fig. 29B) described the collections of Hartweg in Mexico and Guatemala in Plantae Hartwegianae (1839-1857) and also many of the species of the journey around the world of H.M.S. Sulphur. In Kew, Bentham maintained a close relationship with Joseph Hooker, son of the director and also an excellent botanist, with whom he began the publication of Genera Plantarum, a joint effort to resume all genera of flowering plants and gymnosperms. As an author, Bentham probably wrote more descriptions of plants - new to science - than any other person in his day.

Another English collector, William Lobb (18091863), traveled through the Caribbean, Panama and South America, employed by the firm of Veitch in Chelsea. Veitch sent Lobb on a collecting expedition to South America, and he became the first commercial orchid hunter (Black, 1973: 61). Later, he spent several months in the neighborhood of Panama and Chagres, but according to Hemsley, appears to have dried very few plants (Hemsley, 1887: 134). 
"The earliest preserved herbarium specimen from Belize is attributed to the firm of Messrs. Loddiges of England. The specimen, the type of Polystachya clavata Lindl. (1842), is preserved at Kew" (Balick et al., 2000: 5).

The expedition of H.M.S. Herald (1844-1851) was the fourth of the already mentioned series of voyages undertaken by the British Navy to explore the coasts of the American Pacific. Carl Berthold Seemann (1825-1871) (Fig. 29C), who from his youth had had the ardent wish to see foreign countries, devoted much of his time to the study of the natural sciences, especially botany and anthropology (Anonymous, 1871: 1678). In 1844 he traveled to Kew, to become a botanist. There he met W. J. Hooker, who recommended him to succeed Thomas Edmonston, who had lost his life accidentally in Ecuador. In this way he came to participate in the expedition, which explored, among other regions, the isthmus of Panama and western Mexico. He arrived in Panama the $22^{\text {nd }}$ of September, 1846 and joined the crew of the Herald in January of 1847. "Having paid a visit to Acapulco, and measured some of the volcanoes of Guatemala, the vessels sailed for Panama, where they arrived on the $17^{\text {th }}$ of January, 1847 , and were joined by Mr. Berthold Seemann..." (Seemann, 1852-57: 6). In May Seemann was in Coiba, the largest island in the Central American Pacific and later his favorite place for the collection of plants. In December of the same year he explored the Darién and in 1848 Chiriquí. He traveled through Mexico in 1848 and 1849. "When in 1848 Berthold Seemann pointed out that 'the isthmus of Panama, this part of New Granada that, like a bridge, connects the two great continents of America, their flora, fauna and races', he became perhaps the first scientist to describe Panama as the biological bridge of the Americas" (Heckadon-Moreno, 1998: 31).

“About this time, Dr. Seemann's scientific labours attracted the attention of the Imperial German Academy of Naturalists, and soon after he was made a member..." (Anonymous, 1871: 1678). A short time later he was elected Vice-president for life.

He returned to Panama and met von Warscewicz. Seemann wrote: "We spent several days in Taboga, the most beautiful island in the bay. A mount rises in its center of about 1,000 feet of altitude, cultivated with orchards and vegetables almost to its summit. Small streams run to the valley where, between palms and tamarinds, the huts of the natives lie almost hidden" (Heckadon Moreno, 1988: 27). He returned to England in 1851, with more than 1,000 specimens of plants. Between 1852 and 1857, Seemann published his The Botany of the Voyage of H.M.S. Herald, a book in four volumes, one of which is the Flora of the Isthmus of Panama. It is the first flora of Central America after Mociño's Flora de Guatemala and Beurling's Primitiae florae portobellensis, and Seemann described there 104 species of orchids. In 1853 he started the journal Bonplandia, which, though published in Hannover, he edited in London, and to which many of the leading botanists of all nations contributed. In 1865 he returned to Central America, employed by English interests to explore and operate gold mines in Nicaragua, where he started the operations of the mine of El Javali, in Chontales.

From Nicaragua he traveled frequently to Panama, and although fully occupied with his business affairs, he always found time for botanical exploration. At some point he must have visited Costa Rica, if we believe Endrés, who in 1869 wrote to Captain Dow: "Please do let me know whether and when Dr. Seemann will return" (letter to Capt. Dow, November 3, 1869). He dreamed with going back some day to scientific investigation, but died in Chontales in October of 1871, at the age of fortysix, another victim of yellow fever.

Among Seemann's collections are the type specimens of Pleurothallis perpusilla (Seemann 1565, Panama) and Masdevallia chontalensis (Seemann 180, Nicaragua), both described by Reichenbach.

Seemann met in Chontales the English geologist and naturalist Ralph Tate (1840-1901). “... [Tate] made a small collection of plants at Chontales... at about the same date as Seemann, and perhaps in company with him, for the numbers are often [...] the same in the two collections" (Hemsley, 1887: 132-133). Among the collections by Tate are Physurus vaginatus Hook. and Isochilus linearis R. Br. Dendrobium seemannii, L. O. Williams, Taeniophyllum seemannii Rchb. f. and Trigonidium seemannii Rchb. f. were dedicated to Seemann. The only illustration of Orchidaceae in Seemann's work is that of Cypripedium hartwegii Rchb. f. (Fig. 29D). 

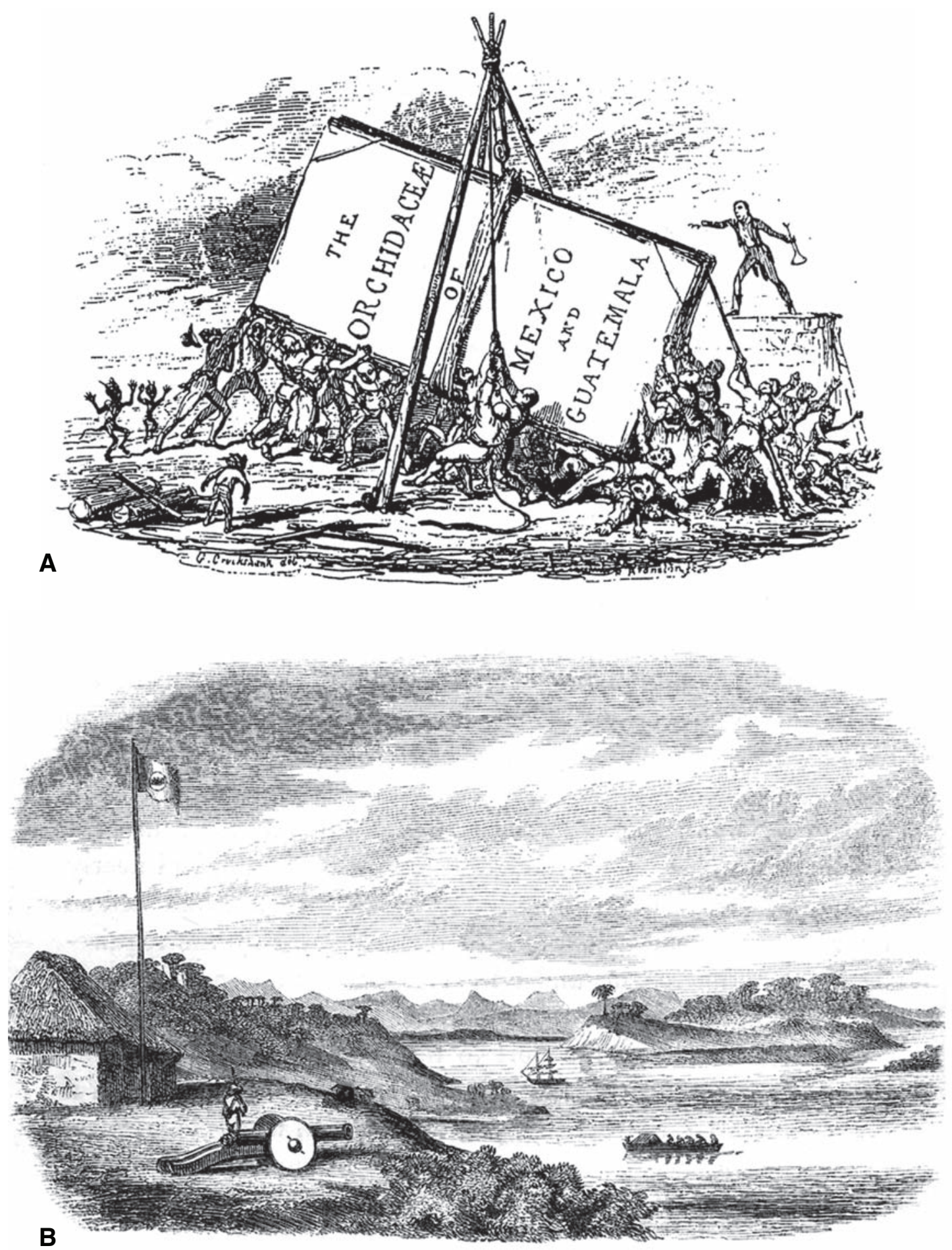

Figure 28. A - Vignette by George Cruikshank. From Bateman, 1837-43. B — The Port of El Realejo. In Wells, $1857: 64$. 

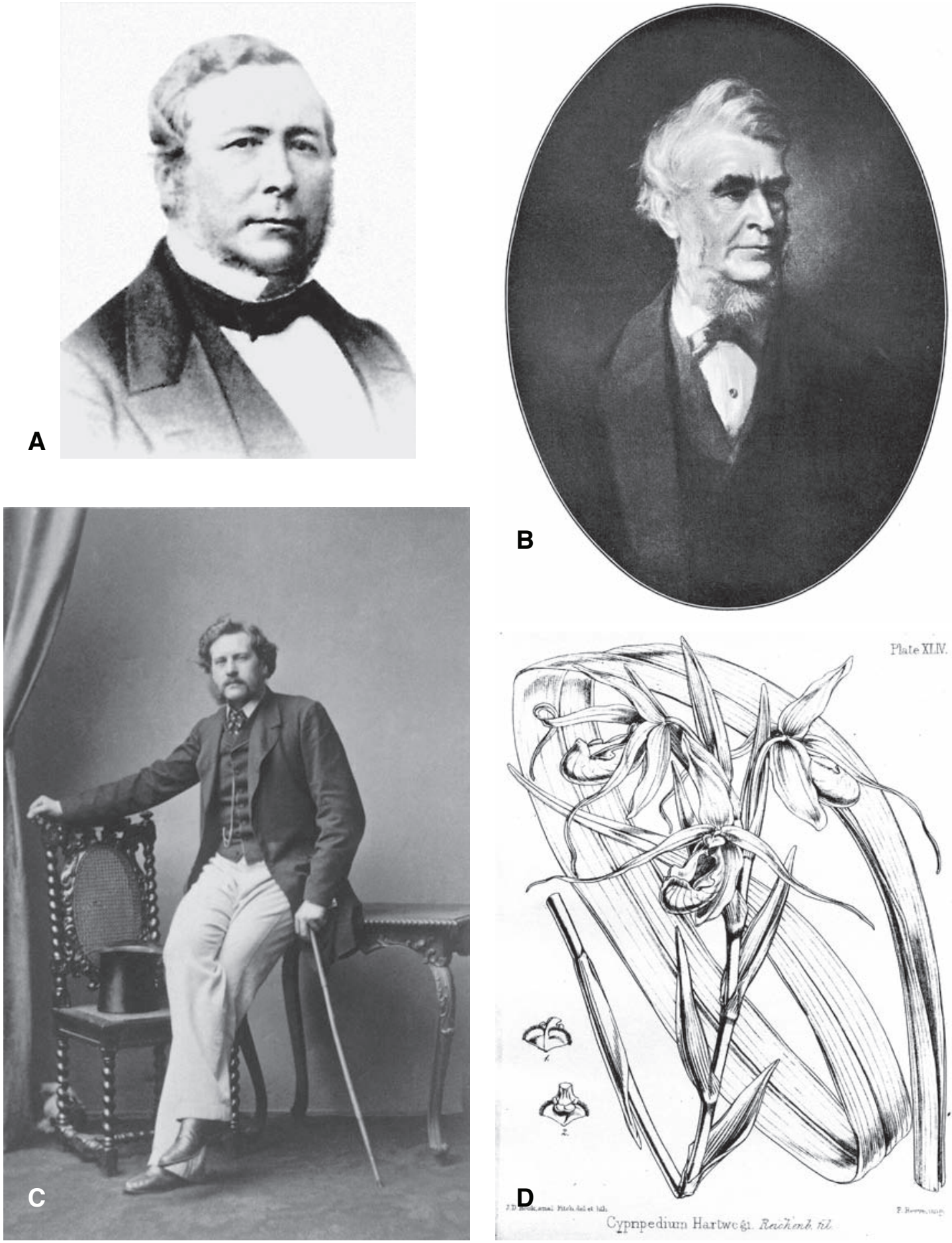

Figure 29. A - Karl Theodor Hartweg (1812-1871). Courtesy of Rudolf Jenny. B — George Bentham (1800-1884). Courtesy of Rudolf Jenny. C - Carl Berthold Seemann (1825-1871). From Gardeners' Chron., 1871. Courtesy of the Hunt Institute for Botanical Documentation. D - Cypripedium hartwegii Rchb. f. In Seemann, 1852-57: pl. XLIV. 


\section{The German-Belgian connection}

"To the combined action offorces, to the influence of inanimate creation on the animated world of animals and plants, to this harmony will I always turn my eyes".

Alexander von Humboldt (1769-1859), in the journal of his voyage to America,

June $15^{\text {th }}, 1799$

The botanical explorations of Cuming, Skinner, Hartweg, Hinds and Seemann originated in the spirit of imperialist expansion which characterized the Victorian era. Cuming and Skinner were true examples of the English attempts to dominate world trade. Hartweg was one of many instruments used by the English upper classes to satisfy their enthusiasm for orchids as decorative subjects and Hinds and Seemann represented the scientific interests of a Great Britain that had achieved complete control of the oceans.

A current of 'liberalism' developed in the rest of Europe after 1830 that intellectually defended freedom of thought and praised technology and the natural sciences. The liberals inherited the ideals of Enlightenment and the French Revolution and where therefore often subject to a fierce political repression. It was so that a very different group of European adventurers, naturalists and scientists began arriving in Central America shortly after independence. They were individuals whose countries of origin had no practical interest in the new republics: merchants, scientists and political expatriates who in only a few years made great contributions to the knowledge of the orchids in Central America. With their English colleagues they had in common their 'Orchidomania', both in the horticultural and the scientific meaning of the word. Why did Germany, and above all Belgium contribute with so many illustrious names to the history of orchidology during the first half of the XIX century? For Germany the answer lies perhaps in a long botanical tradition and the influence of Humboldt on the romantic-liberal movement of the epoch. In the case of the Belgians, it may have been the nationalistic euphoria after the birth of Belgium as an independent nation.

Let us remember that, as a result of the Congress of Vienna, the Prince of Orange had been proclaimed King of the United Low Countries in 1815. In 1830, the French speaking regions of the Low Countries gained their independence, forming the Kingdom of Belgium. King Leopold I ascended to the Belgian throne in July, 1831.

William Bullock (ca. 1773-1849) was en English traveler, naturalist and antiquarian. Bullock began as a goldsmith and jeweler in Sheefiled. He used his wealth to accumulate a large collection of artifacts, antiquities and stuffed animals. In the late 1790s Bullock founded a Museum of Natural Curiosities in the city, which moved to Liverpool in 1801. In 1808 he published a descriptive catalogue of the works of art, armory, objects of natural history, and other curiosities in the collection, some of which had been brought back by members of James Cook's expeditions. In 1809, Bullock moved to London and the collection was housed in the newly built Piccadilly Egyptian Hall. The collection, which included over 32,000 items, was disposed of by auction in 1819.In 1822, Bullock went to Mexico [becoming so the first European to set foot in this country after Thomas Gage in 1625] and brought back many artifacts and specimens which in 1824 formed a new exhibition in the Egyptian Hall, entitled Ancient and modern Mexico. This exhibition was the first exhibit in Europe of Mexico's natural history and ancient culture after the country's independence from Spain. Included among the curiosities exhibited by Bullock were a few birds mounted on artificial palms and cacti, and picturesquely arranged around them some Mexican mammals (Stresemann, 1954: 86).

A second visit to Mexico, and to the USA, took place in 1827. Bullock's publications include $A$ concise and easy method of preserving subjects of natural history (1817), Six months residence and travels in Mexico (1824), and Sketch of a journey through the western states of North America (1827).

"In Germany, the news of mysterious Mexico having become accessible even to the ordinary traveler excited the curiosity of a wealthy nobleman, the Count of Sack, chamberlain to the King of Prussia. He had recently returned from a voyage to Egypt and Cyprus where he had made a small collection of birds and he at once felt inclined to visit Mexico, provided that there was a collecting naturalist of good reputation to go with him. A gardener [...] by the name of Ferdinand Deppe, was recommended for this task by Professor Hinrich Lichtenstein, director of the Zoological Museum of Berlin University (Streseman, 1954: 86). 
It was so that Ferdinand Deppe (1794-1861) came to Mexico for the first time in 1824, in the company of the Count von Sack. However, as soon as they reached Mexico, the difficult character of the Count made Deppe go his own way, beginning a series of travels through the country, collecting birds for the Zoological Museum and plants for the Botanical Garden of Berlin. In 1828 he traveled to Mexico again, this time in the company of doctor Christian Julius Wilhelm Schiede (1789-1836), who was a physician and a passionate botanist. "They expected to make a living in Mexico by selling zoological and botanical specimens to European Museums and dealers. [...] But they were soon disappointed [...] and although part of the material which the two friends had collected up to May 7, 1829, had been acquired by the museums of Berlin and Vienna, the financial result of their efforts was far from what they had expected" (Streseman, 1954: 88). Both were guests of Sartorius and explored in depth the environs of El Mirador and the states of Veracruz and Tabasco. Deppe had collected earlier in Guatemala, although no collections by him in this country have been identified.

Despite the short time they spent in Mexico, Deppe and Schiede discovered a great number of new orchid species. Worthy of mention are: Gongora galeata (Lindl.) Rchb. f. (Deppe s.n ), Lycaste deppei (Lodd.) Lindl. (Deppe s.n.), Stanhopea oculata (Lodd.) Lindl. (Deppe s.n.), Vanilla pompona Schiede (Schiede \& Deppe s.n.), Vanilla sativa Schiede (Schiede \& Deppe s.n.), Vanilla sylvestris Schiede (Schiede \& Deppe s.n.), Isochilus major Schltdl. \& Cham. (Schiede \& Deppe 1046), Vanilla pompona Schiede (Schiede 1043), Campylocentrum schiedei (Rchb. f.) Benth. \& Hemsl. (Schiede s.n.), Dichaea neglecta Schltr. (Schiede 1053), Pleurothallis schiedei Rchb. f.. (Schiede, W 25687), and Lepanthes schiedei Rchb. f. (Schiede s.n.) Many species were dedicated to them and Schiede was honored with a new genus created by Schlechter: Schiedeella (Fig. 30A). Aside from their botanical interests, Deppe and Schiede were important contributors to the study of Mexican fauna and collaborated with the German zoologist Wiegmann, an important investigator of tropical amphibians and reptiles. Schiede made also interesting observations on general aspects of the vegetation in the regions which he visited (Schiede, 1829-1830). While Deppe returned to Germany in 1829 , Schiede settled in Mexico, where he died in 1836, a victim of typhus.

Carl Christian Sartorius (1796-1872) was a German traveler who arrived in the region of Veracruz shortly after the independence of Mexico. Son of a protestant priest, he had been in jail and had lost his position as a teacher in Germany for political reasons, and decided to emigrate to Mexico. The majority of the Spanish residents in the region of Veracruz had emigrated to Cuba after Mexico's independence and so Sartorius, in company with the Swiss Carl Lavater ${ }^{21}$, was able to purchase in 1826 a large part of the 'Hacienda Amazónica', an estate that had been the property of Francisco Arrillaga, with a total area of 12,000 acres. Sartorius established his residence in a place called 'Paso de los Monos' (= 'pass of the monkeys'), which he called 'El Mirador' (= 'the look-out point'). El Mirador soon became a place of refuge for all naturalists who visited the area and is perhaps the most frequently cited Mexican locality of collection during the whole XIX century. Sartorius' political ideals were soon put into practice in Mexico. His "ideal city", as he called her, was to be a German city. He built a community house, a library, and rooms for research and teaching. He publicized his project in Germany and, in 1833, the first group of settlers came to Mexico. After one year, 45 settlers lived in Sartorius 'Monte Libre' (= 'free mountain'). But the conditions were very harsh and Sartorius' was soon left alone with his plans. A passionate botanist and generous host, Sartorius took into his house many of the travelers, especially Germans, who explored the Mexican Southeast during a good part of the century. Among them were Karwinski, Schiede, Deppe, Hartweg, Heller, Galeotti, Leibold, Linden, Liebmann and Purpus. Many of them, like Sartorius, had left Europe for political reasons.

Florentin, Sartorius' son, continued his father's tradition. El Mirador was a meeting place for naturalists and botanists until the first years of the $\mathrm{XX}$ century. Sartorius herbarium is now at the Smithsonian Institution and contains specimens collected mainly at El Mirador, among which we can find Epidendrum viridipurpureum Lindl., Pleurothallis tenuissima Rchb. f., Lepanthes pristidis Rchb. f., Epidendrum cochleatum L., Epidendrum polybulbon

${ }^{21}$ Lavater was Swiss consul in Mexico from 1827 to 1832. 
Sw. and Maxillaria variabilis Batem. A list of species collected by Sartorius was published by Reichenbach in 1856 under the name of Orchideae Mirandolanae (mexicanae) Sartorianae (Reichenbach, 1856). We remember El Mirador in Cyclopogon miradorensis Schltr., whose description is based on a collection by $\mathrm{J}$. A. Purpus 1n 1922 (J. A. Purpus 92, El Mirador). It is said that during his short stay in Mexico (1864-1867), the unfortunate Maximillian of Hapsburg bought an estate called 'Jalapilla', adjacent to 'El Mirador', with the purpose of enlarging his collections of plants and butterflies and also to chat and exchange scientific information with his neighbor. Maximillian had little time to enjoy the beauties of Mexican nature. He died in 1867, executed by the troops of Benito Juárez.

An interesting book about Mexico, Mexico als Ziel für Deutsche Auswanderer, was published by Sartorius in 1850. An English translation, Mexico and the Mexicans, was published in London in 1859. In this book (version of 1975), Sartorius writes about the tropical forests: "Each tree is covered by countless plants, from fungi in the roots to orchids in its branches" (Sartorius, 1975: 15) (Fig. 30B). Johann Moritz Rugendas (1802-1858), famous romantic German painter, was a friend of Sartorius and spend three years at El Mirador. The London edition (1859) of Sartorius' book was beautifully illustrated with engravings based on Rugendas paintings during his stay in Mexico (Fig. 30C).

Although born in Hungary, Wilhelm Friedrich Freiherr von Karwinski von Karwin (1780-1855) came to Mexico in 1827 supported by the "DeutschAmerikanischer Bergwerksverein zu Elberfeld" (= 'German-American Mining Company of Elberfeld') to explore the possibilities of securing mining concessions in the country but also moved by his botanical interests. "Karwinski was educated in Vienna and had become a mining engineer of some distinction. After working more than a decade in Spain he inherited some property in Bavaria and moved there in 1815 . He became interested in traveling to America, and after unsuccessful attempts to associate himself with the Brazilian expeditions of Martius... he visited Brazil, apparently at his own expense, in 1821-23" (McVaugh, 1980: 141). Of interest for our study are Karwinski's collections near Oaxaca and Tehuantepec during his first trip to Mexico (1827-1832) where he collected, among others, the type of Habenaria clypeata Lindl. and Mormodes pardina Batem. The botanical specimens from Karwinki's first trip to Mexico went to the Botanical Garden in Munich. "Karwinski's second trip to Mexico (18411843) was undertaken when he was 60 years old, under the auspices of five different sponsors in St. Petersburg (now Leningrad). By the term of this agreement he was to look for plants and animals, and also, primarily, to search for minerals in commercial deposits. His trip was very successful, botanically speaking. He brought back more than 2000 gatherings..." (McVaugh, 1980: 144). The specimens from this trip are mostly in Leningrad. Some of his collections of Orchidaceae where Cranichis tubulosa Lindl. and Isochilus cernuus Lindl.. Reichenbach dedicated to him his Epidendrum karwinski Rchb. f., today a synonym of Prosthechea bicamerata (Rchb. f.) W.E. Higgins, from a specimen collected by Karwinski in Teoxomulco, Oaxaca. Lindley named in his honor his Cyrtochilum karwinski and Martius his Cattleya karwinski.

His main explorations during this trip where in the northern lowlands of Veracruz, where, during a few months, he traveled together with the Danish botanist F. M. Liebmann. As Liebmann wrote on February $21^{\text {st }}$, 1841: "Mexico's present situation makes it to a certain extent advisable with combined strengths to brave the dangers with which a completely demoralized population, anarchy and lawlessness will each day confront us..." (McVaugh, 1980: 146).

The exploratory activities of a surprising group of botanists and collectors from a small country that had gained its political independence only a few years earlier, began with the arrival in our region of Henri Guillaume Galeotti (1814-1858), a native of Versailles but sponsored by the Vandermaelen brothers, Belgian nurserymen. "The two brothers, both passionately interested in cartography and the natural sciences, were particularly sensitive to the echoes of the voyages of von Humboldt. [...] Later, from 1835 to 1840, the Vandermalen brothers would finance the expedition of botanist and geologist Henri Galetotti..." (Ceulemans et al., 2006: 24).

Galeotti had been born in Paris, from an Italian father and a French mother, and followed his father when he established himself in Brussels. In 1843 he obtained the Belgian citizenship (Touret \& Visser, 2004: 84). In 1835 Galeotti left Hamburg for Mexico, where he spent 
five years, collecting mainly in Veracruz, Mexico and Oaxaca. Like many others, he was a guest of Sartorius in El Mirador. He established botanical stations both there and in Zacualpán. In 1838 he climbed Mount Orizaba in the company of Ghiesbreght, Funck and Linden (Galeotti, 1861: 271-73). Galeotti's herbarium was estimated at 7,000 to 8,000 specimens, containing many new species, that were later described by himself in conjunction with the French botanist Achille Richard. In May of 1836 he wrote from Mexico: "I have gathered already a great number of vegetables, many of which still lack a scientific denomination; they will fill the greenhouses from Messieurs Vandermaelen with infinity of beautiful and curious plants" (Diagre, 2004: 36). After his return to Belgium in 1840, Galeotti was elected correspondent of the recently founded 'Société Royale d'Horticulture de Belgique', a position he held until his death in 1858 (Quetelet, 1859: 143). "[Galeotti] trusted the description of the orchids to Achille Richard, the cacti to Lemaire, the Gramineans to Trinius and the ferns to Martens" (Crépin, 1800-1883: 434) (Fig. 31A). His herbarium was acquired by the Society and remains in Brussels. "[...] He went into business in Schaerbeck, but his efforts failed in the wake of the economic crisis of 1848; he appears to have possessed little commercial acumen" (Ceulemans et al., 2006: 55).

Some of the species of Orchidaceae collected by Galeotti in Mexico are: Barkeria melanocaulon A. Rich. \& Gal. (Galeotti 5069), Bletia adenocarpa Rchb. f. (Galeotti 5345), Cyclopogon luteo-albus (A. Rich. \& Gal.) Schltr. (Galeotti s.n.), Cyclopogon saccatus A. Rich. \& Gal. (Galeotti 9124), Epidendrum galeottianum A. Rich. \& Gal. (Galeotti 5194), Epidendrum longipetalum A. Rich. \& Gal. (Galeotti 5238), Epidendrum propinquum A. Rich. \& Gal. (Galeotti 5265), Masdevallia galeottiana A. Rich. \& Gal. (Galeotti 5075), Pleurothallis violacea A. Rich \& Gal. (Galeotti s.n.), Prosthechea chondylobulbon (A. Rich. \& Gal.) W. E. Higgins (Galeotti s.n.), Schiedeella violacea (A. Rich. \& Gal.) Garay (Galeotti 5120). Two orchid genera were named in honor of Galeotti: Galeottia (Fig. 31B) by his friend and colleague Richard and Galeottiella by Rudolf Schlechter.

Achille Richard (1794-1852) (Fig. 31C) had studied medicine but his interests inclined soon towards Botany, and he became one of the most important botanists of his time. In 1819 he published the first edition of his Eléments de Botanique. The Orchidaceae were his favorite family, and his first important work in systematic botany was the Monographie des Orchidées des îles de France et de Bourbon, in 1828. When Galeotti returned from Mexico in 1841, Richard took charge of the study and description of the new species of Orchidaceae planning to publish, together with the former, a monograph of the Mexican species of this family. The first part was published in 1845 . Richard's death in 1852 and financial problems made the publication of the rest of this monograph an impossible task (Veyret, 1997: 17).

The Austrian Carl Bartholomäus Heller (18241880), professor at the famous 'Theresianum' academy in Vienna, left England on October 2, 1845 in the company of Hartweg (Anonymous, 1854: 117), and collected in Mexico between 1845 and 1848, becoming one of the many guests of Sartorius at El Mirador. In 1846 he sent 14 boxes of orchids to Vienna (Anonymous, 1846: 216). Among his collections we can find the types of Govenia deliciosa Rchb. f. (Heller, El Mirador, W-Rchb. 42259), Mormolyca lineolata Fenzl. (Heller s.n., El Mirador) and Epidendrum helleri Fenzl. ex Hemsl. (Heller s.n). Heller's accounts of his travels through Mexico are of great interest, especially the phytogeographical description of the region around the Orizaba volcano (Heller, 1847). Before traveling to Mexico with Hartweg, Heller had tried to organize an expedition on his own, for which he had chosen young Benedikt Roezl as his assistant, but the project failed due to the lack of financing (Block, 1985: 1201-1202).

A native of Luxembourg, Jean Jules Linden (18171898) (Fig. 31D) moved as a young man to Belgium, where he became one of the first students of the recently founded University of Brussels. At the age of nineteen he was entrusted by the Belgian government (at the suggestion of Barthélemi Du Mortier, botanist and man of state) with his first scientific mission that would take him to South America (Linden, 1894: 117). Between 1835 and 1837, he explored the Brazilian provinces of Rio de Janeiro, Spiritu-Santo, Minas Gerais and Sao Paulo. "Unlike many plant hunters who went to work purely for commercial reasons, Jean Linden had a botanical interest in many species, not just the orchid. It is thanks to him that we have so many varieties of fern, palm, begonia, bromeliad, and so on" (Ceulemans et al., 2006: 7). 
His second expedition, in the company of his countrymen Funck and Ghiesbreght (who took part as a zoologist), departed for Havana in October of 1837 and went on to Mexico, resting at El Mirador of Carl Sartorius. Here he met Galeotti, who had arrived in Mexico three years earlier. They proceeded to the east: "Linden first went to Yucatan, and thence to the States of Chiapas and Tabasco; visiting and exploring the districts of Ciudad Real, Cacaté, San Bartolo Titotoli, Santiago de Tabasco, Teapa, Puyapatengo, etc. where he formed by far the largest collection we have seen from those parts of Mexico" (Hemsley, 1887: 126). He continued from there to northern Guatemala returning then to the coast of the Gulf of Mexico. "In 1839-40, a disaster threw the smooth running of the expedition into turmoil. Jean Linden fell seriously ill, stricken by a violent attack of the vómito negro, which Europeans call yellow fever. [...] A natural haemorrhage saved his life, but it took a painful three-month recovery before he could return to his collecting" (Ceulemans et al., 2006: 57). Funck and Ghiesbreght re-embarked for Brussels in September 1840. Linden was left on the American continent and eventually returned home via Havana and the United States.

A third and last expedition, between 1841 and 1844, would take him to Venezuela and Colombia (where he would meet again with Hartweg), in the company of Joseph Schlim and Funck. "No later than October 1845 - he had been home barely 11 months - he entrusted his old traveling companions, Nicholas Funck and Louis-Joseph Schlim, with a mission to Venezuela and Colombia".

“[...] Linden did not leap blindly into the horticultural trade but viewed his careers as a long-term proposition. He began with an audacious and clever stroke that proved vital in bringing himself to public attention. He wrote to eminent English botanist, John Lindley, asking him to draw up a scientific description of the orchids discovered on his recent travels. [Lindley] accepted Linden's proposal and began his work of taxonomy which resulted in the publication of Orchidaceae Lindenianae, or Notes upon a collection of Orchids Formed in Colombia and Cuba by Mr. J. Linden (Lindley, 1846). [...] Linden's maneuver was brilliant. [...] This scientific recognition gained him entrance to the world of professional botanists as well as winning the confidence of growers and orchid lovers"
(Ceulemans et al., 2006: 105-106). After starting business in Luxembourg, he established himself in Brussels in 1851, where he found greater possibilities to commercialize his plants and where he found clients who where willing to pay considerable sums for new species, especially orchids. From 1851 to 1861 he was the director of the Royal Zoological and Botanical Gardens at Leopold Park in Brussels. In addition to the great number of species he introduced into Europe, Linden had the merit of studying closely the conditions in which the orchids grew in nature and to adapt the cultural methods in Europe to these conditions, thus creating in his greenhouses 'real' microclimates for the plants he imported. Linden, who maintained close relations with English horticulturists, quickly adopted the new techniques of the Industrial Revolution and built greenhouses of gigantic proportions in Ghent and Brussels, becoming soon the favorite supplier of the members of the upper classes. Among his clients he even counted the Czar of Russia.

The Linden name is associated with a number of important publications: L'Illustration horticole (1854-1896), and above all Pescatorea (1860) and Lindenia (1885-1906), continued by his son Lucien), commonly ranked amongst the most magnificent and outstanding works in orchid literature. Some of the species the types of which were collected by Linden and deserve to be mentioned are: Brachystele minutiflora (A. Rich. \& Gal.) Burns-Bal. (Linden 1237), Gongora truncata Lindl. (Linden s.n.), Notylia orbicularis A. Rich. \& Gal. (Linden 216), Oncidium lindenii Brongn. (Linden s.n.), Prosthechea panthera (Rchb. f.) W. E. Higgins (Linden 1236), Sarcoglottis corymbosa Garay (Linden 1232), Stelis ciliaris Lindl. (Linden 203), and Stelis purpurascens A. Rich. \& Gal. (Linden 211).

Linden had an enormous influence on European orchidology during the last two thirds of the XIX century. His nurseries, managed by his son Lucien after his death, survived until World War I. "It can be said of Jean Linden that, in addition to his scientific merits, he also had outstanding commercial talents. In him, moreover, scientific discipline, a feeling for new discoveries, a love for botanical science and an aesthetic sense were harmoniously combined. It is these qualities that have made Linden an important historical figure" (Ceulemans et al., 2006: 7). 
The Belgian Auguste Boniface Ghiesbreght (18191893) and the Luxembourgian Nicholas Funck (18161896) explored Mexico (especially the states Tabasco and Chiapas) together with Linden. While Funck later joined Linden in his third expedition to South America, Ghiesbreght returned to Mexico in 1840, where he formed important collections. "He introduced many fine plants to the nurseries of Van Houtten and Verschaffelt" (Anonymous, 1893: 634). Ghiesbreght had been hired as the zoologist of the expedition, and in 1842 sold insects to the Paris Museum, for 30 francs per hundred specimens (Papavero \& Ibáñez-Barnal, 2001: 83). During the years of 1850-1855 he made his third voyage to Mexico and his second to Chiapas, forgetting the dangers he had encountered before and which had almost cost him his life. He died in Mexico, at San Cristóbal de las Casas, in February of 1893 (Anonymous, 1893: 634). Ghiesbreght was perhaps the botanist with the greatest knowledge of the flora of northern Mesoamerica during the first half of the XIX century. Although his collections were primarily of plants from other families, he discovered an important number of new species of Orchidaceae that were described by Richard and Galeotti in the Annales des sciences naturelles, a journal whose publication had begun some years earlier in Paris, edited by Adolphe Théodore Brongniart. Ghiesbreght would become Linden's lifelong friend and collaborator. "Captivated by the novelties of a tropical flora, his earliest and latest field of research, and apparently his favorite one, was the south-eastern-most part of Mexico, comprising the states of Tabasco and Chiapas" (Anonymous, 1889: 585).

Funck (Fig. 32A), who was Linden's favorite illustrator, also made important contributions to the knowledge of the orchids of Central America. "He is [...] inextricably linked with the life of Jean Linden. [...] His name is also to be found amongst the administrators of the Linden companies [...] The friendship between the two men was further strengthened when Funck and Linden married two Luxembourg sisters, Catherine and Anna Reuter, on 9 April 1849 and 13 October 1845 respectively" (Ceulemans et al., 2006: 27). Among the types collected by Ghiesbreght and Funck, or dedicated to them, are the following: Brachystele sarcoglossa (A. Rich. \& Gal.) BurnsBal. (Ghiesbreght s.n.), Calanthe calanthoides (A.
Rich. \& Gal.) Hamer \& Garay (Ghiesbreght s.n.) (Fig. 32B), Encyclia ghiesbreghtiana (A. Rich. \& Gal.) Dressler (Ghiesbreght 6, Oncidium ghiesbreghtianum A. Rich. \& Gal. (Ghiesbreght W 27024), Spiranthes cinnabarinus Hemsl. (Ghiesbreght s.n.), Epidendrum funckianum A. Rich. \& Gal. (Funck s.n.), and Pelexia funckiana (A. Rich. \& Galeotti) Schltr. (H. Galeotti 5171). Richard and Galeotti dedicated the genus Ghiesbreghtia and Schlechter the genus Funckiella to these two great Belgian botanists.

The German Friedrich Ernst Leibold (1804-1864) arrived in Mexico in 1839. As one of many guests of Sartorius, he collected mainly in Zacuapán, in the neighborhood of El Mirador. Reichenbach named after him Leochilus leiboldi and Hemsley mentions many of his collections, such as: Epidendrum seriatum Lindl., Sobralia macrantha Lindl., Govenia mutica Rchb. f., Maxillaria pumila Hook. and the types of Brassavola (=Homalopetalum) pumilio Rchb. f. and Lepanthes pristidis Rchb. f. Reichenbach described many of the species collected by Leibold in Klotzsch's "Beiträge zu einer Aequinoctialflora Amerika 's"(1849).

Emmanuel Ritter von Friedrichsthal (1809-1842) was born in Bohemia and in 1839 traveled through Nicaragua and Costa Rica, continuing to Panama, Guatemala and Yucatán. "He disembarked in San Juan del Norte, in Nicaragua, at the beginning of 1839, having been before in the Antilles, and after exploring the Pacific coast of the other Central American countries, arrived in Costa Rica, possibly via Puntarenas" (León, 2002: 132). Friedrichsthal drew maps, took barometric measurements, investigated the conditions of the natural history and ethnography and sent reports to his government about the technology, industry and commerce of the countries he visited (Wurzbach, 1858: 360). "He botanized extensively in Costa Rica between 1839 and 1842, along the Río San Juan and from Guanacaste to Cartago" (Grayum et al, 2004: 2). However, all of his collections at Kew are labeled 'Guatemala'. Friedrichsthal, like many others before him, applied the name Guatemala to Central America as a whole, probably keeping with the customs of colonial times of calling the region 'Captaincy General of Guatemala' or 'Kingdom of Guatemala'. The confusion is clear in the description of one of the new species of Orchidaceae known from Friedrichsthal's collections: Maxillaria friedrichsthallii 

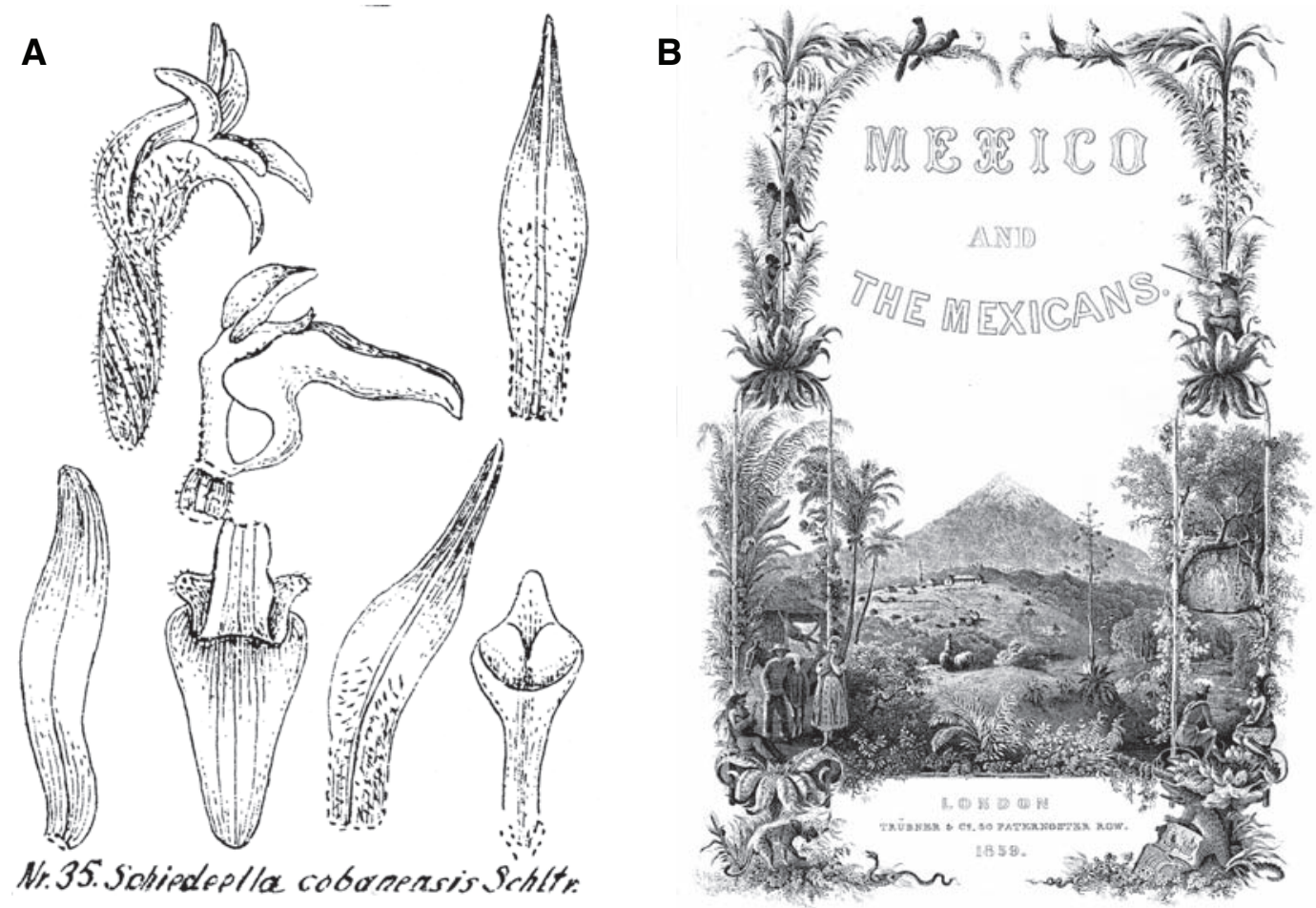

C

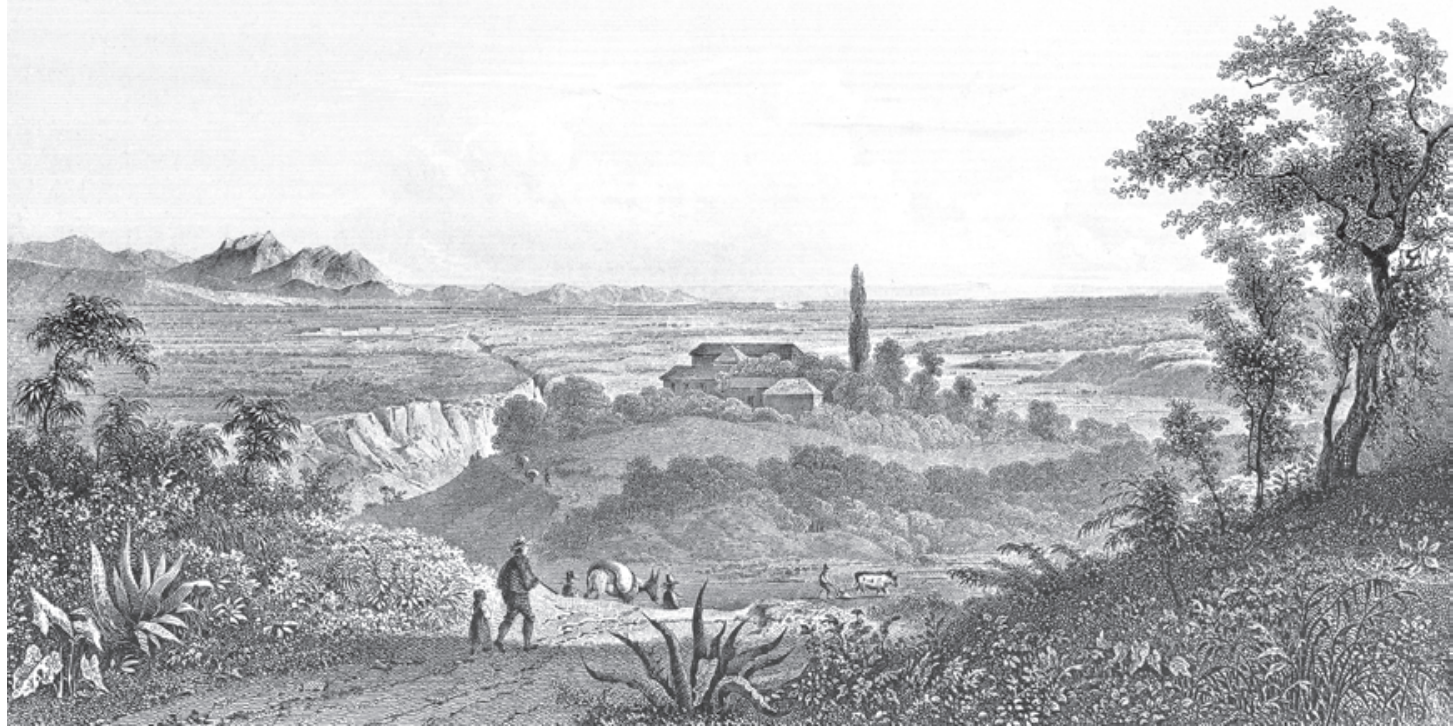

FiguRe 30. A - Schieedella cobanensis Schltr. Drawing by R. Schlechter. In Schlechter,1931, plate 9, illustration 35. B - Frontispiece of Sartorius' work, Mexico and the Mexicans, 1850. C - J. M. Rugendas: The Mirador looking towards the Gulf. In Sartorius, 1975: 8. 
A

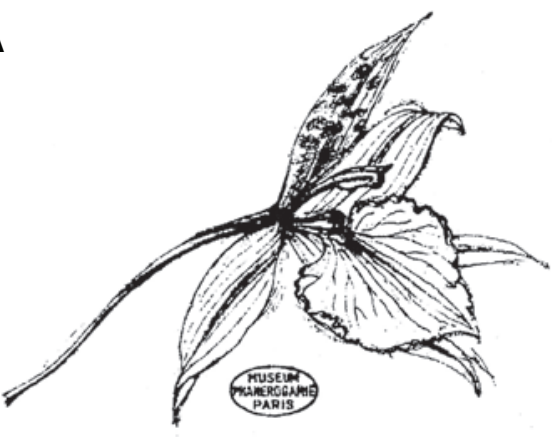

Odontoglossum corulascens nob.

C
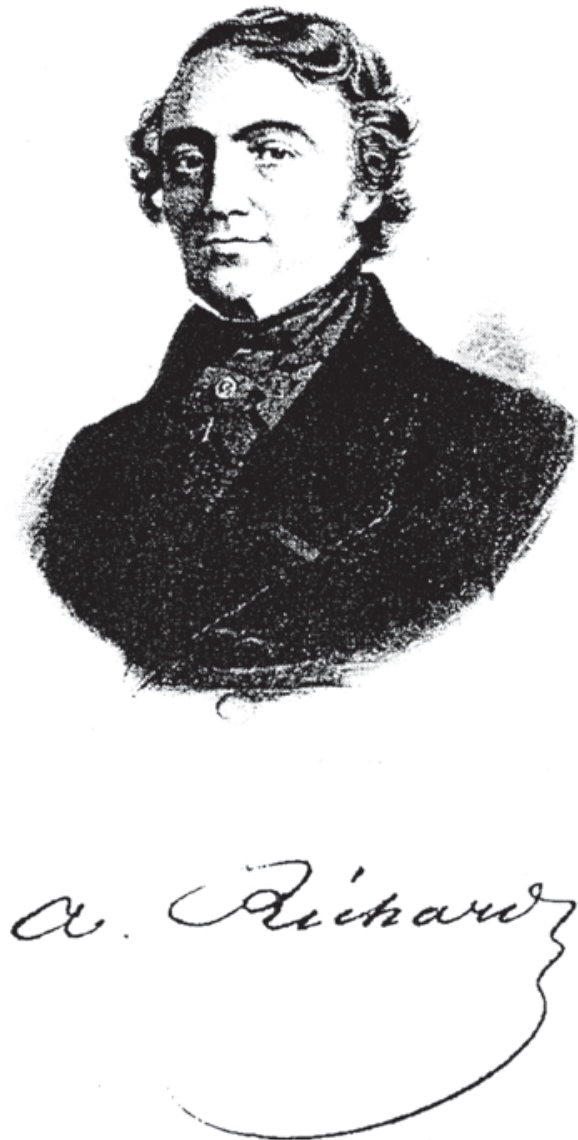

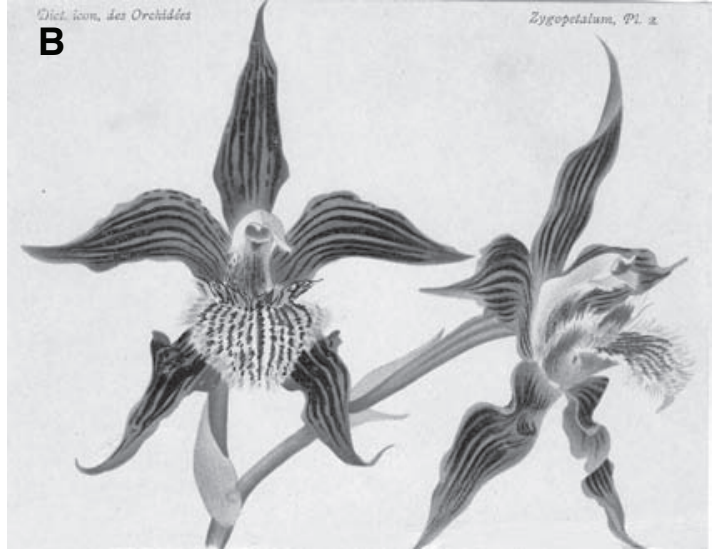

D

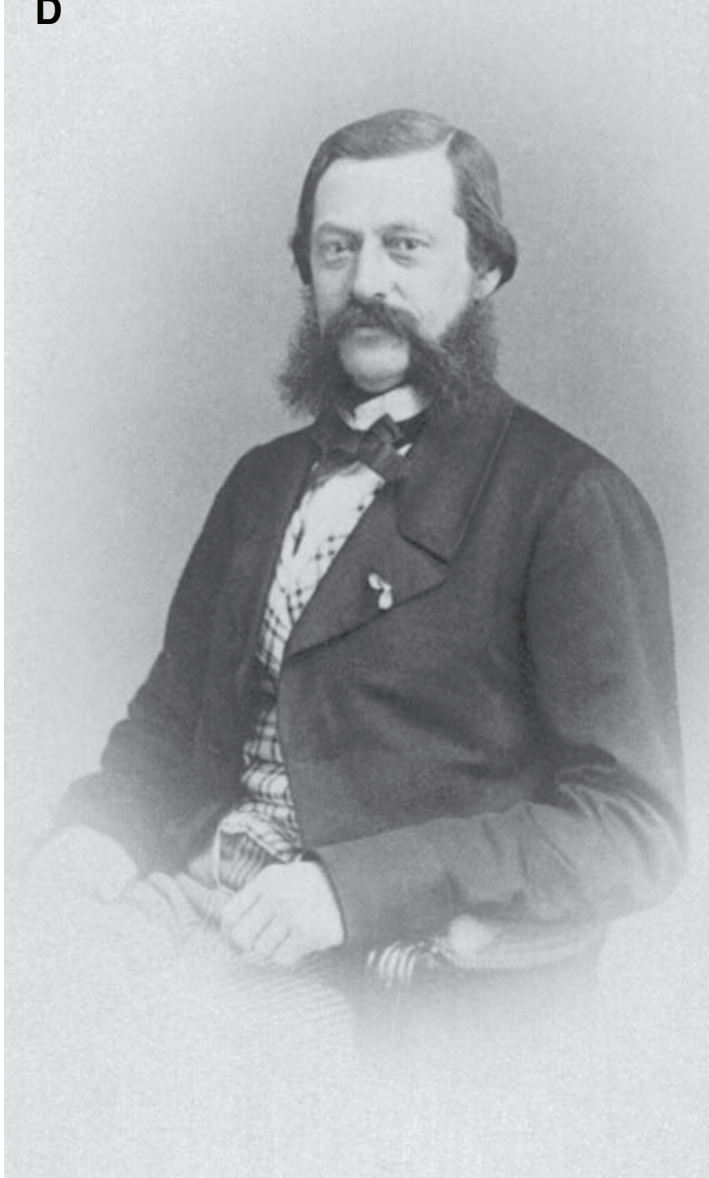

Figure 31. A - Odontoglossum caerulescens A. Rich \& Gal. A drawing by Galeotti with the determination by Richard. In Veyret, 1997: 16. B - Galeottia grandiflora A. Rich. \& Gal. Illustration by A. Goosens in Cogniaux \& Goosens, 18961907. C - Achille Richard (1794-1852). In Veyret, 1997: 5. D - Jean Jules Linden (1817-1898). From Gardeners' Chronicle, courtesy of the Hunt Institute for Botanical Documentation. 

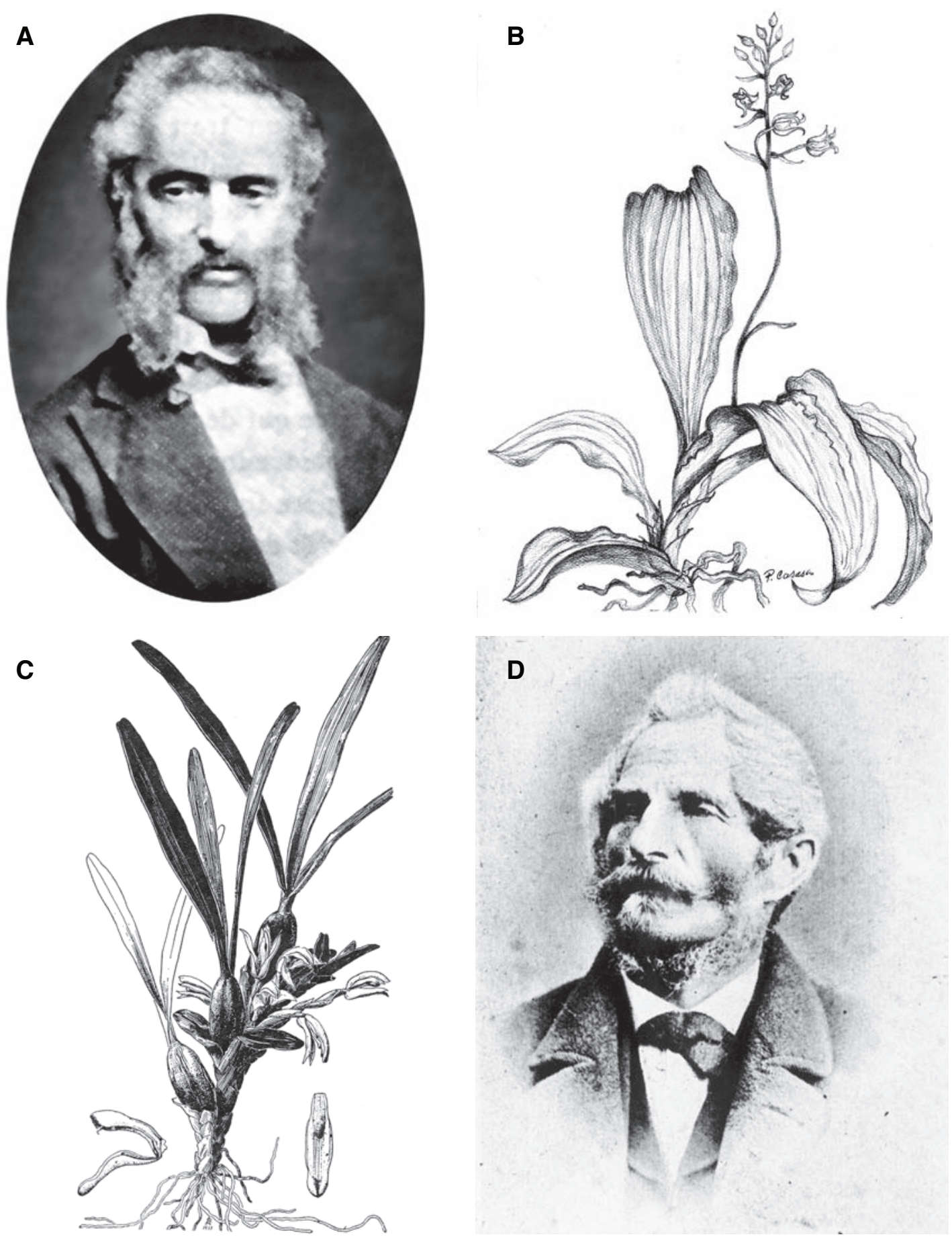

Figure 32. A - Nicholas Funck (1816-1896). Courtesy of Rudolf Jenny. B - Calanthe calanthoides (A. Rich. \& Gal.) Hamer \& Garay. Illustration by Pilar Casasa. C - Maxillaria friedrichsthalii Rchb.f. Illustration by Blanche Ames, courtesy of the Oakes Ames Orchid Herbarium, Harvard University. D — Josef Ritter von Rawiez Warscewicz (1812-1866). Courtesy of the Hunt Institute for Botanical Documentation. 

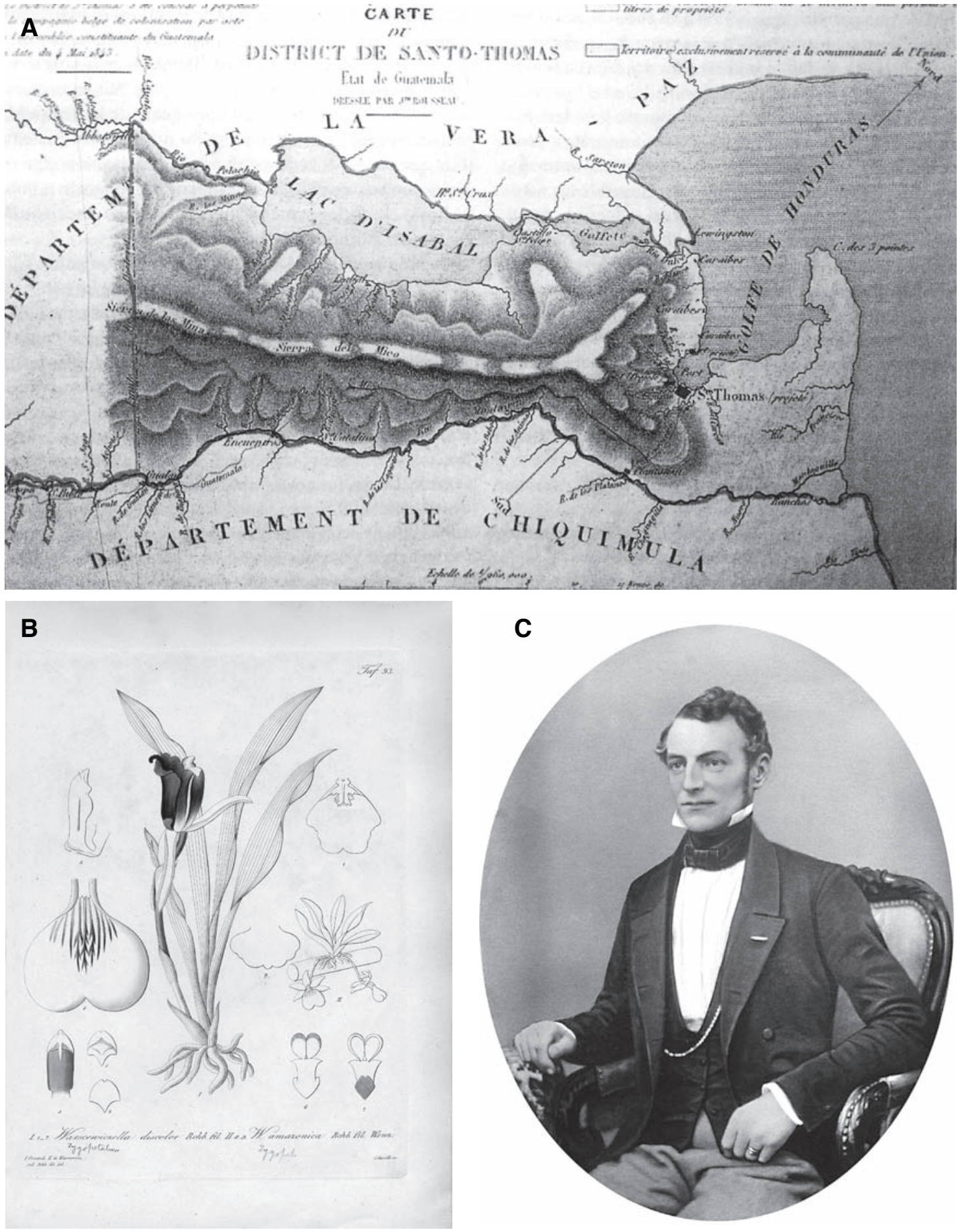

Figure 33. A - Map of the Belgian colony in Santo Tomás, Guatemala. In Wagner, 2001: 42. B - Warczewiczella discolor Rchb.f. Xenia Orchidacea I, Plate 93. C - Michael Frederik Liebmann (1813-1856). Courtesy of the Botanical Garden \& Museum, Copenhagen. 
Rchb. f., (Friedrichsthal, AMES 25856) (Fig. 32C). In Reichenbach's description, the locality of collection is referred to as: Guatemala, Chontales, in Monte Aragua, although it is well known that Chontales is in Nicaragua. Other collections by Friedrichsthal include the type of Ornithocephalus inflexus Lindl. (Guatemala, am Fluss Torre), Gongora quinquenervis Ruiz y Pav. (Guatemala, San Juan River (!)) and Schomburgkia tibicinis Batem. (Río de Mico, Petén). "Friedrichsthal is considered one of the pioneers of expedition photography. Already in the year after Daguerre's technique was publicized [1837], he employed this new technique to depict Maya ruins. In 1840, he was the first European to describe Chichén Itzá".

He must have met Skinner, who in one of his letters to Alexander Mac Donald in Belize asks: "Did le Chevalier Frederickstal [sic] find much up the river?" (Letter from Skinner to Mac Donald, Feb. 26 ${ }^{\text {th }}, 1841$ ). It was, by the way, Mac Donald's wife who introduced from Belize into England the type specimen of Brassavola (=Rhyncholaelia) digbyana Lindl., today the national flower of Honduras ${ }^{22}$. A different version states that the plant was sent by Governor Digby, and named in honor of his kinsman, Lord Digby; it had been collected by employees of Messrs. Brown, Ponder, and Co., of Belize, who dealt in mahagony and logwood (Boyle, 1901: 151). A large part of his collection and equipment was stolen during a robbery in the province of Yucatan, at the southern end of the peninsula of the same name. At the end of October 1841 he reached Vienna, badly suffering from the serious illness he had caught in Latin America and that was to lead to his death a few months later.

"Last Monday George brought here a Pole - a great traveller \& one of the first botanists in the world. His name is Warscewicz.... He talks a mixture of Spanish and Polish, \& wears a beard, in fact, is all hair, from his nose downwards!". Mrs. Skinner, in a letter to her friend Juliana Raymond dated April 15, 1850, described with these words her first encounter with Josef Ritter von Rawiez Warscewicz (1812-1866) (Fig. 32D). Warscewicz was born in Lithuania, of Polish ancestors, mostly military (Lückel, 1982: 125), and "received his initial training in Botany at Rumzill's [really Jundzill] Botanical Gardens in Poland [actually in Vilnius,
Lithuania] and at the Berlin Botanic Gardens, and then joined a Belgian contingent of settlers [in Guatemala] in 1845 to collect plants for the nurseryman Van Houtte of Ghent, Belgium" (Milligan \& Banks, 1999: 22). Van Houtte owned a large garden in Santo Tomás, now Matías de Gálvez, Guatemala (Savage, 1970: 275). The colonization program in Santo Tomás had started in 1834, when the Guatemalan Congress passed a law promoting the development of the Departments of Verapaz, Livinston and Santo Tomás. Colonization began in 1836 by the British 'Commercial and Agricultural Company of the Eastern Coast of Central America' but in 1841 the British interests were sold to the Belgian Colonization Company (Wagner, 2007: 17-22) (Fig. 33A).

But the new Belgian colony in Santo Tomás, Guatemala, was a complete failure. "They sold him the idea that he would find a prosperous town full of rich settlers. When he arrived, in February of 1845, Warscewicz found that instead of the promised city there was only a hamlet of straw huts. Instead of rich and active settlers he found immigrants so sick that they looked like corpses raised from the dead. From the 32 healthy and strong individuals who arrived with Warscewicz from Europe to join the colony, only our botanist and the group's physician survived" (Heckadon-Moreno, 1998 62). The Belgian Colony was officially dissolved by the Guatemalan government in 1853 (Wagner, 2007: 33). Thanks to Humboldt's recommendation [Humboldt had previously recommended him to the Botanical Garden in Hamburg], Warscewicz initiated correspondence with Skinner, with whom he did not start off well, possibly because they did not meet personally until 1850 (Skinner was at the time in England). "I have had enough of him... (Letter from Skinner to Hooker, 15.09.1846)". “...And I am disgusted with Warscewicz and almost feel inclined to have nothing more to do with him" (Letter from Skinner to Hooker, 15.12.1846). But the relations would improve, until Skinner became an admirer of the extravagant Pole.

"From Guatemala, Warscewicz traveled to El Salvador, where, due to extensive deforestation, he found only few plants. He went on to Nicaragua and met there Dr. Oersted, who informed him of the best regions for botanical exploration. Together they

\footnotetext{
${ }^{22}$ The name honors Edward St. Vincent Digby, an orchid grower from Minterne, Dorsetshire, who first received the plant from Mrs. Mac Donald.
} 
explored the forests of Nueva Segovia, collecting 2,000 specimens of orchids". His next destination was Costa Rica, where he arrived in 1848 and then Panama, collecting later in several countries of South America.

From a letter from Warscewicz dated March 15, 1848 (unknown recipient) we can see how difficult his travels were and understand the hardships he went through: "My journey by land (500 leagues) from Guatemala to Costa Rica was very hard; hunger, thirst and other contrarieties bothered me all the time; only the wonderful and exuberant vegetation helped me endure so critical a situation; this vegetation was my constant companion along the way [...] Presently I am traveling to Panama and Veraguas... I need money to travel and collect with profit - I have been waiting for it in vain for already a long time, since what I received from my friends and sympathizers in Germany in exchange for the considerable shipment of seeds, plants and orchids which I sent last year from Guatemala was barely enough to ship the plants and return the expenses" (Méndez \& Monge-Nájera, 2003: 205). In 1850 he passed again through Costa Rica and Panama, returning to Europe after a bad attack of yellow fever. There he finally met Skinner, who took him into his house because of Warscewicz's ruinous financial situation ("poor fellow, I am afraid he will find it difficult to recover his expenses"; Letter from Skinner to Hooker, 03.04.1850). After he met him, Skinner wrote enthusiastically to Lord Derby: "He is strong as iron in constitution, fearless as a lion of dangers \& enthusiastic beyond description" (27.04.1850).

He spent several months in Berlin as assistant to Reichenbach, describing over 300 species of orchids. In those days he published a list of orchids brought by him from Central America, which he offered for sale (Warscewicz, 1850). Not used to sedentary work, he embarked for America again in 1851 and passed a last time through Panama. At the end of the year he was in Guayaquil, where he was robbed and lost his money and equipment, returning finally to Europe in 1853 (Anonymous, 1854a: 96). He was offered the position of supervisor at the Botanical Gardens of Krakow that he held until his death in 1866. "Together with the director Ignacy Rafel Czerwiakowski he published Catalogus Plantarum (Cracoviae 1864), listing 8,911 taxa cultivated in the garden, including some 300 species of Orchidaceae" (Yearsley, 2004: 159).

It was undoubtedly in Costa Rica and Panama where he collected the greatest number of orchids. In Costa Rica he explored chiefly the central region of the country and climbed the Barba and Irazú volcanoes. In Panama, his favorite collecting sites where the highlands of Chiriquí, which he came to consider as an orchidological paradise. It is again Skinner, in one of his many letters to Hooker, who tells us about the newly discovered beauties: "Mr. Warscewicz has sent me some 20 boxes of orchids... He is now in Veraguas on his way south, but so rich do I observe Costa Rica to be, I will persuade him to return and winter in Veraguas and Costa Rica... They are splendid examples of the richest orchid country in the world" (Letter from Skinner to Hooker, 11.07.1848).

Reichenbach described his collections in 1854 Orchideae Warscewiczianae Recentiores and in 1866 under the title of Orchideae Warscewiczianae and wrote: "the name of Von Warscewicz shines among those who have enlarged in a very considerable form the knowledge of orchids (Reichenbach, 1866; 4)." Some of the types collected by Warscewicz are: Epidendrum incomptum Rchb. f. (Warscewicz s.n., Panama), Elleanthus hymenophorus (Rchb. f.) Rchb. f. (Warscewicz s.n., Panama), Lacaena spectabilis (Klotzsch) Rchb. f. (Warscewicz W-Rchb. 44742), Maxillaria aciantha Rchb. f. (Warscewicz s.n., Costa Rica), Maxillaria atrata Rchb. f. (Warscewicz s.n., Guatemala), Maxillaria ringens Rchb. f. (Warscewicz s.n., Guatemala), Mesospinidium warscewiczii Rchb. f. (Warscewicz s.n.), Oerstedella centropetala (Rchb. f.) Rchb. f. (Warscewicz s.n., Panama), Oncidium warscewiczii Rchb. f. (Warscewicz s.n., Costa Rica y Panama), Prosthechea brassavolae (Rchb. f.) W. E. Higgins (Warscewicz W-Rchb. 64, Panama), and Sobralia warscewiczii Rchb. f. (Warscewicz s.n., Panama). Reichenbach named after him the genus Warscewiczella and a great number of species (Fig. 33B).

While collecting in Tropical America, Warscewicz sent to the Botanical Garden in Krakow a number of interesting orchids that unfortunately were lost during a severe winter. Those orchids that were rescued, were used by Franck, Governor of occupied Poland during World War II, as a decoration of his residence in Krakow... and were never returned to the Botanical 
Garden (Sampolinski, 1963: 214). Warscewicz had also interest in hummingbirds, "certainly a choice of interests in which he was to be envied" (Standley, 1925: 354).

Augustus Fendler (1813-1883) was born in Gumbinnen, Prussia, and came to the United States in 1836 to work variously at a tanyard in Philadelphia, a lamp factory in New York, and a gas works in St. Louis, until he discovered that a market existed for dry plants. George Engelmann, of St. Louis, Missouri, trained him as a collector. Fendler began his travels in the southwestern United States and collected later in Mexico, Nicaragua, Panama and Venezuela. In 1846 he was in Nicaragua, where he made a small collection of plants near Greytown (San Juan del Norte). He went on to Panama, in 1850, and his collections of this area are preserved at Kew and Missouri. In Panama he collected, among others: Oncidium ampliatum Lindl. (Fendler 331), Dimerandra emarginata (G. Mey.) Hoehne (Fendler 332), Dichaea panamensis Lindl. (Fendler 333) and Polystachya foliosa (Lindl.) Rchb. f. (Fendler 334). Only three new types of orchids are known among Fendler's collections, although all appear to be from Venezuela: Cranichis fendleri Schltr., Liparis fendleri Schltr. and Stelis fendleri Lindl. He returned to Germany and in the eighteen sixties we find him again in the United States, where he worked as an assistant to the great botanist Asa Gray. He then took up what Gray in dismay called "speculative physics", publishing a thin book, The Mechanism of the Universe (1874). Perhaps disappointed with its reception, Fendler spent the rest of his days on the island of Trinidad, where he died in 1883.

\section{The Scandinavians}

"Our Genus is Homo and our species is sapiens, and Linnaeus gave us our name. Thus we write our name Homo sapiens L."

Anonymous

Carl von Linné (1707-1778) is called, with justice, "the father of taxonomy". In his famous Species Plantarum of 1753, he set the foundations for modern botanical nomenclature. Linné was not only the greatest botanist of his century, but also founded a school of scientists whose names had enormous relevance in the second half of the XVIII and all of the XIX century.

Among his disciples and followers we find Pehr Kalm (1716-1779), who traveled during three years studying the plants of the North American colonies; the unfortunate Pehr Löfling (1729-1756), who participated in the Spanish expedition to the Orinoco and Daniel Solander (1733-1782), who was Cook's naturalist during his first voyage around the world and introduced to Europe the first collections of plants from Australia and the South Pacific, and was also in Surinam (Steele, 1964: 13).

In tropical America one must mention the Dane Julius von Roth (1737-1793), who was in Jamaica, Puerto Rico and the Lesser Antilles between 1757 and 1791 and above all the great Swede Olof Swartz (1760-1818) who explored Jamaica, Cuba and Haiti from 1784 to 1786, later publishing his Flora Indiae Occidentalis (1797-1806), where he described many new species of orchids. And, although no orchids are known among his collections, it is important to name here Johann Emmanuel Billberg (1798-1845), a young Swedish physician who visited Portobello in Panama in 1826 and made there an important collection of plants. Nearly 30 years later, after Billberg's death, Beurling published his Primitiae florae portobellensis, the first formal list of Panama plants, based upon this collection" (Standley, 1928: 42).

Two descendants of Linné's great school, both Danes, were protagonists in the history of our orchids during the first half of the XIX century:

Michael Frederik Liebmann (1813-1856) (Fig. 33C), studied in Copenhagen under the great Danish botanist Frederik Schouw and departed in 1840 to Mexico, thanks to a grant from the King of Denmark, to form botanical and zoological collections. In the company of a gardener, he soon established himself in the region of Veracruz and was one more of the numerous guests of Carl Sartorius in his estate El Mirador. He seems to have collected also in Guatemala $^{23}$. The orchids collected by Liebmann were later studied by Kraenzlin (1920) and Louis O. Williams (1938-39). He collected in the area until 1843, when he returned to Denmark, with a herbarium of 40,000 plants and considerable zoological collections. In 1845 he was appointed professor of botany at the University of Copenhagen

${ }^{23}$ Ames and Correll, 1985: 475, mention a collection of Epidanthus paranthicus (Rchb. f.) L.O. Wms. by Liebmann in Guatemala. 
and in 1849 director of the botanical Gardens. Alone and in conjunction with other botanists he published many new species, but his death at a relatively young age meant that many of the natural orders were left untouched. One of his most important works, Chênes de l'Amerique Tropical (= Oaks of tropical America) was unfinished and was later completed by Oersted.

Some of the specimens collected by Liebmann became the types for new species: Dichaea liebmanni Rchb. f. (Liebmann s.n., El Mirador), Jacquiniella leucomelana (Rchb. f.) Schltr. (Liebmann s.n., Mexico), Odontoglossum beloglossum Rchb. f. (Liebmann, W-Rchb. 43391, Mexico), and Ponthieva campestris (Liebm.) Garay (Liebmann 313, Veracruz).

According to Hemsley, for almost all we know of the botany of Costa Rica we are indebted to Anders Sandoe Oersted (1816-1872) (Fig. 34A), who explored this country and Nicaragua between 1846 and 1848 (Hemsley, 1887: 130). He was born at Rudkjobing on June 21,1816 in a family which boasted important names in sciences and politics (Lind, 1913: 17). “... After several years of teaching and investigation in Denmark, he started in 1845 a scientific expedition to the Dutch islands in the Caribbean and Jamaica (Poulsen, 1848: 876-877). From there he went to Nicaragua at the end of 1846, where he arrived first at Bluefields and went then to San Juan del Norte. It seems that he entered the country [Costa Rica] through Puntarenas" (León, 2002: 133). He collected intensively in Costa Rica and Nicaragua, especially in the great volcanic chain that includes the Irazú, Barba and el Viejo volcanoes, forming a collection of more than 900 species of superior plants, among them some 80 Orchidaceae that were later described by Reichenbach in his Orchideae Oerstedianae, that form part of his great work on the orchids of Central America of 1866.

He established his headquarters in San Antonio de Belén, to the west of the capital (Calvert \& Calvert, 1917: 19-20). In February of 1848 he went to the region of Guanacaste. "The purpose of this trip, promoted by the government of Costa Rica, was to study the possibility of opening a canal that would communicate the bay of Salinas with the lake of Nicaragua. Oersted presented a plan for the construction of the canal (Oersted, 1851), but no further attention was paid to the project".
Oersted describes the two existing roads of that time to the Atlantic Ocean: the almost abandoned road from Cartago to Matina and Moín, where he notes that in the plains of Turrialba the vanillas dominate among the forest vegetation and the road of Sarapiquí, by which he returns to San Juan del Norte and from there to Europe (Oersted, 1863: 3-5) (Fig. 35A).

He returned to Denmark in 1848 and was later appointed professor of botany, succeeding Liebmann in this position (Brown, 1872-1873: 4).

Oersted was a great naturalist and a first class observer, who left vivid descriptions of the landscape of the different regions of his travels. En 1863 he published his work on Central America: L'Amerique Centrale, recherches sur sa flore et sa geographie physique (=Central America, studies about its flora and physical geography). "A posthumous work, 'Praecursores Florae Centroamericana' published in Copenhagen in 1873, contains fragments of articles by Oersted and contributions of other authors about his collections of mosses, Araceae and others" (León, 2002: 136).

Among the many species discovered by Oersted, all described by Reichenbach, are the following: Beloglottis costaricensis (Rchb. f.) Schltr. (Oersted s.n., Costa Rica), Bulbophyllum aristatum Rchb. f. (Oersted s.n., Central America), Bolbophyllaria oerstedii Rchb. f. (Oersted 6746, Nicaragua) (Fig. 34B), Catasetum oerstedii (= maculatum) Rchb.f. (Oersted s.n., Nicaragua), Dichaea oerstedii (= glauca) Rchb. f. (Oersted s.n., Nicaragua), Epidendrum oerstedii Rchb. f. (Oersted s.n., Costa Rica), Habenaria oerstedii Rchb. f. (Oersted s.n., Nicaragua), Lockhartia oerstedii Rchb. f. (Oersted W-Rchb. 44337, Costa Rica), Oncidium oerstedii Rchb. f. (Oersted s.n., Nicaragua), Pleurothallis segoviensis Rchb. f. (Oersted s.n., Nicaragua), Polystachya masayensis Rchb. f. (Oersted s.n., Nicaragua), and Odontoglossum (= ticoglossum) oerstedii Rchb. f. (Oersted s.n., Costa Rica).

Reichenbach honored him in his description of the genus Oerstedella.

So ends the history of orchids in Central America in the first half of the XIX century. Some 25 collectors, all of them Europeans (with the exception of the Mexicans Lexarza and La Llave), discovered in the three decades after the independence more than 300 species of Orchidaceae new to science. 


\section{'Manifest Destiny'}

"We may confidently assume that our country is destined to be the great nation of futurity"

John L. O'Sullivan, about

'Manifest Destiny', 1839

No nation ever existed without some sense of national destiny or purpose. Manifest Destiny -- a phrase used by leaders and politicians in the 1840 s to explain continental expansion by the United States -- revitalized a sense of "mission" or national destiny for many Americans. As Sullivan wrote: "This country will conquest or annex all lands. It is its Manifest Destiny" (Quesada, 2007). Expansionists were also motivated by more immediate, practical considerations. Southerners eager to enlarge the slave empire were among the most ardent champions of the crusade for more territory. Washington policy-makers, anxious to compete with Great Britain for the Asia trade, had long been convinced of the strategic and commercial advantages of San Francisco and other ports on the Pacific coastline of Mexican-owned California.

\section{The Mexican-American war and the decline of British hegemony}

\section{"Remember The Alamo!" 26}

Battle of San Jacinto, April 21, 1836

As soon as Houston's long awaited order to advance was given, the Texans did not hesitate. The shouts of "Remember the Alamo" rang along the entire line. Within a short time, 700 Mexicans were slain, with another 730 taken as prisoners. The battle for Texas was won. The independence of Texas from Mexico led to annexation and to the Mexican-American war of 18461848, resulting in the acquisition by the United States of the States of Texas, New Mexico, Arizona, Nevada, California, Utah, and parts of Colorado, Wyoming, Kansas and Oklahoma. Almost one third of the present area of the United States, nearly a million square miles of territory, changed sovereignty.

Several botanists were in the expedition that was later sent out to survey the Mexican-American border, in order to define the limits between both countries. Among them was Charles Wright, who would afterwards explore Nicaragua and the Antilles. However, the true importance of the MexicanAmerican war consisted in the fact that it represented the beginning of the end of British hegemony in our region. "By mid-century, Americans were competing with the British for influence in eastern Nicaragua. After the 1849 gold rush in California, interest in building a transoceanic canal across Nicaragua was intense. The British were seen as adversaries, and a series of confrontations took place along the coast, including an incident in which an American warship bombarded and destroyed Greytown (Bell, 1989: vi)." Thus the United States took the first steps of its 'manifest destiny' as a world empire that some fifty years later would become the sole arbiter of the fate of the Central American countries. During the second half of the XIX century, the expansionist ambition of the United States would focus increasingly on Central America and the Caribbean. With the turn of the century, the Spanish-American war, the independence of Panama from Colombia (enforced by the United States) and the occupation of Nicaragua by the Marine Infantry in 1912 converted the Caribbean in a true Mare Nostrum of the American navy (Pérez Brignoli, 2000: 22).

Political, economical and social life of Central America, although still strongly influenced by the ideas of European liberalism, gravitated each day more strongly into the United States orbit. The most important political decisions in the life of the Banana republics during the second half of the XIX century were made in Washington and in the headquarters of the multinational companies in New York and Chicago. The history of orchids in Central America was not immune to these developments. The European monopoly of botanical exploration in the region started to fade. The Royal Botanic Gardens at Kew had become, during the first half of the XIX century, the indisputable center of world orchidology. Although Kew has retained, until the present days, a preeminent role, its attention began to focus more and more on the colonies of the growing British Empire in Africa and Asia, and on South America, where North American influence was not yet strong. The list of the collectors in Panama between 1700 and 1923 and their nationalities published by Dwyer leaves no doubt about

${ }^{24}$ The Alamo fell to the Mexican troops of General Santa Ana on March 6, 1836. All survivors were put to the sword. 
the increasing American hegemony (D'Arcy \& Correa, 1985: 180 (Fig. 34C)). A gentlemen's agreement seems to have been established, where Monroe's expression 'America for the Americans' had its counterpart in a thought that was never set in writing: 'the British Empire for the British'.

Two institutions were founded in the United States that in the following decades would be leaders in the exploration of the Central American territories and would have an enormous influence on the scientific life of the region. Ironically, both were created by British citizens. In 1846 an act of Congress was approved to carry out the terms of the will of James Smithson (1756-1829), a prominent English scientist who, strangely enough, had never visited America. Smithson bequeathed his entire estate to the United States of America "to found at Washington, under the name of the Smithsonian Institution, an establishment for the increase and diffusion of knowledge..."

Henry Shaw (1800-1889) (Fig. 34D), a native of Sheffield, England, moved to Saint Louis, Missouri, in 1819. He had such success in his business that he was able to retire at the age of 40 . On a trip back to England, he was inspired by the grounds of Chatsworth, the most magnificent private residence in Europe. When he returned to the U.S., he decided to begin his own botanical garden. Shaw opened his garden to the public in 1859. It grew in the European tradition of horticultural display combined with education and the search for new knowledge. This institution, now known as the Missouri Botanical Garden, is acclaimed today as being a leader in botanical investigation, with projects in the five continents.

To the aforementioned institutions we must add the important accomplishments in Central America of the New York Botanical Garden, created in 1891 by the botanist Nathaniel Lord Britton, the foundation in 1893 of the 'Columbian Museum of Chicago', known today as Field Museum of Natural History, fundamental to the history of the orchids of Central America in the XX Century, and the creation in 1894 of the United States National Herbarium.

While Mexico struggled in never ending internal fights for power after the disaster of the Mexican-
American war ${ }^{25}$, in which Mexico had lost two fifths of its territory, botanical exploration continued. In 1850 the Royal Horticultural Society sent the Dalmatian Mateo Botteri (1808-1877) to collect in Mexico. After the financial resources of the Society failed, Botteri stayed collecting on his own and selling his specimens in London. "His collections of plants were very fine and extensive, and there is a full set in the Kew Herbarium, chiefly from the neighborhood of Orizaba..." (Hemsley, 1887: 133). Botteri settled in Mexico and died in the vicinity of Veracruz. According to Schlechter (1918: 323), there were many orchids among his specimens, although most of them were described from collections by others. One of them was Cranichis cochleata, common in Veracruz, Chiapas and Guatemala, and described years later by Dressler as a new species from a collection by M.C. Carlson.

Frederick Mueller ( - ca. 1855), a native of Alsace, came to Mexico in 1853, to collect for the firm of Schlumberger in Mulhouse. Hemsley mentions several collections by Mueller, all from the region of Veracruz, based on a complete set that is at Kew. Worthy to mention are Cattleya citrina Lindl. (Müller s.n.), Hartwegia purpurea Lindl. (Müller 1414), Odontoglossum cordatum Lindl. (Müller 488), Spiranthes orchioides Hemsl. (Müller 810), Stanhopea bucephalus Lindl. (Müller 503) and Stanhopea tigrina Batem. ex Lindl. (Müller 976), as well as the type of Lepanthes orizabensis R. E. Schult. \& G. W. Dillon (Müller s.n., Orizaba, Veracruz). He died in strange circumstances. "It is supposed that he was murdered and concealed, as he disappeared and was never heard of afterwards" (Hemsley, 1887: 134).

The German dentist Wilhelm Schaffner (18301882), whom we remember in Cranichis schaffneri Rchb. f., settled in Mexico around 1856. Although his collections are of great importance, they were made outside of the limits of

Another German, Karl Theodor Mohr (1824-1901), better known for his Plant Life of Alabama (1901) emigrated from his native country to the United States in 1848 and traveled to Panama and Mexico (1857) before he established himself as a druggist in Mobile, Alabama, where he remained for the rest of his life

\footnotetext{
${ }^{25}$ General Santa Ana, who had commanded the Mexican troops during the war, had to go into exile. He returned to power in 1853 until in 1855 he was overthrown by Benito Juárez, who governed until 1872 and would have to face, during his period, the French invasion.
} 

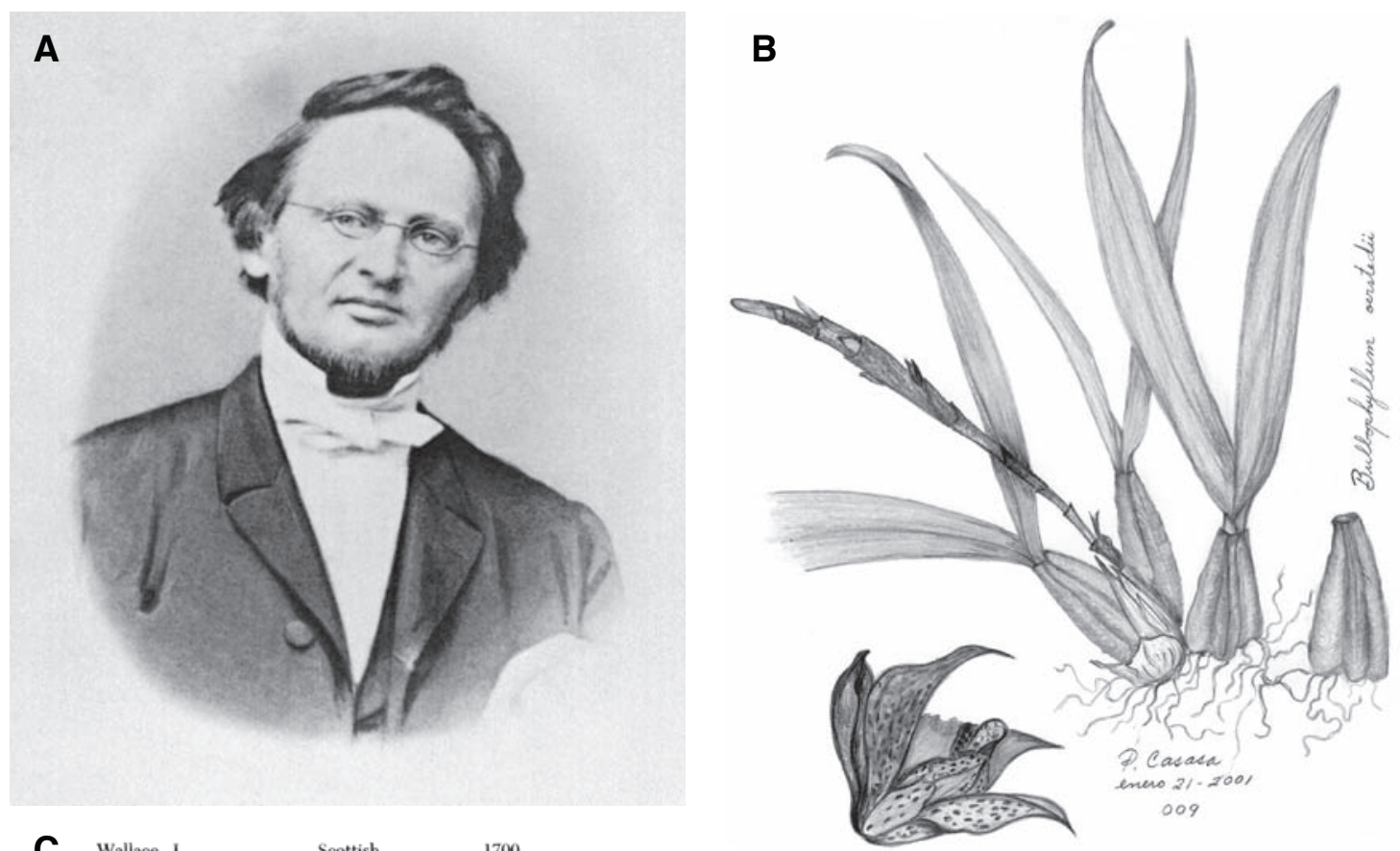

\begin{tabular}{|c|c|c|}
\hline Wallace, $\mathbf{J}$. & Scottish & 1700 \\
\hline Jussieu, Jos. De & French & $17 ? ?$ \\
\hline Millar, $\mathbf{R}$. & English & 1734 \\
\hline Nee, L. & French & 1789 \\
\hline Haenke, $T$. & Bohemian & $1790-1791$ \\
\hline Billberg, J. & Swedish & 1826 \\
\hline Dahlin, E. & Finnish & $1826-1831$ \\
\hline Cuming, $\mathrm{H}$. & English & $1830-1831$ \\
\hline Hinds, B. & English & 1837 etc. \\
\hline Barclay, G. & English & 1837 etc. \\
\hline Sinclair, A. & English & 1837 etc. \\
\hline Lobb, W. & English & 1843 \\
\hline Seemann, B. & German & 1846:1849 \\
\hline Warscewicz, J. & Polish & $1848 ; 1850$ \\
\hline Behr, $\mathrm{H}$. & German & 1848 \\
\hline Fendler, A. & American & $1848-1849$ \\
\hline Ball, J. & Irish & 1852 \\
\hline Halsted, M. & American & $1850-1854$ \\
\hline Kuntze, $\mathrm{O}$. & German & 1874 \\
\hline Duchassaing, E. & French & $1849-1851$ \\
\hline Hayes, $\mathbf{S}$. & American & before 1863 \\
\hline Roezl, B. & Czech & 1869 \\
\hline Hart, J. & English & 1885 \\
\hline Cowell, J. & American & 1905 \\
\hline Howe, M. & American & 1909-1910 \\
\hline Williams, R. S. & American & 1908 \\
\hline Pittier, $\mathrm{H}$. & Swiss & $\begin{array}{l}\text { 1910-1911; } \\
\text { 1914-1915 }\end{array}$ \\
\hline Powell, C. & American & $1907-1927$ \\
\hline Ostenfeld, C. & Dane & $1921-1922$ \\
\hline Bro. Gervais & Panamanian & 1912 \\
\hline Bro. Celestine & Panamanian & 1912 \\
\hline Steven, F. L. & American & 1924 \\
\hline MacBride, J. & American & 1918 \\
\hline Rose, J. & American & 1918 \\
\hline Maxon, W. & American & $1911 ; 1923$ \\
\hline Hitchoock, A. A. & American & 1911 \\
\hline Killip, E. P. & American & 1917-1918; 1922 \\
\hline Piper, C. V. & American & 1923 \\
\hline Goldman, F. A. & American & 189?-19?? \\
\hline
\end{tabular}

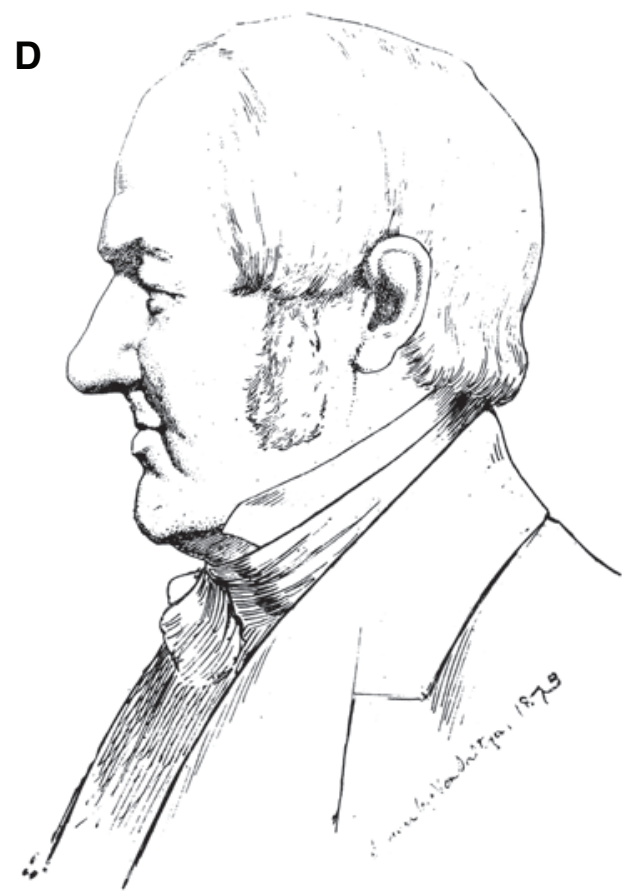

FiguRe 34. A - Anders Sandoe Oersted (1816-1872). Courtesy of Rudolf Jenny. B - Bulbophyllum oerstedii (A. Rich. ) Griseb. Illustration by Pilar Casasa. C - Collectors in Panama 1700-1923, and their nationalities. In D'Arcy \& Correa, 1985: 180. D - Henry Shaw (1800-1889). Sketch in a postcard from MLB's postcard series, courtesy of the Hunt Institute for Botanical Documentation. 


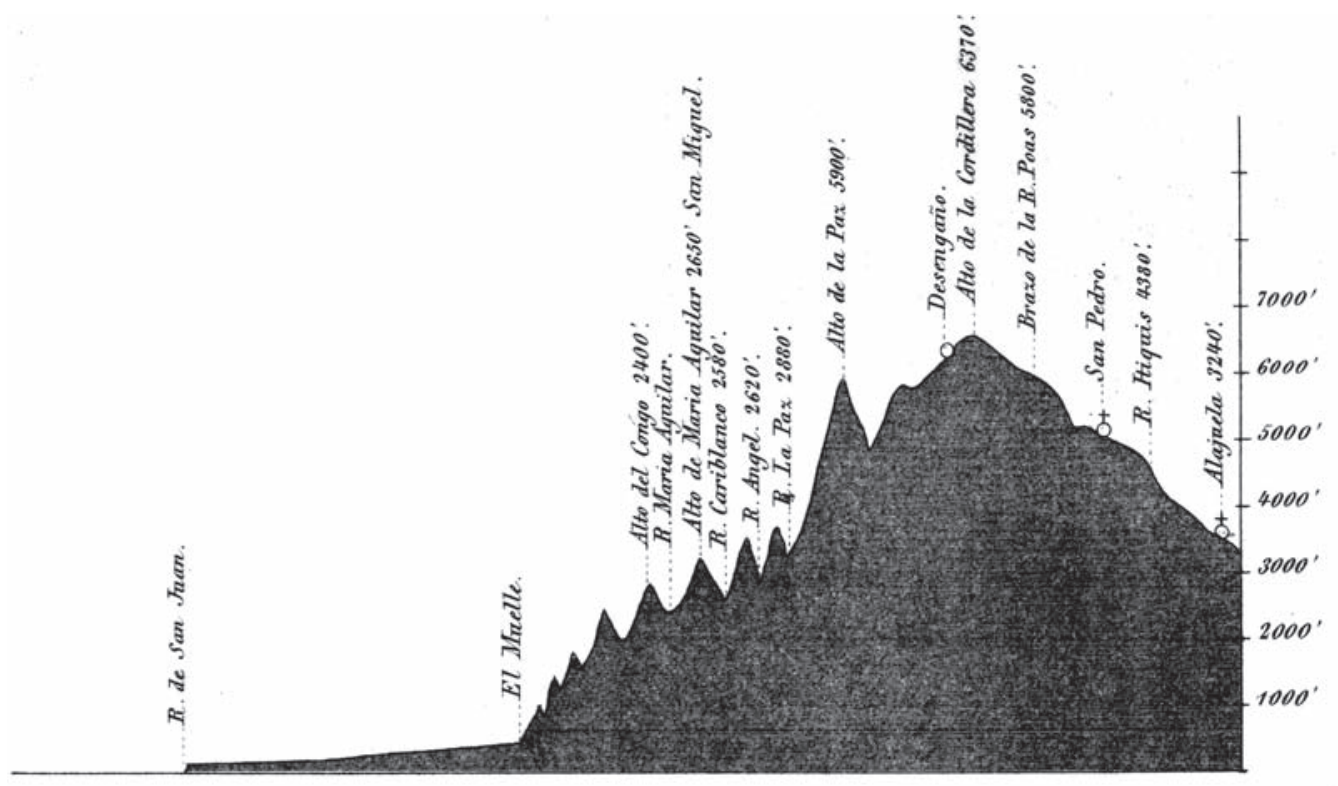

\section{Profil du chemin de Rio du San. Juan à Alajuela.}

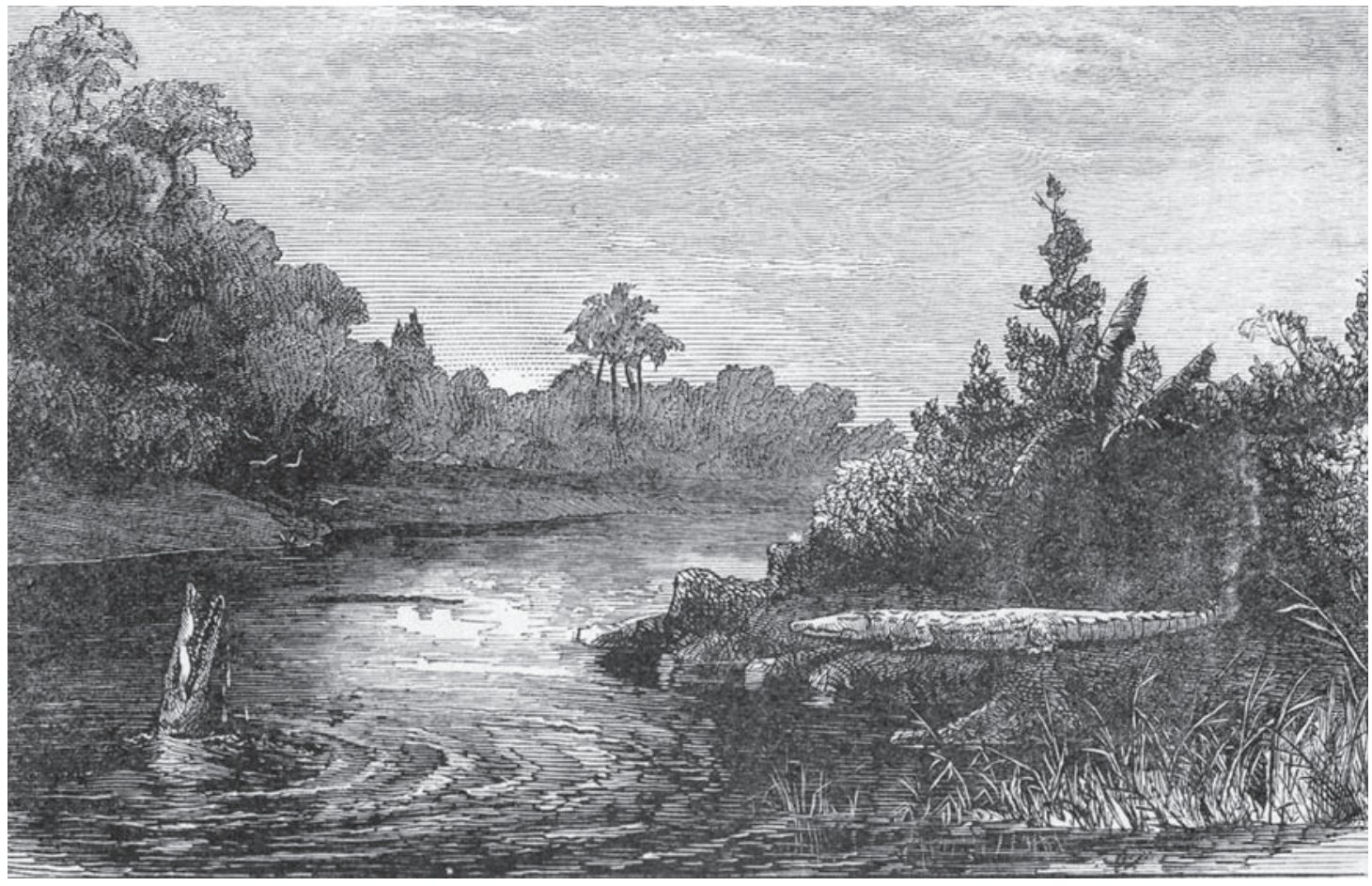

Figure 35. A - Oersted: altitude profile of the road to Sarapiquí. Plate 1, Oersted, 1863. B - Alligators in San Juan River. In Belt, 1874: 9. 
(Wunderlin et al., 2000: 64). Little is known of Mohr's collections in Mesoamerica, except for one specimen of Epidendrum propinquum A. Rich. \& Gal. (Mohr 570, Veracruz).

\section{The California gold rush and the interoceanic canal}

"Boys, by God, I believe I have found a gold mine!" James Wilson Marshall, January 12, 1848

The discovery of gold in California was the spark that started the most massive human migration in the history of America. Over 90,000 persons traveled to California in the two years that followed Marshall's discovery, and over 300,000 in 1854. The gold fever in California led to the exploration of shorter routes between both oceans. The San Juan River in Nicaragua and the Isthmus of Panama became the passages for fast travel from the Atlantic to the Pacific coast. One must consider that the journey by land from the East Coast of the United States to California took five months: a truly painful prowess (Guier, 1971: 82). Thousands of adventurers (initially North Americans and later from all over the world) came to Central America, a forgotten region that suddenly became one of the areas of greatest traffic in passengers and in the focus point of world attention.

"We arrived in Panama on January 19, 1849, after an absence of almost nine months. The stories of the recently discovered Californian mines... brought such a number of adventurous emigrants that the usual facilities of food and lodging collapsed completely" (Berthold Seemann, cited in Heckadon-Moreno, 1998: 27). The Clayton-Bulwer Treaty of 1850 , although permitting England to retain her positions in Belize, the Mosquito Coast and the Bay Islands, accepted for the first time the U. S. pretensions to control the future interoceanic canal. "In this way Great Britain, although maintaining all her possessions in Central America and still retaining much power during the 1850 's, began ceding ground in favor of the United States" (ObregónQuesada, 1993: 115). As the Nicaraguan historian José Dolores Gámez wrote ingenuously several years later, "the American government, having noticed the conduct of the British towards us, came generously to our help" (Gámez, 1888).

Effective control of the area by the United States had begun in 1847, with the foundation of the 'Panama
Railroad Company', with the purpose of building a railroad between Colón and Panama City. Two years later, in 1849, the North American tycoon Cornelius Vanderbilt founded the 'American Atlantic Pacific Ship Canal Company', with the intention of building an interoceanic canal in Nicaragua. The San Juan River and the Lake of Nicaragua were initially used for this passage. Vanderbilt's first steamers navigated the San Juan River in 1851, while the first train crossed the isthmus of Panama on January 28, 1855. The competition between both routes was strong, but as soon as the railroad was built, Panama began to be preferred, being much more comfortable and secure than the tortuous passage of the San Juan River, full of obstacles and immersed, since 1855, in the war against Walker (Fig. 35B). Wells (1854) mentions a third route, which consisted in an interoceanic railroad in Honduras, from the Atlantic coast to the Gulf of Fonseca. However, this plan never became reality, due to geographic and financial difficulties (Wells, 1982: 117). The Panama route declined again after the completion of the construction of the railroad between San Francisco and the Eastern States in 1869 (Reclus, 1881: 55-56).

Among the foreign adventurers and the employees of the North American companies we find numerous names that are relevant to the history of orchids in Central America. Botanical exploration of the region entered a new era, facilitated by improved routes of communication and by the growing commercial relations between the Central American republics, Europe and the United States. Referring to Costa Rica, Evans wrote: "Two events outside [of C. R.]... reversed the scientific community's disinterest... international demand for coffee and speculation of a trans-isthmus canal in lower Central America" (Evans, 1999: 16).

Hans Hermann Behr (1818-1904) (Fig. 36A), German botanist and entomologist, poet and novelist, was born at Colthen in East Germany. After graduating in medicine at Wurzburg, he was encouraged by his mentors, Karl Ritter and the famous German explorer, Alexander von Humboldt, to visit Australia (Kraehenbuehl, 2002: 1). Behr visited Australia in 1844 and settled in 1862 in California, where he was named curator of entomology of the California Academy of Science. He was responsible, through his contacts in Australia, where he had worked with the prestigious 
botanist Baron von Mueller, for the introduction of Eucalyptus into California. From his Australian collections, Schlechtendahl (1847) described as new species of Orchidaceae Caladenia behrii y Diuris behrii. In 1888, Behr published his Flora of the Vicinity of San Francisco. Behr had visited Central America around 1849 and collected several specimens of orchids in the region of Chagres, Panama, among them the type specimen of Scaphyglottis behrii Rchb. f. ex Hemsl. (Behr s.n., Chagres, Panama). "As a physician he was second to none in medical knowledge and kept well posted on the progress in medical science. It cannot be said that he loved his profession. Still less did he understand the art, so highly developed among modern physicians, of making it pay" (Essig, 1965: 555).

The English sailor John Melmoth Dow (1827-1892) (Fig. 36B) was already introduced in the previous chapter. Until 1850 he had transported passengers across the isthmus by the Nicaragua route. As captain of the steamers Columbus and Golden Age, he inaugurated the Central American service of the 'Panama Railroad Company Steamship Line', traveling from Panama to San Francisco, along the western coast of Central American. He developed a strong friendship with Skinner and Salvin and was responsible for the safe transportation of many live orchid plants from Central America to England. Of him writes Bovallius: “... since long time known for his generosity and indefatigable good will towards the researchers of the nature of these regions" (Bovallius, 1974: 99). Bateman honored Dow with the dedication of his Cattleya dowiana and Endrés and Reichenbach did the same with Lycaste dowiana. Dow was also interested in marine fauna and sent important collections to the Smithsonian Institution in Washington. In his navigation diary, on October 16, 1854, he wrote: "The health of the Isthmus is good, and the railroad is progressing with great rapidity...". However, the health cannot been as good as Dow thought, if we believe a popular saying cited by Bovallius in his book, in that "under each crosstie of the rails lies the body of a Chinese or a white man..." (Bovallius, 1974: 34).

Edouard Placide Duchassaing de Fontbressin (1819-1873), a French citizen, was born in the island of Guadeloupe and took a medical degree in Paris. He returned to practice medicine in that island, and at St. Thomas, he made natural history collections from 1844 to 1848 . Because of the revolution in the latter year he moved to Panama, where he collected between 1849 and 1851. "During these years he had a sanitarium at Panama, and in his leisure time collected plants in the neighborhood of the city and on Taboga Island" (Standley, 1928: 44-45). Although he did not collect many orchids, he is famous for having discovered the largest terrestrial orchid in Central America: Selenipedium chica Rchb. f. (Duchassaing s.n., Panama) ${ }^{26}$ (Fig. 36C). The plants collected by Duchassaing where twelve to fifteen feet high and had been bought by him from an Indian chief (Anonymous, 1923: 69). Duchassaing reported that the fruits of S. chica produced a fragrant substance similar to that of vanilla. For this reason they were called in Panama 'vainilla de árbol' (= 'tree vanilla'). The specimens collected by Duchassaing were sent to Walpers, from whom they were purchased by Grisebach. They were the base for Grisebach's Novitiae flora panamensis (Bonplandia 6: 2-12, 1858), where some new species are described. Of great importance were also Duchassaing's contributions to the investigation of marine fauna, of which he made important collections in Panama.

Moritz Wagner (1813-1887) (Fig. 36D) and Carl Ritter von Scherzer (1821-1903), the former German and the latter Austrian, traveled in 1852 through the United States, and embarked for Central America in the first months of 1853 (Wolkenhauer, 188: 92). Wagner, the more important of the two for our story, was an experienced traveler, influenced by the ideas of Humboldt and Darwin. He received his education at the University of Augsburg, worked later as a clerk in a trading company in Marseille and went in 1834 to Paris, Erlangen and Munich to study natural sciences. He visited Algeria in 1836-38, studied geology in Goettingen from 1838 to 1842 and explored the Caucasus and Armenia in 1842-46. Italy followed in 1846-49 and Asia Minor, Persia and the Kurdistan in 1850-51. Wagner \& Scherzer arrived at San Juan del Norte in April of that year and traveled to Costa Rica by way of the rivers San Juan and Sarapiquí.

The first notice of this route dates back to 1620 , when Diego de Mercado, at the request of the Spanish authorities, who were interested in finding a way between the Atlantic and the Pacific because of the

${ }^{26}$ The stems of Selenipedium chica reach often a height of 5 meters. 
insalubrity of Panama, submitted a report to the government in Guatemala in which he stated that he had found the desired communication along two different routes. "The first one navigating upstream along the 'Desaguadero' [ = the Drainage = the San Juan River] to the mouth of the Sarapiquí, then upstream for more than twenty leagues and from that point to the Royal Embarkment (the mouth of the Tempisque River on the Gulf of Nicoya). The road was of 'hard earth and not marshy' and only 15 leagues long...”. The other route consisted in what was later known as the Nicaragua Canal, sailing the San Juan River upstream to the Lake of Nicaragua and building from there a canal to the Pacific Coast (Secretaría de Gobierno, 1924: 330-331). This road of Sarapiquí was the only communication between the central valley of Costa Rica and the Atlantic port of Greytown, in Nicaragua, from where the ships sailed to the United States and Europe, and was of great importance in the history of the botanical exploration of the country, until it was replaced by the route Puntarenas-Balboa-Colón, after the railroad across the isthmus of Panama was built (inaugurated in 1855). Steamships sailed from Greytown to Southampton (Royal West Indian Mail Steamers) and to New York (Atlantic and Pacific Ship Canal Company) twice a month. The journey to New York took 7 days, to Southampton 32 days. (Molina, 1851: 41). The old road to Sarapiquí was replaced in 1880 by the 'road of Carrillo,27, which communicated San José with the Sucio River and joined there the new railroad to Port Limón. Finally, the railroad between San José and Port Limón was completed in 1890. From the builder of both routes, Minor C. Keith (1848-1922), who traveled frequently to the Costa Rican Atlantic region, we have this description of the tropical rain forest: "Their trunks were covered by climbing plants and parasites of reddish colors and various shades of green, by lichens, fungi, bromeliads, and the most beautiful orchids" (Salazar Navarrete, 2004: 126).

After being in Costa Rica, Wagner and Scherzer collected in Nicaragua, Honduras, El Salvador and Guatemala, "although very few species were described based on specimens collected by Wagner and Scherzer.
The reason for this could be the loss of the botanical collections during the earthquake of El Salvador in 1854, when Wagner almost lost his life" (León, 2002: 139). Wagner returned to Europe and shortly thereafter, in 1857 , sponsored by King Maximilian II of Bavaria, returned to Panama and Ecuador. He dedicated considerable time to the study of the possibility of connecting the two oceans, a subject on which he published several articles. Moritz Wagner and Carl Scherzer wrote in 1856 The Republic of Costa Rica in Central America, published in German. Their descriptions of the flora, fauna and culture are still very interesting. "No other foreign author has described with more sympathy the tiny state called by them the most gentle and peaceful among the fraternity of the republics of Spanish America, a country blessed by Heaven, where nature displays in the slopes of the mountains the most wonderful variety of climates and products" (Pittier, 1908: 19).

Descriptions of orchids are frequently found in the pages of this book: "Parasitic plants [...] climbers, vines, pendent vegetables and orchids, which group themselves often in the branches in the forms of candelabrums, of bouquets or also of stars..." "Higher up [on the trunks] begin the tillandsias, ipomeas, loranthaceae, agaves, cacti, dendrobiums [sic] [...]" "The begonias and orchids on the trees $[. .$.$] were here$ of a particular magnificence". "[...] The ostentatious orchids, which -for their rare forms- resemble butterflies or humming-birds with extended wings, grow on many live or dead trunks" (Wagner \& Scherzer, 1856: 122, 136, 137, 168). Wagner discovered the type of Triphora wagneri Schltr. (M. Wagner 1778, Panama) and several species were dedicated to him, such as Bulbophyllum wagneri Schltr. and Stelis wagneri (Schltr.) Pridgeon \& M. W. Chase.

Scherzer would write later his Travels in the free states of Central America: Nicaragua, Honduras and San Salvador and gained worldwide fame through his discovery in 1854 in Guatemala of the manuscript of the Popol Vuh by Friar Francisco Ximénez, which he published for the first time in Vienna, in $1861^{28}$. In 1863 Wagner wrote The province of Chiriqui in Central America. No orchid collections by Scherzer are known,

\footnotetext{
${ }^{27}$ So named in remembrance of Braulio Carrillo (1800-1845), President of Costa Rica between 1835 and 1837 and again between 1838 and 1842, who first thought of a road to the Atlantic along this route.

${ }^{28}$ Although Scherzer's publication came first, it was Charles Etienne Brasseur de Bourbourg who gave the manuscript the name of Popol Vuh, Le Livre Sacré et les mythes de l'antiquité américaine, and who made it known worldwide.
} 
but his discovery of Anthurium scherzerianum Schott (Scherzer s.n., Guatemala) was of high importance for European horticulture, of great value as breeding stock for numerous ornamental hybrids (León, 2002: 139).

If you travel to the Mexican village of Santecomapán (Veracruz), you will find a street called 'Calle Don Benito' (= 'Street of Mr. Benito'). Behind this name we find one of the less scrupulous orchid hunters in history, who during 20 years ransacked the forests of Mexico, Central and South America with a passionate mixture of ambition and madness: Benedict Roezl (1824-1885) (Fig. 37A). Born in Horomerice (Bohemia), he worked as a gardener in various European countries. He came to Belgium and became head gardener for the Belgian Government's School of Agriculture, after working for five years for Louis van Houtte, proprietor of the Royal Nurseries in Ghent, where he was in charge of the orchid section Yearsley, 1996: 357). “[...] Roezl's first attempt in the horticultural business had failed. He then turned his hand to the demanding task of collecting, working for himself and for the Londonbased Sander" (Ceulemans et al., 2006: 149). He emigrated to Mexico in 1854, founding a gardening establishment in the capital of the country, associated with the German Besserer (Regel, 1885: 330). In 1861 he established a nursery with European fruit trees in Santecomapán, with a French partner, a Monsieur Chabé (Block, 1985: 1204). "Nature has emptied here its Cornucopia; all illusions of those Europeans who come to tropical countries, often destroyed by reality here they become true" (Otto, 1862: 59).

"When fighting sharpened between the Mexicans headed by President Benito Juarez and the forces of Emperor Maximilian of Hapsburg, Roezl joined the ranks of Juarez and organized the defense of the city and port [of Santecomapán]. Because it was anticipated that the French allies of Maximilian would land their soldiers on the shores of the Gulf of Mexico... Juarez sent 200 men from his army to help Roezl. He proved to be a good commander. To frighten the superior forces of the French and deter them from landing, he constructed along the mall an odd defense. On carriage wheels he mounted long poles. From a distance, they looked like huge cannons. The ruse worked. The French ... observed this 'heavily armed' port and gave up the idea of landing there" (Block, 1985: 1205).

An untiring traveler, Roezl went from Mexico to
Cuba and then to California. In 1868 in Cuba, during the demonstration of an agricultural machine that he had invented for the production of ramie threads, he had lost his left hand that was replaced by an iron hook. This gave him great notoriety for the rest of his life. The Cubans gave him afterwards the nickname 'El Moche' (= 'the cripple'). "He established ramie plantations in Cuba and built factories for the production of threads and fabric from the fibre [...] Roezl was named an honorary member of the Havana Academy of Science. His portrait was hung in the auditorium of the academy, and his original ramie processing machinery was exhibited at the Havana Museum" (Block, 1985: 1206). Boyle amuses us with the story of the collection by Roezl of Cattleya skinneri alba. In 1870, Roezl was in the neighborhood of Tetonicapan, Guatemala, and was ambushed by bandits who held him for ransom in a small village. Finally he was set free, and the priest of the village invited him to his house. "It stood beside the church, hardly less primitive. Roezl glanced at the roof of this structure in passing. It has been mentioned that the Indians have a pleasant custom of removing any orchid they find, notable for size and beauty, to set on the church roof or on trees around it. [...] It was with curiosity rather than hope, therefore, that Roezl scrutinised the airy garden. [...] In one big clump he saw something white - looked more closely — paused. The plant was Cattleya skinneri certainly. How should a white flower be there? All other collectors, perhaps, at that time, would have passed on, taking it for granted that some weed had rooted amid the clump. But for many years Roezl had been preaching that all Cattleyas of red or violent tint, so to class them roughly, must make albino 'sports'. [...] A wondrous instinct guided him. [...] The end is foreseen. Roezl carried on his White Cattleya and sold it to Mr. George Hardy of Manchester for 280 guineas" (Boyle, 1901: 59-66).

Roezl did not return to Santecomapán and donated his gardens there to his nephews Frank and Eduard Klaboch. He went afterwards to Panama, Colombia and Venezuela. From Boyle (1983: 139) we have the following anecdote: "The railway fare [from Panama] to Colón was sixty dollars at that time, and [Roezl] grudged the money. Setting his wits to work, Roezl discovered that the company issued tickets from station to station at a very low price for the convenience of its employees. Taking advantage of that system, he 
crossed the isthmus for five dollars...!". He passed again through Panama and Costa Rica and went on San Francisco. After being once more in Colombia he returned to Europe. In 1872 he came back to America. $\mathrm{He}$ arrived in Colorado and traveled again to Mexico. He continued to Panama and Venezuela. From there to Cuba and once again to Veracruz. Again to Panama and on to Lima, Bolivia and Ecuador. One last time to Colombia, where he collected during six months for the Linden nurseries in Gant and Brussels, and finally back to Europe. His return was however delayed by eight months at the request of the new Mexican president, Sebastian Lerdo de Tejada. "The president wanted to create in Mexico City the most beautiful capital in the world. Tejada envisioned parks, wide avenues bordered by Eucalyptus trees, and broad plazas with impressive greenery. 'Don Benito' Roezl was appointed as architect for the project, and his success was overwhelming" (Block, 1985: 1208).

He was possibly one of the collectors who caused more destruction, who plundered large regions and sent to Europe tons of orchids. It is believed that Roezl sent approximately one million plants to Europe, about two thirds of them orchids. As Roezl himself later admitted, he collected 3,500 orchids in the Sierra Madre, 8 tons in Panama and Venezuela, and 27,000 plants in Colombia. On February 10, 1873, Roezl wrote from Caracas: “... the first thing I did was to ask for the 'Flor de Mayo' (= 'flower of May')..., as they call here Cattleya mossiae... The answers were negative. I was told that it was extinguished in the neighborhood of La Guaira, as a result of the massive exports to Europe..." (Regel, 1874: 73-74). In 1884 he visited as an expert the International Gardening Exhibition in Saint Petersburg and was awarded the Imperial Russian Order of Stanislaus, for his lifelong achievements. Finally, he returned to Smichow, near Prague, where he died in 1885 and was buried in Prague. Many important people attended his funeral and even the Kaiser was there. The principal horticultural periodicals of Europe applauded the idea of an international committee to erect a monument to this indefatigable explorer. The monument erected in Prague was constructed by Professor Myslbak, a wellknown sculptor in that city (Fig. 37B). Among those who contributed to the monument were the largest European orchid nurseries of that time: Veitch, Sanders and Linden, who had benefited mostly from his collections (Anonymous, 1890; 3). Strangely enough, although Roezl had lost his left hand, the statue shows him with both hands!

Numerous species were described based on his collections, most of them by Reichenbach who published in 1877 his Orchideae Roezlianae nova seu criticae. Among the species that he discovered and those dedicated to him, we find: Bletia roezlii Rchb.f. , Cattleya roezlii Rchb.f., Dracula benedictii (Rchb.f.) Luer, Dracula roezlii (Rchb.f.) Luer, Lepanthes roezliana Luer \& R. Escobar, Masdevallia benedictii Rchb.f., Maxillaria roezlii Rchb. f. ex Linden, Miltoniopsis roezlii (Rchb.f.) God. Leb. (Fig. 37C), Paphiopedilum roezlii (Rchb.f.) Pfitzer, Pescatoria roezlii Rchb.f., Phragmipedium roezlii (Rchb.f.) L.A. Garay, Pleurothallis roezlii Rchb.f.., Sobralia roezlii Rchb.f., Telipogon benedictii Rchb.f., Telipogon roezlii Rchb.f., and Zygopetalum roezlii Rchb.f.

If anybody wanted to blame orchidology for being one of the causes of the destruction of nature, he would have in collectors like Roezl his best argument. We must however take into account that what today is considered a crime, was seen as a prowess during the XIX century. Boyle gives a terrifying account of the methods by which orchids were collected during those years: "[The collector] hires natives, twenty or fifty or a hundred, as circumstances advise, and sends them out to cut down trees, building meantime a wooden stage of sufficient length to bear the plunder expected. This is used for cleaning and drying the plants brought in. Afterwards, if he be prudent, he follows his lumbermen, to see that their indolence does not shirk the big trunks - which give extra trouble naturally, though they yield the best and largest return. It is a terribly wasteful process. If we estimate that a good tree has been felled for every three scraps of Odontoglossum which are now established in Europe that will be no exaggeration. And for many years past they have been arriving by the hundreds or thousands annually! But there is no alternative. An European cannot explore the green wilderness overhead; if he could, his accumulations would be so slow and costly as to raise the proceeds to an impossible figure. The natives will not climb, and they would tear the plants to bits. Timber has not value in those parts as yet, but the day approaches when Government must 
interfere" (Boyle, 1983: 71-72). And similar words from Williams: “...the plants are heedlessly torn from their natural habitats, which are sometimes ruthlessly cleared of the beautiful flowers that cannot be replaced in the locality. We are sorry to hear of some of our collectors having so little respect for these treasures of nature's production that they gather all they can, having no regard for the future, and not even leaving a few plants in the locality to increase and multiply by shedding their seed to germinate naturally over the mountains, rocks, and trees" (Williams, 1885: 13). "[...] Very few of our present day collectors have retained that enthusiasm which allowed their predecessors to bear all hardships with joy, all their disappointments with serenity. Roezl was one of the last representatives of those glorious few who, in all respects, were characteristic of his time" (Anonymous, 1885: 222).

In 1853, one year before Roezl traveled the first time to America, James Veitch acquired the Chelsea nurseries from Messrs. Knight and Perry. Veitch's second son, Harry James Veitch (1840-1924) made an apprenticeship at the famous French nursery firm, Vilmorin-Andrieux \& Co., in Paris, and returned in 1858 to help his father. "His industry and business sense rapidly became apparent, and the firm of Messrs. James Veitch \& Sons soon enjoyed the reputation of being the foremost nursery business in the world. Harry's influence in the business extended over almost the whole of his long and useful life. "The Veitches sent numerous plant collectors to the various parts of the world and rendered a great service to botany and horticulture by their introduction of new species and hybrids" (Reinikka, 1995: 247). Among the Veitch's collectors who visited our region we find Gustav Wallis, A. R. Endrés, Gottlieb Zahn, George Downton, Carl Kramer and Richard Pearce. A detailed account of Veitch's most important publication, the Hortus Veitchii, published in London in 1906, is given in the following chapter.

John Dominy (1816-1892), the nurseries' chief hybridizer, is credited with raising (1854) and flowering (1856) the world's first orchid hybrid (Calanthe $\times$ Dominii), which lead to the breeding of hundreds of new orchids as well as the establishment of a new branch of horticulture. This was a highly controversial achievement in Victorian Britain as it was regarded as tampering with nature. "Sir Harry Veitch retired from business in 1914. With his brothers John and Arthur both deceased, there was no successor in the family, and rather than losing the recognized reputation which the firm had acquired, he disposed of the nursery and sold the land for redevelopment" (Reinikka, 1995: 249). Many new orchid species and hybrids were dedicated to the Veitches, among them: Cypripedium veitchianum C. Lem., Dendrobium veitchianum Lindl., Macodes veitchii Boxall, Masdevallia veitchiana Rchb.f., and Phalaenopsis veitchiana Rchb.f.

A word must be said at this point about Karl Eduard Ortgies (1829-1916). He was born in Bremen, Germany, and chose the career of a gardener. For many years, he worked in England in the gardens of Chatsworth, Syonhouse and Regents Park, and in Belgium, at the Van Houtte establishment. In the summer of 1855 he was called to become Chief Gardener at the Botanic Garden in Zurich, a call he obeyed, although he hated to leave the Establissement and the Van Houtte family that had become dear to him. The Zurich Botanic Garden, weakly donated, was supposed to raise the necessary funds by selling plants and seed, without neglecting its scientific duties, since it had to provide the University of the canton and the Zurich Polytechnikum (only recently founded at that time) with the necessary plants for lectures. Ortgies was not only able to achieve the necessary funds by trade, he also made remarkable profits that he was able to use for the renovation of the old conservatories, the building of new conservatories, water supply, a rock garden for Alpines, and so on. Considering his efforts, he received from the High Government on his 20 year jubilee the title of an Inspector and a considerable raise of his salary. $\mathrm{He}$ was especially interested in introducing new or rare plants, and knew to use his contacts to overseas countries. All the many deliveries by Roezl arrived at the market by intercession of Ortgies. From Zurich he ran a huge import nursery, held many auctions in London and had business contacts with the leading market gardens of England, Belgium and Germany. If Roezl was able to finish his life as a financially comfortable owner of a house in tranquility - a fate that unfortunately only very few plant hunters have he owes it all to his diligent and true friend Ortgies. After Roezl, the deserving traveler Wallis applied for 
the help of the proven agent Ortgies. Unfortunately Ortgies was able to help him for just a few years, since Wallis soon became ill and was ailing slowly until he closed his tired eyes forever at the hospital in Cuenca, Ecuador. After Wallis, there were Lehmann in Colombia and Pfau in Costa Rica; both sent their most valuable finds to the Zurich Botanic Garden. In between there were Fuchs in Guatemala, Garnier in Cuba, Gaibrois and Bruchmüller in Colombia, and Besserer in Mexico who also used the agency of Ortgies. Several new orchid species were named in his honor, among them: Aerides ortgiesiana Rchb.f., Anoectochilus ortgiesii Van Geert, Broughtonia orgiesiana (Rchb.f.) Dressler, Encyclia ortgiesii (Regel) Schltr., Masdevallia ortgiesiana Rolfe ex Rolfe, and Microchilus ortgiesii (Rchb. f.) Ormerod.

The Germans Carl Hoffmann (1833-1859) (Fig. 37D) and Alexander von Frantzius (1821-1877) came to Costa Rica in 1853, bearing letters of recommendation from Nees von Esenbeck, President of the German Academy and from Alexander v. Humboldt for President Juan Rafael Mora. They arrived at Greytown (San Juan del Norte) as passengers of the brig Antoinette, together with a group of German immigrants, and continued to Costa Rica along the road of Sarapiquí (Hilje Quirós, 2007: 71). Frantzius was a reputed professor at the Physiological Institute in Breslau and Hoffmann was well-known for his practical and literary works during the cholera epidemics in Berlin during the years of 1848 and 1849 (Anonymous, 18153: 233). Soon they began to explore the country with the purpose of collecting specimens, mainly botanical. Hoffmann was later a physician in the Costa Rican army during the war against the troops of pro-slavery activist W. Walker, while Frantzius soon became a successful businessman and owner of a pharmacy. "Hoffmann and Frantzius spent their leisure times, the first dedicated to the collection of plants and the study of their natural distribution, the second to similar studies in mammals and birds" (León, 2002: 139-140).

Hoffmann climbed two of Costa Rica's most important volcanoes: on May 5, 1855 the Irazú volcano near the city of Cartago, from where he described "a magnificent orchid of the genus 'epidendron' with fire-red flowers that did not grow as a parasite on the trees but between the rocks on the hill..." (Hoffmann, 1856), and in August of the same year the Barva volcano, in the province of Heredia, where it caused him "extraordinary pleasure an extraordinarily rare orchid with its lip pointed upward in form of a helmet..." (Hoffmann, 1858). In his narrative about the excursion to the Barva, Hoffmann counts the number of orchids that he found: "Of orchids, on the Barva 8 and of those 4 terrestrials and 4 parasites, and on the Irazú only two parasites" (Hoffmann, 1858).

The collections of Hoffmann, who sent them to the herbarium in Berlin, to the renowned botanist Johann F. Klotzsch, were described in 1866 by Reichenbach as Orchideae Hoffmannianae (Reichenbach, 1866: 102). One can find among them the types for three new species: Pelexia hoffmannii Rchb. f. (C. Hoffmann s.n., Barba in Costa Rica, 1855), Epidendrum (=Prosthechea) ionophlebium Rchb. f. (C. Hoffmann s.n., Costa Rica: Curidabad, 1857) and Ponera albida Rchb. f. (C. Hoffmann s.n., Llanos del Carmen, 1857). Among other activities, Hoffmann also published a bilingual newspaper, called Costa Rica Deutsche Zeitung (=Costa Rican German Newspaper). He published the paper, which circulated on each Sunday morning, together with two other Germans by the names of Kurtze and Streber (Hilje Quirós, 2007: 81). He dreamed of writing a book with the title Flora and Fauna of Costa Rica, but he had to abort this idea because of the war and his illness. After the war against Walker, he retired to Puntarenas, where he died in 1859. His mortal remains were brought to San José in 1929, where they were buried with military honors (Alfaro, 1963: 51).

Von Frantzius returned to Germany in 1865, but he left a profound impression in Costa Rica. His establishment, managed afterwards by José Cástulo Zeledón, became the favorite center of reunion for foreign and national naturalists. Some of them formed a group nicknamed "the drugstore gang" (L.D. Gómez, pers. comm.), which had extraordinary importance in the development of natural sciences in Costa Rica during the last years of the XIX and the first decades of the XX century.

Together with Hoffmann and von Frantzius arrived the gardener Julian Carmiol (1807-1885), in the company of his brothers Franksius y Robert. He 
would stay in Costa Rica for the rest of his life. His real name was Julian Carnigohl, a widower whose wife had died in Germany a few months earlier. He came to Costa Rica with four children, Ana, Berta, Franz, and Julio Carnigohl. When they arrived in Costa Rica they changed the name to Carmiol. "A naturalist by profession, he felt especially attracted to horticulture and ornamental plants, as well as to wildlife and ornithology..." (Carmiol Calvo, 1973: 4). He travelled to the Smithsonian Institute and to England in 1867, and seems to have had an arrangement with Osbert Salvin (one of the editors of the Biologia Centrali-Americana), to collect birds and butterflies in Costa Rica (Letter from Salvin to Dow, November 1, 1867). In a letter to Professor Spencer F. Baird of the Smithsonian Institute (April 29, 1862) Captain John M. Dow refers to a collection of birds from Costa Rica: "The person I bought them from is a German gardener living in the outskirts of the city". "Many of the Costa Rican plants that were adopted by European floriculturists owe their introduction to this humble German gardener" (Pitier, 1908: 21). Carmiol also collected herbarium material and birds, which he sent to American and European institutions. We know, from letters by Baird and Salvin, that in 1867 he formed a large collection of objects of natural history which he personally took to Washington and London. Bovallius tells us about Carmiol in his old years, during the Swedish biologist's visit to Costa Rica in 1882: "I paid several visits to an old German collector and merchant, Carmiol, and I never tired to admire his beautiful orchard, where he had collected a large amount of rare plants from all regions of Costa Rica.... For those who study this [...] flora in the museums of Berlin and London, the name of Carmiol is well known, because many interesting species have been sent by him to their collections" (Bovallius, 1974: 120).

Among his collections of orchids we find Lycaste xytriophora Linden \& Rchb.f. and Epidendrum campylostalix Rchb.f. Helmuth Polakowsky wrote about another orchid, Vanilla sp., in 1876: "I have never found vanilla in the market and only in the house of a German gardener [J. Carmiol] did I see by chance fresh pods, which his people had brought him from the forests behind Angostura" (Polakowski, 1940). As Frantzius wrote: "Nobody has examined so thoroughly the slopes of the Central American mountains" (González, 1921: 87). We remember Carmiol in Phaedranassa carmioli Baker, of the Amaryllidaceae and Crotalaria carmioli Polakows. of the Leguminosae. Besides being a gardener, Carmiol owned a restaurant in San José.

The Moravian Evangelical Church of Herrenhut in Saxony, Germany (known as the "Bruedergemeinde", or "Community of the Brothers") began to send missionaries to the Caribbean in the early years of the XVIII century, founding an establishment in Suriname (Dutch Guyana) in 1735. These missionaries traveled along the Antilles and the Central American coast and much later founded a mission in the Mosquito Coast. "[The missionaries] waged war against the native shamans, or sookia (sukia), [...] and today the remaining sukia must practice under considerable stigma. [...] After living in local communities for many years, the missionaries produced the first grammars and dictionaries of the Miskito language and successfully translated the Bible" (Bell, 1989: vii-viii).

Heinrich Rudolf Wullschlaegel (1805-1864) came in 1849 to the mission of the "Bruedergemeinde" in Suriname. To communicate with the natives, the missionaries had to learn their language, a mixture of English, Dutch, Portuguese and African elements, known today as Sranan. Wullschlaegel created a "Negro English Grammar" and a "German-Negro English Dictionary" which were published in 1856 and 1865 in Germany. Wullschlaegel traveled to Brazil, the Antilles and the Mosquito coast. An amateur botanist, he made some interesting collections. In Jamaica he discovered the type of Lepanthes wullschlaegelii Fawc. \& Rendle (Wullschlaegel, s.n.) and in Suriname Macroclinium wullschlaegelianum (Focke) Dodson (Wullschlaegel s.n.). In the Mosquito Coast he collected four species of orchids (all on the same day, January 5, 1855, and in the same locality: 'Pearlkey Lagoon'), that were described by Reichenbach in his ORCHIDEAE WULLSCHLÄGELIANAE (Reichenbach, 1866: 104), among which is the type of Dichaea trulla Rchb. f. (Wullschlägel s.n., 'Pearlkey Lagoon auf Palmen'). Reichenbach dedicated to him in 1863 the genus Wullschlaegelia, from a plant collected originally by Swartz in Jamaica and described as Cranichis aphylla Sw. 

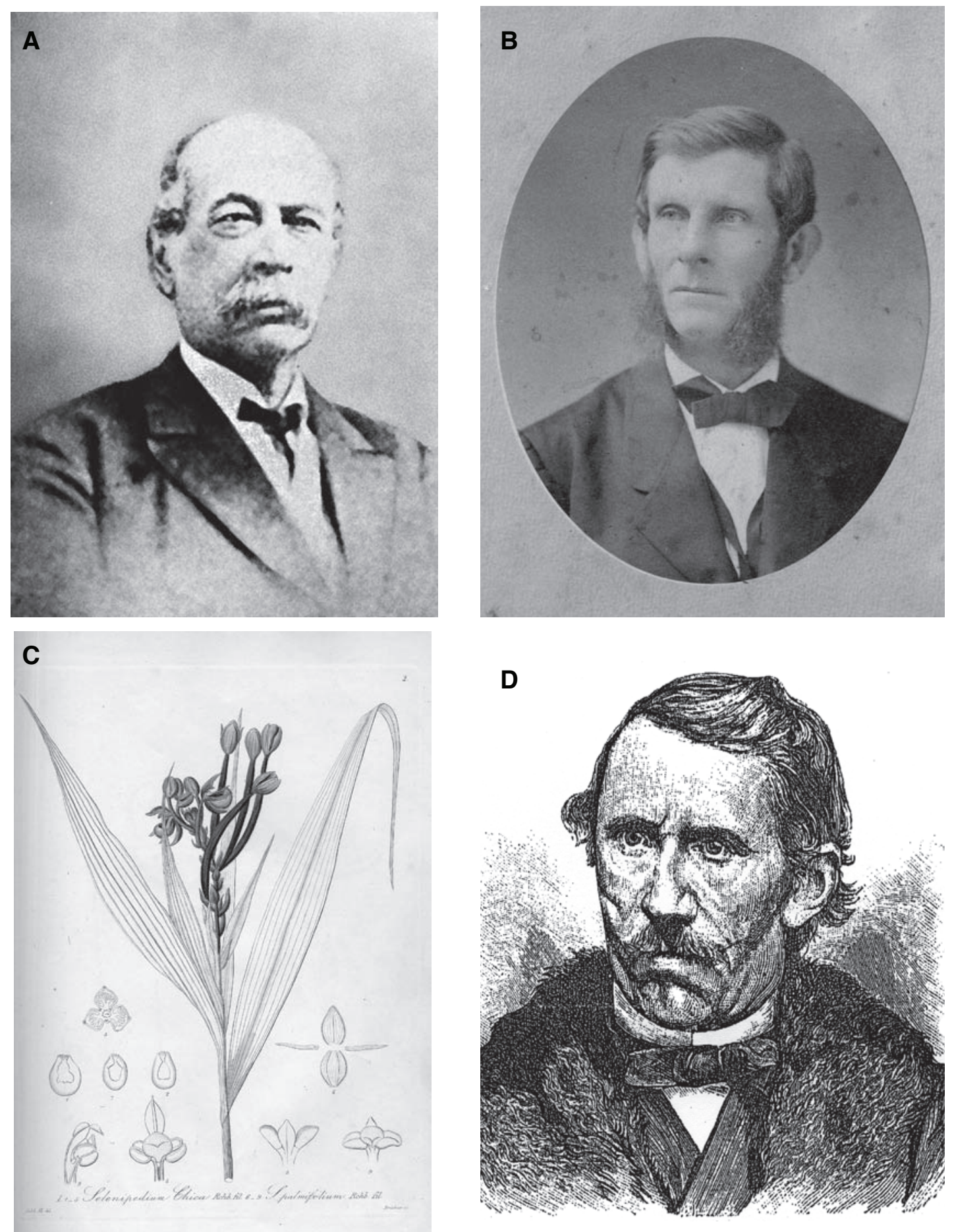

FiguRe 36. A - Hans Hermann Behr (1818-1904). Courtesy of Rudolf Jenny. B — John M. Dow (1827-1892). Courtesy of Cornell University, Ithaca, New York. C — Selenipedium chica Rchb.f. Xenia Orchidacea I, Plate 2. D — Moritz Wagner (1813-1887). Courtesy of Rudolf Jenny. 

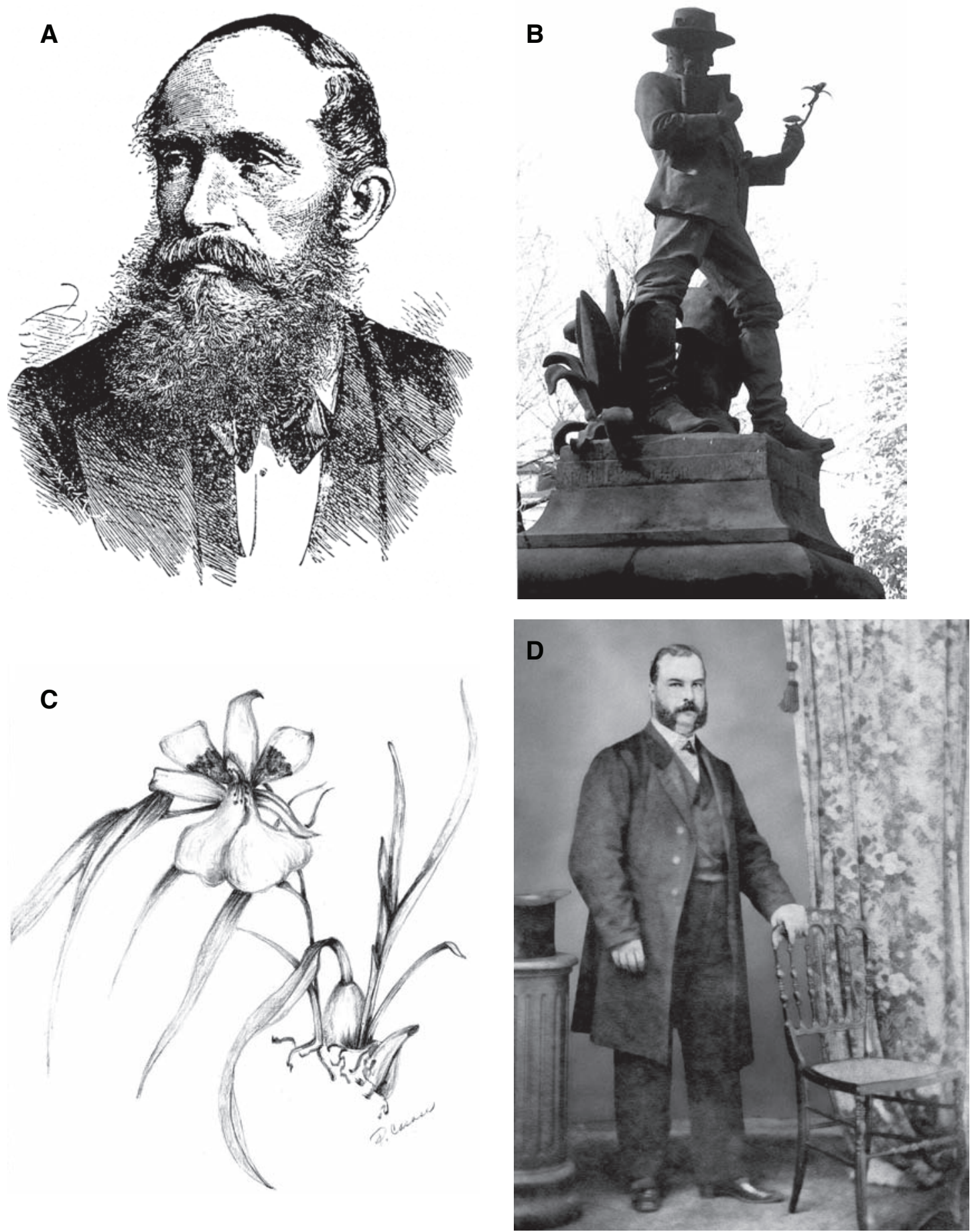

FiguRE 37. A - Benedict Roezl (1824-1885). Contemporary portrait, courtesy of Rudolf Jenny. B — Statue of Roezl in Prague, which shows him with an orchid in his hand and an Indian at his feet. Photograph by Pavel Kindlmann. C Miltoniopsis roezlii (Rchb. f.) God. Leb. Illustration by Pilar Casasa. D — Carl Hoffmann (1833-1859). Photograph by William Buchanan, courtesy of Silvia Meléndez. 


\section{William Walker in Central America}

"The best field to exercise slavery is tropical America..."

William Walker (Obregón Quesada, 1993: 176)

After the failure of the Central American Federation, the conservatives dominated the political life of Central America, under the notorious leadership of Rafael Carrera, the Guatemalan dictator. "Several liberal attempts to restore the Union, articulated usually as a response to British hostilities, ended as complete failures" (Pérez Brignoli, 2000: 103). Carrera, enemy of the Federation, defeated all his adversaries reestablishing the 'conservative peace'. But new and serious turbulences appeared, which threatened the region. In 1854, the Liberal party in Nicaragua was fighting the Conservative party for power and losing. In desperation, they sought out William Walker's military assistance to help them topple the Conservatives ${ }^{29}$. In 1855 , Walker responded and led them in the capture of the city of Granada. He double-crossed the Liberals, however, and made himself President of Nicaragua in 1856 being quickly recognized by the United States government as such. "He was a man with a very concrete plan: to conquer Nicaragua, then the rest of Central America, to build the Canal and to impose slavery" (Obregón Quesada, 1993: 176). Arrogant as all defenders of the colonial interests of the United States, Wells wrote in 1857: "From the Mexican highlands to the isthmus of Panama, the feeling prevails among all inhabitants that, although it will mean the ruin of the race that until recently has governed their destinies, they will soon be forced to join the flag of the stripes of the Union, and continue as satellites in the orbit of the same planet" (Wells, 1982: 466). However, Walker's supporters appropriated a transit company steamer owned by the American industrialist Cornelius Vanderbilt and Vanderbilt retaliated by financing the conservative forces against Walker. Walker was overthrown in a battle in 1857, and despite his attempts to recapture Nicaragua he never again regained control. The British captured Walker in Honduras in 1860 during another takeover attempt and he was promptly executed by the Honduran authorities.
But the constant wars and political struggles in the region where no apparent obstacles for the travelers and naturalists who continued arriving in Central America. Paraphrasing what Skinner had said years earlier, 'they continued coming in spite of themselves'. Orchidomania and their fascination for natural history were always stronger than any other consideration.

Charles Wright (1811-1865) had taken part as a botanist in the expedition that had surveyed the Mexican-American borders after the war of 18461848. In 1853, he joined the United States North Pacific Exploring Expedition, also known as the Ringgold and Rodgers Expedition for its captains. This expedition traveled around the world, stopping in such places as Australia, Hong Kong, Japan, and the islands of the Bering Straits, before arriving in San Francisco. Wright spent the winter in California and then asked to leave the expedition, which was due to continue south around Cape Horn and then to New York. After leaving the expedition, Wright took a steamer to Nicaragua, where he arrived in February of 1856, collecting for about eight weeks. He arrived at San Juan del Sur mid-February, 1856 and went to Virgin Bay, which was his base for two months. He made excursions to the Pacific coast and to an island in Lake Nicaragua. While in Nicaragua, Wright also discovered another hazard of fieldwork: political unrest. Wright had to be careful in the content of his letters to Asa Gray, as negative comments about the government would be censored. Wright also suspected that more innocent letters were also seized from the mail. One letter that did get through to Gray describes the trouble that Wright had in trying to leave Nicaragua. Rumors were flying that outward bound transport would soon be halted, so Wright hastily tried to arrange his journey to New York. For a time it seemed that no amount of money could either secure a berth or charter a ship, but eventually Wright was able to arrange transport back to the United States.

Among Wright's collections in Nicaragua we find some orchids, such as Epidendrum imatophyllum Lindl., Pleurothallis cardiothallis Rchb. f. and Brassavola nodosa Lindl. and also new types: Camaridium wrightii Schltr. (Wright s.n., Nicaragua), Ornithidum paleatum Rchb. f. (Wright s.n., Nicaragua),

\footnotetext{
${ }^{29}$ William Walker was born in 1824 in Nashville, Tennessee. After graduating, he worked for a time as a lawyer and became finally a soldier of fortune, participating in several political adventures in Mexico and California.
} 
and Stelis parvula Lindl. (Wright 9, Nicaragua). After spending some time in Wethersfield and Cambridge, Wright went on the first of a series of travels to Cuba, during the period between 1856 and 1867. His work was described by the botanist August Grisebach in his Plantae Wrightianae e Cuba Orientali, published in two parts in 1860 and 1862.

"The renowned gardens of Herrenhausen, in the vicinity of Hannover, Germany, were created in 1866 by the Duke Johann Friedrich von Calenberg. It was there that the famous Wendland dynasty was born, a family of gardeners and botanists of enormous prestige. The Wendland dynasty began with Johann Christoph Wendland (Wendland I) in 1778, continued with his son Heinrich Wendland (Wendland II) and ended with his grandson Hermann Wendland (18251903) (Fig. 38A). It was this Wendland III who departed from Germany in 1856 on an extended voyage through Central America and who returned to Herrenhausen with a collection of orchids that contained 134 different species. A special greenhouse, called 'Costa Rica-Haus' was inaugurated exclusively for this collection" (Jenny, 1995: 34). It is curious to think of Wendland collecting orchids in this country at the same time that Juan Rafael Mora led the Costa Ricans in the fight against the filibusters.

The idea of traveling to Central America was born during a visit by George U. Skinner to Herrenhausen. It was then when Wendland expressed his wish to travel to the Tropics. A few weeks later, Skinner wrote from London to the Director of Herrenhausen, advising to allow Wendland to travel to Central America, and inviting him to Guatemala. The journey was authorized and Wendland traveled von Hannover to Southampton, across the Atlantic to Belize and finally to Guatemala, where he stayed for several weeks, enjoying Skinner's hospitality. In the first weeks of 1857 he traveled to El Salvador, where he took a ship to Puntarenas (Costa Rica), arriving there in March 1857. He soon made the acquaintance of Frantzius and Hoffmann, who were helpful in organizing Wendland's excursions to the mountains surrounding San José. He collected also at the mouth of the Sucio River and in San Ramón, in addition to his collections on the road to Sarapiquí (Pittier \& Durand, 1893: 137). In August 1857 he started on his way home, traveling over Sarapiquí and the San Juan River to San Juan del Norte (Nicaragua), where he found a ship to Southampton, arriving back in Hannover on September 20 (Knoll, 2005: 3-4).

Most of the new orchid species discovered by Wendland were described by Reichenbach in his ORCHIDEAE WENDLANDIANAE (Reichenbach, 1866: 61). The following shall be mentioned: Arpophyllum medium Rchb. f. (Wendland 190, Guatemala), Cyclopogon prasophyllum (Rchb. f.) Schltr. (Wendland 297, Guatemala), Epidendrum myodes Rchb. f. (Wendland 111, Costa Rica), Epidendrum nitens Rchb. f. (Wendland 324, Guatemala), Epidendrum nubium Rchb. f. (Wendland 33, Guatemala), Erythrodes vesicifera (Rchb. f.) Ames (Wendland s.n., Costa Rica), Malaxis wendlandii (Rchb. f.) L. O. Wms. (Wendland s.n., Costa Rica), Myrmecophila wendlandii (Rchb.f.) G.C. Kennedy (Wendland s.n., Guatemala), Pelexia gutturosa (Rchb. f.) Garay (Wendland s.n., El Salvador), Pleurothallis fuegii Rchb. f. (Wendland s.n., Guatemala), Sarcoglottis sceptrodes (Rchb. f.) Schltr. (Wendland 388, Guatemala), and Stelis leucopogon Rchb. f. (Wendland 895, Costa Rica).In 1887, Reichenbach named in his honor a new species, imported by Sander \& Co. from Colombia: Masdevallia wendlandiana Rchb. f.

Wendland collected in Guatemala, El Salvador and Costa Rica. No collections by him are known from Nicaragua, a country he probably avoided due to the war against Walker. Wendland's interest in orchids, although responsible for very important discoveries, was secondary. His main field of knowledge were the Palmaceae, a family in which he was considered the leading world expert of his time. He made important contributions to Oersted during the great Danish scientist's work on Central America. Oersted wrote : "I must add that M. H. Wendland, to whom science owes so much for his beautiful investigations of the American palms, has also gathered a considerable herbarium in Central America, part of which he has been kind enough to put at my disposal for this work..." (Oersted, 1863).

Born at Park Hatch, Godalming, Frederick Du Cane Godman (1834-1919) was a keen student of natural history from his earliest days. At Cambridge he became an intimate friend of Alfred and Edward Newton and of Osbert Salvin (1835-1898), all enthusiastic students of bird life. Godman and his friend Osbert Salvin were enthusiastic followers of Darwin, and together they decided to produce a work that should review 
every form of life in a definite part of the world. They chose Central America, and this became the lifework of these two friends. It was 1879, 36 years before the 63 volumes of this vast undertaking, Biologia Centrali-Americana, were completed. The two friends were editors, securing experts to write on their own branches of knowledge, and devoting themselves to the birds and butterflies. They had traveled many times to Guatemala between 1857 and 1874, preparing zoological but also botanical collections. “...there are two separate collections of flowering plants in the Kew Herbarium- one, consisting of about 250 species, dated 1861, and the other, consisting of about 350 species, dated 1873-74, and ascribed to Mr. Salvin alone" (Hemsley, 1887: 136).

Salvin had the fortune of finding in his wife Caroline a magnificent botanical illustrator. He lived in Guatemala and appreciated its natural beauties, but never could accept the customs of his adoptive country. In a letter to his father in January, 1858, he wrote: “... George Skinner and I went to Ocatenango... to collect orchids... the country is very full of resources... The only thing against it is the miserable race of Spaniards, but this evil is by degree being diminished by the increase in foreigners". Among his collections is the type of Ornithocephalus salvinii Rchb. f. ex Hemsl. (Salvin s.n., Barranca Honda, Guatemala) and many specimens of the genus Lepanthes.

The German Carl Kramer had been sent to Japan in 1857 and arrived in Costa Rica in 1866, via Panama, to search for Cattleya dowiana, which had become Skinner's obsession. Kramer discovered the type of Ticoglossum krameri (Rchb.f.) R. Rodríguez ex Halbinger, but this seems to have been his only success in Central America. In the words of Veitch, he resulted "... unsuitable for the work" (Veitch, 1906: 55). Odontoglossum krameri Rchb. f., Leptorchis krameri Kuntze and Liparis krameri Franch. \& Sav. were dedicated to him. However, Oncidium kramerianum Rchb. f., as many wrongly assume, was not dedicated to him but to his father, gardener of Herr Jenisch at Flotbeck Park near Hamburg, where it first flowered in 1854 (Veitch, 1963: 47). He lived later for long years in Manaos, Brazil, where he was in charge of the botanical training of young Erich Bungeroth, who would become famous for his collections in Brazil,
Venezuela and Colombia (Blossfeld, 1965: 113).

Richard William Pearce (1838-1867) had collected for Veitch in South America, and had visited Chile, Peru and Ecuador. In Peru he collected the type specimens of Masdevallia veitchiana Rchb. f., Phragmipedium pearcei (Rchb. f.) Rauh \& Senghas and Chloraea pearcei Phil. Pearce traveled in 1867 to Peru, in search for another shipment of Masdevallia veitchiana. "Unhappily -for us as well as for himselfhe was detained in Panama. Somewhere in those parts there is a magnificent Cypripedium with which we are acquainted only by the dried inflorescence, named planifolium. The poor fellow could not resist this temptation. They told him at Panama that no white man had returned from the spot, but he went on. The Indians brought him back, some days or weeks later, without the prize; and he died on arrival" (Boyle, 1983: 87). He was only 29 years old and died a victim of yellow fever.

The physician Carl Gustav Bernoulli (18341878) was born in Basel, Switzerland, into a family whose ancestors had been famous physicists and mathematicians. The family had its origin in Antwerp, Belgium, having to flee to Frankfurt in the XVI century from the persecutions of the Duke of Alba, and moving in 1622 to Basel (Meyer-Holdampf, 1997:21). After graduating in medicine in 1857, and strongly influenced by the ideas of Alexander von Humboldt, Bernoulli traveled in 1858 to Guatemala. He lived most of the time in Retalhuleu, where he had a coffee plantation and maintained at the same time his medical clinic and a pharmacy (Fig. 38B). Anticlerical by nature, he blamed the church for the backwardness of Guatemala in those days. In 1868 he traveled for a short period of time to Europe. During this time he visited the herbariums of the botanical gardens of Berlin, Hamburg, Amsterdam, London and Paris, always moved by his desire to write a flora of Guatemala. In 1872 he sent 5 boxes with his botanical collections and other objects of natural history to Europe, intended among others for Hooker, Kuhn, De Candolle and Reichenbach (Meyer-Holdampf, 1997: 72, 85).

After meeting Baron von Tuerckheim, he started in 1877 on his last excursion, for which he tried to find in Europe a young botanist to travel with him. With the help of professor August Heinrich Rudolf Grisebach he paid all expenses for the arrival of the 
German botanist Oscar Richard Cario (1856-?), who became the companion of his last voyage (Müller, 1878: 720). He visited the ruins of Palenque and took part in the excavation of the temples of Tikal. Bernoulli found the temples completely covered by vegetation. Impressed by the quality of the wooden lintels of the doors of Temple IV, he took them out "with permission of the government" (so says the Museum of Cultures, in Basel, where the doors arrived in 1878, a few months after his death). An important number of new species of Orchidaceae were found among Bernoulli's and Cario's collections. They were described chiefly by Schlechter. The following shall be mentioned: Deiregyne nelsonii (Greenm.) BurnsBal. (Bernoulli \& Cario 644, Guatemala), Erythrodes lunifera (Schltr.) Ames (Bernoulli \& Cario 669, Guatemala), Habenaria tetranema Schltr. (Bernoulli 325, Guatemala), Lemboglossum majale (Rchb. f.) Halb. (Bernoulli 338, Central America), Oncidium bernoullianum Kraenzl. (Bernoulli 339, Guatemala), Ornithocephalus tripterus Schltr. (Bernoulli \& Cario 667, Guatemala), Pleurothallis bernoullii Schltr. (Bernoulli \& Cario 499, Guatemala), Ponthieva pulchella Schltr. (Bernoulli \& Cario 487, Guatemala), Stelis cleistogama Schltr. (Bernoulli \& Cario 344, Guatemala), Stelisovatilabia Schltr.(Bernoulli\& Cario s.n., Guatemala), Stelis oxypetala Schltr. (Bernoulli \& Cario 624, Guatemala), and Stelis tenuissima Schltr. (Bernoulli \& Cario 590, Guatemala). He kept close relationships with the leading American botanists of his time. In one of his letters to Joseph Henry, Director of the Smithsonian Institution, he claimed: "I possess valuable collections of this country... so that I can offer to American botanists collections that may be interesting to them...". Asa Gray, Director of the Botanical Garden of Harvard University mentioned in February, 1848: "Dr. Bernoulli is right saying that the Botany of Guatemala is very little known, and that his collection will be full of interest" (Meyer-Holdampf, 1997: 142). Bernoulli died on May 18, 1878 in San Francisco, during his return travel to Switzerland, from a tropical illness he had contracted in the region of Petén. Years later, in 1897, the Bryologia guatemalensis ex collectionibus Domin. Bernoulli \& Cario (1866-1878) was published in the Bulletin de l'Herbier Boissier, based on the herbarium of Bernoulli and Cario. Schlechter dedicated to Cario
Pleurothallis carioi Schltr. (Bernoulli \& Cario 496) and Stelis carioi Schltr. (Bernoulli \& Cario s.n.) (Fig. 38C). Bernoulli's herbarium was sent to Donnell Smith in Baltimore for revision. However, Donnell Smith returned it untouched since he could not dedicate himself to this task due to ill health. The herbarium returned to Basel, where it was donated to the University by a brother of Bernoulli.

Sutton Hayes (?-1863), was a doctor and naturalist with the El Paso and Fort Yuma Wagon Road Expedition in 1857-1858. Born in Columbia County, New York, he apparently graduated in medicine in New York City. He studied botany for several years during a period of living in Paris, France. After leaving the Wagon Road Expedition, he developed tuberculosis and went to what is now Colon in Panama, collecting there extensively until his death in 1863. When he stopped in Puntarenas on his way to Panama in 1860 , Hayes became perhaps the first North American to botanize in Costa Rica (Grayum et al., 2004: 7). On April 18, 1860, Captain Dow wrote to Professor Baird, of the Smithsonian Institute: "Dr. Sutton Hayes, who brought me a letter of introduction from you I have met twice... He is an indefatigable laborer in his efforts to illustrate the botany of the Isthmus, where he has located himself ever since the failure of the Darién expedition, to which he was attached." Hayes also collected in El Salvador and Guatemala. Again Dow to Baird (June 6, 1860): "Dr. Hayes is now in Guatemala, pursuing his investigations. He came on board at a port in Salvador on my last voyage. He looks bad, and I very much question whether he will live to again visit this coast".

Among his Panamanian specimens we find Brassavola nodosa Lindl., Trichopilia sp., Lockhartia pallida Rchb. f. (Hayes 106), Cyclopogon prasophyllum Schltr. (Hayes 138), Sobralia fenzliana Rchb. f. (Hayes 493) and the type of Campylocentrum panamense Ames (Hayes 1389). In 1860 he spent several months in El Salvador and Guatemala, from where his collections of Sobralia macrantha Lindl (Hayes s.n., Guatemala), Spiranthes aurantiaca (Llave \& Lex.) Hemsl. (Hayes s.n., Guatemala) and Spiranthes rosulata (W. Baxt.) Lindl. (Hayes s.n., Guatemala) are preserved. Hayes contributed in great measure to complete the list of plants of Panama that had been published some years earlier by Seemann. 


\section{The Mexican Empire of Maximilian of Hapsburg}

"The government of the republic will fulfill its duty to defend its independence, to repel foreign aggression, and accept the struggle to which it has been provoked, counting on the unanimous spirit of the Mexicans and on the fact that sooner or later the cause of rights and justice will triumph".

Benito Juárez, President of México, 1862

In 1859, a group of Mexican conservatives approached Ferdinand Maximilian Joseph, Archduke of Austria, Prince of Hungary and Bohemia (1832-1867), offering him the throne of Mexico. Although he initially refused, the French occupation of the Mexican capital and the pressures of Napoleon III convinced him, and he was crowned as the Emperor of Mexico in 1864. A passionate lover of nature, he organized during his short reign a scientific commission that was sent out to explore the flora and fauna of Mexico. Among the members of this commission Eugene Bourgeau (1813-1877) $)^{30}$ had a prominent place. He prepared extensive collections of plants that are today at the Natural History Museum of Paris. Among his specimens are numerous species of Orchidaceae, some of which were new to science: Bletia greenmaniana L. O. Wms. (Bourgeau 2812), Epidendrum bourgeavii Schltr. (Bourgeau 3104), Malaxis lepidota (Finet) Ames (Bourgeau 3008), and Pleurothallis bourgeaui Kraenzl. (Bourgeau 2469).

Pierre Marie Arthur Morelet (1809-1892) was a French naturalist, born in Lays. Morelet had been a member of the commission to Algeria (1841), mainly as a natural artist, drawing any natural findings. He took particular interest in mollusks, which he published many works on, particularly the species of Africa. Morelet was appointed as a corresponding member of the Mexican scientific commission, mainly because he had traveled between 1846 and 1848 through southeastern Mexico and Guatemala. After visiting Yucatan, Morelet came into Guatemala through the Mexican state of Tabasco and following the course of the Usumacinta River. He traveled through Petén and all the way to the highlands of Cobán. After visiting the capital of Guatemala he returned to Europe. Morelet wrote an interesting account of his travels (Morelet, 1876), with beautiful illustrations and several references about orchids. Traveling with his companion, the faithful seaman Morin, Morelet wonders in the neighborhood of Palenque about "onion-shaped plants" which cover the tree trunks and delights in the aroma of Vanilla. In Dolores he notes the "myriads of parasites" in the shadow of the forests, among which he mentions an orchid species [Stanhopea sp.] white as a lily and with a strong benzene aroma which attracts swarms of butterflies of the most beautiful species. In Lanquin, were he was the guest of the local priest, he finds again Vanilla which he became as a gift and which he finds commonly in cultivation and sees again in Cobán (Morelet, 1876: 194, 222, 284). As a tribute by Gabriel Bibron and Auguste Duméril, Morelet had a species of crocodile named after himself: Morelet's Crocodile or, Crocodylus moreletii Bibron \& Duméril. Morelet had found this crocodile in the swamps of Yucatan. Morelet died of natural causes in 1892, in Dijon.

Ludwig Hahn (?-1873) lived in Mexico from 1855 and years later formed part of the scientific expedition of which Bourgeau was part. Hahn was a botanist, and his mission was to study Mexican plants, collect them and send them to Europe. This he did, but he fell in love with Mexico and never went back. He changed his name from Ludwig to Luis and became a Mexican citizen. He died in Mexico, we believe, in 1873. Luis Hahn was not only a botanist but an accomplished musician. He played the piano, sang and composed. He wrote a series of pieces for piano that he called 'Recuerdos de México' (= 'Remembrances of Mexico'). Among his collections are several orchids, such as Epidendrum equitans Lindl., Epidendrum rigidum Jacq., and Habenaria lactiflora A. Rich. \& Gal.

After several years of fighting against French occupation, the troops of Benito Juárez finally captured Maximilian in Querétaro. On June 19, 1867 , he died in front of a firing squad, at the side of his generals Miramón and Mejía.

${ }^{30}$ Bourgeau had previously been a botanical collector in Spain, North Africa and the Canary Islands. 
The Spanish Scientific Commission to the Pacific 1863-1866. The Scientific Commission to the Pacific was the most important scientific enterprise of 19th century Spain. In the spring of 1862, the Ministry of Development decided to add a scientific team to a naval squadron that the government of General O'Donnell sent to America as part of its Pan-Hispanic politics. The group of naturalist travelers was formed by six professors of the Natural Science Museum of Madrid and two assistants: a taxidermist and an illustrator, and photographer. Their mission was to form scientific collections that would enrich the Spanish museums and contribute to develop the program of acclimatization of exotic plants and animals that would be useful for the Spanish economy. The expedition visited Brazil, Uruguay and Chile, before turning northwards towards Ecuador, Central America and California, returning to Spain at the end of 1865 . Only a small part of the collections of the Commission have been studied and we cannot confirm the collection of orchid specimens by its members. The herbarium of Juan Isern y Batlló (1821-1866), the Commission's botanist, was studied in part by José Cuatrecasas and awaits further research at the Royal Botanical Garden in Madrid.

\section{Lindley and Reichenbach: change of the guard}

"Central America has, according to our present knowledge, one of the richest orchid floras. Fortune not only smiled at me bringing into my hands many of the best collections of this region, richer than Lindley ever obtained them, but I can trust in ... many more shipments from there."

H. G. Reichenbach (1866, introduction)

"[...] The British horticulturist and botanist John Lindley (1799-1865) is the perfect example of high society's passion for botany in the 1800s" (Ceulemans et al., 2006: 107). Lindley was the most important orchidologist in the first half of the XIX century and described the majority of orchids that were discovered in Central America. His close relation with the Botanical Gardens at Kew, during a time when British power dominated the five continents, brought into his hands, for identification, new species from all over the world. However, during the first years of the second half of the century, a new star arose in the name of Heinrich Gustav Reichenbach (1824-1889) (Fig. 38D), who had published in 1852 his dissertation on the structure of the pollen masses in orchids and had started, in 1854, the publication of his Xenia Orchidaceae, which he would complete in 1883.

Son of the famous botanist Heinrich Gottlieb Reichenbach, Reichenbach filius soon began to be recognized as Lindley's protégé, being first his assistant and later his competitor in the identification of new species. Nonetheless, they were bound by a close friendship that lasted until Lindley's death. Reichenbach's evolution as an orchid expert is evident if we observe chronologically the collections which were studied between 1830 and $1860^{31}$. The majority of the Central American specimens of Loddiges, Cuming, Skinner, Hartweg, Hinds, Sinclair and Barclay were identified by Lindley.

The descriptions of the new species discovered by Schiede, Deppe and Linden are divided between Lindley and Reichenbach. However, beginning with Seemann, and continuing with Friedrichsthal, Warscewicz, Liebmann, Oersted, Behr, Duchassaing, Roezl, Hoffmann and Wendland, it is almost exclusively Reichenbach who studied and identified the Central American collections. Many of the new species were described by Reichenbach in his Contributions to the orchidology of Central America, published in Hamburg in 1866. When Lindley died in 1865, Reichenbach became the virtual dictator of orchidology, although he was not immune from criticism. The botanist George Bentham criticized his determinations for ignoring structural characteristics other than those of the flower and an obituary in the Proceedings of the Linnean Society later referred to the 'many puzzles in his descriptions, which of late years had assumed an esoteric character' (Elliot, 1994: 441). When Reichenbach died in 1889, he left his enormous herbarium, including all the material that had been contributed by other botanists during his life, to the Imperial Museum of Vienna. It contained more than 700,000 specimens, of which some 52,000 where orchids. The sheets usually showed very rude but very characteristic drawings. Reichenbach's will read textually: "My herbarium and my botanical library,

\footnotetext{
${ }^{31}$ For chronological comparisons one must take into account that study and identification of species often took place two or three years after the date of collection, due to the length of the expeditions and the difficult conditions of travel.
} 
A

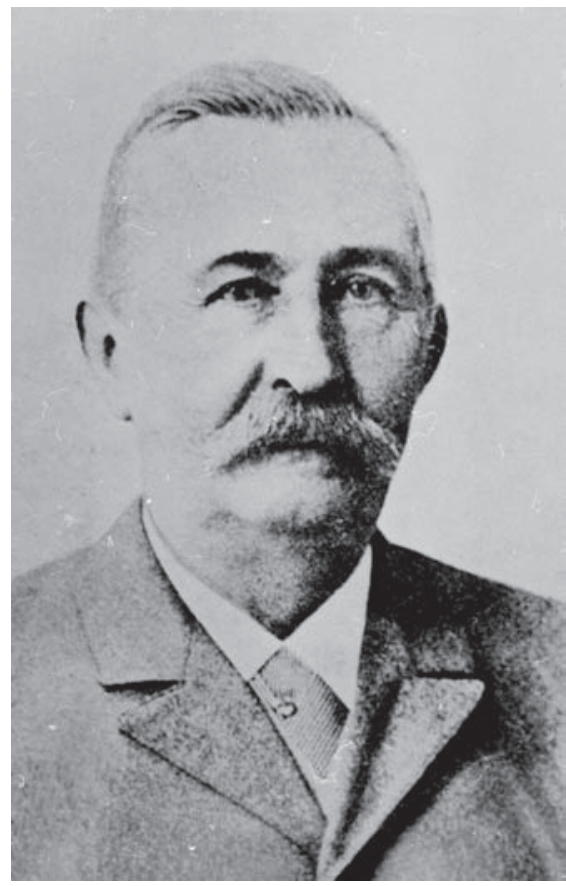

C

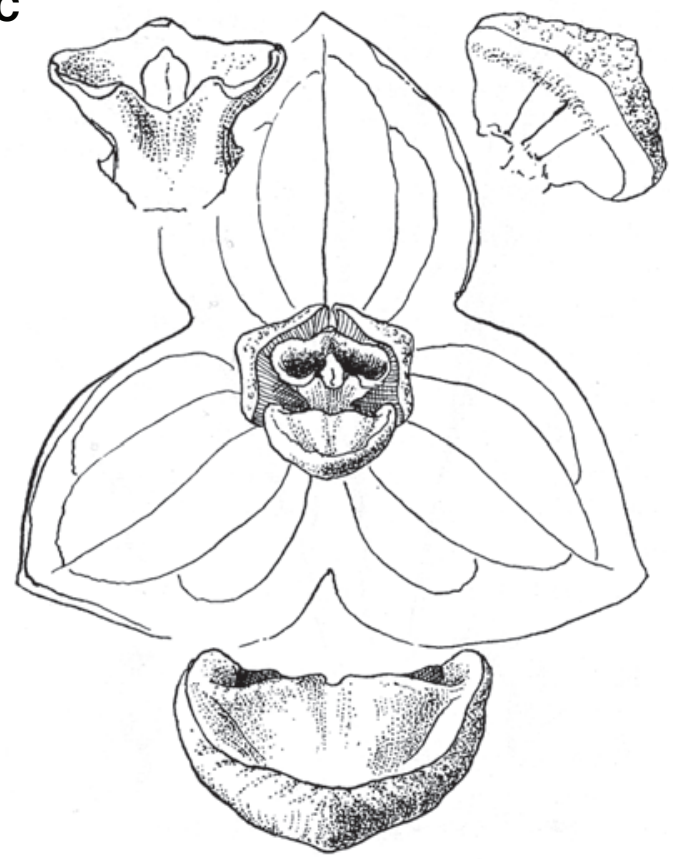

B

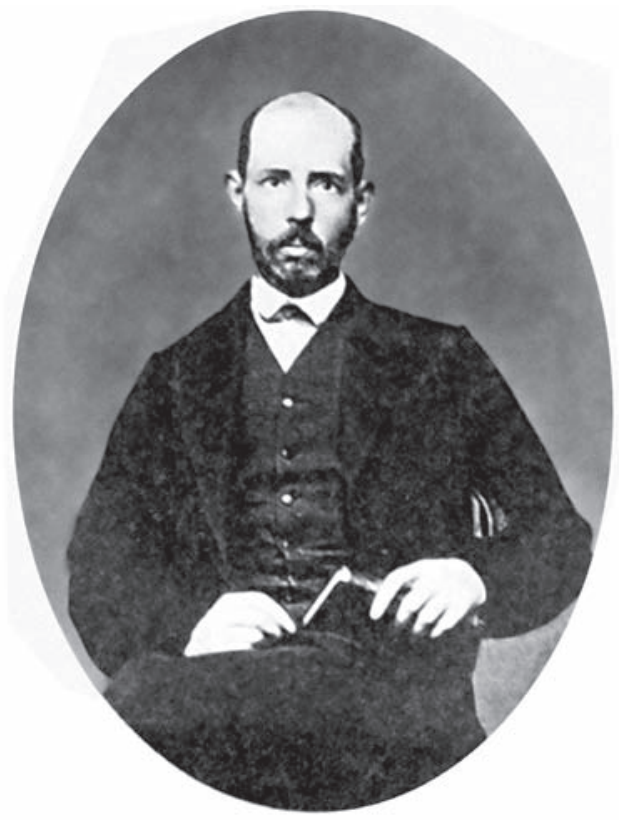

D

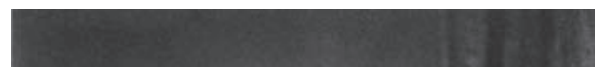

FiguRE 38. A - Hermann Wendland (1825-1903). Courtesy of Rudolf Jenny. B — Carl Gustav Bernoulli (1834-1878). Courtesy of Rudolf Jenny. C - Stelis carioi Schltr. Illustration by Blanche Ames, courtesy of the Oakes Ames Orchid Herbarium, Harvard University. D - Heinrich Gustav Reichenbach (1824-1889), at age 38. Courtesy of the Hunt Institute for Botanical Documentation. 
A

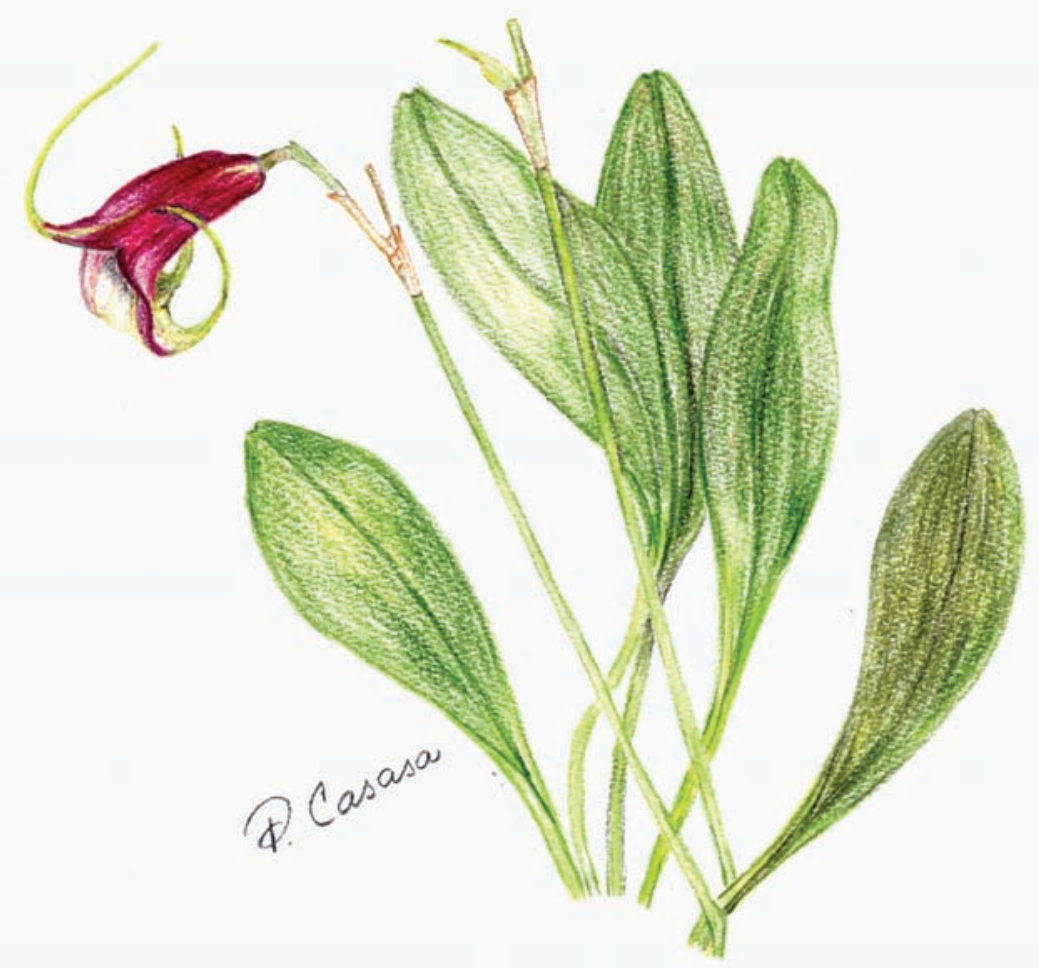

B

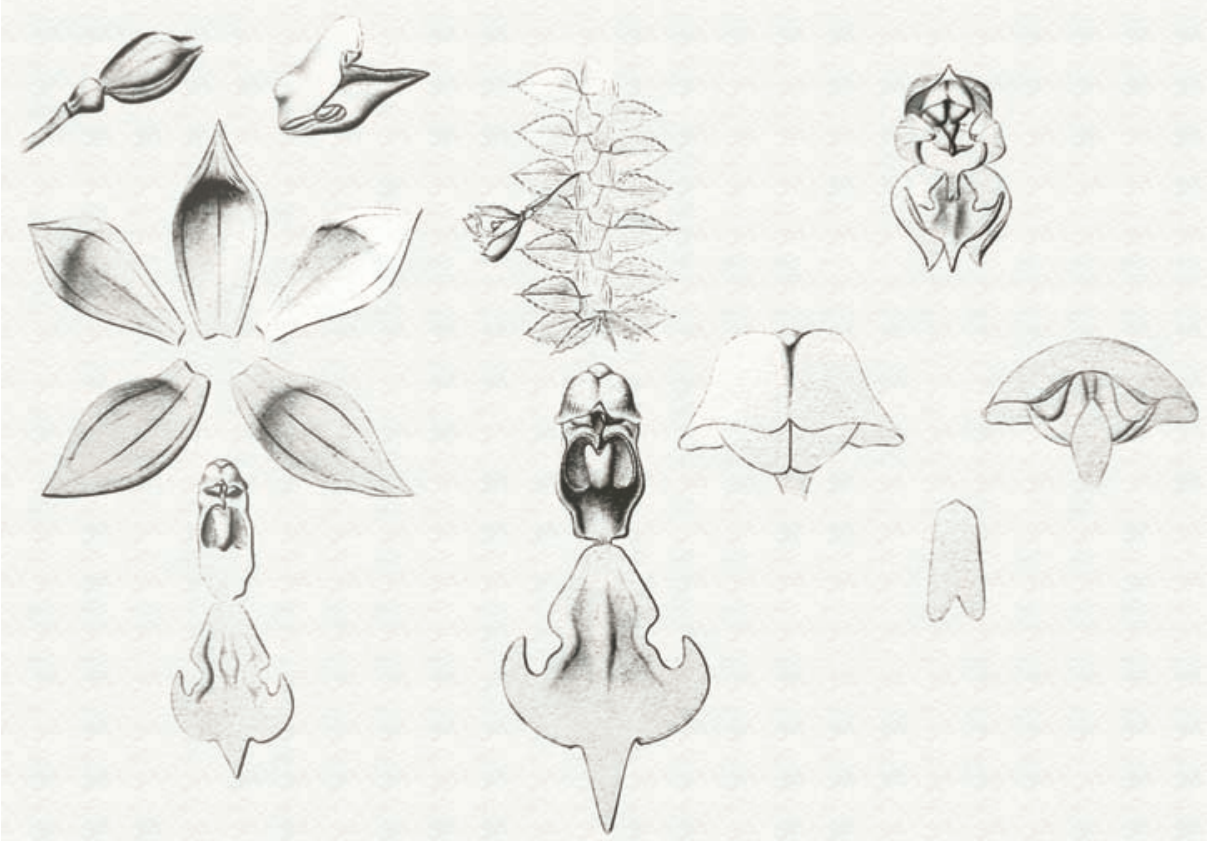

FiguRe 39. A - Masdevallia reichenbachiana Endrés ex Rchb.f. Illustration by Pilar Casasa. B — Dichaea viridula Pupulin. Drawing by A.R. Endrés. 
my instruments, collections of seeds, I accrue to the Imperial Hof Museum in Vienna, under the condition that the preserved Orchids and drawings of Orchids shall not be exhibited before twenty-five years from the date of my death have elapsed..." (Elliot, 1994: 440).

The immediate stimulus for the making of the will was no doubt the incorporation, in 1879, of Robert A. Rolfe to the scientific staff of Kew, who within a few years had become responsible for the orchids at the herbarium. Once Kew realized that it had a competent in-house specialist, it ceased to send its orchids to Reichenbach for identification. "Seldom has anyone's reputation suffered a reversal so quickly" (Elliot, 1994: 440). The loss of all of Reichenbach's material was a terrible blow for science. To aggravate this, the First World War began in 1914, when the twenty five years stipulated in the will had just elapsed. This delayed until the twenties the study of the materials that the controversial German botanist had accumulated during his life. Oakes Ames had harsh words for Reichenbach: "Reichenbach, as I see the situation now, rose to eminence as an orchidologist simply because of unexampled opportunity. When I review the sensations stimulated by his famous herbarium preserved at Vienna, I find them far from flattering. The lack of data, the indecipherable handwriting, the scrappy specimens [...], and the odd bits of paper that bear meager and often inadequate information, give rise to disgust.... If we compare Reichenbach with Lindley, the former suffers prodigiously!... Yet, the Reichenbach herbarium has been an almost insuperable obstacle to the progress of orchidology for over twenty years, because its founder violated the very spirit of science" (in a letter to Charles H. Lankester, Oct. 18, 1922).

Respected as one of the greatest orchidologists of the XIX century and hated for being responsible for 25 years of obscurantist interregnum, Reichenbach will nevertheless always have a preeminent place in the history of the orchids of Central America. A new genus, Reichenbachanthus Barb. Rodr., and a great number of species were dedicated to Reichenbach: Barbosella reichenbachiana (Endrés ex Rchb.f.) Schltr., Chondrorhyncha reichenbachiana Schltr., Elleanthus reichenbachianus Garay, Epidendrum reichenbachianum Schltr., Habenaria reichenbachiana Barb. Rodr., Laelia reichenbachiana Wendl. \& Kraenzl., Lycaste reichenbachii Gireoud ex Rchb.f., Malaxis reichenbachiana (Schltr.) L.O. Williams, Masdevallia reichenbachiana Endrés ex Rchb. f. (Fig.
39A), Odontoglossum reichenbachianum F. C. Lehm., Pleurothallis reichenbachiana Schltr., Sievekingia reichenbachiana Rolfe, and Stanhopea reichenbachiana Roezl ex Rchb.f.

\section{'Señor' Endrés}

"... one of those collectors who cared more for science than for sovereigns".

H. G. Reichenbach (1883)

Little is known about the origins and life of Augustus R. Endrés (1838-1875). "His last name is Spanish, yet he wrote his notes in English. He was referred to as a 'halfcaste' (Veitch, J. H., Hortus Veitchii, 1906), a label that may indicate parentage of a North American or European and a Latin American" (Atwood \& Mora de Retana, 1999). Gómez (pers. comm.) tells us that Endrés was Austrian and that his last name is more or less common in Austria and Switzerland. Bateman, while complaining about the lack of new Odontoglossum from Costa Rica, changes the spelling of his name: "In Mexico, from which much novelty was expected, little has been added to the number of Odontoglossum previously known, and the same may be said of Costa Rica, notwithstanding the vigorous exertions of Mr. Endries" (Bateman, 1874). Now we have reasons to believe that he was French, from the region of Alsace, but much of his life remains a mystery. The quality and precision of the botanical descriptions and illustrations (most of them in pencil) that were attached to his herbarium specimens is astounding, which leads to the assumption that he had a solid academic training, which he probably received in England. His use of the English language, precise and cultivated, points in the same direction (Fig. 39B). He came to Central America in 1866, recommended by Skinner and employed by Bateman to collect orchids in Guatemala and Costa Rica (Anonymous, 1913: 341). It is possible that Skinner recommended him after the disappointment he suffered with Enrique Arce, a Guatemalan collector who had not met Skinner's expectations in the search for Cattleya dowiana. Endrés came the first time to Costa Rica in 1866, and remained for several months in the Atlantic lowlands, until he arrived at San José in May of 1867. He had disembarked in Greytown and came to San José following the route of Sarapiquí.

While Endrés was in Costa Rica, Gottlieb Zahn traveled in Central America, 1869-1870. The main 
object of his journey was the introduction of the rare Miltonia endresii, discovered by Warscewicz about 1849 , but that had previously resisted all attempts at introduction. Zahn was equally unsuccessful with this plant. In 1869 he was proceeding to Costa Rica, when he perished by drowning" (Anonymous, 1913: 263). We remember him in a bromeliad, Guzmania zahnii (Hook. f.) Mez. Endrés was hired in 1871 by the firm of Veitch to replace Zahn and collected Miltonia endresii, Cattleya dowiana, Masdevallia reichenbachiana and others, then considered of little horticultural value. For some reason, Veitch did not consider Endrés a successful collector. "The mission, which terminated in April 1873, was expensive and scarcely a success" (Veitch, 1906: 61). Endrés lived in San José and San Ramón, and collected in all accessible regions of Costa Rica, from Ojo de Agua to the mountains of Talamanca, the region of Dota, hills of Candelaria and Aguacate, San Ramón, Sarapiquí, etc. (Fig. 40A). He sent a great amount of materials to Reichenbach. "The rich collections prepared by Endrés have remained unstudied and wait for their identification in Reichenbach's herbarium" (Schlechter, 1918: 351). During these years, Endrés collected in the company of George Downton (?-1895), a British citizen who came to Central America in 1871, also hired by Veitch. Downton traveled to England escorting the first shipments of Endrés. After traveling to Chile in October of 1871, he terminated his contract in 1873 and settled in Central America, where he joined a firm of coffee planters and died in 1895 (Anonymous, 1913: 263).

Among the many new species discovered by Endrés we find the types of Barbosella prorepens (Rchb. f.) Schltr. (Endrés 271, Costa Rica), Pleurothallis endotrachys Rchb. f. (Endrés s.n., Costa Rica) and Stelis endresii Rchb. f. (Endres W 18468, Costa Rica). The following species were dedicated to him: Anathallis endresii (Luer) Pridgeon \& M. W. Chase, Chondroscaphe endresii (Schltr.) Dressler, Epidendrum endresii Rchb.f. (Fig. 40B), Habenaria endresiana Schltr., Kefersteinia endresii Pupulin, Lepanthes endresii Luer, Maxillaria endresii Rchb.f., Mesospinidium endresii (Kraenzl.) Garay, Miltonia endresii Nichols., Telipogon endresianum Kraenzl. and Zootrophion endresianum (Kraenzl.) Luer. Rudolf Schlechter dedicated to him the genus Endresiella, today a synonym of Trevoria. From at least one of his specimens, we know that he collected also in
Panama. A specimen of Rodriguezia leochilina Rchb. f. (Goniochilus leochilinus (Rchb. f.) M. W. Chase) in Vienna bears a label in Reichenbach's handwriting which says: "Rodriguezia? - Panama - Endres".

Besides collecting orchids, Endrés at some point collected birds. A collection was received in 1867 at the Smithsonian Institution of which Lawrence wrote: "A small but important collection of hummingbirds has been received this summer, collected by A. R. Endrés in Costa Rica" (Lawrence, 1882: 308). Another mystery is a series of specimens allegedly collected by Endrés in Peru and Brazil. There is no information about travels by Endrés to these countries, but in the collection of Orchidaceae at the Natural History Museum in London we find 19 specimens apparently collected by Endrés in Peru and one in Brazil. In the database of the herbaria of Harvard University Endrés is also mentioned as a collector in Costa Rica and Peru. ¿Did Endrés visit these countries, or did he receive plants from there (from other collectors) while he was in Costa Rica?

To understand the enigma of A. R. Endrés in the history of the orchids of Central America, the attempt must be made some day to research his life, starting with all the material that is kept at Vienna. This will help in understanding the relations between Endrés and Reichenbach, probably not always fortunate if we consider the difficult character and egotism of the great German orchidologist. Curiously, Reichenbach ignored during his life many of the specimens which he received from Endrés, which in many cases proved to be new genera or species. The material kept at Vienna was studied later, among others, by Ames, Schlechter, Kränzlin, Garay, Luer, Dressler, Dodson and Pupulin. Perhaps it was all a deference of Reichenbach to Endrés, who, according to Luer, "judging from the numerous notes indicating figures, intended pages and volumes, [...] was apparently preparing a publication" (Luer, 1995: 133). Endrés collected in Costa Rica until 1874 or 1875. This same year he traveled to Colombia, where he was murdered in Riohacha (Swinson, 1970: 123). According to Jorge Munera, Endrés, whom he calls 'one of the greatest collectors', was shot to death in a street of this small town on the Caribbean coast of Colombia (Munera, 2005). Reichenbach never kept the promise expressed in the Gardener's Chronicle obituary (Fig. 40C). Life and death of A. R. Endrés remain as one of the best guarded secrets in the history of Central American orchids. 


\section{Other travelers in Central America (I): 1839-1870}

Put everything into your pocket!

Baron Hügel's advice to botanists

There are several very interesting accounts of travels through Central America, written by persons who came for various motives (never primarily as botanists), but which contain some interesting descriptions, which shall be commented hereafter.

John Lloyd Stephens (1805-1852), born in Shrewsbury, New Jersey, traveled in 1834 through Europe, Palestine and Egypt, in the company of Frederick Catherwood, an Englishman who would illustrate most of his travel journals. In 1839, Stephens and Catherwood decided to explore Central America. United States President Van Buren, in order to support the expedition, gave Stephens a diplomatic commission. He visited Belize, Guatemala, Honduras, Costa Rica and Nicaragua and dedicated his main efforts to the explorations of the Mayan ruins of Copán (Honduras), where Catherwood made beautiful illustrations. In Guatemala, he made the acquaintance of George U. Skinner: "[...] I went to the house of Mr. Zebadous ... There I met Mr. Chatfield, General Consul of Her British Majesty, and Mr. Skinner, who had arrived during my absence". In another chapter he mentions the firm of Klee and Skinner, who "where the most important foreign merchants in Guatemala" (Stephens, 1971: 277, 222). Stephens became later one of the directors of the American Ocean Steam Navigation Co. He was in Panama with the purpose of exploring the terrain for the construction of a railroad through the isthmus and was later president of the Panama Railroad Company, which would become so important for the botanical exploration of the region.

Ephraim George Squier (1821-1888) (Fig. 40D) "came to Nicaragua in the year of 1849 as charge d'affairs of the United States and while occupying this diplomatic position rendered valuable services fighting England's expansionistic tendencies in the Mosquito Coast. The Clayton-Bulwer Treaty of 1880 between the United Stated and Great Britain, which guaranteed effectively for half a century Central America's independence, was signed mainly through his efforts. An enthusiastic promoter of the opening of an interoceanic canal, he contributed, through his studies and research, greatly to broaden the geographical and geological knowledge relative to the Central American Isthmus. He returned to Central America in 1853 to direct studies for the Honduran Interoceanic Railway Company, of which he was Secretary and whose interests he had been promoting in Europe; but this railway project was later abandoned" (Fernández Guardia, 1972: 265-266). Squier traveled through Nicaragua, El Salvador and Honduras, but it was Nicaragua the country he knew best. He wrote an important book about this country, which was published in 1860 (cited here is the Spasnish version of 1972). In several passages of his book, Squier describes the trees of the forest, full of 'parasites', in many cases surely orchids. "The pendent branches full of parasites..." "From there on the countryside [...] is full of 'jicarales' (Crescentia spp.) covered to such extent with parasitic plants that they almost conceal the branches of these trees". He also mentions a narrative by his friend Julius Froebel about his ascent to the Telica volcano, near León, in which he writes: "On the highest rim of the crater I found an orchid, whose crimson stems are similar to some varieties of our German orchids" (Squier, 1972: 319, 404, 436).

Julius Froebel (1805-1893), nephew of Friedrich Froebel the celebrated educational reformer and founder of the kindergarten system, had been sentenced to death in 1848 for his participation of the German Revolution of that year, and fled to the United States. He arrived in Nicaragua in 1850, where he made important studies about the language of the Sumo Indians. His studies of Mayan architecture and linguistics are still used extensively. In 1857 he was in Belize, studying the suitability of British Honduras for German emigration.

Friedrich Wilhelm Adolph Marr (1819-1904) was born in Magdeburg, Germany, a son of the famous actor Heinrich Marr. The discovery of the Californian gold mines and the projects for an interoceanic canal in Nicaragua or Panama awakened his interests, and in 1852 he traveled to New York and from there to Nicaragua and Costa Rica. While in Nicaragua, he practiced as an improvised physician. In Costa Rica he became an engineer and finally a merchant, until he returned to Germany in 1853 , with a commission by the Costa Rican government to bring German colonists to the country. He failed in this purpose and returned to Costa Rica in 1854, where he established himself as a merchant in Puntarenas. He returned to Hamburg 
in 1859 and died in 1904 in extreme poverty. Marr published in 1863 a book about his journey, in which he presents beautiful descriptions of the nature that he encountered in the Central American countries (Marr, 1863). It is sad that his racist tendencies diminished the value of his writings. In several parts of his book, Marr writes about the orchids that he encountered on his way: "On the big trees often thirty or more orchid species had found a host, in the most bizarre forms and sizes." "On the riverbanks, the powerful vines that fall into the water, the wild plantains, the green physiognomies of the orchids!" "There I turned my eyes to the giants of the forest, to the wildly entangled vines, the bizarre forms of the orchids, the fabulous fans of the wild palms..." (Marr, 1870: 166, 188, 172).

William Vincent Wells (1826-1876) formed an association called the Honduras Mining and Trading Company early in 1854 with James Davenport Whelpley, and Byron Cole. Wells traveled to Honduras through Nicaragua looking for the gold mines of Olancho, and he wrote Explorations And Adventures In Honduras (Wells, 1857). William V. Wells was one of the pioneers during the gold rush in California. One of his partners, Byron Cole, was one of the instigators of William Walker's invasion of Nicaragua in 1856. In his travel journal, Wells described what where undoubtedly orchids, near the Nicaraguan city of Chinandega: “...parasitic plants, adorned with showy flowers, hung from the branches, which presented fantastic forms...". Wells was not the first to confuse epiphytic plants with parasites. Some months later, already in Honduras, he writes about the "solemn greatness of these forests: the ceibas (Ceiba pentandra), of gigantic proportions, with the hanging gardens of parasites on their branches ..." (Wells, 1857).

The Irishman Thomas Francis Meagher (18231867) came to Costa Rica in 1858 and again in 1860. From his travels he wrote his well-known Holidays in Costa Rica. During an excursion to the valley of Orosi, Meagher writes: "We rode the last part of the journey towards the rivers with the eyes fixed on the canopy of the trees, full of orchids ..." (Meagher, 1859).

A narrative of a journey along the Panama Railroad by Oran (?-?) in 1859 includes the description of a huge ceiba, the famous 'Stephen's tree': “This Titan of the tropics measured no less than five yards in diameter at its base, including the broad plane-shaped roots that extended out on every side like buttresses, and towering up without a branch for nearly a hundred feet, supported a canopy of foliage full fifty yards in diameter... A little reconnaissance rewarded us with several fine specimens of orchidaceae with which the trunks and branches of many of the trees were studded" (Vargas, 2008: 159).

The German Karl Albert Ludwig von Seebach (1839-1880) traveled through Central America during the years of 1864 and 1865, studying mainly the volcanoes of the region. In March of 1865 he climbed the Turrialba volcano in Costa Rica. During the ascend, he describes the tropical forest: "Vines and epiphytic orchids hang from the trees, which, hidden from our view, announce their presence through their sweet perfume" (Seebach, 1892).

Frederick Boyle (1841-1883) arrived in Greytown, Nicaragua, on November 12, 1865, having traveled via Kingston (Jamaica) and Aspinwall (today Colón, Panama) in the company of his friend John Gladwyn Jebb. Boyle became years later a well-known writer on orchid matters. However, as Boyle explains in the preface to the book that he wrote about this journey, his interests during this trip were different. "The main object of the travels [...] was to examine the antiquities of Nicaragua". Boyle sailed on a small steamer on the San Juan River to Granada, and from there rode to the mining region of Chontales, where he spent some time digging out Indian graves in search for antiquities. Along the way to Libertad, the main village in this region, he writes, "every branch was decked with a fringe of orchids"; and, lying under a big tree, he saw that "purple dendrobia boldly clung to the lianas, parasites of a parasite" (Boyle, 1868). "Who in a volume could tell the story of this tree and its inhabitants, could describe the variety, the loveliness of its vegetation, the millions of its living things..." (Boyle, 1874). In January of 1866 Boyle had returned to Granada, from where he explored the surroundings until the first days of March. In March of 1866, Boyle sailed from the port of El Realejo to Puntarenas, in Costa Rica, riding from there to San José, the capital of the country. "The beautiful purple orchids, for which Costa Rica is famed [Guarianthe skinneri], hung trailing down from walls and branches..." as Boyle noticed (Boyle, 1868). After a few weeks in San José, he returned to Greytown along the road of Sarapiquí. In Greytown he embarked for 
his return trip to England. His collections of antiquities went to the British Museum.

Thomas Belt (1832-1878), English geologist and naturalist, was born at Newcastle-on-Tyne in 1832, and educated in that city. As a youth he became actively interested in natural history through the Tyneside Naturalists Field Club. In 1852 he went to Australia and for about eight years worked at the gold-diggings, where he acquired a practical knowledge of ore deposits. In 1860 he proceeded to Nova Scotia to take charge of some gold-mines, and there met with a serious injury, which led to his return to England. In 1861 he wrote on the origin of mineral veins in Australia. Later on he was engaged for about three years at Dolgelly (North Wales), another though small gold-mining region, and here he carefully investigated the rocks and fossils, his observations being published in an important and now classic memoir in the Geological Magazine for 1867. In the following year he was appointed to take charge of some mines in Nicaragua, where he passed four active and adventurous years (1868-1872) the results being given in his The Naturalist in Nicaragua (1874), a work of high merit. In this volume the author expressed his views on the former presence of glaciers in that country. In subsequent papers he dealt boldly and suggestively with the phenomena of the Glacial period in Britain and in various parts of the world. After many further expeditions to Russia, Siberia and Colorado, he died at Denver on the 21st of September 1878 and was buried there. Belt arrived at Greytown, as did most of the Europeans traveling to Nicaragua, and gives an interesting description of the route along the San Juan River to the Lake of Nicaragua. The mine managed by Belt was in the region of Chontales, in the Santo Domingo valley, where he made the acquaintance of the well-known German botanist Dr. Seemann, who was the manager at that time of the neighboring Javalí mine. Seemann died at Javalí; and Belt read the Burial Service over him, as was his custom upon the death of any European. Although Belt's main interests were in geology and entomology, he made interesting observations about orchids. "Beyond the brushwood, which grows where the original forest has been cut down, there are large trees covered with numerous epiphytes - Tillandsias, orchids, ferns, and a hundred others, that make every big tree an aerial garden". "Excepting near the river, the country was very thinly timbered; and it was pleasant, after riding across the open plains, exposed to the hot rays of the sun, to reach the shady banks of the stream, by which grew many high thick-foliaged trees, with lianas hanging from them, and bromelias, orchids, ferns, and many other epiphytes perched on their branches". "This rock, on the southern and most perpendicular side, weathers to a whitish colour, and is called Pena Blanca, meaning the white peak. It is visible from some points on the savannahs. During the summer months it is, on the northern side, covered with the flowers of a caulescent orchid (Ornithorhynchos) that has not been found anywhere else in the neighbourhood; and the natives, who are very fond of flowers, inheriting the taste from their Indian ancestors, at this time, often on Sundays ascend the peak and bring down large quantities of the blossoms. Its colour, when it first opens, is scarlet and yellow". "A ridge on the eastern side runs up to within about 200 feet of the summit, and so far it is accessible. Up this I climbed to the base of the brown rock, the perpendicular cliff towering up above me; here and there were patches of grey, where lichens clung to the rock, and orchids, ferns, and small shrubs grew in the clefts and on ledges. There were two fine orchids in flower, which grew not only on the rock, but on some stunted trees at its base...". "Amongst the numerous plants that do not provide houses, but attract ants to their leaves and flower-buds by means of glands secreting a honey-like liquid, are many epiphytal orchids, and I think all the species of Passiflora". "Many epiphytes grew on the oaks, amongst which the mottled yellow flower of an orchid hung down in spikes six feet long" (Belt, 1874: 7, 42, 110, 153, 174, 188). "Mr. Belt is a close, an accurate, and an intelligent observer. He possesses the valuable faculty of wonder at whatever is new, or strange, or beautiful in nature; and the equally valuable habit of seeking a reason for all that he sees. Having found or imagined one, he goes on to make fresh observations and seeks out new facts, to see how they accord with his supposed cause of the phenomena. $\mathrm{He}$ is a man of wide experience; having travelled much in North and South America and in Australia, as well as in many parts of Europe - and always with his eyes open - before visiting Nicaragua. He is a geologist and an engineer, and knows how to overcome obstacles whether caused by the perversity of man or the forces of nature" (Wallace, 1874). 


\section{The ERA OF LIBERALISM}

"Paz, educación y prosperidad material" (= 'Peace, education and material prosperity') Slogan of the liberal reform in Guatemala, 1871

"The immense ideological power of the Church was a notorious characteristic in the formation of Central American society... The establishment of secular power was slow and difficult; a first attempt was made in the second half of the XVIII century, under the Bourbons of enlightened Spain. But one has to wait until the end of the XIX century to observe a moderate laic triumph: this is the liberal era, the era of positivism, of education controlled by the State and the definitive consecration of freedom of religion (Pérez Brignoli, 2000: 27)". “... the fight between liberals and conservatives (clericals) fills the history of Central America in the second half of the century..." (Halperin Donghi, 2001: 258).

In Guatemala the liberal revolution triumphed in 1871, dominated by the figure of president Justo Rufino Barrios, who was responsible for a radical agrarian reform and the expropriation of ecclesiastical possessions. In 1876 liberal ideas gained strength in El Salvador, during the presidency of Rafael Zaldívar (1876-1885) and under strong Guatemalan influence. Nicaragua and Honduras were an exception, with reforms that were frustrated or incomplete. While Walker's defeat in Nicaragua was followed by more than thirty years of conservative governments, regional fragmentation, difficulties in communications and backwardness hindered in Honduras the consolidation of the State. In Costa Rica, the liberal reforms initiated in the forties by president Braulio Carrillo were continued by president José María Castro Madriz, who fought for public education and for the freedom of the press, and by the 'progressive authoritarianism' of dictator Tomás Guardia (1870-1882). The first public schools and the first universities of Central America were founded during those years.

"After most of Latin America achieved independence from Spain in the early nineteenth century, foreign naturalists began to visit the new republics, as part of a flood of foreign soldiers, miners, engineers, adventurers, missionaries and others. The botany practiced by these foreign naturalists was essentially extractive. They extracted botanically significant plants in much the same way that foreign corporations such as the United Fruit Company extracted bananas from Central America... By the late nineteenth century, the most important herbaria of Latin American plants were to be found in Europe and North America... Beginning in the last quarter of the nineteenth century, however, many Latin American countries began to produce their own botanical inventories and national floras. The growing official interest in the natural world coincides with the liberal era in Latin America that lasted roughly from 1870 to 1930 . National botanical inventories appealed to Latin America's liberal elites for ideological and practical reasons. During the liberal era, national governments pursued the goals of 'order and progress', enlisting science and technology to help rationalize and modernize the state, the economy, and society. They pursued economic growth through the export of tropical commodities - ranging from industrial commodities such as rubber and henequen to luxury foods such as coffee, sugar and bananas. This meant that during the liberal era many Latin American economies -and by extension the statesdepended heavily upon plants... The leaders in each country began to take an interest in botany that offered the possibility of increasing the production of existing export crops and of discovering new ones. Many Latin American governments established or revived national botanical gardens, agricultural experiment stations, and natural history museums, whose research agendas included surveying the nation's plants, compiling national herbaria and, most significantly, producing national floras" (McCook, 2002: 514-515).

Liberal ideas also led to the creation of private gardens and collections, combining leisure with scientific interests. In the history of the orchids of Central America the legendary orchid hunter began to be displaced by the scientific collector. Although great quantities of plants where still collected and sent to Europe and later to the United States, the shipments of herbarium specimens began to outnumber those of live plants. A further contribution to this development were the improvement of methods for the reproduction of orchids from seed in England, which began in 1849 and the production of the first hybrids by John Dominy in 1854. "Gradually [...] the interest in imported species waned as commercial success in orchid hybridization 
increased" (Reinikka, 1995: 66). The era of the great collectors, of the great adventurers and gatherers of living plants, came slowly to an end, and gave way to a large group of scientific travelers, whose main interest was the collection of herbarium specimens. An additional reason for this change were the rising costs of the expeditions.

As Boyle wrote in 1893, "twenty years ago, nearly all the great nurserymen in London used to send out their travellers; but they have mostly dropped the practice. Correspondents forward a shipment from time to time. The expenses of the collector are heavy, even if he draw no more than his due. [...] Then, grave losses are always probable -in the case of South American importations, certain. It has happened not once but a hundred times that the toil of months, the dangers, the sufferings, and the hard money expended go to absolute waste. Twenty or thirty thousand plants or more an honest man collects, brings down from the mountains or the forests, packs carefully and ships. [...] The cases arrive in England - and not a living thing therein!" (Boyle, 1983: 68).

\section{German (and other) collectors in the second half of} the XIX century. Germany played always an important role in the history of Botany. When national unity was achieved, symbolized by the crowning of Wilhelm I as German Emperor in 1871, natural sciences received a new impulse. The Royal Herbarium in Berlin, created in 1815 under the tutelage of the Royal Prussian Academy of Sciences to host the collections of de C. L. Willdenow, became in 1879 the Royal Botanical Museum of Berlin, to which the Botanical Garden was attached in 1910.When the German Empire expanded during the 1880 s, with the incorporation of the colonies of Cameroon, Togo, German SouthWest Africa, Eastern Africa, South Pacific Territories, Kiautschou, New Guinea and Samoa, a great wave of emigrants began to leave Germany. During the last 30 years of the XIX century more than 4 million Germans left for America, Africa and Asia in search of fortune.

Great opportunities presented themselves to German explorers and scientists to explore little known territories. Reichenbach had, until his death in 1889 , an inexhaustible source of new orchid species that were sent to him from all confines of the globe. His place would be occupied very soon by a young scientist who, at the age of 19, embarked on his first exploratory mission to colonial Africa: Rudolf Schlechter.

The new wave of German collectors in Central America began with Gustav Wallis (1830-1878) (Fig. 40F), who was born with a physical limitation: he was deaf and mute until six years of age, when he learned to articulate, although a speech defect persisted during his entire life (Reinika, 1995: 234). Despite of his problem, and of a childhood filled with penuries, he showed always an indomitable will and enormous energy. $\mathrm{He}$ learned gardening and botany in Germany, where he made his first collections while studying the flora of the Alps. He first traveled to America in 1856, collecting in Southern Brazil. In connection with a German house he started a horticultural establishment, but owing to the failure of the parent firm in 1858 Wallis was left practically penniless (Veitch, 1906: 63). He continued collecting in Brazil, employed by Linden, and explored the Amazonas River from its mouth in the Atlantic to its source. "At the end of September 1868, utterly exhausted by arduous journeys, he returned to Europe. ... He received the Great Gold Medal for Botany at the International Exhibition in Paris and also a premier prize from the Belgian Government" (Yearsley, 2007: 108). During the years of 1860 to 1864 he collected again in Brazil and passed in 1865 to Colombia y Ecuador, arriving in 1868 in Panama, from where he made an excursion to the border of Costa Rica. He returned to Europe and in 1869 came under contract with Veitch to explore the Philippines. He went to Japan and then to the United States and returned to Europe. He was sent in 1872 to Colombia, in what would be his last travel to South America. Upon the termination of his contract with the Veitches he continued to collect plants in South America, among them many orchids. Reinikka suggests that he arrived in Panama after 1875 (Reinikka, 1995: 235), but he must have been earlier in Central America, because Reichenbach described Trichocentrum capistratum Rchb. f., based on a collection by Wallis in Costa Rica in 1871, and Zygopetalum (= Kefersteinia) lacteum Rchb. f. (Wallis s.n., Panama) in 1872. The majority of his collections (as had the collections of Roezl some years before) arrived at the London market by intermediation of Eduard Ortgies, an important German orchid merchant based in Zurich, Switzerland (Anonymous, 1894: 225229). 
Wallis published a few new species, presumably based on material collected while he worked for Linden, which resulted in a strong personal attack by Linden (1875), who accused Wallis of being a corrupt collector with little knowledge of plants. "I found him penniless, unknown, abandoned. When he left me he had a reputation, a small fortune [...]. I took him from the Amazon Delta to the Isthmus of Panama, a journey which cost me 125,000 francs: an enormous sum compared with the paltry returns resulting from the specimens arriving in poor condition..." (Ceulemans et al., 2006: 146). Wallis answer was a letter of 18 pages and consisted in citing previous letters by Linden, in which he was congratulated for his work and excellent collections (Jörgensen, 2003). In Panama he suffered a bad attack of yellow fever, from which he barely recovered. He continued working and arrived in Ecuador, but a second attack, combined with dysentery, proved fatal. "Letters from the collector Edward Klaboch carried the news that Wallis died in the hospital at Cuenca, Ecuador, on 20 June 1878" (Reinikka, 1995: 235). More than 20 species of Orchidaceae carry his name, among them Oerstedella wallisii (Rchb. f.) Hágsater, one of the most beautiful species of this genus.

Carl Ernst Otto Kuntze (1843-1907) (Fig. 41A), the famous German botanist and naturalist, crossed Costa Rica from the Atlantic to the Pacific in 1874, and complains in his book (Kuntze, 1881) that he saw only six species of orchids. He had previously explored the isthmus of Panama, between Colón and Panama City. The results of his botanical explorations were published by Kuntze in his Revisio Generum Plantarum that appeared in several parts between 1891 and 1898. It contained a large section on Kuntze's nomenclatural system that became the source of a great deal of controversy. In the third volume, Kuntze replied to many of his critics and introduced much new material. It was published in two parts in 1893 and 1898 and contains a lengthy summary of his nonconformist system. For the rest of his life, Kuntze was engaged in disputes with the botanical community on the basic questions of plant nomenclature. An enemy of Linné's binomial system of nomenclature, he spoke of the date of 1753 (when Linné promulgated his system) as 'a horrible fiction and mistake that I cannot accept as a scientific and honest man' "(Anonymous,
1907: 67). In his Revisio Generum Plantarum, Kuntze describes over 1,000 new species of Orchidaceae. One of his collections was dedicated to him by Cogniaux: Campylocentrum kuntzei Cogn. ex Kuntze (= Campylocentrum micranthum (Lindl) Rolfe - Bolivia). According to some sources, Kuntze was in Mexico at the beginning of the XX century, where he collected in the states of Veracruz, Puebla and Oaxaca (Anonymous, 1906: 167). However, no records of collections of Orchidaceae have been found from these travels.

As one of many German emigrants who traveled to the tropics searching for fortune, Baron Hans von Tuerckheim (1853-1920) (Fig. 41B) arrived in Guatemala in 1877. He settled in the region of Alta Verapaz, near Cobán, where he acquired the farm 'Chicoyogüito', thanks to a letter of recommendation from the German Charge of Affairs Werner von Bergen (Wagner, 2007: 178). There he lived, producing coffee and studying the flora and fauna of the region. It is said that he was disinherited by his German family, because he married a Guatemalan dancer. From 1883 to 1895 , von Tuerckheim substituted for the Charge of Affairs at the German vice-consulate in Cobán, until he decided to sell his farm and return to Germany. In 1906 he returned to Guatemala for a short period and left finally Central America in 1914. The collections by von Tuerckheim whose numbers start with "II" are all from this last journey. In 1910 he made a short trip to the Dominican Republic (March-June, 1910), as German consul in that country. From this trip we know of several collections (Pleurothallis appendiculata Cogn., Tuerckheim 3233). When he started to have financial problems due to the fall of the international coffee prices, he began collecting plants and seeds at a larger scale, which he exported to laboratories and botanical gardens. At a certain point of his research in Guatemala he received financial support from John Donnell-Smith, the great North American botanist, who distributed von Tuerckheim's specimens to the most important herbaria of the world (Maldonado Polo, 1996: 135). Donnell-Smith published also his Enumeratio Plantarum Guatemalensium, describing von Tuerckheim's collections in Guatemala, including 40 species of orchids (Donnell-Smith, 1889: 41.45). His collections form the base for a more exact knowledge of the orchid flora of Guatemala, mainly that of Alta Verapaz, especially because he occupied 

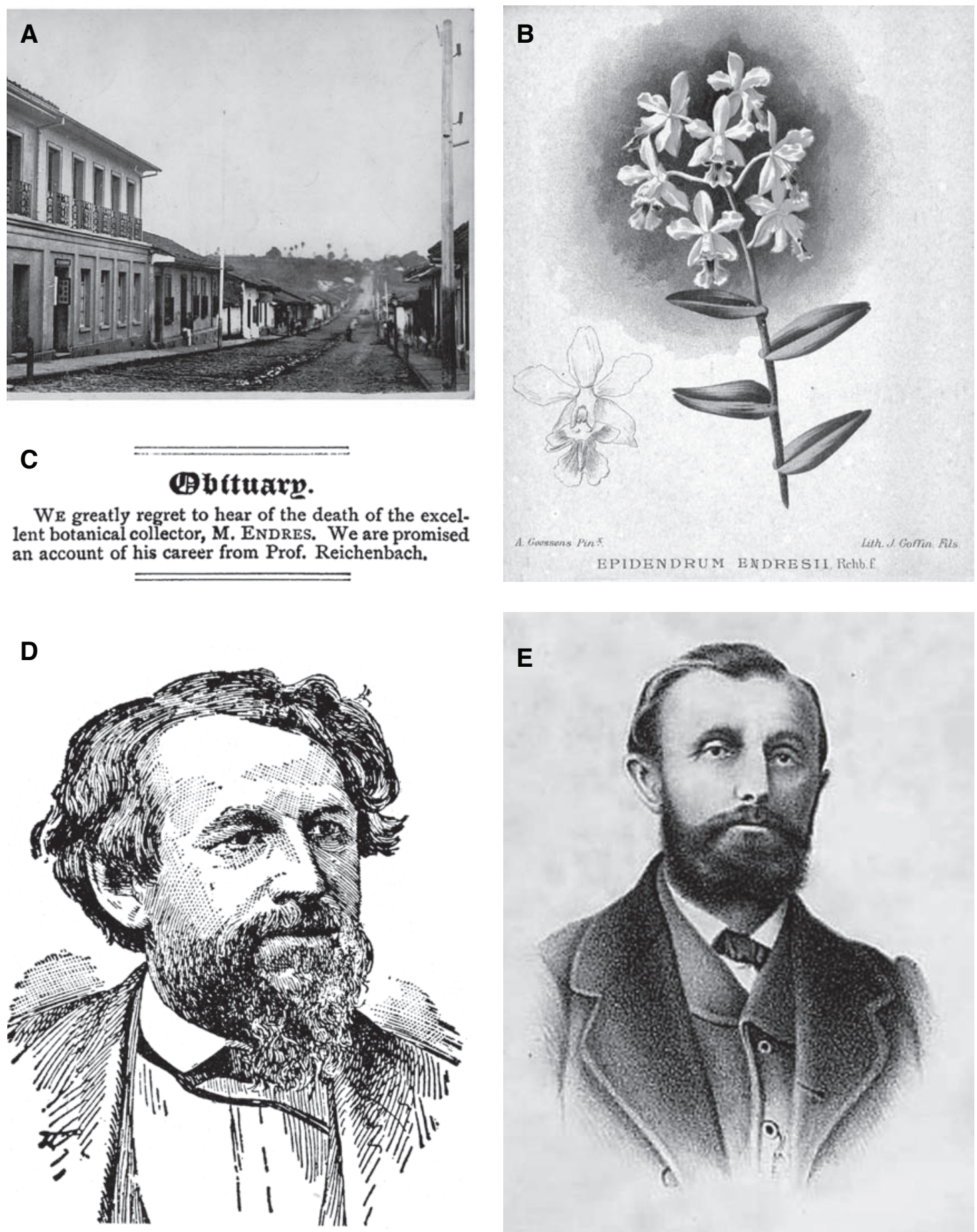

FiguRE 40. A - San Jose in Endrés' time. 19th century postcard, courtesy of Alvaro Castro. B - Epidendrum endresii Rchb.f. Illustration by A. Goosens, in Cougniaux and Goosens, 1896-1907. C — Endrés' obituary in the Gardeners 'Chronicle, May 8, 1875. D - Ephraim G. Squier (1821-1888). In Squier, 1972: 28. E — Gustav Wallis (1830-1878). Courtesy of the Oakes Ames Herbarium, Harvard University.. 


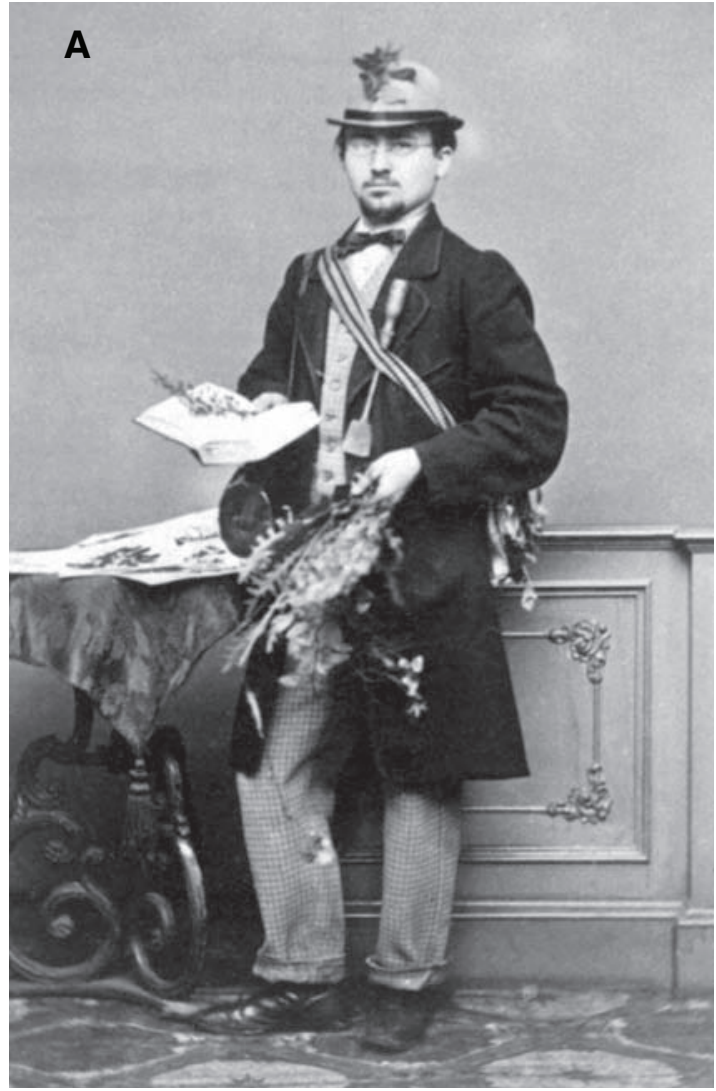

B
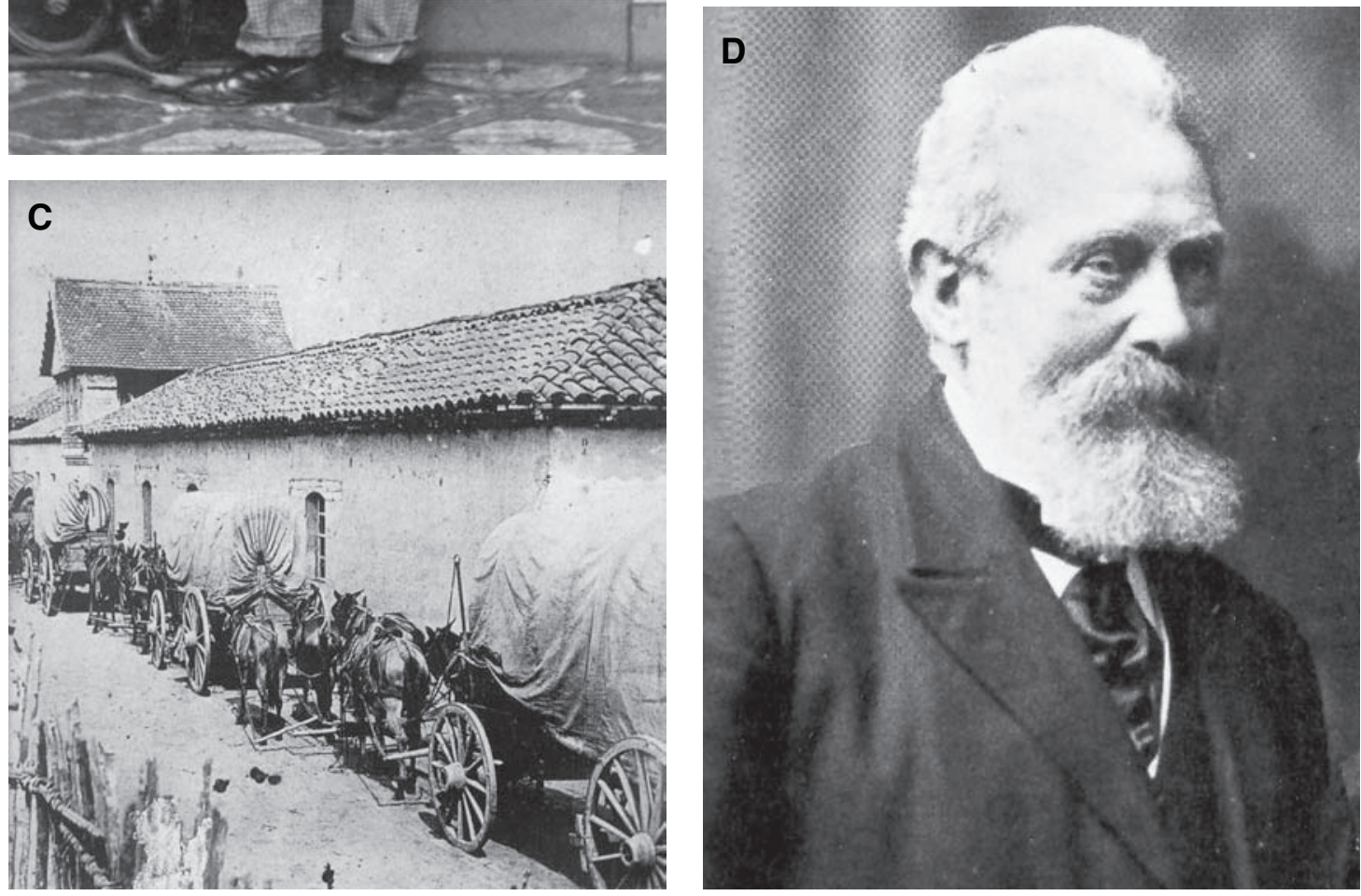

Figure 41. A - Carl Ernst Otto Kuntze (1843-1907). Courtesy of the Hunt Institute for Botanical Documentation. B - Hans von Tuerckheim (1853-1920). Courtesy of Freddy Archila. C - The city of Cobán, 19th century. In Wagner, 2001: 121. D — Frederick Sander (1847-1920). In Swinson, 1970, after p. 190. 
himself also with the less showy species. "The study of the collections prepared by Baron von Tuerckheim in the area of Cobán has made us discover a surprising number of new species" (Schlechter, 1918: 343).

Among the many types of new species that he discovered, are the following, described mainly by Ames and Schlechter: Aspidogyne stictophylla (Schltr.) Garay (Tuerckheim II 1994), Dichaea intermedia Ames \& Correll (Tuerckheim II 1798), Dichaea muricatoides Hamer \& Garay (Tuerckheim s.n.), Dichaea tuerckheimii Schltr. (Tuerckheim s.n.), Dryadella guatemalensis (Schltr.) Luer (Tuerckheim II 490), Dryadella linearifolia (Ames) Luer (Tuerckheim 7784), Encyclia tuerckheimii Schltr. (Tuerckheim 2456 ), Epidendrum cerinum Schltr. (Tuerckheim 4179 ), Epidendrum isomerum Schltr. (Tuerckheim II 167), Epidendrum mixtum Schltr. (Tuerckheim II 1868), Epidendrum pseudoramosum Schltr. (Tuerckheim II 1951), Erythrodes tuerckheimii (Schltr.) Ames (Tuerckheim 733), Microstylis tuerckheimii Schltr. (Tuerckheim 1017), Platystele jungermannioides (Schltr.) Garay (Tuerckheim 698), Scaphyglottis cuneata Schltr. (Tuerckheim s.n.), Scelochilus tuerckheimii Schltr. (Tuerckheim II-1919), Stelis fulva Schltr. (Tuerckheim 4064), Stelis gracilis Ames (Tuerckheim 7681), and Stelis rubens, Schltr. (Tuerckheim II 1061). Platystele jungermannioides is one of his most interesting collections, being reputedly the smallest orchid in the world. He is also mentioned in relation to the discovery of Catlleya bowringiana Veitch: "A planter named Turkheim [sic] sent it from British Honduras to Mr. Bowring of Forest Farm, Windsor, in 1884" (Boyle, 1901: 37). Von Tuerckheim was also interested in many other plants families, and many new species were described and dedicated to him, such as: Coccobola tuerckheimii Donn. Sm. (Polygonaceae), Panicum tuerckheimii Hackel (Poaceae), Lyonia tuerckheimii Urb. (Ericaceae), Phyllanthus tuerckheimii G.L. Webster (Euphorbiaceae), Phaseolus tuerckheimii Donn. Sm. (Fabaceae), and Columnea tuerckheimii Sprague (Gesneriaceae). Von Tuerckheim met briefly Bernoulli, before the Swiss went on his last expedition to the region of Petén in 1877.

The city of Cobán (Fig. 41C) and the department of Alta Verapaz occupy a special place in the history of Guatemalan orchidology, similar to that of San
Ramón in Costa Rica. With its very humid climate (Cobán in the language of the Q'eqchi' means "between rainfalls") the region offers an enormous diversity of orchids and has traditionally been the birthplace of the best nurseries in the country. Cobán was founded on August 14, 1543 by Dominican friars and Emperor Charles V named her 'Imperial City'. The following species of orchids were dedicated to the city: Jacquiniella cobanensis (Ames \& Schltr.) Dressler, Maxillaria cobanensis Schltr., Pleurothallis cobanensis Schltr., and Spiranthes cobanensis Schltr.

The types of the first three were collected by von Tuerckheim. The fourth was collected by Friedrich Carl Lehmann, of whom we will talk shortly.

The demand for orchids during the last quarter of the century escalated and the collection of plants from the wild and their shipment back to Britain (and subsequently to the rest of Europe) became a major industry. The time was right for Henry Frederick Conrad Sander (18471920) to set up business as an importer and commercial grower of orchids. Sander faced stiff opposition from already well-established firms, such as James Veitch, Hugh Low, William Bull and others, and he teetered on the brink of bankruptcy on several occasions. But eventually Sander (later Sander and Sons) became the largest orchid establishment in Europe.

Frederick Sander (Fig. 41D) was born in Bremen (Germany) but moved to England at age 16. Marriage in 1870 to Elizabeth Fearnley, daughter of a rich printer was the catalyst for Sander's rise to fame, as she provided him with the funds to enter business by purchasing a seed business at Saint Albans, a short distance northwest of London. He soon entered into a profitable arrangement with the Czech orchid collector Benedict Roezl and they prospered together until Roezl died in 1884. More and more collectors were employed until at one point he had 23 'travelers' collecting orchids for him throughout the world. Several of them (Oversluys, Falkenberg, Forget, etc.) collected for Sanders in our region. The supply of plants of all kinds grew to such an extent that Sander found it necessary to set up a second nursery in Bruges (Belgium), where 250 glass-houses were eventually constructed, of which 50 were used to house orchids. Some idea of the scale of Sander's operations can be gained from his claim that he imported more than one million plants of just one orchid species, Dendrobium phalaenopsis var. schroederiana, from 
New Guinea. Between 1888 and 1894 Sander devoted a great amount of work and money on the publication of Reichenbachia, a series of beautiful orchid illustrations, in Boyle's worlds "that great monument to orchidology, printed in four languages. [...] Sander employed the most skilful craftsmen to be found, the finest paper, the most deliberate and costly processes, to rival great works of the past ..." (in Swinson, 1970: 17). Volume I of the first series came out in 1888, containing forty-eight plates. Volume two, with the same number of plates, came out in 1890. In 1892 and 1894 the two volumes of the second series appeared, again with a total of ninety-six plates. "It is no wonder that Sander often remarked that the project almost ruined him" (Swinson, 1970: 100). In 1902 Sander's three sons (Louis, Fearnley and Fred) were taken into partnership but the orchid boom was nearing its end. New species were becoming harder to find and they did not command such high prices as they had in the past. Most other nurserymen no longer employed plant collectors, but bought orchids on commission, so that any losses incurred during shipment (a frequent occurrence) were borne by the collector, not by the nurseryman. But Sander remained loyal to his long-time collectors Forget and Micholitz, who remained in his employment until they retired in 1914.

World War I and the German occupation of Belgium forced the Sander family to leave Bruges but thanks to the services of a Swedish manager the nursery survived the war, although many orchids died during winter because of fuel restrictions. Frederick Sander also survived the war, but in declining health and he died in 1920, aged 72 years. He had become a legend in Europe. Most royal families grew orchids and they all knew him personally and respected his advice. He received honors from many of them. Sander exhibited orchids throughout Europe during his long career and won innumerable trophies for his displays, and awards and gold medals for his orchids. Such was his fame that he was known as 'The Orchid King'. Sander was Royal Orchid Grower to Queen Victoria from 1886 and a foundation member of the Orchid Committee of the Royal Horticultural Society. A great number of new species were dedicated to him. From the American Tropics we find among them: Calanthe sanderiana B.S. Williams, Epidendrum sanderi A.D.Hawkes, Gongora sanderiana Kraenzl., Houlletia sanderi
Rolfe, Laelia sanderiana Crawshay, Lueddemannia sanderiana Kraenzl., Maxillaria sanderiana Rchb.f. ex Sander, Odontoglossum sanderianum Rchb.f., Oncidium sanderae Rolfe, Oncidium sanderianum Rolfe, Schomburgkia sanderiana Rolfe, Sobralia sanderae Rolfe, and Zygopetalum sanderianum Regel.

"Though the precise date that Sander sent out his first travellers cannot be stated with certainty, it must have been very soon after he opened up his shop in 1876..." (Swinson, 1970: 44). One of these travelers was Martien Oversluys, a (Dutch?) collector with long experience in South America, who came to Costa Rica in 1878 in search of Oncidium splendidum A. Rich. ex Duch. Boyle gives us an account of his travels from one part of the country to the other, during five years in which Oversluys went from North to South and East to West, but "not a peon could be found in the woods to recognize the sketch which Mr. Sander had given him" (Boyle, 1901: 243). "It may grow in heaven or in other places, but it is not to be found in Costa Rica" (Oversluys in a letter to Sander, in Swinson, 1970: 101. "Irritated and despairing as time went by, but not permitted to abandon the search, the collector found diversion now and again in a gallop through the neighboring States. And once he pushed as far as Guatemala" (Boyle, 1901: 37). Here Boyle relates the story of how Oversluys attempted, in vain, to collect a large number of Cattleya bowringiana from the roof of a church in a small Indian village, having to flee for his life after being discovered. Some years later, he returned to Guatemala. "[In March 1889] Oversluys was writing from Guatemala that he was sending off sixty-nine cases of orchids, including 2,000 plants of Oncidium splendidum (Fig. 42A). This must have delighted Sander's heart, for this was the plant he had dispatched him to find several years earlier" (Swinson, 1970: 101). Oversluys was an interesting character, and a confirmed pessimist, and like Micholitz he was never afraid to tell Sander what he thought of him. So he writes: "I duly received your letter of the 6th May and am very astonished at the order you give me to collect in this month Lycaste skinneri. You know as well as I do that it is in full growth from April till the end of October and cannot be collected in these months.' In his quaint English, he also gave some vivid pictures of the problems besetting the orchid hunter: ' 3 rd September, 1890, Cobán. I got the plants, many in fine pieces, but now have the painful trouble of how I can 
get them away from Cobán. At the moment I do not know, as the season of heavy rainfall has settled in. I sit here before the question. How can I begin to pack and get them all away? I had the plants cleaned, arranged under the trees in the shade, I will see they are given much care and try to keep them in good condition... and when carts go down I will see they are packed and sent away by and by. Mules are not to be had in Cobán and from Guatemala drivers will not come up. All transport here is done on men's backs" (in a letter to Sander, in Swinson, A., 1970, op. cit., p. 102).

At the end of 1894, only three travelers remained with Sander: L. Forget, the German William Micholitz, and Oversluys, who was almost at the end of his career. In April 1895 he was again in Cobán, where he had been sent to collect once more Lycaste skinneri: "I have already 5,000 plants and think within ten days more I'll have at least 8,000 . There is one thing that troubles me about your letter of the $25^{\text {th }}$ February, which I got yesterday. That is you hope I will not take up too much money. [...] Will you please explain to me how I should collect up to 10,000 Lycaste in one month, before the season is finished, with seventy-five to hundred pounds? [...]" A few days later: "Oncidium splendidum is getting scarce. I told my men to look out for further spots" (letter to Sander, in Swinson, 1970: 127). After this no further news appear from Oversluys, and what happened to him is unknown. "Probably though, as there is no record of his being killed or dying on the job, he merely left Sander's services or gave up orchid hunting and returned home. His final letters indicate a trend [...]: increasing expenses and the drying up of orchid grounds" (Swinson, 1970: 127).

"Falkenberg perished at Panama..." This statement has been repeated over and over in many orchid histories. However, according to Frederick Sander, who was his employer and should know better, Carl Falkenberg (1850-1880) (Fig. 42B) died at Saint Thomas, one of the Virgin Islands (Sander, 1880). Born in eastern Germany, Falkenberg came in 1878 to Sander's nursery, asking to be sent as a plant collector to South America. Both Sander and Roezl, who was present, advised the young man to stay in Europe, pointing at the extreme difficulties he would have to encounter. But nothing changed his mind and a few weeks later he was on his way. He was immediately successful (Reichenbach, 1880: 232) and became soon famous for his eye for rare plants and for his skill in packing them, most of which arrived in Europe in perfect condition. His main collecting ground was Colombia and he was probably on his way home when he passed through Panama, in the first months of 1880. If he died in Panama, delirious with yellow fever (Munera, 2005), or went already ill onboard his ship, dying shortly afterwards in Saint Thomas, is a mystery which will probably remain unsolved. Reichenbach named in his honor Restrepia falkenbergii, which Falkenberg had collected in Colombia, but perhaps his most important discovery was Vriesea falkenbergii W. Bull, a bromeliad which grows in Panama and won a First Class Medal at an exhibit in Kensington, a few months before Falkenberg's death.

We know little about another of Sander's collectors, Friedrich Christian Bartholomaeus (1854-1904), who apparently collected in South America between 1882 and 1892, but also in Panama and in Mexico. From this last country we know of his collection of Laelia anceps var. schroederiana (Bock, 2008).

Friedrich Carl Lehmann (1850-1903) went to South America as a collector for the firm of Hugh Low \& Co. of London. Around 1878 he settled in Popayán, Colombia, where he held the position of consul of Germany until his death. He made very important discoveries of new Colombian species, especially in the genus Masdevallia, which was his favorite. In 1883 he was described as "the most important traveler and collector in the United States of Colombia and neighboring territories of our time" (Anonymous, 1883: 287). Reichenbach published his Orchidaceae F. C. Lehmannianae ecuadorenses (Reichenbach, 1878) where he described Lehmann's collections in Ecuador from the year 1876. At the beginning of the 1880s he traveled to Costa Rica, Panama and Guatemala. Although the exact dates of his journey are not known, the first clearly dated collection from our area is Physurus lehmannii Schltr. (Lehmann 1757, Costa Rica), in 1882. In a short time he discovered numerous new Central American species, described later by Schlechter and Kränzlin: Dichaea suaveolens Kraenzl. (Lehmann 1642, Guatemala), Maxillaria stenostele Schltr. (Lehmann 1236, Costa Rica), Maxillaria turialbae Schltr. (Lehmann 1098, Costa Rica), Physurus lehmannii Schltr. (Lehmann 1757, Costa Rica), Physurus nigrescens Schltr. (Lehmann 
s.n., Costa Rica), Pleurothallis jalapensis (Kraenzl.) Luer (Lehmann 1296, Guatemala), Stenorrhynchus guatemalensis Schltr. (Lehmann s.n., Guatemala), Spiranthes cobanensis Schltr. (Lehmann s.n., Guatemala), Stelis crescentiicola Schltr. (Lehmann 4540, Panama).

An important number of the orchids collected by Lehmann were described by F. Kränzlin under the title of Orchidaceae Lehmannianae in Guatemala, Costarica, Columbia et Ecuador collectae, quas determinavit et descripsit (Kraenzlin, 1899). Lehmann liked to say: "I attribute my good health, and even my life mainly to two things: First, when in danger either from natives or, worse still, from lawless white men, I never produce a revolver or other weapon... Secondly, I never drink water without first boiling it" (Taylor, 1975: 177). His precautions did not help him. He shared the fate of many other explorers of these regions and died by drowning in 1903, while trying to cross the Timbiquí River with the intention of visiting a gold mine in which he had interests. His herbarium and his drawings were sold by his widow to the herbarium at Kew. Lehmann was also an excellent illustrator. Many of the pencil drawings with which he accompanied his herbarium specimens are preserved at the herbarium at Kew. He also wrote the notes for the geographical description in the monograph of Masdevallia edited by the Marquis de Lothian and illustrated by Miss Woolward (Woolward, 1896), where his extensive knowledge about the plants in their native habitats can be appreciated (Fig. 42D). A new genus was dedicated to him by Kraenzlin: Neolehmannia.

The botanist Gustav Niederlein (1858-1924) was the last German collector to visit Central America in the XIX century. Niederlein came very young to Argentina, where since 1878 he explored the flora of the province of Córdoba. He settled in Argentina and in 1893 was appointed as commissioner of that country to the Universal Exposition of Chicago. He stayed for several years in the United States and in 1896 acquired, for several museums of Philadelphia, the collection of objects of natural history that Costa Rica had sent to the Exhibition of Chicago. For this reason he was named consul of Costa Rica in Philadelphia (González 1921: 223-224). In 1897 he traveled through Central America and visited the Central American Exposition in Guatemala. In
Honduras he collected Pleurothallis niederleinii Schltr. (Niederlein s.n.) and Spiranthes hondurensis Schltr. (Niederlein s.n.). While in Philadelphia he published several works about Central America: The State of Nicaragua, The Republic of Guatemala and The Republic of Costa Rica (1898).

"[...] the world - the whole way of life of which orchids had been such a typical expression - came to an abrupt end on the outbreak of the First World War in 1914 and even prior to this there were signs of change. The despoiling of the world's tropical wild places could not continue unchecked and the trade in the export of tropical species never recovered" (Black, 1973: 56).

\section{Hemsley and the 'Biologia Centrali-Americana'.} Godman y Salvin were mentioned in the last chapter. They made the decision to "produce a work which should review every form of life in a definite part of the world". This work, the Biologia Centrali-Americana, resulted from the contributions of the best specialists in its time in all fields of natural history, and is perhaps the most monumental biological publication of all times. It contains 1677 illustrations, of which more than 900 are in color. It was published at irregular intervals during 36 years (1879 a 1915). The preface is by Sir J. D. Hooker. This work, written over a century ago, is an obligatory reference for anybody wishing to study Central America's biodiversity.

William Botting Hemsley (1843-1924) (Fig. 42D), in charge of the Botany for this work, published the first list of the orchids of Central America and Mexico (Hemsley, 1879), a condensed version of the one that would later appear in volume III (1883) of the botany of the Biologia Centrali-Americana. During the same period he published the description of an important number of botanical species in his Diagnoses plantarum novarum vel minus cognitarum Mexicanarum et Centrali-Americanarum (Hemsley, 1878-1880). Hemsley became in 1899 Keeper of the Herbarium and Librarian of Kew, in which positions he served until his retirement in 1908 (Jackson, 1924: 77). The final version of Hemsley's Orchideae can be found in volume III of the Botany and is dated November 1883. It lists 927 different species distributed in 100 genera, indicating their localities of collection in Mexico and Central America. 109 plants are illustrated, but no orchids. 
Thus, despite all efforts by collectors and botanists, at the end of the XIX century less then one third of all presently known Central American orchid species had been identified. In volume IV of March 1887, Hemsley wrote a historical sketch of the botanical exploration of the region. Restrepia hemsleyana (today a synonym of $R$. antennifera Kunth) was dedicated to him by Rudolf Schlechter. In recognition of his services Hemsley was elected an Honorary Member of the Natural History Society of Mexico (Anonymous, 1925: 22). He passed away in Broadstairs, on October 7, 1924.

\section{The Botanical Station in Belize (1892-1921).} Originally the nation's capital, popular lore has Belize City built on a landfill of mahogany chips and rum bottles, both ingredients generated by the British pirates of the XVIII century (Miller \& Miller, 2002: 70). At the beginning of the XIX century, all Guatemalan trade passed through this port. The common route left the Central American capital and had to cross the fearful 'Montaña del Mico' (= 'Mountain of the Monkey') to arrive finally at the port of Izabal. Here the merchandise was embarked on small vessels that sailed along the coastline to Belize, from where British ships would carry it, via Jamaica, on to England. During the 1840s trade with the United States began to flourish, again through Belize (Fig. 43A).

Skinner used this route for many years to ship his orchids to England and it was not until 1855, when the Panama railroad was inaugurated, that Belize lost its importance for Central American trade to Europe and the United States.

An Account of the British Settlement of Honduras, written by Captain George Henderson of the $44^{\text {th }}$ Regiment of the British Army, contains the earliest detailed description of the natural history of Belize (Henderson, 1811). Interspersed with descriptions of the economic activity of the colony (mostly based on timber) are numerous references to the conspicuous or useful plants, often referred to by scientific and common name" (Balick et al., 2000: 5). But Henderson did not mention any orchids. In fact, few orchids from Belize were known during the XIX century. Leaving aside the types of Polystachya clavata Lindl. (1842) and Brassavola digbyana Lindl., already mentioned, there is only the publication by Reichenbach, in 1876, of Epidendrum (= Encyclia) belizense.

Stephens, the great North American traveler, wrote that in 1841 the territory of Belize counted no more than 6,000 inhabitants, of which 4,000 were Negroes employed by the wood cutters (slavery had been abolished in 1839). "Government House is built on a beautiful site at the end of the city, with a park that extends to the water and is adorned with coconut palms" (Stephens, 1841: 15). It was on the site of the Governor's kitchen garden where years later the Botanic Station of Belize (also known as Botanic Center) was built, the first botanical garden to be established in Central America.

A botanical research facility was formally proposed by J. D. Hooker, Director of Kew from 1865 to 1885 , and adopted by the Secretary of State for Colonies in 1884 (Balick et al., 2000: 6). It was given a one-acre terrain behind Government House and began functioning in 1892. A postcard dated 1904 depicts an orderly garden with well-maintained paths. George Samuel Jenman (1845-1902) assisted in the establishment of the Botanical Station. Jenman, who had arrived in Guyana in 1879 as Government botanist and Superintendent of Gardens to work on the enhancement project of the Georgetown area, came to Belize in October of 1890. During that time he made a collection of Arpophyllum giganteum Lindl. (Jenman s.n., Belize). George S. Jenman was an important figure in the botanical exploration of Guyana, and collected the types of two new orchid species for that region: Cattleya jenmanii Rolfe (Jenman s.n.), and Sievekingia jenmanii Rchb.f. (Jenman s.n.). Robert A. Rolfe named in his honor a new genus of Orchidaceae: Jenmania, with a single species, Jenmania elata (J. Zahlbr.) Rolfe. The Jenman Herbarium of the University of Guyana was named in his honor.

James McNair was the first superintendent (1892 to 1896), followed by Eugene Campbell (1896 to 1920), who presided over the station for most of its brief existence. On several occasions Campbell wrote of his dissatisfaction with the size and location of the station at Belize City and proposed creating a permanent station in the Stann Creek District, probably where the Forestry Department now has a field station. Charles Hummel assumed control over the station in 1821, after which the project was abandoned (Balick et al., 2000: 6). 
TABLE 7. Species of Orchidaceae that grew in the Botanical Station of Belize in 1899 (Balick et al., 2000: 14) .

\begin{tabular}{|c|c|}
\hline Botanical name as it appears in the original list & Botanical name today \\
\hline Brassavola nodosa & Brassavola nodosa (L.) Lindl. \\
\hline Brassavola grandiflora & Brassavola grandiflora Lindl. \\
\hline Brassavola cuspidata & Brassavola cuspidata Hook. \\
\hline Brassia maculata & Brassia maculata $\mathrm{R} . \mathrm{Br}$. \\
\hline Epidendrum cochleatum & Prosthechea cochleata (L.) W.E. Higgins \\
\hline Epidendrum radicans & Epidendrum radicans Pavón ex Lindl. \\
\hline Epidendrum acicularis & Encyclia bractescens (Lindl.) Hoehne \\
\hline Epidendrum bootheri & Prosthechea boothiana (Lindl.) W. E. Higgins \\
\hline Epidendrum stamfordianum & Epidendrum stamfordianum Batem. \\
\hline Epidendrum atropurpureum & Encyclia cordigera (Kunth) Dressler \\
\hline Epidendrum alatum & Encyclia alata (Batem.) Schltr. \\
\hline Epidendrum alatum majus & Encyclia alata (Batem.) Schltr. var. majus \\
\hline Galeandra Batemanii & Galeandra batemanii Rolfe \\
\hline Catasetum tridentatum & Catasetum tridentatum Hook. \\
\hline Cattleya skinneri & Guarianthe skinneri (Batem.) Dressler \& N. H. Williams \\
\hline Cattleya Gaskelliana & Cattleya gaskelliana B. S. Wms. \\
\hline Oncidium luridum & Trichocentrum luridum (Lindl.) M.W. Chase \& N. H. Williams \\
\hline Oncidium papilio & Psychopsis papilio (Lindl.) H. G. Jones \\
\hline Dendrobium moschatum & Dendrobium moschatum Sw. \\
\hline Dendrobium fimbriatum & Dendrobium fimbriatum Hook. \\
\hline Stanhopea grandiflora & Stanhopea grandiflora (Lodd.) Lindl. \\
\hline Schomburgkia undulata & Schomburgkia undulata Lindl. \\
\hline Vanilla planifolia & Vanilla planifolia Andr. \\
\hline
\end{tabular}

Eugene Campbell made several collections of Orchidaceae during his time as superintendent of the Botanical Station: Brassavola cucullata (L.) R. Br. (Campbell s.n.), Cycnoches ventricosum Bateman (Campbell s.n.), Encyclia alata (Batem.) Schltr. (Campbell s.n.), Epidendrum ciliare L. (Campbell s.n.), and Rhyncholaelia dygbiana (Benth.) Schltr. (Campbell 104).

A list of the plants in cultivation at the Botanic Station in 1899 can be found in the archives of Kew, sent by C. A. Moloney, Governor and Commander-inChief. This list is apparently the earliest list of plants collected or introduced into the colony, and it shows 23 species of orchids. [Table 7] Among the species mentioned in this list is Prosthechea cochleata, the "Black Orchid", Belize's National Flower. There is another list in the archives of Kew, indicating that there was an herbarium at the Botanic Centre. The whereabouts of these collections are however unknown" (Balick et al., 2000: 15).

\section{Central American orchids in England at the end of} the XIX century ${ }^{32}$. Among the most important English establishments dedicated to the import and growing of orchids were the house of B.S. \& H. Williams (Victoria and Paradise Nurseries) and that of James Veitch in Chelsea, of which we talked in the previous chapter. The first one produced the famous The OrchidGrower's Manual, (first edition 1852), and the second a catalogue, the Hortus Veitchii, published in 1906.

The Williams were great promoters of British orchidomania, particularly Benjamin who began, in 1851 and at the suggestion of John Lindley, a divulgative series entitled Orchids for the Millions, published in The Gardeners' Chronicle. From this series the famous Orchid Album was derived, a monthly publication with illustrations by John Fitch.

The Orchid-Grower's Manual contains 796 pages, with 310 line illustrations. We are following here the $7^{\text {th }}$ (last) edition, published in 1894, which lists a total of 3,359 taxa of which the authors consider that 2,650

32 This chapter follows mostly Gómez, 2007. 

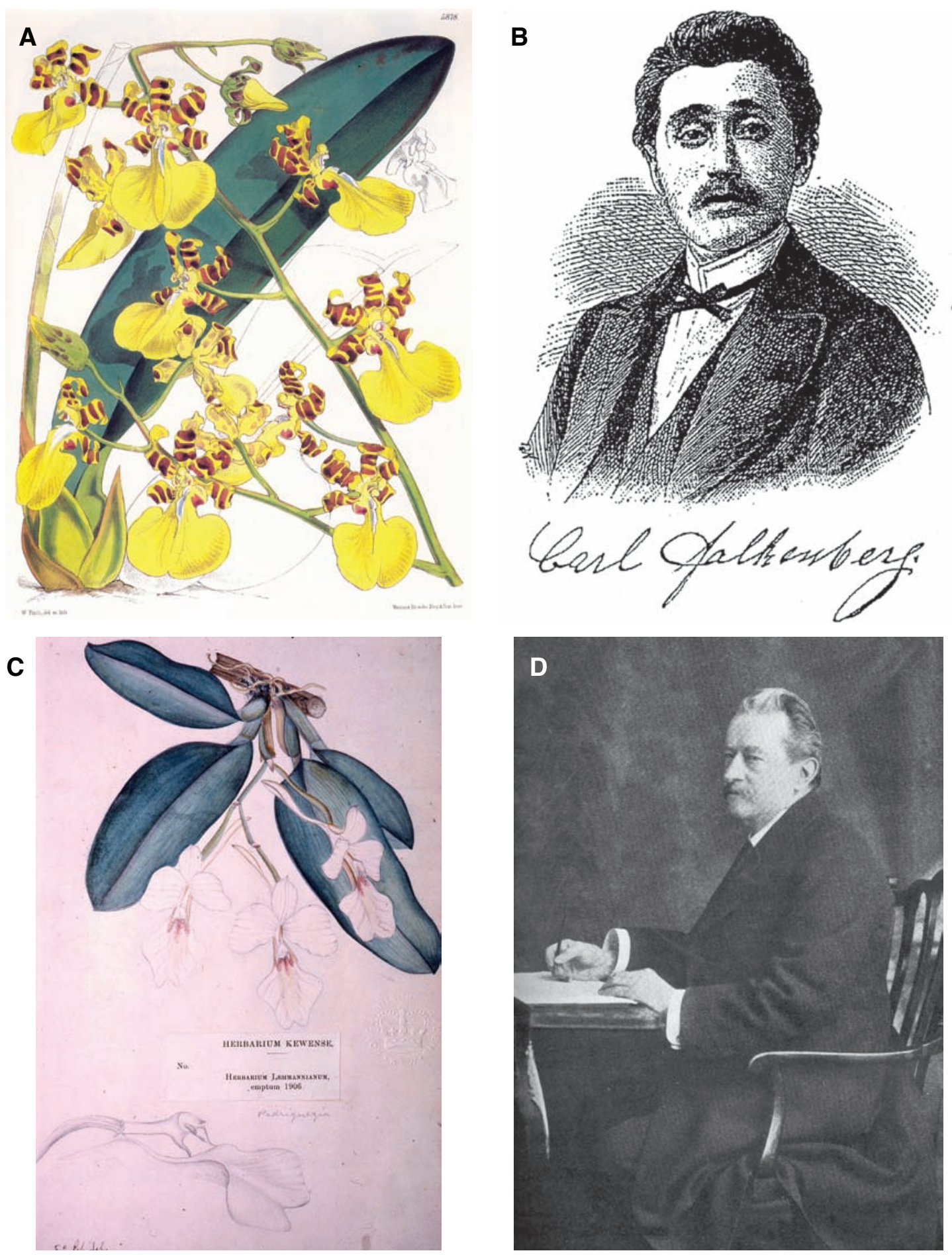

FiguRe 42. A - Oncidium splendidum A. Rich ex Duchartre. Curtis's Botanical Magazine, plate 5878. B — Carl Falkenberg (1850-1880). In Sander, 1880: 173. C - Illustration of a species of Rodriguezia by F.C. Lehmann. Courtesy of Rudolf Jenny. D - William Botting Hemsley (1843-1924) Courtesy of Rudolf Jenny and the Royal Botanic Gardens at Kew. 

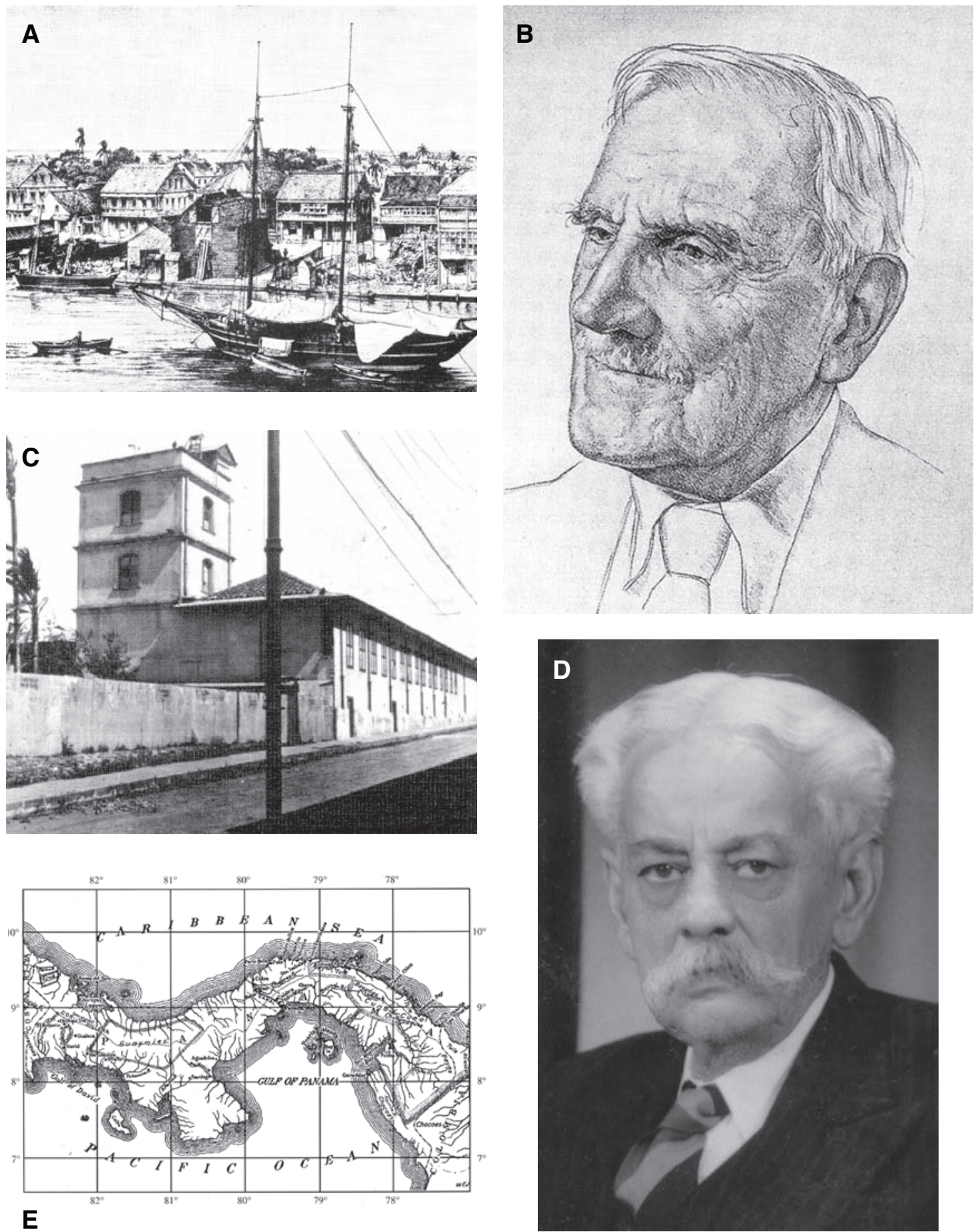

$\mathbf{E}$

Figure 43. A - Old Belize City. Front cover of Thomson, 2004. B - Henri Francois Pittier (1857-1950). Portrait by Sava Botzaris (Caracas, 1942) in the frontispiece of Häsler \& Baumann, 2000. C - Meteorological Institute, San José. Courtesy of L.D. Gómez. D - Anastasio Alfaro (1865-1951). Courtesy of his grandson, Rodrigo van der Laat Alfaro. E — Map of Panama by Pittier. In Heckadon-Moreno, 1998: 113. 
are valid names. From the valid names, 163 correspond to Central American species.

The Hortus was a limited edition for private distribution, beautifully bound and that used a watercolor paper of heavy weight. The edition was obviously prepared for a select and wealthy list of clients, and was divided into five sections or chapters. Part one is a history of the Veitch family and of the creation of the company and its evolution. Part two is dedicated to short biographies, with interesting notes, of the travelers and collectors sponsored by Veitch $\&$ Son, which amount to a total of 22 , between 1840 and 1905. Section three is destined to biographical data about the main horticulturists, most of them dedicated to the hybridization of orchids. Section four is the one that is of interest to us. It bears the title of Orchid Species. A list of the principal orchid species introduced by Messrs. Veitch. The list mentions 219 species with its author, origin, often curious notes and a very brief description. Of these species 23 are Central American.

Because of the different selection criteria, in Veitch for a wealthy clientele and in Williams based on a populist attitude of orchids for the millions, any analysis or numerical comparison would be useless. It is clear, however, that Central American orchids played a very important role in the early development of professional and amateur orchidology.

\section{Costa Rica: the National Museum and the 'Instituto Físico-Geográfico'}

"The interest for natural sciences is proportional to the spiritual development of the nations"

Karl Wercklé

(In a letter to Dr. N. L. Britton,1901)

Botanical exploration of Central America was in the hand of foreigners during the entire century. "Costa Rica attracted more botanists and plant hunters than the neighboring countries. Although the list by Lanjouw (1945) is not complete, it shows that in the XIX century Costa Rica was visited by 10 scientists or collectors, Nicaragua by 5, Panama by 6 and Guatemala by 7 . This preference can be explained because the publications by the foreigners who visited the country after Independence were very favorable to Costa Rica" (León, 2002: 154). However, the last two decades of the century showed for the first time the development of a 'national science' in Central America. In Costa Rica, "as part of an educational reform aimed at secularizing public education, the government of president Bernardo Soto (1885-1889) hired a group of European academics to staff the two new public high schools in the capital, San José (The 'Liceo de Costa Rica' for boys and the 'Colegio Superior de Señoritas' for girls, both founded under Soto's administration). The arrival of these academics marks the beginning of a small scientific renaissance in Costa Rica. Two institutions symbolize this renaissance: the Instituto Físico-Geográfico (IFG) (='Physical-Geographical Institute') and the National Museum, founded in 1887 and 1889 , respectively."

Among the hired teachers were Pablo Biolley (1861-1908) and Henri Francois Pittier (1857-1950) (Fig. 43B), who arrived in 1886 and 1887. Pittier lived in Costa Rica until 1905 and during these years conducted a systematic exploration of the Costa Rican flora that had no equal in his time in any country of tropical America. From these efforts resulted the publication of the Primitiae Florae Costaricensis, the first flora of Costa Rica, a work that unfortunately was not concluded ${ }^{33}$. The Primitiae was published in conjunction with a Belgian colleague, Téophile Alexis Durand (1855-1912) and appeared in three volumes and 12 fascicles, published from 1891 to 1905 (Grayum et al., 2004: 12). According to Paul C. Standley, in his introduction to the Flora of Costa Rica: "Henri Pittier has undoubtedly gained a more intimate knowledge of the natural history and especially the botany of Central America and northwestern South America than has ever been possessed by any single person" (Standley, 1937:49).

The combined labors of Pittier, Alfaro, Tonduz, Biolley, Wercklé, Brenes and the Brade brothers resulted in the formation of the National Herbarium that counted initially with more than 5,000 species. Citing Standley again, in 1903 the National Herbarium "was unequaled below the Río Grande del Norte" (Standley, 1937:50). Pittier's other goal was the creation of a map of Costa Rica. Cartographic work began in 1891 and

\footnotetext{
${ }^{33}$ Only the first two volumes of the Primitiae Flora Costaricensis were published. Pittier expected Schlechter to write the fascicle on the orchids, which never happened.
} 
went on until the publication of the map in 1904. A great part of the botanical exploration of the country followed the routes of the mapping expeditions. "Perhaps the most important result of these efforts were his travels to the southern region of the country, almost unexplored at that time" (Castro Castro \& Colombo Víquez, 1989: 114). Although hired to teach at secondary schools, Pittier had more ambitious ideas and immediately after his arrival in Costa Rica started to fight for the formation of a meteorological observatory and an institute. The Meteorological Institute (Fig. 43C) was founded in April 1888, under the direction of Pittier.

"Shortly before Pittier arrived, a young Costa Rican named Anastasio Alfaro (1865-1951) (Fig. 43D) had persuaded the government to organize a national museum. Alfaro had overcome the obstacles facing any student of the sciences in Costa Rica (such as the lack of mentors and facilities) to become an essentially selftaught naturalist and archaeologist and a collaborator with several important U.S. scientists. Minister of Development Cleto González Víquez... had dispatched Alfaro on a mission to the United States to learn about the latest techniques in museum organization. On Alfaro's return in May 1887, the government funded the creation of the Museo Nacional and named Alfaro its first director" (Eakin, 1999: 127). Pittier, who had been in Costa Rica for only two months, was named on the Board of Directors of the Museum, together with Pablo Biolley and José Cástulo Zeledón.

With the publication of a list with the known plants of Costa Rica, an interest awoke in professor Alfaro for the study of botany which lasted to his last days (Alfaro, 1888). Alfaro wrote, a few months after the inauguration of the Museo Nacional: "And in no way can this void [the absence of studies about the vegetation of the country] be filled if not with the formation of collections in which day by day the material accumulates that is indispensable to achieve a correct scientific knowledge" (cited in Viales \& Clare, 2006: 12). He paid great attention to orchids, ferns, mosses and cacti, making important discoveries in each of these groups. The list published by Alfaro was an extract of the botanical part of the Biologia Centrali-Americana of W. B. Hemsley (from the Botanic Gardens at Kew), edited by the British naturalists Godman and Salvin some years earlier.
Unfortunately, Alfaro and Pittier, the two major scientific entrepreneurs in the small country, never could agree on how to organize their operations. In 1889 the government consolidated the Museum and the Meteorological Institute into one center, the 'Instituto Físico-Geográfico Nacional de Costa Rica’. This was a temporary triumph for Pittier, who was named director. However, integration only lasted a few months and the Museum was again separated from the rest of the Institute. In 1890, Pittier became part of the staff of the recently founded School of Agriculture, where he as in charge of the practical instruction. In 1898, a severe economic crisis led the government to cut expenses and to eliminate entire agencies and departments. One of them was the Instituto Físico-Geográfico. "The small staff of the Museum took custodial care of the collections that Pittier and Alfaro had amassed over the previous decade (especially the Herbario Nacional)" (Eakin, 1999: 133). But Pittier continued fighting. In 1901 he apparently persuaded politicians of the practical benefits that his research in economic botany could bring. The government, at a time when the nation was feeling the worst consequences of coffee monoculture, revived the IFG, which absorbed the Museo Nacional as one of its divisions. However, constant intrigues and lack of funds led to Pittier's final falling out with the government. In 1905 he left the country to work in the United States and on to a long and distinguished career in Venezuela until his death in 1950. With his departure, the Instituto lost its creator and engine, and Costa Rica a dynamic and prolific scientist.

"Within a month, Anastasio Alfaro became the new director of the Instituto. The government assigned an assistant to care for the collections in each of the three sections: the Museo, the observatory, and the herbarium. In effect, the Instituto was reduced to a collection of plants and an assistant who made daily meteorological observations. In 1910 the observatory became an official division of the Museo Nacional, and the Instituto essentially ceased to exist in name as well as fact" (Eakin, 1999: 135-136). Alfaro was not really a botanist and even less an orchidologist. In Pittier's opinion, "Alfaro is hardly a collector, botanically speaking... He is before everything a native lawyer and his work in natural history is of the amateur kind" (Häsler \& Baumann, 2000: 145). Notwithstanding, 
he collected many specimens that were described as new species of Orchidaceae, and many others were dedicated to him: Epidendrum alfaroi Ames \& Schweinf. (A. Alfaro, 174), Epidendrum anastasioi E. Hágsater, Maxillaria alfaroi Ames \& Schweinf. (A. Alfaro, 284), Stelis alfaroi Ames \& Schweinf. (A. Alfaro, s.n.). Lankester and Ames had great respect of him: "Some interesting, and baffling specimens have just arrived from your hacienda. Also a few good things from Alfaro..." (Letter from Ames to Lankester, Jan. 23rd, 1926).

From the beginning, Pittier had considered the botanical exploration of Costa Rica as one of the main activities of the Instituto Físico-Geográfico. "Pittier began sampling plants for the herbarium in the vicinity of San José and eighteen months later had collected 2,500 specimens" (León, 2002: 147). Pittier collected in Costa Rica until his departure in 1905. During the same year he visited and collected in Guatemala. Between 1906 and 1907 he was again briefly in Guatemala, El Salvador, Honduras and Costa Rica. Finally, he traveled to Panama employed by the United States Department and collected there intensively between 1910 and 1917. In 1908, with the support of the United States government, he published his important work Plantas Usuales de Costa Rica (Pittier, 1908).

In Costa Rica, Pittier had researched in geology, meteorology, ethnology, botany, cartography and archeology. In Panama, without forgetting his other interests, he dedicated himself almost exclusively to the botany. From 1910 to 1912 he took part in the 'Biological Exploration of Panama' of the Smithsonian Institution, collecting over 4.000 specimens (Fig. 43E). "With these words he described his first encounter with the astounding biodiversity of the isthmus: 'I set everything up Friday night and yesterday, December 31, 1910, I began collecting. From the beginning I convinced myself of the impossibility of finishing the task alone, confronted with a profusion of plants flowering in these first months of the summer or dry season.' [...] He asked to be assisted by William R. Maxon, from the New York Botanical Garden, to study the mosses, cacti, orchids and bromeliads. [...] He had tried to get Adolphe Tonduz as his assistant, but his countryman had already departed from Costa Rica to Guatemala (Heckadon-Moreno, 1998: 81)." Upon returning to Washington, he set himself to analyze and publish the scientific information of his vast collection of plants from Panama, many of them new to science. In this research he was assisted by a young botanist who would later become famous in the history of the botanical exploration of Central America: Paul C. Standley. "Pittier was the driving force behind the decision of [Panamanian] president Porras to establish within the Ministry for Development... the Agricultural Service [...] The 'Estación Experimental de Matías Hernández', the first agricultural research center in Panama, was established in 1916. Pittier was its first director" (Heckadon-Moreno, 1998: 87).

He was always interested in orchids. While working on his Primitiae Flora Costaricensis he sent a great number of specimens to his friend Théophile Durand in Brussels, who passed them on to Schlechter in Berlin for identification. The orchids collected in Panama during his work for the United States government went the same way. "In Panama he had obtained specimens from the collections of David D. Gaillard and Mrs. Harry Harwood Rousseau and had formed, during the botanical exploration of the Smithsonian (together with Maxon) a large collection of orchids in the Canal Zone and Chiriquí" (Standley, 1925: 357-358). Among the latter 18 new species were found. After initial differences (Schlechter during some time refused to return the material sent by Pittier), Pittier worked together with Schlechter until the death of the German scientist in 1925. In 1906, Schlechter dedicated a new genus of Orchidaceae to Pittier: Pittierella (today a synonym of Cryptocentrum).

Among the types of new species discovered by Pittier are: Cranichis pittieri Schltr., Epidendrum cardiophorum Schltr. (Pittier 9519, Costa Rica), Epidendrum henrici Schltr. (Pittier 2176, Costa Rica), Epidendrum insulanum Schltr. (Pittier 16350 Herb. Nac., Costa Rica), Kefersteinia costaricensis Schltr. (Pittier 16058, Costa Rica), Lockhartia pittieri Schltr. (Pittier 3401, Panama), Microstylis (= Malaxis) carpinterae Schltr. (Pittier \& Tonduz 4394 Herb. Nac., Costa Rica), Notylia pittieri Schltr. (Pittier 6850, Costa Rica), Oncidium pittieri Schltr. (Pittier 10310, Costa Rica), Oncidium salvadorense Schltr. (Pittier 5753, El Salvador)., Prosthechea abbreviata (Schltr.) W. E. Higgins (Pittier \& Tonduz s.n., Costa Rica), Sauroglossum nigricans Schltr. (Pittier s.n., 
Costa Rica), Scaphosepalum elasmatopus Schltr. (Pittier 3229, Panama), Scaphosepalum pittieri Schltr. (Pittier 11143, Costa Rica), Stelis chiriquensis Schltr. (Pittier 3228, Panama), Stelis panamensis Schltr. (Pittier 4490, Panama), Stelis perplexa Ames (Pittier 308, Guatemala), and Vanilla pittieri Schltr. (Pittier 6600, Costa Rica). Pittier's orchids are probably in the National Herbarium in Washington" (Häsler \& Baumann, 2000: 206). Pittier moved in 1922 to Venezuela and spent the rest of his life in this country, where he founded the National Park System and died in 1950. The Henri Pittier National Park, located along the Coastal Range in northern Venezuela, was created in 1937 and named in his honor. He returned to Costa Rica for a brief visit in 1938, for the celebration of the $50^{\text {th }}$ anniversary of the 'Colegio Superior de Señoritas'.

Pablo Biolley (1861-1908) formed part of the first group of Swiss teachers hired by the government of Bernardo Soto. Biolley established himself permanently in Costa Rica, obtaining the Costa Rican nationality and marrying a Costa Rican. He died in 1908 at the very young age of forty six. His sister Estela arrived in 1889 and was for many years a teacher at the 'Colegio Superior de Señoritas'. Biolley accompanied Pittier during many of his explorations and was, for a short period (1904) director of the Instituto Físico-Geográfico. Although his main interest was in entomology, he made important contributions to the knowledge of the Costa Rican flora. To him we owe, among others, the discovery of the types of Masdevallia ecaudata Schltr. (Biolley 3127, Costa Rica), Maxillaria biolleyi (Schltr.) L. O. Williams (Biolley 1052, Costa Rica) and Telipogon biolleyi Schltr. (Biolley 1340, Costa Rica).

Shortly after his arrival in Costa Rica in 1887, Pittier ..."obtained from the government the necessary funding for the assignment of a person in charge of the botanical service, for which he chose Adolphe Tonduz (1862-1921) (Fig. 44A), who was assistant at the botanical garden of Lausanne, Switzerland, and arrived in Costa Rica in June of 1889" (León, 2002: 147). "Botanical exploration of Costa Rica was not only closely related with [Tonduz], but depended heavily on him" (Häsler \& Baumann, 2000: 151). However, Pittier was not easily satisfied. In a letter to John H. Barnhart (1915) he wrote: “Adolphe Tonduz has been and is still, a laborious and painstaking collector, responsible for almost $60 \%$ of the 20,000 specimens of the Instituto Físico-Geográfico, ... but his collections contain again and again the same species and comparatively few new things." Tonduz' collecting excursions were best described by himself in his Herborisations au Costa Rica (1895). Pittier and Tonduz collected at times together, discovering several new species, among them Epidendrum abbreviatum Schltr. (Pittier \& Tonduz s.n. - Costa Rica). After Pittier left Costa Rica, Tonduz went to work for the United Fruit Company. In 1908 he held again the position of curator of the National Herbarium and in 1911 he went to Guatemala, where during a short period he occupied a position in the department of phytopathology of the Direction of Agriculture. He died in Guatemala, a victim of alcoholism, in December 1921. With sadness we read Lankester's words to Ames: "Poor Tonduz was also hopeless in this regard [alcoholism] and the possession of a small sum of money was immediately fatal. I kept him here 10 months during our previous stay in Cóncavas (Lankester's farm near Cartago) and had him 'dry' the whole time, clothed [and] fed... he became a new man, but a salaried position in Guatemala broke him completely (in a letter to Ames, 1922)."

Costa Rica owes to Tonduz the discovery of many new orchid species, most of them described by Schlechter (1923). Worthy of mention, among others, are the following: Bulbophyllum vinosum Schltr. (Tonduz 13734, Costa Rica), Camaridium dendrobioides Schltr. (Tonduz 17620 Herb. Nac., Costa Rica), Epidendrum acrochordonium Schltr. (Tonduz s.n., Costa Rica), Epidendrum majale Schltr. (Tonduz 17620 Herb. Nac., Costa Rica), Masdevallia tonduzii Woolward (Tonduz s.n., Costa Rica), Microstylis microtoides Schltr. (Tonduz s.n., Costa Rica), Ornithocephalus tonduzii Schltr., (Tonduz s.n., Costa Rica), Pleurothallis tonduzii Schltr. (Tonduz 17646 Herb. Nac., Costa Rica), Stelis aemula Schltr. (Tonduz $17632 b$ Herb. Nac., Costa Rica), Stelis conmixta Schltr. (Tonduz 17632a Herb. Nac., Costa Rica), and Stelis sarcodantha Schltr. (Tonduz 17632 Herb. Nac., Costa Rica). From his time in Guatemala we know several collections of Orchidaceae: Scaphyglottis crurigera (Bateman ex Lindl.) Ames \& Correll (Tonduz 409, Guatemala), and Osmoglossum convallarioides 
Schltr. (Tonduz 523, Guatemala) and at least one new type: Pleurothallis pacayana Schltr. (Tonduz 413 Guatemala). The illustrious trio of Swiss naturalists is remembered in Costa Rica's geography: the district of Biolley and the village of Santa María de Pittier, in the province of Puntarenas, and the peaks of Tonduz and Pittier, in the mountain range of Talamanca, remind us of those initial glorious years when the first national scientific institutions were born.

\section{Other collectors at the end of the XIX century}

\section{"Normal people do not collect plants"}

Franco Pupulin, 2004 (pers. comm.)

Ludwig Kienast-Zölly grew orchids in his native Hirslanden (Zurich), Switzerland, and occasionally sent plants to Reichenbach or to Kew for identification, among them Epidendrum kienastii Rchb. f., which was named in his honor. The archives of the Swiss Confederation indicate that Kienast-Zölly was "Consul général honoraire" in Mexico, in the period between 1870 and 1875. He lived, according to Boyle, for many years at Orizaba (Veracruz), "where he collected orchids with enthusiasm for his own delight." Boyle goes on: "an Indian servant gave zealous help, partly, doubtless, for love for the flowers, but partly also for love of the master whose 'bread he had eaten' from childhood [...]."Boyle continues telling us the story of Sobralia kienastiana (which was the pride of KienastZölly's collection for many years), a crazy account of Indian chiefs, Catholic priests, human sacrifice and an orchid laid before the 'Blessed Mother', called 'the Devil's Flower' (Boyle, 1901: 163-169). Other orchid species dedicated to Kienast-Zölly were Oncidium kienastianum Rchb. f., Ponera kienastii Rchb. f. and Trichopilia kienastiana Rchb. f. Kienast-Zölly was a contributor to the Gardeners' Chronicle, where he wrote on Mexican orchids.

Another Swiss, Rudolf Richard Pfau ( -1897), founded in San José, Costa Rica, in the final years of the XIX century, a nursery that sold a great variety of ornamental plants. He also collected native plants for exportation. Through his collections we know that he was also in Panama and Colombia, and at least one of the new species described from plants sent to Europe by Pfau came from Mexico: Vanilla pfaviana Rchb. f. Other species discovered by Pfau were: Epidendrum pfavii Rolfe (Pfau s.n., Costa Rica), Pleurothallis pfavii Rchb.f. (Pfau s.n., Panamá), Sobralia pfavii Schltr. (Pfau s.n., Costa Rica), Telipogon pfavii Schltr. (Pfau 930, Costa Rica), and Trichocentrum pfavii Rchb.f. (Pfau 60, Panamá). Pfau wrote the first work published in Costa Rica about the orchids of this country: New, Rare and Beautiful Orchids of Costa Rica (ca. 1895), of greater interest for horticulture than for botany. In this work, Pfau gives advice as to how to grow and pack orchids for exportation, and includes a list of the species he had for sale in his nursery (Fig. 44B). But Pfau's voice is also one of the first to address the rising concern about the destruction of our nature, when he describes one of our most beautiful orchids: "Cattleya skinneri, some ten years ago, was a common Orchid all over Central America; but in the last few years it has been exported by shiploads; and to-day - at least in Costa Rica - it has almost become rare" (Pfau, 1895: 6). Pfau also wrote several articles about Central America and its orchids, such as The climate of Central America, Orchid culture (1883), Notes on the fertilization of Orchids in the Tropics (1894) and Costa Rica and its Orchids (1896). As did Roezl and Wallis, Pfau sold his plants in Europe through the agency of Eduard Ortgies in Zurich. Many of his specimens are part of the Reichenbach herbarium in Vienna, often accompanied with beautiful illustrations by Pfau (Fig. 44C).

"By the turn of the century, U.S. scientists had replaced Europeans as the Instituto's principal collaborators. The first was apparently Sereno Watson (1826-1892), who had made important botanical explorations in California and went for a short period of time to Guatemala (1885), but had to stop due to illness. There he made several collections of Orchidaceae, among them the type of Pleurothallis (=Trichosalpinx) blaisdelli S. Watson (Watson, s.n., Guatemala), named in honor of his travel companion, F. E. Blaisdell and Notylia guatemalensis Schltr. (Watson, s.n., Guatemala). Watson, curator of the Gray Herbarium at Harvard until his death, was possibly who interested Donnell Smith in the flora of Central America" (Williams, 1972: 203).

George Franklin Gaumer (1850-1929), president of the Natural History Society of Kansas University, established himself in 1884 in Yucatán, where he resided until his death. He was also briefly in Honduras and Guatemala (1885). Gaumer stands out for having 
been the first to collect in the island of Cozumel (18851886), collections that were described by Hemsley (Hemsley, 1887b). Besides the types of Triphora yucatanensis Ames (Gaumer 1008, Yucatán) and Epidendrum yucatanense Schltr. (Gaumer 588), we find numerous other orchids among the specimens collected by Gaumer, such as: Ionopsis utricularioides (Sw.) Lindl. (Gaumer 23305), Rhyncholaelia digbyana (Lindl.) Schltr. (Gaumer 23357), Leochilus scriptus (Scheidw.) Rchb. f. (Gaumer 23358), Harrisella porrecta (Rchb. f.) Fawc. \& Rendle (Gaumer 23359), Oncidium sphacelatum Lindl. (Gaumer 23664), Lophiaris oerstedii (Rchb. f.) R. Jiménez \& Carnevali (Gaumer 23813), Encyclia belizensis (Rchb. f.) Schltr. (Gaumer 23916), and Psygmorchis pusilla (L.) Dodson \& Dressler (Gaumer s.n.).

The Czech Eduard Klaboch (1852-1915), a nephew of Benedikt Roezl, collected mostly in Ecuador but was in Guatemala in 1885, from where we know of his collections of Epidendrum elegans (Knowles \& Westc.) Rchb. f. and Spiranthes acaulis (J. E. Sm.) Cogn. He was killed in Mexico.

John Hinckley Hart (1847-1911), an Englishman who worked for the Department of Botany in Jamaica, visited Bocas del Toro (Panama) between November and December of 1885 , where he collected extensively in a region that had been scarcely explored. We know of only one specimen of Orchidaceae among his collections: Brassavola nodosa (L.) Lindl. (Hart 111).

Edward Shuttleworth (1829-1909) (Fig. 44D) collected in 1873 for William Bull in Colombia. He collected several new species of Masdevallia and was successful to bring them back to England alive. After his return from South America he founded, together with John Carder (-1908), another of Bull's collectors, his own company under the name of Shuttleworth and Carder. Like Shuttleworth, Carder was a gardener by training and like him, worked for William Bull's nursery in Clapton, England, and collected plants in South America. There are no accounts of Shuttleworth or Carder traveling to Costa Rica, but the database of the Missouri Botanical Garden lists two species as collected by them in this country: Masdevallia astuta Rchb. f. (Costa Rica, Shuttleworth \& Carder, s.n.) and Masdevallia demissa Rchb. f. (Costa Rica: collected by Mr. Carder, and grown by Messrs. Shuttleworth $\&$ Carder). Several orchid species were dedicated to the two partners: Stanhopea shuttleworthii Rchb. f., Restrepia shuttleworthi Rolfe, Masdevallia shuttleworthi Rchb. f., Masdevallia carderi Rchb. f. and Oncidium carderi Rchb. f. (Jenny, 2003: 36-37).

In the meantime, Carl Thieme collected in Honduras between 1887 and 1890 (Fig. 45A). He sent his specimens to Donnell Smith for identification. "The collections of Dr. Thieme, now in the U. S. National Herbarium, are the only important ones I know of from Honduras before 1900. No Honduran, as far as I know, became interested in the native flora until the 1940's." (Williams, L.O., 1972). To him we owe Pelexia hondurensis Ames (C. Thieme 785) and Physurus vaginatus Hook. (C. Thieme 681).

"Shortly after his death, his collections of insects and his manuscripts, which must be very important..., were sent to Germany... (Pérez Estrada, 1952: 153)." A man with a strange character, Thieme never admitted women in his house. "Although a real man of science, the rarities of his social life were not those of a scientist but those of a human being who carries in his soul an emotional disturbance and a grief that only death can bring to an end. Through vague accounts of his fellow countrymen it was known that he had been married and that his wife, in whom he had set all of his confidence, failed her duties in such a manner that the affronted husband was brought to the brink of madness" (Pérez Estrada, 1952: 152).

Reverend Heinrich Theophile Heyde and his nephew Ernesto Lux collected extensively in Guatemala between 1889 and 1894. Amongst their over 6,000 collections there are hundreds of orchids, mentioned in Orchids of Guatemala and Belize by Ames \& Correll (1985). Oakes Ames described several new species among their specimens: Habenaria macroceratitis Willdenow var. brevicalcarata Ames (Heyde \& Lux 6383, 1894), Odontoglossum majale (Heyde \& Lux 3502, 1892), Sarcoglottis zamororae Ames (Heyde \& Lux 4625, 1893), and Sarcoglottis orbiculata Ames (Heyde \& Lux 3504, 1892).

John Donnell Smith (1829-1928) (Fig. 45B), a retired captain of the Confederate Army and botanist at the Johns Hopkins University worked with Anastasio Alfaro and Pittier and made two trips to Costa Rica in the 1890s" (Eakin, 1999: 141). Although he had no special interest in orchids, his work as a botanist was important and he collaborated with Pittier in his 
Primitiae Flora Costaricensis, for which he wrote the fascicles on the orders of Polypetalae and Gamopetalae of the second volume. In Costa Rica he collected Oncidium ascendens Lindl. in 1894 (J.D. Smith 4592). $\mathrm{He}$ also worked in Guatemala, where he made important contributions, "not only through his own work, but because he financed other scientists such as Tuerckheim, Father E. T. Heyde and his nephew Ernesto Lux, W. C. Shannon, Juan J. Cooper [in Costa Rica], Carl Thieme [in Honduras] and others (Maldonado Polo, 1996: 135)." He distributed many specimens of the Central American flora among the main herbariums of the United States and it may have been through him that Ames made his first contacts with the orchids of the region (Williams, 1972: 201).

Among the collections of Donnell-Smith in Guatemala we find the following orchids: Epidendrum arbuscula Lindl. (J. D. Smith 2635), Epidendrum atropurpureum Willd. (J. D. Smith 2225), Epidendrum imatophyllum Lindl. (J. D. Smith 1584), and Nageliella purpurea (Lindl.) L. O. Wms. (J. D. Smith 2643). Donnell Smith was appointed an Honorary Associate of the U.S. National Herbarium in 1905, a position that he retained until his death in 1928. "Captain Smith published no fewer than 39 contributions to the Central American flora, all in the Botanical Gazette..." (Williams, 1972: 201). Of great importance for the knowledge of the flora of Guatemala where his Enumeratio Plantarum Guatemalensium (Donnell-Smith, 1889-1907). His herbarium of Central American material, with over 100,000 specimens, is preserved at the Smithsonian Institution. Louis O. Williams called him 'the Father of Botany in Central America.' He is commemorated, among others, with the moss genus Donnellia and Donnelsmithia (Apiaceae).

William Cummings Shannon (1851-1905), an American surgeon, collected specimens of Orchidaceae in Guatemala during 1891 and 1892 (Barkeria skinneri, Govenia bella, Osmoglossum pulchellum) and went later on to Honduras and El Salvador (1893). He botanized sparingly in the Guanacaste region of Costa Rica during the same year (Grayum et al., 2004: 17).

Under contract with Anastasio Alfaro, Juan J. Cooper (1843-1911) collected plants and birds in Costa Rica for local and foreign institutions. He was employed by the National Museum and appointed interim director in 1896. For several years he send herbarium specimens of dicotiledons and monocotiledons to John Donell Smith from the neighborhood of Cartago and the Atlantic region. Several new species of orchids were described from specimens collected by Cooper: Epidendrum selaginella Schltr. (Cooper 523), Physosiphon cooperi Ames (Cooper 481), Pleurothallis cooperi Schltr. (Cooper s.n.), and Stelis cooperi Schltr. (Cooper 562). Charles Leonard Smith (1866-1923) and Bohumil Shimek (1861-1937), American botanists specialized in ferns, collected several species of Orchidaceae in Nicaragua in 1893 (Leochilus labiatus and Psygmorchis pusilla).

Another American, Charles Fuller Baker (18721927) brought together a large collection of more than 2,500 samples in the Nicaraguan Pacific region beginning in 1895. A few orchids, collected in León and Granada in 1903, can be found among his specimens (Encyclia gravida and Laelia rubescens).

Before turning the century, special mention must be made of U. S. biologist Edward William Nelson (18551934), who made extensive botanical explorations throughout Mexico together with Edward A. Goldman from 1892-1896. An autodidact, Nelson had participated in the famous Death Valley Expedition from 1890-91, in the newly created Division of Ornithology and Mammalogy of the Bureau of Biological Survey. He worked in every state in Mexico and on all coastal islands, as well as in northern Guatemala. In Chiapas, well within our area of study, he discovered an important number of new orchid species, most of which were later described by Ames. Worthy to mention are the following: Bletia nelsonii Ames (Nelson 913), Erythrodes chicharrasensis Ames (Nelson 3808), Erythrodes mexicana (= vesicifera) Ames (Nelson 3777), Malaxis macrantha Ames (Nelson 3124), Microstylis (= Malaxis) nelsonii Ames (Nelson 4782), and Pleurothallis nelsonii Ames (Nelson 3763).

Charles Frederick Millspaugh (1854-1923), the first Curator of Botany of the Field Museum in Chicago, selected Peru as the Museum's center of floristic research. He looked however also to Central America. On board of the famous yacht 'Utowana' he traveled through the Caribbean in 1898-99, touching land in Cozumel Island and Yucatan, where he collected, among others, Spiranthes orchioides (Sw.) Rchb. f. (Millspaugh 1616, Yucatan), Brassavola cordata 
Lindl. (Millspaugh 1797, Island of Cozumel) and Oncidium cebolleta (Jacq.) Sw. (Millspaugh 1617, Pisté, Yucatan). He described his collections in 1900. Millspaugh was at that time already famous for his work American Medicinal Plants (1887).

\section{Other travelers in Central America (II): 1870-1900.}

We continue with accounts of travels through Central America, written by persons who came for various motives (never primarily as botanists).

In 1874, the German Helmuth Polakowsky (18471917) came to Costa Rica, hired to teach lessons of Chemistry, Physics, Botany, Mineralogy and Zoology at the National Institute of San José. Polakowsky traveled throughout the country and left various detailed accounts, among which "La República de Costa Rica" stands out (Polakowsky, 1940). In addition to his comments about the Vanilla that Carmiol had in his house, he writes in his books about the common plants of Costa Rica: "The largest number of parasites belong to the family of the orchids and Bromeliads. Among the first I mention the genus Epidendrum (there are many species), Lelia [sic], Oncidium, Trichopilae [sic], Odontoglossum and the rarest Catleyas [sic] (such as Dowiana and Stanhopea [sic]). In no private garden have I seen these plants growing in large numbers; at the most one or two hang in the corridors of the 'haciendas' growing on a piece of wood, and nobody knows or chooses the species with particularly beautiful flowers" (Polakowsky, 1940). Specimens of Epidendrum ciliare L., Epidendrum paniculatum Ruiz \& Pav. and Stelis sp. were collected by Polakowsky in 1875 (Polakowsky 382) and are today in the orchid collection of the Natural History Museum in London.

The British traveler John W. Boddam-Whetham (1843-?) arrived at the Guatemalan port of San José in October of 1875. From the capital he made 'some interesting trips, east and west', and continued then to Cobán in Alta Verapaz. He went on over the mountains to the region of Petén and finally by canoe on the Usumacinta River to the island of Carmen in the Gulf of Mexico.

Two years later Boddam-Whetham published an account of his travels with the title of Across Central America (Boddam-Whetham, 1877). In his narrative, orchids are frequently mentioned. Between Guatemala and Esquipulas, he finds "many of the large trees [...] adorned with a most beautiful rose-coloured orchid -I think a Lycaste Skinneri- whose large flowers gave a wonderful glow to the grey trunk and green leaves among which they were perched. It appeared to me that they had been transplanted, as they were seldom far from the ground, and generally on trees overhanging a native hut; to an Indian an orchid is a sacred flower, and as none of the trees in that locality, except those near houses, were similarly decorated, it is not improbable that superstition rather than a love of gardening accounted for their appearance." And he complains: "Guatemala is rich in these lovely plants -the élite of the floral kingdom- and every day I had cause to regret my limited knowledge of botany; and after I had left the country, when showing what I had collected and describing what I had not, I often found I had taken the chaff and left the grain". Once in Esquipulas, he describes the procession of the pilgrims who came to the village to worship the Holy Christ: "They were all decked with garlands of the tillandsia, and in their hands they carried brilliant orchids. Some of the different companies carried spikes of the beautiful rose-coloured orchid I have before mentioned; others carried a species of Epidendrum whose rich orange flowers contrasted with the creamy blossoms of an Odontoglot which seemed a great favourite. Panicles of one of the commonest orchids in Guatemala -an Oncidium- were used in great profusion, and their long drooping stalks covered with small yellow flowers looked very graceful". Riding back to Guatemala he "entered a beautiful country [which] was a region of orchids, and each species seemed to have its favourite locality. In one spot a Stanhopea flourished, the flowers of this kind being a bright yellow, barred with chocolate. In another, the trees bore no other species, except one whose flowers were shaped like a China rose and of a delicate pink hue. I gathered twenty of these blossoms off one tree, and I recalled to mind that once or twice in London I had paid five shillings for a single specimen". He continued and crossed the border to Honduras, wanting to inspect the ruins of Copán. "The forest was damp and hot, and for that reason a wild garden of ferns, orchids, and creepers..."

Some weeks later, in the first days of 1876 , he rides from Guatemala to Cobán. Close to this city, amidst a terrible down-pour, he crosses a river and finds a place that "in fine weather must be a perfect Paradise 

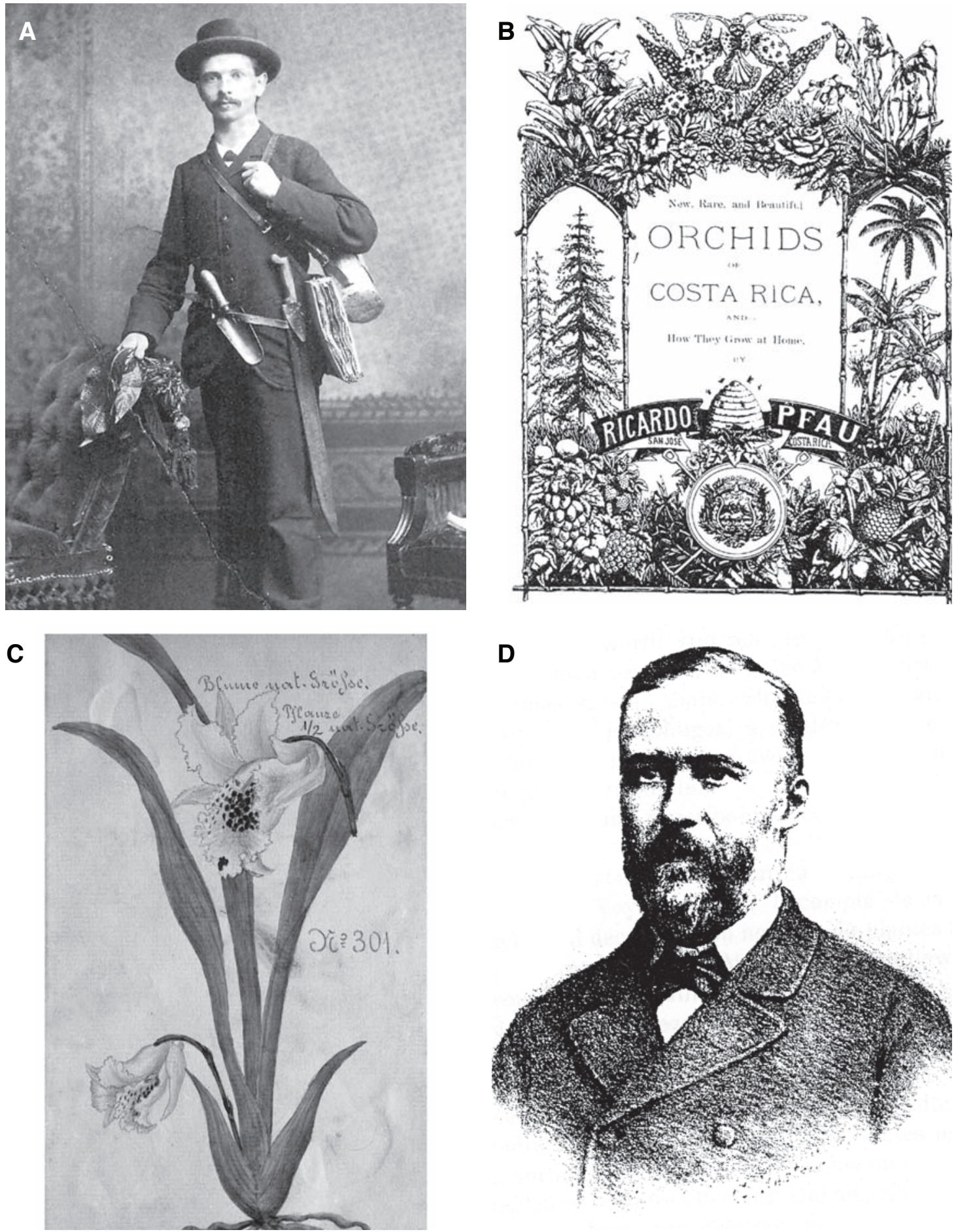

Figure 44. A — Adolphe Tonduz (1862-1921). Courtesy of L.D. Gómez. B — Front cover of Pfau's book and advertisement of his nurseries. C - Chondroscaphe bicolor (Rolfe) Dressler. Illustration by R. Pfau. Courtesy of F. Pupulin. D — Edward Shuttleworth (1829-1909). Anonymous, 1889b: 1. 

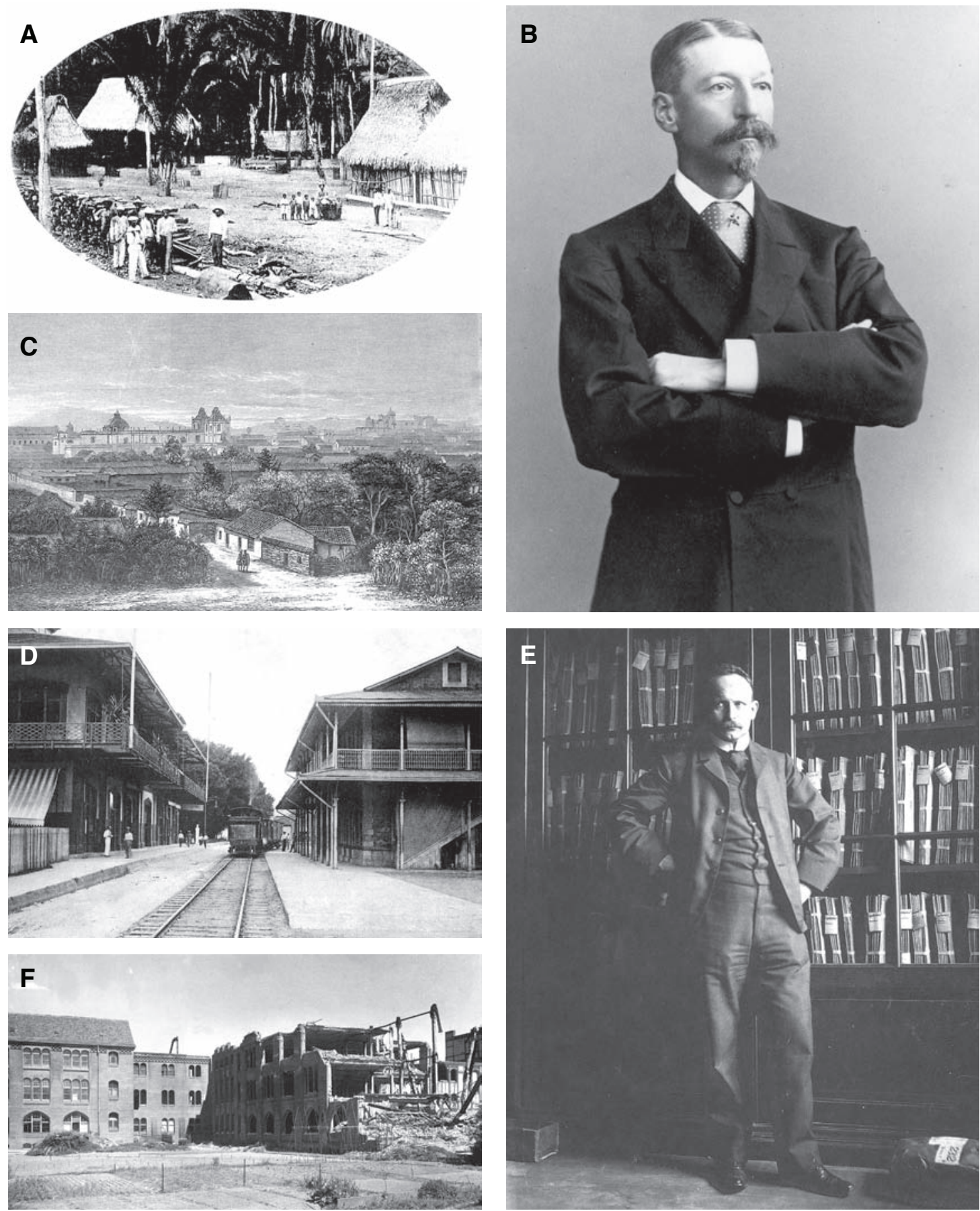

Figure 45. A - San Pedro Sula at the time of Thieme's collections. In Escoto, 2002: 28. B — John Donnell Smith (1829-1928). Courtesy of Jaime García. C - The city of Guatemala. In Boddam-Whetham, 1877, frontispiece. D — United Fruit Co. Lodge and Station in Port Limón, ca. 1915. Photograph by Manuel Gómez Miralles in Leiva Coto, 2004: 83. E — Rudolf Schlechter (1872-1925), in the Herbarium of the Botanical Museum inBerlin, 1909. F — The Herbarium in Berlin, after its destruction in March, 1943. (E-F, Courtesy of Dr. N. Kilian, Archives BGBM Berlin-Dahlem). 
[...] The branches which arched the deep stream on our right were loaded with orchids and parasites, over whose blossoms a few humming birds hovered as if in defiance of the rain...” (Fig. 45C). After Cobán, he crosses the mountains and begins the descend to the Atlantic regions. "The scenery is splendidly tropical; vines and orchids festoon the trees, from which you are saluted by the merry chatter of the parrots..." And two leagues later he arrives at a shrine dedicated to Our Lady of Candelaria, where the offerings, among them orchids, were very numerous (Boddam-Whetham, 1877: 150, 151, 167, 172, 186, 261-262). Already on his way home, in Petén, near the village of Tenosique, he found Peristeria elata Hook. "Here for the first time I saw the curious Holy Ghost orchid -Espíritu Santoso called on account of the yellow dove-like form that stands in the centre of the white globular flower". And in the same area: "One portion of the wood glowed so brilliantly with a crimson flush that I went to see the cause. It proved to be a number of splendid orchids whose flowers graduated in colour from a pale pink to a bright spotted crimson, the inner cup being pink and white. The blossoms grew on a long spike, one of which I measured, being over five feet in length, and having on it more than one hundred flowers. Afterwards I saw many trees laden with them, but all near Tenosique and none on the other side of the river" (Boddam-Whetham, 1877: 311).

Armando Reclus (1843-1927), an officer in the French Navy, traveled to Panama on two occasions, during the years of 1876 to 1878 , recognizing and surveying possible routes for a future interoceanic canal. In 1878 the Colombian government finally granted a French company the right to build a canal across the isthmus. Napoleon Bonaparte Wyse, Armando Reclus and Pedro J. Sosssa presented the plans for the famous project and founded the Universal Company of the Interoceanic Canal. A description of the travels by Reclus was published in Madrid (Reclus, 1972). We find in it some interesting references. Describing the merchandises that were offered to the travelers in the railroad station of Gatún, Reclus writes: "They also offer a plant from the Orchid family (Peristeria elata), the Holy Ghost flower, which grows in great numbers in the neighborhood, and is very rare further away, as it seems; on the corolla of this flower, deliciously scented and of a color white as wax, the stamen and pistils form a small group that resembles a tiny dove variegated with red". Months later, already in the region of Darién, he describes 'espavé' trees (Anacardium excelsum): "Their short, wide and curved trunk, [...] can almost be described as disappearing under the stems of thousands of orchids..." (Reclus, 1972: 50, 182).

The British Mary Lester traveled in 1881 through Honduras, riding from Amapala, on the Pacific Coast, all the way to San Pedro Sula, where she expected to find employ as a teacher. She marveled about the forest: “... we went into a labyrinth, going in and out, where the soil was firmer, free from the extended, uncovered roots of the trees, and from the garlands of parasite plants that fell from above..." (Lester, 1971: 196).

Carl Bovallius (1847-1917) descended from a family from Northern Sweden. His father, Robert Bovallius, was the Royal Librarian in Stockholm. Carl studied at the University of Upsala, where he became a professor in Biology. In 1881 he asked for a leave of absence and traveled to Central America. He visited Panama (February to July, 1882), Costa Rica (July to October, 1882) and Nicaragua (October, 1882 to April, $1883)$, returning to Europe in 1883 . The observations made during his journey were the base for Viaje por Centroamérica (1881-1883), published in 1887 in Upsala and translated later into Spanish in 1977. In his work he writes about a trip to the Atlantic region of Costa Rica, in the company of Julian Carmiol and Anton Huebsch, a botanist from Bohemia who had made the trip mainly "to collect and study orchids". From the Hacienda Caño Seco, near Siquirres, where they stayed for several weeks, Bovallius and Huebsch continued to the region of Talamanca, in the company of Costa Rican Bishop Bernard August Thiel. Jerónimo Fernández, the priest who acted as the chronicler of the expedition, tells us about the indian village of San José Cabécar, where Huebsch found "an orchid unknown to science" (Bovallius, 1977: 125). Huebsch, a collector for Sander in St. Albans, traveled also in Ecuador and Colombia, where he discovered three new species: Maxillaria huebschii Rchb. f., Oncidium huebschii Rchb. f. and Masdevallia huebschiana Kraenzl. In Costa Rica he collected the type specimen of Masdevallia flaveola Rchb. f. In the type protologue we read: "discovered by Hübsch for Mr. F. Sander, who has just imported a stock of it". From the same 
year (1884) is his collection of another new species, Masdevallia anchorifera Rchb. f. (Hübsch s.n.; Costa Rica, without locality). Bovallius tells us about his experiences in the Costa Rican rainforest, and about his encounter with "the almost soporific aroma of Vanilla ... so strong that it almost produced indisposition". Sometime later, he traveled from San Juan del Norte to the Lake of Nicaragua on the San Juan River, and described in his journal the beauty that he encountered: "As the sun rose we climbed again on the steamer and never tired to admire the majestic landscape around us. Heliconias with white stems could be seen in great numbers, which made a showy contrast to the dark green, luxuriant vegetation in the background. Species of ficus with thick, brilliant leaves, passion flowers with large white and red flowers, [...] leafy bromeliads, and orchids with colors from purple velvet to the most delicate waxy yellow, made up a decoration to the green walls so brilliant and strong that any description will seem pale against it” (Bovallius, 1977: 171, 207).

\section{The New Empire}

"Company no heart"

Popular saying in the Costa Rican Atlantic regions

The introduction of bananas in Central America led to the colonization of the Atlantic region and to the consolidation of the influence of the United States on the political and economical life of the young republics. "Banana plantations began during the decade of 1870, with shipments from the coast of Honduras that were sold in New Orleans.... The United Fruit Company was founded in 1899. Together with the Cuyamel Fruit Company (with which it merged in 1929) and the Standard Fruit and Steamship Company, it monopolized the banana activities in the whole Central American area and the Caribbean" (Pérez Brignoli, 2000: 126-127) (Fig. 45D). The dominance of the United States increased after the SpanishAmerican War (1898), during which Spain lost, besides the Philippine Islands, Cuba and Puerto Rico, her last possessions in America. Cuba became a protectorate and Puerto Rico is presently an "Associated State" of the United States.

\section{The 'Big Stick' policy}

"Speak softly and carry a big stick, and you will go far."

African proverb

In 1901 Theodore Roosevelt (1858-1919), who had become a hero during the war against Spain, was elected President of the United States. In 1904 the "Roosevelt Corollary" was added to the Monroe Doctrine, declaring that the United States would exercise force to maintain the stability in the Western Hemisphere. Directed at Europe, the Roosevelt Corollary stated that the United States would consider any interference in the affairs of small, poor Latin American nations a violation of the Monroe Doctrine. The first application of the Corollary occurred in 1905, when Roosevelt sent Marines to the Dominican Republic to manage the country's European debts. This was the beginning of the "Big Stick Policy". A controversial figure, Roosevelt was a great conservationist and naturalist, considered in his time one of the greatest U. S. experts in large American mammals. During his tenure in the White House from 1901 to 1909 , he designated 150 National Forests, the first 51 Federal Bird Reservations, 5 National Parks, the first 18 National Monuments and the first 4 National Game Preserves. Altogether, in the seven-and-one-half years he was in office, he provided federal protection for almost 230 million acres, a land area equivalent to that of all the East coast states from Maine to Florida. In 1916, Roosevelt took part in an expedition to Brazil, exploring the course of the Juruena River. The great orchidologist F. C. Hoehne, who was part of the expeditionary group, found a new species of Catasetum, that was dedicated to Roosevelt: Catasetum rooseveltianum Hoehne.The United States intervened in 1903 in favor of the independence of Panama, obtaining a contract that would allow them to begin, one year later, the construction of the canal, which was inaugurated in 1914. The Canal Zone was ceded in perpetuity to the United States. Liberal revolts against the conservative regime of Adolfo Díaz were on the point of victory when U.S. troops were sent to Nicaragua to help put them down. After the entry of American Marines, the U.S. would essentially rule the country until 1925 through a series of puppet dictators. In 1926, when a Liberal insurrection was started by Augusto César Sandino (1895-1934), the U.S. 
government hastily landed forces. Dedicated to freeing the country of foreign domination and improving the lot of Nicaraguan peasants, Sandino would fight a war against U.S. Marines and the National Guard for the next eight years. The Marines withdrew in 1933, leaving Anastasio Somoza as commander of the National Guard. In 1937 Somoza, who had been responsible for the murder of Sandino in 1934, was elected president, initiating a dynasty of dictators that would rule the country for the next forty years. The antagonism between the dictatorship and the ideals of Sandino would mark the history of Nicaragua during the rest of the XX Century. "The penetration of foreign capital - especially North American after World War I - complements the already close relations of Central America to international trade... The powerful banana companies, with extensive interests in a vast scope of activities (plantations, railways, shipping lines, communications, etc.) played an increasingly relevant role" (Pérez Brignoli, 2000: 127).

While Europe struggled with the problems and the misery of the postwar years, the establishment of communism and the rapid rise of fascism, the United States consolidated, during the first three decades of the XX century, their new American empire. In the same manner, European explorers and scientists, who had dominated the history of orchids in Central America during the past four centuries, yielded the field to a new generation of U. S. botanists, especially after the deaths of Rolfe in 1921 and of Schlechter in 1925, giving way to what Robert Dressler would coin, years later, "botanical imperialism" (in a letter to E. Greenwood, January 5, 1981).

In Costa Rica, the strong impulse given to the botanical exploration of the country by the 'Instituto Físico Geográfico' and the National Museum in the last years of the XIX century continued until after World War I. It was the only Central American country where a strong group of national scientists and naturalists was formed, working together with foreign residents. In Panama, the impulse came from the construction of the canal, which attracted the interest of institutions such as the Smithsonian and the Missouri Botanical Garden. In northern Mesoamerica, Guatemala, Yucatan, Belize, and to a lesser degree Honduras, were explored in the first years of the XX century by naturalists who followed the archeological exploration of the ancient Mayan cities.

\section{Rudolf Schlechter}

"Without a good memory it is of no use trying to be a botanist; one had better give it up and be a merchant"

Rudolf Schlechter (Reinikka, 1995: 293)

The previous quote is characteristic of the egotistic self-confidence of the great German orchidologist Friedrich Richard Rudolf Schlechter (1872-1925) (Fig. 45E), a man of driving ambition, a great capacity for work and a remarkable memory, of whom it is said that at an early age had set for himself the goal of describing at least one new orchid every day (Reinikka, 1995: 293-294). Schlechter was born in Berlin where he served an apprenticeship as a horticulturist, first in the well-known commercial nursery of F. Bluth, and later in the gardens of the University of Berlin (Loesener, 1926: 912). At nineteen years of age he left Europe on botanical explorations that carried him to Africa, Sumatra, Java, Celebes, Borneo, New Guinea, the Bismarck Archipelago and Australia. Of utmost importance were his explorations of New Guinea (1901-1902 y 1906-1909) where he discovered over 1,100 new species of Orchidaceae, described in his work Die Orchidaceen von Deutsch-NeuGuinea, published in 1914. "Between collecting trips Schlechter continued his visits to London, always stopping in at the herbarium at Kew and the British Museum. He was considered an interesting figure, but being not respectful of persons or things, he was apt to tread on other people's feelings and sensibilities. He was dogmatic in his convictions, a characteristic which did not assist in making him popular; but on the basis of his achievements and experience, he was accorded great respect" (Reinikka, 1925: 294).

Schlechter's work had been preceded, after the death of Reichenbach, by Ernst Hugo Heinrich Pfitzer (18461906). Pfitzer, since 1872 professor and director of the Botanical Garden of Königsberg (Prussia), dedicated himself to the classification of the Orchidaceae and published in 1895 his Beiträge zur Systematik der Orchideen ( $=$ 'Contributions to the Systematics of Orchids'). Of jovial character, Pfitzer was respected all over Europe. It was his untimely death, at only 60 years of age, which really opened the way for Schlechter.

Schlechter described, in his Orchidaceae novae et criticae (1906-1907), for the first time new orchid 
species from Central America, which were specimens collected by von Tuerckheim in Guatemala (which he received from Donnell-Smith) and in Costa Rica by Pittier and others, which were sent to Schlechter by Durand: Cranichis guatemalensis Schltr. (von Tuerckheim 1379), Epidendrum isomerum Schltr. (von Tuerckheim II 167), Physurus tuerckheimii Schltr. (von Tuerckheim 733), Camaridium costaricense Schltr. (Tonduz 12429), Epidendrum selaginella Schltr. (J. Cooper 523), Epidendrum wercklei Schltr. (Wercklé 16419), Lockhartia pittieri Schltr. (Pittier 10592), Pittierella calcarata Schltr. (Tonduz 9682), and Vanilla pittieri Schltr. (Pittier 6600).

Shortly after first describing new Central American orchids comes Schlechter's first contact with Ames. In a letter written from German New Guinea, Schlechter congratulates Ames on his paper on the Orchids of Mount Halcon in the Philippines. After having published in 1914 his studies of the orchids of the Andean countries in South America, Schlechter wrote in 1918 a general recapitulation of the orchids of Central America in his work: Kritische Aufzählung der bisher aus Zentral-Amerika bekanntgewordenen Orchidaceen (= 'Critical enumeration of the orchids that so far are known from Central America') where he enumerates 132 genera of orchids with 1,325 species for Central America and Mexico (about 400 more than those mentioned by Hemsley a quarter of a century earlier). The lack of knowledge about the orchid flora of certain countries is notorious. Schlechter mentions only eight species for Belize, 13 for El Salvador and 18 for Honduras, while he counts 396 and 366 for Costa Rica and Guatemala, 57 for Nicaragua, 117 for Panama and 688 for México. In this work, Schlechter describes also in detail the geography and climate of the Central American regions, analyzing for the first time the phytogeographical distribution of orchids in Central America. In his correspondence with Lankester, Ames wrote sharply about Schlechter's work: "Schlechter's list of Central American orchids is an undigested compilation which bristles with errors" (Letter to Lankester, December 30, 1922).

From 1921 onward Schlechter held the position of curator of the herbarium of the Berlin Botanical Garden, amassing an enormous collection of Orchidaceae. His interest in the orchids of Central America was maintained until his death. In 1919
Schlechter wrote to Alberto M. Brenes and Amparo de Zeledón in Costa Rica, asking them to prepare new collections in the country. Shortly after Rolfe's death in 1921, Charles C. Powell sent him numerous herbarium specimens from Panama, which often proved to be new species. With the material received from Costa Rica and Panama, Schlechter published in 1922 his Orchidaceae Powellianae Panamenses (collections by C. Powell), followed one year later by Additamenta ad Orchideologiam Costaricensem (collections by Brenes, Brade, Tonduz, Wercklé and Acosta).

In 1926, one year after his death, his system for the classification of the Orchidaceae saw the light of day: Das System der Orchidaceen. This system was widely accepted for the next three decades. If we study Schlechter's catalogue of publications, we find that he wrote 233 works about orchids in which he described 177 new genera and 5,592 new species, approx. 14\% of all valid species known today (Senghas, 2002: 4).

Hoehne dedicated to him the genera Schlechterella and Rudolfiella and many other orchidologists honored his name in a great number of species, among which the following can be named: Bifrenaria rudolfii (Hoehne) Carnevali \& G. A. Romero, Dichaea schlechteri J. P. Folsom, Eltroplectris schlechteriana (Porto \& Brade) Pabst, Epidendrum rudolfianum Hoehne, Epidendrum schlechterianum Ames, Erythrodes schlechteriana (Hoehne) Pabst, Habenaria rudolfi-schlechteri Hoehne, Maxillaria rudolfii Hoehne, Maxillaria schlechteri Foldats, Maxillaria schlechteriana J. T. Atwood, Platythelys schlechterana (Hoehne) Garay, Pleurothallis schlechteriana Ames, Prescottia schlechterii Hoehne, Schiedeella schlechteriana Szlach. \& Sheviak, Schomburgkia schlechterana H. G. Jones, and Stelis schlechterana Garay.

Rudolf Schlechter died on November 15, 1925, from a tropical disease that had troubled him since the travels of his youth. His large herbarium, to which the collections of Kraenzlin and Mansfeld (who took his position after his death) were later incorporated, was completely destroyed during an Allied bombardment in March of 1943 (Fig. 45E). Only those specimens that were on loan to other institutions escaped the fire, plus a series of copies that Schlechter had prepared on behalf of Oakes Ames, at that time director of the Botanical Institute of the University of Harvard, in Massachusetts. 
After Schlechter's death, his wife Alexandra continued with this work. Schlechter dedicated to her, a short time before his death, the genus Sobennikkoffia Schltr., from Madagascar (1925) ${ }^{34}$.

Hans Sydow (1879-1946) was a bank employee and amateur botanist, who collected in Africa for the Berlin Museum (ca. 1912). Ames mentioned that he had been sent by Schlechter to Costa Rica in his letters to Charles H. Lankester, but there is no evidence that he ever collected orchids. We know however that Sydow visited Costa Rica through several publications, in which he describes his collections of fungi (which where his specialty), based greatly on collections prepared by Alberto Ml. Brenes, of whom we will talk later.

\section{Oakes Ames}

"I am afraid that my boyish enthusiasm must seem to you inordinately intense, but I take courage in the thought that you have experienced similar enthusiasm among those fluttering things that seem to rival the orchids in beauty or color-patterns. The collector's spirit, whether the hobby centers in plants or animals is specifically the same and the victims of it understand each other."

(Letter from Oakes Ames to

Charles H. Lankester, August 24,1923)

Oakes Ames (1874-1950) (Fig. 46A), son of a cultivated and wealthy family in New England, graduated from Harvard University in 1899 and was named shortly afterwards director of its Botanical Museum. He was Schlechter's main competitor during the last two decades of the life of the great German scientist and at the same time his friend and admirer. During his whole career, Ames maintained a great interest in the Orchidaceae, dedicating his free time completely to the taxonomic study of this family. After Schlechter's death he became the world's foremost authority in orchidology. Married to Blanche Ames, he had in his wife an excellent illustrator whose drawings enriched many of Ames' publications. "Seldom in botanical history have science and art been so happily and fruitfully joined" (Mangelsdorf, 1948: xv).
Although he dedicated himself initially to the orchids of Malaysia, Indonesia and the Philippines, he soon became interested in the species of the American tropics. In 1905 Ames began the publication of Orchidaceae: Illustrations and Studies of the Family Orchidaceae, in seven volumes. It is in volume II (1908) where he described the first species of Central America, all based on specimens distributed by J. Donnell-Smith, collected by William Nelson and Hans von Tuerckheim in Chiapas and Guatemala, or by R. S. Williams in Panama: Epipactis dolabripetala Ames (Nelson 3211 - Chiapas), Malaxis macrantha Ames (Nelson 3124 - Chiapas), Masdevallia tubuliflora Ames (von Tuerckheim 512 - Guatemala). Masdevallia tuerckheimii Ames (von Tuerckheim 464 - Guatemala), Physurus polygonatus Ames (von Tuerckheim 7678 - Guatemala), Physurus purpureus Ames (von Tuerckheim 8000 - Guatemala), Physurus venustulus Ames (von Tuerckheim 8591 - Guatemala), Pleurothallis hastata Ames (von Tuerckheim 501- Guatemala), Pleurothallis repens Ames (von Tuerckheim s.n.- Guatemala), and Stelis williamsii Ames (Williams 970 - Panama). Thus Ames entered into the world the orchids in Central America, only two years after Schlechter described the first orchids from this region.

In one of his fundamental works, Schedulae Orchidianae, published in ten fascicles between 1922 and 1930 with the collaboration of Charles Schweinfurth (who was his disciple and friend for over 35 years), Ames described numerous new species for Central America. Years later, in 1936, Ames published (again with the collaboration of Schweinfurth) The genus Epidendrum in the United States and Middle America, a work in which we find again many new species of our region. Together with Donovan S. Correll he prepared an extensive work on the orchids of Guatemala, that was published in three parts between 1952 and 1956. Finally, in the numerous publications of Paul C. Standley related to the flora of Central America, Ames authored, without exception, the list of orchids for each country.

In 1922 he began his relationship with Charles $\mathrm{H}$. Lankester, an English naturalist who lived in Costa Rica, which bore many fruits and lasted until Ames' death. The first contact with Lankester became a

\footnotetext{
${ }^{34}$ Alexandra Vasilevna Sobennikoff, the daughter of a Russian tea Merchant, had married Schlechter in 1910. They had two daughters, Alexandra and Julia.
} 
reality thanks to Powell, who had met don Carlos some years earlier (Fig. 46B). In his answer to the letter from Powell that is shown above, Ames is delighted to learn that he can count on Lankester's help: "Now that I know from your letter that he has contemplated sending his things to me, this day begins with plenty of sunshine even though heavy clouds obscure the sky" (Letter from Ames to Powell, 6.10.1922). Ames was undoubtedly playing a double game: while he could not severe his relations with Schlechter (the German had too much information that Ames needed desperately), he tried to block Schlechter's access to Powell's and Lankester's materials.

In 1923, Ames paid a brief visit to Central America. He visited Panama, where he met Powell and also Costa Rica, where he made contact with Amparo de Zeledón. Lankester (who could not meet with Ames during his brief stay in the country) wrote to him: "The Zeledóns are old friends of mine; don José has been for nearly 60 years a keen ornithologist. I was delighted to find that you had called on her [doña Amparo] and if she leaves the Schlechter camp may get you a lot of material, tho' it is rather late in the day" (Letter from Lankester to Ames, April 30, 1923). He finally went on to Honduras, where he collected in the neighborhood of Tela and found several new species, among them: Campylocentrum hondurense Ames (Ames II 210), Pelexia callosa Ames (Ames II 259), and Pleurothallis hondurensis Ames (Ames II 201). He passed briefly through Puerto Limón in 1928 and was a last time in Costa Rica in 1932 (Ames-Plimpton, 1979: 353). Curiously, during his various visits, he never could meet Lankester, his life-long friend.

His studies of the orchids of Central America were always overshadowed by his competition with Schlechter and the urgent need to receive new collections, in a tireless effort to surpass the great German in the description of new species. We find numerous expressions of this rivalry in the correspondence of Ames with Lankester, from which we have extracted the following examples: "We must work fast if we hope to keep abreast of the Germans. I was surprised to see how far reaching their efforts have been to secure a monopoly of tropical American species" (Sept. 17, 1922). "If you decide to make specimens for me, please begin as soon as possible. Time is very precious" (October 10, 1922). "I wish we could get out another number of Sched. Orch. based on your work. We might beat Schlechter and give him food for thought" (May 28, 1923). "Standley is in New York to-day. When he arrives in Costa Rica, shower orchids on him. Make it a rule that no orchid goes unpressed" (November 13, 1923). "At this stage of the undertaking, quantity rather than quality is important" (December 3, 1923). He also mocked the German mania of splitting the family of Orchidaceae in more and more genera and species: "As my old teacher, Dr. Farlow, used to tell us, when referring to the modern systematists: 'if they can see a difference, then a new genus is made; if they can imagine a difference, then a new species is described" (Letter from Ames to Lankester, February 6, 1924). But these phrases can give us a wrong picture. In spite of the passionate rivalry, Ames respected and admired Schlechter throughout his life. Let us see other expressions, again in Ames' correspondence with Lankester: "From the South of France, Col. Godfery writes that Schlechter is seriously ill... I have not heard from Schlechter for over four months, and I had begun to fear that he was angry or in some way provoked by some act of mine" (March 23, 1924). "I should not have begun this letter with a reference to myself. I should have expressed to you my deep sorrow at the news that came in this noon from Alexandra Schlechter. Schlechter died early in November. I had known of his illness and on the ninth of December I sent aid to Mrs. Schlechter to meet the heavy burden of a hospital bill. But I had been led to believe that there were hopes for recovery. What a place the old world is. There comes a time when death plays round us like heat lightning. And then it begins to thin the ranks of those we called friends. It is a wonder we are able to carry on" (December 3, 1925).

Another little known aspect of the relationship between both orchidologists is that Ames contributed financially to the publication of part of Schlechter's work on the orchidaceous flora of the Andean countries. After finishing volume II (Colombia), Schlechter ran out of funds for the remaining three volumes. "I was fortunate that Prof. Oakes Ames, in Boston, put at my disposal the means which guaranteed the completion of the printing of this work" (Schlechter, 1922b: v).

In the summer of 1924, Ames agreed to pay some 400 German gold marks as a subsidy to publish Kraenzlin's Monograph of Masdevallia. In return for 
this favor, the Ames Orchid Herbarium now possesses a rather large part of the Kraenzlin Herbarium, especially of the species described by him. Of great importance is Ames' herbarium. "The Ames Orchid Herbarium, which now comprises 65,000 critically determined specimens as well as large numbers of line drawings, tracings, and photographs of type material from the large orchid herbaria of Europe, has become the largest single orchid herbarium in the world [...] Only the Lindley Herbarium at Kew and the Reichenbach Herbarium in Vienna are comparable in scope [...] the Ames Orchid Herbarium has become the centre for most of the taxonomic studies on the orchid flora of the Philippines and of the New World" (Schultes, 1951: 224-225).

Several new genera of Orchidaceae were dedicated to Ames: Amesia A. Nelson \& J. F. Macbr., Amesiella Schlechter ex Garay, Oakes-amesia C. Schweinf. \& P. H. Allen; and many species, among them: Bulbophyllum amesianum J. J. Smith, Dendrobium amesianum Schltr., Epidendrum amesianum Correll, Habenaria amesiana Schltr., Notylia amesii L. B. Sm. \& S. K. Harris, Schiedeella amesiana L. A. Garay, Spiranthes amesiana Schltr., and Vanda amesiana Rchb. f. Loefgrenianthus blanche-amesiae (Lófgren) Hoehne was dedicated to his wife.

Ames' wife Blanche passed away in 1969, at the age of ninety-one. She had gained world recognition as the outstanding botanical illustrator of her time (Anonymous, 1969: 313).

Charles C. Schweinfurth (1890-1970) (Fig. 46C) was Ames' most important assistant and also his great friend during thirty five years. He was hired in 1915 to work in the herbarium to look after the living orchids in Ames's greenhouses. "This new appointment turned out to be one of the rare concurrences of fate when the right man was given the right job at the right time (Botanical Museum Harvard University, 1983: 29).” Although his main interest were the orchids of Peru, about which he published an important work, his contributions to the identification of many Central American species were fundamental. Thus, if in most of the descriptions of new species of the XIX century we read the famous abbreviations of "Lindl.", "Batem.", "La Llave \& Lex.", “A. Rich. \& Gal." and "Rchb. f.", the first decades of the XX century are clearly dominated by
"Schltr.", "Ames" and "Ames \& C. Schweinf." A new genus, Cischweinfia (he signed "C. Schweinf."), was dedicated to Schweinfurth (Fig. 46D), as well as many species: Acoridium schweinfurthianum Ames, Catasetum schweinfurthii D. E. Benn. \& Christenson, Dendrobium schweinfurthianum A. D. Hawkes \& A. H. Heller, Epidendrum schweinfurthianum Correll, Grastidium schweinfurthianum (Hawkes \& Heller) S. Rauschert, Mormolyca schweinfurthiana Garay \& Wirth, Oerstedella schweinfurthiana (Correll) F. Hamer \& Garay, Pleurothallis schweinfurthiana L. O. Williams, Pleurothallis schweinfurthii Garay, Rhynchopera schweinfurthii (Garay) Szlach. \& Margonska, and Sauroglossum schweinfurthianum Garay. As Garay wrote in his friend's obituary: “The world of orchids is today immensely richer because there was a Charles Schweinfurth intimately associated to it..." (Garay, 1971: 12).

\section{Costa Rica: the years of 'doña' Amparo ${ }^{35}$}

"[Doña Amparo] has secured for herself a permanent place of honor in the history of the botanical exploration Costa Rica."

Rudolf Schlechter (1923: 4)

José Cástulo Zeledón, disciple of Alexander von Frantzius, continued managing his establishment (the famous 'Botica Francesa') after Frantzius' returned to Germany in 1869. Inspired by von Frantzius, José C. Zeledón went to work at the Smithsonian Institution in Washington. He returned to his country in the late 1870 s as the first formally trained Costa Rican scientist. Bovallius wrote in 1881: "I used the days which I spent in the central plateau in excursions ... among them some in the company of Dr. José Zeledón, a physician and certainly the most prominent ornithologist of Costa Rica" (Bovallius, 1974). Some years later he married Amparo López-Calleja (1870-1951) (Fig. 47A), who had been born in 1870 in Camagüey, Cuba. Her father, a wealthy landowner of Spanish origin, had fled from Cuba to Costa Rica after the independentist uprisings against Spain, which had increased after 1860. Doña Amparo de Zeledón, as she was respectfully called, supported her husband's scientific activities (Zeledón had become Costa Rica's leading ornithologist) and became herself involved in collecting native plants,

35 'Doña': title given to a lady, equivalent to the English Mrs. but used only before Christian names. 
especially orchids, which she grew in her large garden in San José.

Costa Rica's agricultural economy began to stagnate at the turn of the century, diminishing the government's ability and willingness to support expensive institutions and research projects (McCook, 1999: 119). Contributions of private sponsors were of fundamental importance during this period. Amparo de Zeledón sponsored many of the collecting excursions throughout Costa Rica of the Swiss Adolphe Tonduz (of whom we talked in the last chapter) and the Alsatian Karl Wercklé (1860-1924). During the first two decades of the $20^{\text {th }}$ century, Tonduz and Wercklé were responsible for the collection of over two thirds of the 20,000 specimens in Costa Rica's National Herbarium. In 1919, after receiving a letter from Rudolf Schlechter asking for Costa Rican orchid material, doña Amparo reacted with enthusiasm, arranging for Tonduz to press plants from her orchid garden and sending Wercklé out on new collecting excursions. The results were three shipments of herbarium specimens that were received by Schlechter between 1921 and 1923, and that were described as Orchidaceae Amparoanae in his Additamenta ad Orchideologiam Costaricensem (Schlechter, 1923). Among the specimens received from Amparo de Zeledón, Schlechter found three new genera and 62 new species. Lankester wrote with envy: "No wonder Schlechter had a rich CR collection, he had the whole of the orchids from the National Herbarium!" (In a letter to Ames, November 30, 1923). Schlechter honored doña Amparo with the dedication of a new genus: Amparoa (Fig. 47B) and numerous new species, among them: Cycnoches amparoanum Schltr., Dichaea amparoana Schltr., Epidendrum amparoanum Schltr., Gongora amparoana Schltr., Habenaria amparoana Schltr., Isochilus amparoanus Schltr., Maxillaria amparoana Schltr., Scaphyglottis amparoana (Schltr.) Dressler, Sobralia amparoae Schltr., Stelis amparoana Schltr., and Trigonidium amparoanum Schltr. After her husband's death in 1924, Amparo de Zeledón continued with her scientific interests and formed part, from 1929 to 1932 (together with O. Jiménez, C. Lankester and A. Alfaro) of the Board of Directors of the National Museum. However, she began dedicating her efforts and wealth more and more to religious works, which she continued later in Honduras. She died in Tegucigalpa, the $20^{\text {th }}$ of April of 1951 (Standley, 1952: 68-69). Her importance in the history of Central American orchidology is fundamental, not only because of the new species that were discovered through her efforts, but because she became the center of the Costa Rican scientific world during the first decades of the XX century. Her love for plants was inherited by her niece Herminia LópezCalleja (Fig. 47C).

Karl Wercklé (Fig. 47D) came to Costa Rica for the first time in 1897, the year in which his first orchid collections are dated. He did not come directly from Europe, but emigrated to the United States, where he worked as a horticulturist in the nurseries of John Lewis Childs, in New York. Childs sponsored Wercklé's first journey to Costa Rica, in search of plants and seeds of ornamental value, for acclimatization in the American gardens. As early as 1899 , Childs' commercial catalogue described a plant "collected in the mountains of Costa Rica by Mr. Carlos Wercklé" (Childsia wercklei) (Gómez, 1978: 373. He returned to the United States in 1898 and in 1902 came back to Costa Rica, where he stayed until his death. In an article of 1909 with the title La subregión fitogeográfica costarricense (= 'The Costa Rican phytogeographical subregion'), Wercklé described Costa Rica as "the privileged region of Tropical America", adding that "in truth, it is unlikely that any other country contains a flora containing the same number of species in a territory of the same size." "The cause of this 'great exuberance', argued Wercklé, was Costa Rica's irregular, mountainous geography, that created a great range of atmospheric and climatic conditions in a small area. These diverse climatic conditions, in turn, produced a wide variety of species. The diversity of Costa Rica's plant species was even more than that found in Nicaragua and Panama, Costa Rica's comparatively flat and botanically homogeneous neighbours" (McCook, 1999: 119). Shortly thereafter Wercklé published the first scientific article ever written in Costa Rica about the orchids of this country: Las Orquídeas de Costa Rica (Wercklé, 1913). Wercklé died in 1924 (the same year of the death of José Cástulo Zeledón), a victim of alcoholism. "Doña Amparo de Zeledón... attended to his funeral, burying the friend in the family mausoleum, where he still rests next to ‘don' José Cástulo...” (Gómez, 1978: 366). We remember him in Standley's words: "There is no doubt that Wercklé received a good education, and he was 

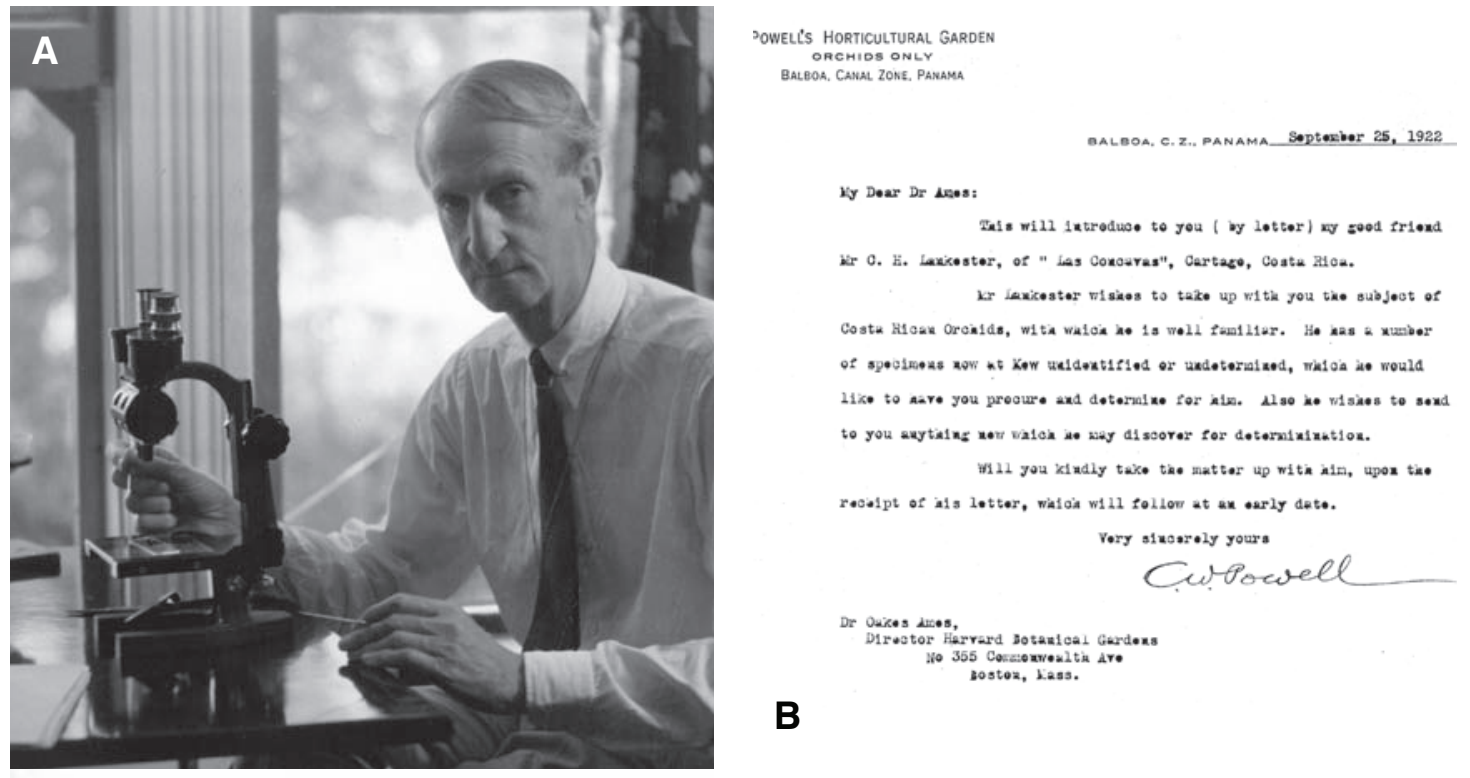

KY Dear Dr Lees:

Tals will 1atroduoe to you ( by lotter) ay good friend

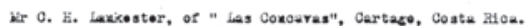

Kr fevicester wishes to teke up with you tike subject of

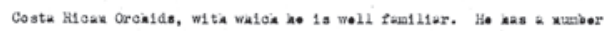

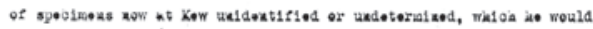

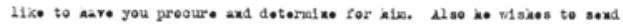

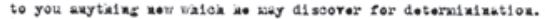
will gou kiadiy teke the matter up with nise, upon tine roosipt of als lotter, wialoin will follow at ax early deto.

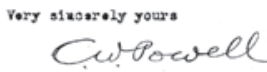 Bostez, Lass.

B
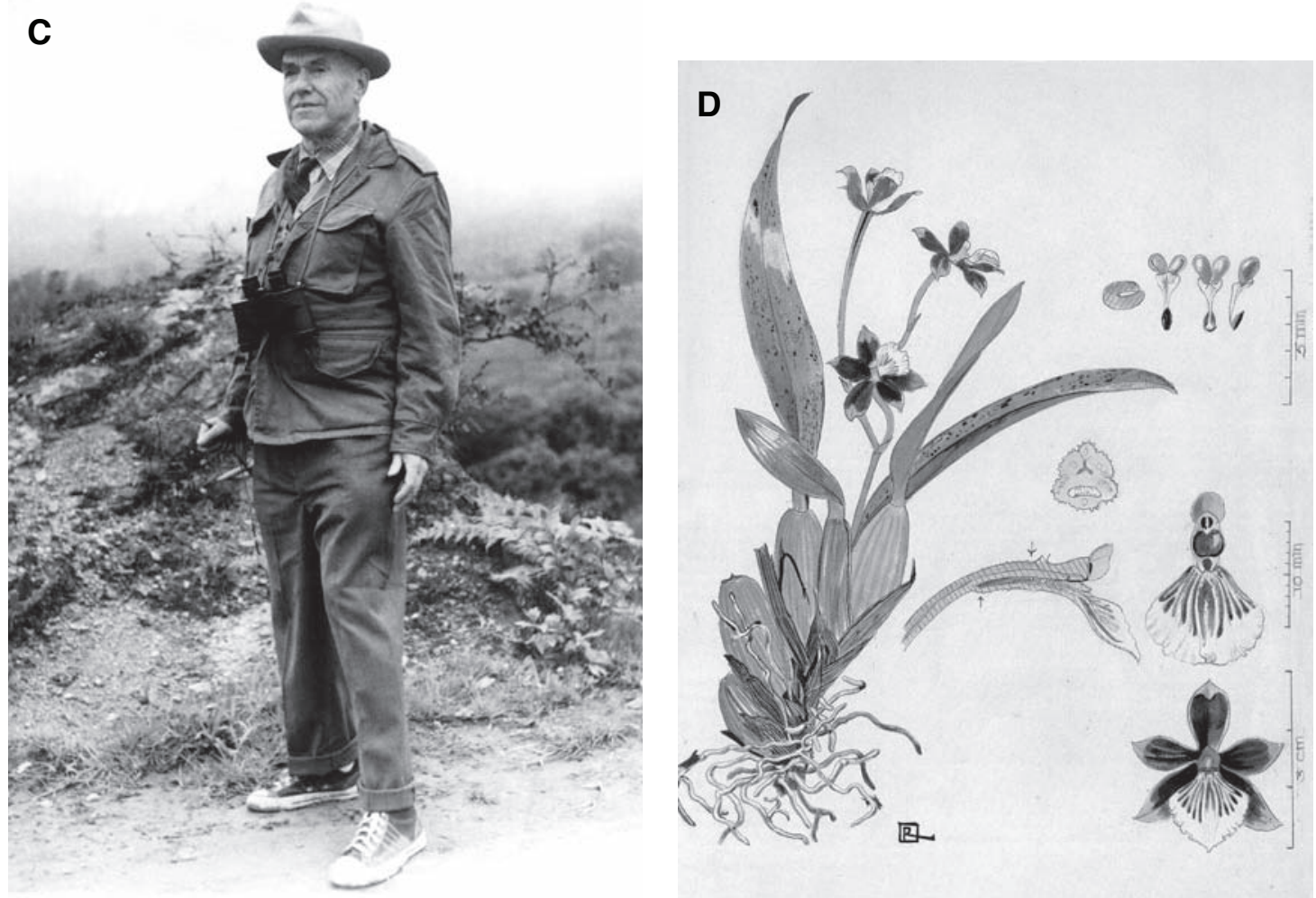

Figure 46. A - Oakes Ames (1874-1950). Courtesy of the Oakes Ames Herbarium, Harvard University. B - Letter from Powell to Ames (Sept. 25, 1922) introducing Charles H. Lankester. C - Charles C. Schweinfurth (1890-1970). Courtesy of the Oakes Ames Herbarium, Harvard University. D - Cischweinfia pusilla (C. Schweinf.) Dressler \& N. Williams. Watercolor by Rafael L. Rodríguez. Courtesy of the University of Costa Rica. 

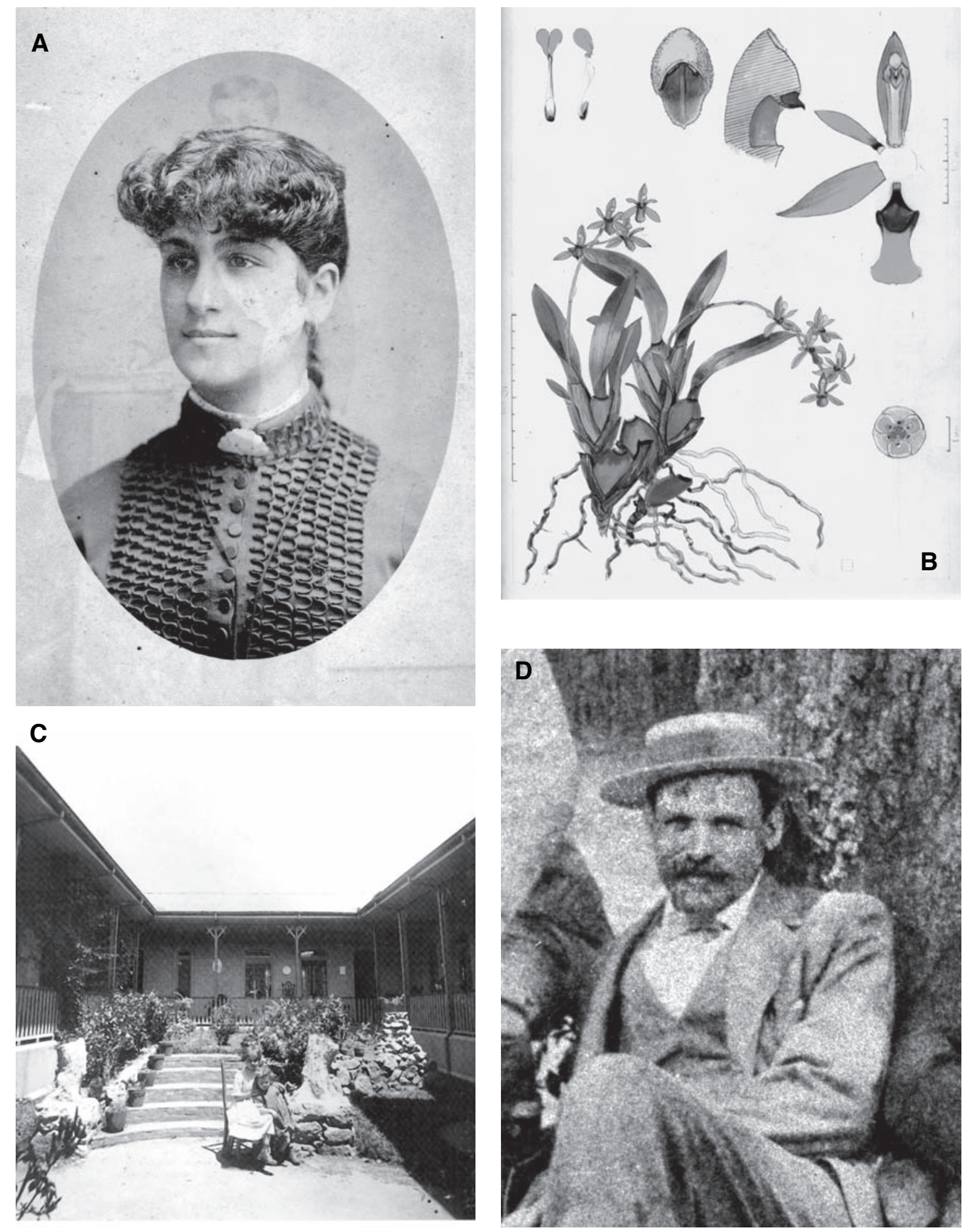

FiguRe 47. A — Amparo López-Calleja (1870-1951). Courtesy of Conchita Guzmán. B - Amparoa costaricensis Schltr. Watercolor by Rafael L. Rodríguez. Courtesy of the University of Costa Rica. C - Residence of Amparo de Zeledón in San José. Courtesy of Jaime García. D — Karl Wercklé. Courtesy of Luis Diego Gómez. 
a man of exceptional native talent [... ] Wercklé did not distinguish himself for his herbarium specimens, although it is true that a good many specimens of his collecting are found in herbaria. His favorite way of preserving an interesting plant was to roll it into a bundle and stuff it in a pocket, where it remained indefinitely. It is thus only too easy sometimes to recognize in the herbarium his specimens, without even looking at the label" (Standley, 1926: 221).

Among the new species discovered by Wercklé we find: Epidendrum carolii Schltr. (Wercklé 101), Epidendrum flexicaule Schltr. (C. Wercklé s.n.), Epidendrum prostratum Schltr. (Wercklé - 683 in Herb. O. Jiménez), Epilynajimenezii Schltr. (Wercklé-670 in Herb. O. Jiménez), Habenaria plantantheroides Schltr. (C. Wercklé s.n.), Masdevallia cyathogastra Schltr. (Wercklé - 842 in Herb. O. Jiménez), Masdevallia diantha Schltr. (Wercklé- 673 \& 843 in Herb. O. Jiménez), Pleurothallis bifalcis Schltr. (C. Wercklé s.n.), Scaphyglottis jimenezii Schltr. (Wercklé - 682 in Herb. O. Jiménez), Sigmatostalix hymenantha Schltr. (C. Wercklé s.n.), Stelis nutantiflora Schltr. (Wercklé 840 in Herb. O. Jiménez), and Stelis rhodochila Schltr. (Wercklé - 839, 845 \& 857 in Herb. O. Jiménez). Many others were dedicated to him by Schlechter and other authors: Chondrorhyncha wercklei (Schltr.) C. Schweinf., Dichaea wercklei Schltr., Elleanthus wercklei Schltr., Epidendrum wercklei Schltr., Eriopsis wercklei Schltr., Habenaria wercklei Schltr., Kefersteinia wercklei Schltr., Lepanthes wercklei Schltr., Malaxis wercklei Ames, Maxillaria wercklei (Schltr.) L. O. Williams, Oncidium wercklei Schltr., Pleurothallis wercklei Schltr., Scaphyglottis wercklei Schltr., Schiedeella wercklei (Schltr.) Garay, and Sobralia wercklei (Schltr.) L. O. Williams .

At some point Ames wanted to hire Wercklé as a collector and sought information from Lankester, who answered: "Wercklé is a dipsomaniac, an appalling wreck of a fine intelligence, but has still a good local knowledge and might be of use yet" (Letter to Ames, October 11, 1922). "Towards the end of his life, Wercklé forgot all moderation and like any other alcoholic, roamed through the city, in rags and without a place to live... Some tell that he spend the nights in an unoccupied niche of the General Cemetery, to which he gained access at nightfall, others that he passed his deliriums in a shed in the property of the Zeledón family, or now and then in the always open house of Alfredo Brade, a German gardener who always showed towards him hospitality and warmth" (Gómez, 1978: 364).

Alberto Manuel Brenes (1870-1948) (Fig. 48A) was born in San Ramón, Alajuela, and studied in Costa Rica until 1890, when he left Central America for Europe on a government grant. He spent a short time in Paris and from there went on to Lausanne, Switzerland, where he studied during one year at the university followed by a time in Geneva, where he stayed until 1898, taking courses in Botany and Natural History (Jenny, 2000: 20). Botanist of the National Museum for many years, he continued botanical explorations after Pittier left the country in 1903. When Standley wrote his Flora of Costa Rica in 1937, Brenes had accumulated an herbarium of over 20,000 specimens which, for the quantity and quality of its materials, did not find its equal in Central America. His collections came primarily from the region of San Ramón de Alajuela. From there he sent Schlechter a large collection of orchids in 1922. In 1919 Schlechter made contact with Brenes after receiving a letter from Tonduz, suggesting that orchids should be collected for a Costa Rican orchid flora (Jenny, 2000: 20). Schlechter described this collection in his Additamenta ad Orchideologiam Costaricensem under the title of Orchidaceae Brenesianae and highlighted the good quality of the included specimens. Only the collections organized by doña Amparo de Zeledón could stand up to those of Brenes, among which Schlechter identified some 90 new species". In 1920 Brenes became the head of the section of botany at the Museo Nacional, a position he held until 1935.

Schlechter named a new genus after him: Brenesia (Fig. 48B) and a great number of species, among which the following are worthy to be mentioned: Barbosella brenesii Schltr., Brachystele brenesii (Schltr.) Schltr., Campylocentrum brenesii Schltr., Catasetum brenesii Schltr., Dichaea brenesii Schltr., Elleanthus albertii Schltr., Encyclia brenesii Schltr., Epidendrum brenesii Schltr., Habenaria brenesii Schltr., Lepanthes brenesii Schltr., Maxillaria brenesii Schltr., Notylia brenesii Schltr., Oncidium brenesii Schltr., Pleurothallis brenesii Schltr., Ponthieva brenesii Schltr., Stelis brenesii Schltr., and Trichocentrum brenesii Schltr.

Of difficult character, Brenes often avoided contact with his botanist colleagues, and rejected several times 
Ames' approaches. Ames always wanted Brenes to collect for him but complained to Lankester: "Brenes is as dumb as a turtle and behaves like one. He belongs, I imagine, to that human group that is characterized by an unlimited capacity to take offense at well meant attentions..." (Letter to Lankester, May 2, 1925). Pittier complained also: "I must state that when I departed from Costa Rica in 1900, I left a herbarium of several thousands of plants [...] In 1939, [...] this collection still existed in perfect conditions. Therefore, I cannot understand the title of 'founder of the Costa Rican Herbarium', which Mr. Brenes attributes to himself in several publications. I say this without diminishing his merits as an active collector, but making clear that this does not constitute a botanist..." (Letter to Mariano Montealegre, October 13, 1943). Brenes taught at the best schools of Costa Rica and wanted to retire to Switzerland, where he planned to write a great flora of Costa Rica. According to Echavarría Campos, he had a girlfriend in Switzerland, Edda by name, and he had promised to marry her and bring her to Costa Rica once he had made enough money. However, he lost everything in the earthquake of Cartago (1910) and told his friend afterwards that "he wanted Edda to believe him dead, because he had nothing more to offer..." (Echavarría Campos, 1966: 21, 61). His name is still respected in the country. Brenesia, the scientific journal of the Department of Natural History of the National Museum, was named after him. Schlechter praised Brenes' collections, because they contained not only precise references as to the localities of collection, but also indications of the color of the flowers, an information of great value for the scientist. According to Schlechter, this data gives us "for the first time a more precise image of the plants in question, since previous collectors considered this indications to be superfluous" (Schlechter, 12923: 159). We conclude with Standley: "How fortunate botanical science would be if only there were more collectors of equal industry and discrimination!" (Standley, 1937: 53).

Costa Rican fine arts during the first decades of the century were equally attracted by the magic of orchids. The famous poet Lisímaco Chavarría (1878-1913) wrote in 1913 his romantic poem Manojo de Guarias $^{36}$ (= 'A handful of Guarias'): "To you I offer the delicate bouquet of fresh native parasites..." Chavarría incurs in the popular error of confusing epiphytes with parasites. The German painter Emilio Span (18691944) came to Costa Rica in 1906 , after having spent several years in Guatemala. A teacher at the Faculty of Fine Arts, Span traveled through Costa Rica's countryside, portraying the beauties of nature, among them many orchids (Loaiza, 1973: 41) (Fig. 48C). As Lankester wrote to Ames in 1927: “...Emilio Span, an elderly artist who has recently made with Brade's help a really fine collection of 'botanical' orchids..." Together with Enrique Echandi and Tomás Povedano, Span was chosen, in 1925, to represent Costa Rica at the Panamerican Art Exposition, sponsored by the Los Angeles Museum.

We know very little about Guillermo Acosta Piepper (1878-1955) (Fig. 48D). He was a farmer, merchant, miner and Political Chief of San Ramón. His grandfather, August Piepper, had arrived in Costa Rica in 1854 on board of the Antoinette, together with Hoffmann, von Frantzius, and Carmiol, to form part of the German colony which Baron von Bülow had founded in La Angostura. He had been sent by his family to London, where he studied business administration, returning to San Ramón to manage the family's fortune, which was considerable. Acosta sporadically collected orchids and sent a small collection to Schlechter, who described it in his Additamenta ad Orchideologiam Costaricensem (1923) under the title of Orchidaceae novae et rariores collectorum variorum in Costa Rica collectae. In this collection, Schlechter found a new genus, that he dedicated to don Guillermo: Acostaea. It is surprising that Reichenbach made no reference whatsoever to this species, having seen the magnificent illustration and detailed description that had been sent to him by Endrés (Fig. 49A). Other species were also dedicated to Acosta by Schlechter: Dichaea acostaei Schltr., Lepanthes acostaei Schltr., Maxillaria acostaei Schltr., Pleurothallis acostaei Schltr., Scaphyglottis acostaei (Schltr.) C. Schweinf., and Stelis acostaei Schltr. We don't know how Acosta made contact with Schlechter. It might have been through Alberto M. Brenes (who was also a native of San Ramón), or through his family's contacts in Germany (Acosta's mother, Adelina Piepper, was a German citizen, and don Guilermo married another German, Herminia Beer). Acosta was

\footnotetext{
36 'Guaria is in Costa Rica the vernacular name for orchids, especially Cattleyas. Guarianthe skinneri Dressler \& W. E. Higgins, Costa Rica's National flower, is commonly known as 'Guaria Morada', the 'Purple Guaria'.
} 
also a friend of Otón Jiménez, who remembers how don Guillermo helped him during one of Adolphe Tonduz' 'alcoholic journeys': "Don Anastasio Alfaro, director of the National Museum, asked me to bring back Tonduz [who was in San Ramón], to avoid sanctioning him for abandoning his duties. A Roman enterprise! I had to ask the Political Chief of San Ramón, Guillermo Acosta Piepper, for help, and through his paternal intervention I managed to put him on a horse and in a ten-hour journey, step by step, we reached Grecia and from there, in another similar journey, Alajuela. It was then easy for me to bring him to the house of my neighbor, David Mora" (Jiménez, 1971: 63).

It is sad that the three emblematic species which Schlechter dedicated to the Costa Rican collectors of the first years of the XX century: Amparoa, Brenesia y Acostaea costaricensis have disappeared, by the inexorable rules of botanical nomenclature, having been converted in synonyms of Rhynchostele beloglossa, Pleurothallis johnsonii and Specklinia mirifica. To the town of San Ramón de Alajuela, from where he obtained so much material during many years, Schlechter dedicated the genus Ramonia, with one single species: Ramonia pulchella ("the beautiful"), that was later transferred to Scaphyglottis. From the region around San Ramón Schlechter said that it was an "Eldorado for the orchid collectors" (Schlechter, 1923).

Tonduz was the great intermediary between Schlechter and those who collected in Costa Rica during the first years of the last century. This seems to have been the case of the relation between Schlechter and the exceptional orchid collections made between the years of 1908 and 1910 by the brothers Alexander C. and Alfred Brade, German nationals who had established themselves in Costa Rica.

Alexander Curt Brade (1881-1971) (Fig. 49B), by profession an architect, was the driving force behind those collections. Alexander Curt came to Costa Rica in 1908 invited by his brother but stayed only for a short time, traveling in August of 1910 Brazil, where he reached glory as one of South America's greatest orchidologists. His collection of the type of Epidendrum pinniferum C. Schweinfurth (A. C. Brade 335, may 1936) is however evidence that Brade returned at some point to Costa Rica, probably to visit his brother. During his stay in Costa Rica, the brothers explored the surroundings of San José, the mountains of Tablazo, Candelaria, Carpintera and the natural paradise of La Palma. Longer trips followed to the Miravalles volcano, the Barva and to the Atlantic Coast. The great variety of ferns drew Alexander's interest, and influenced by the writings of several European specialists he started to study them, discovering over 60 species new to science, described by Christ, Rosenstock and Hieronymus (Pabst, 1967: 161). In the meantime, his brother Alfred dedicated himself almost exclusively to orchids. Guido Pabst (1914-1980), the great Brazilian orchidologist, founded in 1958 the 'Herbario Bradeanum' in Rio de Janeiro and began in 1969 the publication of the journal Bradea, thus honoring the name of who had been his teacher for more than thirty years.

Alfred Brade (1867-1955) had arrived at Puerto Limón in 1893 and after two years of work in the banana plantations of the Atlantic region found a position in the nurseries of Julian Carmiol in San José. With Carmiol he shared his enthusiasm for Botany and he dedicated himself for years to explore all accessible regions in the country. After several years he made himself independent from Carmiol and founded the Brade Nurseries (Jiménes, 1957: 2). With the years he dedicated himself more and more to horticulture and finally abandoned botanical exploration completely. He was however "famously generous, and his personal garden was in many ways more of a botanical garden than a commercial enterprise" (Grayum et al., 2004: 14). Rudolf Schlechter, in his Additamenta ad Orchideologiam Costaricensem dedicated an entire chapter to the collections that he had received from the Brade brothers: Orchidaceae Bradeanae Costaricenses (Schlechter, 1923). Schlechter described there over 50 new species for Costa Rica, a number that gives us an idea of the importance of those collections. Schlechter praised the great quality and excellent preparation of the Brade's herbarium specimens and called the collection "a milestone in the botanical exploration of the country "(Markgraf, 1973: 4). Among the many new species discovered by the Brades we find: Habenaria irazuensis Schltr. (A. u. C. Brade 1069), Lepanthes blephariglossa Schltr. (C. Brade s.n.), Lepanthes bradei Schltr. (C. Brade s.n.), Osmoglossum convallarioides Schltr. (A. \& C. Brade 1292), Pleurothallis schulzeana Schltr. (C. Brade s.n.), Pogonia nitida Schltr. (C. Brade s.n.), Sarcoglottis 
bradei Schltr. (C. Brade s.n.), Stelis bradei Schltr. (C. Brade s.n.), Sarcoglottis costaricensis Schltr. (C. Brade s.n.), and Warrea costaricensis Schltr. (A. Brade 16327). As could be expected, numerous species where named in honor of the Brades: Barbosella bradeorum Schltr., Cranichis bradei Schltr., Cyclopogon bradei Schltr., Dichaea bradeorum Schltr., Dipteranthus bradei Schltr., Elleanthus bradeorum Schltr., Epidendrum bradeanum Kraenzl., Goodyera bradeorum Schltr., Habenaria bradei Schltr., Laelia bradei Pabst, Lepanthes bradei Schltr., Lycaste bradeorum Schltr., Masdevallia bradei Schltr. ex Hoehne, Maxillaria bradeorum (Schltr.) L. O. Williams, Octomeria bradei Schltr., Pleurothallis bradeorum (Schltr.) Ames, Hubb. \& Schweinf., Pogonia bradeana Kraenzl., Polystachya bradei Schltr. ex Mansf., Sarcoglottis bradei Schltr., Sobralia bradeorum Schltr., Sophronitis bradei (Pabst) Van den Berg \& M. W. Chase, Stelis bradei Schltr., Stenorrhynchos bradei Schltr., Trichosalpinx bradei (Schltr.) Luer, and Zygostates bradei (Schltr.) Garay.

'Bradei', 'Bradeorum', 'Bradeanum'... are all normal epithets that remember and honor the Brade brothers. But only a few know that Liparis fratrum Schltr. was also dedicated to them (from the Latin fratrum = 'belonging to the brothers').

\section{Otón Jiménez}

One of the most vivacious and enjoyable gentlemen (and botanists) to be met anywhere Louis O. Williams (1972: 206)

Schlechter wrote: "a young collector stands out lately in Costa Rica, O. Jiménez, who in a short period of activity has already found a series of new species and, through his efforts, promises to enrich in an important way our knowledge about the flora of that country, especially of the Orchidaceae" (Schlechter, 1918: 325). Otón Jiménez (1895-1988) (Fig. 49C) had the good fortune to study at the Liceo de Costa Rica in its golden age, with teachers like Emel Jiménez, Dr. Michaud and Biolley. Of a precocious intelligence, he was only 17 years of age when he was appointed as director of the Herbarium of the National Museum, a position he held until 1914. He remembers his first encounter with Charles H. Lankester in 1911: "I still remember his smile while shaking hands with me, observing my youngster-look due to the short trousers, long socks and occasionally a sailor-type blouse, the usual attire of the students of those years ..." (Jiménez, 1967: 248). His friendship with Lankester, that lasted throughout their lives, converted him into a lover of orchids, accompanying the great Englishman on many of his collecting trips, during which he found several new species: Epidendrum obliquifolium Ames, Hubb. \& Schweinf. (Jiménez 972), Habenaria jimenezii Schltr. (Jiménez 631), Stelis jimenezii Schltr. (Jiménez 621), and Stelis tonduziana Schltr. (Jiménez 618 ). He had the privilege to grow up during a period when the botanical exploration of Costa Rica was in full effervescence. "By 1914 Costa Rica had become the center of scientific research in tropical America" (Evans, 1999: 20). Jiménez knew personally the great botanists of his time: Wercklé, Pittier, Tonduz, the Brade brothers, Donnell Smith, Britton, Dr. Patiño (Colombia), Wilson Popenoe, Maxon (with whom he collected orchids in the region of Varablanca), Standley, Williams and Allen, and furthermore married a daughter of Anastasio Alfaro. In 1915, Pittier described him as follows: “... a disciple of Tonduz and a student of pharmacy, who has already done a large amount of collecting and may yet surpass" his master (Letter from Pittier to J. H. Barnhart, 1915). Because of the ups and downs of the Museum after the departure of Pittier, and because of his studies in Pharmacy, 'Oto' could not continue with the Botany, as he wished. However, during the remaining years of his life, he dedicated to Botany as much time as he could (which unfortunately was not much). After this period, since the collections at the Museum were not well organized and sometimes were lost, he started to send his collections abroad, I believe for the rest of his lifetime. I know that in the process many got lost, especially those destined to Europe.his later work, besides collecting and taxonomy, was oriented to the investigation of the nourishing properties of certain plants, or to the study of certain drugs (Silvia Troyo, pers. comm.). Together with Lankester, he had to suffer Ames' impatience: "When may I expect the specimens that Jimenez has in hand? Now is the time to get this material under the lens" “'Otón' has not sent me a scrap. I think it will be wise if you remind him of my needs and accompany him to the post office with the package" (Ames to Lankester, in letters from August and December, 1923). But it was not Ames 
but Schlechter and several other scientists who really valued Jiménez' work, naming in his honor a series of new species: Epidendrum jimenezii E. Hágsater, Epilyna jimenezii Schltr., Habenaria jimenezii Schltr., Lepanthes jimenezii Schltr., Masdevallia jimenezii Königer, Pachystele jimenezii Schltr., Scaphyglottis jimenezii Schltr., and Stelis jimenezii Schltr. In addition to being an excellent botanist, Jiménez was a prolific writer, who left interesting articles about Von Frantzius, Humboldt, Wercklé, Tonduz, Brade, and Lankester; an important bibliographical source for the study of scientific life in Costa Rica during the XIX and the first half of the XX century. "It is much to be regretted that the demands of business affairs have precluded a greater amount of personal field work on the part of one who has such a keen perception of facts and the ability to discover them in strange places" (Standley, 1937: 53).

Amelia Smith Calvert (1876-1966) and Philip Powell Calvert (1871-1961) came to Costa Rica in 1909 and stayed one year in the country. As entomologists, the main purpose of their visit was the study of the seasonal distribution of dragonflies. However, they were interested in all fields of natural history and published an account of their travels throughout the country, under the title of $A$ Year of Costa Rican Natural History (Calvert \& Calvert, 1917). Although orchids are frequently mentioned in their work, the book is of some interest because the Calverts met and became friends of several of the characters that are now part of our orchid history. One of the Calvert's first acquaintances was Alfred Brade, whom they visited at his home where he had a "flower garden, with a few animals in captivity, which formed one of the sights of San José at this time" (Calvert \& Calvert, 1917: 30). They set up their headquarters in Cartago, from where they made excursions in all directions, starting to explore the flanks of the Irazú volcano and continuing than to the south, to the foothills of the Cordillera of Talamanca, where they often found great numbers of Epidendrum radicans. Finally, in March of 1910, they met the Lankesters, who invited them to their house in Cachí. The invitation was accepted and the Calverts went by train to Paraíso and then rode to Lankester's farm. "Mr. Lankester's house was beautifully situated half a mile from the Reventazón
River and about a hundred and fifty feet above it. It was not a typical Costa Rica residence, for although built of adobe it was two-storied and had no patio. A wide veranda or "corridor" ran across the entire front on the first and second floors, charming places, for they were set with plants and hung with baskets of orchids, some of which were in full flower when we were there" (Calvert \& Calvert, 1917: 160) (Fig. 49D). In many of their excursions the Calverts traveled in the company of Costa Rican naturalist José Fidel Tristán (18741932), who was a magnificent guide and became their best friend in the country. The also received help from naturalist Anastasio Alfaro and well know ornithologist José Cástulo Zeledón. Near Guápiles, on the Atlantic side of the mountains, they were the guests of Mr. R. E. Woodbrigde, manager of the United Fruit Company, who was extremely fond of flowers. "All around the balconies were numerous potted plants and hanging baskets of orchids, ferns, caladiums and begonias" (Calvert \& Calvert, 1917: 284). And while climbing the Poás volcano, they found that "all trunks and branches, even the stems of small bushes, were thickly covered with soft bright green moss, and the epiphytes were mostly green bromeliads and orchids." Finally, near the Tempisque River, in Guanacaste, they passed "a number of trees bearing orchids with medium-sized pinkish flowers, which were called 'guarias'; the same name is applied to Cattleya in the interior of the country, but these orchids were not Cattleya" (Calvert \& Calvert, 1917: 354, 418). On May 4, 1910, while preparing to return to Limón and to their ship to the United States, the Calverts were caught by the terrible earthquake that destroyed Cartago, and barely saved their lives and their collections.

Harvey Elmer Stork (1890-1959) was a U. S. botanist who made important collections of orchids in Costa Rica. He collected in the country from 1920 to 1932, and was also in Peru, Nicaragua and Guatemala (1938-1939) where he collected with Oliver Butler Horton (Habenaria bractescens Lindl. -Stork \& Horton 8832 - Guatemala). Many years later, in 1956, he returned to Costa Rica. He had met Lankester in 1923: "On Friday past I had the pleasure to take two botanists for a short woodland ramble (Dr. Stevens ${ }^{37}$... and Mr. Stork..) (Letter to Ames, June 25, 1923)."

\footnotetext{
${ }^{37}$ Frank Lincoln Stevens (1871-1934), was professor of Biology at the North Carolina College of Agriculture and Mechanic and a botanical collector who did NOT collect orchids.
} 
Professor of Botany at Carleton College (Minnesota), Stork collected in Costa Rica over 1,200 specimens of plants. "The material gathered by Prof. H. E. Stork is just about finished. Two new Epidendrums and what I take to be a new Stelis" (Letter from Ames to Lankester, November 8, 1923). Some of the new species of Orchidaceae collected by Stork were: Epidendrum linifolium Ames (Stork 417), Epidendrum storkii Ames (Stork 460), Oncidium storkii Ames \& Schw. (Stork s.n.), Stelis storkii Ames (Stork 2103), and Telipogon storkii Ames \& Schw. (Stork 2101). Rafael Lucas Rodríguez described him as follows: "Harvey Stork was a North American of gigantic stature who, when he first visited the isthmus, walked all the way from David to Bocas del Toro, in Panama, to gain knowledge of the country. I went everywhere with him the last time he visited Costa Rica, and although he was already very old, I had problems trying to walk as he did" (Rodríguez, 1972: 14). The list of localities reveals that Stork collected primarily in the Central Valley, near Cartago and Orosi, making some excursions into Guanacaste, Pérez Zeledón and Puerto Limón. At some point he collected together with Willard Winfield Rowlee (1861-1923) to whom we owe Pleurothallis rowleei Ames (W. W. \& H. E. Rowlee 236). Rowlee made important investigations on balsa wood in the Canal Zone, Costa Rica, Guatemala, Honduras and Nicaragua.

Carroll William Dodge (1895-1988) came to Harvard University as Instructor in Botany and was made Assistant Professor and Curator of the Farlow Library and Herbarium in 1924. While at Farlow from 1924 to 1931, Dodge doubled the herbarium collections by purchase and collection. Some of his collections came from expeditions to the Gaspe Peninsula, Canada (1923) and parts of Latin America. In 1925 he was briefly in Panamá and Costa Rica, a country where he returned in 1929 , to study tropical mycoses on a Guggenheim Fellowship. Dodge received a second Guggenheim Fellowship for studies in Europe, and after his return in 1931, he became Professor of Botany at Washington University and Mycologist at the Missouri Botanical Garden. It was during his years in St. Louis that medical mycology and lichenology became his major research interests. He taught and visited in Latin America in Panama (1934-1935); Costa Rica (1936); Guatemala (1940-
1942); Chile (1950, 1960); and Brazil (1959). In Costa Rica he collected throughout the country on two occasions (November 1929 - May 1930 and July 1936 - May 1937), often in the company of the brothers Juvenal and Remo Valerio. Among his specimens we find a good number of Orchidaceae, among others Oncidium bryolophotum Rchb. f. (Dodge 4781), Masdevallia striatella Rchb. f. (Dodge 4786), Masdevallia reichenbachiana Endres ex Rchb. f. (Dodge 6145), Oncidium ascendens Lindl. (Dodge 6388), Hexisea bidentata Lindl. (Dodge 6389), Psygmorchis pusilla (L.) Dodson \& Dressler (Dodge 16510) and Malaxis soulei L.O. Williams (Dodge 9080). While in Panama, he led a botanical expedition with Julian Steyermark in 1934-35, and collected in the company of Paul H. Allen and Abel A. Hunter. Brassavola nodosa (L.) Lindl. (Dodge 16903) and Sobralia decora Batem. (Dodge 106a) are among his Panamanian specimens.

\section{Charles Herbert Lankester}

"Twenty three years ago today, the good ship 'Atrato' (now alas asleep in the depths off the $N$. Irish coast) left Southampton with myself on board en route for C.R., and here I am still ..."

Charles H. Lankester

(letter to Ames, December 12, 1923)

Of only 21 years of age, Charles Herbert Lankester (1879-1969) (Fig. 50A), arrived at Puerto Limón in December, 1900 and went on by train to the capital of Costa Rica, arriving just in time to take part in the "Ball of the New Century" offered by Costa Rica's President Rafael Yglesias in the National Theater of San José. Better known as 'don Carlos', Lankester had been born in Southampton, England, and came to Costa Rica to occupy a position as assistant in the "Sarapiquí Coffee Estates Company". His contract was for three years, with free travel from and to London, and with a salary of one hundred and fifty 'colones' (a stately sum at that time) (Urbina Vargas, 2005: 9). Sarapiquí proved too humid for the commercial production of coffee and the plantations had to be abandoned three years after the arrival of don Carlos in Costa Rica. It was here, however, surrounded by the most exuberant tropical vegetation, that his interest arose for plants, insects and birds. "Don Carlos Lankester arrived at 
the right place at the right time to join into the active biological exploration of Costa Rica, perhaps the most exciting place biologically on our continent (Williams, 1969: 860)." "He had the opportunity to meet professor Pittier when he visited this interesting region, beginning a friendship which lasted during all of his life" (Jiménez, 1967: 252). When his contract expired, Lankester returned to England, but came back to Costa Rica a few months later, called by Pittier to take over the experimental station which the United Fruit Company planned to establish in Zent, a project that never became reality. In the following years he worked in several farms, collected insects for doctor Schaus and birds for the Carnegie Institute in Pittsburgh. In 1908 he accepted the administration of a coffee farm in Cachí, owned by Cecil V. Lindo, where he lived for nine years with his wife Dorothea Hawker (Fig. 50B) and his young family. It was during those years that don Carlos began his collections in the nearby woods, which in many cases proved to be new species. He sent his first specimens for identification to Rolfe, at Kew. One of them (Lankester 021, 1915, neighborhood of Cachí) is probably the first new species of Orchidaceae discovered by Lankester: Pleurothallis costaricensis Rolfe.

Robert Allen Rolfe (1855-1921) (Fig. 50C), who had stepped into the position of world master of orchidology after the death of Reichenbach, was Lankester's logical contact, who in a journey to England in 1920 brought an important collection of orchids to Kew. Rolfe's sudden death left this collection unstudied, as happened to another collection of Panamanian orchids, prepared by C. W. Powell. Rolfe died at the age of 65 , just when he was about to set out on his first trip to Tropical America (Panama and Costa Rica) (Reinikka, 1995: 278). “Kew had promised financial help and extended his term of service to include this field work, and the untimely end of a cherished wish was a great disappointment to Powell and the writer, both of whom had derived much encouragement and help from his kindly cooperation and guidance" (Lankester, 1944: 10-11). One of Rolfe's fundamental achievements was the foundation of the Orchid Review in 1893, of which he was the editor until his death in 1921. Shortly before his death he was awarded the Victoria Medal of the Royal Horticultural Society (Stapf, 1921: 8).
After a brief interlude in England and Africa (1920-1922), Lankester returned to Costa Rica and moved later (1924) to live at "Las Cóncavas", a coffee farm that he had acquired in the vicinity of Cartago. The year 1922 was an turning point in Lankester's career as an orchidologist: it brought the first contact with Oakes Ames, that would develop into a deep friendship. Ames, after returning from a trip to Europe, wrote to Lankester: "At Kew I saw many specimens collected by you in Costa Rica, the greater part unnamed. As it will take some time for Kew to recover from the loss of Rolfe and as the Germans are making great efforts to assemble Costa Rican material through Wercklé, Jimenez and Tonduz, it seemed to me that you might be willing to co-operate with me by stimulating orchidological interest among your neighbors" (Letter from Ames to Lankester, September 17, 1922). Lankester answered immediately and became so, for the next 25 years, the favorite collector of Ames, who discovered among the specimens received from Las Cóncavas more than 100 new species. Many were dedicated to Lankester, such as: Campylocentrum lankesteri Ames, Cranichis lankesteri Ames, Dichaea lankesteri Ames, Dipterostele lankesteri (Ames) Garay \& G. A. Romero-González, Epidendrum lankesteri Ames, Habenaria lankesteri Ames, Hexisea lankesteri Ames, Lockhartia lankesteri Ames, Malaxis lankesteri Ames, Maxillaria lankesteri Ames, Notylia lankesteri Ames, Oncidium lankesteri Ames, Ornithocephalus lankesteri Ames, Stelis lankesteri Ames, Stellilabium lankesteri (Ames) Dressler, Telipogon lankesteri Ames, and Trigonidium lankesteri Ames. He also found a new genus amongst Lankester's collections: "There seems to be a new genus among your specimens. Lankesterella would be a good name (Letter from Ames to Lankester, April 18, 1923). The new genus was published in May, 1923. Ames never stopped expressing his admiration and gratitude: “... for what you have done my gratitude is immeasurable. I am mindful of the great service you have done in my behalf and I realize that there was no need for you to regard me as anything more than a pestiferous nuisance; a botanical mendicant reaching out toward you, a greedy hand" (Letter to Lankester, December 16, 1923). 
In Las Cóncavas, during the next 33 years and while he continued sending plants to Ames, Lankester created the orchid garden that would become the Mecca of all botanists who passed through Costa Rica, not only because of the plants, but also for don Carlos' vast knowledge of the country and its nature (Fig. 50D). "Generous to a fault, hospitable to all, he was counselor to all scientists who came to Costa Rica. His interests were catholic - butterflies, birds, but most especially epiphytic plants, orchids, bromeliads and aroids" (Williams, 1972: 207). "A naturalist in the best and widest sense of that word" (Standley, 1925: 274). His business affairs suffered many ups and downs, and he often thought about returning to England. "It is just possible I may complete sale of this place during the coming week; if so Costa Rica will soon see me no more" (Letter to Ames, December 17, 1925). But he continued and never abandoned the country. In July of 1925 , Lankester was elected as an honorary member of the American Orchid Society.

After 1932, the correspondence between Ames and Lankester became less frequent. Ames was approaching 60 years of age and Lankester already passed 50. The initial passion gives way to a more serene and calm relationship. But their friendship continued until the death of the great American orchidologist in 1950.In 1956, when Lankester could not manage his farm because of his age, he sold "Las Cóncavas". His wife had died, his children were far away, and don Carlos had no success in finding someone to care for his garden. He then moved his garden to a nearby property known as "Silvestre". It was on this property where, years later, the Lankester Botanical Garden of the University of Costa Rica was established. However, despite of his age, he continued collecting. One of his last specimens has the number 1761, a plant of Warrea costaricensis Schltr., collected in February of 1960, when Lankester was already 81 years old. In the last years of his life Lankester lived in Moravia, where he continued cultivating orchids to the last day. It is said that shortly before passing away he confessed to his daughter Dorothy: "I am only sorry that, with all the opportunities I had, I never made enough money" (R. Lankester, pers. comm., 2004). In the words of Rafael Lucas Rodríguez, one of his close friends, “... his friends have at least the consolation that he had no long agony, and that his last days were rather happy, with a celebration of his $90^{\text {th }}$ birthday in June and the Garden Club awarding him a gold medal only last week" (In a letter to Robert Dressler, July 10, 1969.

Except for a few articles, Lankester left a very limited amount of publications. He prepared a manual about the orchids of Costa Rica, that was approved for publication by the American Orchid Society in 1968, a year before his death, but the project was never completed (Lankester, 1944). The manuscript, with the title Costa Rican Orchids, is now part of the library of the Lankester Botanical Garden, awaiting to be published together with a biography of the great naturalist. Lankester's only son, John Maurice Hawker Lankester (1913-), became also interested in orchids and in 1952 collected a new species, Epidendrum puteum Standl. \& L.O. Williams, that flowered at Las Cóncavas (John M.H. Lankester, 1606).

Alfredo Sancho (1876-1929) was Lankester's good friend and companion on many collecting trips. Brother of the writer Mario Sancho and of Francisco and Carlos Sancho, who owned farms in Peralta and La Estrella (to the East and South of Cartago), he introduced Lankester to the orchidaceous flora of the regions where his brothers worked. Lankester himself owned for a short period of time a farm in Peralta, a project he abandoned for economic reasons. During their collecting trips, Lankester and Sancho collected a great number of new species, that were named in honor of Sancho and his favorite collecting sites: Epidendrum sanchoi Ames, Lepanthes sanchoi Ames, Pleurothallis sanchoi Ames, Stelis sanchoi Ames, Encyclia peraltensis (Ames) Dressler, Pleurothallis peraltensis Ames, Chondrorhyncha estrellensis Ames, Epidendrum estrellense Ames, and Lepanthes estrellensis Ames. In a letter to Ames, Lankester shows the great affection he felt for the Sanchos: "I hope you may have time to meet Mario Sancho [at that time Consul of Costa Rica in Chicago]. His brother Alfredo, to whom you dedicated a Lepanthes and a Pleurothallis, has at various times helped on the good cause, and we had the pleasure of seeing them both here last night... they are worthy representatives of the best of the old Cartago gente" (Letter to Ames, July 30, 1924). 

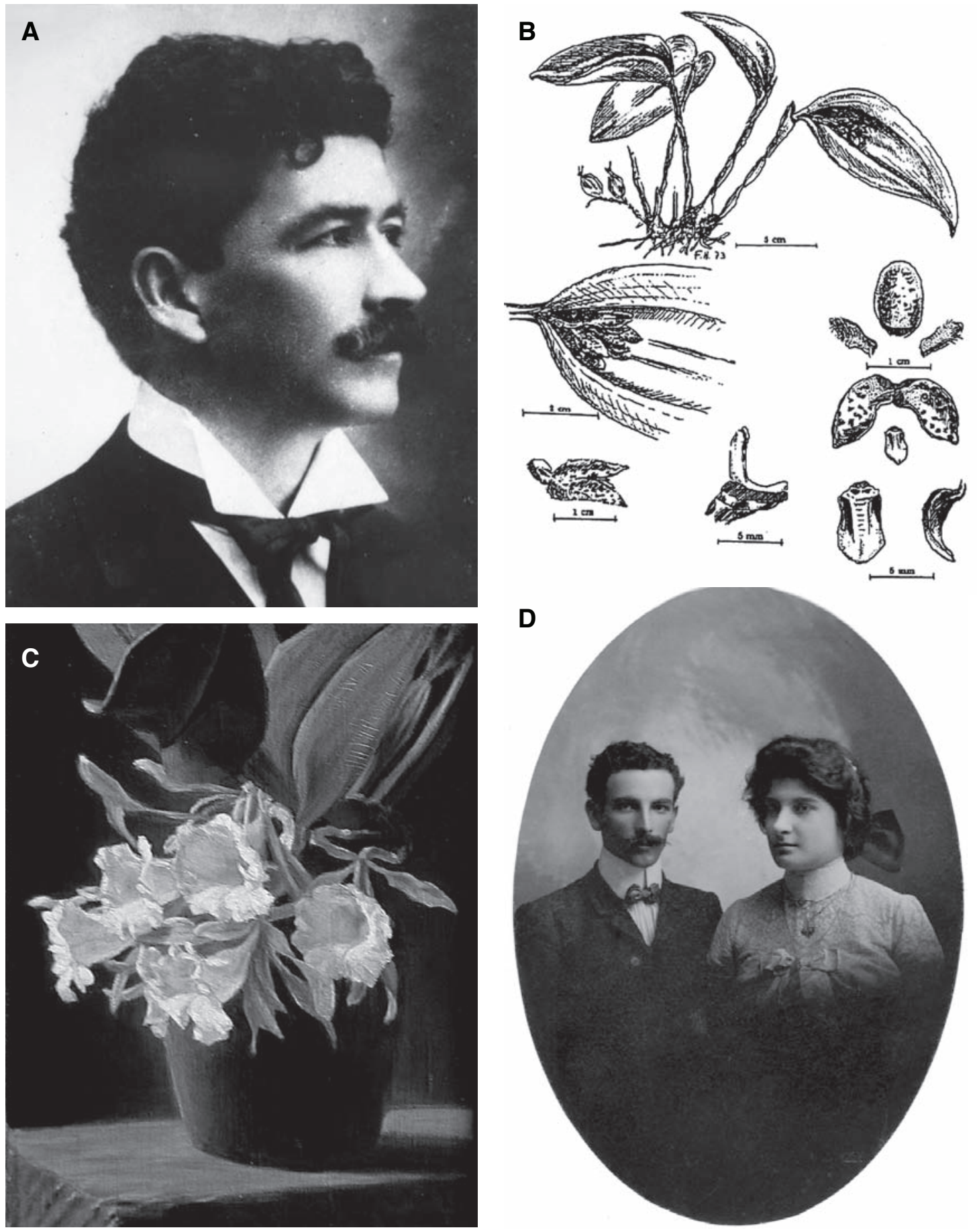

FiguRe 48. A — Alberto Manuel Brenes (1870-1948). Courtesy of Jorge Gómez Laurito. B — Brenesia costaricensis Schltr. Illustration by Fritz Hamer in Jenny, 2000: 21. C - Trichopilia galeottiana A. Rich. \& Galeotti. Oil on canvas by Emilo Span. In Loaiza, 1973. D — Guillermo Acosta Piepper (1878-1955) and his wife Herminia Beer. Courtesy of Albán Cambronero Acosta. 

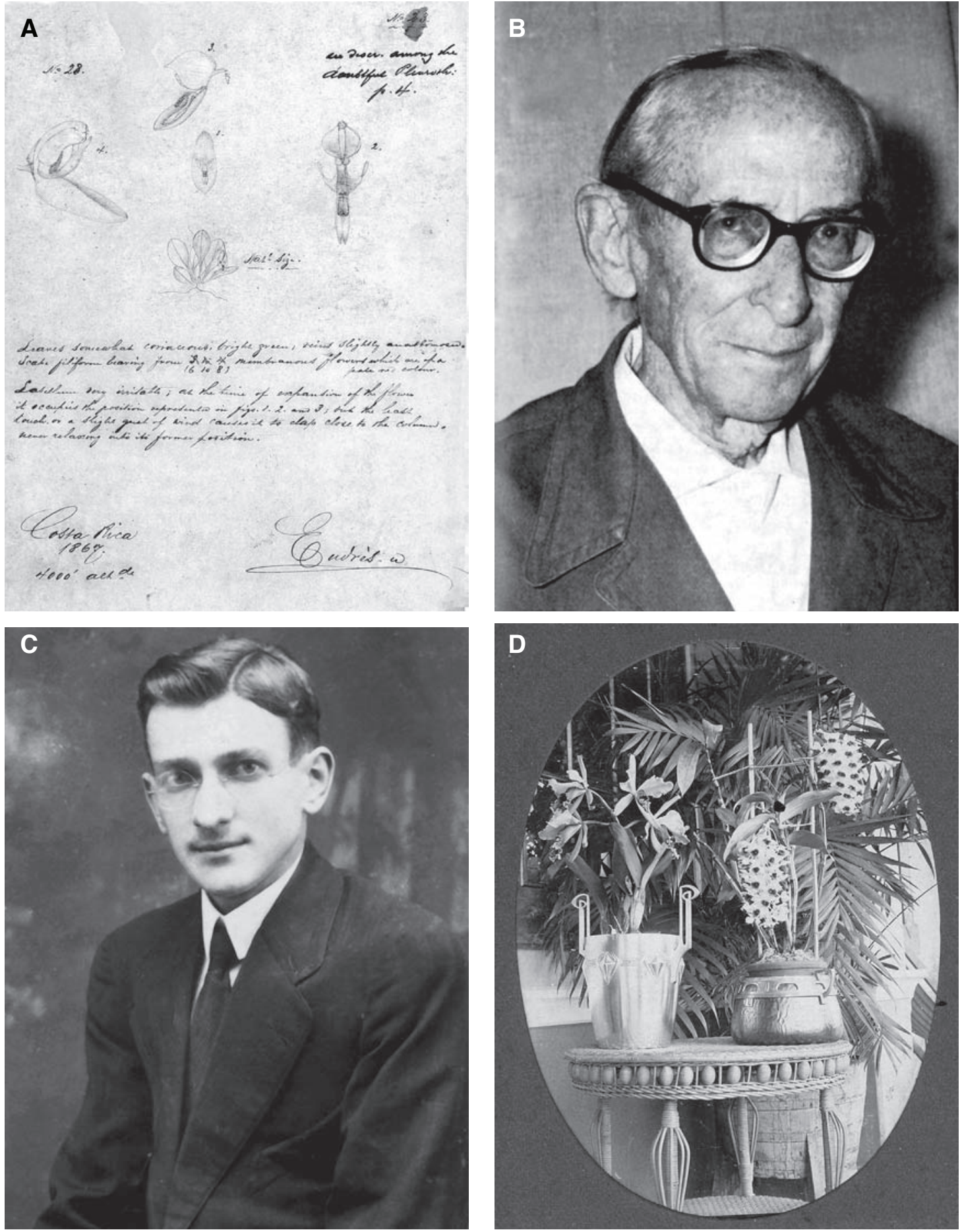

Figure 49. A - Acostaea costaricensis Schltr. Illustration by A.R. Endrés. Courtesy of the Natural History Museum in Vienna. B - Alexander Curt Brade (1881-1971). In Pabst, 1967: 61. C — Otón Jiménez (1895-1988) in 1919. Courtesy of Silvia Troyo. D — Orchids in Lankester's house in Cachí. Courtesy of Ricardo Lankester. 

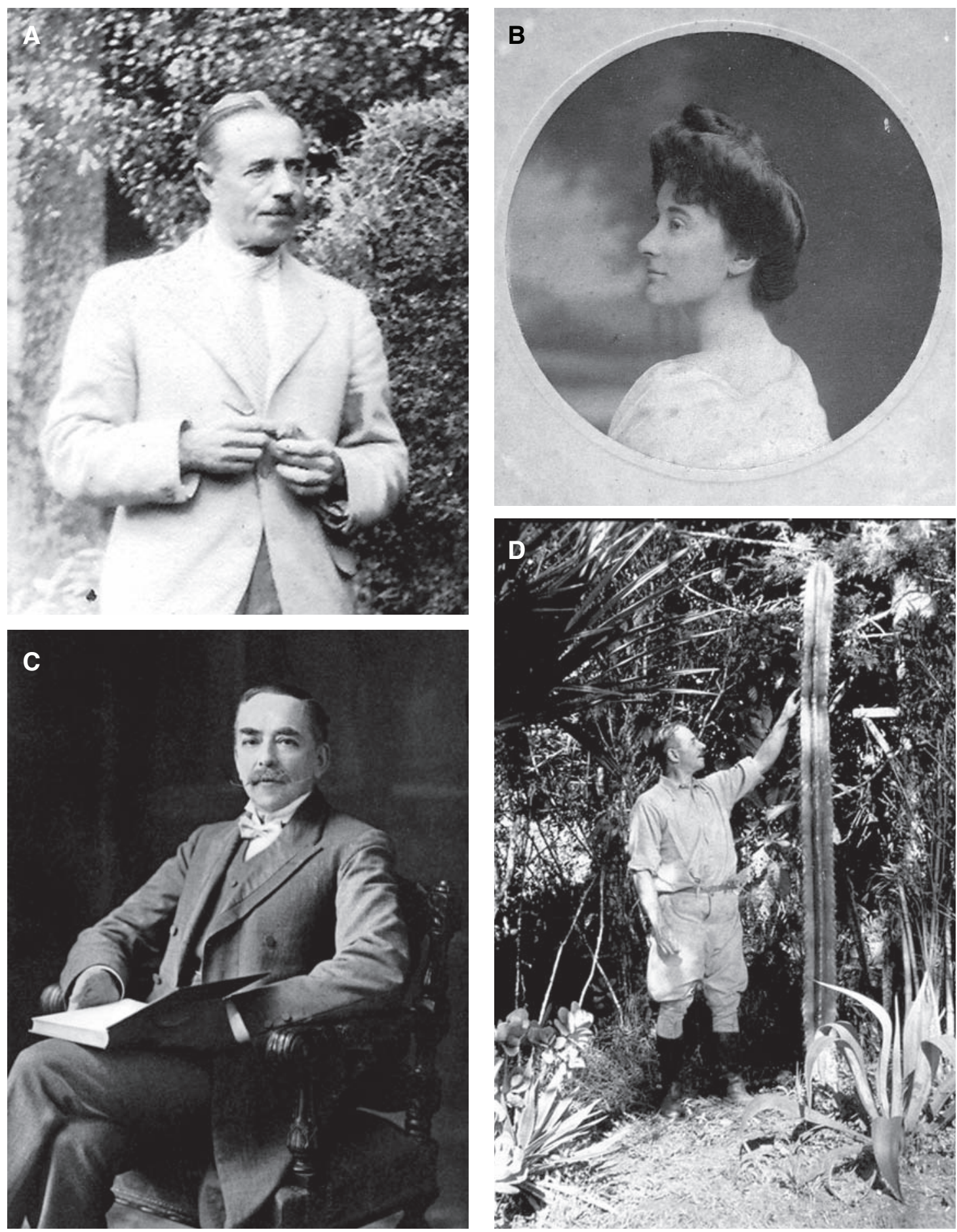

FiguRE 50. A — Charles Herbert Lankester (1879-1969). Courtesy of Ricardo Lankester. B — Dorothea Hawker, Lankester's wife. Courtesy of Ricardo Lankester. C - Robert Allen Rolfe (1855-1921). Courtesy of the Oakes Ames Herbarium, Harvard University. D — Lankester in 'Las Cóncavas', 1936. Courtesy of Ricardo Lankester. 

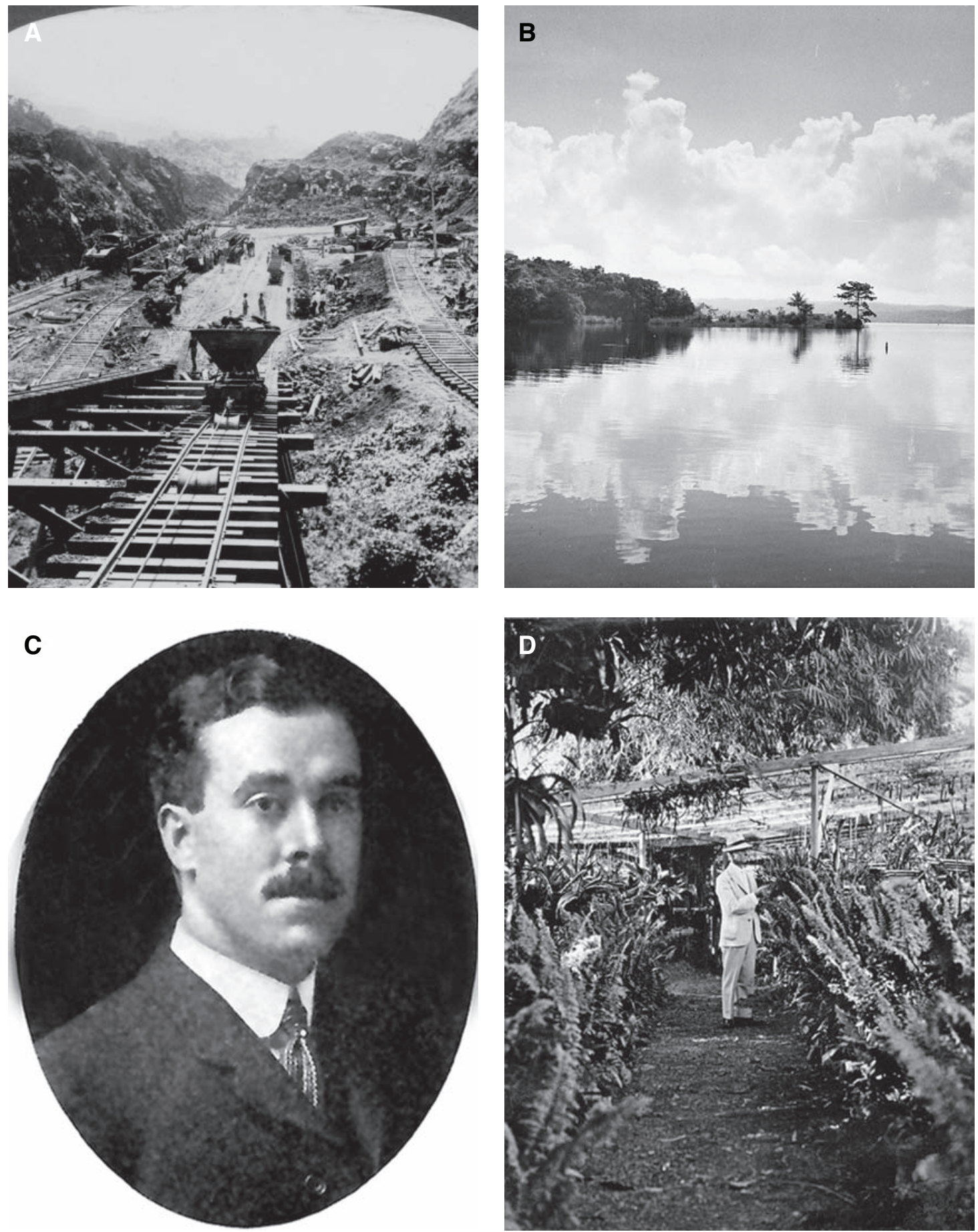

FiguRe 51. A — Panama Canal under construction (1907). B - Barro Colorado Island as seen from Gatún Lake. Courtesy of the Missouri Botanical Garden. C - William Ralph Maxon (1877-1948). In the frontispiece of Fern Bulletin, 1903, vol. 11. Courtesy of Dr. Gustavo Romero. D — Charles Wesley Powell (1854-1927). Courtesy of the Hunt Institute for Botanical Documentation. 


\section{The orchids of the Panama Canal}

"Since its completion in 1914, the Panama Canal has been Panama's economic base, and the United States presence has been the republic's major source of frustration"

(http://www.canalmuseum.com/ stories/history_of_panama_001.htm)

"Completely different from Suez, where the desert hardly provoked any naturalistic concerns, the tropical nature of Panama was a complex challenge to Science.... At the center of these concerns about the impact of the canal on the surrounding environment was the formation of Lake Gatún. Its waters, while flooding the lower course of the Chagres River, would drown or drive away the majority of the plants and animals and would extinguish many unknown species.... Other unknowns were the changes that could take place once the waters and organisms of both watersheds came together..." (Heckadon-Moreno, 1998: 74) (Fig. 51, A-B). There was also a practical interest in undertaking a biological survey of such importance: to enrich the collections of Panamanian flora and fauna in the museums of natural science in the United States. Leaders among those who undertook the biological exploration not only of Panama, but of the whole American continent, where two institutions which had been founded fifty years earlier: the Smithsonian Institution and the Missouri Botanical Garden.

\section{The biological exploration of the Smithsonian} Institution. "... When the floodgates of the great earth dam which impounded the Chagres River started to close in April of 1910... the world's largest artificial lake started to form: Lake Gatún. Suddenly, with the imminent flooding of over 60 villages and hundreds of square miles of jungle, the biological study of the region affected by the canal works became a scientific priority. Never before had the biologists had the unexpected possibility of exploring the highest tree tops by simply rowing a boat [...] In this odyssey of knowledge that took place on the isthmus, the Smithsonian Institution of Washington D. C., which undertook the first great biological survey of Panama between 1910 and 1912, played a principal role" (Heckadon-Moreno, 1998: 73-74).

The first group of a great number of specialists in different branches of biological sciences which would visit the canal during the following years, gathering information and extensive collections, disembarked in Colón on December 28, 1910. In charge of the Botany was Henri Pittier, from the U. S. Department of Agriculture, who resided in Panama from 1910 to 1912. According to the original plan, the study would require one year and would be limited to the immediate neighborhood of the canal excavations. However, the need to extend the area of study became clear very soon, and the explorations were extended to the whole territory of Panama. Field work, which lasted until March of 1912, began after Pittier's request was granted and he could count on the help of William R. Maxon, who arrived in Panama in February, 1911. Pittier collected and classified 1,750 species of plants in 154 different localities, among them many orchids. "After he returned to Washington [1912], Henri and his young assistant Paul C. Standley attacked the gigantic task of analyzing and publishing the scientific data of the vast collection of Panamanian plants [with the help of European specialists], many of them new to science. The publications were to appear under the joint seal of the U. S. National Herbarium and the Smithsonian Institution" (Heckadon-Moreno, 1998: 84). Pittier wanted to write his final report in Latin, the classical language of Botany, employed by nine tenths of the systematic botanists, but he encountered resistance among the members of the Editorial Committee, who wanted everything to be written in English. Finally, the Secretary of the Smithsonian decided salomonically to publish the manuscripts part in Latin and part in English. The quarrel with the languages delayed the publications and upset the relations between the American and European naturalists. These difficulties paled however at the outbreak of World War I, when the relations among the international scientific community were finally and completely disrupted (Heckadon-Moreno, 1998: 85).

William Ralph Maxon (1877-1948) (Fig. 51C) worked during his whole life for the New York Botanical Garden and the U. S. National herbarium. He had collected plants with Pittier in Chiriquí as early as 1900. In 1905 he visited Guatemala and in 1906 Costa Rica (Maxon, 1906). He arrived in Costa Rica at Puerto Limon and collected in the provinces of San José, Cartago and Alajuela. Some of the orchids of the Maxon herbarium were given to him by Pablo Biolley, who cultivated them in his garden in San José (Nash, 1907). Maxon spent a time during 1911 in Panama, where he 
formed a large collection of orchids together with Pittier, exploring not only the Canal Zone but also Chiriquí and other regions. Pittier remembered the collections in El Boquete (Chiriquí): "The district is wonderfully rich in orchids... We hope to have soon in Washington living specimens of many of the specific types collected by Warscewicz in the same region" (Heckadon-Moreno, 1998: 108). Somewhat later (1923) he was again in Panama, Costa Rica and Nicaragua, where he collected in the company of Harvey and Valentine. In Costa Rica he became a friend of Lankester and Otón Jiménez: "Maxon has just advised his departure from CR. Am regretful not to have seen him again. He + Otón Jiménez went to Varablanca, a wonderful orchid region..." (Letter from Lankester to Ames, July 27, 1923). He discovered several new species of orchids, described initially by Schlechter (who had worked together with Pittier in the identification of the specimens from the Smithsonian's exploration) and later by Ames, many of which were dedicated to him: Cranichis pseudociliata Schltr. (Maxon \& Hay 3208, Guatemala), Elleanthus caricoides Nash. (Maxon 692, Costa Rica), Lepanthes maxonii Schltr. (Maxon 5494, Panama), Malaxis maxonii Ames, (Maxon, Harvey \& Valentine 7770, Nicaragua), Pelexia maxonii Ames, Pleurothallis monstrabilis Ames (Maxon \& Harvey 8096, Costa Rica), Pleurothallis propinqua Ames (Maxon \& Harvey 8268, Costa Rica), and Stelis maxonii Schltr. (Maxon 5697, Panama). Several species that were in the private collections maintained in the Canal Zone by Mrs. D. D. Gaillard and Mrs. H. H. Rousseau and which Schlechter described as new species, were incorporated to the Panamanian collection of orchids by Maxon and Pittier: Aspasia rousseauae Schltr., Epidendrum rousseauae Schltr., and Maxillaria rousseauae Schltr.

\section{The orchid garden of Charles Wesley Powell}

"The Powell orchid garden at Balboa is one of the most interesting sights of the Canal Zone, and botanically by far the most remarkable thing to be seen there. It is something unique in tropical America, if not in the whole world."

Paul C. Standley (1925: 359)

In 1915, Charles Wesley Powell (1854-1927), in charge of a dispensary in the Canal Zone, became seriously interested in orchids and began to amass a complete collection of Panamanian species. "Mr. Powell's idea was to accumulate as representative a Panamanian collection of orchids as possible and take them to England, where he contemplated making his home..." (Anonymous, 1929: 335). Powell had lived during a short time in Guatemala and went to Panama in 1907, shortly after the construction of the canal had been initiated. During many years, often in the company of A. A. Hunter, he undertook a systematic exploration of many regions throughout the country, and especially of the high mountains of Chiriquí. What began as a pastime became with the years a true passion. A layman in botanical matters, Powell began cultivating orchids in his garden (Fig. 51D) and forming a good specialized library. From 1916 onwards, he had the support of Christopher Cheeseman, who collected orchids for Powell until the former's death in 1927 (Pring, 1927: 75 ). As soon as he realized that many of his plants were not described in his books, he made contact with Rolfe at Kew, to whom he sent in 1920 a series of herbarium specimens, but Rolfe died before he had a chance to study Powell's collection (Standley, 1925: 359). Powell sent then another collection to the German orchidologist Dr. Rudolf Schlechter, who published a work about the orchids of Panama (Schlechter, 1922). In this work he described 184 species, of which 75 were new to science. Schlechter wrote to Powell in 1921: "Your exploration of the orchid flora of Panama is one of the most important facts in orchidology during the later years" (Letter to Powell, 14 December, 1921). Shortly thereafter Schlechter made an attempt to gain Lankester as a collector: "Do try to induce Mr. Lankester to send materials to me too" (Letter to Powell, 21 November, 1922).

In 1922 Powell began his relation with Ames, who wrote triumphantly: "Mr. Powell is now collecting for me. He will send nothing more to Schlechter" (Letter to Lankester, January 13, 1923). It is true that since that year Powell sent only duplicates to Schlechter. In addition, he kept Ames informed by transcribing to Ames every letter he wrote to or received from the German orchidologist. One of the species that Ames had looked for, for years, was Selenipedium chica Rchb. f. Great was his joy when he received, shortly before embarking for Europe, a cablegram from Powell confirming that he had found the desired plant (Fig. 52A). 
With the specimens that Powell sent to Ames, the number of Panamanian species known to science increased to 341 . Ames, trying to play his cards on both sides of the ocean, wrote to Powell in 1922: "Notwithstanding my friendly relations with Schlechter, nobody would receive with greater joy the news that you decided to keep America free from Germany in the realm of Panama orchids" (Letter to Powell, October 10,1922). And Ames continued a few months later: "I wish we could keep Schlechter out of the American field" (Letter to Powell, December 12,1922). Ames went so far as to sign with Powell a formal contract in which the latter would collect orchids for him for US $\$ 100,00$ per month. "There can scarcely be for any tropical country a record of one person who has contributed so much to the knowledge of the orchid flora" (Standley, 1925: 359). Ames praised the quality of his work: "His indefatigable zeal is one of the joys in my contemplation of Central American orchidology. His specimens are often works of art" (Letter from Ames to Lankester, August 24, 1923). George H. Pring, during a visit to Powell in 1923, wrote that "in examining Mr. Powell's herbarium specimens I was particularly interested in the retention of the natural color of foliage and flowers" (Anonymous, 1924: 179).

Powell collected an endless number of new species that in many cases were dedicated to him (especially by Schlechter), among them: Coryanthes powellii Schltr., Cycnoches powellii Schltr., Dichaea powellii Schltr., Dresslerella powellii (Ames) C. A. Luer, Encyclia powellii Schltr., Epidendrum powellii Schltr., Gongora powellii Schltr., Govenia powellii Schltr., Leochilus powellii Schltr., Lycaste powellii Schltr., Maxillaria powellii Schltr., Mormodes powellii Schltr., Ornithocephalus powellii Schltr., Palmorchis powellii (Ames) Schweinf. \& Correll, Polystachya powellii Ames, Restrepia powellii Schltr., Rossioglossum powellii (Schltr.) Garay, Sarcoglottis powellii Schltr., Scaphyglottis powellii Schltr., Sobralia powellii Schltr., Stelis powellii Schltr., Trichopilia powellii Schltr., and Xylobium powellii Schltr. In 1925 he visited Lankester in Costa Rica, who in turn traveled to Panama in 1927: "I have just spent a fortnight with my fellow sufferer from orchiditis, CWP, + it was a very delightful time of talk and talk and then talk. I wish we could have had you there as High Priest of our cult" (Letter from Lankester to Ames, July 17, 1927).
Powell died shortly thereafter, being 72 years of age, on August 18, 1927. “... his friend, A. A. Hunter, chief of the postal office of Balboa, was put in charge of Powell's orchidarium that had been bequeathed by him, in 1926, to the Missouri Botanical Garden" (Heckadon-Moreno, 1998: 153). A lectotypification of Powell's Panamanian orchids was undertaken by Christenson in 1991.

Abel Aken Hunter ( - 1936) was Powell's great friend and had collected orchids with him since 1915. In his Orchidaceae Powellianae Panamenses, Schlechter dedicated five new species to him: Coryanthes hunteriana Schltr., Encyclia hunteriana Schltr., Epidendrum hunterianum Schltr., Pleurothallis hunteriana Schltr., and Sarcoglottis hunteriana Schltr. After Powell's death, Hunter took over the direction of the Tropical Station that the Missouri Botanical Garden had established in Panama, and maintained this position until his own death in 1936. In 1935 he collected intensively with Paul Allen, discovering no less than four new species: Epidendrum cocleense Ames, Hubb. \& Schw. (Hunter \& Allen 389): Masdevallia tenuissima C. Schweinf. (Hunter \& Allen 587): Ornithocephalus cochleariformis C. Schweinf. (Hunter \& Allen 383), and Pleurothallis rotundata C. Schweinf. (Hunter \& Allen 561).

\section{The Tropical Station of the Missouri Botanical Garden}

"Plans have been perfected by the Missouri Botanical Garden of St. Louis, Missouri, U.S.A., for the establishing and maintaining of an Orchid Botanical Garden on the Isthmus of Panama. It is designed to have sent there from all parts of the world the desirable plants from abroad, to cultivate, propagate, and have their flowers on display for the knowledge and pleasure of the people resident in the Canal Zone, and Republic of Panama"

(Anonymous, 1926: 227)

Early in the 20th century, the Missouri Botanical Garden began sending its researchers into tropical climates, seeking to catalogue the diverse species in these rich environments. The English horticulturist George Henry Pring (1885-1974), who had served an apprenticeship at Kew, had arrived at the Garden in 1906 
as responsible for the orchid collection and with the goal to raise it to a level even higher than the collection at Kew. During Pring's 63 years in Saint Louis, the orchid collection of Missouri increased from 300 to over 50,000 plants. When the First World Orchid Conference was inaugurated in Saint Louis in 1954, Pring, then 69 years of age, had the honor to preside. Pring made trips to remote locations in Mexico and in 1923 visited the Panama Canal Zone, where he spent six months and met Powell. Pring collected together with A. A. Hunter in Chiriquí, trying to increase Powell's collection (Pring, 1927). Famous for one of the world's finest collections of living plants, a great interest arose for Panama in the Garden, especially because of the orchid collection of C. W. Powell and his offer to donate it to the institution. In 1926 the Missouri Botanical Garden created a 'tropical station' at the foot of Ancón Hill, on lands granted by the Canal Zone government. Powell retired this same year and when his collection passed into the custody of the Tropical Station, he was appointed as its first director (Fig. 52B).

A. A. Hunter, Powell's great friend, took over Powell's position in 1927 and kept it until his death in 1936. Due to the high costs of operation, the Tropical Station was transferred in 1939 to the Canal Zone Government. Paul Allen was its last director. During its almost 13 years of existence, the Tropical Station supplied the greenhouses in Saint Louis with a constant flow of living plants. Powell's collection marked the beginning of the Garden's reputation in orchid horticulture. Among its collections of plants no less than 75 new orchid species were described, the majority of which had been collected by Hunter and Allen. George Pring returned to Panama in 1928 and made several collections of orchids, among others: Catasetum warczewitzii Lindl. \& Paxt., Acineta chrysantha (Morr.) Lindl., Oncidium anthocrene Rchb. f., Peristeria elata Hook., and Odontoglossum schlieperianum Rchb. f.

\section{The Smithsonian Tropical Research Institute}

"Let us propose to ourselves to find an area of tropical forest, large enough and unaltered, where men of science can come to study."

James Zetek (Heckadon-Moreno, 1998: 141)

"When the Panama Canal was built, Lake Gatún was formed by the impounding of the Chagres River, the waters flooded the valleys and the hills became islands. The highest peak, Barro Colorado..., became the largest island of the new lake" (Heckadon-Moreno, 1998: 139). The island was declared a protected area in 1923 and a small biological station was established on it. The Institute for the Research of Tropical America was established in order to manage the island and the station. Diverse scientific and academic institutions of the United States, including the Smithsonian Institution, were part of the Institute, that was directed by the National Research Council. James Zetek was appointed as the resident administrator.

James Zetek (1886-1959), North American entomologist of Czech origin, had arrived in Panama in 1911 to research on malaria. A passionate conservationist, Zetek fought during twelve years for support, in Panama and abroad, to convert Barro Colorado into a natural park, an area of jungle in good condition, with many plants and animals, where the naturalists could expand their knowledge in all areas of the biological sciences. With the support of Panamanian President, Belisario Porras, and of the Governor of the Canal Zone, Jay J. Morrow, as well as of Thomas Barbour, from Harvard University, Zetek finally reached his goal (Croat, 1978: 49). From 1923 to 1956 , Zetek would be the dedicated and visionary administrator of the Biological Station at Barro Colorado. His work was paramount. Fighting with limited budgets, surviving the years of the Great Depression and World War II, Zetek was called, with justice, the 'guardian of Barro Colorado' (Fig. 52C). In 1946 the United States Congress transferred Barro Colorado to the Smithsonian Institution, that has managed it ever since. Zetek continued as resident administrator until his retirement in 1956. In 1964 the station was named "Smithsonian Tropical Research Institute".

A large number of researchers have passed through Barro Colorado and by 1930 , one hundred eighteen scientific papers had been published by naturalists who had studied on the island. Besides being an excellent administrator, Zetek continued with his scientific activities, becoming interested also in plants. "He collected fewer plants than most collectors of his time but his collections are among the most selective. Though Zetek was not a botanist by profession, his correspondence with Standley indicates that he had a keen botanical awareness" (Croat, 1978: 51). 
He collected several orchids, among which we can find Catasetum bicolor Klotzsch, Chondrorhyncha lipscombiae Rolfe, and Trigonidium egertonianum Batem. Standley dedicated to him several species in other plant families, such as Eugeniea zetekiana in the Myrtaceae and Saurauia zetekiana in the Actinidiaceae.

Other American collectors, 1900-1930. Other great North American institutions were also of importance for the biological exploration of Central America during the first decades of the XX century. Among them are the New York Botanical Garden, the U. S. National Museum and the Field Museum of Natural History of Chicago.

Robert Statham Williams (1859-1945) was a selfeducated naturalist who began his botanical collections in the mining fields of Alaska during the years of 1898 and 1899. A short time later, Williams came to the New York Botanical Garden with a position as an assistant. In 1901 he was sent by the Garden to South America, returning with a large collection of plants from Bolivia and Peru. Schlechter wrote about his collections in Bolivia: "The few orchids which I have seen are proof that the collection must contain many interesting things" (Schlechter, 1922b: 13). In 1903 he was sent to the Philippines and he made his last excursion in the first months of 1908, to Panama, where he collected in the region of Penonomé and the eastern provinces (Standley, 1928: 45-46). Ames described interesting new species of orchids among his collections in Panama: Oncidium ebrachiatum Ames \& C. Schweinfurth (Williams 975), Pleurothallis canae Ames (Williams 971), Pleurothallis praegrandis Ames (Williams 973), Pleurothallis williamsii Ames (Williams 976), Stelis parvibracteata Ames (Williams s.n.), and Stelis williamsii Ames (Williams 970).

Ellsworth Paine Killip (1890-1968) (Fig. 52D), a botanist, was raised in the State of New York and graduated from Rochester University in 1911. From 1919 he was part of the staff of the U. S. National Museum, becoming head curator in 1946, after Maxon's retirement. Killip specialized in the taxonomy of South American plants and traveled several times to Colombia, Venezuela, Peru, Brazil, Argentina, Chile and the Antilles. He collected on several occasions together with Maxon and
Standley. He lived in Balboa from September 1917 to May 1918, and during this time he made botanical collections to the east of Panama City. In the spring of 1922, while on his return from Colombia, he prepared another collection of plants in the area (Standley, 1938: 46-47). During his last excursion to Panama he collected some plants in Barro Colorado (1948). Killip made numerous collections of orchids from which some new species were described: Camaridium grandiflorum Ames (Killip 3565, Panama), Erythrodes killipii Ames (Killip 3561, Panama), Habenaria patentiloba Ames (Killip 3124, Panama), Ornithocephalus lanuginosus Ames (Killip 3314, Panama), Pleurothallis falcatiloba Ames (Killip 3540, Panama), Pleurothallis killipii Garay, and Scaphyglottis laevilabia Ames (Killip 3113, Panama). Other species were dedicated to him, such as Elleanthus killipii Garay and Epidendrum killipii Hágsater \& L. Sánchez Saldaña. In 1929 Killip worked for a period of time in Madrid, where he opened the old boxes containing the collections of the Royal Botanical Expedition to New Granada of José Celestino Mutis (1783-1808), until then forgotten and never studied. His 'rediscovery' led to the distribution of parts of the collections to different museums around the world and to a renewed interest in the work of Mutis.

Leslie Alva Kenoyer (1883 - ) came to Panama in 1927 and worked for some time at Barro Colorado, where he made important studies and published an important work on the ecology of the tropical rain forest of Barro Colorado. During his stay on the island he collected some 700 plants, that were the base for the publication of a supplement to the flora that Standley had previously published in 1927 (Kenoyer \& Standley, 1929). He collected some orchids, such as Habenaria alata Hook. (Kenoyer 249) and Scaphyglottis longicaulis S. Wats. (Kenoyer 251). Standley dedicated to him Solanum kenoyeri, in the Solanaceae.

Although important collections were made in Panama during the first three decades of the XX century, "until 1930 the collectors who came to Panama visited only a relatively small portion of the country and, with the notable exception of Henri Pittier, most collected in a relatively restricted area, many of them never leaving the region of the isthmus" (Croat, 1978: 49-50). 


\section{Paul C. Standley and the Central American floras}

"When we remember the incredible number of seeds produced by orchids, we wonder only that they do not dominate vegetation everywhere in the Tropics."

Paul C. Standley (1925: 377)

Paul Carpenter Standley (1884-1963) (Fig. 53A), botanist of the U. S. National Museum, arrived at the port city of La Libertad, El Salvador, on December 19, 1921. Thus arrived for the first time in Central America the man who was probably the most important figure in the history of botanical exploration of the region during the first half of the XX century. In a conversation with Otón Jiménez, Pittier said: "Much can be expected from such a young and capable element" (Jiménez, 1963: 2). For over forty years, Standley collected intensively in all of the countries of Central America and published a series of fundamental works about their floras. He acquired an intimate knowledge about the region, not only about its botanical aspects, but also about its culture and traditions. He was a friend of all Central American scientists of his time and contributed like no other person to further the study and research among the local naturalists and collectors, contributing to the development of the existing herbaria and to the creation of many new ones. "...Standley hoped that every Central American country would have a botanical library adequate for the study of its flora, and a comprehensive herbarium, formed by local collectors" (McCook, 1999: 119).

Standley was an indefatigable worker. "Nothing interrupted his work when he collected, except for the few seconds he needed to light a new cigarette on the butt of the old one" (Jiménez, 1963: 4). As a collector he was able to amass collections of hundreds of plants in only a few days and as a writer he produced more publications about the flora of Central America than any other botanist before or after him. "He spoke good Spanish and wrote even better in Latin..." (HeckadonMoreno, 1998: 167). He had a devilish work schedule of 12 to 14 hours a day, never married and was a chain-smoker: thus he spent his life. Standley's Trees and Shrubs of Mexico (1920-1926) is still one of the most important books on the subject, a publication "that alone exceeded the lifetime achievement of most botanists" (Williams, 1963: 27).
Standley published a short article in 1924 ('The Republic of El Salvador'), but the Lista preliminar de las plantas de El Salvador (Standley \& Calderón, 1925) was Standley's first work about Central American flora. Published together with Dr. Salvador Calderón (1879-1940), the list was based on more than 4,600 specimens that Standley and Calderón collected over a period of five months, from December 1921 to May 1922 (with the help of Dr. José Ma. Carrillo) and described more than 2,000 plants, including 63 species of orchids distributed in 28 genera. Among them we find Corymborkis forcipigera (Rchb. f. \& Warsz.) L. O. Wms. (Standley 20132 - Ahuachapán), Cattleya aurantiaca (Bateman ex Lindl.) P. N. Don (Standley 19977 - Ahuachapán) and Barkeria obovata (C. Presl.) Christenson (Standley 19429 - San Salvador). During the following decades, Standley returned often to El Salvador, where he had doctor Mario Levy van Severen as assistant and companion. Van Severen prepared a personal orchid herbarium that was later sent to Louis O. Williams and is now deposited at 'El Zamorano', in Honduras. Salvador Calderón (Fig. 53B) continued with Standley's work and to his efforts we owe the creation of the Salvadorian Herbarium, housed in the Salvadorian Directorate of Agriculture. This herbarium comprised, in 1922, over 2,000 collections of local plants. The genus Calderonia, from the family of the Rubiaceae, was dedicated by Standley to Dr. Calderón. As in all works written by Standley, it was Oakes Ames who identified the species of Orchidaceae contained in this list. While in El Salvador, Standley went to Guatemala (1922), from where we have his collection of Pleurothallis purpusii Schlechter (Standley 23901). Standley had his first experience with the orchids of Panama in the years of 1912-1914, when, as an assistant to Pittier, he was in charge of the classification and identification of the plants collected during the great expedition of the Smithsonian. Therefore, when the Governor of the Canal Zone wrote to the Secretary of Agriculture of the United States in 1921, asking for the best expert in tropical plants to prepare a book about the vegetation of the canal, Standley seemed to be the most logical choice (Heckadon Moreno, 1998: 167).

Standley arrived in Panama in November of 1923 and in the following five months collected 7,500 plant specimens in the Canal Zone. On January 17, 1924 and during a week in November of 1925 


\section{CABLEGRAM}

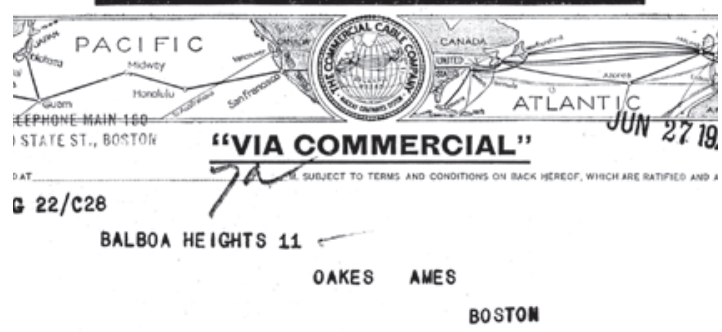

Found SELEUPEDIUM Chica pLANT PLeasant voyage

POWELL

\section{A}

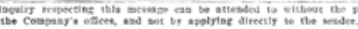

\section{C}

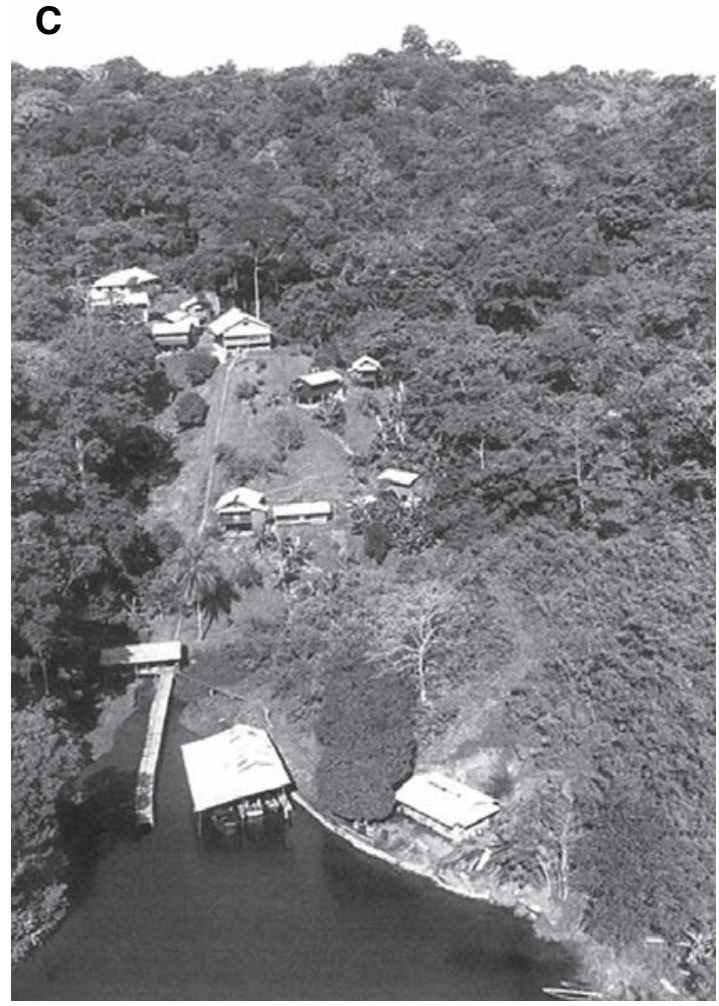

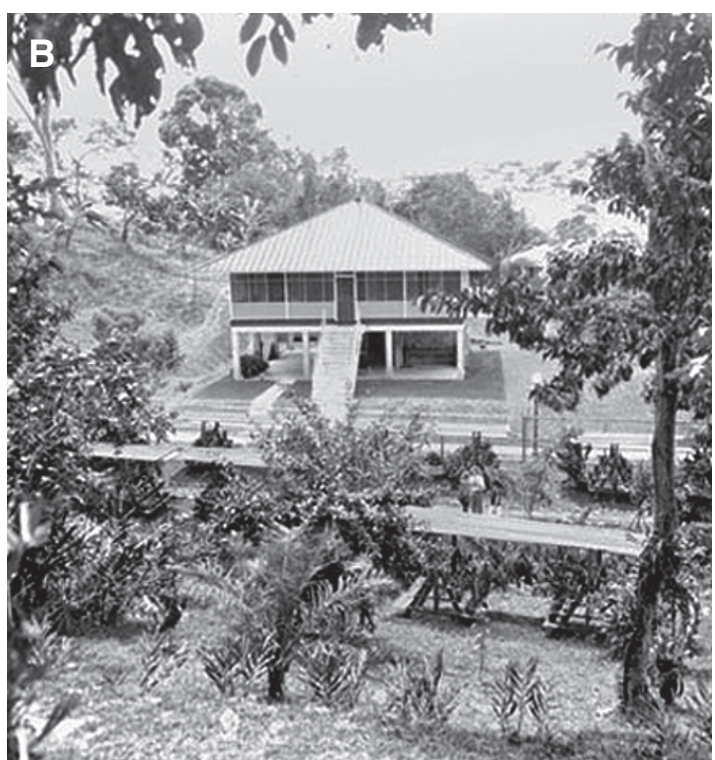

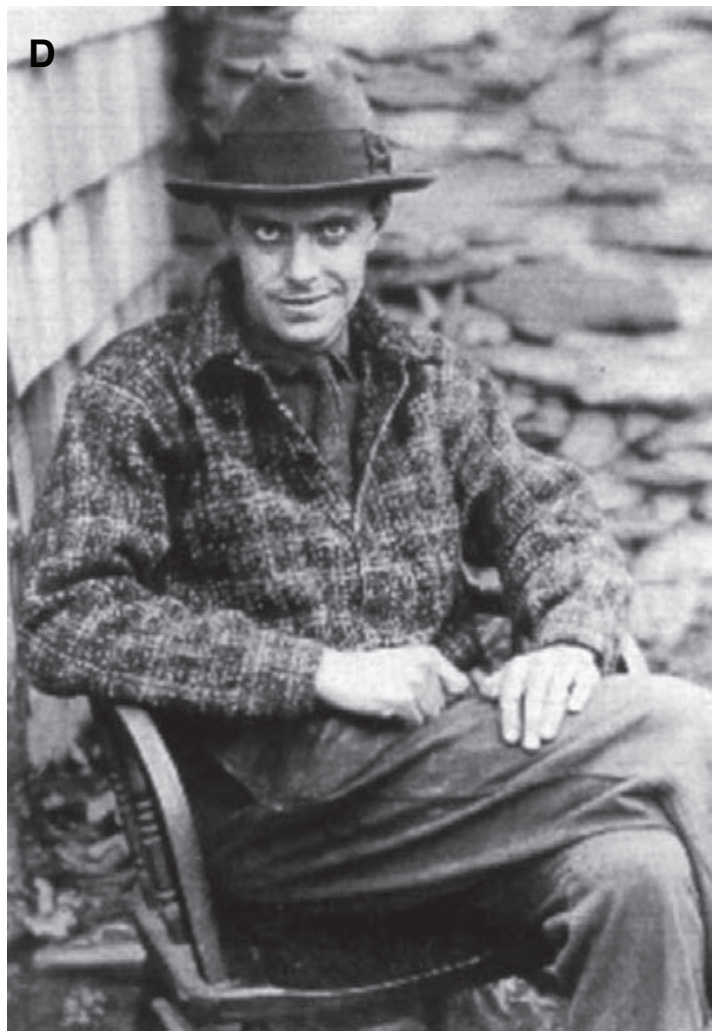

Figure 52. A - "Have found Selenipedium chica plant. Pleasant voyage. Powell". Courtesy of Dr. Gustavo Romero. B -

The Tropical Station of the Missouri Botanical Garden in 1928. Courtesy of the Missouri Botanical Garden. C - Aerial view of Barro Colorado. Courtesy of the Missouri Botanical Garden. D - Ellsworth Paine Killip (1890-1968). Courtesy of the Hunt Institute for Botanical Documentation. 

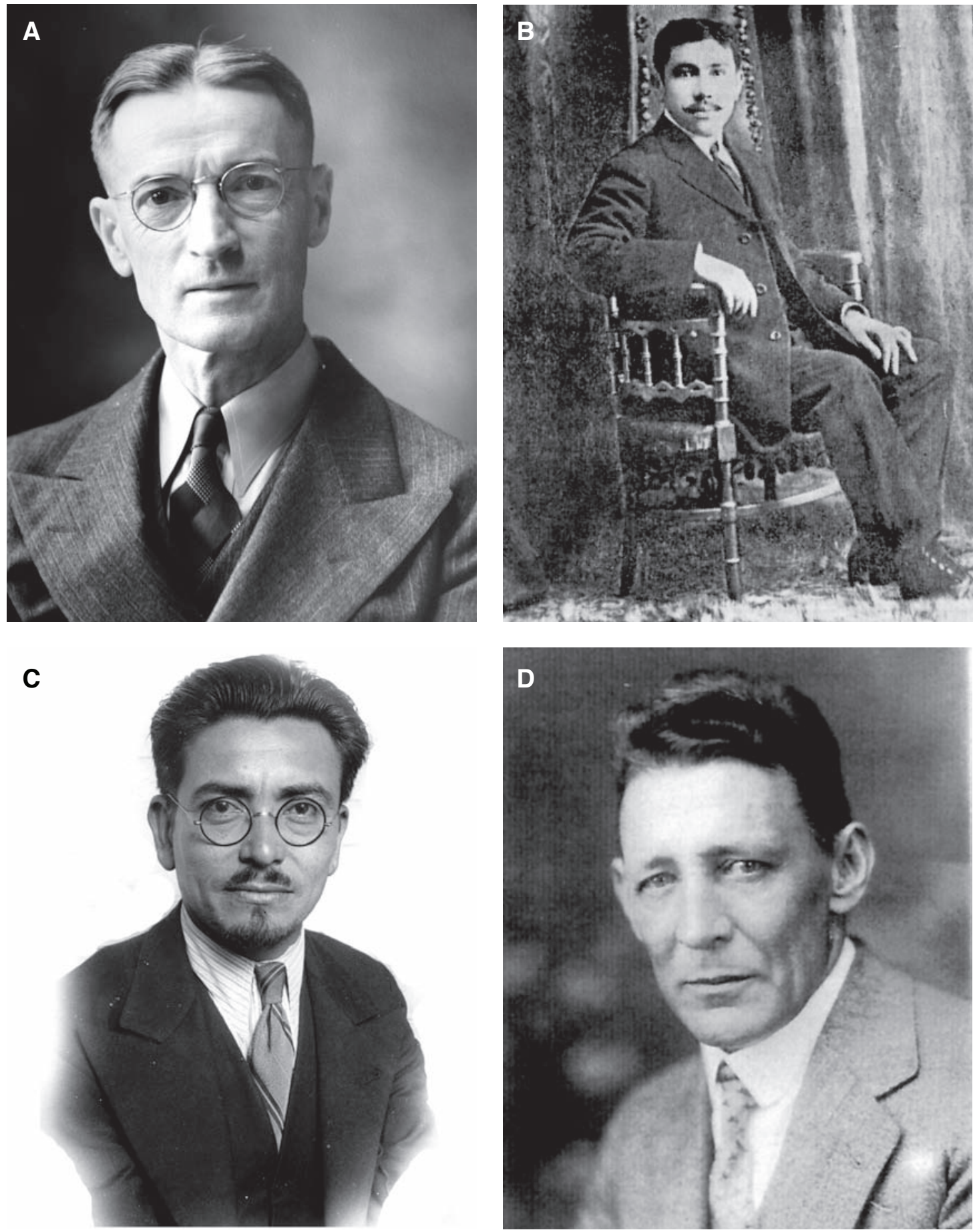

Figure 53. A — Paul Carpenter Standley (1884-1963). Courtesy of Jorge Gómez Laurito. B — Dr. Salvador Calderón (1879-1940). Frontispiece of Revista de la Escuela de Farmacia 3(37-38). C - Juvenal Valerio Rodríguez (1900-1971). Courtesy of his son, Juvenal Valerio. D - Wilhelm Heinrich Ferdinand Nevermann (1881-1938). Courtesy of Helga Nevermann. 
(during his second stay in Panama), Standley collected 800 additional plants on the island of Barro Colorado, recently established as a protected area. $\mathrm{He}$ also studied the specimens obtained in the XIX century by Fendler along the Chagres River and the collections of R. S. Williams, Pittier and Maxon. Standley's first work about the Panamanian flora was his Flora of Barro Colorado Island, published in 1927 by the Smithsonian Institution. As was previously mentioned, the collections by Kenoyer were the base for the publication of a first supplement to this flora (1929). A second supplement was published by Standley in 1930. "A botanist from the north can find no better place than Barro Colorado Island in which to make his acquaintance with the luxuriant tropical vegetation that is so unlike the plant life of the temperate regions..... Except for the lack of the expected brilliant flowers, which seldom or never materialize in lowland tropical forest, the newcomer will find his dreams of tropical plant life fully realized" (Standley, 1927: 7). "When Standley collected it was always with a view to writing a flora, and he tried to obtain as large a representation of species as possible" (Williams, 1963: 27). The monumental Flora of the Panama Canal Zone was published in 1928. In this flora, the section on Orchidaceae was again the work of Ames, who described 134 species in 57 genera.

The two visits by Standley to Panama were followed by extensive collecting trips to Costa Rica, a country that Standley visited during the first months of 1924 and then again between December of 1925 and March of 1926. Standley collected in Costa Rica an enormous amount of material (over 15,000 plant specimens) with the result of no less than 30 orchid species that were new to science. Worthy of mention are the following: Brachionidium pusillum Ames \& Schweinf. (Standley \& Valerio 49068), Brachionidium valerioi Ames \& Schweinf. (Standley \& Valerio 50759), Dichaea standleyi Ames (Standley 37440), Epidendrum anoglossoides Ames \& Schweinf. (Standley \& Valerio 50731), Epidendrum exiguum Ames \& Schweinf. (Standley \& Valerio 47036), Epidendrum guanacastense Ames \& Schweinf. (Standley \& Valerio 45089), Epidendrum triangulabium Ames \& Schweinf. (Standley \& Valerio 45970), Eurystyles standleyi Ames (Standley 33747),
Habenaria aviculoides Ames \& Schweinf. (Standley \& Valerio 42118), Lepanthes acoridilabia Ames \& Schweinf. (Standley 42717), Lepanthes standleyi Ames (Standley 33800), Lockhartia integra Ames \& Schweinf. (Standley \& Valerio 44675), Maxillaria chartacifolia Ames \& Schweinf. (Standley \& Valerio 45989), Maxillaria parvilabia Ames \& Schweinf. (Standley 32939), Maxillaria valerioi Ames \& Schweinf. (Standley \& Valerio 46940), Octomeria valerioi Ames \& Schweinf. (Standley \& Valerio 44769), Pleurothallis casualis Ames (Standley 36517), Pleurothallis quinqueseta Ames (Standley 36283), Pleurothallis simplex Ames \& Schweinf. (Standley \& Valerio 44023), Pleurothallis standleyi Ames (Standley 33607), Scaphosepalum standleyi Ames (Standley 34447), Stelis standleyi Ames (Standley 39483), Stenorrhynchos standleyi Ames (Standley 34429), Telipogon ampliflorus Schweinf. (Standley 42021), and Telipogon standleyi Ames (Standley 34120). In Costa Rica, Standley became acquainted with the most relevant naturalists of his time: Anastasio Alfaro, Alberto M. Brenes, Amparo de Zeledón, Otón Jiménez, Ferdinand Nevermann and Charles Lankester. He always remembered the gesture of the Lankesters in December of 1925, while he was collecting in the region of Santa María de Dota: "The writer has not forgotten that they sent a special messenger upon a two days' journey to bring a greeting at Christmas time"(Standley, 1937: 59).

Of special importance for the success of Standley's excursions and for his growing relationship with Central America was the figure of Juvenal Valerio Rodríguez (1900-1971). Recommended initially by Otón Jiménez, Valerio was Standley's companion during his first visit to Costa Rica during a short tour to the Bajo de la Hondura. When Standley returned in 1925, Valerio never left his side, being his guide to the region of Santa María de Dota and the Cerro de las Vueltas, in an extensive tour through Guanacaste and finally to the lowlands of the Atlantic coast.. The botanist Rubén Torres Rojas (1890-1978) was also a frequent companion of Standley and Valerio during their excursions across the country (Grayum et al., 2004: 20). Juvenal Valerio (Fig. 53C) was born in Santo Domingo de Heredia. He showed a true passion for nature since he was a boy and so clear was his vocation that in 1919 and 1920, during a leave of 
absence of the professor of Natural Sciences at the Normal School, Valerio was called to substitute for him, being at the same time a student and the teacher of his classmates.

In 1924 Juvenal Valerio was called by the Ministry of Education to assist Standley during his excursions in Costa Rica. Standley wrote in 1926: "I have great hopes in what Valerio will collect in Guanacaste. He knows now how to make collections and when he has gone out alone, he has made the greatest collections, larger than those of any botanist that I know" (Letter to Otón Jiménez, 1926). In 1937, Valerio was Director of the National Museum of Costa Rica. Through his relation with Standley, he was invited in 1940 as a special guest to the VIII Pan-American Scientific Congress in Washington, D.C. A short time later, in 1942, he became, together with Standley, one of the founders of the Pan-American Agricultural School "El Zamorano", in Honduras. Don Juvenal returned to Costa Rica and continued until his death dedicated to the study of the national flora, as a researcher at the Tropical Agricultural Center for Research and Education (CATIE), in Turrialba, and as a teacher at the University of Costa Rica. When he died, his body was carried to his home town, where he had asked to be buried. The whole country reacted in indignation when the local priest refused to let Valerio's remains into the church, for the only reason that he had been a mason. Many orchid species carry his name: Brachionidium valerioi Ames \& C. Schweinf., Lepanthes valerioi Luer, Maxillaria valerioi Ames \& C. Schweinf., Octomeria valerioi Ames \& C. Schweinf., Ornithocephalus valerioi Ames \& C. Schweinf. and Schiedeella valerioi (Ames \& C. Schweinf.) Szlach. \& C. J. Sheviak .

Standley and Valerio planned to publish a flora of Costa Rica in Spanish. Valerio argued to his superiors that a Spanish edition was essential so that it would be accessible to naturalists, students and the public of Costa Rica. But Valerio's hopes vanished after the elections in the spring of 1936. Although the first fascicles were published, the new government, due to the economic crisis, cancelled the publications of all works of general interest, including the Flora de Costa Rica. The Field Museum of Chicago published the Flora of Costa Rica in four parts, between October of 1937 and November of 1938. 979 species of Orchidaceae were mentioned in its Part I (1937). "[Valerio] was a tireless worker, always patient and considerate, even when he had frequent reason for provocation to quite other moods. His kindness and friendship will always be treasured by one who often has sorely tried both" (Standley, 1937: 60-61).

From November 1927 to March 1928 Standley explored the region of Tela, in the northeastern coast of Honduras, using as his headquarters the Experiment Station of Lancetilla, of the Tela Railroad Company. With the collaboration of Wilson Popenoe, director of the station, and of Victor M. Cutter, president of the United Fruit Company, Standley wrote a Flora of Lancetilla Valley that was published in 1931. Standley enumerated in this work 50 species of Orchidaceae in 25 genera. Oakes Ames was again responsible for the determination of the orchids, as was usual in all of Standley's floras. One year earlier, in 1930, Standley had published a Flora of Yucatán (Standley, 1930b), in which he mentioned 21 species of orchids in 13 genera. However, Standley admitted that he had never visited the region and that his work was based solely on herbarium specimens. "Of the various floras prepared by the present writer, this is the only one covering a region in which he has not himself collected. His personal experience with the Yucatan flora is a remote and intangible one, consisting as it does of a view of the low green shore from the deck of a ship bound southwards to Guatemala" (Standley, 1930b: 166). In fact, the orchids enumerated by Standley were those collected by George Gaumer some years earlier. Finally, Standley prepared, in collaboration with his good friend S. J. Record, The forest and flora of British Honduras (1936). Samuel Jones Record (1881-1945) collected in Guatemala, Belize and Honduras between 1926 and 1927 and was in Belize with Standley in 1936. In this work, Standley and Record mentioned 21 species of orchids in 13 genera. One of the few specimens of orchids collected by Record was Erythrodes querceticola (Lindl.) Ames (Record s.n., Belize). The story of Standley and the orchids of Central America does not end here. We will come back to this great character in the next chapters, because Standley would continue to be an outstanding figure in the history of the Central American flora until his death in 1963.

Wilhelm Heinrich Ferdinand Nevermann (1881- 
1938) (Fig. 53D), was born in Hamburg and arrived in Costa Rica on board of the steamer "Reventazón", of the United Fruit Company's Great White Fleet in October 1909, having graduated with honors as a mechanical engineer a few years earlier. After exploring the whole country and having formed a family, Nevermann acquired in 1918 a farm which he called 'Hamburgo', in El Cairo de Siquirres, in the Atlantic region of Costa Rica. While investigating the insects that attacked his banana plantations, an interest arose in Nevermann by which he became not only one of Costa Rica's most important entomologists, but a world authority on this subject. The call by the German government after World War I to all German citizens living abroad to help refurbish the collections of the German museums that had been destroyed was followed by Nevermann, who with increasing frequency sent his insect collections to Germany. In these years he established close relations with Berlin's Museum and Botanical Garden. But Nevermann "not only sent insects but also plants. There is a beautiful white orchid, Coryanthes nevermannii, which we owe to him" (Anonymous, 1938: 341). This reference is curious because there is no record of an epithet 'nevermannii' in the international registers of botanical nomenclature. The answer to this riddle can be found in a letter by Rudolf Schlechter to Nevermann dated May 8, 1925: "The two orchids which were sent to me interested me vividly. The double inflorescence with the big pendent flowers is a new species of Coryanthes, which I will soon describe as Coryanthes nevermannii Schltr. It is the first species of Coryanthes that until now I have known from Costa Rica. It is for me a special pleasure to dedicate this plant to you. Not smaller interest raised the slender-leaved Vanilla. This one also has not yet received a name. It will carry your name as Vanilla nevermannii Schltr." (Letter from Schlechter to Nevermann, May 8, 1925). Schlechter died six months later, in November 1925, and the species dedicated to Nevermann were never published. When in 1943 Schlechter's herbarium was consumed by the bombs, all evidences of Nevermann's collections disappeared. Thus we will never know for sure which species correspond to Coryanthes and Vanilla nevermannii. Last mentioned was Coryanthes nevermannii by Charles Lankester in his manuscript
Costa Rican Orchids, when he writes about the orchids of the Atlantic coast of Costa Rica: "Another 500 feet of elevation brings Stanhopea ecornuta, Aspasia epidendroides and rarities like Coryanthes nevermannii into the picture, ..." (Lankester, 1944: 16). and in a letter to Ames from 1928: "Coryanthes nevermannii - I cannot find publication of this name, but Nevermann certainly told me Schlechter had dedicated it to him. I ... will write to Nevermann for confirmation" (Letter from Lankester to Ames, December 4, 1928).

Schlechter had previously described a new orchid species based on a collection by Nevermann: Gongora unicolor Schltr. (Las Mercedes, Ebene von Limon - Nevermann, im November 1921) and mentioned another of his collections: Trichocentrum brenesii Schltr. (Nevermann s.n., without indication of locality).

In 1936 Nevermann took over the Chair of Entomology at the National School of Agriculture. A short time later he died in an unfortunate accident. During the night of June 30, 1938, while studying the nocturnal behavior of a species of ant, he was shot by the son of a neighbor who mistook him for an intruder. He died three days later in the United Fruit Company's hospital in Puerto Limón and his remains were buried in the Lutheran Cemetery of San José (Anonymous, 1938: 334). Standley visited Nevermann in his farm, where he collected several species of orchids. "To Mr. Ferdinand Nevermann there are special obligations for a most pleasant and profitable visit to his fincas in the lowlands along the Reventazón River. Enviable is the botanist who receives a welcome from so considerate a host, or visits the forest with so competent a guide" (Standley, 1937: 59). Among Standley's orchid specimens we find at least one new species collected at the finca 'Hamburgo' of Ferdinand Nevermann: Lepanthes confusa Ames \& Schw. (Standley \& Valerio 48709, Costa Rica: Limón: Hamburg Finca, on the Rio Reventazón below Cairo, alt. 55 m).Standley dedicated to Nevermann several species in other plant families, among them Dichapetalum nevermannianum in the Dichapetalaceae and Ardisia nevermannii in the Myrsinaceae. Other botanists visited Nevermann, among them Carroll W. Dodge, who in 1930 collected in his farm a specimen of Cryptarrhena lunata $\mathrm{R}$. Br. (C.W. Dodge 7757). 


\section{Northern Central America: 1900-1930}

"Poor Mexico, so far from God and so close to the United States."

Porfirio Díaz, Mexican dictator

During the first decades of the XX century, El Salvador, Honduras and Nicaragua remained largely unexplored, with the exception of the regions where the United Fruit Company established its experimental stations in the banana plantations of the Atlantic. After Standley, these three countries were completely forgotten by orchidology for nearly fifty years. If one observes the collections of the main herbaria, it becomes clear that the number of specimens collected was ridiculously small as compared with the work that was done in Guatemala, Costa Rica and Panama. And leaving out L. O. Williams' list of 1956, nothing was published about the orchids of these countries until well into the second half of the XX century.

After Standley's Flora of the Lancetilla Valley, and with the sole exception of a brief account in the work by Yuncker (1938), nothing else was ever written about the orchidaceous flora of Honduras.

El Salvador did not fare much better, with the exception of the works of David Joaquín Guzmán Martorell (1843-1927). Guzmán received his doctorate in Medicine in Paris (1863-1868), which he concluded with his Essai de topographie physique et médicale de la République de El Salvador, Amérique Centrale (1869). He was founder and first director of the National Museums of El Salvador and Nicaragua (in the company of the naturalist Diocleciano Chaves, 1897), as well as of the Botanical Garden of San Salvador, in May of 1886. The first National Exhibition in 1904, which took place in the Model Farm of San Salvador (today the National Zoo) was also organized by him. Guzmán wrote Especies útiles de la flora salvadoreña (San Salvador, 1918 and 1926), in which he described 900 species of the flora and mentioned fifteen species of orchids native to his country (the showier ones), which he considered only from the point of view of their usefulness (as Vanilla pompona Schiede) or ornamental value, adding some instructions for their cultivation. The list of orchids of El Salvador of David Guzmán is based on a previous study by Dr. Darío González (1833-1910), who, together with Guzmán, was a pioneer of the botanical study of the country. Both were loyal followers of the liberal philosophy, anticlericals who believed in laic education as the principal tool for the development of the country and who held important positions in El Salvador's educational institutions. Guzmán and González played an active role in the campaign that led to the expulsion of the Order of the Jesuits from El Salvador (1872). According to González, the most important Salvadorian orchid species were Epidendrum atropurpureum, Epidendrum radicans, Epidendrum ciliare, Arpophyllum spicatum, Cattleya skinneri, Cattleya aurantiaca, Lycaste suaveolens, Stanhopea bucefalus, Odontoglossum grande, Oncidium ampliatum, Trichopilia tortilis, Trichopilia suavis, Vanilla pompona, Odontoglossum salvadorense and Laelia rubescens. Additionally he mentions several species that are grown in El Salvador and were introduced from Mexico, Guatemala, Costa Rica and Panama. Guzmán had a close relation to the Costa Rican naturalists of his time and in his works he frequently mentions Pittier and Wercklé. The French Félix Choussy, an engineer of the National Agronomy Institute of Paris, directed during the first years of the century the School of Agronomy of San Salvador. Several fascicles on the Salvadorian flora, based on Choussy's herbarium, were published years later (Choussy, 1976). Four species of orchids were mentioned: Habenaria alata Hook., Cattleya skinneri Batem., Sobralia macrantha Lindl and Stanhopea costaricensis Rchb. f. The Lista preliminar de las plantas de El Salvador (1925) by Standley and Calderón was published in 1925, but it was Hamer, in 1974, who began the systematic study of the orchids of the country, with the publication of his Orquideas de El Salvador (Hamer, 1974 \& 1981).

In Nicaragua, Diocleciano Chaves (1844-1936), together with the Brothers of La Salle Antonio Garnier and Artemio René, accomplished great botanical work in the area around Managua (1923-1929), gathering over 6,000 collections, some of them in the company of William R. Maxon. In 1886 he received the commission from President Zelaya to establish the National Museum. The museum was inaugurated 
in 1900 and its first director was the aforementioned Salvadorian David J. Guzmán. Antonio Garnier would continue his botanical collections until 1938. Under his specimens we find Maxillaria tenuifolia Lindl., Epidendrum lacustre Lindl., Prosthechea chacaoensis (Rchb. f.) W.E. Higgins, Cyclopogon elatus (Sw.) Schltr., Cattleya aurantiaca (Bateman ex Lindl.) P.N. Don and Lockhartia amoena Endres \& Rchb. f. Miguel Ramírez Goyena (1857-1927), third director of the National Museum of Nicaragua, published 1909 a Flora nicaragüense (1909) in which he mentioned 94 species of orchids. "A flora of Nicaragua published in 1909-1911 probably is not really a flora of Nicaragua, and so far as I know was not based on specimens. A persistent rumor has it that this 'flora' was written in Honduras but funds could not be found to publish it there. The title was changed and funds found for publication in Nicaragua. Many plant names do not represent plants found in any Central American country" (Williams, 1972: 205). However, Ramírez Goyena was important in the development of the natural sciences in Nicaragua. The herbarium of the Autonomous National University of Nicaragua-León carries his name. After this, seventyfive years had to pass until F. Hamer began his long series of publications (beginning in 1982) about Nicaraguan orchids, with the first fascicle of Icones Plantarum Tropicarum (Hamer, 1982-1985). One of the few collections of Orchidaceae that we know from Nicaragua during this period is that of Franz Eccarius Schramm (1873-1949), a missionary of the Moravian Evangelical Church who in 1924 collected the type of Campylocentrum sullivannii Fawc. \& Rendle (Schramm s.n., Costa de los Mosquitos).

The cause for the slow advance of the botanical sciences during this period can perhaps be found in the statement of Pérez Brignoli: "Education played a secondary role. The ambitious plans of common education, typical of the liberal period, remained, with the exception of Costa Rica, on paper. The vast majority of the rural population never escaped illiteracy. In the national budgets, the assignments for 'Public Instruction' were always surpassed by the expenses of the military. The universities had a mediocre existence, reduced to the formation of lawyers and a few other liberal professions..." (Pérez Brignoli, 1985: 140).
Yucatan, Guatemala, Belize and Honduras. One of the largest collections of plants from Yucatán was that of Georg Eduard Seler (1849-1922) and his wife Caecilie Seler-Sachs (1855-1933). Eduard Seler, without doubt, stands out among the numerous German researchers who dedicated their life to the study of the national and cultural history of Mexico and Central America. Since the last years of the XIX century, Seler's writings were fundamental to the study of the autochthonous Mesoamerican cultures, so much that Seler became the 'father of American studies', both in Germany and in Mexico. The merits of his wife Caecilie must also be credited. She was Seler's companion on all of his travels, which could be financed thanks to her personal wealth. Caecilie Seler made important investigations, complementary to those of her husband, wrote and published the travel journals and edited the works of her husband after his death. She was also an extraordinary pioneer in natural and archeological photography. The Selers collected in Guatemala and Chiapas between 1887 and 1899; in Yucatán in 1902-1903; in Yucatán and Campeche in 1907 and again in Yucatán in 1911. Th. Loesener published an interesting account of their travels in Plantae Selerianae (Loesener, 1899 \& 1906) with descriptions of the orchids by R. Schlechter.

Among their Guatemalan collections Schlechter described four new species: Epidendrum papyriferum Schltr. (Seler 2316, Huehuetenango), Microstylis minutiflora Schltr. (Seler 2347, Huehuetenango), Habenaria selerorum Schltr. (Seler 2492, Alta Verapaz), named in his honor, and Stelis guatemalensis Schltr. Other collections by Seler mentioned by Ames were: Epidendrum cochleathum L. (Seler 2328), Epidendrum diffusum Sw. (Seler 2320), Habenaria limosa (Lindl.) Hemsl. (Seler 2294), Nageliella angustifolia (Booth ex Lindl.) Ames \& Correll (Seler 2623), Odontoglossum bictoniense (Batem.) Lindl. (Seler 2326), Oncidium suttoni Batem. ex Lindl. (Seler 2454), and Spiranthes cinnabarina (Llave \& Lex.) Hemsl. (Seler 2396).

Albert Wendt (1887-1958), a collector of German origin, was in Guatemala in 1900 and collected the type of Lepanthes oreocharis Schltr. (A. Wendt s.n.). The botanist Orator Fuller Cook (1867-1949) and the geologist Robert Fiske Griggs (1881-1962) collected in Guatemala between 1902 and 1906. In the year of 1903 Cook spent a brief time in Costa Rica and 
visited also Chiapas in 1906. Cook had graduated from Syracuse University and was later employed by the New York State Colonization Society, making three trips to Liberia to prepare for the 'repatriation of the American Negro'. In 1898 he entered the service of the United States Agricultural Department and was in charge of the introduction of tropical plants. He was an authority on pre-Columbian agriculture.

Robert F. Griggs would later be famous for directing the expeditions to Alaska of the National Geographic Society between 1915 and 1919. From Cook and Griggs we have several collections of Orchidaceae, all made in Guatemala: Cyrtopodium punctatum (L.) Lindl. (Cook \& Griggs 368), Leochilus labiatus (Sw.) O. Ktze. (Cook \& Griggs 24), Pleurothallis circumplexa Lindl. (Cook \& Griggs 456), Scaphyglottis confusa (Schltr.) Ames \& Correll (Cook \& Griggs 401), Scaphyglottis minutiflora Ames \& Correll (Cook \& Griggs 267), Scaphyglottis prolifera Cogn. (Cook \& Griggs 840), and Spiranthes funckiana A. Rich. \& Gal. (Cook \& Griggs 66).

“... A young botanist from the United States collected nearly a thousand numbers in Belize between 1905 and 1907... Morton E. Peck (1871-1959) probably doubled the number of Belize specimens which then existed in the world's herbaria" (Balick et al., 2000: 15). It was the first large collection to come from the colony (Williams, 1972: 203). Before Peck's arrival, the region was practically unknown botanically. Peck came to Belize sponsored by the Iowa State College and collected mainly in the region of the Manatee River (district of Belize). His specimens were identified by B. Robinson of the Gray Herbarium and we find among them 53 species of plants new to science. Among Peck's collections we find Corymborkis forcipigera (Rchb. f. \& Warsz.) L.O. Williams (Peck 610), Habenaria mesodactyla Griseb. (Peck 966) Huntleya fasciata Fowlie (Peck s.n.), and Huntleya lucida (Rolfe) Rolfe (Peck s.n.).

Charles Clemons Deam (1871-1959) began collecting plants in the last years of the XIX century, when his doctor ordered long walks to counteract ill effects of his job. From then on he dedicated most of his time to botanical interests. At first he considered the whole world his subject and made some trips to Central America at the turn of the century to collect plants there. Soon after, though, he decided to concentrate on Indiana and by the end of his career claimed that he had been in and collected plants from every township of the state. By the time he gave his herbarium to Indiana University it contained at least 63,000 specimens, some of which he was first to identify. Deam traveled to México in 1900 (he collected in Oaxaca and Morelos) and to Guatemala in 1904 and 1909, where his collections centered on the regions of Zacapa, Izabal and Petén. In Guatemala he discovered the type of Epidendrum deamii Schltr. (Deam 6198, Guatemala) and collected many other orchids, such as: Epidendrum adenocarpum La Llave \& Lex. (Deam 6249B), Epidendrum aromaticum Batem. (Deam 6073), Epidendrum chinense (Lindl.) Ames (Deam 212), Nageliella purpurea (Lindl.) L. O. Williams (Deam 6084), and Spiranthes tonduzii Schltr. (Deam 96). Charles Deam had a strong, frequently violent temper. He became a botanist of world fame although he never earned a university degree. In his honor, his admirers named Lake Deam, in Hoosier National Park. Three universities gave him honorary titles.

William Ashbrook Kellerman (1850-1908) was the first professor of Botany at the University of Eastern Ohio and founded the herbarium of this learning center in 1891. In 1905 he began a series of travels to Guatemala, convincing the University to approve the idea of a School of Tropical Botany. Unfortunately, Kellerman's career ended abruptly, a fatal victim of a tropical disease during his fourth excursion to Guatemala. Ames \& Correll mention some of his collections of Orchidaceae in Guatemala: Epidendrum clowesii Batem. ex Lindl. (Kellerman 6036), Laelia glauca (Lindl.) Benth. (Kellerman 5566), Maxillaria densa Lindl. (Kellerman 6703), Maxillaria variabilis Batem. (Kellerman 7043), Prescottia tubulosa (Lindl.) L. O. Williams (Kellerman 5577), and Spiranthes hemichrea Lindl. (Kellerman 6564).

In 1904, U. S. botanist George P. Goll ( - ), who worked for the Smithsonian Institution, collected several species of orchids in Guatemala, among them the type of Cranichis pseudociliata Schltr. (Goll 205). Goll also collected: Campylocentrum micranthum (Lindl.) Rolfe (Goll 71), Cranichis sylvatica A. Rich. \& Gal. (Goll 205), Habenaria monorrhiza (Sw.) Rchb. f. (Goll 172), Oncidium ensatum Lindl. (Goll 135), and Sobralia decora Batem. (Goll 48). 
Frederick Lewis Lewton (1874-1959), collaborator of the Smithsonian Institution, made several collections of Orchidaceae in Guatemala during the year 1906, among which we find specimens of: Dichaea hystricina Rchb. f. (Lewton 439), Dichaea panamensis Lindl. (Lewton 272), Notylia barkeri Lindl. (Lewton 276), Oncidium pusillum (L.) Rchb. f. (Lewton 293), Oncidium sphacelatum Lindl. (Lewton 305), and Scaphyglottis minutiflora Ames \& Correll (Lewton 268). In 1912, Lewton was named curator of the Division of Textile Plants of the U. S. National Museum. He is remembered in Polygala lewtonii Small (Polygalaceae), collected by him in 1894.

Theodore Dru Alison Cockerell (1866-1948), a man who was an internationally known scientist, a prolific writer, and a highly regarded teacher at the University of Colorado in Boulder, was the elder brother of the noted British scholar Sir Sydney Cockerell and labored in relative obscurity in America while his brothers and their families were basking in the limelight of smart British society. He became the greatest specialist on bees in the world. His contribution to the understanding of wild bees is monumental and by 1938 he had published the names and descriptions of 5,480 new species and subspecies. Of special interest to this story is his discovery of "the orchid bee" Euglossa imperialis Cockerell (1922), the most abundant orchid bee in lowland forest in Panama. Cockerell published his Notes on Lycaste (1919), where he described Lycaste alba (Dombrain) Cockerell as a new species, based on living plants that his wife had brought from Guatemala several years earlier. Rolfe refuted the new species, that has since then been maintained as a variety of Lycaste skinneri (Bateman ex Lindl.) Lindl.

Sidney Fay Blake (1892-1959) was a precocious botanist, who at the age of 18 had already written three important papers on botanical matters. He graduated from Harvard University and in 1918 was named assistant botanist of the U. S. Department of Agriculture. He traveled in this position to Honduras and Guatemala in 1919. In this last country he collected some orchids: Spiranthes guyanensis (Lindl.) Cogn. (Blake 7609), and Spiranthes tortilis (Sw.) L. C. Rich. (Blake 7567). Blake became famous for his work Geographical Guide to the Floras of the World, which he published together with Alice Cary Atwood (Blake, 1942-1961).
Joseph Harry Johnson (1894-1987) arrived in Guatemala in December of 1919 and made very important collections in the region of Alta Verapaz. A dozen new species were described among Johnson's collections: Epidendrum neurosum Ames (Johnson 141), Epidendrum pachyrachis Ames (Johnson 305), Epidendrum prorepens Ames (Johnson 234), Lepanthes appendiculata Ames (Johnson 879), Lepanthes inaequalis Schltr. (Johnson 886), Lepanthes johnsonii Ames (Johnson 420), Pleurothallis abjecta Ames (Johnson 905), Pleurothallis amethystina Ames (Johnson 878), Pleurothallis johnsonii Ames (Johnson 901), Pleurothallis samacensis Ames (Johnson 765), Stelis chihobensis Ames (Johnson 939), and Stelis johnsonii Ames (Johnson 252).

Herbert Spinden (1879-1967) was born in South Dakota. During his teen years, he worked on the railroad and eventually went to Alaska in search of gold. Spinden went on to attend Harvard University from 1902 until 1909, where he received his Ph.D. in Anthropology. In 1920 he took the position of curator at the American Indian Art and Primitive Cultures Museum at the Brooklyn Institute and spent the rest of his life studying the Mayan civilization. He visited the main archeological sites in Yucatán, Guatemala, Honduras and Belize. He tried unsuccessfully to convince Ames to travel with him to Yucatan. During one of his trips to Central America in 1923, and probably induced by Ames, he collected several species of orchids in the north coast of Honduras and in Guatemala: Brassia caudata (L.) Lindl. (Spinden s.n., Honduras), Chysis bractescens Lindl. (Spinden s.n., Guatemala), Epidendrum cochelatum L. (Spinden s.n., Guatemala), Epidendrum condylochilum Lehm. \& Kraenzl. (Spinden s.n., Guatemala), Epidendrum stamfordiaunum Batem. (Spinden s.n., Guatemala), Ionopsis utricularioides (Sw.) Lindl. (Spinden s.n., Honduras), Maxillaria densa Lindl. (Spinden s.n., Guatemala), Maxillaria tenuifolia Lindl. (Spinden s.n., Guatemala), Meyracyllium trinasutum Rchb. f. (Spinden s.n., Guatemala), Oncidium sphacelatum Lindl. (Spinden s.n., Guatemala), Scaphyglottis behrii (Rchb. f.) Benth. \& Hook. (Spinden s.n., Honduras), Stelis perplexa Ames (Spinden s.n., Honduras), and Pleurothallis ophiocephala Lindl. (Spinden s.n., Guatemala). Later, in 1924, he published a work on which he had been working on for four years and with 
the subject of the reduction of the Maya dates. In this, he gave the correlation of dates with our calendar and the Maya calendar. In 1930, John E. Teeple proved the dates to be wrong, a devastating blow to Spinden. He spent the rest of his life defending his correlation.

Winslow Roper Hatch (1908- ) and Carl Louis Wilson (1897-) collected in Guatemala in 1926. We know their specimens of Habenaria quinqueseta (Michx.) Sw. (Wilson 39B), Brassavola nodosa (L.) Lindl. (Wilson s.n.), Pleurothallis dolichopus Schltr. (Hatch \& Wilson 369), Pleurothallis glandulosa Ames (Hatch \& Wilson 344) and Maxillaria purpurea (Spreng.) Ames \& Correll (Hatch s.n.). Hatch collected later in Costa Rica (1937).

Clayton Dissinger Mell (1875-1945), who had worked with Record on Timbers of Tropical America (1924), collected in Nicaragua and Mexico (Oaxaca, Veracruz and Chiapas) between 1923 and 1945. From Chiapas we have his collection of Bletia tenuifolia (Mell 2084, 1933).

Duncan Stevenson collected from 1927 until 1929 together with J. N. Oliphant ( - ) in the Cayo district of Belize and in the Cockscomb Mountains. Among his collections we find Sobralia bradeorum Schltr. (Stevenson s.n.).

Of much greater importance was Cyrus Longworth Lundell (1907-1994) who collected in Guatemala, Belize, Yucatán, Quintana Roo and Honduras in the years of 1928-1938. Lundell collected a large number of specimens and the plants of Belize and Guatemala constitute an important base for his numerous publications of the plants of the Maya regions, especially his monumental work The Vegetation of Peten (1937). Types of new species of Orchidaceae discovered by Lundell were: Pleurothallis yucatanensis Ames \& C. Schweinf. (Lundell 912, Yucatán), and Ponthieva parviflora Ames \& C. Schweinf. (Lundell 1213, Campeche). Among other collections of orchids by Lundell we find: Habenaria bractescens Lindl. (Lundell 3324, Guatemala), Dichaea muricata (Lundell 6552, Belize), Vanilla planifolia Andrews (Lundell 164, Guatemala), Sobralia decora Batem. (Lundell 2961, Guatemala), Spiranthes guyanensis (Lindl.) Cogn. (Lundell 3704, Guatemala), Spiranthes orchioides (Sw.) A. Rich. (Lundell 3484, Guatemala) and Stelis ciliaris Lindl. (Lundell 2141, Guatemala). In 1933 Lundell was in charge of supervising the collections of Percival Gentle in Belize (see later). Thus he became one of the foremost experts in the flora of the region. His later explorations in the region of Petén were fundamental for the completion of Ames $\&$ Correll's work on the orchids of Guatemala and Belize. Of great importance was also the botanical expedition to Yucatán and Quintana Roo, undertaken by Lundell from May through August, 1938 (See Lundell, 1938).

Conrad Vernon Morton (1905-1972), botanist and a world authority in ferns, collected during a period of time in Guatemala (1928), from where we know of his specimens of: Epidendrum chinense (Lindl.) Ames (Morton 425), and Isochilus major Cham. \& Schlecht. var. amparoanus (Schltr.) Correll (Morton 263). Morton came to the Smithsonian as assistant of the Division of Plants of the U. S. National Museum. In 1948 he was appointed Curator of the newly established Division of Ferns, Department of Botany. Morton was made Senior Botanist in 1970, a position he retained until his death.

During the same period (1928) Hugh Charles Sampson (1878-1953) and John Sidney Karling (18981995) came to Belize, where they collected some specimens of Orchidaceae: Catasetum integerrimum Hook (Sampson s.n.), Clowesia russelliana (Hook.) Dodson (Sampson s.n.), Encyclia bractescens (Lindl.) Hoehne (Sampson s.n.), Encyclia chacaoensis (Rchb. f.) Dressler \& Pollard (Sampson s.n.), and Oncidium carthagenense (Jacq.) Sw. (Karling s.n.).

A very significant series of collections of plants were made by William A. Schipp (1891-1967), beginning in 1929 and continuing for many years. Schipp, of Australian origin, came to Belize determined to make his living as a botanical explorer. His Flora of British Honduras, Price List of Seeds and Herbarium Material (1933-34) is really only a list of his collections and emphasizes items for sale (Balick et al., 2000: 18). Schipp had among his clients the main herbaria of Europe and the United States. Determinations were made by Paul C. Standley at The Field Museum in Chicago and forwarded to Schipp in exchange for a set of duplicates.He collected several orchids (all in Belize), among which we find: Bletia purpurea (Lam.) DC. (Schipp 782), Brassia maculata R. Br. (Schipp S-843), Campylocentrum micranthum (Lindl.) Maury (Schipp 8-841), Campylocentrum poeppigii (Rchb. 
f.) Rolfe (Schipp S-39), Chysis laevis Lindl. (Schipp S-838), Corymborkis forcipigera (Rchb. f. \& Warsz.) L. O. Williams (Schipp 8-302), Ionopsis utricularioides (Sw.) Lindl. (Schipp 917), Jacquiniella equitantifolia (Ames) Dressler (Schipp 852), Masdevallia tubuliflora Ames (Schipp S-102), Oncidium ensatum Lindl. (Schipp 780), Ornithocephalus bicornis Lindl. ex Benth. (Schipp S-839), Pleurothallis marginata Lindl. (Schipp 918), and Psygmorchis pusilla (L.) Dodson \& Dressler (Schipp 879). Shipp's collections in Belize and Guatemala were of excellent quality and as many as 154 were types for new taxa. His departure from Belize in 1937 marked the end of a golden age of sorts. During his tenure a Department of Forestry was active and numerous articles and several books were published about the flora.

Joseph Charles Comeille Bequaert (1886-1982), a Belgian naturalist who would become years later the foremost expert in the freshwater mollusks of the Belgian Congo, collected in Yucatán, near the famous ruins of Chichén Itzá, during the year of 1929. Shortly thereafter he went on to Guatemala, where he collected, among others: Dichaea muricata (Sw.) Lindl. (Bequaert 47), Habenaria repens Nutt. (Bequaert 50), Spiranthes trilineata var. thelymitra (Rchb. f.) L. O. Williams (Bequaert 6), and Stelis bidentata Schltr. (Bequaert 48).

The first known collection of Orchidaceae by James Beach Edwards is the type of Octomeria hondurensis Ames (Edwards 304, Lago Yojoa, Honduras), that is dated October 29, 1929. From then on and until March 1934, we find at least thirteen new species which Edwards discovered, most of them described by Ames, for whom Edwards worked: Bletia edwardsii Ames (Edwards 24), Bletia papillifera Ames (Edwards 277), Epidendrum comayaguense Ames (Edwards 333), Epidendrum cystosum Ames (Edwards 675), Epidendrum dickinsonianum Withner (Edwards 400), Epidendrum edwardesii Ames (Edwards 122), Habenaria hondurensis Ames (Edwards 267), Hexadesmia hondurensis Ames (Edwards 334), Oncidium hondurense Ames (Edwards 101), Pleurothallis comayaguensis Ames (Edwards 338), Pleurothallis oscitans Ames (Edwards 515), Sobralia edwardsii Ames (Edwards 299), and Vanilla insignis Ames (Edwards 407). Edwards spent apparently a short time in Guatemala, from where we know of only one collection: Maxillaria elatior (Rchb. f.) Rchb. f. (Edwards 609, November 1933). In a letter from Ames to Lankester we read: "Mr. J. B. Edwards has been finding some interesting orchids in Honduras, near Tegucigalpa, He has turned up some of the fine old things that used to appear in collections forty years ago but have given way to the unpraiseworthy craze for hybrids" (June 11, 1933). He seems to have been a discriminating and careful collector. After almost four years of collecting in Honduras, he gathered no more than 750 orchids; however, the number of new species is proportionally very high.

\section{Other collectors in Mexico during the first years of the $\mathrm{XX}$ century}

“...a good many German and Belgian collectors have been here; I would have found more plants if it was not for that".

C. A. Purpus

(In a letter to Brandegee, January 1907)

The botanical exploration of southern Mexico stopped almost completely for a long time, due to the chaos that reigned in the country and the perils to which naturalists (especially U. S. citizens after $1916^{38}$ ) were exposed during the violent years of the Mexican Revolution. During a great part of the history of Mexico, a small minority had control of both power and the largest part of the country's wealth, while the majority of the population lived in misery. As the gap between rich and poor widened during the dictatorship of General Porfirio Díaz, the low classes lost their political voice. Opposition to Díaz surged when Francisco Madero, educated in Europe and California, initiated a series of strikes throughout the country. Díaz was forced to hold elections in 1910, and although he tried to ignore the results, he was forced to resign in 1911. Madero became president but found opposition in Emiliano Zapata, who was not willing to wait for the orderly implementation of the agrarian reform that Madero proposed. Thus began a time in

\footnotetext{
${ }^{38}$ In response to an attack by the troops of Pancho Villa to the city of Columbus (New Mexico), the United States sent troops to invade Mexico. This generated a strong anti-American feeling among the Mexican population and was often the cause for violent actions against citizens of this country.
} 
which the country divided itself in the support of different factions, and groups of 'guerrilleros' swept the countryside, destroying and burning haciendas and ranches. Madero was taken prisoner and executed and the country lived in a state of chaos and disorder during many years. Pancho Villa dominated the north and several groups fought for political power. Finally, Venustiano Carranza came to the Presidency and organized an important convention that promulgated the Constitution of 1917, still in force, and in which the agrarian reform played an important role. Carranza was followed by others who continued his reforms and who founded, years later, the 'Partido Revolucionario Institucional' (= 'Revolutionary Institutional Party'), that became the dominant political force during the following 70 years. The Botanical Garden of the Forest of Chapultepec was founded in 1922, with Alfonso Herrera as director. It would become over the years one of the fundamental institutions in the botanical research of Mexico.

Cyrus Guernsey Pringle (1838-1911) (Fig. 54A) was one of the first North American and European botanists who arrived in Mexico in the last years of the XIX century and first decades of the XX, and collected extensively in the Pacific states of the United States, Cuba (1903) and in Mexico (between 1880 and 1909). In 1902, Pringle was appointed curator of the herbarium at the University of Vermont, where he deposited his large collection of plants. At the time of his death he had accomplished a surprising amount of botanical work. He had distributed to various herbaria over 500,000 specimens of some 20,000 different species. Among these, 29 new genera and over 1,200 new species could be found. Pringle was called "the Prince of botanical collectors". His Mexican collections were described in Plantae Mexicanae, published in parts in the periods between 1885-1887 and 1889-1906. In our area of study, Pringle collected two new species of orchids: Pelexia pringlei Fernald (Pringle 8122, Veracruz), Spiranthes pringlei S. Watson (Pringle 8197, Veracruz). Many others were dedicated to him, among them: Corallorhiza pringlei Greenm., Cyclopogon pringlei (S. Watson) Soto Arenas, Encyclia pringlei (Rolfe) Schltr., Epipactis pringlei Gand., Habenaria pringlei B.L. Rob., Malaxis pringlei Ames, Microstylis pringlei S. Watson, and Pleurothallis pringlei Schltr.

The first orchids collected by Pringle were described by Benjamin Lincoln Robinson (1864-1935), who had been assistant to Sereno Watson at the Gray Herbarium and whom he succeeded as curator in 1892. Robinson held this position with almost no interruptions until his death. Robinson described Habenaria pringlei in 1892 in Descriptions of new plants collected in Mexico by C. G. Pringle and Isochilus unilateralis in 1894 in Descriptions of new and hitherto imperfectly known plants collected in Mexico by C. G. Pringle.

In the history of the Missouri Botanical Garden Jesse More Greenman (1867-1961) played a preeminent role. Greenman made important collections in Mexico in the years of 1906-1912 and in 1922 traveled through Central America, where he collected between January and April in Panama, Costa Rica, Nicaragua and Guatemala. From this journey we have the following specimens of orchids: Pleurothallis floribunda Poepp. \& Endl. (Greenman 5481, Costa Rica), Stelis $s p$. (Greenman 5492, Costa Rica), Sobralia powellii Schltr. (Greenman 5788, Nicaragua), and Cohniella cebolleta (Jacq.) Christenson (Greenman 5906, Guatemala). But Greenman's importance is not primarily based on his collections, but on his position of curator of the herbarium of the Missouri Botanical Garden, a position he held from 1913 until 1948, a period in which he gave enormous support to students and collectors to collect in the American tropics, using as headquarters the Tropical Station which the Garden had founded in Panama in 1926 (Riley, 1995: 20). Under Greenman's supervision students were formed of the stature of Mildred Mathias and above all Julian Steyermark, who with the years would become an important figure in our history. The herbarium increased during his tenure from 600,000 to $1,500,000$ specimens. Robert Woodson, assistant and successor of Greenman, began the project of the Flora of Panama, that was published between the years of 1943 to 1980 and gave a great impulse to the orchidology of the southern part of our region (D’Arcy, 1980). Greenman was honored by L. O. Williams in his description of Bletia greenmaniana, a new species described from a specimen collected by Bourgeau in 1865 in the region of Orizaba, Mexico (Bourgeau 2812). In 1898 Greenman described several new species of orchids in Diagnoses of new and critical Phanerogams: Corallorhiza involuta Greenm., and Corallorhiza pringlei Greenm., and in 1900, in New species and varieties of Mexican plants (Orchidaceae): 
Spiranthes pringlei var. minor Greenm., Spiranthes nelsonii Greenm., and Spiranthes tenuiflora Greenm.

"Without any doubt, Carlos Alberto Purpus [18511942] figures among the most productive of collectors who have been in our country. His collections in Mexico possibly exceed 17,000 examples..." (Sousa Sánchez, 2002). After having completed his studies in Pharmacy, Purpus traveled in 1887 to the United States, to collect plants for a nursery in Darmstadt, Germany, the city where he had studied. He visited Mexico for the first time in 1898, collecting on the peninsula of Baja California and in 1905 he arrived at Veracruz, at the Hacienda El Mirador of Florentino Sartorius in Zacuapam, Veracruz. Zacuapam would be his residence and center of operations for the rest of his days. In 1907, Purpus was named a botanical collector, without pay, of the University of California, Berkeley. His collections of Mexican plants would be in charge of Townshend Stith Brandegee, who would make the determinations. The collections by Purpus led to a series of articles published by Brandegee, between 1909 and 1912, under the title of Plantae Mexicanae Purpusianae. The Mexican Revolution broke out shortly after Purpus had settled in Veracruz. Purpus wrote: "Because of the conditions of insecurity that prevail in many states, I could only explore in Veracruz and part of Puebla. Thus, I visited Tehuacán and Esperanza. It would have been very risky to make more distant excursions. The Zapatistas were everywhere" (In a letter to Brandegee, 1914). The year 1908 was one of the pleasantest of Purpus' life in Mexico: he was visited by his brother, Joseph Anton, who worked as an inspector of the Botanical Garden of Darmstadt (Germany) in the company of his chief, director of said garden, and by his friend Brandegee. "In 1913 he made a series of trips to Chiapas, a state in which there are data [from his collections] until 1925. His localities in Chiapas are always related to coffee plantations, property of Germans who emigrated from Guatemala during the 1890's, especially to the region of Soconusco" (Sousa Sánchez, 2002). In 1915 a period of recession begins, owing to lack of communication, and to the dangers implicit in the Revolution. During this period the letters of Purpus are a series of dreams that the normal lines of communication may return soon, of unrealized plans of future visits to Chiapas and even to South America. Otto Nagel, of whom we will talk later and who became a good friend of Purpus, came to Veracruz in 1925 and stayed at his house for several years (Hartmann, 1968: 191). But Purpus never left El Mirador. There he died, in the hacienda that will always have a place of honor in the history of the orchids of northern Mesoamerica, on January 17, 1941, being 90 years of age. Purpus collected many orchids, among them the following ones, new to science. Many of them carry his name: Encyclia purpusii Schltr. (Purpus s.n.), Epidendrum incomptoides Ames (Purpus 299), Govenia purpusii Schltr. (Purpus 2613), Lepanthes congesta R. E. Schultes (Purpus 1355), Odontoglossum purpusii Schltr. (Purpus s.n.), Pleurothallis purpusii Schltr. (Purpus s.n.), Sarcoglottis purpusiorum Schltr. (Purpus s.n.), Scaphyglottis purpusii Schltr. (Purpus 2153), Stanhopea purpusii Schltr. (Purpus s.n.), Stelis confusa Schltr. (Purpus 2122), and Stelis purpusii Schltr. (Purpus 2111). His friend and mentor Brandegee honored him with a genus of the Rosaceae: Purpusia.

Johann Heinrich Rudolf Schenck (1860-1927) had collected in Namibia (German West Africa) in 1885 and Brazil (1885-1887), from where we know of his collection of the type of Pogoniopsis schenckii Cogn. (Schenck 2765, Rio de Janeiro). In 1908-1909 he collected in Mexico in the company of Joseph Anton Purpus, brother of C. A. Purpus. During a short time they coincided at the hacienda El Mirador with T. S. Brandegee. Schenck was known for his Text Book of Botany at High Schools (1894), that was used until the second half of the XX century, and for the publication of the famous Vegetationsbilder (= 'Images of nature'), that were published between 1902 and 1920.

While the intention of Brandegee was to prepare herbarium specimens, J. A. Purpus and Dr. Schenck collected primarily living plants, especially succulents, that were to form part of the collection of the Darmstadt Botanical Garden. The work rhythm to which C. A. Purpus was accustomed, plus the hardships of the regions through which they traveled, were too much for the European botanists; J. A. Purpus fell ill with malaria and Dr. Schenck with intestinal problems. On October 14, 1909, they embarked in Veracruz for the return journey to Europe (Sousa Sánchez, 2002). Among his Mexican collections Schlechter discovered the type of Epidendrum subuliferum Schltr. 
(Schenck 673). Cogniaux and Kraenzlin dedicated several species to him, among them: Epidendrum schenckianum Kraenzl., Habenaria schenckii Cogn., Stelis schenckii Schltr., and Zootrophion schenckii (Cogn.) Luer.

The exact date in which Sander hired the French collector Louis Forget (- 1915) (Fig. 54B) is not clear. However, it is said that he had started collecting for Sander thirty years before he died (Swinson, 1970: 224). This puts the beginning of his colleting activity for the St. Albans firm at around 1885. On the other side, in a letter to Sander dated May 27, 1897, Forget writes: "Being forced to return to England by your disgraceful treatment I received from your house which has thoroughly disgusted me, I have determined to resign my post as a collector ... It is now seven years since I started collecting for you, and I think you should have had more confidence in me ... as I have always done my best for you". This would put the date of his initial contract with Sander at 1890. Anyway, although he collected for Sander for a long period of time, and was in his contract almost until his final day, it is clear that his relations with his employer were not always happy. After this letter, Forget came home, but soon his problems were sorted out and he was back in the jungles. But to judge from his correspondence, the money situation did not improve: "I am perplexed... I do not know what to do ... when will you send the draft?" (Swinson, 1970: 128). Forget collected mainly in South America, but in 1910 he was sent to Mexico, in the search of Laelia gouldiana. Forget arrived in Veracruz in November of 1910, with an order from Sander which read: "When you find the plant I would like 3,000 as quickly as you can send them.” Forget finally found the plant, after only four days of search. On February 10, 1911, Sander wrote to the director of the Royal Botanic Gardens in Kew: "It is 23 years since I collected this beautiful species, and until Monsieur Forget sent this consignment no plants had been collected... This Laelia flowers at Christmas ... over two hundred spikes, each carrying many flowers, and Forget writes it was a dazzling and wonderful sight" (Swinson, 1970: 191-193). Several orchids were dedicated to him: Brassia forgetiana Sander, Cattleya forgetiana Rolfe, and Masdevallia forgetiana Kraenzl. Sander brought in 1917 Epidendrum tricarinatum to flower, Forget's last discovery from Peru. "This bright purple flower was to serve as Forget's epitaph, for he had died of a heart attack in Rennes on the $10^{\text {th }}$ August, 1915. Of him Sander wrote: 'He was absolutely fearless out in the forests, but disliked intensely the noise and bustle of London and any large town. ... Louis Forget was every inch a man" " (Swinson, 1970: 226).

Per Karl Hjalmar Dusen (1855-1926) was an important Swedish botanist who collected mainly in Brazil. Born in Vimmerby, he studied at the Technical University of Stockholm and traveled in 1901 to Brazil, where he worked as an assistant at the National Museum in Rio de Janeiro. Kraenzlin described his collections (1921) and the epithet dusenii is frequent in the orchidaceous flora of that country. From one of his collections in Parana he was honored with a new orchid species Cryptophoranthus dusenii Schltr. He was in Mexico around 1912 and collected the type of Epidendrum heteroglossum Kraenzl. (Dusen s.n., Veracruz). He collected over 84,000 plants during his life. His herbarium is at the Imperial Museum for Natural History in Stockholm (Anonymous, 1949: 33). Charles Russell Orcutt (1864-1929) had collected in Baja California between 1882 and 1886 and came to Veracruz in 1910, where he collected Dichromanthus cinnabarinus (La Llave \& Lex.) Garay (Orcutt 4286) and the type of Schiedella pubicaulis (L. O. Williams) Burns-Bal. (Orcutt 5056).

The Lancetilla Experiment Station. It seems strange to talk about somebody who was an expert in avocados in a history about orchids. Frederick Wilson Popenoe (1892-1975) established in 1925 the Lancetilla Experiment Station as a farm for the research on banana of the United Fruit Co. The name Lancetilla derives from a small but very spiny indigenous palm (Astrocaryum standleyanum) whose spines have the shape of small lances and is found with relative frequency in the valley of Tela. The land on which the station is located, eight kilometers to the south of Tela, was originally the property of the Atlantic Fruit Co. and was later transferred to the United Fruit Co. Although Lancetilla was established originally for the research on bananas, it very soon expanded its activities. Thanks to Popenoe's efforts, research was extended to other areas. When Popenoe left Lancetilla in 1941, the garden's collection contained 764 varieties of plants, 636 species, 392 genera and 105 families 
on a total of 78 hectares. The United Fruit Company kept control and maintained the station until 1974, when the gardens were donated to the government of Honduras. The government neglected the installations, causing the loss of many of the precious plants. After several years under government control, the garden was transferred to the administration of the ESNACIFOR, the National School for Forestry Sciences. Since then, Lancetilla has managed to become auto sufficient and very productive as a center of research and production. Under the name of Lancetilla Botanical Garden, it is the second in importance of its kind in the world.

In 1929 Wilson Popenoe and his wife acquired the ruins of a colonial mansion in Antigua, Guatemala, and began a complete restoration. Today, occupied by their daughters, 'Casa Popenoe' is one of the most important colonial buildings in Antigua and a must-see for any tourist. Finally, Wilson Popenoe became in 1942 the founding director of the Pan American Agricultural School "El Zamorano", near Tegucigalpa, of which we will talk later. Popenoe received honorary degrees from Pomona College and the University of Florida and many awards in recognition of his work from scientific societies and foreign governments.

He was during his whole life a passionate researcher on avocados (Persea americana) and traveled across the American continents in search of new species to improve those that were under cultivation. His most important discoveries were the base for his Manual of Tropical and Subtropical Fruits, published in 1920. Standley dedicated to him many species of other families, among them Begonia popenoei from the Begoniaceae and Ficus popenoei from the Moraceae.

Lancetilla has only an indirect relation to our history. But during many years it was a place that attracted naturalists from all over the world, who used the Experiment Station as their headquarters and made great contributions to the knowledge of the flora of the region. As Standley wrote: "Never have I worked amid such agreeable surroundings, with so many comforts, and with so many conveniences for the successful prosecution of field work. Fortunate are those who have the opportunity of working in such a congenial atmosphere as prevails in Lancetilla" (Standley, 1931: 49).

In the neighboring town of San Pedro Sula, the brothers Héctor and Tito Pérez Estrada established a private botanical garden, at the same time of the establishment of Lancetilla. Wilson Popenoe wrote: “... the brothers Pérez Estrada are two unique characters in Honduras, as their garden is unique not only in this country but in the whole territory between Mexico and Panama... For many years they have cultivated hundreds of exotic plants that have been introduced from all regions of the world, transforming this garden into a beautiful flower garden of Nature..." (Escoto, 2002: 102-103). The garden was reestablished in 1994 under the name of 'Jardín Botánico Municipal Pérez Estrada'. Tito Pérez Estrada was considered the first botanist of San Pedro Sula. To him we owe the only known biographical sketch about the life of Dr. Karl Thieme (Estrada, 1952).

\section{From the 'GoOd Neighbor' POLICY TO WORLD WAR II}

\begin{abstract}
"In the field of world policy I would dedicate this nation to the policy of the good neighbor - the neighbor who resolutely respects himself and, because he does so, respects the rights of others".
\end{abstract}

Franklin Delano Roosevelt

President Franklin Delano Roosevelt (1882-1945) took office in 1933 determined to improve relations with the nations of Central and South America. Under his leadership the United States emphasized cooperation and trade rather than military force to maintain stability in the hemisphere. Roosevelt's Secretary of State, Cordell Hull, participated in the Montevideo Conference of December 1933, where he backed a declaration favored by most nations of the Western Hemisphere: "No state has the right to intervene in the internal or external affairs of another". Roosevelt stated, "The definite policy of the United States from now on is one opposed to armed intervention". In 1934, at Roosevelt's direction, the 1903 treaty with Cuba that gave the United States the right to intervene to preserve internal stability or independence was abrogated. Although domestic economic problems and World War II diverted attention from the Western Hemisphere, Roosevelt's Good Neighbor policy represented an attempt to 
distance the United States from earlier interventionist policies, such as the Roosevelt Corollary and military interventions in the region during the 1910s and 1920s. The Great Depression in the United States was a hard blow to the Central American economies. "The Central American countries, small producers in the concert of nations, were extremely vulnerable to the fluctuations of the external situation. Their economies were not diversified and the main export products -coffee and bananas- where nothing but 'dessert' on the tables of the European or American consumers" (Pérez Brignoli, 2000: 127-128). Their societies were marked by deep social inequalities that soon led to the formation of the first labor unions and the first communist parties in the region. Central America led a political life of exclusions. "In practice, the life of the liberal institutions and laws was above all this: an immense monologue of the ruling classes with themselves" (Pérez Brognoli, 2000: 129). Coups d'etat, controlled elections and candidates imposed by the government were the rule in political life.

The concentration of power in a few hands and the preeminence of the military produced such typical dictators as Manuel Estrada Cabrera (1857-1948), in Guatemala, the 'Señor Presidente' in Miguel Ángel Asturias' magnificent novel. After Cabrera, Guatemala was ruled from 1931 to 1948 by General Jorge Ubico (1878-1946), "Educator and Protector of the Youth".

It was General Jorge Ubico who signed the presidential decree declaring Lycaste skinneri var. alba as the National Flower of Guatemala, on February 11, 1934. He followed the recommendation of Mrs. Leticia M. de Southerland, president of the International Flower Exhibition held in Miami in 1933.

General Maximiliano Hernández Martínez (18821966) served as president of El Salvador from 1931 to 1944. His regime was a strict dictatorship that suppressed a Communist-led uprising during its initial days in office, with an estimated number of fatalities of between 10,000 and 30,000. Nicaragua and Honduras followed similar paths. While Nicaragua in 1934 came under the rule of the Somoza dynasty, that would control the country until 1979, Tiburcio Carías Andino (1876-1969), "Doctor and General", ruled in Honduras from 1933 to 1948 with a very strong hand for the Hondurans and a white glove for the United Fruit Company.
To the South, Costa Rica and Panama became the exceptions. In Costa Rica, although the country suffered as much as its neighbors from the results of the economic world crisis, regular elections were held during this period. Political life in the country was only disrupted by the great strike in the banana plantations of the Atlantic region (1934) and by the short civil war of 1948. Panama battled hard to maintain its democratic regime, with the omnipotent United States often being the judge over bitterly fought political campaigns.

To the North, Lázaro Cárdenas (1891-1970) was elected president of Mexico in 1934 and founded the National Revolutionary Party, predecessor of the present Institutional Revolutionary Party. Under the slogan of "Mexico for the Mexicans", Cárdenas confronted the United States after expropriating the foreign oil companies. His six-year term marked a turning point after the turbulent post-revolutionary years and was a period of political stability, characterized by important advances in education and public works. In Belize, still a British colony, Antonio Soberanis Gómez (18971975) became in 1934 a strong union leader and a precursor of the independence movement.

\section{Orchidology in Central America, 1930-1950}

"When we solve the riddles of the forests, we will know the history of tropical life".

Rehn (1927: 26)

After the deaths of Rolfe (1921), Schlechter (1925) and Kraenzlin (1934), European Botany lost its ground in Central America, and orchidology became an American monopoly that would last until the present days. At Harvard, Ames and Schweinfurth continued working on the Orchidaceae of Central America in an enormous personal effort that lasted until the end of their lives. But the botanical exploration of the region came more and more under the influence of two great institutions: the Field Museum of Natural History in Chicago and the Missouri Botanical Garden at Saint Louis.

When Paul C. Standley joined the staff in 1927, the interests of the Field Museum centered mainly on Mexico, Guatemala and Belize. During the XX century, the Museum sponsored or co-sponsored more than sixty botanical expeditions to the American tropics.

The Missouri Botanical Garden became the leading 

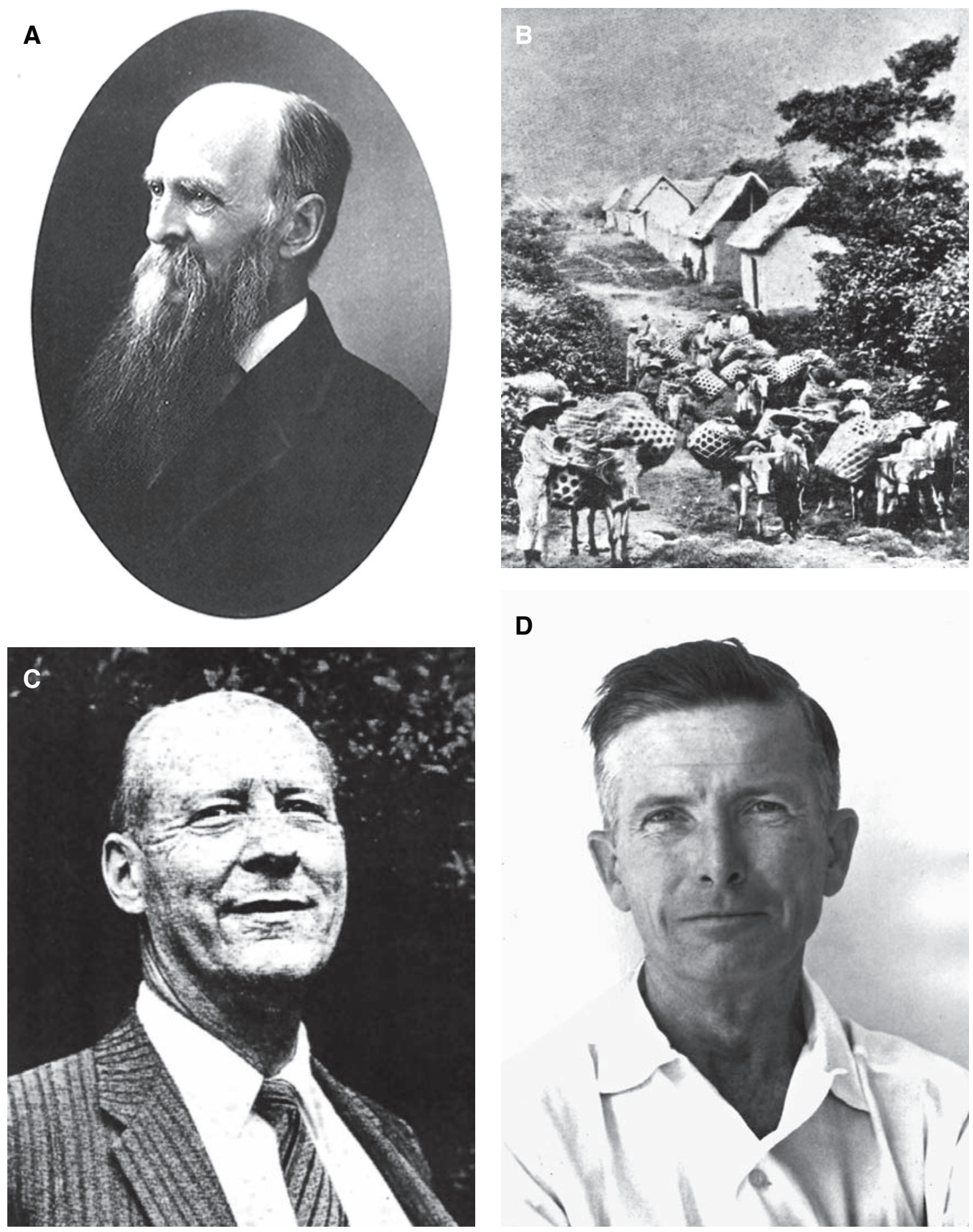

Figure 54. A — Cyrus Guernsey Pringle (1838-1911). Courtesy of the Oakes Ames Herbarium, Harvard University. B Louis Forget on his way through a village in Colombia with a consignment of Cattleyas collected for Sander. In Black, 1973: 66. C — Robert Everard Woodson (1904-1963). In Anderson \& Van Schaak, 1964: 46. D — Paul Hamilton Allen (111-1963). Courtesy of L. D. Gómez. 

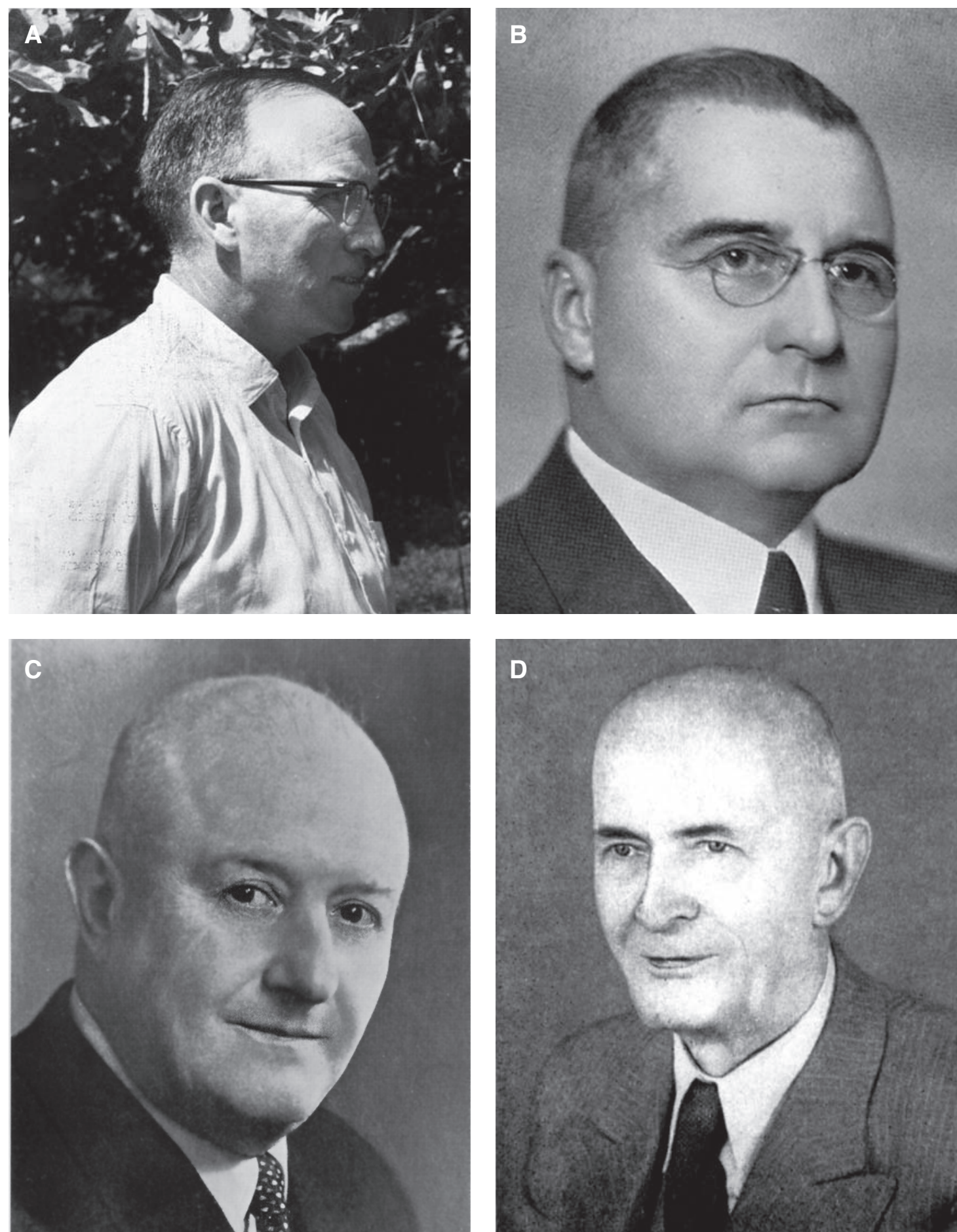

Figure 55. A — Louis Otho Williams (1908-1991). Courtesy of L. D. Gómez. B — Otto Porsch (1875-1959). Courtesy of Ronald Díaz Bolaños. C — Giorgio Cufodontis (1896-1974). Courtesy of Ronald Díaz Bolaños. D — Walter Kupper (1874-1953). Courtesy of Günter Gerlach. 
institution in the research of the orchids of Panama, especially after Paul H. Allen arrived at the Tropical Station in 1934. Both the Field Museum and the Missouri Botanical Garden established the world's major collections of Central and South American plants.

\section{The Flora of Panama (I)}

"In the western hemisphere, the mountainous area comprising the present Republics of Costa Rica, Panama and Colombia probably has the richest, and most highly developed of the several complex orchid floras..."

Paul H. Allen (1953: 20)

In the 1930s and 1940s, a number of resident and foreign botanists had collected orchids in Panama. However, although Pittier had included the country's orchids in the final reports of the biological survey of the Smithsonian (1912), Schlechter had published his Orchidaceae Powellianae Panamenses (1922) and the Orchidaceae were part of Standley's floras of Barro Colorado (1927) and the Canal Zone (1928), no formal orchid flora of Panama would be published until the last years of the first half of the XX century.

"[French-born] A. M. Butcher, who had changed his name from Bouché, brought his family to the isthmus in 1907 and went to work for the Canal on the construction of the Gatún Spillway and hydroelectric plant that supplied the electricity and power to run the Canal" (Anonymous, 1970: 3). Two sons of Butcher (or Bouché) are important in our story. One of them, Adrien, kept his original French family name; the other, Henry, went along with his father and named himself Butcher.

During his many years on the Isthmus, Adrien M. Bouché (1898 - ) "spent his spare time rambling around the country as a botanist, researching local plants and passing on the information he gathered to drug companies, research laboratories and other scientific institutions.... His extensive plant research has not been limited to pharmaceutical plants alones. Bouché has also devoted many years to collecting and studying flowering plants and parasites and has several varieties of orchids named for him"(Anonymous, 1970: 3). Among his collections is the type of Sobralia bouchei Ames \& Schweinf. (A.M. Bouché s.n.- 1930). Other collections by Bouché include Oncidium ochmatochilum Rchb. f. (A.M. Bouché 9), Epidendrum oncidioides var. ramonense (Rchb. f.) Ames, Hubb. \& Schweinf. (A.M. Bouché 10), and Sobralia atropubescens Ames \& C. Schweinfurth (A.M. Bouché 2755).

Henry P. Butcher was known for his keen knowledge of the orchids of Panama and collected for more than 50 years between 1933 and 1986, although he had never received any botanical education. He lived in the area of Volcán, province of Chiriquí, and among his specimens we find Sievekingia suavis Rchb. f. (Butcher s.n.), Kegeliella kupperi Mansf. (Butcher s.n.), Stanhopea pulla Rchb. f. (Butcher s.n.), Coryanthes maculata Lindl. (Butcher s.n.), Telipogon dendriticus Rchb. f., and the type of Gongora maculata Lindl. var. latibasis C. Schweinf. \& Allen (Butcher s.n.). Dressler wrote to him, with some frustration: "This business of new species turning up in two or three places at once is unnerving. It makes me wonder if we really know anything about Central American orchids or not" (Letter from Dressler to Butcher, July 1, 1963). So many species were discovered thanks to Butcher's collections that Dressler wrote to him in 1963: "Cal [Dodson] and I have been talking for a couple of years of doing a supplement to the Orchids of Panama. ... There have been many species added to the flora of Panama since the orchid section was published, especially through your collections..." (Letter from Dressler to Butcher, May 10, 1963). Named in Butcher's honor were: Dryadella butcheri Luer, Masdevallia butcheri Luer, Pleurothallis butcheri L.O. Williams, Sievekingia butcheri Dressler, Stelis butcheri Luer, Stellilabium butcheri Dressler, Telipogon butcheri Dodson \& R. Escobar. Of interest are Butcher's Notes from Panama (1959 \& 1965), where he describes his orchid collecting adventures in that country. Butcher had a life-long relation with the Missouri Botanical Garden and with many renowned botanists from his time: Louis Williams, Walter Lindsay, Alex D. Hawkes, Alphonse Heller, Robert E. Woodson, Leslie A. Garay, Carl Withner, Clarence Horich, P. Allen, Robert L. Dressler and Charles Schweinfurth.

E. D. Starry collected in Panama in July and August, 1931. Among his specimens we find Palmorchis powellii (Ames) C. Schweinf. \& Correll (Starry 323) and Catasetum viridiflavum Hook. (Starry 119). 
Otis Shattuck collected several orchid specimens between 1931 and 1937, such as Elleanthus trilobulatus Ames \& C. Schweinf. (Shattuck 123), Pleurothallis verecunda Schltr. (Shattuck 722), Pleurothallis ovatilabia Ames \& C. Schweinf. (Shattuck 226), Epidendrum stangeanum Rchb. f. (Shattuck 454) and Epidendrum moyobambae Kränzl. (Shattuck 216). Miconia shattuckii Standl. of the Melastomataceae was named in his honor.

Robert Hugo Woodworth (1902 - ) and Paul Anthony Vestal (1908 - ) were in the Canal area in February and March of 1932. Among their over 700 collections are Epidendrum anceps Jacq. (Woodworth \& Vestal 66a), Epidendrum ibaguense H.B.K (Woodworth \& Vestal 703), Scaphyglottis behrii (Rchb. f.) Bent. \& Hook. (Woodworth \& Vestal 592), Catasetum viridiflavum Hook. (Woodworth \& Vestal s.n.), and Trigonidium egertonianum Batem. (Woodworth \& Vestal 593). We remember Woodworth in Machaerium woodworthii Standl. of the Fabaceae and Vestal in Ipomoea vestalii Standl. of the Convolvulaceae.

Russell Jacob Seibert (1914 - ) came to the country in 1935 and collected in the Canal Zone, Chiriquí and Bocas del Toro until 1940, often in the company of Woodson and Allen. His orchid specimens include Habenaria bicornis Lindl. (Seibert 326), Cleistes rosea Lindl. (Seibert 594), Elleanthus capitatus (Poepp. \& End1.) Rchb. f. (Seibert 140), Palmorchis trilobulata L. O. Williams (Seibert 459), Lepanthes chiriquenses Schltr. (Seibert 174) and the type of Telipogon seibertii Dodson \& R. Escobar (Woodson, Allen \& Seibert 961, Chiriquí 1938).

William Randolph Taylor (1895-1990) collected several orchid specimens in 1934: Pleurothallis ghiesbreghtiana A. Rich. \& Gal. (Taylor 1511), Hexisea bidentata Lindl. (Taylor 1509), Trigonidium egertonianum Batem. (Taylor 1515), Oncidium ampliatum Lindl. (Taylor 1512), and Lockhartia micrantha Rchb. f. (Taylor 1510).

Among the orchid collections of E. M. Kieswetter (1937) we find Epidendrum anceps Jacq. (Kieswetter s.n.), Warrea costaricensis Schltr. (Kieswetter s.n.), Ondontoglossum cariniferum Rchb. f. (Kieswetter s.n.), Oncidium cabagrae Schltr. (Kieswetter s.n.) and Oncidium globuliferum H.B.K (Kieswetter s.n.).

In 1938, Mary Elizabeth Spence Davidson collected in Chiriquí the type specimen of Pleurothallis cardiochila L. O. Williams (M. E. S. Davidson 119 - Chiriquí). Other of her orchid specimens were Elleanthus aurantiacus (Lindl.) Rchb. f., (M. E. S. Davidson 123), Stelis skutchii Ames (M. E. S. Davidson 270), Stelis storkii Ames (M. E. S. Davidson 988), Stelis vestita Ames (M. E. S. Davidson 696), Pleurothallis urbaniana Rchb. f. (Davidson 187), Maxillaria pittieri (Ames) L.O. Williams (Davidson 117), and Masdevallia attenuata Rchb. f. (M. E. S. Davidson 1271).

Walter R. Lindsay collected in Panama between 1934 and 1941. Lindsayella amabilis Ames \& C. Schweinfurth (W. R. Lindsay \& G. H. Bevins s.n., Chiriquí, 1937 = Sobralia callosa, L.O. Williams) was named in his honor.

Gene and Peggy White resided in the country between 1935 and 1940 and collected Masdevallia ecaudata Schltr. (White \& White 81), Pleurothallis homalantha Schltr. (White \& White 80), Pleurothallis tuerckheimii Schltr. (White \& White 18), Epidendrum prismatocarpum Rchb. f. (White \& White 203) and Epidendrum pygmaeum Hook. (White \& White 205). "Among the most interesting botanical collections made in Panama during the year 1937 is a series of seventy-five numbers sent to the Missouri Botanical Garden by Gene and Peggy White" (Woodson \& Seibert, 1938: 823).

Victor Wolfgang Friedrich Heinrich von Hagen (1908-?) and his wife Christine von Hagen collected in Honduras (1937-38) and in Chiriquí in 1940 (Stenorrhynchos navarrensis Ames (v. Hagen 2111). Von Hagen is better known for his travels throughout the continent following the trails of the ancient civilizations and for his popular writings about Latin American traditions and cultures.

H. von Wedel collected in 1940 and 1941. In Bocas del Toro he discovered two new species: Pleurothallis ellipsophylla L. O. Williams (H. von Wedel $560-$ Bocas del Toro) and Epidendrum rigidum Jacquin var. angustisegmentum L. O. Williams (H. von Wedel 1708 - Bocas del Toro). Other orchid specimens collected by von Wedel include: Sobralia rolfeana Schltr. (H. von Wedel 409), Pleurothallis brighamii S. Watson (H. von Wedel 185), Epidendrum boothi (Lindl.) L. O. Wms. (H. von Wedel 123), Epidendrum stenopetalum Hook. (H. von Wedel 765), and Epidendrum anceps Jacq. (H. von Wedel 2081). Many plant species were named in 
his honor, among them Anthurium wedelianum Croat from the Araceae and Peperomia wedelii Yuncker from the Piperaceae.Von Wedel had also interests in ornithology and was an excellent photographer. According to Woodson, "there is probably no one in the vicinity of the Chiriquí Lagoon who is quite so familiar with the country and its inhabitants as Mr. Wedel" (Woodson \& Seibert, 1942: 272).

Ivan Murray Johnston (1898-1960) collected during World War II intensively in San José Island in the Bay of Panama, together with Carl Oskar Erlanson (1901-) and others, resulting in the publication of a flora (Johnston, 1949). In 1946 he found the type of Lycaste campbelli C. Schweinf. (Johnston 1371). Other of his orchid specimens are Aspasia principissa Rchb. f. (Johnston 1015), Xylobium foveatum (Lindl.) G. Nicholson (Johnston 1117), and Dichaea panamensis Lindl. (Johnston 1216).

"Botanical activity leading to a Flora of Panama began in 1934 with the efforts of R. E. Woodson, Jr., and his associates from the Missouri Botanical Garden" (Croat, 1978: 50). Robert Everard Woodson (1904-1963) was in Panama between 1938 and 1940. He formed part of the team that would prepare, several years later, the monumental Flora of Panama of the Missouri Botanical Garden. Woodson (Fig. 54C) collected mostly in the company of Robert Walter Schery (1917-1987). Together, they initiated the Flora of Panama in 1943. "Subsequent collecting in Panama by staff and students of the Missouri Botanical Garden has yielded an estimated 73,000 collections" (Croat, 1978: 50). Woodson taught in St. Louis, Missouri. Among his students was Dr. Jorge León Arguedas, who would become one of the most prominent botanists of Costa Rica in the second half of the XX century. Among Woodson's collections were the types of: Malaxis woodsonii L.O. Williams (Woodson, Allen \& Seibert 831 and 832, Chiriquí), Pleurothallis macrantha L. O. Williams (Woodson \& Schery 66 , Chiriquí), Sarcoglottis woodsonii (L.O. Williams) Garay (Woodson \& Schery 753, Chiriquí), and Zygopetalum parviflorum L. O. Williams (Woodson \& Schery 605, Chiriquí).

Paul Hamilton Allen (1911-1963) (Fig. 54D), a student at the Missouri Botanical Garden, was sent to Panama as an assistant to the botanical expedition of Carroll Dodge and Julian Steyermark and assumed in 1936 the direction of the Tropical Station in Cerro Ancón. At the same time he acted as botanical consultant for the schools in the Canal Zone and was finally named superintendent of the Experimental Gardens of the Canal Zone, better known as the Summit Botanical Garden. "Between 1937 and 1947, under the auspices of the Missouri Botanical Garden, he was part of 17 expeditions to the forests of Panama and collected over 7,000 species of plants. He was, after Pittier, the naturalist who explored the most remote regions of the geography of the isthmus" (Heckadon Moreno, 1998: 182). Allen was "one of the most meticulous collectors ever to work in Central America" (Williams, 1972: 207). His achievements were outstanding, especially if we take into account that Allen never received a formal biological education, nor earned any academic degree. It would be impossible to name all new species of Orchidaceae that were discovered by Allen and all of those that were named in his honor. Here are just a few of them: Oncidium parviflorum L. O. Williams (P.H. Allen 2937, Panama), Maxillaria repens L. O. Williams (P.H. Allen 2968, Panama), Epidendrum allenii L. O. Williams (P.H. Allen 2203, Panama), Ada allenii (L.O. Williams ex C. Schweinf.) N.H. Williams (P.H. Allen 5150, Panama), Macroclinium alleniorum R.L. Dressler \& F. Pupulin (P.H. Allen 5244, Costa Rica), Masdevallia allenii L.O. Williams (P.H. Allen 1230, Panama), Maxillaria allenii L.O. Williams (P.H. Allen 1650, Panama), Oncidium allenii Dressler (P.H. Allen, Panama), Pleurothallis allenii L.O. Williams (P.H. Allen 12400, Panama), Sobralia allenii L.O. Williams (P.H. Allen 2686, Panama), and Stelis allenii L.O. Williams (P.H. Allen 2952, Panama). After returning from a wartime study of rubber resources in Colombia, Allen went to Harvard in 1946 to study the orchid material there.

The third and fourth parts of the Orchidaceae for the Flora of Panama, which were written by Allen, were published in 1949. (The first two parts had been written by L.O. Williams and published in 1946). For this work, he asked Charles Lankester for advice: "Through the grapevine, I have heard that you have done a manual on the Orchids of Costa Rica. It is most fortunate in my opinion that you have done so, since you have seen more species in the field than any living collector. It now seems probable that I may be saddled with the job of completing Dr. Louis Williams half finished 
manuscript on the Orchids of Panama, and since many species are common to both countries I would like to see your manual, and have the benefit of your advice before making a spectacle of myself in print" (letter from Allen to Lankester, November 12, 1946). In a letter to Ames (1947) he wrote: "Work continues on the collection of the orchids of Panama, which seem to have no end; each field trip brings to light new species or geographical distributions.... Although I have not seen New Guinea or the mountains of Brazil, I would bet the area comprised by Costa Rica, Panama and Colombia against any other in the world" (Heckadon Moreno, 1998: 183). "It is regrettable that Allen was not invited to participate more fully in the preparation of the other parts of the Panama Flora, for he knew the plants of that country firsthand better than any other contemporary botanist" (Hodge, 1964: 74).

He resided for several years at Palmar Sur, Costa Rica (1948-1953), and found a great many tree species not seen before. His The Rain Forests of Golfo Dulce (1956) is an outstanding contribution to our knowledge of the rain forests in Central America, even though the work describes a limited geographical area. In 1952, Allen published a fundamental work on Cycnoches. For a brief interval Allen returned to the United States as Director of the Fairchild Botanical Garden at Miami, but was soon back in Central America, where he worked with Williams and Standley at 'El Zamorano'. During this period he was loaned to the Government of El Salvador to conduct a survey of that country's forest resources and returned in 1959 to Honduras, as Director of the Lancetilla Experiment Station. He had in preparation an account of the woody plants of El Salvador at the time of his death. Oskar Pank (1912- ), a German gardener who resided in El Salvador since 1952, was Allen's frequent companion during his collecting excursions (Hamer, 1973 (I): 13). Pank would be during more than two decades the resident botanist of La Laguna Botanical Garden, in San Salvador, after its foundation in 1978. Paul Allen was also a gifted photographer and his wife, Dorothy, a magnificent botanical illustrator. Beautiful examples of her skills were the illustrations to The Orchids of Panama (1953), a reprint of Allen's work that was originally published in The Orchid Journal. Allen's personal herbarium, more than 5,000 sheets, is now at the Escuela Agrícola Panamericana in Honduras with the exception of a representative series of plants collected in the valleys of Río Tuyra and Río Yape, which was destroyed by a fire which badly damaged the administration building of the Tropical Station in Balboa, the night of September 1, 1937 (Woodson \& Seibert, 1938: 823).

Harry A. Dunn ( -1977) lived in Ancón, in the Panama Canal Zone, and devoted a lot of field work in the company of Paul Allen in search of Cycnoches. Epidendrum dunni A. D. Hawkes was named in his honor. A resident of over 30 years of the Canal Zone, Dunn spent days and months botanizing, collecting orchids and studying meso-american archeology throughout Central America, becoming known as "the orchid man" in Panama. In his collecting of plants he was highly conservation-minded long before many plant collectors had such concerns. The patio of the Dunn home, near the old Tivoli Hotel in the Canal Zone, was a veritable orchid botanical garden (Davidson, 1979: 150).

Louis Otho Williams (1908-1991) (Fig. 55A), a native of Jackson, Wyoming, earned his bachelor's and master's degrees under botanist Aven Nelson of the University of Wyoming. His doctoral studies in plant systematics were at Washington University and the Missouri Botanical Garden, where he became a student of Jesse M. Greenman, his second prominent mentor (Burger, 1991: 355). He served as a research assistant at the Ames Orchid Herbarium of Harvard University for seven years, during which he edited the American Orchid Society Bulletin. His successful editorship was responsible for increasing the Society's membership from two hundred to three thousand. Orchids, American floristics, and useful plants were his main interest, and he published nearly 300 scientific articles dealing with these areas. He spent a time in Mexico (1938), in an attempt to obtain for Harvard the magnificent collection of Mexican orchids built up by the recently deceased E. M. Oestlund. This collection was the primary source of data for the Orchidaceae of Mexico that was in very late draft in 1942, when Williams left to work on a rubber procurement project in Brazil, where he stayed until 1945. "On returning to Harvard, Louis found that while inflation had raised most prices, Harvard salaries hadn't followed suit, and he checked out some other possibilities. On receiving a good and interesting offer, he went to see Oakes 
Ames, to say that he would have to leave, with some regrets, because he and his wife Terua could not get by on his salary from the Herbarium. He was startled when Ames flew into a rage and accused Louis of treachery for even thinking of leaving, pushing the manuscript of the Orchidaceae of Mexico across the desk to Louis, saying that Louis was welcome to go, and to take his draft with him, because it would never be published by Harvard" (Greenwood, 1992: 128). During his brief stay at Harvard he finished the first two parts of the Orchidaceae for the Flora of Panama that were published in 1946. He collected a great number of species and many were dedicated to him, among others: Bulbophyllum williamsii A.D. Hawkes, Corallorhiza williamsii Correll, Cyclopogon williamsii C.H. Dodson \& R. Vásquez Ch., Cyrtochilum williamsianum (Dodson) Dalström, Epidendrum williamsii C.H. Dodson, Lepanthes williamsi Salazar \& Soto Arenas, Malaxis williamsii Ames, Maxillaria williamsii C.H. Dodson, Pleurothallis williamsii Ames, Scelochilus williamsii C.H. Dodson, and Stelis williamsii Ames. He was a leading pioneer in tropical plant taxonomy, and that interest led him to return to the tropics in the 1950s. In Honduras, he helped to establish and direct a large herbarium at the Escuela Agrícola Panamericana ['El Zamorano'], and additionally developed a regional natural history library and launched the journal Ceiba. It was in Ceiba where he published his major contributions to the orchid flora of our region, after his Orchids of Panama: The Orchidaceae of Mexico (1951) and An Enumeration of the Orchidaceae of Central America, British Honduras and Panama (1956).

During his previous travels to Central America and his ten-year stay in Honduras, Williams also collected in Guatemala, El Salvador, Nicaragua and Costa Rica, where he became a good friend of Charles $\mathrm{H}$. Lankester. "A number of times we had the pleasure of having don Carlos in our house in Honduras and here in the United States, and to visit him in his home in Costa Rica” (Williams, 1969: 860). After Ames' death in 1950, Williams became the undisputed authority in Central American orchids. In 1960, he joined the staff of the Field Museum of Natural History in Chicago, and by 1964 had become head of the department of Botany. Known as a capable and approachable administrator, he rebuilt the department, revived its floristic programs, and developed grant support. His botanical collections numbered more than 43,000. Following his retirement, Williams continued his research and supervised the completion of the Flora of Guatemala. Following his death in 1991, his widow, Terua, wrote the index and final volume of this work. Williams' library and private herbarium are now part of the Marie Selby Botanical Garden.

\section{The 'great depression' of Costa Rican orchidology}

"During the 1930s, agricultural experiment stations, natural history museums, and botanical gardens were shut down or had their budgets curtailed even further. The National Museum of Costa Rica was incorporated into the University of Costa Rica, following a common pattern in Latin America during the 1930s and 1940s. Even so, the Museum remained almost moribund until the 1960 s...

(McCook, 1999: 120)"

In the 1930s, Costa Rican orchidology began to languish. Only Lankester continued with the exploration of the country, although his legendary capacity for the discovery of new species seemed to be coming slowly to an end. Aside from the economic troubles brought by the Great Depression, it was simply too much for the small republic to overcome the departure of Pittier to the United States (1905) and A. C. Brade to Brazil (1910); the premature deaths of Biolley (1908), Tonduz (1921), Wercklé (1924), and Sancho (1929); the retirement of Alberto M. Brenes in 1930, the reduced botanical activity of Otón Jiménez due to his multiple business affairs and the voluntary exile of Amparo de Zeledón to Honduras. Although several collectors visited Costa Rica during that period, it would take the country until the early 1970 s to recover from such losses.

The Austrian Biological Expedition to Costa Rica (1930) was perhaps the last attempt to restore European Botany to the leading role it had played during the preceding centuries. The expedition arrived in Costa Rica in March, 1930, after stopping in Trinidad and Venezuela, where several collections were made. The group of scientists, which stayed in Costa Rica until the month of August, was led by the ornithologist Moriz Sassi (Bauernfeind, 1966: 
126). Part of the expedition were also the biologists E. Reimoser and C. Fr. Roewer. Dr. Otto Porsch (1875-1959) (Fig. 55B), who in 1921 had succeeded Karl Wilhelm as director of the botanical garden of the University of Natural Resources at Vienna, was responsible for the botanical collections and director of the expedition (Díaz Bolaños, 2007: 7). His main collaborator was the botanist Giorgio Cufodontis (1896-1974) (Fig. 55C) (Grayum et al., 2004: 20). An expert in flower pollination, Porsch had traveled to Brazil in the first years of the XX century and collected many new types of Orchidaceae, such as Meiracyllium wetsteinii Porsch, Physurus austrobrasiliensis Porsch, Masdevallia zebrina Porsch, Physurus kuczynskii Porsch, Campylocentrum chlororhizum Porsch, Catasetum fimbriatum Rchb.f. var. aurantiacum Porsch, Catasetum ornithorrhynchum Porsch, Cranichis microphylla Porsch, Habenaria paulensis Porsch, Habenaria wacketii Porsch, Pleurothallis bupleurifolia Porsch, Pleurothallis laxiflora Porsch, Stelis guttifera Porsch and Stenorhynchus loefgrenii Porsch, all published in 1905 in the Oesterreichische Botanische Zeitschrift (=Austrian Journal of Botany).

Porsch wrote: "Because of the great number of types [of hummingbirds] in small areas, Costa Rica was the richest region for a possible and multiple answers to this question [the relation between flowers and their pollinators]" (Porsch, 1931: 11). If we follow Dressler, Porsch's writings must be taken carefully: "I think that Porsch's paper [...] is really a classic of how to get 40 pages of publication out of one short paragraph of data" (In a letter to R.L. Rodríguez, 2 November, 1967). Porsch and Cufodontis could be proud to travel through Costa Rica in the company of the best guides they could think of: Ferdinand Nevermann was their host in his 'Finca Hamburgo' and their guide through the Atlantic region, Charles Lankester showed them the best of his orchid garden in Cóncavas, Alfred Brade hiked with them to the summit of the Turrialba volcano and Alberto M. Brenes traveled with them through Guanacaste and the southern Osa Peninsula. Brenes would write, two years later, an account of his journey to Guanacaste with the expedition (Brenes, 1956).

Among the orchid specimens collected by the expedition and reported by Cufodontis (1933) were: Vanilla fragans (Salisb.) Ames (Cufodontis
735, Hamburg Farm), Stelis thecoglossa Rchb. f. (Nevermann 496, Vulcanus Irazu), Maxillaria crassifolia (Lindl.) Rchb. f. (Brenes 162, Golfito). Lepanthes brenesii Schltr. (Lankester 802, Las Cóncavas), Brassavola nodosa Lindl. (A. Brade 799, Las Cóncavas), and Cattleya dowiana Batem. (A. Brade 818, Vulcanus Turrialba, floruit culta). Porsch and Cufodontis were also responsible for the discovery of two new species of Erythrina (Fabaceae): Erythrina globocalyx Porsch \& Cufod. and Erythrina gibbosa Cufod. However, the expedition did not meet the expectations, at least from the botanical point of view. Less than 900 specimens were collected and almost nothing was published about the scientific results, in part because of the political disturbances brought by the rising Nazi movement, which led a few years later (1938) to Austria's annexation by Germany.

Expelled from the university in 1934 for his notorious right-wing inclinations, Porsch wrote in 1932 a phytogeographical description of Costa Rica (Porsch, 1932), in which he followed closely the previous work by C. Wercklé (1909). Cufodontis wrote five articles about the results of the scientific expedition, which he published in German and Italian (Díaz Bolaños, 2008).

U.S. botanist Austin Smith (1881-1948) was born in Ohio and came to Costa Rica in 1920. He lived in Guanacaste until 1937 and then settled in the small town of Zarcero de Alfaro Ruiz (Grayum et al., 2004: 22). Smith made a living as a horticulturist, exporting plants and seeds to the United States, and collected, among others, Prosthechea brassavolae (Rchb. f.) W.E. Higgins (Smith 1048), Crossoglossa fratrum (Schltr.) Dressler (Smith 1055), Sobralia leucoxantha Rchb. f. (Smith 1173), Elleanthus wercklei Schltr. (Smith 1343) and Habenaria aviculoides Ames \& C. Schweinf. (Smith 1376). Paullinia austin-smithii Standl. of the Sapindaceae carries his name. Smith was also interested in ornithology and wrote several articles about his observations of Costa Rican birds.

The Swiss Walter Kupper (1874-1953) (Fig. 55D), was the first botanist to climb Cerro Chirripó, Costa Rica's highest peak and collected in this country from November 1931 to July 1932, a journey sponsored by the Bavarian Academy of Science (Sussengut, 1954: 170). Kupper was Curator of the Botanical Garden in Munich, Germany, a position he held until his 
retirement in 1940. Maxillaria thienii Dodson (Kupper 374) is one of his orchid specimens and Mansfeld described a new species, Kegeliella kupperi based on one of his collections near Tilarán, in Costa Rica. In a narrative about his collecting experiences in Costa Rica, Kupper compares the size of the country ("not even as large as Bavaria") with the number of orchid species that can be found, "larger than in any other tropical country” (Kupper, 1938: 2). During the same journey Kupper visited Christian Halbinger, in Mexico. They became close friends and Kupper sent years later his collection of Vandas to Halbinger, fearing that they could be destroyed during World War II.

Fernando Solís Rojas collected some orchids between 1935 and 1949: Pleurothallis amparoana Schltr. (Solís 345), Xylobium powellii (Solís 354), and Pleurothallis dolichopus Schltr. (Solís 473).

"In 1943, a visiting American team, led by C. A. Merker and including fellow forester William R. Barbour and botanists Elbert Luther Little Jr. (1907- ) and Wiliam Adams Dayton (1885-1958), surveyed Costa Rican forest resources in connection with the U.S. war effort, producing, among other things, an annotated list of important forest trees and a crude vegetation map of the country" (Grayum et al., 2004: 23). Among their orchid collections were Nidema boothii (Lindl.) Schltr. (Barbour 1037), and Arpophyllum giganteum Hartw. ex Lindl. (Barbour 1035).

Richard W. Holm (1895-1987) and Hugh H. Iltis (1925-), botanized in various neglected corners of Costa Rica in 1949, including the northern plains of the Guatusos. Their painstaking collections include Corymborkys forcipigera (Rchb. f. \& Warsz.) L.O. Williams (Holm \& Iltis 104), Govenia Lindl. sp. (Holm \& Iltis 136), Pleurothallis phyllocardioides Schltr. (Holm \& Iltis 195), Elleanthus cynarocephalus (Rchb. f.) Rchb. f. (Holm \& Iltis 406), and Oncidium bryolophotum Rchb. f. (Holm \& Iltis 631).

Although the harvest of those years was meager, not everything was lost. Alexander F. Skutch (1904-2004) (Fig. 56A), who lived in Costa Rica from 1935 until his recent death, soon became one of the country's most respected leaders in the study of natural sciences and in the development of a new relationship between mankind and its natural environment. At the age of 16, after reading Shelley's poetry and essays, he decided to become a vegetarian. Although love and affection for animals were his initial reasons, he later found scientific arguments and often stated that one of the main causes for the destruction of tropical forests was the need to clear great extensions of land for grazing. After graduating as a Bachelor of Botany at John Hopkins University, in Baltimore (1925), he traveled in 1926 to Jamaica, to study the leaf anatomy of bananas at a plantation of the United Fruit Company (UFC), which was the base for his doctoral theses Anatomy of the Leaf of Banana, Musa sapientum L. var. Hort. Gros Michel, in 1928. The same year he received a grant to continue his research on banana in another of the UFC experiment stations near Almirante, in Panama. These were his first contacts with tropical nature. In the early 1930s he traveled to Honduras, Guatemala, Ecuador, Venezuela and Costa Rica. As a result, he published many papers on tropical flora and fauna and became soon one of the world's leading ornithologists.

"In 1933-34, Alexander F. Skutch obtained a small but excellently prepared collection from several departments [of Guatemala], mainly in Huehuetenango and Quiché" (Ames \& Correll, 1985: viii). Among his orchid collections from Guatemala we find Habenaria entomantha (Llave \& Lex.) Lindl. (Skutch 519), Habenaria monorrhiza (Sw.) Rchb. f. (Skutch 1377), Triphora trianthophora (Sw.) Rydb. (Skutch 494), Cranichis apiculata Lindl. (Skutch 923) and a new species, Epidendrum skutchii Ames, Hubb. \& C. Schweinf. (Skutch 1715).

He came to Costa Rica in 1935, to the valley of El General, with contracts to collect plants for museums and botanical gardens in the United States and Europe. This income was sufficient for Skutch to continue with his scientific studies on birds. His collections of orchids from Costa Rica include Masdevallia nidifica Rchb. f. (Skutch 171), Xylobium foveatum (Lindl.) G. Nicholson (Skutch 2147), Ponthieva racemosa (Walter) C. Mohr (Skutch 2198), and again a new species, Stelis skutchii Ames (Skutch 3126). Several years later (1941) he bought a small farm on the Peñas Blancas river, that he called "Los Cusingos", the local name for the orange beaked toucanet (Pteroglossus frantzii) where he lived for over 60 years until his death in 2004. In 1950 he married one of Charles H. Lankester's daughters, Pamela, who died in 2001. 
Henry Teuscher and the Montreal Botanical Garden. The Montreal Botanical Garden was born of the dream of the man with both a religious and scientific vocation, Brother Marie-Victorin, born Conrad Kirouack (1885-1944). Passionately inspired by nature, he had founded the Botanical Institute of the Université de Montréal in 1920 and dreamed of creating a great botanical garden for Montrealers, a plan he made public in 1925. Six years later, after much hard work to convince both politicians and members of the local scientific community, his plan finally took shape. When the Garden was founded in 1931, Québec was in the grips of one of the worst crises in its history. Thousands of Montrealers were out of work and, rather than simply paying these relief money, Mayor Camilien Houde came up with the idea of employing them to built the Garden

With the assistance of Henry (Heinrich) Teuscher (1891-1984) (Fig. 56B), a landscape architect of German origin trained in Europe and the United States and a renowned horticulturalist and botanist, Brother MarieVictorin's dream finally became a reality. A man of many talents, Teuscher drew up the first plan of the Garden. In 1936, he was officially appointed Superintendent and Chief Horticulturalist, and later Curator of the Garden, a position he held until his retirement in 1962. He also laid out several of the exhibition greenhouses and assembled some of the Garden's major plant collections. His ideas as a botanist and garden architect were best expressed in his "Programme d'un jardin botanique idéal" (1940). Always trying to expand the Garden's collections, Teuscher traveled in search for orchids to Ecuador (1951 and 1956) and to Panama in 1964. One of his collections in Ecuador gave birth to a new genus named in his honor: Teuscheria Garay, with the type species Teuscheria cornucopia Garay (Teuscher s.n., Ecuador). Teuscher corresponded frequently and received material from the best collectors in our region, such as Harry Dunn in Panama, and years later Clarence Horich in Costa Rica. In addition, he traveled to Venezuela, Ecuador, Trinidad \& Tobago, Jamaica, and Hawaii. Several orchid species were dedicated to Teuscher, among them: Epidendrum teuscherianum A.D. Hawkes, Rodriguezia teuscheri Garay and Telipogon teuscheri Garay. Between 1952 and 1977, Teuscher published 287 articles in the most important orchid journals of his time. The most beautiful plant in the annual orchid show of the Montreal Orchid
Society is awarded with the "Grand prix d'excellence Henry Teuscher". Henry Teuscher will remain, for many orchidologists across the glove, as the symbol of Montreal's orchidology (Boutot, 1984: 4).

\section{The Flora of Guatemala}

"The exceedingly varied types of soil and topography and diverse geological history of the country, ranging from ancient mountain masses connected with North America to relatively youthful volcanic areas, combined with marked altitudinal and climatic variations - hot desert to cold alpine regions - have given Guatemala the richest flora in all Central America with an estimated total of 8,000 species of vascular plants".

(Standley \& Steyermark, 1945: 275)

The project of the Flora of Guatemala became one of the most ambitious enterprises of the Field Museum of Natural History in the 1930s. It was again the prolific Paul C. Standley who in 1938 undertook this enormous work. Standley was later joined in the project by Julian Steyermark, who joined the Museum staff in 1937 and not only made numerous valuable collections in Guatemala, but contributed also to the published flora. Finally, Louis O. Williams joined the staff in 1960 and supervised the completion of the Flora of Guatemala (thirteen parts, 6,528 pages). The treatise of the orchids for the Flora was written by Oakes Ames and Donovan Stewart Correll, a work that would not have been possible without the contribution of an important number of collectors who must be mentioned as precursors to what is still today the main published work on the Orchidaceae of Guatemala.

Margaret Ward Lewis collected in Guatemala from 1928 to 1942 . "When I first came to the tropics some twelve years ago it was to live in a little Fruit Company headquarters town where the seven houses were arranged in a hollow square and every front porch was a potential observatory. Exploration of the surrounding 'bush' was the only escape to a private life... I thought collecting in one family was all I could encompass as a beginner and I had unique opportunities to collect. My husband was at that time Chief Engineer for the [United] Fruit Company and I was in on all felling for a railroad across Montúfar Flats. In a little while 
everybody knew I was interested in orchids and plants -hundreds of duplicates- came in from all sides... Since 1931 except for several visits to the States I have lived here in the City and our collection was considerably amplified by Sunday expeditions and the notes made more useful by taking up photography. From time to time I have made the acquaintance of people in different parts of the Republic who send me anything new they find and even the section foremen on the railroad know enough about orchids to send me any they find in clearing the right-of-way. So no one has had a better chance than I to collect ..." (In a letter from M. Lewis to L. O. Williams, January, 1940). Lewis' collections and diagnostic photographs of Guatemalan orchids were of great importance to Ames' and Correll's work. In Guatemala she met Steyermark, mentioned in several of her letters, and collected with J. R. Johnston in 1940. Among her collections are Cypripedium irapeanum Llave \& Lex. (Lewis 151), Phragmipedium caudatum (Lindl.) Rolfe (Lewis 127), Habenaria monorrhiza (Sw.) Rchb. f. (Lewis 211), Elleanthus capitatus (R. Br.) Rchb. f. (Lewis 168), Sobralia fragans Lindl. (Lewis 320) and Spiranthes amabilis Ames (Lewis 164), as well as at least six new species: Pleurothallis lewisae Ames (Lewis 2), Spiranthes obtecta S. Schweinf. (Lewis 191), Stanhopea lewisae Ames \& Correll (Lewis 140), Cranichis hieroglyphica Ames \& Correll (Lewis 154), Scaphyglottis minutiflora Ames \& Correll (Lewis 105), and Lepanthes excedens Ames \& Correll (Lewis 105). Margaret Ward Lewis' love for Guatemala and its orchids were best described by herself in her article Guatemalan Interlude (1954), that she finished with the sentence: "Orchids are where you find them and I hope, where you leave them" (Ward-Lewis, 1954: 184-190).

Mercedes Aguilar Hidalgo (1905-), a specialist in Phanerogams, collected in 1935 in Guatemala and Belize. Some of her specimens are Habenaria pauciflora (Lindl.) Rchb. f. (M. Aguilar 208), Habenaria strictissima Rchb. f. (M. Aguilar 156), Epidendrum cochleatum L. (M. Aguilar 334), Epidendrum skinneri Batem. ex Lindl. (M. Aguilar 143) and Epidendrum stamfordianum Batem. (M. Aguilar 462).

Biologist, naturalist and pioneer of canopy biology, Marston Bates (1906-1974) made a few collections of orchids in Guatemala in 1935, including Stelis ovatilabia Schltr. (Bates 19), Stelis purpurascens A.
Rich. \& Gal. (Bates 13), Epidendrum boothi (Lind1.) L.O. Williams (Bates 12) and Epidendrum lindleyanum (Batem.) Rchb. f. (Bates 11). Bates was better known as a philosopher of natural sciences and for his books: The Nature of Natural History (1951), Man in nature (1961), and The Forest and the Sea (1960).

Walter Conrad Leopold Muenscher (18911963) collected in 1937 Sobralia macrantha Lindl. (Muenscher 12442), Epidendrum ochraceum Lindl. (Muenscher 12548), Dichaea intermedia Ames \& Correll (Muenscher 12531), Dichaea muricata (Sw.) Lindl. (Muenscher 12543) and Epidendrum repens Cogn. (Muenscher 12542). Muenscher, New York State's 'Wizard of Weeds', was Professor of Botany at Cornell University from 1923 to 1954 . He had special interests in wetlands, poisonous plants, and trees, and was the author of more than 125 articles and several books in addition to Keys to Woody Plants (1950).

One of Lundell's main collaborators was Elías Contreras, with whom he collected in Petén. Some of his orchid specimens are Habenaria bractescens Lindl. (Contreras 1771), Habenaria distans Griseb. (Contreras 2976), Vanilla hartii Rolfe (Contreras 3063), Elleanthus linifolius Presl. (Contreras 2753) and Sobralia fragans Lindl. (Contreras 2836).

John Robert Johnston (1880-1953) collected in Guatemala from 1937 to 1941 . Years before he had botanized in Venezuela (1901-1903) and had written several articles on the flora of the coastal areas and the main islands. He collected Cypripedium irapeanum Llave \& Lex. (Johnston 1645), Habenaria crassicornis Lindl. (Johnston 155), Habenaria entomantha (Llave \& Lex.) Lindl. (Johnston 920), Habenaria quinqueseta (Michx.) Sw. (Johnston 1564), Habenaria repens Nutt. (Johnston 1400), Crybe rosea Lindl. (Johnston 1983) and the type specimens of Leochilus johnstonii Ames \& Correll (Johnston 1864, Guatemala), and Epidendrum altícola Ames \& Correll (Johnston 1472, Guatemala).

Francis Welles Hunnewell (1880-1964) was in Guatemala from1937 to1941. "In recent years, .... Hunnewell has made a small but discriminating collection, primarly in five of the Pacific coast departments" (Ames \& Correll, 1985: viii). Among his orchid collections we find Ponthieva triloba Schltr (Hunnewell 14668), Spiranthes parasitica A. Rich. \& Gal. (Hunnewell 14675), Spiranthes pyramidalis Lindl. (Hunnewell 14672), Pleurothallis grobyi Batem. ex Lindl. (Hunnewell 
14676), and Epidendrum ibaguense H.B.K. (Hunnewell 14670). Hunnewell also collected in Belize.

In 1938 José Ignacio Aguilar collected in Guatemala Habenaria entomantha (Llave \& Lex.) Lindl. (J.I. Aguilar 1534), Habenaria repens Nutt (J.I. Aguilar 311), Elleanthus capitatus (R. Br.) Rchb. f. (J.I. Aguilar 426), Ponthieva triloba Schltr. (J.I. Aguilar 1512), Spiranthes orchioides (Sw.) A. Rich. (J.I. Aguilar 1167), and Epidendrum aricosum Batem. ex Lindl. (J.I. Aguilar 363).

Julian Alfred Steyermark (1909-1988) (Fig. 56C), after being in Panama on a botanical expedition in 1934 and 1935, joined the staff of the Field Museum of Natural History in 1937 and started working with Standley on the Flora of Guatemala, where he collected from 1939 to 1943. Steyermark was St. Louis born and bred, earning his Ph.D. through Washington University in 1933. Steyermark also produced numerous tropical American floras and returned to the Missouri Botanical Garden in 1984 to work on the flora of the Venezuelan Guyana. He was credited in the Guinness Book of World Records for collecting 138,000 plant specimens during his lifetime. While in Guatemala, he collected a great number of orchid specimens, such as Habenaria alata Hook (Steyermark 29538), Habenaria clypeata Lindl. (Steyermark 51804), Triphora cubensis (Rchb. f.) Ames (Steyermark 69559), Cranichis apiculata Lindl. (Steyermark 31701), and Spiranthes aurantiaca (Llave \& Lex.) Hemsl. (Steyermark 50628). He discovered the following new species: Campylocentrum microphyllum Ames \& Correll (Steyermark 37376, Guatemala), Kreodanthus ovatilabius (Ames \& Correll ) Garay (Steyermark 32471, Guatemala), Epidendrum schweinfurthianum Correll (Steyermark 42521, Guatemala), Epidendrum sobralioides Ames \& Correll (Steyermark 42764, Guatemala), and Malaxis steyermarkii Correll (Steyermark 51762, Guatemala). As part of the Flora of Guatemala of Paul Standley and Julian Steyermark, Oakes Ames and Donovan Stewart Correll (1908-1983) wrote the first systematic treatment of the orchids of the country (Ames \& Correll, 1985). A total of 567 species were enumerated. Correll published later a supplement to this work, in which he included the orchids of Belize (Correll, 1985).

Correll, who had spent two years taking voice lessons and singing solos at church and on the radio before going to college, became a research associate at the Botanical Museum of Harvard University (1939-1943). Ames introduced him to orchids and to Economic Botany. In a letter from L. O. Williams to Margaret Ward Lewis (December 7, 1939), he informed her that "A young man, Dr. D. S. Correll, has been added to our staff. The first problem to which he has been assigned is writing up the orchids for Standley's proposed flora of Guatemala. I think that he will undoubtedly do a very good job of it." During World War II he served in the US Navy and was in Panama for a few days in 1945, although we have no records of orchid collections by Correll from that country. At the end of 1947 he was in Mexico (Michoacán and Oaxaca) and from 1947 to 1956 he served in various capacities in the Specialty Crop Introductions Group of the United States Department of Agriculture (Schubert, 1984: 134). In 1956 he became head of the Botany Department of the Texas Research Foundation, Renner, Texas and traveled often to Latin America: Mexico (1958), Ecuador and Bolivia (1958-1960) and again Mexico (1959 and 1965). During the years of 1971-1973, Correll served as Program Director for Systematic Biology at the National Science Foundation, and at the conclusion of his appointment he was invited to join the staff of the Fairchild Tropical Garden, Miami, as taxonomist, to produce a flora of the Bahama Islands, that was published just a few months before his death. Correll published major botanical works. Worthy of mention are his Native Orchids of North America North of Mexico (1950), Manual of the Vascular Plants of Texas (1970), and Flora of the Bahama Archipelago (1982).

\section{The land of Percival Hildebart Gentle}

"We must allow our children the right to experience the beauty of Belize that we have had the fortune to share. We must, in addition, teach the next generation the idea of conservation for, if we fail, we had better teach them survival".

(Manuel Esquivel, Prime Minister of Belize, in the foreword to McLeish et al., 1994).

Harley Harris Bartlett (1886-1960) (Fig. 56D), was born in Anaconda, Montana. He went to Harvard in 1904, working as an assistant to B. L. Robinson and M. L. Fernald, for an A.B. cum laude (1908) in 

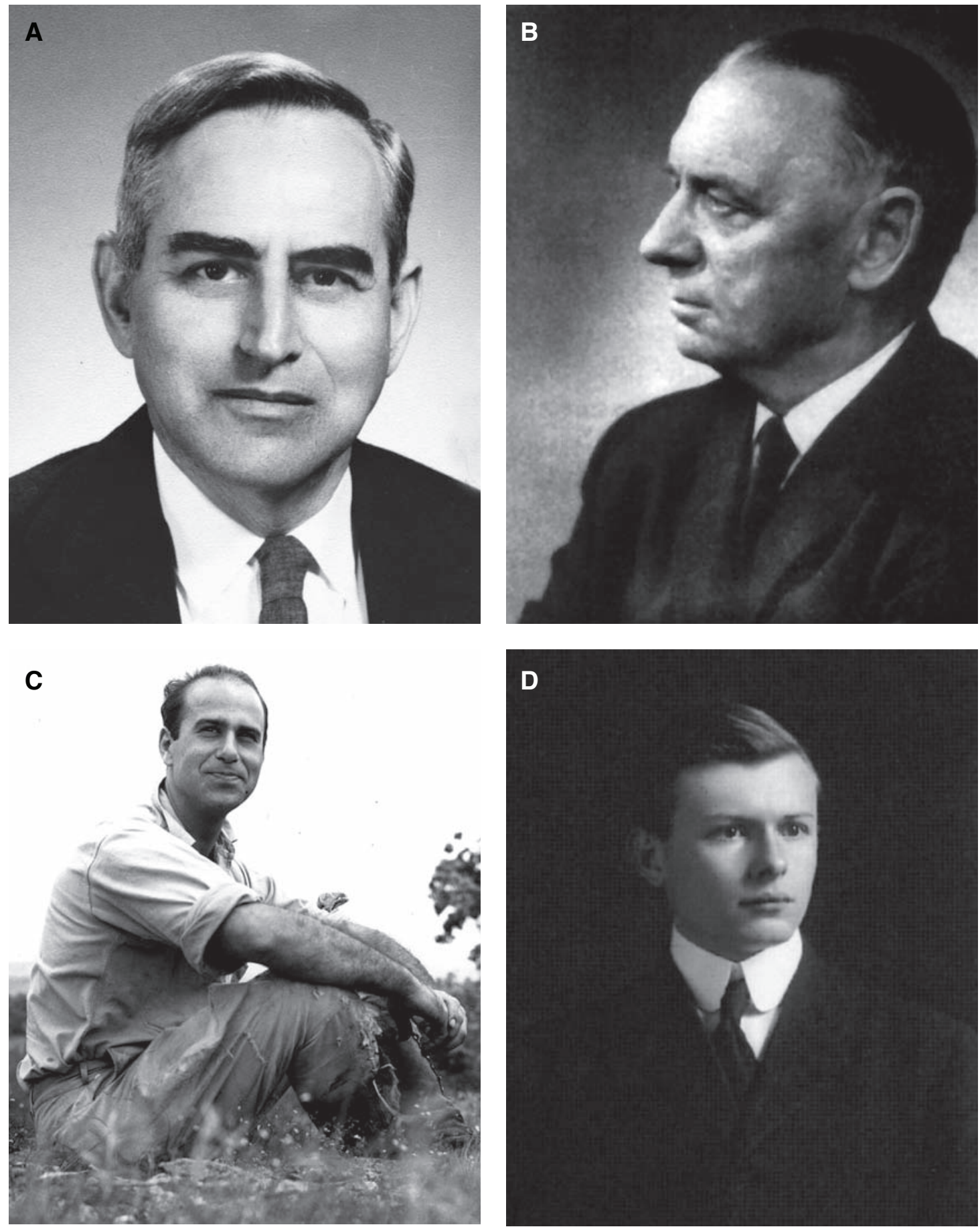

Figure 56. A - Alexander F. Skutch (1904-2004). Courtesy of the Tropical Science Center, Costa Rica. B - Henry (Heinrich) Teuscher (1891-1984). In Boutot, 1984: 3. C — Julian Alfred Steyermark (1909-1988). Courtesy of Barry Hamel, Missouri Botanical Garden. D - Harley Harris Bartlett (1886-1960). Courtesy of the Archives of the Gray Herbarium, Harvard University. 

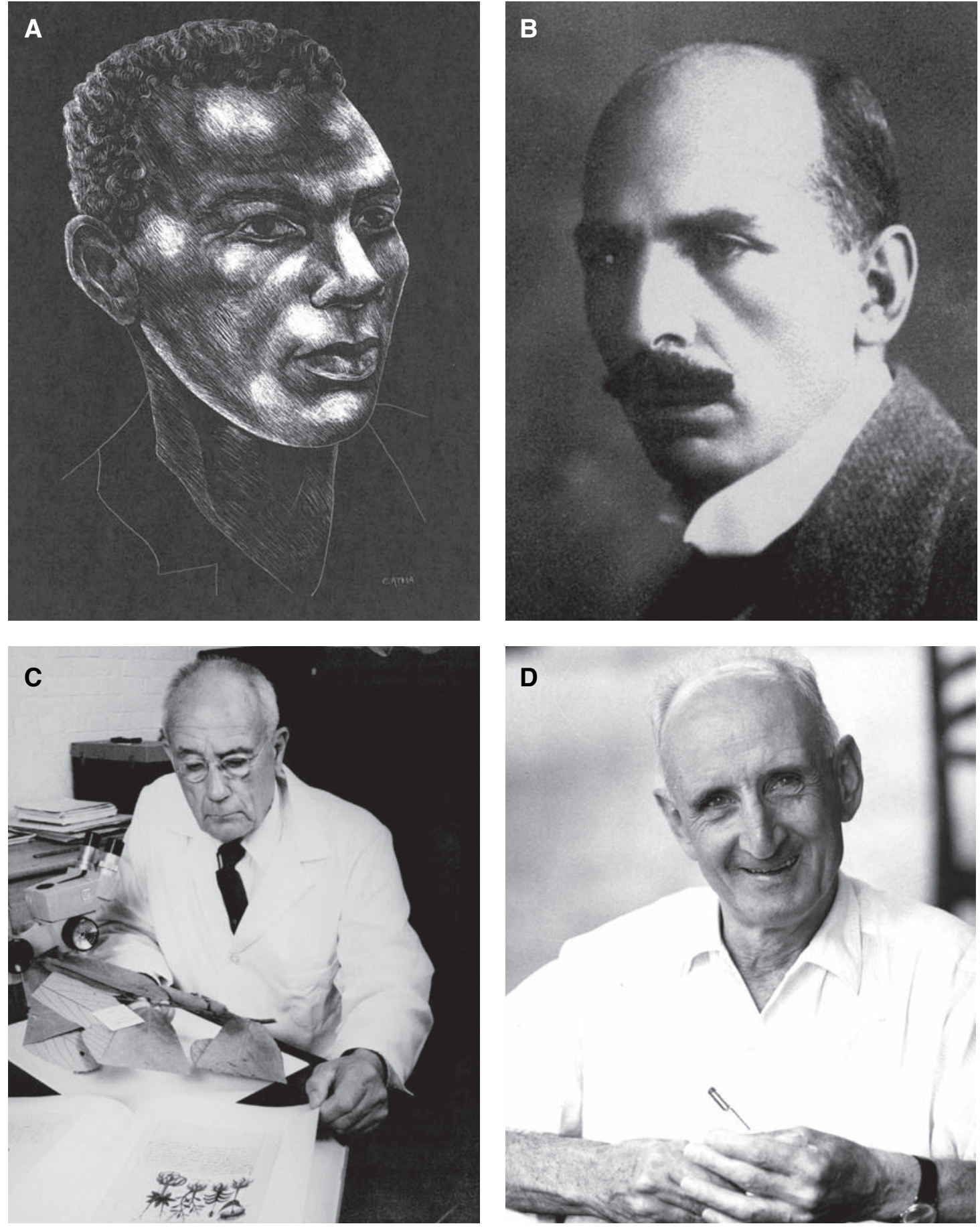

Figure 57. A — Percival Hildebart Gentle (1890- 1958). Portrait by Ellen Atha, with her permission. B — Karl Erik Magnus Östlund (1875-1938). Courtesy of Luis Sánchez, AMO Herbarium, Mexico. C — Richard Evans Schultes (19152001). Courtesy of the Hunt Institute for Botanical Documentation. D - Thomas Baillie MacDougall (1895-1973). Courtesy of Luis Sánchez, AMO Herbarium, Mexico. 
chemistry. In 1909, he came to Washington with the Bureau of Plant Industry as a chemical biologist. During this time he worked on the genetics of Oenothera. In 1915 he became assistant professor of botany at the University of Michigan, full professor in 1921, head of the Botany Department from 1922-47, and Director of the Botanical Garden from 1919-55. In 1918, he explored and botanized in Sumatra with the U.S. Rubber Company. Bartlett, sponsored by the Carnegie Institution and the University of Michigan, had been in Mexico (1930) and collected in 1931 in Guatemala and Belize, where he returned in 1936 and obtained an extensive series of plants in the Belize and El Cayo districts. In Belize he collected Habenaria wercklei Schltr. (H.H. Bartlett 11598), Sobralia bradeorum Schltr. (H.H. Bartlett 11771), Elleanthus graminifolius (Barb. Rodr.) Løjtnant (H.H. Bartlett 11733), Lophiaris lurida (Lindl.) Braem (H.H. Bartlett 12077), Oncidium sphacelatum Lindl. (H.H. Bartlett 12946), and Encyclia belizensis (Rchb. f.) Schltr. (H.H. Bartlett 14068). From Guatemala we have his specimen of Brassia maculata R. Br. (H.H. Bartlett 12699). In 1940, Bartlett was in Panama together with Tobias Lasser (1911-) ${ }^{39}$. They collected among others Campylocentrum micranthum (Lindl.) Maury (H.H. Bartlett \& T. Lasser 16823).

It was undoubtedly a fortunate circumstance that Bartlett, in 1931, could convince Percival Hildebart Gentle (1890- 1958) (Fig. 57A) to collect for him. Gentle, a Belizean-born botanist, devoted the latter half of his professional life to collecting herbarium specimens throughout the country. His collections, among which over 150 new species were found, were sent to the United States and from there distributed to herbaria throughout the world. His collections were a great contribution to Lundell's studies on the flora of Belize. "From 1931 until shortly before his death in 1958, Gentle collected 9756 numbers, easily making him the most prolific collector of the Belize flora.... Percival Gentle had a keen eye for plants he had not previously collected. Based on collection data in our databases, we estimate that he collected approximately $65 \%$ of the flora. His numerous and well-executed collections are a testament to his dedication and skill as a botanist and a legacy enriching our understanding of the Belize flora." Gentle's "botanical efforts during 1931-1958 made possible most subsequent studies involving the Belizean flora" (Balick et al., 2000: 18).Among his orchid collections we can find Ponera striata Lindl. (Gentle 1097), Trigonidium egertonianum Bateman ex Lindl. (Gentle 1122), Maxillaria crassifolia (Lindl.) Rchb. f. (Gentle 1123), Oncidium sphacelatum Lindl. (Gentle 1154), Encyclia bractescens (Lindl.) Hoehne (Gentle 1195), Stelis ciliaris Lindl. (Gentle 1196), Ornithocephalus inflexus Lindl. (Gentle 1312), Brassavola nodosa var. grandiflora (Lindl.) H.G. Jones (Gentle 1313), Scaphyglottis behrii (Rchb. f.) Benth. \& Hook. f. ex Hemsl. (Gentle 1576), Ionopsis utricularioides (Sw.) Lindl. (Gentle 1700), Scaphyglottis leucantha Rchb. f. (Gentle 1781), Maxillaria tenuifolia Lindl. (Gentle 2189), Bletia purpurea (Lam.) DC. (Gentle 2537), Dimerandra emarginata (G. Mey.) Hoehne (Gentle 2541), Brassia maculata R. Br. (Gentle 3023), Sobralia decora Bateman (Gentle 3036), Elleanthus graminifolius (Barb. Rodr.) Løjtnant (Gentle 3065), Prescottia stachyodes (Sw.) Lindl. (Gentle 3492), Habenaria mesodactyla Griseb. (Gentle 3636), Polystachya clavata Lindl. (Gentle 3640), Prosthechea cochleata (L.) W.E. Higgins (Gentle 3974), Habenaria trifida Kunth (Gentle 4036), Scaphyglottis prolifera Cogn. (Gentle 4077), Scaphyglottis minutiflora Ames \& Correll (Gentle 4265), Cryptarrhena lunata R. Br. (Gentle 4266), Ornithocephalus bicornis Lindl. ex Benth. (Gentle 4267), Cryptarrhena guatemalensis Schltr. (Gentle 4309), Sobralia mucronata Ames \& C. Schweinf. (Gentle 4314), Lophiaris lurida (Lindl.) Braem (Gentle 4396), Campylocentrum hondurense Ames (Gentle 4472), Sobralia fragrans Lindl. (Gentle 4925), Campylocentrum micranthum (Lindl.) Maury (Gentle 5049), Campylocentrum tyrridion Garay \& Dunst. (Gentle 5077), Oncidium ensatum Lindl. (Gentle 5147), Lycaste aromatica (Graham ex Hook.) Lindl. (Gentle 5418), Dichaea panamensis Lindl. (Gentle 6032) and Prosthechea pygmaea (Hook.) W.E. Higgins (Gentle 6368). A few months before his death he made his last orchid collection, the beautiful Encyclia belizensis (Rchb. f.) Schltr. (Gentle 9740). Lundell honored him in the genus Gentlea (Myrsinaceae).

\footnotetext{
${ }^{39}$ Lasser, Director of the 'Instituto Botánico' of Venezuela, was the editor of the Flora de Venezuela (1964), for which Ernesto Foldats wrote the treatment of the Orchidaceae.
} 
The Mexican Renaissance (I). With the Mexican Revolution that began after the political events of 1910 the country entered a period of political commotion and fratricidal struggles. The result were almost three decades of economic and cultural penury (Rzedowski, 1981: 7), of which Mexico would only begin to recover during the government of Lázaro Cárdenas (1934-1940). Only Carl A. Purpus, in his beloved Zacuapam, dared to continue his botanical activity during those troubled years.

A new era of Mexican orchidology began with Karl Erik Magnus Östlund (1875-1938) (Fig. 57B). Östlund had been born in Stockholm, where he received the degree of Chemical Engineer in 1897. In 1909 he came to Mexico, as manager of the 'Empresa de Teléfonos Ericsson S.A.' Soon he became interested in the Mexican Orchidaceae and in 1928 he retired and dedicated himself entirely to orchid studies. He prepared detailed drawings from living material, with microscopic sections, exact measurements and color indications. "The Östlund Orchid Herbarium ... was without doubt the finest collection of orchids ever to come out of Mexico. Now I might justifiably go further and say that it was most probably the finest collection of orchids to come out of any country" (Williams, 1951: 5). "The quality of the data of origin, the care with which the specimens were prepared, the abundance of the material, the rigor of the numeration, the extensive additional information and the drawings in the field books, all this in a period of just ten years, is exceptional" (Hágsater et al., 2005: 69). The Östlund heirs donated this collection to the Oakes Ames Herbarium at Harvard University. Duplicate sets of specimens were distributed to many institutions, including the Smithsonian Institute and the Missouri Botanical Garden. Östlund collected the types of two new species: Spiranthes densiflora C. Schweinfurth (Östlund 1513) and Epidendrum cyanocolumna Ames, Hubb. and Schweinf. (Östlund 2413). Two orchid genera: Oestlundia W.E. Higgins and Oestlundorchis Szlach., as well as many species, were dedicated to him: Brassia oestlundiana L.O. Williams, Encyclia oestlundii (Ames, Hubbard \& Schweinfurth) Hágsater \& F.R. Stermitz, Lepanthes oestlundiana R.E. Schult. \& Dillon, Maxillaria oestlundiana L.O. Williams, Mormodes oestlundiana G.A. Salazar Chávez \& Hágsater, and Pleurothallis oestlundiana L.O. Williams.

Otto Nagel (1894-1972) finished his apprenticeship in botany and gardening in Saxony, and came to
Mexico in 1925. He dedicated himself to grafting and the improvement of the orange groves in the state of Veracruz. During this time, he lived in the home of C. A. Purpus, who introduced him to the Mexican flora (Hartmann, 1968: 191). A few years later he was called by Karl E. Östlund: he needed an able assistant and collaborator to increase and take care of his collection and prepare an orchid herbarium. Nagel was the ideal man for this task, and so began a fruitful relationship that would go on for nearly a decade (Halbinger, 1972: 257). Searching for and collecting orchids, Nagel traveled through the whole country. He collected the greater part of the Mexican species and discovered a number of new ones. Many others, including a new genus, were named in his honor: Nageliella L.O. Williams, Bletia nagelii L.O. Williams (Conzatti \& Nagel 7113), Bulbophyllum nagelii L.O. Williams (Williams \& Nagel 3864), Epidendrum nagelii L.O. Williams (Nagel 2063), Lepanthes nagelii Salazar \& Soto Arenas, Maxillaria nagelii L.O. Williams ex Correll, Mormodes nagelii L.O. Williams, Stelis nagelii Solano, and Trichosalpinx nageliana Soto Arenas. Nagel was made head of the Orchidarium of the Biology Institute of the National University in 1959 by its director, the renowned professor Faustino Miranda González (1905-1964). Miranda, born in northern Spain, had come to Mexico in 1939 as a political refugee after the Spanish Civil War, and would play an important role in the development of natural sciences in the country. He spent five years in Chiapas, were he wrote an important work about the vegetation of the region (Miranda, 1952) and founded the Botanical Garden of Tuxtla Gutiérrez. In 1960 he organized the botanical garden of the National University. Both gardens carry today his name.

Miranda plays an important role in our history because he identified over 2,700 plants collected by Francisco Hernández in the XVI century and by his translation of the Badianus Manuscript.

Eizi Matuda (1894-1978) was the only botanist of Asian origin who ever worked in our region. Born in Nagasaki, Japan, he received his degree in Biological Sciences at the Imperial University of Taihoku (Taiwan), in 1914. As a professor and researcher for different universities in Japan, Matuda studied the flora of Korea, Manchuria, Hong Kong, Singapore and Java. In 1922 he came to Mexico and became a Mexican citizen in 1928. Matuda was a field man and traveled into remote areas 
by mule, thus acquiring an excellent knowledge of much of tropical Mexico. Although he specialized in Aroids, he collected and studied Mexican Orchidaceae, and in 1969 published an important book about the orchids of the state of Mexico (Matuda, 1969). An important number of Mexican species was named in his honor: Epidendrum matudae L.O. Williams, Govenia matudae E.W. Greenw. \& Soto Arenas, Habenaria matudae Salazar, Lepanthes matudana G.A. Salazar Chávez \& Soto Arenas, and Pleurothallis matudiana C. Schweinfurth.

Christian Halbinger (1884-1976) was born in Munich and came to Mexico in 1906. He was from the beginning fascinated by the Mexican flora, with an initial interest in Cacti that resulted in the naming of two species: Mammilaria halbingeri und Echeverria halbingeri in his honor. In the 1930's his interest shifted to orchids and he became a founding member of the Mexican Society of Orchid Friends in 1939, together with Carlos Lascuarain, Maximino Martínez and Juan Balme. Halbinger's work with Mexican orchids has been continued by his son Federico (born 1925). Halbinger collected the type specimen of Pleurothallis longispicata L.O. Williams (C. Halbinger 1752). Another Mexican species, Platystele halbingerana (R.E. Schult.) Garay carries his name, and was collected by a good friend of Halbinger, the great ethnobotanist Richard Evans Schultes (1915-2001) (Fig. 57C) during a collecting excursion to Oaxaca in 1939, while searching for plants with hallucinogenic properties. Schultes would become some years later Curator of the Orchid Herbarium of Oakes Ames and later of the Botanical Museum of Harvard University. He is famous in the orchid world for his book Native Orchids of Trinidad and Tobago (1960).

Thomas Baillie MacDougall (1895-1973) (Fig. 57D) was a British subject who came to the United States shortly after World War I. As an amateur biologist, he became related to diverse Natural History institutions, among them the New York Botanical Garden, and was named by several of them collector in southern Mexico. He made the isthmus of Tehuantepec his residence and lived there for over 40 years. In Francisco Ortega, a Zapotec guide and itinerant trader, he found a special friend and companion on most of his collecting excursions, traveling on foot over the greater part of the states of Oaxaca and Chiapas. He discovered innumerable new species, many of which carry his name: Begonia macdougallii, Tillandsia macdougallii, Anthurium macdougallii, etc. (Bravo, 1973: 171-172). MacDougall collected the type specimen of Epidendrum rowleyi Withner \& G.E. Pollard (T.B. MacDougall s.n.) and two orchid species were named after him: Oerstedella macdougallii Hágsater and Sobralia macdougallii Soto Arenas, Pérez-García \& Salazar. MacDougall visited often the Botanical Garden of the National University in Mexico City, where he would discuss his orchid specimens with Otto Nagel and his cacti with Helia Bravo. "Among the species of cacti he discovered is the small and singular Ortegocactus macdougallii, a name that links those two most affectionate friends: Don Francisco Ortega and Don Thomas MacDougall" (Bravo, 1973: 172). All important names in the orchidology of Mexico during MacDougall's life were his friends: Oberg, Pollard, Greenwood, Nagel, Halbinger, Miranda and Matuda, among others.

Franz Mayer (1882-1975) came to Mexico in 1905, under a one year contract with a British bank. He saw the opportunity to make his own career and stayed in Mexico for the rest of his life, being one of the founders of the Mexican Stock Exchange. One of his good friends, Ema Hurtado (the widow of the famous painter Diego Rivera) introduced him to the orchids of Mexico that became his passion. Mayer was a founding member of the 'Sociedad Mexicana Amigos de las Orquídeas' (= 'Mexican Society of Friends of the Orchids') in the early 1940's and later a founding and honorary member of the 'Asociación Mexicana de Orquideología.' Mayer built up one of the largest orchid collections in Mexico. A large part of it was left to the Asociación Mexicana de Orquideología that has kept an important part of it incorporated into the collection it maintains in the Botanical Garden of Chapultepec. "[Mayer] knew how to choose his friends, and there is no doubt that the orchids were the ones he preferred" (Ewald, 1977: 146).

A passionate hunter, Salvador Rosillo de Velasco (1910-1987), began to turn his attention to orchids during his hunting excursions, around the year of 1945 . However, he limited his area of study to the state of Jalisco that lies outside the area of interest of this story.

Aaron John Sharp (1904-1997) collected in Guatemala and Mexico between 1944 and 1946. A native of Ohio, Sharp came to our area to study the floristic relationships with eastern North America. In those years he published an important work about the flora of Chiapas (Sharp, 1945). Sharp was a noteworthy conservationist, who 
spent most of his life trying to create a conscience about the sustainable use of natural resources. In Chiapas he discovered a new species of orchid: Cranichis ciliilabia C. Schweinfurth (Sharp 45977).

\section{Honduras and the Pan-American Agricultural} School of 'El Zamorano'. Many years after most Central American countries had already been thoroughly explored, Honduras was still the noteworthy exception. "The vegetation ofHonduras as a whole is very imperfectly known. With the exception of a few collections which have been made in the Atlantic coastal plain region and at scattered inland points, most of the country remains wholly unexplored in the botanical sense" (Yuncker, 1945: 55). Most of those few collections mentioned by Williams were made by Truman George Yuncker (1891-1964) (Fig. 58A), who organized expeditions into Honduras in 1934 and 1936 and then in 1938 and 1940. After obtaining his Ph.D. from the University of Illinois, Yuncker joined the faculty of DePauw University in 1919 and served as head of the botany and bacteriology department from its establishment in the 1920s until his retirement in 1956. On his second journey to Honduras, Yuncker traveled with Ray Fields Dawson (1911- ) and Howard R. Youse. Yuncker wrote some of the few contributions to the flora of Honduras known from the first half of the century: A Contribution to the Flora of Honduras (1938) and Flora of the Aguan Valley and the Coastal Regions near La Ceiba, Honduras (1940). In the former, 63 species of orchids in 28 genera were described, as usual with the contribution of Oakes Ames. During the expedition of Yuncker, Dawson and Youse, two new orchid species were discovered, that were described by Ames as Lepanthes yunckeri Ames (T.G. Yuncker, R.F. Dawson \& H.R. Youse 6152) and Lepanthes dawsonii Ames (T.G. Yuncker, R.F. Dawson \& H.R. Youse 6152A). Another orchid, Phreatia yunckeri, was described by L.O. Williams from a collection by Yuncker in the South Pacific.

Finally, after many years of neglect, Honduras started to play an important role in the history of our orchids when, after Lancetilla, Wilson Popenoe was called upon by the United Fruit Company President Samuel Zemurray in 1941 to help initiate and develop another U.F.C project. This project was the Pan American Agricultural School, popularly known today as "El Zamorano". The idea was to create a center of learning where Central Americans and other Latin Americans could receive up to date agricultural training to help them develop their countries. Popenoe was chosen to find the site for the new school and become its first director. For weeks Popenoe traveled throughout Honduras and Central America and, in the end, he selected a 3,500 acre property in the Valley of El Zamorano near the Yeguare River and 25 miles away from Tegucigalpa, the capital. The Pan American School of Agriculture was opened in September 1943 on an experimental basis, and the first student body was composed of 73 Mexicans and Central Americans. Williams, who had joined the staff of El Zamorano in the early 1950's, wrote a quarter of a century later: "In Honduras the Escuela Agrícola Panamericana, under the direction of Wilson Popenoe, began systematic botanical explorations in all Central American countries in 1946. This work continues, now in conjunction with [the] Field Museum and with important assistance from the National Science Foundation ... Paul C. Standley joined us occasionally in the late 1940s and permanently in $1950 \ldots$ This exploration is being continued by Prof. Molina and by myself and other associates as time permits. A very fine herbarium of Central American materials is to be found at the Escuela Agrícola Panamericana, as well as a very usable library" (Williams, 1972: 202-205). In a similar way to Lancetilla, El Zamorano has only an indirect relation to our story. But the fact that Williams and Standley spent so many years there, for a short time in the company of Paul H. Allen, made it the most important orchid research center in Central America for the first decades of the second half of the XX century.

The great Paul C. Standley, to whom we owe most of the Central American floras of the first half of the XX. century, chose Honduras as the place where he wanted to spend his last years. In a letter to C.V. Morton he wrote: "I am back in Honduras to stay, I hope, and it is doubtful if I shall ever see the States again. There certainly are plenty of things here to keep me busy, and as long as I am able to crawl around I can find plenty of field work in Central America that is worth while" (In a letter to C.W. Morton, April 12, 1950). During his stay at El Zamorano, Standley planned a flora of Central America. "This plan, for a Middle American flora, was not to materialize, for reasons beyond Standley's control, but the groundwork, in the form of the best herbarium and library in Central America, was completed..." (Williams, 1963: 76-77). 


\section{The SECOND half OF THE XX CENTURY $\mathbf{Y}^{40}$}

He may be a son of a bitch, but he is our son of a bitch!

Franklin D. Roosevelt, about Anastasio

Somoza, President of Nicaragua

The years following World War II show a convulse Central America, struggling with political and social unrests. In Guatemala, the progressive governments of Arévalo and Arbenz (1944-1954) were followed by more than three decades of military rulers and guerilla movements fighting for a fairer social order. All attempts to establish democratic governments in Honduras were aborted by successive military coups. Anastasio Somoza, in Nicaragua, was the only one of the dictators of the 1930s that survived the post-war era, until his regime was overthrown by the sandinista movement in 1979. El Salvador lived through a political evolution very similar to that of Guatemala, with military governments focusing on agricultural diversification and the creation of new industries, politics that were of little benefit to the poorer classes (Pérez Brignoli, 2000: 153-160). Mexico, where since 1940 the social objectives of the revolution had been sacrificed to the acceleration of economic growth, entered finally in a post-revolutionary phase under the presidency of Miguel Alemán (1946-1952) and began an era of ambiguous social and economic politics (Halperin Donghui, 2002: 500-506). In 1968, the country was shaken by strong social protests that ended in the infamous killings in Tlatelolco Square, on October 2 of that same year, one of the most tragic events of modern Mexican history. In Panama, the movement that demanded sovereignty over the canal gained more and more strength and ended with the Torrijos-Carter treaties, signed on September 7, 1977, establishing the transfer of the canal to Panama on December 31, 1999. Only Costa Rica, under the shelter of the social reforms of the early 1940s and the political constitution proclaimed in 1949 which -among other important changes- had abolished the army, seemed to be able to escape the social and political chaos in which the rest of the region was submerged. This allows us to understand why, in the world of orchid research, Costa Rica was the only country in which, slowly, an institutional impulse developed, starting with the legacy of Charles H. Lankester and continuing in the Lankester Botanical Garden of the University of Costa Rica, founded in 1973. In the other countries of the region we find important advances which depended always, however, on individual vocations and on the high human and professional level of their protagonists. Panama represents a special case, where the Smithsonian Tropical Research Institute has made an outstanding contribution to the botanical exploration of the isthmus, together with Mexico, with the outstanding results of the research and studies by the collaborators of the AMO Herbarium.

The Mexican Renaissance (II). The work started by Thomas MacDougall in Oaxaca was continued by a small group of amateurs who gave an enormous impulse to Mexican orchidology. "It was the Christmas season many years ago in Oaxaca, and the tall 'gringa' who had recently come to live in the city stood in the flower market admiring the colorful plants that the Indians of the Sierra had brought in to sell as holiday decorations. She was particularly entranced by the delicate small blossoms on some of the plants, and on noting her interest, a gentleman standing nearby said, 'that is a plant of Odontoglossum cervantesii - an orchid.' Then and there was born in the mind of Ruth Oberg ( - 1970) the desire to learn more about these fascinating plants, and the man speaking to her was none other than Don Tomás MacDougall. What a fortunate meeting!, and the beginning of a friendship that lasted to the end of Ruth's life" (Pollard, 1974: 173). "The enthusiasm and dedication of Ruth to the study of orchids made her an important figure in the renaissance of orchidology" (Soto Arenas, 1992:196). Ruth Oberg became known as the 'Orchid Lady of Oaxaca' and visitors from many areas, among them Glenn Pollard, George Kennedy, Eric Hágsater, Carl Withner, Alphonse Heller, Paul Allen and Edward Greenwood, called to consult her and admire the contributions that she was making toward orchid research. She was especially close to Pollard. Together with Robert Dressler, she joined a group from Harvard University for a collecting trip to a remote part of the State of Chiapas - The Laguna Ocotal Grande, where she collected a new species of

\footnotetext{
${ }^{40}$ The author's decision to exclude from this history all persons living at the time this work was written has the inevitable result that this chapter shows large and unavoidable gaps.
} 
Ornithocephalus, that was later dedicated to her. The expedition was led by Dr. Raymond A. Paynter Jr., Assistant Curator for Birds at the Harvard Museum of Zoology and Paynter suggested Dressler as the botanist who should accompany the group. However, strongminded Ruth Oberg had to give her consent: "I have just spoken to the botanist and it is fairly certain that he will be going along, provided, of course, he meets with your approval. I asked him about the orchid situation and he said that he is perfectly willing to give you first choice on all orchids collected and you may have the disposition of them" (R. Paynter in a letter to R. Oberg, March 25, 1954). In April of that same year, Oberg writes to Dressler and emphasizes her point: "If you collect a single plant which is known to me, so that I can make a record about it, you certainly are welcome to keep it. But if it is something which I will want to study, then I must reserve the right to keep it. Otherwise my making this trip would lose its point" (Letter to R. Dressler, April 19, 1954). When they met, they became immediately good friends, and for the rest of Oberg's life, Dressler would call her "Tía" ('aunt', in Spanish). Oberg described years later the excursion to Laguna Ocotal, in an article published in the journal of the Mexican Society of Orchidology (Oberg, 1974). In the years to come, Oberg send large amounts of plants to Dressler for identification, always complaining that the answers came to slow because of too much work on the side of 'don Roberto'. During the last years of her life, Oberg worked on a book on Mexican orchids, which unfortunately was never published. She wrote to Dressler: "You know how I'm going to start my preface? 'This book has been compiled with the hope it will so irritate someone that he will write a better one!'” (Letter to R. Dressler, June 10, 1966). One of Oberg's constant complaints was the quality of the then existing books on Mexican orchids, especially the one published by Norman P. Wright in 1958. "I certainly don't want to see an Icon. of Mex. Orch. if it is not better than Norman Wright did his book. And he certainly did a job of messing up the text for that folio of Orch. and Humming birds" (Letter to R. Dressler, February 16, 1965). Among the collections made by Oberg we find Maxillaria nagelii L.O. Williams ex Correll (Oberg 95) and Encyclia baculus (Rchb. f.) Dressler \& G.E. Pollard (Oberg 60). Epidendrum obergii A.D. Hawkes had been dedicated to her in 1957 .
Federico (Fritz) Halbinger (1925-2007) (Fig. 58B), was the son of Christian Halbinger and, like his father, an expert on Mexican orchids. In 1969 he was cofounder of the Mexican Orchid Society "Amigos de las Orquídeas" and in 1970 and 1971 he made extensive collecting trips to the mountains of the Sierra Madre in the company of Eric Hágsater, Robert Dressler, and Glenn Pollard. These excursions were very successful, also in terms of the discovery of new species. Shortly after that, the journal "Orquídea (Mex.)" was founded, and Halbinger began with the publication of a series of articles, mainly on the genus Barkeria, that had become his specialty. For this reason Miguel Angel Soto Arenas honored him in 1993 with the new species: Barkeria fritz-halbingeriana Soto Arenas. In the following years Halbinger expanded his interest to the genera Odontoglossum and Laelia, publishing important monographic papers, again mostly in the journal "Orquídea (Mex.)". From 1973 to 1974, Halbinger presided over the Mexican Society of Orchidology.

Glenn E. Pollard (1900-1976) (Fig. 58C) was born in the town of Kelso, Missouri, as the son of a railroad man who moved frequently, so that Glenn's schooling was in varied backgrounds. He graduated in mining and metallurgy at Stanford University in 1923. In 1950 Glenn and his wife Barbara made their first visit to Mexico and the country made such a favorable impression on them that when Glenn retired in 1955, they decided to spend the winter there and eventually made Oaxaca their home. "In Oaxaca the Pollards made friends with Ruth Oberg, who for many years had lived in the suburb of San Felipe del Agua studying orchids, and with Tom MacDougall, who also was widely known in biological circles as a veteran collector of plants and small animals, and was perhaps then the most knowledgeable person concerning the topography and biota of Oaxaca and Chiapas. Ruth introduced Glenn to the fascinating world of orchids and Tom reinforced his budding interest with advice and guidance. Soon Glenn began collecting a few plants, and when the Pollards built their own house in 1959, it included a small orchid house; Ruth Oberg contributed some plants to get the collection well started "(Greenwood, 1978: 9). The new road program which started in the early 1960s in southern Mexico brought wonderful opportunities for Pollard to collect orchids. 

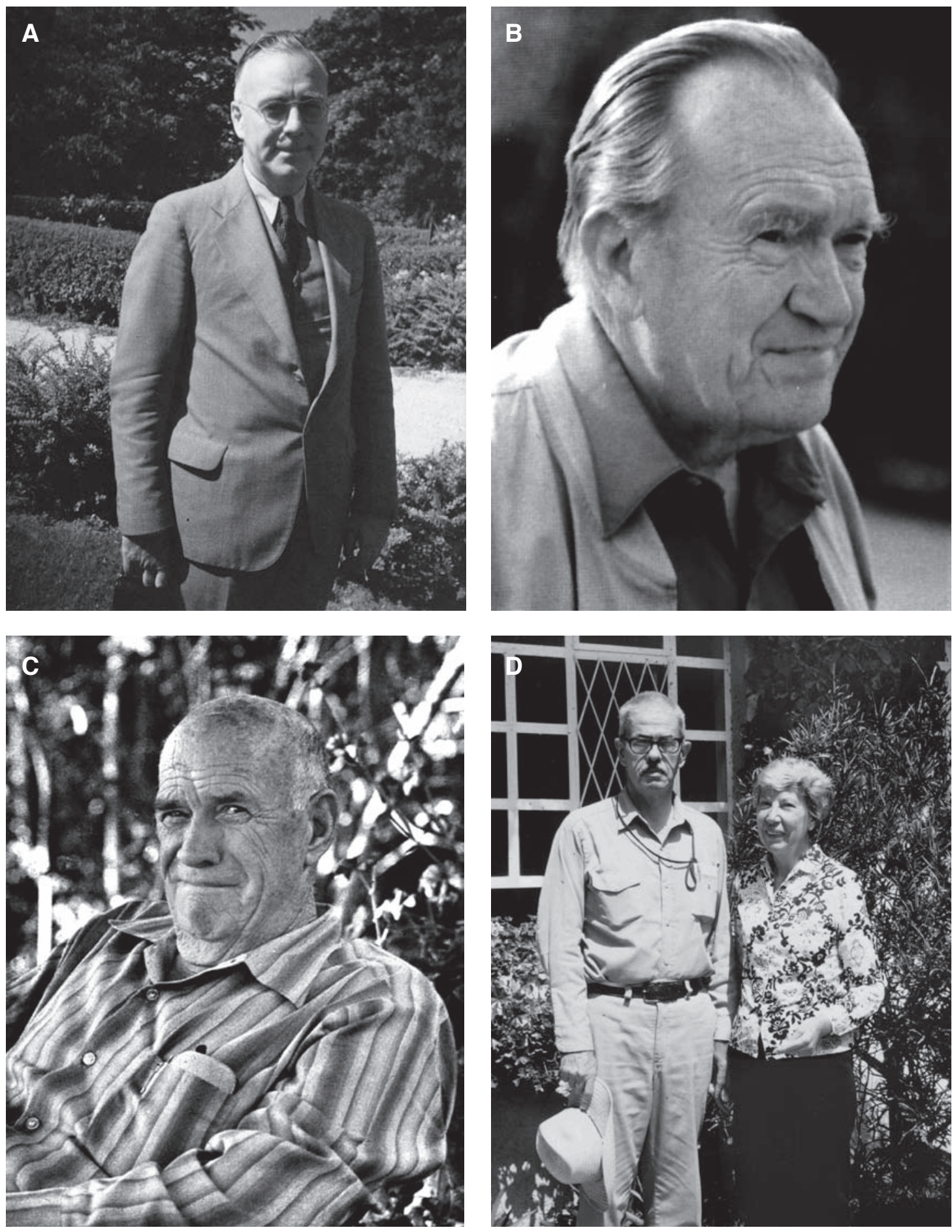

FiguRE 58. A - Truman George Yuncker (1891-1964). Courtesy of the Archives of the Gray Herbarium, Harvard University. B - Federico (Fritz) Halbinger (1925-2007). In Röth, 2007: 72. C — Glenn E. Pollard (1900-1976). Courtesy of Eric Hágsater. D - Edward Warren Greenwood (1918-2002) and his wife Mary Scobbie. Courtesy of Eric Hágsater. 

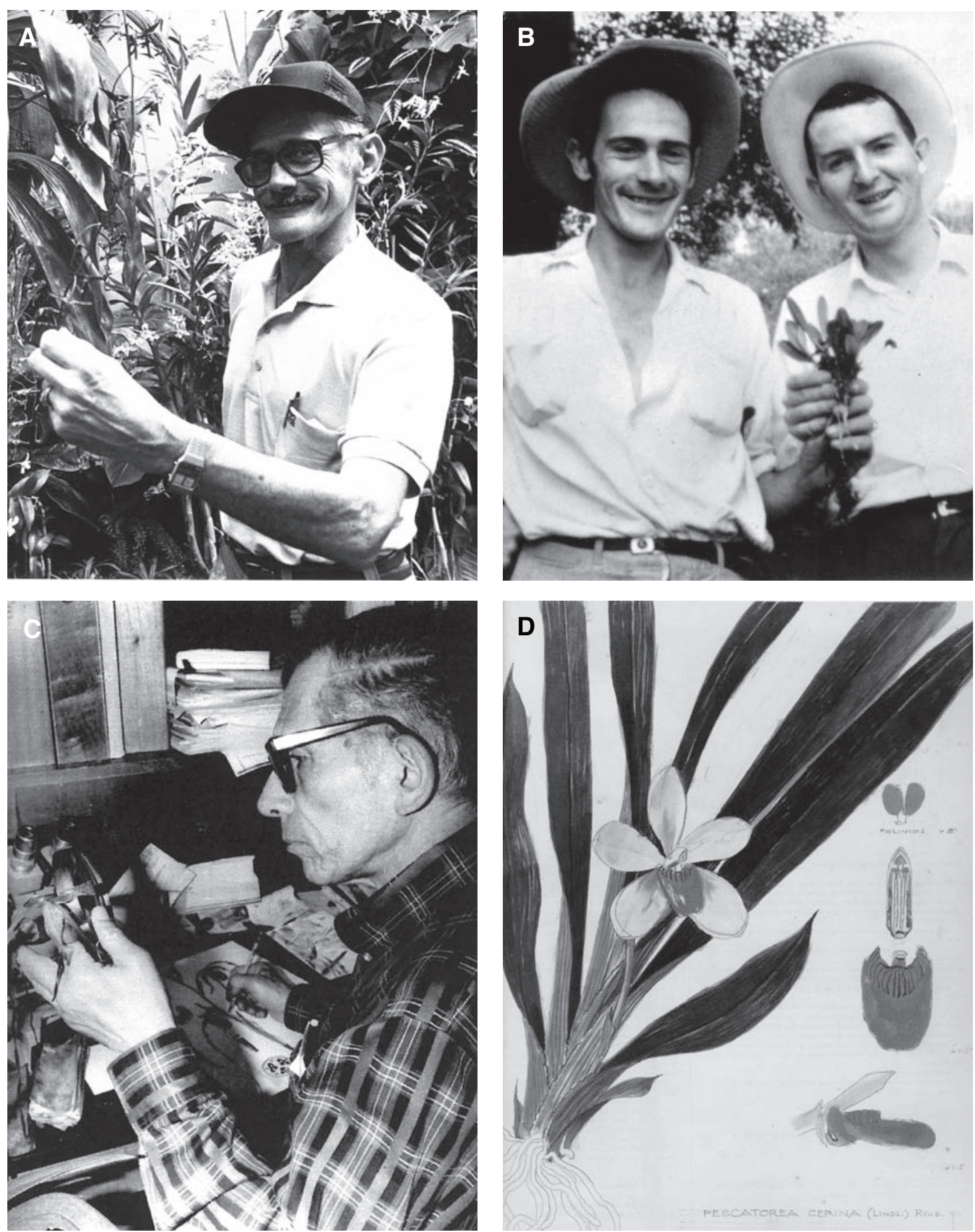

FiguRE 59. A — Clarence Klaus Horich (1930-1994). Courtesy of Rudolf Jenny. B — Jack A. Fowlie (1929-1993) during a visit to Costa Rica (Fowlie on the right. On the left Clarence Horich). Courtesy of Rudolf Jenny. C - Rafael Lucas Rodríguez Caballero (1915-1981). Courtesy of his daughter, Leonora Rodríguez. D - Pescatoria cerina (Lindl. \& Paxton) Rchb. f. Illustration by R.L.Rodríguez in Rodríguez et al., 1986: 203. 
He followed the bulldozers through country hardly explored botanically and still unlumbered and the trees being knocked down by the road gangs made for extremely rich collecting. Pollard's collection became very important, with many rare plants, and turned soon into a focus of interest for orchid enthusiasts and specialists, who came often to visit, among them Louis O. Williams, Calaway H. Dodson and Robert L. Dressler. All became friends and Dressler's interest in Mexican plants led to collaboration and to the joint authorship of The Genus Encyclia in Mexico (Dressler \& Pollard, 1974), Pollards most important contribution to Mexican orchidology. Although he published some eighteen papers on Mexican orchids, Glenn Pollard regarded The Genus Encyclia as his outstanding effort, and the vindication of his hard work and long studies. A loner by nature, his poor health in later years reinforced his dislike for people in groups. Despite this, he was friendly and warm with people he liked, though not everyone met with his approval (Greenwood, 1978: 4). His friends named in his honor Encyclia pollardiana (Withner) Dressler \& Pollard, Malaxis pollardii L.O. Williams, Lepanthes pollardii H.A. Hespenheide and Oncidium pollardi, Dodson \& Hágsater. Withner and Harding honored him with the new genus Pollardia. As a founding member of the Mexican Association of Orchidology, Pollard took an active role in attempts to widen Mexican interest in the orchids of the country. Pollard died in Oaxaca, on March 27, 1976.

"The Greenwoods of the Canadian Embassy in Washington have just left. You may have heard of them, their main interest is in the cacti and in photography, but they also have an interest in orchids and quite a bit of knowledge of them" (R. Oberg in a letter to R. Dressler, August 11, 1960) (Fig. 58D). Edward Warren Greenwood (1918-2002) first came to Mexico with his wife Mary in 1958-1959, when they spent two weeks in Mexico City. There they met plant explorer Tom MacDougall, and Drs. Helia Bravo and Eizi Matuda. During this same vacation, Ed met Glenn Pollard and Ruth Oberg when he went to Oaxaca. At that time, the Greenwoods decided to eventually retire to Mexico. Ed Greenwood worked with the Canadian Embassy, in Washington D.C., from 1959 to 1962 . He kept in touch with the Mexican botanists of the National University, and a close relationship was established with Helia Bravo. Helia had been invited by the Greenwoods to stay at their apartment in Washington, during her stay studying the cactus collections at the United States National Herbarium. Helia always remembered him as a good friend and a very good cook. "He had a keen sense of humor and was a superb raconteur" (Dressler, 2002). Many of Ed's pictures of cacti illustrate Helia and Hernando Sánchez-Mejorada's work on Mexican cactii (1991). It is to be remembered that Greenwood, at that time, followed mainly his interests in the Cactaceae (Reddoch, 2002: 251). After completing the Washington assignment, Ed returned to Ottawa where he started the Native Orchid Location Survey of the Ottawa District, which he later extended to all of Canada. The Greenwoods continued to spend annual leave in Mexico, except during the couple of years when Ed was working in Great Britain. "While on vacation in Oaxaca, in the summer of 1963, Eric Hágsater came through on his way to Chiapas, meeting Ed and Mary at Pollard's place, starting an enduring friendship and collaboration. In July 1964, Ed and Mary traveled with Ruth Oberg, the orchid and cacti lover living in Oaxaca, to Jalisco and Colima, where they met Eric Hágsater and collected together for a couple of weeks". "In 1969, Ed Greenwood moved to London, England, where he was attached to the Canadian High Commission. On his weekends he spent time in the Kew Herbarium and in the libraries at Kew and the British Museum. During his stay in London he amassed an incredible amount of literature about Mexican orchids, mostly photocopies of original descriptions, books on the subject, pictures of type and critical specimens, and became very familiar with the historical collections housed in European herbaria" (Light et al., 2002: v). He also took the opportunity to travel to Vienna: "In early May I shall be in Vienna for a few days working in the Reichenbach Herbarium. Perhaps there may be some items there which I might look up for you..." (In a letter to R. Dressler, March 23, 1973). Ed Greenwood returned to Canada and retired in 1973. At the end of that year he departed with Mary to Mexico, where he stayed for the next 20 years. When the Greenwoods decided to set up their home in Oaxaca, the most productive period in Mexican orchidology began. Shortly after the Greenwoods moved to Mexico permanently, Eric Hágsater revived the old orchid society "Amigos de las Orquídeas”. They began publishing Orquídea (Mex.), where Ed became one of the editors. 
The first years in Mexico were spent in close collaboration with Glenn Pollard and the other orchid enthusiasts living in Oaxaca. Greenwood explored the Oaxacan roads together with Octavio Suárez, a young boy who had been introduced to him by Pollard. In the field, Ed was a terrific observer, always looking for the rarest, smallest, and most inconspicuous terrestrials, in which he became a specialist. "Ed's knowledge of Mexican Spiranthinae eventually became very authoritative [...] However, Ed Greenwood's most important contribution was the formation of a new generation of Mexican orchidists in systematics. His endless enthusiasm was contagious and joining him on field trips was very enlightening (Light et al., 2002: v)." In 1987 he had to travel to Canada and from there he wrote to Dressler: "I was disappointed at missing you in Guadalajara and also at not observing the presentations there by our AMO juniors. You had met only Nacho Aguirre, I believe; how did you like Miguel Ángel Soto and Gerardo Salazar?" (Letter to Dressler, October 31, 1987). "Among his output of about 20 papers were the descriptions of 10 new orchid species" (Reddoch, 2002: 251). Many others were dedicated to him, among them: Acianthera greenwoodii Soto Arenas, Anathallis greenwoodii Soto Arenas \& Salazar, Bletia greenwoodiana Sosa, Dryadella greenwoodiana Soto Arenas, Salazar \& Solano, Encyclia greenwoodiana I. Aguirre-Olavarrieta, Epidendrum greenwoodii Hágsater, Galeandra greenwoodiana N. Warford, Govenia greenwoodii Dressler \& Soto Arenas, Habenaria greenwoodiana R. González, Lepanthes greenwoodii G.A. Salazar \& Soto Arenas, Liparis greenwodiana Espejo, Malaxis greenwoodiana Salazar \& Soto Arenas, Stelis greenwoodii Soto Arenas \& Solano, and Trichosalpinx greenwoodiana Soto Arenas. Greenwood had been involved since 1978 in the fascicles about Orchidaceae of the Flora de Veracruz, and worked later on the project of the Flora Mesoamericana, as a specialist in the genus Govenia. Greenwood had concerns with regard to his appointment as a specialist for the Flora: "because I personally am located in the fringe zone, with mixing of northern and tropical floral elements, there may be some highly specific targets to investigate. On the other hand, my total lack of funds for travel to herbaria and the very limited access to have to the literature are very real limitations on my capability. There is one bright spot, though; my two-year bout with heart trouble is past, after a coronary by-pass job in Houston less than three weeks ago. My work capacity won't be limited by feebleness, I am assured" (letter to Dressler, November 19, 1986). In 1986 Greenwood traveled to Costa Rica, where he came together with Dressler and met Dora Emilia Mora de Retana. In a letter to Dressler, written in March of that year, he expressed his wish to meet in Costa Rica Norris Williams, Calaway Dodson and Carlyle Luer. We don't know if his wish was fulfilled. "Failing health and the advantages of the Canadian public health service finally lured Ed and Mary back to Canada, where Ed continued to correspond with many other orchid enthusiasts in Mexico and elsewhere as long as his health permitted" (Dressler, 2002: 1119). Edward W. Greenwood died in Ottawa on February 24, 2002, at the age of 84. "His energy, enthusiasm, encouragement and expertise, as well as his passion for orchids, will be remembered by many who new him" (Reddoch, 2002: 252).

The role of George C. Kennedy (1919-1980) in the orchidology of Mexico is difficult to judge. On one side, his most important collections were made in South America, or in the northwestern states of Mexico, which lie outside of our area of study. On the other, we know (from her correspondence with Robert L. Dressler) that he was a frequent visitor of Ruth Oberg in Oaxaca and he wrote several important articles on different genera which are widely distributed throughout Mexico, sometimes together with Halbinger, with whom he went on several collecting trips. A graduate of Harvard, Kennedy moved in 1952 to Los Angeles and became a research professor at the Institute of Geo-physics and Planetary Physics at UCLA, where he worked and studied until his death. "As a research professor, he taught no classes but experimented in his lab with two or three post doctoral students each year. Together they made the Kennedy Lab famous throughout the world" (Fowlie, 1990: 8). Kennedy visited Mexico on geological excursions and was immediately fascinated by orchids and Pre-Columbian art. It was said about him that he was 'persona non grata' in Mexico, because he took numerous archeological pieces of the Colima culture out of the country. Hunting after orchids he traveled extensively, and -besides Mexicocollected in Madagascar, Burma, India, Colombia, Ecuador and Peru. He often gave many of his living 
collections from Ecuador to Dr. Calaway Dodson at Selby, but without any collection data, which made Dodson furious, since this made them worthless. In a letter to Hágsater from December 1975 he complains that he was not allowed to take 5,000 plants out of Colombia. Three of Kennedy's collections became the types for new orchids species: Pleurothallis kennedy Luer and Oncidium kennedy Stacy, both collected in Ecuador, and Epidendrum kennedy Fowlie \& Withner, frequent in the Mexican states of Sinaloa and Nayarit, somewhat to the North of our are of study. He had large greenhouses in Los Angeles, and normally did not number his plants until they flowered and he had been able to photograph them. Therefore, Kennedy's numbers correspond to his slides.

Heller and Hawkes: a Nicaraguan interlude. "In May 1973, while watering the garden of his large estate high up the hills overlooking Managua, Alphonse Henry Heller (1894-1973) died of a coronary. He was nearly 79 years old. Born an American, he studied mining engineering, worked for the Atlantic-Richfield Company, lived in San Marino near Los Angeles, founded his own company and became very wealthy. In 1956, at the age of 62, he retired from business, left the United States and took up residence in Nicaragua, where, as a hobby, he first worked on butterflies and then started collecting orchids as a very enthusiastic amateur" (Hamer, 1982-85: 1). Heller had already a large orchid collection in California. In a letter to Dressler, Ruth Oberg writes: "Did I tell you that the Hellers of San Marino and Managua, Nic. came to visit me on their way south? He moved all his orchid plants from Calif. (what a job that must have been!), and now has them planted on trees on the coffee finca he bought about 8 miles from Managua" (Letter to Dressler, November 5, 1957). Heller became a good friend of Oberg and visited her frequently, on his trips from California to Nicaragua.

Dr. Calaway Dodson first met him in 1955 in San Marino, and he later visited him several times in Managua. This is how Dodson characterizes him: "Al Heller was an extreme intense individual. His interests were varied and when he became interested in a particular subject such as orchids, he did so in a profound manner. He consulted all experts in the field, he prepared bibliographies, lists and compiled libraries covering the total range of the subject. He was untiring and worked 16 to 20 hours per day. [...] The results of his efforts are immense. He filled more than 150 notebooks, each two to three inches thick, with notes on orchids alone. He made more than 12,000 collections of Nicaraguan orchids and illustrated most of them in color along with extensive notes on each collection, concerning size, shape, habitat, etc. [...] Unfortunately, his zeal, enthusiasm, and lack of patience allowed little room for constructive criticism from scientific collaborators with the result that in most cases, communication was lost. He was particularly lax in making herbarium specimens to document his citations of species. [...] His illustrations were certainly adequate, though even he did not consider them works of art. Al Heller's contribution to the knowledge of the orchids of Nicaragua was major even though flawed by the lack of corroborating specimens in some cases". (Hamer, 1982-85: 1) “The enormous increase in known orchids in Nicaragua from 1956 to 1973 indicates clearly what may happen in a tropical region when an astute and dedicated person takes up the study of a major component of that flora" (Williams, 1973: 987). When A. Heller died, he left a truckload full of information on local orchids with drawings, descriptions, color slides and specimens of dried plants of Orchidaceae, as well as a large and valuable library, which were donated by his widow Christiane Heller to the Marie Selby Botanical Gardens, then under the directorship of Dr. Calaway H. Dodson. It was this material which formed the nucleus of the rapidly growing research department of that institution. The donation was made with the understanding that arrangements would be made to use Heller's work for a publication and Dodson invited Hamer, who still resided in El Salvador, to have a look at Heller's material, which was the base for the fascicles on Nicaragua of the Icones Plantarum Tropicarum series, written by Hamer and edited by Dodson, and later for the Orchidaceae of the Flora of Nicaragua, published by the Missouri Botanical Garden (Hamer, 2001). The opinions about Heller's work were contradictory. As Hamer writes, "unfortunately the Heller material turned out not to be too useful; I had been warned that “... it would be a mistake to get mixed up with that project, as I feel sure the sketches must be inaccurate (Dr. Fowlie) or "Yes, it is true, Heller sent us a lot of scraps, much of which 
was not even worth putting on a herbarium sheet (Dr. Garay), and "Mr. Heller made very good sketches of the orchids he collected, but usually lousy specimens or none, and these were usually with inadequate data" (Dr. Williams) (Hamer, 1985: 3). "[Heller] had prepared a manuscript or a check list totaling 57 pages, all classified phylogenetically, as proposed by Dr. Dressler. His work was however never published, since his interests had changed" (Hamer, 1985: 1). Alfonso Heller (as he was called in Nicaragua) had amassed information about 650 species, with drawings and descriptions and sometimes photos. About 1968 he suddenly lost interest in orchids and dedicated himself to Nicaraguan archaeology.

Born in Houlton, Maine, Alex Drum Hawkes (1927-1977) commenced working with orchids at the age of eleven. Such famous botanists as Oakes Ames, Liberty Hyde Bailey and David Fairchild were among his early influential mentors. At the age of twelve his first article on the subject was published, the forerunner of many thousands of papers on orchids and other largely tropical plants (Blowers, 1965: 1516). He soon became interested in the orchids of Tropics and at the early age of 23 he published his The Genus Habenaria in Florida (Hawkes, 1950) and one year later his checklist of Cuban orchids (Hawkes, 1951). From 1952 to 1959 he edited the short-lived Orchid Journal, where important articles about the orchids of our region were published. Somewhat later he edited The Orchid Weekly (originally named the South Florida Orchid Weekly) in the years 1958-1967. Then came his first book, Cultural Directions for Orchids (1960), in 1961 Orchids, Their Botany and Culture and in 1965 his Encyclopaedia of Cultivated Orchids, which received very poor reviews from many knowledgeable orchidologists. Probably the harshest critic was that of Leslie A. Garay. "If the author means that Ames through his writings taught him and inspired the writing of this monumental work, then Professor Ames for the first time, although post mortem, became a failure. Professor Ames was known to be a very exact and meticulous researcher and a most careful investigator; yet none of these aspects of Ames' teaching is apparent anywhere in Mr. Hawkes' book". And finally, "I have read this book with the same critical eye as Professor Ames, to whom it is dedicated, would have, and am sure, if he were alive today, he would agree with me that 12 guineas or $\$ 36.00$ is too high a price to pay even for such a large amount of misinformation" (Garay, 1966: 197-199). A highly qualified 'chef', Hawkes wrote also on cooking, and published several popular books on this subject. Hawke's first experience in Central America was in Belize, where he collected orchids in 1958. In 1959 he came to Nicaragua and established a longlasting friendship with Heller, who very soon hired him to help him in his studies of Nicaraguan orchids. "My purpose was, of course, to see and collect orchids, and in this matter I was the guest of Mr. and Mrs. Alfonso H. Heller ...” (Hawkes, 1959). He continued traveling to this country and throughout Central and South America, and discovered, together with Heller, many new species, which were often named in their honor: Epidendrum goodspeedianum A.D. Hawkes, Epidendrum restrepoanum A.D. Hawkes, Epidendrum curtisii A.D. Hawkes, Epidendrum neocauliflorum A.D. Hawkes, Epidendrum vulcanicola A.H. Heller, Eurystyles borealis A.H. Heller, Kegeliella atropilosa L.O. Williams \& A.H. Heller, Odontoglossum subcruciforme A.H. Heller. Pleurothallis lappiformis A. Heller \& L.O. Williams, Pleurothallis exesilabia A.H. Heller \& A.D. Hawkes, Pleurothallis carnosilabia A.H. Heller \& A.D. Hawkes, Pleurothallis chontalensis A.H. Heller \& A.D. Hawkes, Sobralia chatoensis A.H. Heller \& A.D. Hawkes, Sobralia triandra A.H. Heller \& A.D. Hawkes, Epidendrum hawkesii A.H. Heller, Eria hawkesii A.H. Heller, Oncidium hawkesianum Moir, Pleurothallis alexii A.H. Heller, Pleurothallis hawkesii Flickinger, Sobralia hawkesii A.H. Heller, Chondrorhyncha helleri Fowlie, Dressleria helleri Dodson, Lepanthes helleri A.D. Hawkes, Pleurothallis helleri A.D. Hawkes, Pleurothallis helleriana L.O. Williams, Sobralia helleri A.D. Hawkes, Stellilabium helleri L.O. Williams, and Vanilla helleri A.D. Hawkes. Hawkes described the new genera Helleriella and Hellerorchis, named in honor of his friend and patron. He died in Norbrook, Jamaica, where he had spent the last ten years of his life. During his years in Jamaica he wrote for the Jamaica Weekly Gleaner, conducted a radio program on gourmet coking, taught Portuguese at Priory School (he spoke six languages) and had become a reputable artist. 
Clarence Klaus Horich: the last of the adventurers. Clarence Klaus Horich (1930-1994) (Fig. 59A) was born probably 100 years too late. His character, romantic and adventurous, bohemian and dreaming, belonged more to the XIX century than to the hard years of the European post-war. If we want to find a twin soul to Horich's, we have to go back in time to re-discover his alter ego, George Ure Skinner [...], who explored Central America in the first half of the XIX century. [...] Horich dreamed sometimes with living from the orchids. More probably, the orchids ended living from him (Ossenbach, 2003: 47-48). After learning gardening in Lüdenscheid (Germany), Horich emigrated in 1951 to Canada (like so many other Germans who tried to escape the miseries of the destroyed Germany) and soon found employ in the orchid nursery of Albert Withers. It was Withers (who already had collected orchids in South America) who encouraged Horich to follow his steps (Bock, 1994: 121). In 1953 he started on his first collecting expeditions, which led him to Mexico, Central America, Colombia, Ecuador and Bolivia. He not only hunted for plants, but was also interested in living animals. He went after reptiles and snakes for the Canadian Stanley Park in Oaxaca and Chiapas and traveled during 11 months collecting orchids for the English firm of Sanders (Jenny, 2000: 21). In Central America, he collected intensively in El Salvador, Guatemala and Honduras, until he finally settled in Costa Rica in 1957. In 1979 he became a Costa Rican citizen. He became a purveyor of living plants for many botanical gardens, among which we find those of the University of Heidelberg, Montreal, Vancouver, Missouri, Vienna, Berlin, Bonn, Hannover, Frankfurt and the Lankester Botanical Garden of the University of Costa Rica. According to Jenny (2007, pers. comm.), he charged between 5 and 10 Dollars for a good plant, and up to 60 Dollars for rarities such as Coryanthes. In words of Dr. Hans-Georg Preissel, at that time director of the Botanical Garden in Hannover: "A botanical garden needs original material. Horich is for us one of these pioneers who has supplied the collections that make us attractive on an international level" (KRW, 1990).

Nothing could stop him: he wasn't afraid to cross the Reventazón River on precarious ferry cables, nor to cross the Gulf of Nicoya in a small boat with a crew of Coryanthes and ants (Horich, 1984). He didn't have to deal with phytosanitary certificates nor with CITES' rules which would have been intolerable obstacles for somebody like Clarence Horich. Soon he started writing about the plants, the habitat and especially about his adventures on collecting trips. "Between 1953 and 1994 he published more than 230 articles about orchids, and in spite of the fact that the reader had to sift carefully between facts and adventure, those articles contained the best descriptions of localities and habitats we have from Central America. I always found it was a real adventure to travel and collect with him; he was one of the best plant experts in Costa Rica and a day with him in the forest was something like a short and intensive course in botany and ecology. His private plant collection in his backyard in San José was better than most of the collections of Costa Rican plants in botanical gardens. He had an extremely good eye for small plants and he had a sixth sense where and how to find new things" (Jenny, 2000: 21). Horich was proud to have been the guide through Costa Rica's forests of the world's leading orchidologists of his time. Between 1960 and 1965 he traveled through the most remote regions with Jack Fowlie and Cal Dodson. In later years he was the guide of Rebecca Northen, Rudolf Jenny, Eric Hágsater and Robert Dressler, among others.

Rudolf Jenny honored Horich (with whom he had collected orchids in Costa Rica in 1976, 1980, 1984 and 1986) with the dedication of a new genus: Horichia, with the type species Horichia dressleri. Many other species were dedicated to him: Cischweinfia horichii Senghas \& T. Neudecker, Coryanthes horichiana Jenny, Epidendrum horichii Hágsater, Gongora horichiana Fowlie, Lepanthes horichii Luer, Maxillaria horichii Senghas, Mesospinidium horichii I. Bock, Mormodes horichii Fowlie, Pleurothallis horichii Luer, Stanhopea $x$ horichiana Jenny, Telipogon horichianus Braas, and Teuscheria horichiana Jenny \& Braem. Horich's lifelong companion, Elcimey Baldizón, was honored by Hágsater with Epidendrum elcimeyae and by Braas \& Horich with Telipogon elcimeyae.

\section{"It appears Jack Fowlie was a character and is sorely missed. The world is sorely lacking characters these days".}

Anonymous

"I practice medicine so I can afford to study orchids in their native habitats" (Hetherington, 1994: 5). Jack 
A. Fowlie (1929-1993) (Fig. 59B), a family physician, was one of Horich's best friends and visited him in Costa Rica on several occasions. His first expedition with Horich was in November of 1960, together with Noel Gauntlett, Jürgen Hansen and Glenn Hiatt, from the Los Angeles State \& County Arboretum. Then they traveled again, this time to the region of Sarapiquí, together with Ralph Spencer. In one of his articles, Horich muses about Fowlie getting lost in the forest, loosing a valuable camera, climbing down a 50 meter vertical rock and finally coming out with a thick bundle of Pescatoria cerina (Horich, 1978). "Jack [...] had a busy practice when he was not traveling. He loved to talk about orchids and his travels, and he was never reluctant to give medical advice when on a trip or with orchid friends" (Hetherington, 2004: 288). His most valuable contribution to the orchid world was his excellent photography and his ability to write of his travels and of the species he observed. Clarence Horich collaborated with Fowlie collecting a great number of Lycaste species for the research that led to the publication of the latter's most important work: The Genus Lycaste, its specification, distribution, literature and cultivation - a monographic revision (1970). In 1993, Oakeley actualized Fowlie's work, bringing the genus to 45 species and changing some names (Oakeley, 1993). The following orchid species were dedicated to Fowlie: Cyrtopodium fowliei L.C. Menezes, Encyclia fowliei Duveen, Lycaste fowliei Oakeley, Paphiopedilum fowliei L.A. Birk, and Stanhopea $\times$ fowlieana Jenny.

Most of these species were published in The Orchid Digest, the specialized journal of which Fowlie was the editor during many years. In the words of Eric Muehlbauer, "[..] the late Jack Fowlie had been its editor during the 80 's, maybe late 70 's... an incredible character. Had no grasp of written grammar and his own, very unique, ideas on Paphiopedilum taxonomy. That said, he was an incredibly productive writer who traveled to see slippers in situ, and got to know the people in the areas where they grew, and the people who collected them and grew them. His influence helped the Orchid Digest become and remain the great magazine that it still is" (Muehlbauer, 2006). "Typical of his extraordinary interest and drive, prior to his interest in orchid species he wrote a hardbound book, The Snakes of Arizona, in 1965. It is a fascinating study, though I doubt that many orchid fanciers would say that they must see or have it" (Hetherington, 2004: 289).

\section{Rafael Lucas Rodríguez and the Lankester Botanical Garden}

"Those who dedicate too much time to orchids begin as orchidophiles, become soon orchidologists, and end as orchidiots..."

Rafael Lucas Rodríguez, during a lecture (1974)

Schlechter had good reasons to dedicate Ramonia pulchella to the small village of San Ramón, which with a population of bearly 15,000 , has produced more than its share of great biologists. Not satisfied with having Alberto M. Brenes and Guillermo Acosta among its prominent citizens, San Ramón gave birth in the early $\mathrm{XX}$ century to one of the most respected figures of Costa Rica's scientific world: Rafael Lucas Rodríguez Caballero (1915-1981) (Fig. 59C). During one of his first visits to Costa Rica, Robert Dressler visited Rafael Lucas Rodríguez in his office at the University of Costa Rica. As Dressler remembers: "After that, a visit to Costa Rica was incomplete without seeing 'don Rafa', as friends and students called him. Quite aside from our mutual interest in orchids, I was at once impressed by his charm, his intellect and his linguistic skill” (Rodríguez et al, 1986: 10).

Rafael Lucas received his first lessons from his mother, Emilia Caballero, who was a teacher in his home town. After finishing elementary school, he moved with his mother to the United States, where he began his high school studies, which he later finished at the 'Liceo de Costa Rica', one of the best schools of the capital. His friends at school called him "El Sabio" (= the wise man) because of his dedication to his studies. He stayed at the same 'Liceo' as an assistant for Natural History, Zoology and Botany. Blessed by the Muse of arts, he was also employed during those years in the workshop of the famous French sculptor Louis Ferón, where he developed his talents as a jeweller and illustrator. Years later he would design the great mural which Ferón crafted for the 'Golden Room', in San José's old airport building. In 1942, shortly after the University of Costa Rica opened its doors, Rodríguez started his studies in biology at its School of Sciences, and in 1945 received a scholarship which allowed him 
to continue his specialization in plant systematics at the University of California at Berkeley. His teacher was the famous Lincoln Constance, whose illustrious career at Berkeley spanned more than six decades and who wrote several years later: "Rafael was torn between a career as a professional biologist with strong interest in natural history or as an artist with a flair for graphic illustration. He was happiest when these interests coincided in the study of recurring patterns in living organisms" (Rodríguez et al., 1986: 14). Rodriguez' doctoral dissertation was a comparative investigation of the Costa Rican tree Myrrhidendron, in relation to other woody Umbellales, profusely and beautifully illustrated by the author. This publication is still quoted widely years after his death.

After returning to Costa Rica in 1953, Rodríguez was incorporated as a professor at the University of Costa Rica, where he was instrumental in the creation of a Department of Biology, and was appointed as its first director. Under his direction, the Department assumed custody of the University Herbarium (USJ), which had been founded in 1943. Today, the department has become the School of Biology and carries his name.

Rodríguez contributed enormously to the development of the studies of biology in Costa Rica and was one of the first editors of the prestigious Revista de Biología Tropical. Again through his efforts, the first contacts between the University of Costa Rica and the Organization for Tropical Studies were established, a milestone in the history of nature conservation in the country. A many-faceted man, Rodríguez was a leader of the Boy Scout movement in Costa Rica, a passionate stamp collector, and combined his teaching in biology with singing in the University Choir. As his friend and fellow artist Francisco Amighetti wrote: "Like many scientists and artists, Rafael Lucas Rodríguez had the privilege of maturing intelectually while still preserving his childhood spirit intact". Strongly interested in Orientalistim, he believed in a theosophical interpretation of nature and intended to form his students not only as biologists but as true humanists. His passion for botanical illustration led him to organize a special course for the School of Arts, which he called 'watercolor painting for biologists'.

It was because of his reputation as a botanical illustrator that Rodríguez first became interested in orchids. One day in the early 1960's he was approached by the well-known orchidologist Charles Lankester, who asked him to produce an illustration from a live orchid: it was a specimen of Pescatorea cerina (Lindl. \& Paxton) Rchb. f. (Fig. 59D) which became the first of a large number of beautiful orchid watercolors. As Lincoln Constance said, his paintings were 'artistically gorgeous but scientifically accurate' (Rodríguez et al., 1986: 14). Rafael Lucas began in 1966 his most ambitious project, a treatise with the title Orquideas del Istmo Centroamericano, a manuscript that unfortunately was never published, of which large parts are still preserved in the archives of the Lankester Botanical Garden, and that began with the words, in Rafael Lucas' characteristic calligraphy: "Central America is famous for the abundance and above all, the variety of its orchids" (Fig. 60A).

It was for this project that Rafael Lucas began his series of illustrations, which reached the impressive number of 1,092. As Robert Dressler recalls, as time went on, his skill increased and it was easy to see which were the older paintings and which newer. Then he changed to a larger format, with the intention of redoing all of the earlier paintings, as flowers became available. However, many of the illustrations remained unfinished at the time of his death. What Rafael Lucas did not have was a good hand at cultivating orchids. As Dressler puts it: "He didn't have a green thumb" (Rodríguez et al., 1986: 11). His office was usually decorated with the dying remains of many plants that his friends had brought in for him to paint. He was neither a field man. Luis D. Gómez, one of his pupils, tells us that he once had to drag his professor into the field, to admire a tree which was ladden with masses of flowering Trisetella triaristella (pers. comm, 2004). It is not clear why Rafael Lucas did not publish his work. He might have been a perfectionist, waiting to finish his series of paintings before comitting anything to press; he might also, being a specialist in other plant families, have felt somewhat insecure about Orchidaceae. According to L.D. Gómez, don Rafa always complained about the lack of literature, reference collections and time to travel and study type specimens. He never stopped studying: his notebooks are full of annotations and sketches, and he often pasted a photocopy of the original description of a species next to one of his detailed pencil sketches.

In 1969, members of the Latin-American Committee 
of Orchidology proposed to Miguel A. Ramírez the idea of founding a Costa Rican organization which should unite all those interested in the cultivation and conservation of orchids. Ramírez responded with enthusiasm and found immediate support from Rafael Lucas Rodríguez, Dorothy Lankester, daughter of Charles Lankester, who had recently passed away, and Roy Lent. The first meeting of the group was held in a classroom at the School of Biology of the University of Costa Rica on May 16, 1970, and in July of that same year the Costa Rican Orchid Society (Asociación Costarricense de Orquideología, or A.C.O.) was officially constituted, with Miguel A. Ramírez as its first president. And here the links of history can be easily understood: it was Lankester who seduced Rafael Lucas Rodríguez into the world of orchids when he first asked him to paint Pescatoria cerina. And it was one of the main purposes of A.C.O. to save 'El Silvestre', the orchid garden of Charles Lankester and Rafael Lucas Rodríguez who made the international contacts and organized a network of institutions that eventually provided the funds to buy the property and donate it to the University of Costa Rica. On March 2, 1973, Rafael Lucas had the satisfaction of giving the opening address during the official inauguration of the Lankester Botanical Garden (Fig. 60B).

Rafael Lucas Rodríguez was not only a great biologist and a convinced humanist, he was also a man of charm and humor. Robert Dressler, his friend and admirer, remembers an episode which describes vividly Rafael Lucas' character: "In one major botanical congress, we learned that Dr. Rodríguez was to present an afterdinner speech on Recent advances in Algology. None of us knew him to be interested in algae, and there was much speculation on the subject of the speech, but Don Rafa smilingly evaded all leading questions. When the time came, the speech had little to do with algae. Rather, he went back to the Greek, algos = 'pain', and laid the foundations for a new science, the study of pain and more specifically, the pain caused by sitting on hard chairs in classrooms and auditoria, listening to poorly prepared, or overly long lectures illustrated by blurry or upside-down slides. The talk was charming, erudite and very funny. No one suffered the slightest pain on that occasion" (Rodríguez et al., 1986: 10). Rafael Lucas was instrumental in Dressler's early interest in Costa Rican orchids, as it becomes clear when one reads through their mutual correspondence. In 1977 Rafael Lucas was awarded the highest academic honor of the country: the 'Magón', National Award for Cultural Achievement, as a recognition of his extraordinary contributions to botanical science. In the same year, the lagoons of Palo Verde, in the province of Guanacaste, were declared as a Wildlife Refuge under the name Refugio Nacional de Fauna Silvestre Rafael Lucas Rodríguez Caballero (today part of the Palo Verde National Park). In 1979, an exhibit of his botanical illustrations was staged at the Museum of Botany and the Arts at the Marie Selby Botanical Garden in Sarasota, Florida.

On some occasions, Rafael Lucas painted orchids without realizing that they were species new to science, and which were later, in many cases, dedicated to him. This was the case with Epidendrum rafael-lucasii Hágsater, Lepanthes rafaeliana Pupulin, Masdevallia rafaeliana Luer, Encyclia ossenbachiana Pupulin, and Maxillaria rodrigueziana J.T. Atwood \& Mora-Ret. Shortly before his death, in 1980, his paintings were exhibited at the National Museum in San José. In 1986, the University of Costa Rica published a beautiful volume, authored by Dora E. Mora, María E. Barahona and Norris H. Williams, with some texts from Dr. Rodríguez, featuring 143 of the most beautiful orchid paintings by Rafael Lucas, under the name of Géneros de Orquídeas de Costa Rica (Rodríguez et al., 1986).

Rafael Lucas Rodríguez passed away on January 29, 1981, after a long disease. We leave the final words to Francisco Amighetti, Robert Dressler and Rudolf Jenny: "A good man in the broadest sense of the word ... [his paintings] are a wonderful tool for anyone studying the orchids of Costa Rica, and their value will only increase as the availability of orchids in their natural habitat diminishes everywhere.... Dr. Rodríguez death was a tragedy, and we can only imagine what he might have done with another ten or twenty years of life... that charm and intellect that was Don Rafa can never be replaced...An extraordinarely friendly person, a true gentleman and artist " (Rodríguez et al., 1986: 11).

Unfortunately, only about 150 of Rafael Lucas' 1,092 illustrations were recovered by the University of Costa Rica, mainly those that were used for the publication of his book. The rest remained in the hands of his family. The largest part of the legacy of Costa 
A

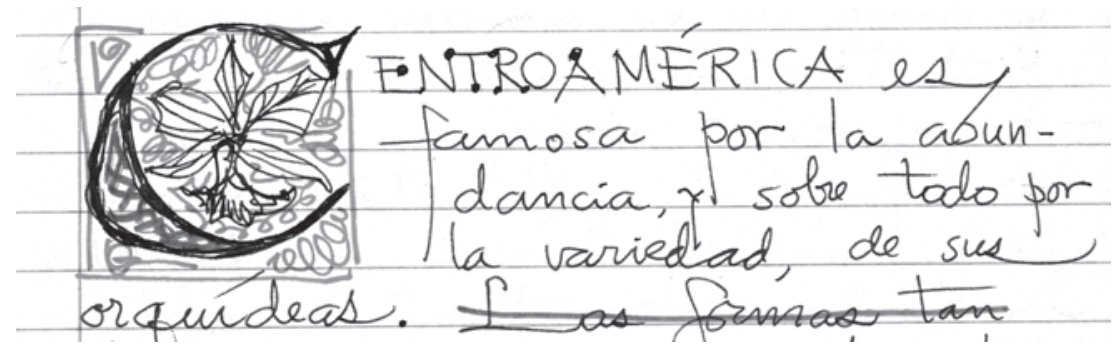

B

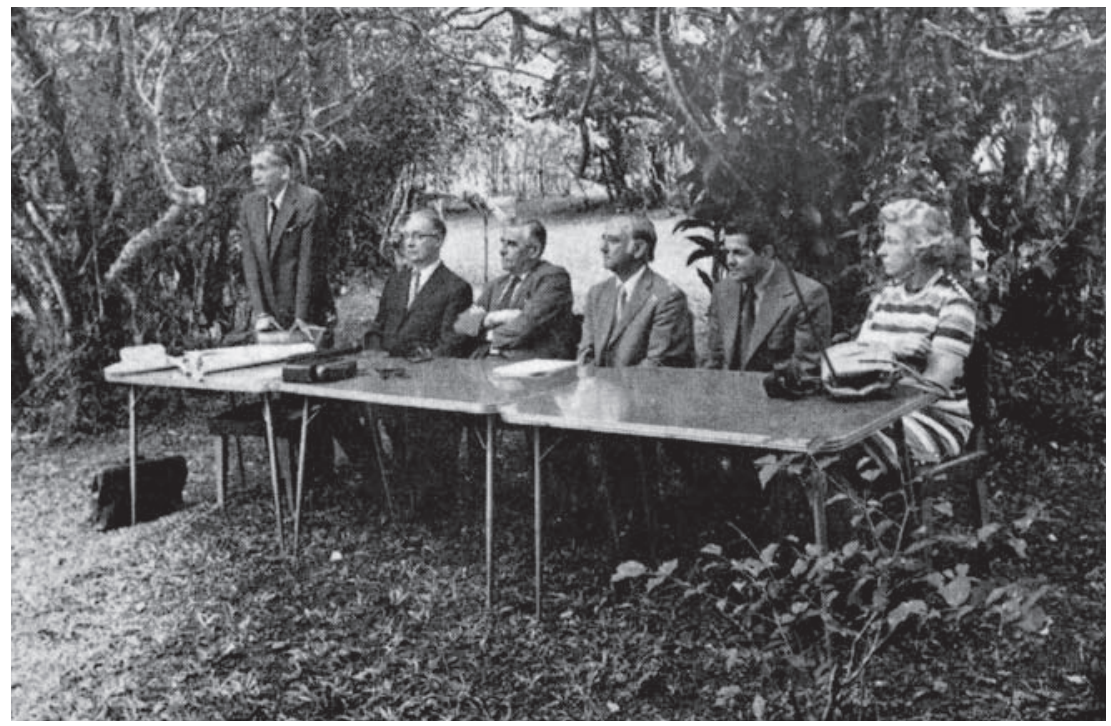

C

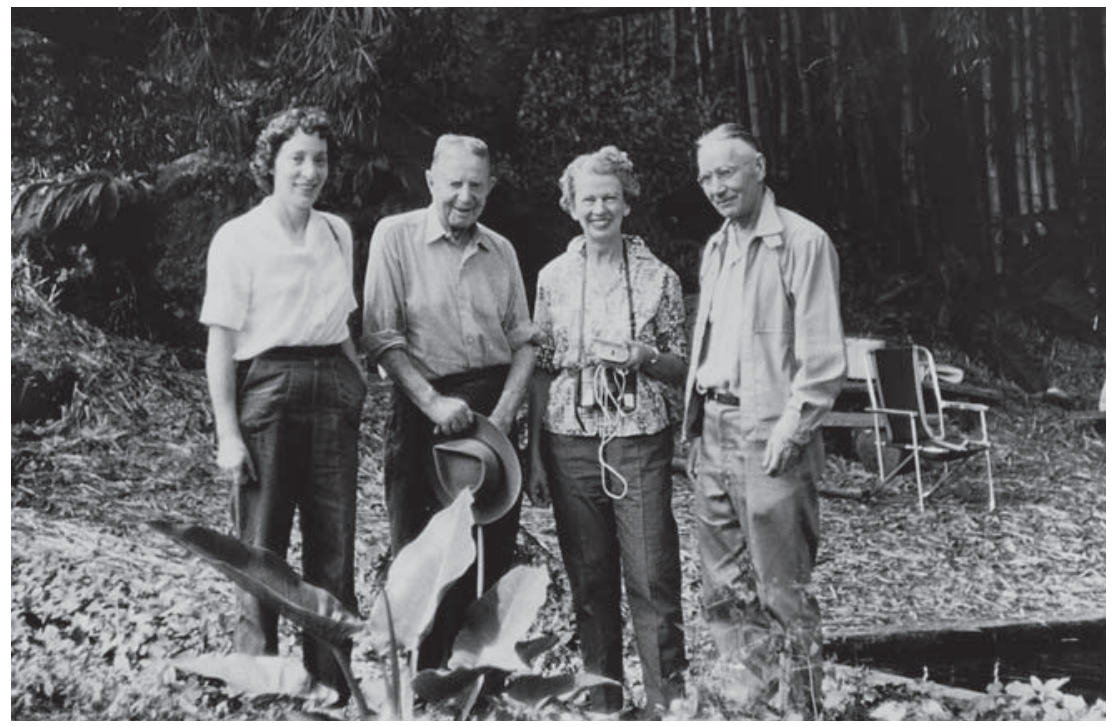

FigURE 60. A — First paragraph of Rodriguez's Orchids of the Central American Isthmus. Courtesy of Lankester Botanical Garden, University of Costa Rica. B - Rafael Lucas Rodríguez inaugurating the Lankester Botanical Garden on March 2, 1973. Courtesy of Ricardo Lankester. C - Rebecca Northen (third from left) with her husband, Charles Lankester, and one of Lankester daughters, during a visit to Costa Rica. Courtesy of James Watson, American Orchid Society. 

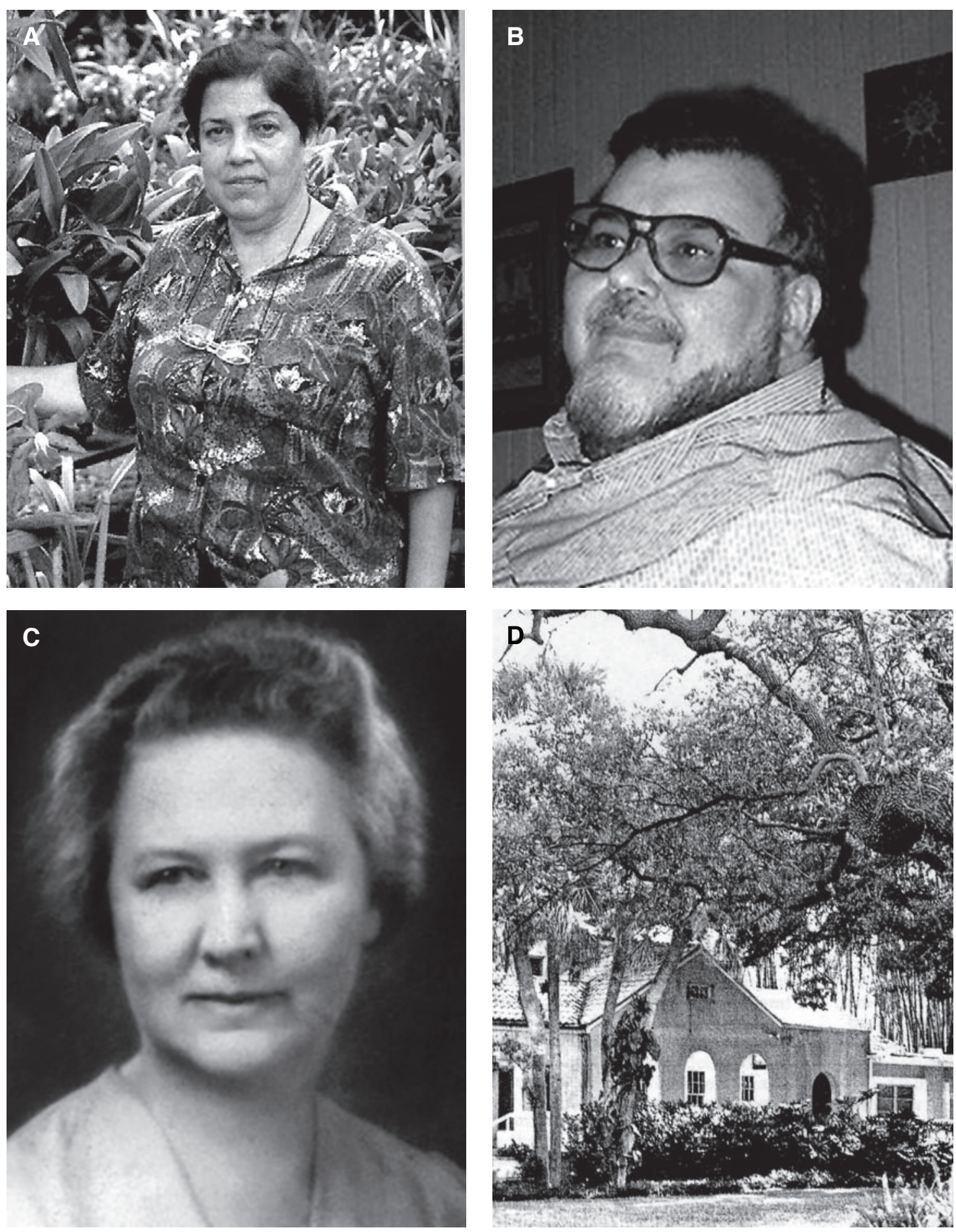

FiguRE 61. A — Dora Emilia Mora de Retana (1940-2001). In Dressler, 2001: 1076. B — Joaquín Bernardo García Castro (1944-2001). Courtesy of Eduado Bitter. C - Marie Selby (1885-1971). Courtesy of Wesley Higgins, Marie Selby Botanical Gardens. D - The Marie Selby Botanical Gardens. In Luer, 1983: 13. 
Rica's most important orchid illustrator is therefore still unknown to the scientific community. Rafael Lucas named Odontoglossum hortensiae in 1979 in honor of his wife Hortensia Sevilla.

Rebecca Tyson Northen (1911-2004) (Fig. 60C) played a vital role in the future preservation of Lankester Garden in Costa Rica, an institution that has become the leading research station for Orchidaceae in our region. She had made the acquaintance of Charles Lankester in the 1950s and was the leader of the campaign that led to the purchase of the garden by the Stanley Smith Horticultural Trust and the American Orchid Society, to be later donated to the University of Costa Rica. Unquestionable one of the most recognizable and popular personalities in the orchid community, Rebecca was friend and educator to countless individuals throughout our fraternity. A trained biologist, Rebecca traveled extensively with her husband Henry in Central and South America, studying and collecting orchids in the wild (Anonymous, 2004: 410). During the 1st World Orchid Conference, held in St. Louis, Missouri, in 1951, Gordon Dillon introduced her as "the mother and father of beginning orchid growers" (Watson, 2002: 12).

\section{Myth and reality: Costa Rica during the years of} Dora E. Mora and Joaquín García. Dora Emilia Mora de Retana (1940-2001) (Fig. 61A) was for many years, after Rafael Lucas Rodríguez, the only Costa Rican orchidologist with a scientific training in Botany. She went her first steps in the field of Botany at the side of don Rafael Lucas. Soon however she began to shine with her own light until she became this almost mythical figure (although often controversial, especially because of her almost dictatorial way to conduct the affairs at Lankester Garden) that we will always remember. With the blessing of Rafael Lucas Rodríguez, she took over as Director of the Lankester Garden in the year of 1979, and kept that post until she retired in the year 2000. During the 22 years in which she was the Director, Dora Emilia had the merit of converting Lankester Garden in an obligatory meeting point for orchidologists from all over the world who visited Costa Rica. Slowly but surely, the Lankester Botanical Garden was transformed from a small farm of 10,7 hectares to a botanical garden of world fame. To the old farm of Charles Lankester came important scientists such as Calaway Dodson, Robert Dressler, Carlyle Luer, Eric Hágsater, John Atwood, Rudolf Jenny, Henry Oakeley and many others. Knowledge about Costa Rican orchids increased enormously: Ames, in 1937, had registered for Costa Rica 133 genera and 959 species (Standley, 1937). In the Lista actualizada de las orquídeas de Costa Rica (1992), published by Dora Emilia Mora and Joaquín García, these numbers increased to 179 genera and 1,416 species.

From 1984 on, Dora Emilia organized courses in orchidology at the University of Costa Rica. The first of these courses was given by Dr. Robert L. Dressler, who at the request of Dora Emilia spent several months in Costa Rica as an invited professor. The projects which resulted from the collaboration between Dora Emilia and Dr. John T. Atwood where the most important contributions to the international projection of the name of the Lankester Botanical Garden. Together with him she published fascicles 15 and 16 of Icones Plantarum Tropicarum, on the orchids of Costa Rica (1992-93), and the treatise about Maxillariinae y Oncidiinae in the Flora Costaricensis of the Field Museum of Chicago (1999). Her friends were always loyal and dedicated five new species to Dora Emilia Mora de Retana. Eric Hágsater named in her honor Epidendrum moraretanae, Günter Gerlach Kefersteinia retanae, Robert Dressler Sobralia doremiliae, Carlyle Luer Stelis morae and Calaway Dodson and Rodrigo Escobar Telipogon retanarum.Dora Emilia Mora de Retana's scientific contributions remained on a domestic level. Her greatest achievement was to maintain during long years a botanical garden amidst enormous financial difficulties and to convert it into a research center to which she was able to attract the world's leading orchidologists.

The year 2001 was not a good one: barely six weeks after the death of Dora Emilia, Dr. Joaquín Bernardo García Castro (1944-2001) (Fig. 61B) passed away in San José. A good friend and collaborator of Dora Emilia Mora, we read about him in the words of Jorge Warner: "Dr. García had a great influence on the development of orchid cultivation as a hobby. He was always willing to share his knowledge with the beginners. He was a master among the orchid growers, who listened carefully as he explained, with in-depth experience and in a very simple form, such complicated 
items as the biochemistry of the color of the flowers or the genetic basics for the production of orchid hybrids. As a member of the Asociación Costarricense de Orquideología (A.C.O.) and especially during his two terms as its President (August 1986 - July 1988 and August 1991 - July 1992), Dr. García was known for his ability to promote, during a period when orchid hybrids were very popular, the cultivation and study of the native species" (Warner, 2002: 1). Joaquín García had a prodigious memory. From John Atwood we have these words: "I do not have the brains of Joaquín; therefore I need a well-organized library" (Warner, 2002: 1). Eduardo Bitter, his life-long friend, remembers Joaquín García's many-sided culture: "Though his insatiable thirst for knowledge and his immense intellectual capacity, he was an expert in many fields: plastic arts, music, theatre, literature, and many others" (Bitter, 2002: 3). And again Jorge Warner: "Joaquín was always a great friend of the Lankester Botanical Garden. In fulfillment of his last wish, his ashes are buried, since September 22 [2001] besides a tree that was planted in his honor in the Garden. With his and Dora Emilia's death, six weeks earlier, we closed a chapter in the recent history of Costa Rica's orchidology" (Warner, 2002: 2). Together with Dora Emilia Mora he published a half dozen of new species and combinations. Franco Pupulin named in his honor Prosthechea joaquingarciana.

The Marie Selby Botanical Gardens. When Marie Selby (1885-1971) (Fig. 61C) was still young, her family moved to Marietta, Ohio where her father studied geology and developed oil-drilling equipment. The family frequently went on camping and hiking trips, creating in Marie a strong love of nature at a young age. Marie met and married William Selby (1884-1956), a partner with his father in the Selby Oil and Gas Company (later to become Texaco Oil). They were wed on January 31, 1908 in Marietta, Ohio. One of their first shared interests was automobile racing, and subsequently Marie became the first American woman to cross the USA by car. William Selby enjoyed fishing and had visited Sarasota before his marriage. When he brought his wife to the west coast of Florida, they purchased seven acres of land bordering on Sarasota Bay and Hudson Bayou. They built a Spanish-style house and lived a quiet life enjoying nature, gardening and boating. Marie was a charter member of Sarasota's first garden club, the Founders' Circle (Marie Selby Botanical Gardens, 2006).

William Selby died on 4 December 1956, after setting up the William B. and Marie Selby Foundation for the community of Sarasota. This Foundation continues to fund many important education and community projects, although it is in no way connected to Selby Gardens except by name alone. After William's death, Marie lived quietly in their home until her death on 9 June 1971. In her will, she left their remaining major asset, the bayside property, "for the enjoyment of the general public" as a botanical garden. The first trustees of the Gardens decided to create a tropically oriented botanical garden with a strong research department. Research was prioritized because it was considered a means of bringing attention very quickly to a new botanical garden. Further, taxonomy was selected as the initial focus because it was thought that this work was relatively inexpensive (ironically, in today's world of DNA and gene mapping, taxonomy has become one of the most expensive scientific pursuits). Selby Foundation funded the purchase of the botanical library, an essential gift that enabled the research program to flourish.

Dr. Cal Dodson, orchid biologist from University of Miami, was the first director of Selby Gardens. Mrs. Selby's physician, Dr. Carlyle Luer, also a renowned orchid specialist, went to Ecuador to interview and persuade Dr. Dodson to take on the leadership of Selby Gardens. Despite the fact that Mrs. Selby was a lover of roses, a mission specializing on epiphytes was chosen because the group represented approximately 20\% of all flowering plants, and many (like orchids) were spectacular to display. Development of the Gardens began in March 1972 with landscaping based on a plan from the Department of Landscape Architecture at the University of Florida, and with construction of greenhouses. Selby Gardens was officially opened to the public on 7 July, 1975. In a very short span of time, Selby Gardens came a long way (Anonymous, 1977: 1) (Fig. 61D). In its first 30 years, the research program has grown, evolved, and diversified. There are three major components to the research program: orchid research, bromeliad research, and canopy ecology (the latter representing the habitat where these epiphytes live). Other tropical botanical topics of study are still part 
of Selby's research component, but these three are the most internationally recognized. The orchid program has featured many world renowned orchidologists over Selby's 30 years, and will hope to expand in the next 25 years to reflect the new directions of genetic research and conservation biology. The bromeliad identification center has grown to become the world's foremost site for taxonomic work on this small albeit unique epiphytic plant family. Only in the past 20 years has Selby become renown for canopy ecology. In addition to housing epiphytes, the forest canopy is reputed to house over half of the species on Earth. This importance of canopy science has expanded as a consequence of the critical global needs to survey this habitat before deforestation practices result in its disappearance.

The research department boasts several valuable collections. Since many orchids, bromeliads and other epiphytes are no longer common in the wild, the collections de Selby have become a valuable global resource. These collections include a herbarium (dried "library" of pressed plants) numbering over 80,000 ; a spirit collection of orchids (flowers of the orchid family preserved in jars of alcohol so as to retain their three-dimensional qualities); a specialized library of botanical volumes; slides and video collections of tropical plant-related visuals; botanical files in the Orchid Identification and Bromeliad Identification Centers; and live collections of tropical plants in the greenhouses. Of special importance, the herbarium boasts approximately 1,200 type specimens, which represent the first collection of a new species. In 2000, the research department was restructured to better serve the needs of an expanding and dynamic program over the next 25 years. The research department is expanding. Over 30 years, a proportionally high number of distinguished botanists have worked for and contributed to Selby's research program. Tropical research has been conducted in Ecuador, Peru, Brazil, Costa Rica, Panama, Belize, Samoa, Australia, Malaysia, and Cameroon as well as Florida. Important events, such as the first and second International Canopy Conferences (1994 and 1998), the First International Epiphyte Conference (1991), and the Orchid Conservation Workshop (1997), have been hosted here. Important publications such as the Icones Plantarum Tropicarum (a field guide to orchids); Selbyana (the Gardens' journal that features articles on epiphytes and other tropical plants, and canopy biology); and most recently a new local series of Florida floral field guides have been produced by Selby scientists. The official Selby Botanical Gardens Press, which oversees all publications of the Gardens, was launched in 2000 .

Three new species of orchids, Erythrodes selbyana Dodson, Telipogon selbyanus N.H. Williams \& Dressler, and Coryanthes selbyana Archila were named in honor of the Marie Selby Botanical Gardens. The Marie Selby Botanical Gardens have collaborated closely, since the early 1990's, with the Lankester Botanical Garden of the University of Costa Rica, and have made the Central American region one of their main research areas.

\section{The Flora Mesoamericana}

That you are 'jefe' of this part of the program [the orchids] is welcome news.

Ed Greenwood in a letter to R. Dressler, May 18, 1983

The first major regional flora ever written in Spanish, Flora Mesoamericana is a collaborative effort of the Missouri Botanical Garden, the Instituto de Biología of the National Autonomous University of Mexico (UNAM), the Natural History Museum, London, and numerous specialists world-wide. In Spanish, the Flora pretends to describe, for the first time, all the vascular plants growing in the southeasternmost (sic) states of Mexico (including the Yucatán Peninsula) and all the Central American republics.

The idea of the Flora Mesoamericana was promoted by Peter H. Raven, Director of the Missouri Botanical Garden, who since 1972 has actively promoted the concept of a Central American Flora. In that year, Raven organized a meeting, in conjunction with the XIX Annual Symposium of Systematics, to discuss the feasibility of the project. Although a general agreement was reached regarding the necessity and usefulness of the project, most among those attending though that the time was not ripe to begin with it. One of the main reasons to doubt that it was the right moment to start with this project was that the Flora of Guatemala and the Flora of Panama had not yet been finished. In 1979, after the conclusion of the Flora of Guatemala 
(1977) and the imminent publication of the last parts of the Flora of Panama, a much broader infrastructure was created, enough to begin with a more extense treatment of the flora of the region. On these bases, Raven, together with José Sarukhán K., then Director of the Instituto de Biología of the National Autonomous University of Mexico, and John F.M. Cannon, Curator of Botany of the British Museum (Natural History), as it was called at that time, proposed a floristic project, even more ambitious, that should cover not only Central America, but also the tropical regions of Mexico, this is, the most important part of the tropical areas of the North American continent. These three institutions became the organizers of the Flora Mesoamericana project.

However, there were still doubts and criticisms, at least amongst the orchidologists. It is interesting to follow an exchange of letters between Ed Greenwood and Robert Dressler regarding the subject of the Flora Mesoamericana. "Missouri Botanical Garden is trying to organize a new "Flora Mesoamericana" and have asked me for an outline of the orchids, with possible contributors. I will give them your name, as well as Eric [Hágsater] and several others from Mexico. I don't know how much we can do, but it could be an interesting project" (Dressler to Greenwood, December 2, 1980). "The "Flora Mesoamericana" project seems dubious to me. Louis Williams reported that the plan is to cover the area from about the Isthmus of Tehuantepec through Panama, using descriptions of not over 100 words and minimum references. Only 5 years are to be allowed for completion and a rather small amount of money, which I have forgotten for the moment. The descriptions appear too brief to serve for more than aids to determination, and in view of almost everyone's findings on the richness of the flora and the poor state of knowledge, the result will be vulnerable to criticism such as yours of Williams and Allen "Orchids of Panama", which covered only about half of the species present. Of course we will help in any way we can if Pete Raven asks us. I fear that there will be gaps in Nicaragua and El Salvador" (Greenwood to Dressler, December 11, 1980). "I agree with all your criticisms of the Flora Mesoamericana project. [...] There was a meeting just a couple of years ago in which everyone said "we're not ready", but Missouri has decided to go ahead, anyway. The project is not without some botanical imperialism, and has left some ill feelings locally" (Dressler [from Panama] to Greenwood, January 9, 1981). "Eric [Hágsater] has put my name, and those of several other amateurs on the list of contributors. I don't really object to this, though I have some misgivings about doing a full flora of an area so little explored ..." (Greenwood to Dressler, May 18, 1983). And finally: "I don' really know what to say about the Flora Mesoamericana. Like yourself, I feel very far from the herbaria here, and field work is both more fun and, I think, more urgent right now. [...] I really don't want to get bogged down in floristic work. This is a poor place to do it, and the institute [Dressler was at the time working at the Smithsonian Tropical Research Institute ] has very little interest in this kind of work. I really don't see much hope of doing a decent treatment of the Central American orchids in the near future. I realize that I haven't answered your questions. The thing is that I don't have any answers" (Dressler to Greenwood, July 20, 1983).

Notwithstanding, the project went ahead, and Dressler kept his position of editor for Orchidaceae. The initial time frame was never maintained. 25 years after the meeting in Missouri, several volumes have been published, but the Orchidaceae are still waiting.

\section{Fritz Hamer and the orchids of El Salvador and} Nicaragua. Fritz Hamer (1912-2004) (Fig. 62A), who passed away recently, the most prominent and maybe the only real expert on the orchids of El Salvador and Nicaragua during the second half of the XX century, was the last of a long list of German collectors and scientists who played a relevant role in the history of Central American orchidology. Fritz Hamer was born in Hamburg, Germany, on November 22, 1912, where he grew up and received his education in business in a Dutch-owned export company. In 1936 his company sent him to Venezuela and a year later to Guatemala, where the onset of World War II found him. In 1942 he was repatriated to Germany, where he served in the Army during the campaign against Russia. At the end of the war he went back to Guatemala for a short period of time and established himself later in El Salvador, where he formed a successful company which imported and distributed machinery and equipment, and which still exists (Douglass, 1980: 19).

Rebecca T. Northen, in a letter to F. Hamer, congratulated him to his work: "This is a most 
remarkable achievement, a real work of love. To search out the orchids remaining in a country so denuded of forest - to find what is left, and put them on record - must have been a tremendous task. And to make anatomical drawings of all, and photographs of most [species], was, I know, a painstaking task. I admire you for doing it, and appreciate the results" (Kennedy, 1977: 212).

His interest in orchids started relatively late in life. Around 1960, someone gave him a Miltonia which caught his artistic eye and led to his first orchid drawing. He began exploring the country in search of orchids, which he cultivated patiently, preparing photographs, illustrations and descriptions. Hamer soon discovered the lack of adequate bibliography about the orchids of his adoptive country. After Standley's and Calderón's Preliminary list of the plants of El Salvador (1925), in which 63 species of orchids in 28 genera were described, nothing else had been published about the orchid flora of the country. Motivated by this, Hamer, who had already published a few articles on the orchids of the country, began in 1971 the preparation of his fundamental work The Orchids of El Salvador, whose first two volumes were published in 1974 by the Ministry of Education of El Salvador. 279 species in 67 genera were described. Hamer, who had no scientific background in the natural sciences, received valuable help in this and all future works from Leslie A. Garay, who became a mentor and friend for the rest of Hamer's life. Social and political unrest, which led later to civil war, made Hamer abandon El Salvador and move to Florida, where he became part of the scientific staff of the Marie Selby Botanical Gardens. It was there where he published, in 1981, the third volume of his work, bringing the number of Salvadorian orchids to 362 species in 93 genera.

When Alphonse Heller died in Nicaragua, all of his drawings, descriptions, color slides and specimens of dried plants of Orchidaceae, as well as a large and valuable library, were donated by Christiane Heller to the Marie Selby Botanical Gardens, then under the directorship of Dr. Calaway H. Dodson. The donation was made with the understanding that arrangements would be made to use Heller's work for a publication and Dodson invited Hamer, who still resided in El Salvador, to have a look at Heller's material. Then there was another development. The Missouri Botanical Garden had committed itself to preparing a Flora de Nicaragua, in cooperation with the University of Managua, and Hamer was asked to take over the family of orchids within that Flora. With Heller's material as a base, Hamer visited the herbaria at Kew, the Field Museum in Chicago, the Escuela Agrícola Panamericana at "El Zamorano" in Honduras, at Managua and at the University of Michigan, finding that there was more material available from former expeditions to Nicaragua. Fascicle seven of the first series of Icones Plantarum Tropicarum, edited by Dodson, which contained the first 100 descriptions and illustrations by Hamer on the orchids of Nicaragua, was published in 1982. During the next years, Hamer published 500 additional plates for the Icones (Hamer, 1982-1985).

Thus it was again Hamer who filled a void in the bibliography of the orchids of Central America. Since the doubtful 'Flora nicaragüense' of Miguel Ramírez Goyena (1909), in which 94 species were listed, nothing else had ever been published about the orchidaceous flora of that country. Between 1988 and 1990 Hamer published in the scientific journal Selbyana (Vol. 10 and 11) his Orchids of Central America - an Illustrated Field Guide, in which he reproduced all his illustrations of the orchids of the region, although without descriptions. The project of the Flora de Nicaragua of the Missouri Botanical Garden became finally a reality in 2001, and again it was Hamer, already 89 years of age, who authored the chapter on Orchidaceae, describing 587 species in 144 genera. A fundamental author for the knowledge of the orchids of our region, Hamer collaborated also with Dr. Carlyle A. Luer translating into German the seven volumes of Thesaurus Dracularum (1988-1994) and the first six volumes of $A$ Treasure of Masdevallia (1996-2001). During his life, Hamer published 14 new species and 9 new combinations of Orchidaceae: Bulbophyllum bandischii Garay, Hamer \& Siegerist, Bulbophyllum burfordiense Garay, Hamer \& Siegerist, Bulbophyllum fraudulentum Garay, Hamer \& Siegerist, Bulbophyllum kegelii Hamer \& Garay, Cyrtopodium punctatum Lindl. var. salvadorense Hamer \& Garay, Dichaea muricatoides Hamer \& Garay, Epidendrum glumarum Hamer \& Garay, Isochilus aurantiacus Hamer \& Garay, Isochilus pitalensis Hamer \& Garay, Neo-urbania nicaraguensis Hamer \& Garay, Mormodes $\times$ salvadorensis Hamer \& Garay, 
Oncidium cheirophorum Rchb.f. var. exauriculatum Hamer \& Garay, Synarmosepalum kettridgei Garay, Hamer \& Siegerist, Beloglottis ecallosa (Ames \& C. Schweinf.) Hamer \& Garay, Calanthe calanthoides (Rich. \& Galeotti) Hamer \& Garay, Cirrhopetalum gusdorfii (J. J. Sm.) Garay, F. Hamer \& E. S. Siegerist, Eltroplectris roseoalba (Rchb.f.) Hamer \& Garay, Encyclia dickinsoniana (Withner) Hamer, Epidendrum pseudopygmaea (Finet) Hamer \& Garay, Miltonioides pauciflora (L. O. Williams) Hamer \& Garay, Neolehmannia curvicolumna (Ames, F. T. Hubb. \& C. Schweinf.) Hamer, and Scaphyglottis minuta (A. Rich. \& Galeotti) Hamer \& Garay. Other species were described based on collections by Hamer and dedicated to him: Beloglottis hameri Garay, Pelexia hameri Garay, and Ponthieva hameri Dressler.

Hamer was married for 42 years to Hedwig Pfister, a neurologist, to whom he dedicated one of the new species he had discovered: Maxillaria hedwigiae Hamer \& Dodson. He had three sons, one of which was murdered in 2003 by kidnappers in El Salvador. Overwhelmed by this tragedy, which cast a shadow over the last months of his life, Fritz Hamer passed away in Sarasota, Florida, on January 13, 2004. His extensive library was donated by his wife Hedwig to the Botanical Garden of La Laguna, in San Salvador. The orchid collection of the Garden was named, in 2005, "Fritz Hamer Orchid Collection".

\section{Guatemala: the heirs of Baron von Tuerckheim .} Otto Tinschert (1915-2006) (Fig. 62B), a giant in the history of the orchidology of Guatemala, passed away on May 16, 2006, at the age of 91. 'Don Otto' had been born in Ottendorf, near the German Atlantic Coast, on March 2, 1915. In love with the sea since his youth, he studied at the Navy Academy at Stralsund and in 1936 sailed around the world on board of school ship 'Gorch Fock' and visited Guatemala, falling immediately in love with the country, as he liked to tell. As an officer, he served in the German Navy during World War II, commanding a submarine during the last years of the conflict. During the difficult post-war years, he found work with a relative, who imported cotton, and became soon an expert in the determination of the quality of the fiber. After being sent to Nicaragua to select cotton that was to be exported to Germany, he received an offer to work in that country and accepted, "thinking that I would be near Guatemala". While attending a meeting of Central American cotton producers, he met Mr. José Quezada, from Guatemala, who convinced him to work in his plantations. Thus he came to Guatemala in 1957, with his wife and two young children, to live in a small house amidst the cotton plantations of Retalhuleu. The third of his sons was born this same year in Guatemala City. While working in Guatemala's southern coast, he began to admire the native orchids and started a small collection in his garden. He always told that "after killing enough of them" he finally understood that he had to learn how to grow them, and wrote to his relatives in Germany to send him a book on orchids. This was the beginning of his life-long romance with these plants.He established himself permanently in Guatemala, traveling after that only to Germany for his yearly visits to his relatives and the reunions with his old submarine crew. In a small VW beetle he traveled throughout Guatemala on difficult dirt roads, eager to learn about the culture of the many Mayan tribes and to admire the ruins of their magnificent architecture.

Interested in the enormous genetic potential that he saw in the native orchids of his collection, he soon learned to grow them from seed, improvising a small laboratory and constructing his own equipment, which later included a home-made laminar flow hood. Thus he began the first important line of work for which he became well-known, producing a great number of hybrids, many of which received important AOS awards and became commercially important in the United States. When his laboratory facilities improved, he began what would become his main interest in life: the reproduction from seed of especially interesting native species, which were threatened by extinction. His first big success was Lycaste skinneri var. alba ('The White Nun'), Guatemala's National Flower, which today is almost impossible to find in nature. Most plants of this species which are currently cultivated came from Otto's laboratory. Disappointed by the tragic situation of the deforestation in Guatemala, and with little hope of detaining it, he began, with a small group of interested friends, to promote the creation of a National Botanical Garden, which could fill in the voids in the areas of research, study, sustainable use and conservation of the country's flora. He worked arduously towards this ideal, convincing 
and motivating universities, foundations and other organizations. This idea, which was first born in Otto's mind, is still being discussed, with some hope of it becoming reality. In the same field, he worked in Petén, a region whose forests were heavily exploited for wood, trying to rescue the enormous numbers of plants of orchids and other interesting epiphytes, which are left to rot after the large felled trees are cleaned off their branches, before transporting them to the sawmills. For this project he obtained the support of the Armed Forces, who allowed him to plant the rescued plants on the trees of a forest at an Air Force base. The Air Force would also contribute with labor and the logging companies were expected to bring from the mountains everything that grew on the trunks of the trees and was usually left over. Although the loggers initially accepted, they never kept their part of the deal.

In recognition for his conservation efforts, Otto Tinschert was in 1999 presented by the President of Guatemala, Álvaro Arzú Irigoyen, with the Presidential Medal of the Environment. Franco Pupulin named a new Guatemalan species in his honor: Kefersteinia tinschertiana (2004), now also found in Mexico. He was a mentor to many students interested in the cultivation of orchids and the methods of reproduction of these plants. He was always willing to share his knowledge and to collaborate with persons or institutions who asked him for help, Tinschert co-authored with Moisés Béhar the book Guatemala y sus Orquideas (1999), destined to bring to the wide public the beauty of the local native species. In the international field, Otto was a member of the Conservation Committee of the American Orchid Society and of the Mesoamerican Orchid Specialist Group of the International Union for the Conservation of Nature (IUCN). He participated in several World Orchid Conferences.

He was a hard worker, an honest man and an enthusiastic and joyful person, beloved by all who knew him. He loved living in Guatemala and had bought, long years ago, an old abandoned corn field, without trees except for one old avocado. Otto planted over 3,000 trees and built his home. In the meantime the property lies in Guatemala's most exclusive residential area and the house, in the midst of forests and gardens, is truly what Otto called "my home-made paradise". There he spent his last years, in the company of friends and relatives who loved him, growing his orchids and helping the young beginners as much as he could. This was undoubtedly his best legacy (Béhar \& Ossenbach, 2006: 490).

Otto Mittelstaedt (1919-2000) (Fig. 62C), was "an extraordinary man and a beautiful person, who helped more than anyone to the knowledge of the orchids of Guatemala" (In the words of Moisés Behar, his close friend). He was the son of the German Paul von Mittelstaedt and Emilia Villegas, a Spaniard. His father came to Guatemala in 1896, from the port of Kiel, and began to work, together with countrymen who had established themselves earlier, in the growing of coffee. Mittelstaedt was born in Cobán, Guatemala, on April 19, 1919. He went to Grammar and High School at the German High School of the capital. Shortly after finishing High School he married Maria Concepción Sobalvarro, and moved with his wife to live and work in a coffee plantation that had been bought by his mother in the coffee region of southern Guatemala. Working with the energy and enthusiasm that were his traits, together with his wife and hand in hand with the workers, he transformed the property in a short period of time in one of the most productive and best organized coffee plantations of the country. In the 1980 's, with the coffee plantation that he had inherited from his mother in full production and in a good financial situation, but yet still in the prime of his life, he returned to his native and beloved Cobán to dedicate himself to his passion for orchids, leaving the coffee plantation to his sons. Cobán, capital city of the department of Alta Verapaz, lies in a region with a high level of humidity and altitudes which range from 3,000 meters to sea level. "In Cobán it rains during 13 months of the year", say its inhabitants. Mountainous and with such a variety of climates, it is the region with the largest density and diversity of orchids in Guatemala. Through the good efforts of his son-inlaw, Don Otto acquired a rural property, close to the city, which had already a small nursery with some orchids, mainly Lycaste. When Mittelstaedt acquired the property, the terraces where full of metal bird cages, since the previous owner had dedicated himself to illegal cock-fights.

Mittelstaedt became part of the small group of amateurs of the 'Asociación Verapacence de Orquideología' (= Orchid Society of Alta Verapaz), 
and dedicated himself to strengthen the organization of the group, planning collecting excursions to the mountains, an annual exhibition and contributing to increase the number and the knowledge of its members. He was elected Secretary of the Society and in this position, which he held until his death, he acted really as an Executive Director. With the Society, he explored the mountains of the area and of other regions of Guatemala to appreciate its orchids and to collect specimens, always insisting in avoiding depredation. During these excursions several new species were found and many others, which although already described, had not been seen in their natural habitats for many years. He worked without tiring during the whole day, with the help of Juanito, his right hand, caring for and improving his collection, which came to be the largest and most complete collection of national orchids, specializing in Lycaste (which he reproduced from the back bulbs), until he had over 1,000 plants, maintained in conditions very similar to their natural habitat, under a plantation of giant ferns. His nursery 'Vivero Alta Verapaz' was for many years of great interest for tourists and orchid lovers who visited Cobán. Every night he worked in his small studio, quiet and separate from the main house, typing with two fingers on an old typewriter. He received the main orchid journals, and formed an important collection of books. He wrote Las Orquídeas, Guía Práctica para su Cultivo (= The Orchids, practical guide to their cultivation) and Orquideas terrestres de Guatemala (= Terrestrial Orchids of Guatemala), which he printed privately. The latter are not well known and have not been studied in the country. He also wrote various articles about little known genera and several amusing and didactic stories. All these publications were typed by him, reproduced on a mimeograph, and primitively bound in a very limited edition of no more than 100 copies, without a commercial interest and with a purely didactic finality and only for the use of friends and members of the Society. He took it upon himself to organize the annual exhibitions, held at the beautiful Convent of Santo Domingo in Cobán, specialized in native species of Guatemala. The judges were members of the American Orchid Society, always very interested to come to Guatemala, which sometimes made it difficult to limit the number of invited judges. Both the exhibitions and his private collection attracted numerous foreign visitors. Otto, besides being a hard worker, was a very kind person, a good entertainer and a man who offered with pleasure, and no second interest, all of his knowledge. Although he loved traveling within the country, he did not like to leave Guatemala and, notwithstanding his interest for orchids, he did not accept invitations to attend exhibitions in order to give lectures in other countries. He died in Cobán. Two new species were dedicated to him: Lepanthes mittelstaedtii Luer \& M. Behar and Epidendrum mittelstaedtii Hágsater.

Oscar Archila (1939-2007) (Fig. 62D) was the son of a Spaniard and a German-Indian (Quetchí) mother, from whom he inherited the empiric knowledge and the passion for orchids. Together with his sons, he founded more than 35 years ago an Orchid Experiment Station, with the "most complete" (In the words of his son Fredy ) collection of Guatemalan Encyclias, with over 35,000 plants in cultivation. The Station functions as a rescue center for flora and is certified under the regulations of CITES and CONAP (National Council for Protected Areas). Archila made his first contacts with nature as a hunter, and later as an orchid collector and grower. He spent days without end collecting in the mountains, even during the civil war years in the 1970s and 1980s, risking going into war areas and mined fields, in his efforts of reaching remote collecting grounds in the search for rare species. Oscar Archila passed away in Cobán, on December 12, 2007. The Experiment Station continues in the hands of his sons.

The Flora of Panama (II). The Flora of Panama of the Missouri Botanical Garden had been initiated by Robert E. Woodson, who edited the first parts with the assistance, until 1952, of Robert W. Shery. From about the time of Shery's departure until the late 1950's there was a hiatus on the activity of the Flora.

In the 1960's a series of expeditions was sent to Panama from St. Louis. John Duncan Dwyer (19152005) (Fig. 63A) was one of the most noteworthy collectors of that period. Dr. Dwyer had joined the Saint Louis University in 1953 and immediately became the chairman of the biology department, a position he held until 1963. He taught at the University for more than 30 years and was well known for his excellence 

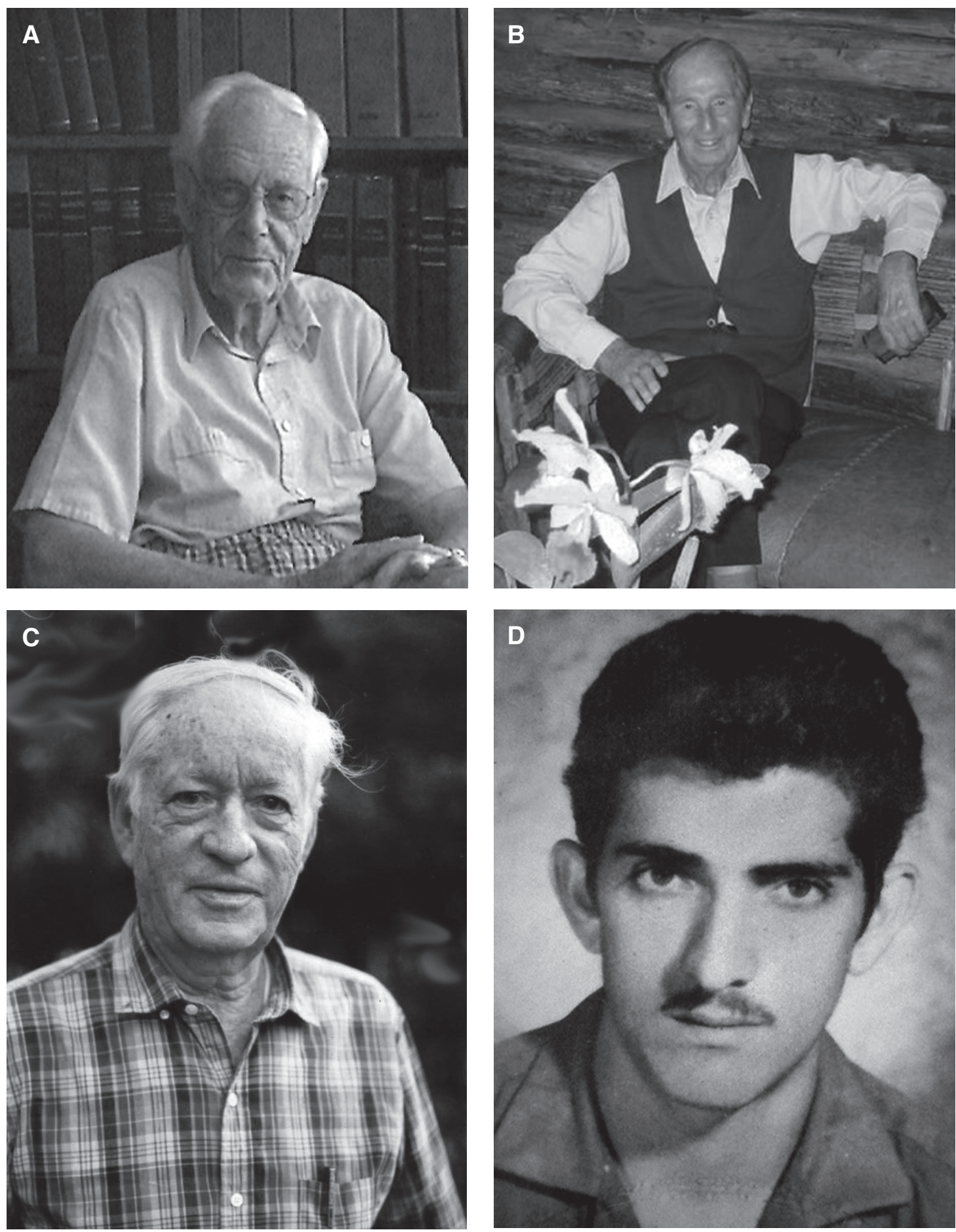

Figure 62. A - Fritz Hamer (1912-2004). Courtesy of his widow, Hedwig Hamer. B - Otto Tinschert (1915-2006). Courtesy of Moisés Béhar. C - Otto Mittelstaedt (1919-2000). Courtesy of Moisés Béhar. D — Oscar Archila (19392007). Courtesy of his son, Fredy Archila. 


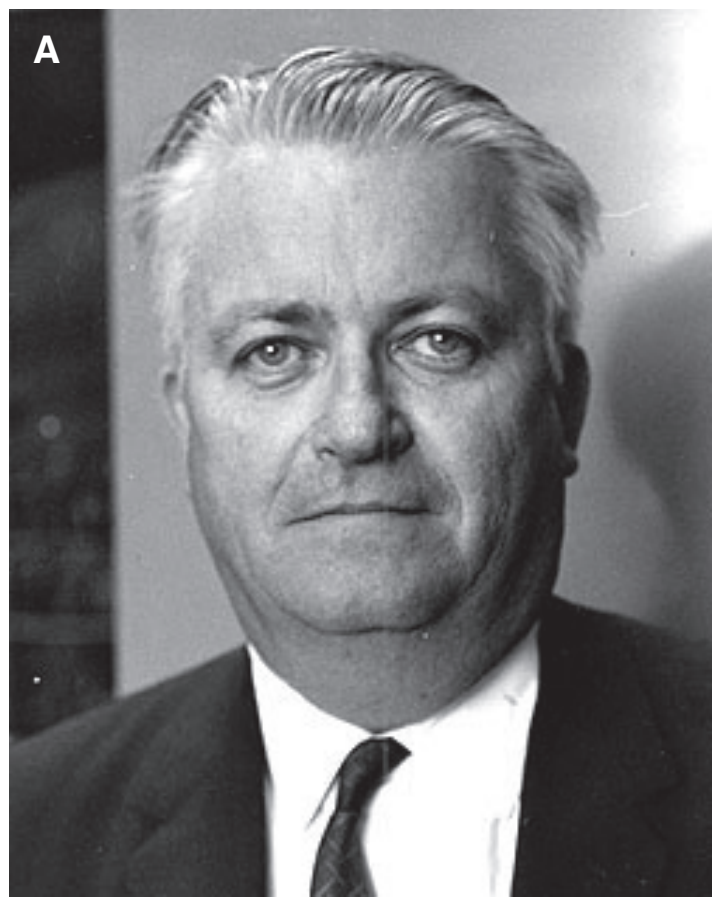

B
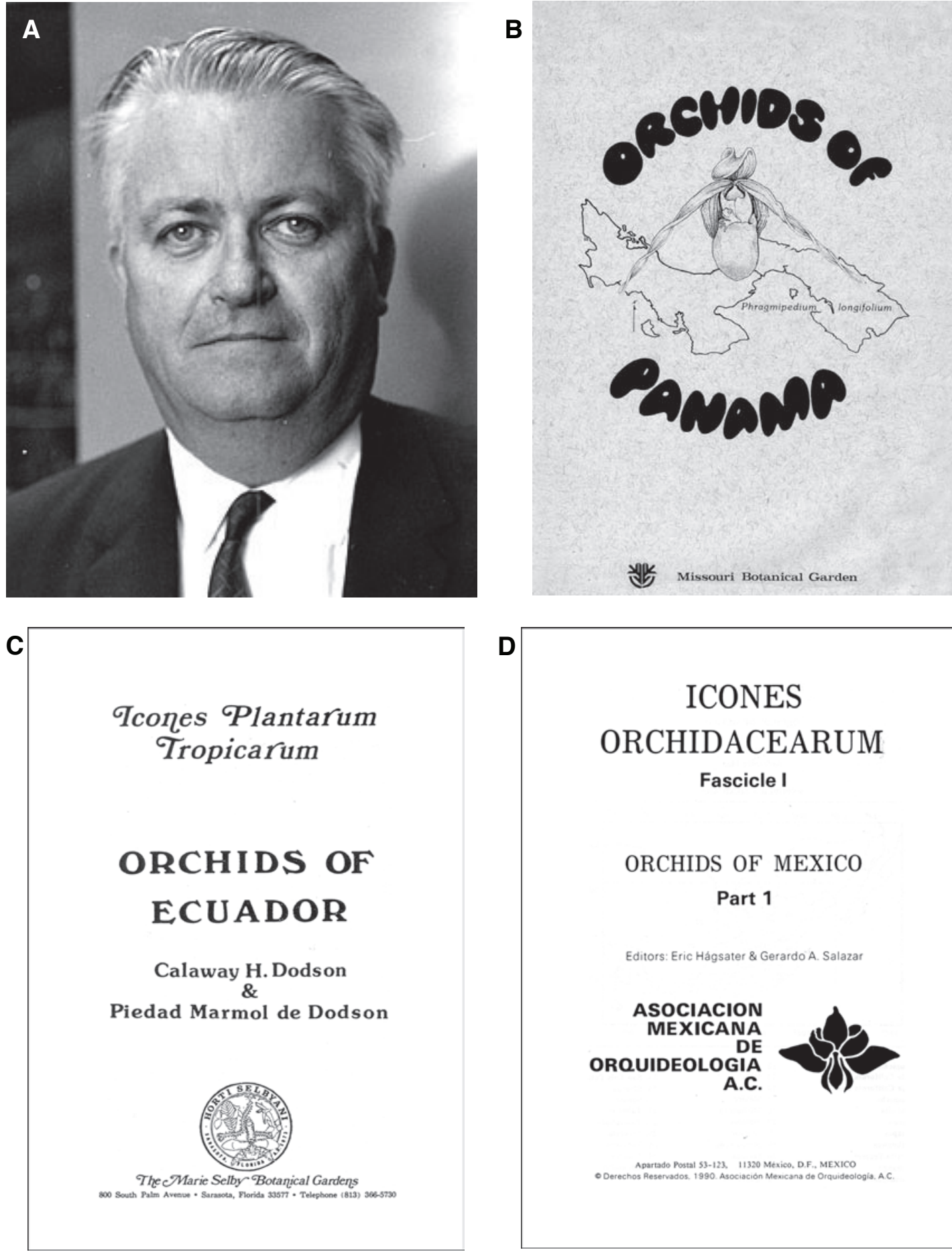

D

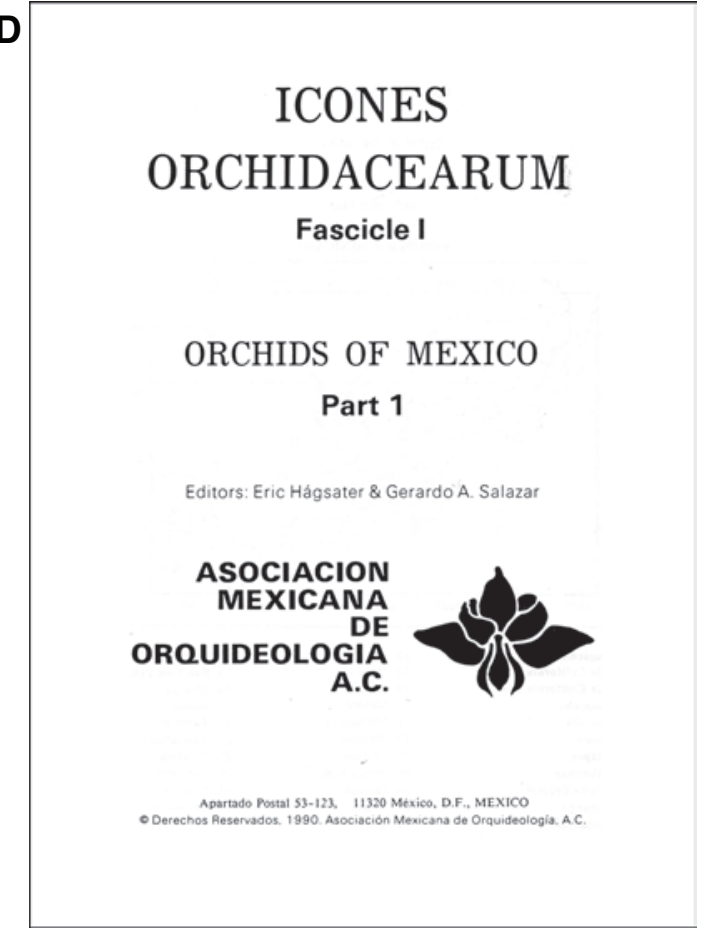

Figure 63. A - John Duncan Dwyer (1915-2005). B - Reprint of the Flora of Panama, Orchidaceae, by Williams and Allen. Missouri Botanical Garden, 1980. C - Frontispiece of the first fascicle of Icones Plantarum Tropicarum. Marie Selby Botanical Gardens, 1980. D — Frontispiece of the first fascicle of Icones Orchidacearum. AMO Herbarium, 1990. 
in teaching, research and service. He retired in 1985, becoming professor emeritus in biology. Although Dr. Dwyer's specialty was the classification and evolution of tropical, Latin American plants, his primary work concentrated on plant groups that made useful drugs and resins. He became a pioneer in the young field of bio-prospecting when he devised simple ways for plant collectors to discriminate between species that could prove beneficial to human health and those that could not. A world traveler, Dr. Dwyer completed field work in the Republic of Panama, Belize and Guatemala. He also collected and preserved plant specimens in other Central American countries as well as in Colombia, Peru, Ecuador and Saudi Arabia. Many of these specimens are housed at the Missouri Botanical Garden. Dr. Dwyer was a research associate of the Missouri Botanical Garden since 1954, and in 1984 was elected Fellow of the Linnean Society of London, which was founded in 1788 and is the oldest existing society in the world devoted to the life sciences. Interestingly, Dr. Dwyer also served as a consultant for the St. Louis Coroner's Office, examining victims of poisoning for plant toxins. During his field trips in Central America, Dwyer collected, among others, Encyclia belizensis (Rchb. f.) Schltr. and Ornithocephalus inflexus Lindl, both in Belize. In Guatemala he found Maxillaria friedrichsthalli Rchb. f. and Pleurothallis brighamii S. Watson, and in Panama the type specimen of Epidendrum dwyeri (Dwyer \& Hayden 7733), which was dedicated to him by Eric Hágsater.

Thomas B. Croat, who directed the project in the 1970's, relinquished management of the Flora of Panama in 1977 to William Gerald D'Arcy (19311999), who saw the work to completion (D'Arcy, 1980: vi). Dr. D'Arcy was born in 1931 in Calgary, Canada, and graduated with honors in political economy from the University of Alberta in 1954. Between 1960 and 1966, he owned and managed a softdrink bottling factory in Tortola in the British Virgin Islands, where he kindled an interest in the local flora. Encouraged by several botanists, he decided to change careers. Dr. D'Arcy enrolled in the botany master's program at the University of Florida. In 1968, he was recruited for the Ph.D. program at Washington University and the Missouri Botanical Garden, where he worked under Walter Lewis. He became involved in the Flora of Panama program and wrote his thesis on the
Solanaceae of Panama. He received his degree in 1972 and, at age 41 , began his career as a research botanist at the Missouri Botanical Garden. There he compiled the first computerized database for the Flora of Panama (or any other large flora) using software he wrote himself, since it was before the era of readily available technology. While in Panama, D'Arcy collected, among others, Epidendrum bisulcatum Ames (D'Arcy 10944), Pleurothallis cf. dentipetala Rolfe ex Ames (D'Arcy 10927), Pleurothallis crocodiliceps Rchb. f. (D’Arcy 10897b), and Sigmatostalix picturatissima Kraenzl. (D’Arcy 10600A). In April 1980, with all treatments ready in at least a manuscript form, a symposium was held in Panama City to celebrate completion of the Flora. In this same year, the Missouri Botanical Garden published a reprint of the Orchidaceae by Williams and Allen, which included "A checklist of the orchids of Panama as known today", by Dr. Robert L. Dressler (Williams \& Allen, 1980) (Fig. 63B). Many new species of plants were dedicated to him, among them Rondeletia darcy Dwyer from the Rubiaceae and Anturium darcy Croat, from the Araceae.

\section{Icones Plantarum Tropicarum \& Icones}

Orchidacearum. In 1980 the Marie Selby Botanical Gardens began a project which was enormously useful for researchers and amateur-lovers of our orchids: the first of the two series of Icones Plantarum Tropicarum (IPT) (Fig. 63C). Although both series also treated South American orchids, the Icones of Nicaragua and Costa Rica were of great importance. As doctor Calaway H. Dodson wrote: "the Icones Plantarum Tropicarum concept is not new in publishing. Similar projects date back to the beginning of plant classification. The idea that 'a picture is worth a thousand words' is well applied here. Most treatments of floras of tropical countries published during the last 50 years have been long on text and short on illustrations. The expense of preparation and publication of illustrations was commonly cited as the reason. [...] The publication of a series of illustrations by Dunsterville \& Garay in Venezuelan Orchids Illustrated prompted the development of the IPT project. In that case, 6 volumes containing 1,000 superb illustrations with accompanying text were published over a 17 year period (1959-1976). “...A large number of species are known only by published descriptions and herbarium 
specimens. For the orchid taxonomist this is rather like a chocolate cake with the sugar left out - pretty difficult to utilize. The situation was made more palatable when Stalky Dunsterville and Leslie Garay published their splendid series on the orchids of Venezuela. One corner of the cake was now sweet" (Dodson, 1981). "Cal Dodson and I talked a lot about the Icones during our long field trips in Ecuador. His intention, when he was director at Selby, was to put at the disposal of orchidologists and amateurs all drawings which were in the archives. Since he only wanted to publish the illustrations, he did not intent a very scientific text which would imply the revision of a lot of material, but would only include the basic information related to the specimen used for the illustration. Hence the simple description, which should be a complement to the illustrations, adding short notes from his experience, of that of the collectors and illustrators. It was important to cite the specimen on which the illustration was based. Due to this intention, he did not intent a taxonomic revision, although eventually several new species were published. After the change of direction at Selby, Cal decided to continue with IPT II in San Louis, Missouri. I know that he tried to obtain permission from the widow of Rafael Lucas Rodríguez to publish his drawings in the series, but she thought that a fortune should be paid to her, so that an agreement was not possible. Fortunately, Rafael Lucas allowed me to photograph (slides) and photocopy all his illustrations of Epidendrum, which has been very useful for my work" (Hágsater, 2007, pers. comm.).

In 1990, Eric Hágsater and his collaborators at the AMO Herbarium of the Mexican capital began with the publication of a similar series to IPT, which was called Icones Orchidacearum (Fig. 63D). "Icones Orchidacearum, as a difference to IPT, has intended from the beginning to be a very rigorous taxonomic work, in two directions. On one side, it wants to be the work of reference for the orchids of Mexico, with the collaboration of multiple authors in the genera of their expertise, and with the illustrations of many other collaborators, trying to promote botanical illustration among young biologists, following a certain pattern regarding the details to be illustrated. The 'executive' editor was initially Gerardo Salazar, now substituted by Miguel Ángel Soto, who has already in preparation the next volume, which will be number 10 . The dream would be to complete all Mexican species. On the other side, there is the series on the genus Epidendrum, where I have had the collaboration of several executive editors, today Luis Sánchez. This series intends to be the publication of the revision of the genus, giving place in the beginning to new species, and now also to those previously described, for which we have been preparing illustrations based on the type specimens or, if not possible, from material that has been collected or grown, or other herbarium specimens when nothing else is available" (Hágsater, 2007, pers. commm.).

The National Orchid Societies. We have read about the interest in orchids shown by the prehispanic cultures in Central America. Orchids were grown and collected by the first inhabitants of our region not only for medicinal and economical purposes, but also for their ornamental value. From Friar Francisco Jiménez we learned how, during colonial times, the Indians in Guatemala collected orchids and put their flowers on the altars, while Francisco Antonio de Fuentes y Guzmán describes the practical uses given to orchids by musicians and candy-makers. Bateman, in one of his vivid descriptions, gives us the following account on the popularity of orchids in XIX century Mexico: "In Mexico, where the 'language of flowers' is understood by all, the Orchidaceae seem to compose nearly the entire alphabet. Not an infant is baptised, not a marriage is celebrated, not a funeral obsequy performed, at which the aid of these flowers is not called in by the sentimental natives, to assist the expression of their feelings; -they are offered by the devotee at the shrine of his favorite saint, by the lover at the feet of his mistress, and by the sorrowing survivor at the grave of his friend... (Bateman, 1837-1843: 8)." Seemann, in his Botany of the H.M.S. Herald, tells us how in Panama "[The] Espiritu Santo or Holy Ghost plant (Peristeria elata, Hook.) bears a flower resembling a dove, and is, like the Flor de semana santa (= Holy Week Flower), another Orchidea, almost held in religious veneration, and eagerly sought for when in blossom" (Seemann, 1852-1857: 71). Boyle, in 1893, writes about the craziness for the alba varieties of certain species: "Even the half-castes of Mexico, who have no soul, apparently, for things above horseflesh and cockfights, and love-making, reverence this saintly bloom [Laelia anceps var. alba]. The Indians 
adore it. Like their brethren to the south, who have removed every plant from Cattleya Skinneri alba for generations unknown, to set upon their churches, they collect this supreme effort of Nature and replant it round their huts. So thoroughly has the work been done in either case that no single specimen was ever seen in the forest. Every one has been bought from the Indians, and the supply is exhausted; that is to say, a good many more are known to exist, but very rarely now can the owner be persuaded to part with one. [...] Roezl and the early collectors had a 'good time' buying these semi-sacred flowers from the priests, bribing the parishioners to steal them, or, when occasion served, playing the thief themselves" (Boyle, 1983: 120-121). As we have seen, literature is full of examples of the interest in orchids in our region during the XIX century. But it was not until the 1940's that the first efforts were made to create organizations with the purpose of uniting all those interested in the growing, study and conservation of orchids.

In Mexico, in 1942, a group was formed with the name "Amigos de las Orquídeas" (= Friends of the Orchids) which organized in Chiapas the First International Congress of Orchidology, sponsored by Rafael Pascasio Gamboa, then governor of the state. The "Amigos de las Orquídeas" functioned during 15 years but then lost most of his members and ceased to exist. In 1966, Joaquín Ibarrola had the idea of reviving the "Amigos de las Orquídeas" and in 1971 the new association was legally registered by Eric Hágsater as “Asociación Mexicana de Orquideología, A. C." (= Mexican Society of Orchidology). It keeps meeting since then in Mexico City, as well as in the regional offices of Cuernavaca, Morelos; Jalapa, Veracruz; Morelia, Michoacán; Huixquilucán and Atizapán, Mexico; as well as with associated members throughout the country. The journal Orquidea is a scientific publication of the Mexican Society of Orchidology, focused mainly on the orchid flora of Mexico and Tropical America. This journal, which was first published in 1971, includes papers on systematics, ecology, conservation, anatomy, physiology and other aspects of the biology of the orchids.

In 1968, Helena de Ospina, president of the Orchid Society of Colombia and wife of Mariano Ospina, president of the Latin American Committee of Orchidology, traveled through Central America promoting the creation of national orchid societies. In El Salvador the ambassador of Colombia invited a group of interested friends and on October 21, 1968, the Salvadorian Society for Orchidology (ASO) was founded with an initial 30 members. The Society has as its objectives the study, cultivation, conservation and propagation of orchids, with special interest in the native species of El Salvador. During the first years, the members of ASO, guided by German botanist Oskar Pank and by Cleon Clason, an excellent photographer, dedicated themselves to explore the country, collecting species which were classified and described by Fritz Hamer and became the base for his future publications. Then came the war years, which forced the collectors to remain in the cities, and more and more foreign plants began to be imported.

In Costa Rica, the same Helena de Ospina proposed to Miguel Ángel Ramírez the idea of creating an organization with all those interested in the cultivation and conservation of orchids. On April 4, 1970, Ramírez sent out a letter to several well-known orchid-lovers, inviting them to found the Costa Rican Society of Orchidology. With the help of Dorothy Lankester and Rafael Lucas Rodríguez Caballero, the first meeting was held on May 16, 1970, in the School of Biology of the University of Costa Rica. On July 31, 1970, in a meeting held at the residence of María Eugenia de Roy and with the collaboration of Fritz Trinler and Dirk t'Höen, the bylaws of the new association were presented and approved. The Society was legally registered this same year. Under the presidency of Miguel Ángel Ramírez the first National Orchid Show was held in San José, during May 8 and 9 of 1971, with a total of 147 plants being exhibited.

In 1973, a group of conscious persons, knowing of the dangers to which many native species of Guatemalan orchids were exposed, founded the "Asociación Guatemalteca de Orquideología (AGO)" (= Guatemalan Socierty of Orchidology) to conserve and protect their orchids. Among the founding members rose the great figure of Dr. Moisés Behar, today retired in Curitiba, Brazil. Today AGO has more than 100 members, all enthusiasts of the orchids, their cultivation, identification, propagation and conservation. The efforts of AGO's members have been internationally recognized. The annual orchid shows are held in February in Guatemala City, with a great variety of genera and species, both 
native and exotic. The Society supports the maintenance and preservation, as well as the proper handling of the natural habitats of the orchids. Several years later, in 1979, the "Asociación Altaverapacense de Orquideología" (= Orchid Society of Alta Verapaz) was founded in Cobán, Guatemala, after a visit by Dr. Karlheinz Senghas of the University of Heidelberg.

In the year of 1977, a large number of orchid enthusiasts came together in Panama to listen to the experiences in orchid growing of Robert Dressler, renowned scientist of the Smithsonian Institute.
During this meeting Walter Maduro was elected as the first president of a new association, called the Panamanian Society of Orchidology. One year later the first national orchid show was held at the Museum of the Panamanian Man, an exhibition that brought together the native and exotic species and hybrids of orchids owned by the members of the new society. In the month of October of 1992 the association was finally registered in the Public Registry. Its logo shows Panama's National Flower, Peristeria elata, popularly known as the Holy Ghost Orchid.

AcKNOwLEDGEMENTS. Many friends have helped to make this book a reality. To try and comment on each one's specific contribution could lead to unjust appreciations and unforgivable oversights. Therefore, I will limit myself to mentioning them in alphabetical order, begging for excuses if I forgot anybody: Fredy Archila, Joseph Arditti, Michael J. Balick, Moisés Behar, Eduardo Bitter, Mario Blanco, Paloma Blanco, Pilar Casasa, Pilar de San Pío, Susan Donogue, Kerry Dressler, Robert Dressler, Jaime García, Günter Gerlach, Luis Diego Gómez, Eric Hágsater, Hedwig Hamer, Barry Hammel, Stanley Heckadon-Moreno, Leonardo Hernández, Wesley Higgins, Luko Hilje, Pierre Jacquet, Rudolf Jenny, Pavel Kindlmann, Stephen Kirby, Isobyl la Croix, Ricardo Lankester, Hilda León-Paéz, Jorge León, Leoncio López Ocón, Steve Manning, Stuart McCook, Helga Nevermann, Marc Nir, Mary Noble McQuerry, Henry Oakeley, Gabriela Ossenbach, Enid Picado, Franco Pupulin, Leonora Rodríguez, Gustavo Romero, Willy Salazar, Luis Sánchez Saldaña, Esthela Sandoval, Walter Schug, Philip Seaton, Michael Seaward, Miguel Ángel Soto Arenas, Angela Todd, Silvia Troyo, Erich Vogt Sartorius, James Watson, and Mayela Zamora. To all, once again, a thousand thanks! 